\title{
Summary of Wind Data from Nuclear Power Plant Sites
}

by

M. Gary Verholek

March 1977

Prepared for the Energy Research and Development Administration under Contract EY-76-C-06-1830 
NOTICE

This report was prepared as an account of work sponsored by the United States Government. Neither the United States nor the Energy Research and Development Administration, nor any of their employees, nor any of their contractors, subcontractors, or their employees, makes any warranty, express or implied, or assumes any legal liability or responsibility for the accuracy, completeness or usefulness of any information, apparatus, product or process disciosed, or represents that its use would not infringe privately owned rights.

PACIFIC NORTHWEST LABORATORY

operated by

BATTELLE

for the

ENERCY RESEARCH AND DEVELOPMENT ADMINISTRATION

Under Contract EY-76-C-06-1830

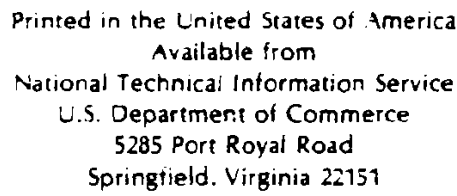

Price: Printed Copy \$__ ; Microfiche $\$ 3.00$

NTIS

- Pages Selling Price

$001-025 \$ \$ 4.50$

$026-050 \quad \$ 5.00$

$057-075 \quad \$ 5.50$

$076-100 \quad 56.00$

101-125 \$6.50

$126-150 \quad \$ 7.00$

$151-175 \quad \$ 7.75$

$176-200 \quad \$ 8.50$

201-225 $\$ 8.75$

226-250 $\$ 9.00$

$251.275 \quad \$ 10.00$

$276-300 \quad \$ 10.25$ 
NUCLEAR POWER PLANT SITES

by

M. Gary Verholek

March, 1977

Battelle

Pacific Northwest Laboratories

Richland, Washington 99352 


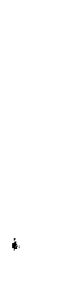




\section{CONTENTS}

FIGURES. . . . . . . . . . . . . . . . . . . . . iii

TABLES . . . . . . . . . . . . . . . . . . . iii

INTRODUCTION . . . . . . . . . . . . . . . . . 1

OBJeCtIVE. • . . . . . . . . . . . . . . . . . 1

DATA . . . . . . . . . . . . . . . . . . . 2

ANALYSIS . . . . . . . . . . . . . . . . . 5

RESULTS. . . . . . . . . . . . . . . . . . . 16

REFERENCES ......................... 17

APPENDIX A: Tabulation by State of Nuclear Power Plant

Sites and Selected wind Energy Related

Data. . . . . . . . . . . . . . A-1

APPENDIX B: Alphabetical Tabulation of Nuclear Power Plant Sites and Selected Wind Energy Related Data............. B-1

APPENDIX C: Alphabetical Compilation of Site Descriptions and Data... . . . . . . . . . . C-1 


\section{FIGURES}

1 Nuclear Power Plant Sites . . . . . . . . . . . . . . 3

2 Observed Versus Calculated Velocity-Duration Curves for South Texas, TX . . . . . . . . . . . . . . 11

3 Square Root Normal Distribution for South Texas, $\mathrm{TX}$. . . . . . . . . . . . . . 12

4 Curvilinear Normal Distribution for Pebble Springs, OR. . . . . . . . . . . . . . 13

5 Square Root Normal Distribution for Pebble Springs, OR. . . . . . . . . . . . . . . 14

\section{TABLES}

1 Velocity Frequency Distribution for Browns Ferry, AL. . . . . . . . . . . . . . . . . 7

2 Power Estimates for Browns Ferry, AL, Based on Arbitrary Velocity Limits. . . . . . . . . . . 8

3 Joint Frequency Distribution of Velocity

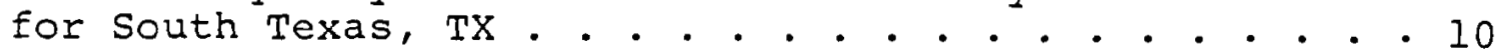


SUMMARY OF WIND DATA FROM NUCLEAR POWER PLANT SITES

M. Gary Verholek

\section{INTRODUCTION}

our country's urgent need to develop alternate energy sources has spawned federal support for a national wind Energy Conversion Program (WECP). This program is sponsored by the U. S. Energy Research and Development Administration (ERDA) through the wind system Branch of the Department of Solar Energy. The primary goal of the WECP is the development and commercialization of durable and economically viable wind Energy Conversion systems (WECS). In order to determine where WECS turbines could be effectively used and how much energy is available for exploitation, special wind climatology studies are required. While several such studies have been conducted already $1,2,3,4$, further work is needed to expand and improve our existing data base. This study is intended to provide additional data for inclusion in assessments of available wind energy •

\section{OBJECTIVE}

This study was undertaken to provide a summary of wind data from nuclear power plant sites. National weather service archives are an immediately obvious source of wind data, but additional data sources are also available. Utility companies proposing to build nuclear power plants are required to establish on-site meteorological monitoring programs that include towers for collecting wind and temperature data for 
use in environmental impact assessments. These data are available for more than one hundred planned or operating nuclear power plant sites (Figure 1). A list of the sites, by state, is provided in Appendix A, while Appendix B contains an alphabetical list of the sites.

This site wind data provides a valuable addition to the existing NWS data sets, and significantly enlarges the multilevel data presently available. The wind data published through the NRC is assembled and assessed here in order to provide a supplement to existing data sets.

\section{$\underline{\text { DATA }}$}

The Nuclear Regulatory Commission licensing process for nuclear reactor power plants requires that the controlling utility conduct an extensive meteorological monitoring program on the proposed power plant site. Information about on-site meteorological programs is published through the NRC under a docket number assigned to each nuclear unit. Depending on the appropriate stage of the licensing procedure and plant construction phase, relevant meteorological information is published in such documents as Environmental Reports (ER), Preliminary Safety Analysis Reports (PSAR), and/or Final Safety Analysis Reports (FSAR), which are available to the general public.

These documents are maintained at PNL in loose-leaf and microfiche form. The microfiche files were the primary source of most of the information.

The meteorological studies are required by the NRC to provide information on the diffusive characteristics of the atmosphere at the plant sites. The studies provide stability 


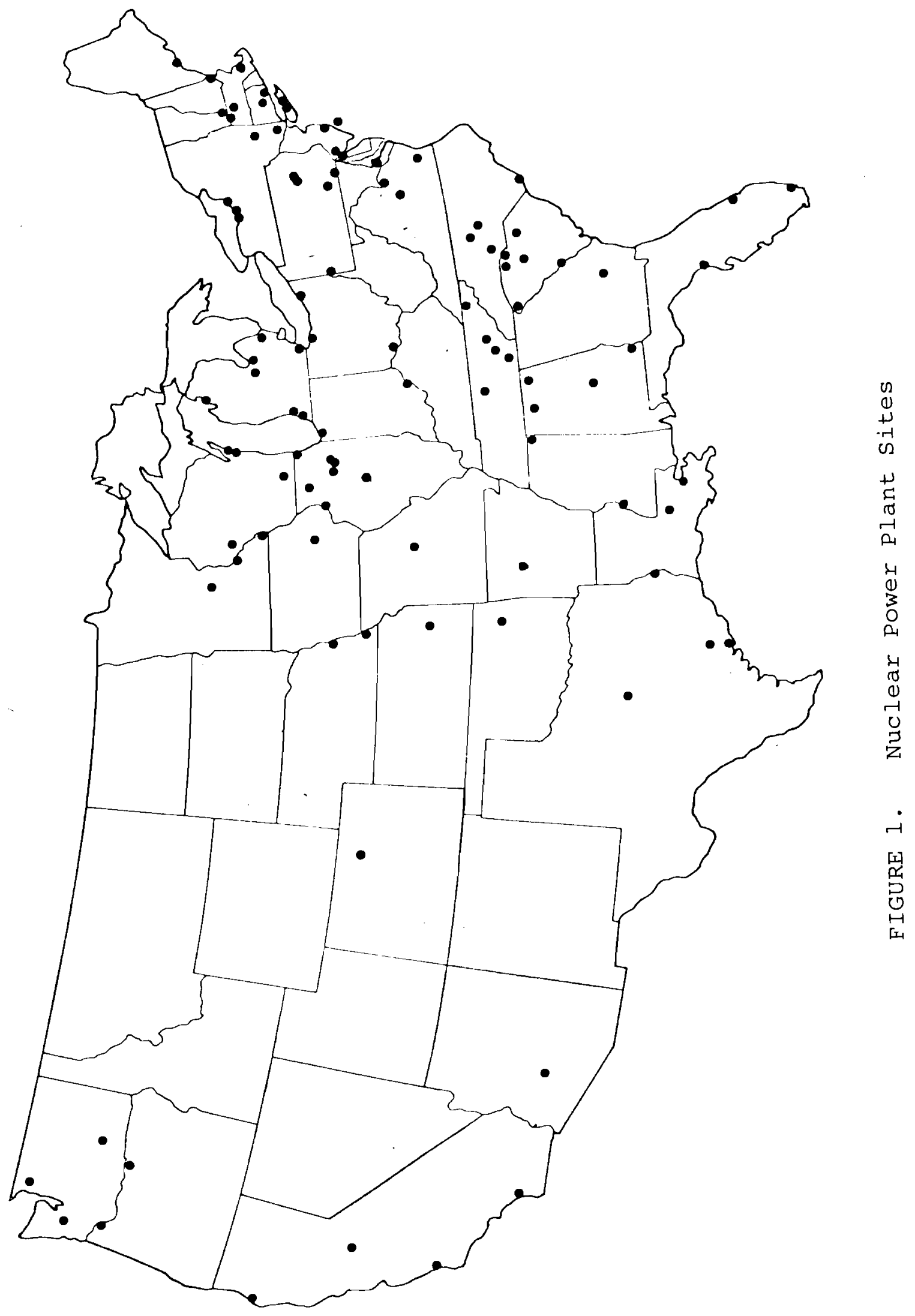


and wind information for input into diffusion estimates. Because of the NRC requirement for stability data, the on-site meteorological program usually consists of a meteorological tower for wind and temperature lapse rate determination. Very often the utility company instalis more than the required number of wind sensors on the tower. The data from supplemental sensors are not always published, even though the data were often found to be available at the utility company offices. Processing and publication of the additional data are left to the discretion of the utility companies. We have included such data when made available to us.

Wind data are usually published as joint frequency tables (speed and direction) for each stability category. For the purpose of this study, these data are summarized on an annual basis to include all stability classes. The annual joint frequency tables are presented as a part of Appendix $C$.

The records available through the NRC usually cover a period of one or two years, primarily because sufficient time has not elapsed for longer coverage. Fully licensed, operating units are required to maintain meteorological monitoring systems, but they are not required to publish data on a continuing basis. Hence, longer (>2 $\mathrm{yr}$ ) periods of data are available at the utility company for longer periods, as well as for additional tower levels, but often these are not published. We have tried to collect and present all wind data published through the NRC, as well as some additional data from sites where publication of wind data is not yet required.

Descriptive information was gathered in addition to wind data in order to help assess the representativeness of the relatively short-term data. Information includes details of site location and topography, which are needed to assess the 
effect of local influences on the general wind field. The meteorological towers were placed on-site to satisfy requirements for diffusion studies; thus the location may not be ideal by WECS standards. Site and topographical information is vital in assessing the applicability of the data to WECS requirements.

A brief description of the on-site wind measurement program was also obtained in order to provide some level of appreciation for the scope of the overall meteorological program. Those sites where data have not been obtained for all instrumented levels are shown in Appendix $C$. Information on specific wind instrumentation used at each site is also presented in this report. It is sufficient to note that the NRC has a rigorous Quality Assurance program and, therefore, the data should be viewed with a rather high degree of confidence while being assessed for its representativeness.

The descriptive information on Site Location, Topography and On-site Wind Measurements is included in Appendix $C$. Each site is presented in alphabetical order, with the site description followed by the wind data for that site.

\section{ANALYSIS}

The power available in the wind is a product of the kinetic energy per unit mass of moving air and the mass flow rate through a cross-sectional area $A$, so that

$$
\mathrm{p}=\frac{1}{2} \dot{\mathrm{m}} \mathrm{v}^{2}=\frac{1}{2}(\rho \mathrm{AV}) \mathrm{v}^{2}=\frac{1}{2} \rho \mathrm{A} \mathrm{v}^{3}
$$

where $\mathrm{V}$ is wind speed and $p$ is air density. Another common form is expressed as power per unit area: 


$$
\frac{P}{\bar{A}}=\frac{1}{2} \rho v^{3}
$$

Previous estimates of wind power potential in the United States $1,2,4$ have been based on statistics of the mean wind speed at various locations across the country. However, because of the cubic response to wind speed, a climatological distribution of speeds, rather than a mean wind speed, should be used to calculate power. For a given distribution $f(v)$ of wind speed $v$, the average power $\overline{\mathrm{P}}$ from a wind-powered generator is given by

$$
\bar{P}=\int_{0}^{\infty} P(v) f(v) d v
$$

where $\mathrm{P}$ is given in (I) above. The frequency distributions of wind speeds must then be specified in order to determine the average available power.

In attempting to apply the above expression to the wind data from the nuclear power plants, a preview of the data revealed that frequency distributions were generally in the form of frequency per wind speed interval. In a great many cases, the upper wind speed interval was unbounded, and the size of the wind speed categories, the number of categories and the lower limits of the unbounded high speed categories varied considerably from site to site. In view of the nonuniformity of the data, several approaches were examined in order to select a single method capable of adequately specifying the frequency distribution to be used in power estimations.

The simplest approach would be to take the median value of the given speed intervals and use a summation approximation of the form:

$$
\frac{\mathrm{P}}{\mathrm{A}}=\frac{1}{2} \rho \Sigma_{i} \mathrm{f}_{\mathrm{i}} \mathrm{v}_{\mathrm{i}}^{3}
$$


According to Reed (1974), this provides an acceptable approximation to within $20 \%$ and is extremely easy to use. However, since a great many of the data sets from the nuclear sites have unbounded upper speed intervals, a corresponding median value cannot be calculated. Assigning a systematically, but arbitrarily, determined median value would still result in power estimates of questionable validity.

of the 184 distributions in this report, 141 have unbounded upper intervals. Frequencies for these intervals range as high as $55 \%$ with speeds as low as $>5.59 \mathrm{~m} \mathrm{~s}^{-1}$ (Clinton). As a more typical example, we might use the $91 \mathrm{~m}$ level at the Browns Ferry site in Alabama, summarized in Table 1.

TABLE 1. Velocity, Frequency Distribution for Browns Ferry, AL $(91 \mathrm{~m})$

$\begin{array}{cr}\frac{\left.\text { u* } \text { (ms }^{-1}\right)}{0.22} & \text { Freq. }(\%) \\ 1.52 & 0.11 \\ 2.41 & 5.75 \\ 3.31 & 9.98 \\ 5.54 & 11.54 \\ 8.22 & 30.45 \\ 10.91 & 27.55 \\ >10.91 & 10.63 \\ & 3.98 \\ \text { *This is the upper limit of the speed } \\ \text { interval except where shown as >v. }\end{array}$

Using equation (4) above with $p=1.293 \mathrm{~kg} \cdot \mathrm{m}^{-3}$, and assigning arbitrary limits to the upper speed category, power estimates can be obtained and are shown in Table 2 . 
TABLE 2. Power Estimates for Browns Ferry Based on Arbitrary Velocity Limits

\begin{tabular}{|c|}
\hline $\mathrm{v}_{\mathrm{ma}}$ \\
\hline $\begin{array}{l}12 \\
15\end{array}$ \\
\hline $\begin{array}{l}20 \\
30\end{array}$ \\
\hline
\end{tabular}

\begin{tabular}{c}
$\mathrm{P} / \mathrm{A}\left(\mathrm{w} / \mathrm{m}^{2}\right)$ \\
\hline 176 \\
193 \\
232 \\
358
\end{tabular}

It is evident that even though the unbounded interval accounts for only $3.98 \%$ of the wind speeds, the cubic relationship causes the power estimate to be very sensitive to the velocity chosen as the upper limit. Since the majority of the distributions have unbounded upper intervals, we have no choice but to consider this method to be inappropriate for use with these data.

On the other hand, the reported frequencies could be used to determine an approximating distribution function, such as the Weibull ${ }^{5}$, the Normal ${ }^{6}$ or perhaps a Square Root-Normal ${ }^{7}$. Applications of proper integration techniques require extensive curve-fitting calculations and efforts to fit weibull distributions to the NRC data did not produce satisfactory results.

For the Weibull distribution the cumulative probability of finding a speed less than or equal to $v_{*}$ is given by

$$
p\left(v \leq v_{*}\right)=1-\exp \left[-\left(v_{\star} / c\right)^{k}\right] \text {. }
$$

Justus, et al. ${ }^{5}$ rearranged Equation 5 into the form

$$
\ln [-\ln (1-\mathrm{p})]=\mathrm{k} \ln \mathrm{v}_{*}-\mathrm{k} \ln \mathrm{c}
$$

and determined $\mathrm{k}$ and $\mathrm{c}$ by least-squares fit of $\mathrm{y}=\mathrm{a}+\mathrm{bx}$, 
where $y$ is $\ln [-\ln (1-p)], b$ is $k$, a is $-k \ln c$, and $x$ is ln $v_{*}$. Using wind data from the $60 \mathrm{~m}$ level at South Texas (Table 3), we obtain $\mathrm{c}=8.51$ and $\mathrm{k}=2.05$. As shown in Figure 2, the plot of the observed velocity-duration curves differs considerably from the values obtained from the weibull distribution. Data from several other sites were also examined and the results were similar. Use of a Weibull approximation is, therefore, considered to be inadequate.

After further examination of the data from the NRC reports, it became evident that 1) the data had to be summarized by hand calculation because of the wide variety of formats the utilities used in reporting to the $\mathrm{NRC}$, and 2) with little additional effort a graphical treatment was possible. The square root of the upper value of each wind speed category versus the cumulative frequency for the category, $\Sigma f\left(v \leq v_{i}\right)$, was plotted on probability paper, and a straight line was subjectively placed through the plotted points to approximate a Root-Normal distribution function. This graphical procedure was applied to the data from each site, and in very nearyy every case, the line was drawn, with confidence. The adequacy of the procedure is typified in Figure 3 as it applied to wind data from south Texas. As an example of a case where the fit was not very good, two plots of Pebble Springs data are presented. Figure 4 is a curvilinear normal approximation and Figure 5 is the straight line, Root Normal approximation. Power estimates are also shown for comparison purposes. While the curvilinear fit is obviously better, the power estimate from the straight line fit is being cited in order to maintain uniformity in the method of calculation.

Available power calculations were made from similar graphs for each site using the summation approximation (4) to the integral form (3). Velocities $v_{*}$ corresponding to certain 


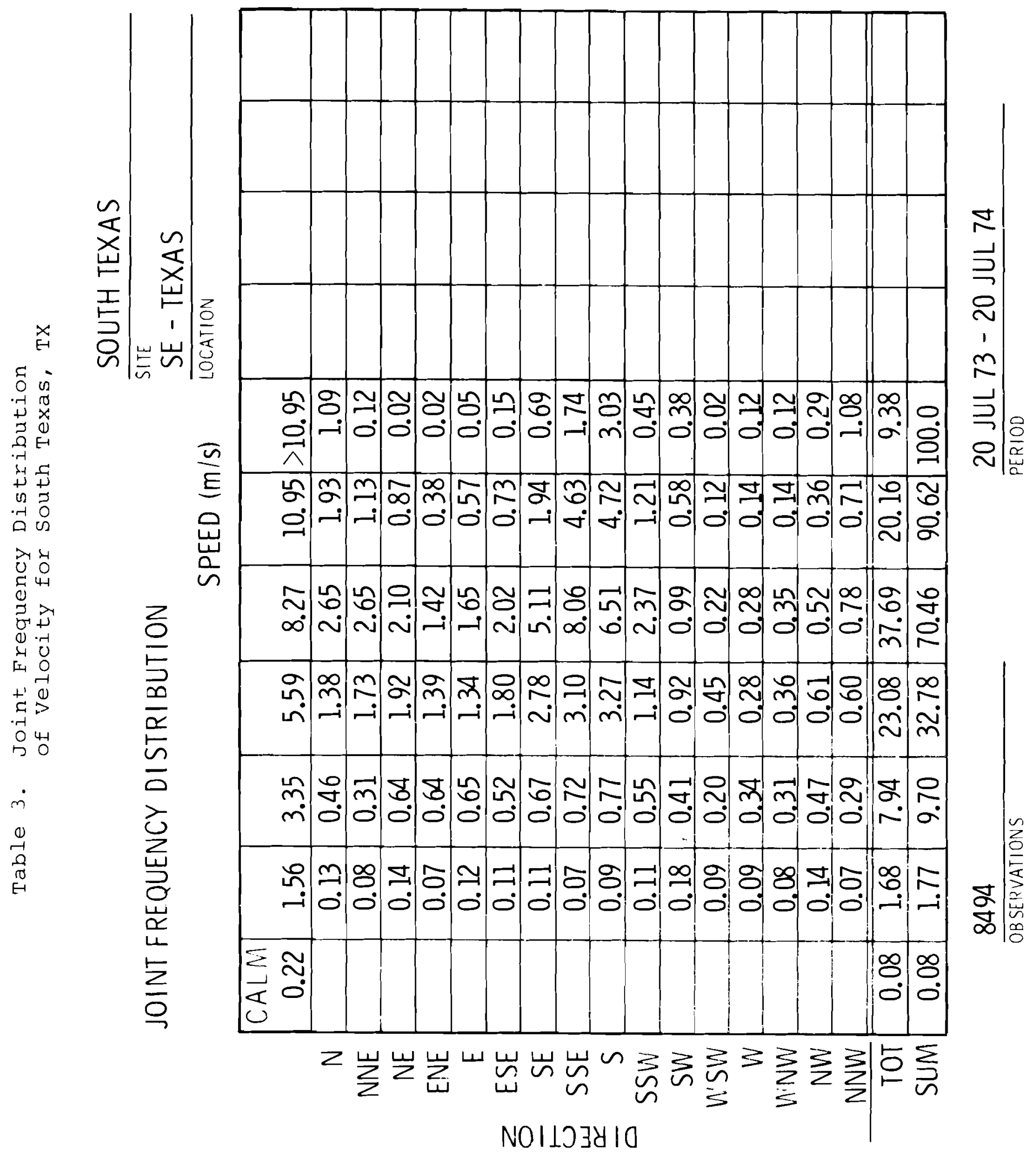




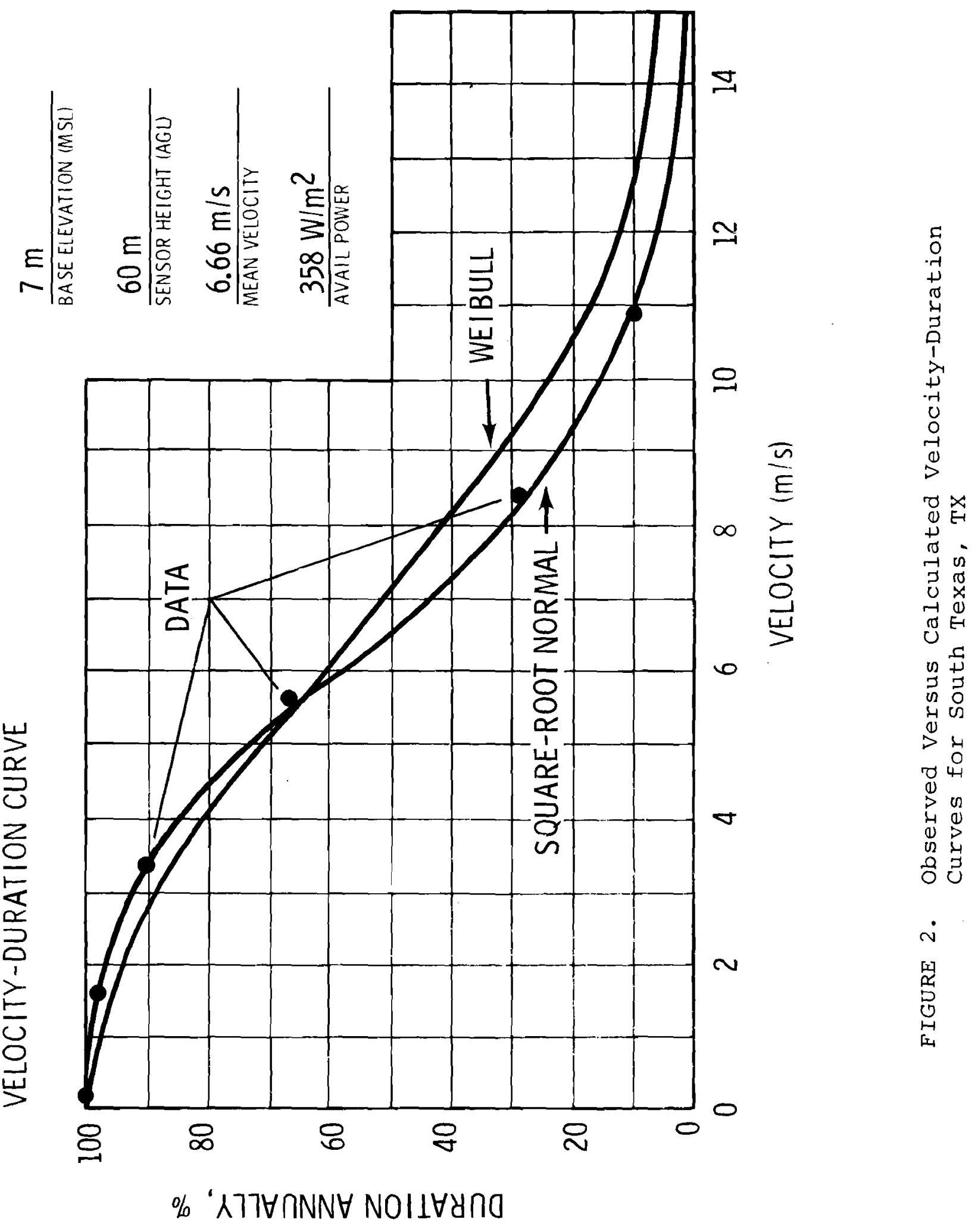




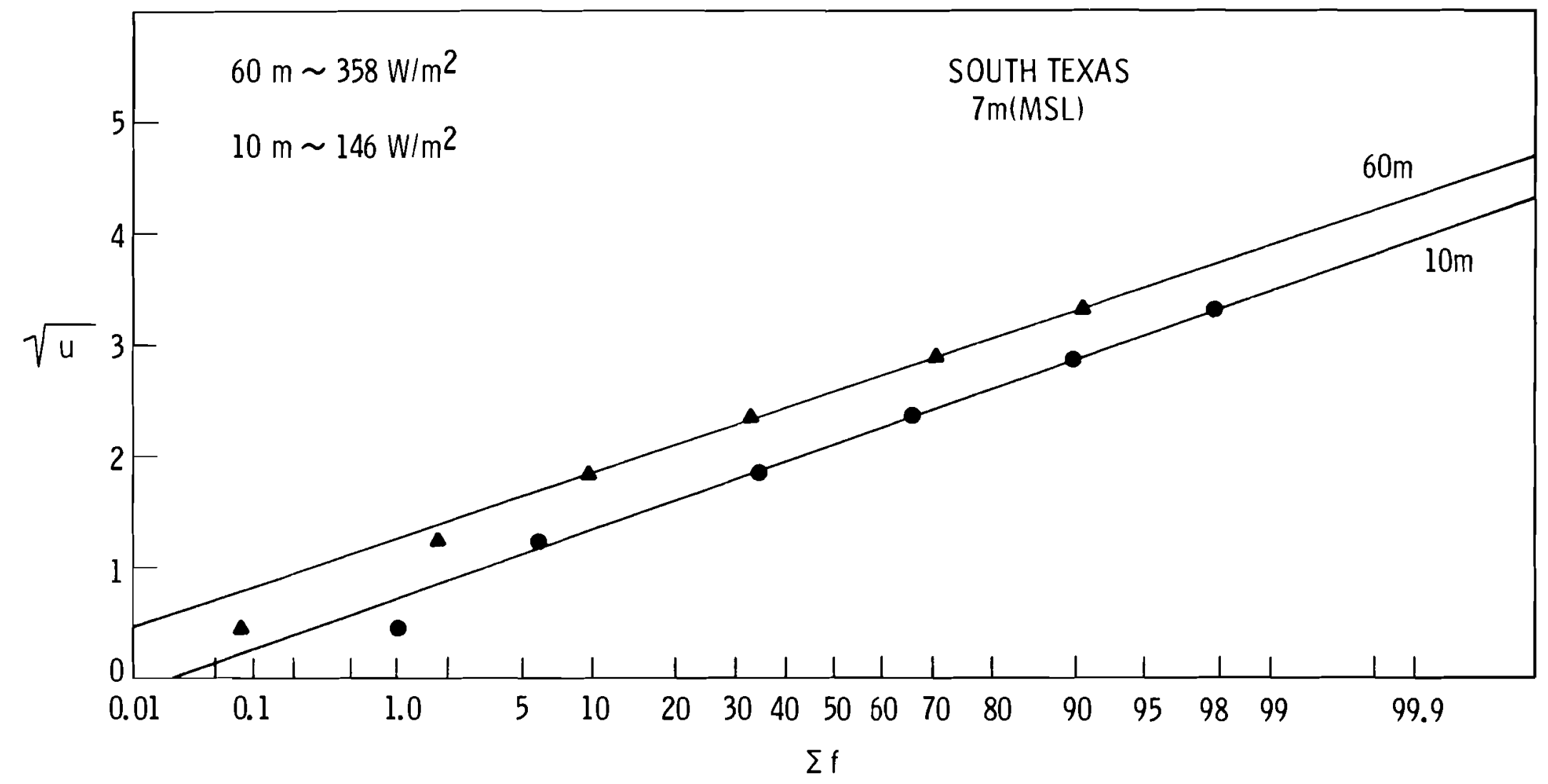

FIGURE 3. Square Root Normal Distribution for South Texas, TX 


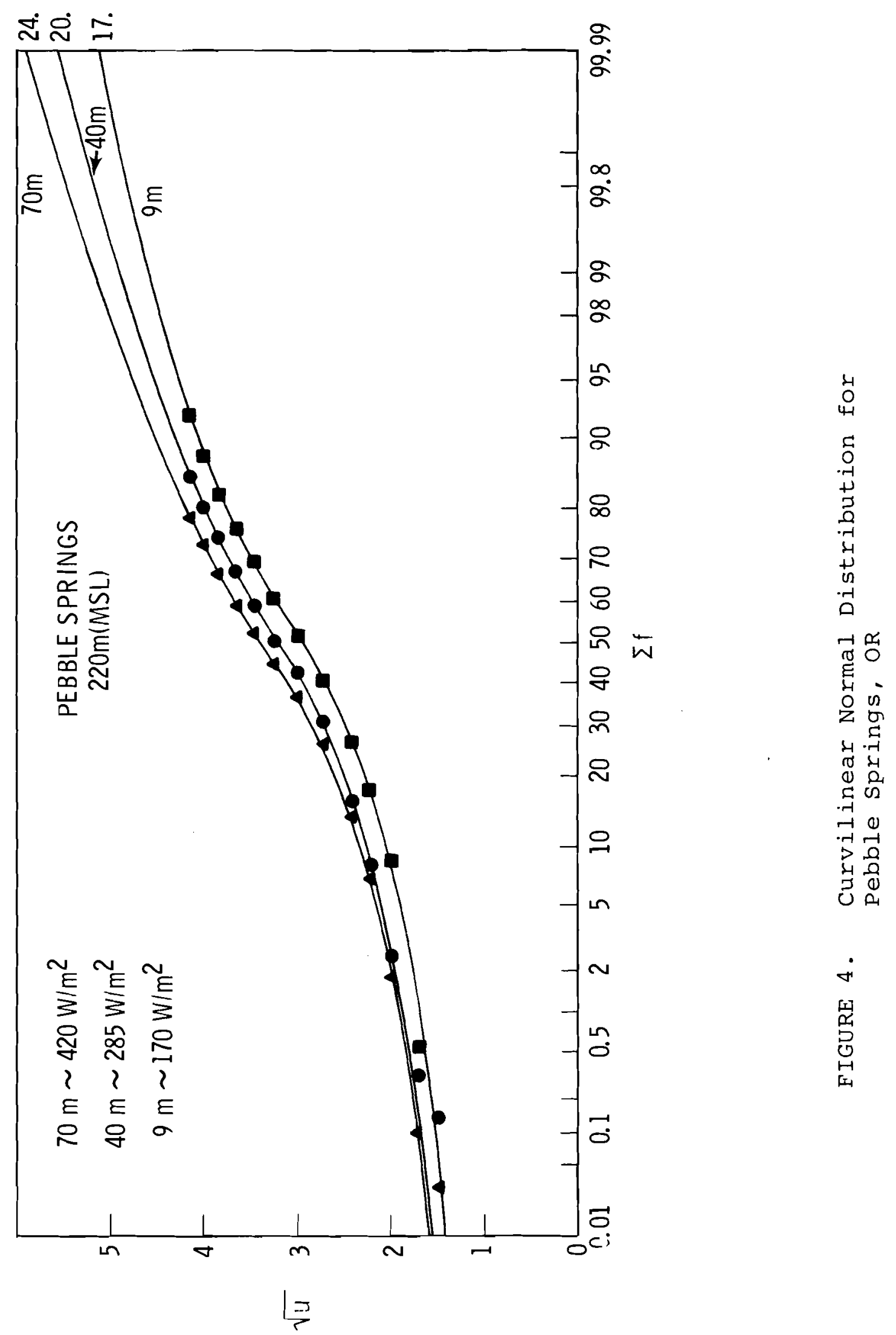




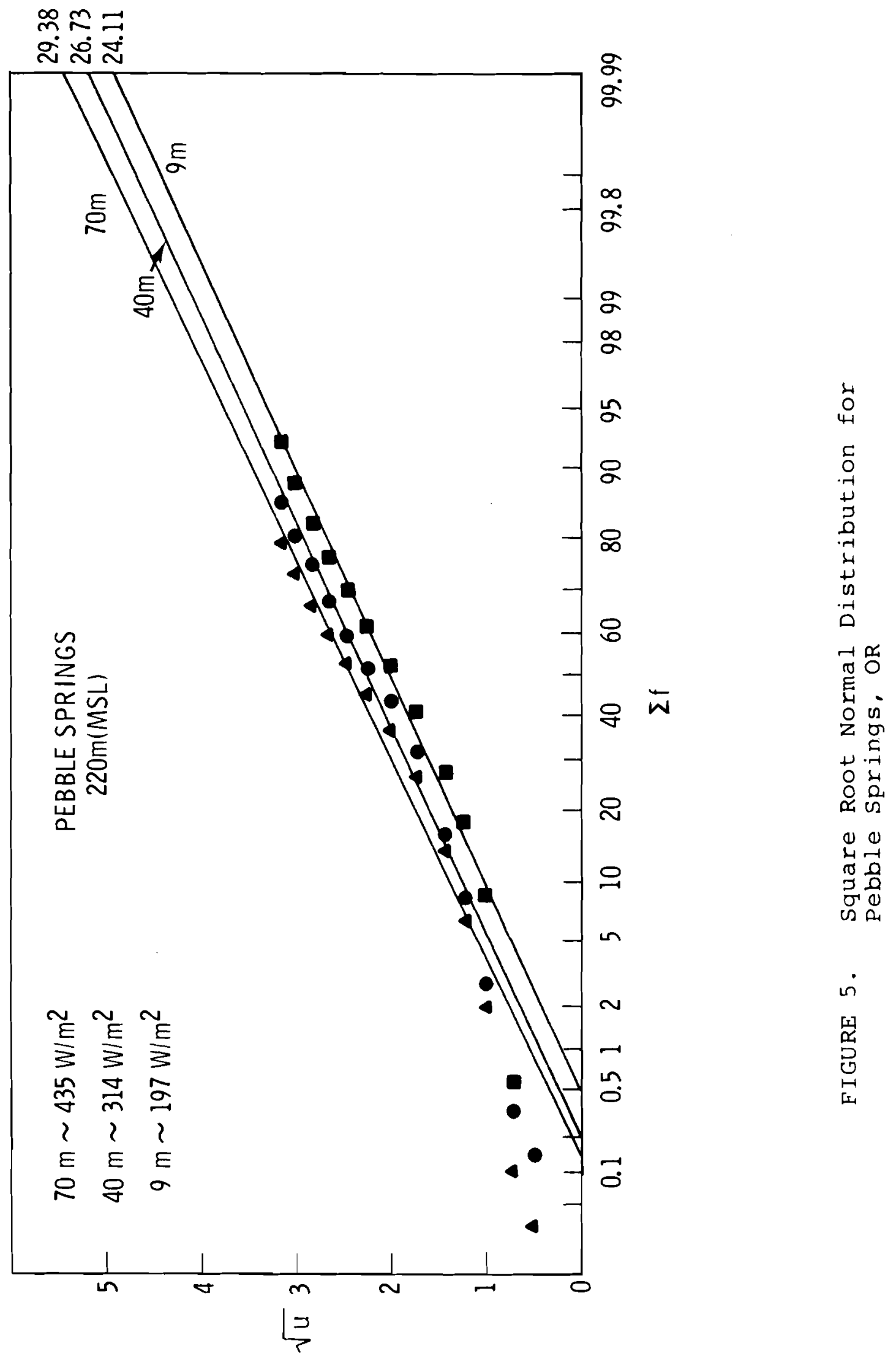


cumulative frequencies, $\left(\sum f=0.02,0.05,0.1-0.9,0.95,0.98\right.$, $0.9999)$ where $\sum f=\sum f\left(v \leq v_{*}\right)$, were determined from the graphs. Two successive velocities determined a velocity interval for which a median value was calculated; the difference of two successive cumulative frequencies determined the frequency of the velocity interval. Equation (4) then becomes:

$$
\frac{P}{A}=\frac{\rho}{2} \sum_{i}\left(\sum f_{i}-\sum f_{i-1}\right)\left(\frac{v_{i}+v_{i-1}}{2}\right)^{3}
$$

Using this method, the distribution curve allows $99.99 \%$ of the frequency distribution to be used in the power calculations, even though the upper limit of the wind speed interval was not specified in the data.

The power estimates given in this report use the density adjusted to sensor elevation according to:

$$
\rho(z)=\rho_{0} \exp \left[-\frac{g m}{R T} \cdot z\right]
$$

If we let:

$$
\begin{aligned}
\rho_{\mathrm{O}} & =1.293 \mathrm{~kg} \cdot \mathrm{m}^{-3} \\
\mathrm{~g} & =9.80665 \mathrm{~m} \cdot \mathrm{s}^{-2} \\
\mathrm{~m} & =28.9 \mathrm{gm} \cdot \mathrm{mole}-1 \\
\mathrm{R} & =8.3144 \times 10^{7} \mathrm{erg} \cdot{ }^{\circ} \mathrm{K}^{-1} \cdot \mathrm{mole} \\
\mathrm{T} & =273^{\circ} \mathrm{K}
\end{aligned}
$$

then (7) becomes

$$
\rho(z)=\rho_{0} \cdot \exp \left(-1.25 \times 10^{-4} \cdot z\right)
$$


This adjustment can amount to decreases in power estimates of $1 \%$ at $100 \mathrm{~m}, 4 \%$ at $300 \mathrm{~m}$ and $6 \%$ at $500 \mathrm{~m}$. When compared to estimates based on standard density, the estimates in this report are more conservative and more realistic.

\section{RESULTS}

Wind data and descriptions for the nuclear power plant sites across the United States have been assembled and presented in narrative and tabular form. This report embodies the following significant features:

- wind data from 104 previously unreported locations

- information from 55 sites that have data at more than one level

- 184 joint frequency distributions available for further analysis

- velocity duration curves for each distribution

- site descriptions including locations and topography

- calculated mean wind speeds

- average available wind power estimates for each distribution

- assemblage and tabulation of a unique data set 


\section{REFERENCES}

1. J. W. Reed, R. C. Maydew, and B. F. Blackwell, wind Energy Potential in New Mexico, SAND 74-0071, Sandia Laboratories, Albuquerque, NM, July 1974 .

2. J. W. Reed, wind Power Climatology of the U.S., SAND 74-0348, Sandia Laboratories, Albuquerque, NM, December 1974.

3. National Wind Energy Mission Analysis Report, General Electric, Unpublished.

4. P. H. Thomas, Electric Power from the Wind, Federal Power Commission, 1945.

5. C. G. Justus, W. R. Hargraves, and A. Yalcin, "Nationwide Assessment of Potential Output from Wind-Powered Generators," J. App1. Meteor. , 15, 673-678, July 1976.

6. T. Wintink, Study of Alaskan Wind Power and Its Possible Applications, E(45-1)-2229 NSF-G-AER-7400239A01, available through NTIS, February 29, 1976.

7. W. K. Widger, "Estimating Wind Power Feasibility," Power Engineering, August 1976. 

APPENDIX A

\author{
Tabulation by state \\ of \\ Nuclear Power Plant Sites \\ and \\ Selected wind Energy Related Data
}

\title{
Legend
}

El. (Base Elevation, MSL) . . . . . . . . . . . . . m

Ht. (Sensor Height, AGL) . . . . . . . . . . . . . m

$\overline{\mathrm{u}}$ (Mean Wind Speed) . . . . . . . . . . . . . . . $\mathrm{m} / \mathrm{s}$

$\mathrm{P} / \mathrm{A}$ (Power per Unit Area) . . . . . . . . . . . . . .

Frequency Distribution

u (Categorical Upper Limit of Wind Speed) . . . . . $\mathrm{m} / \mathrm{s}$

f (Categorical Frequency). . . . . . . . . . . . . 高 
. 


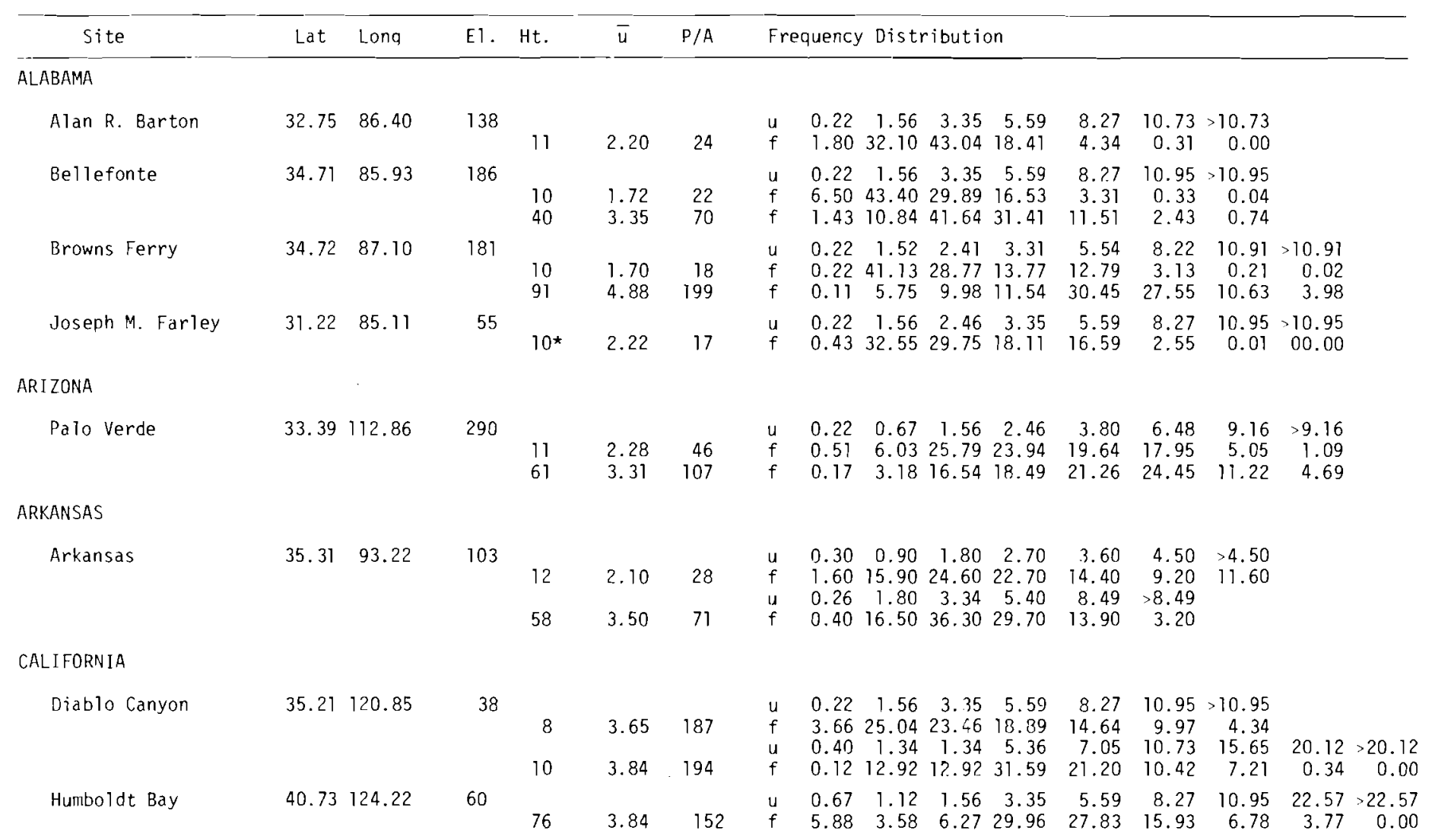




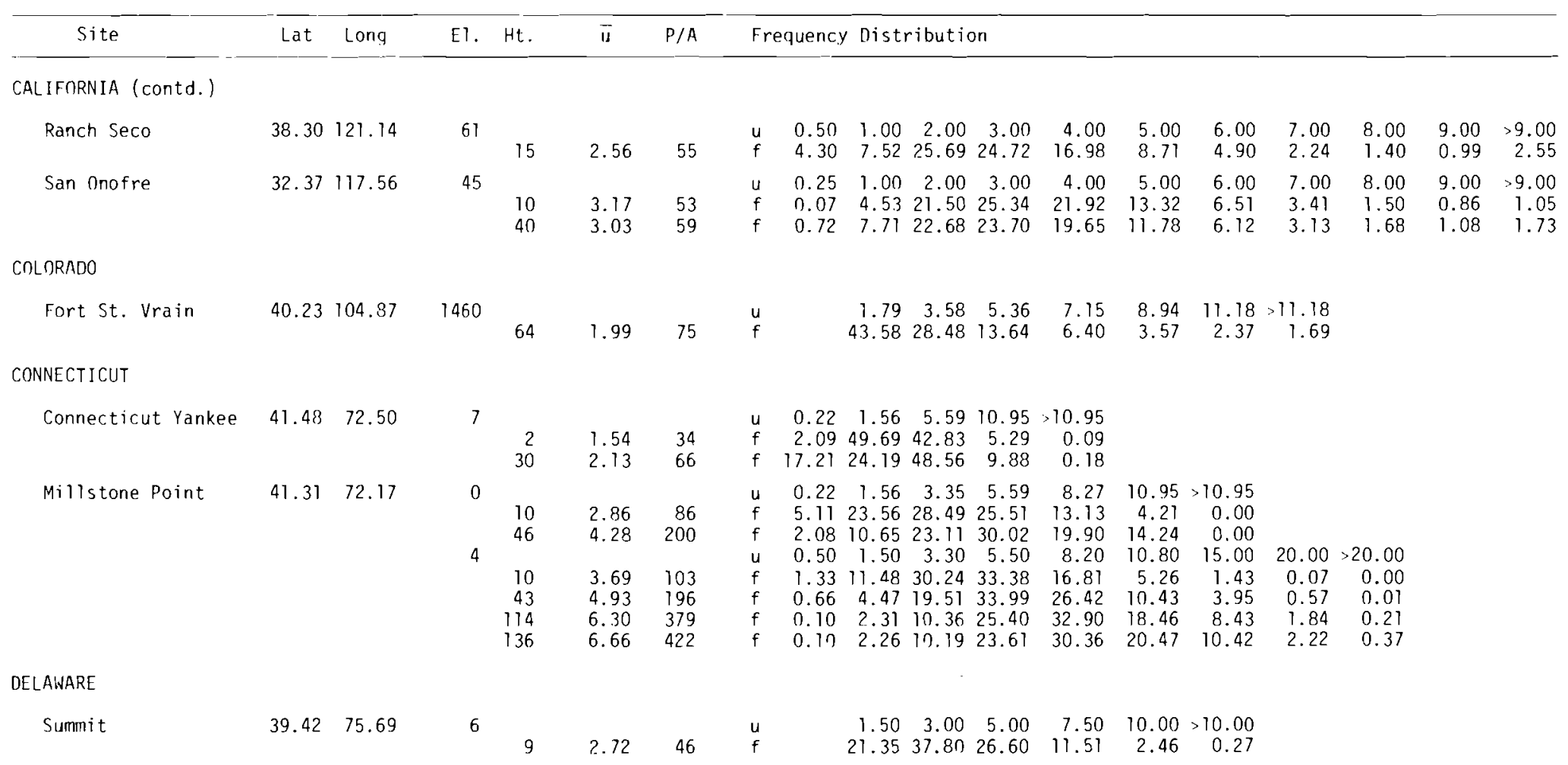




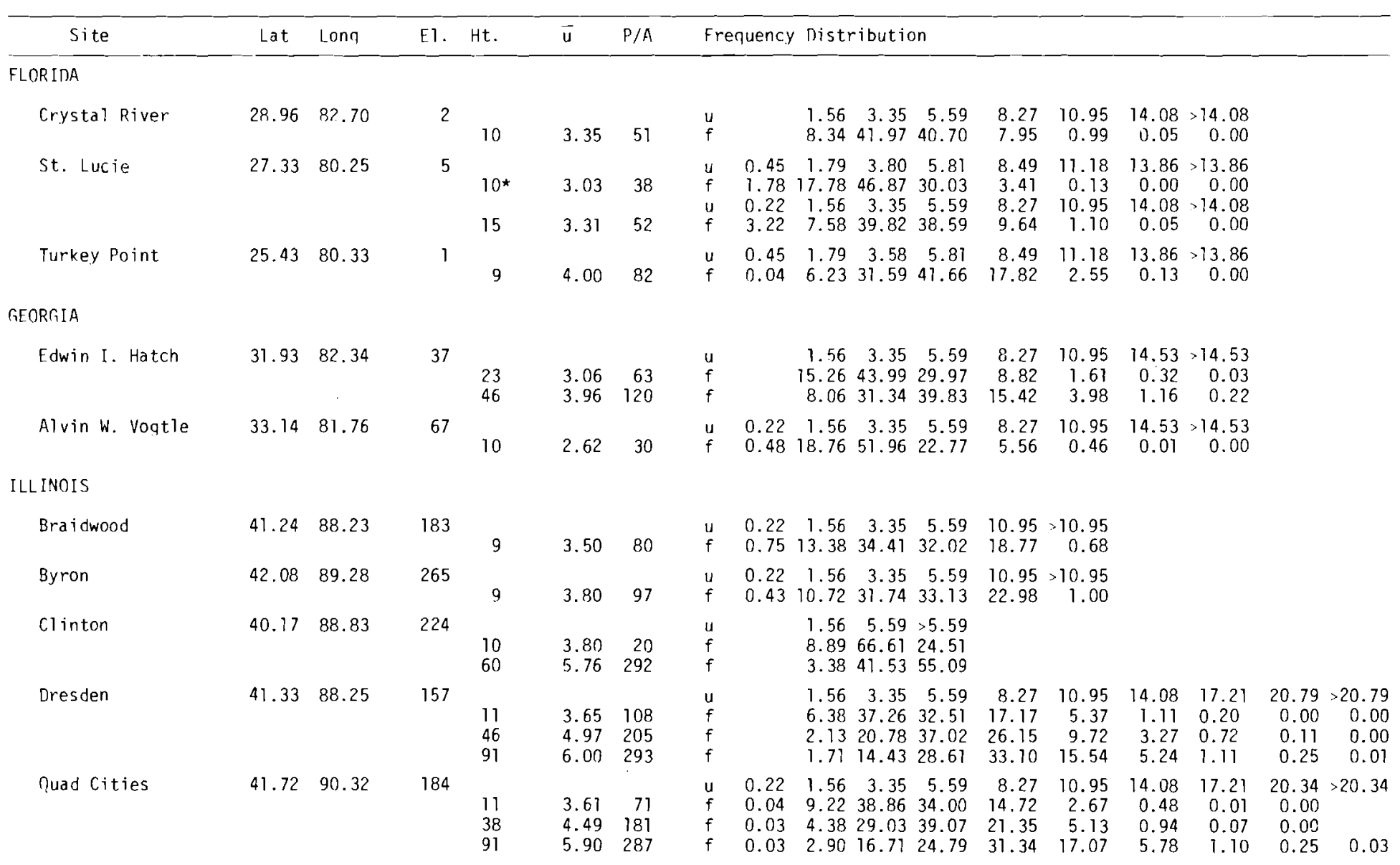




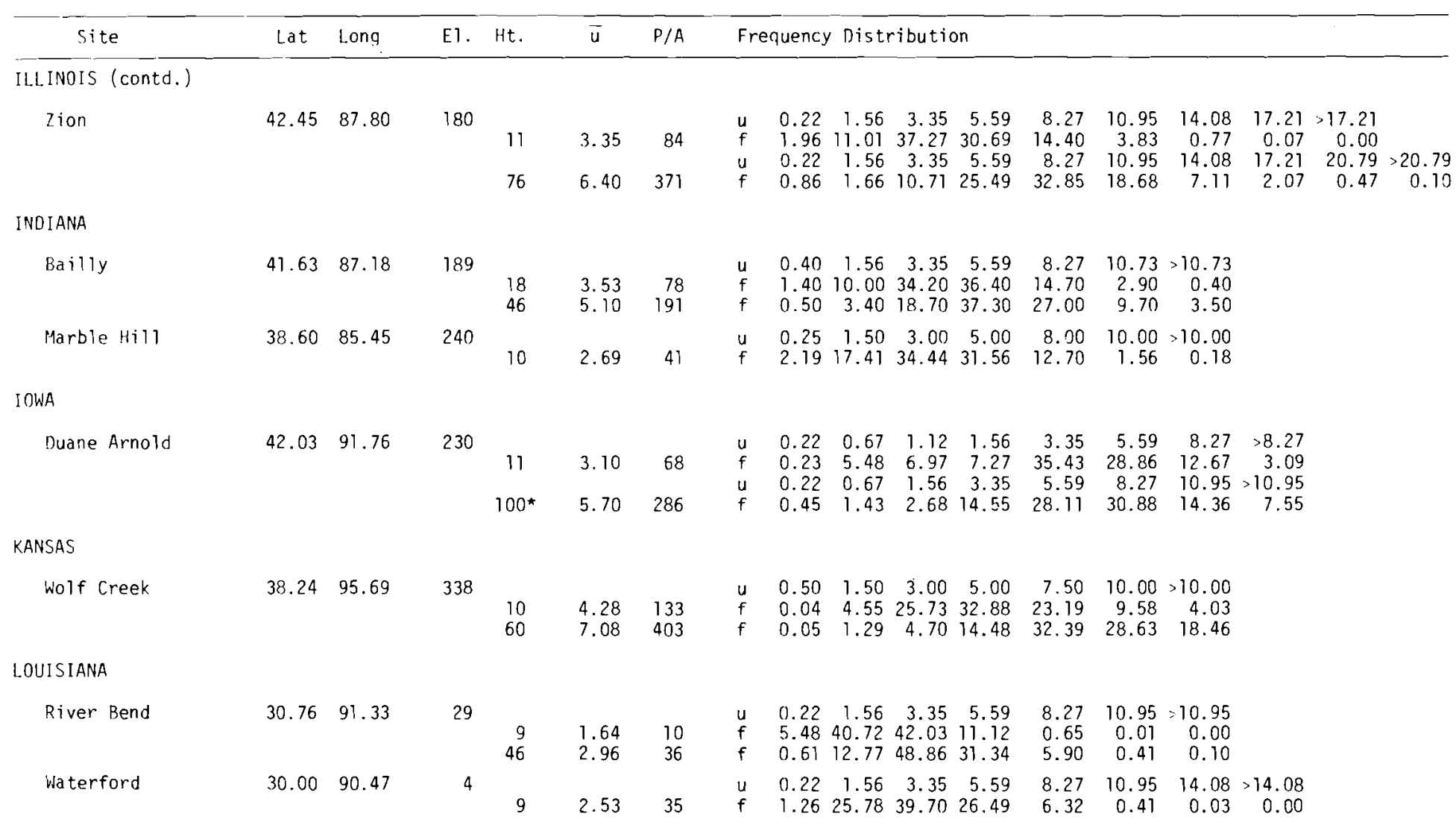




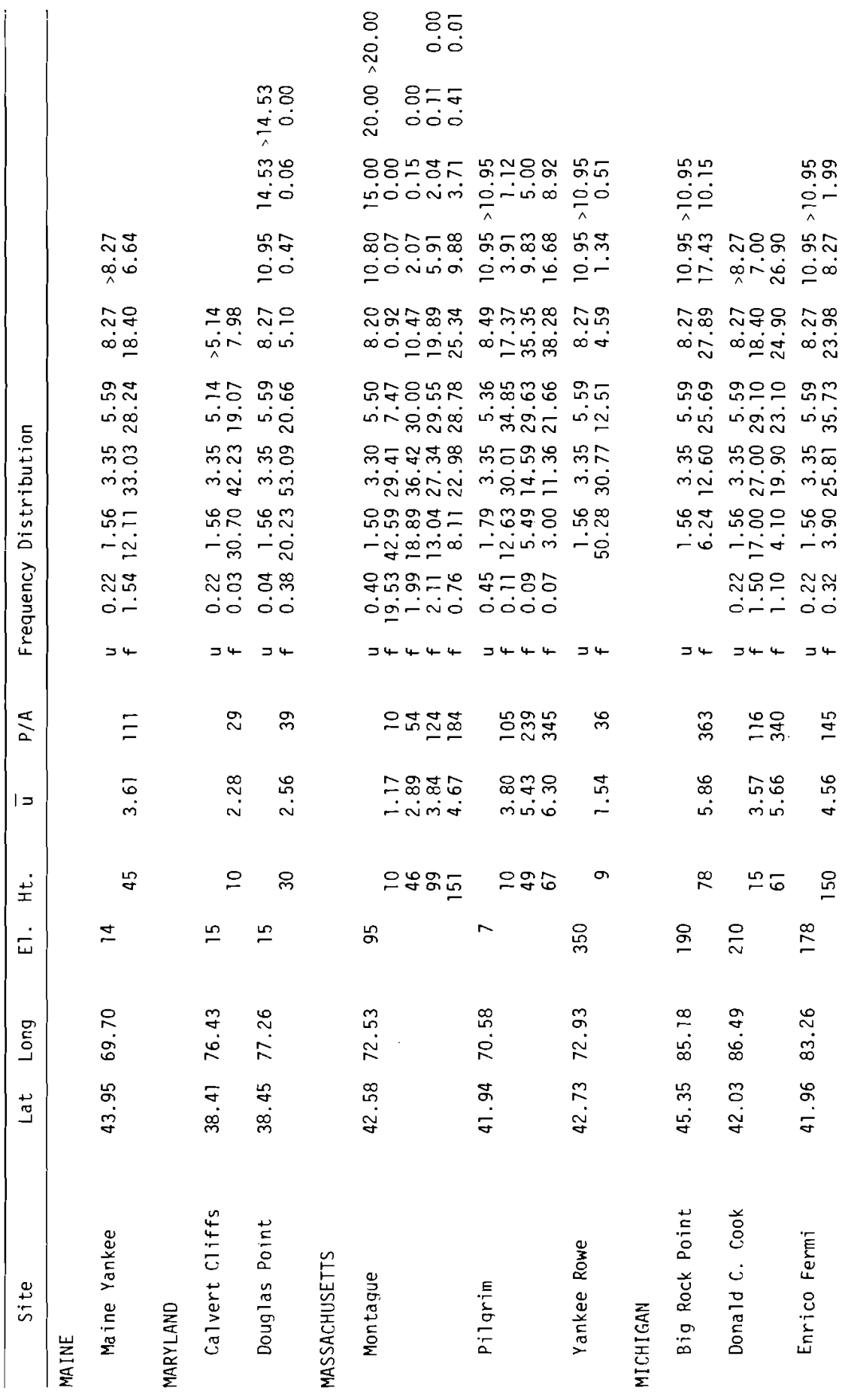




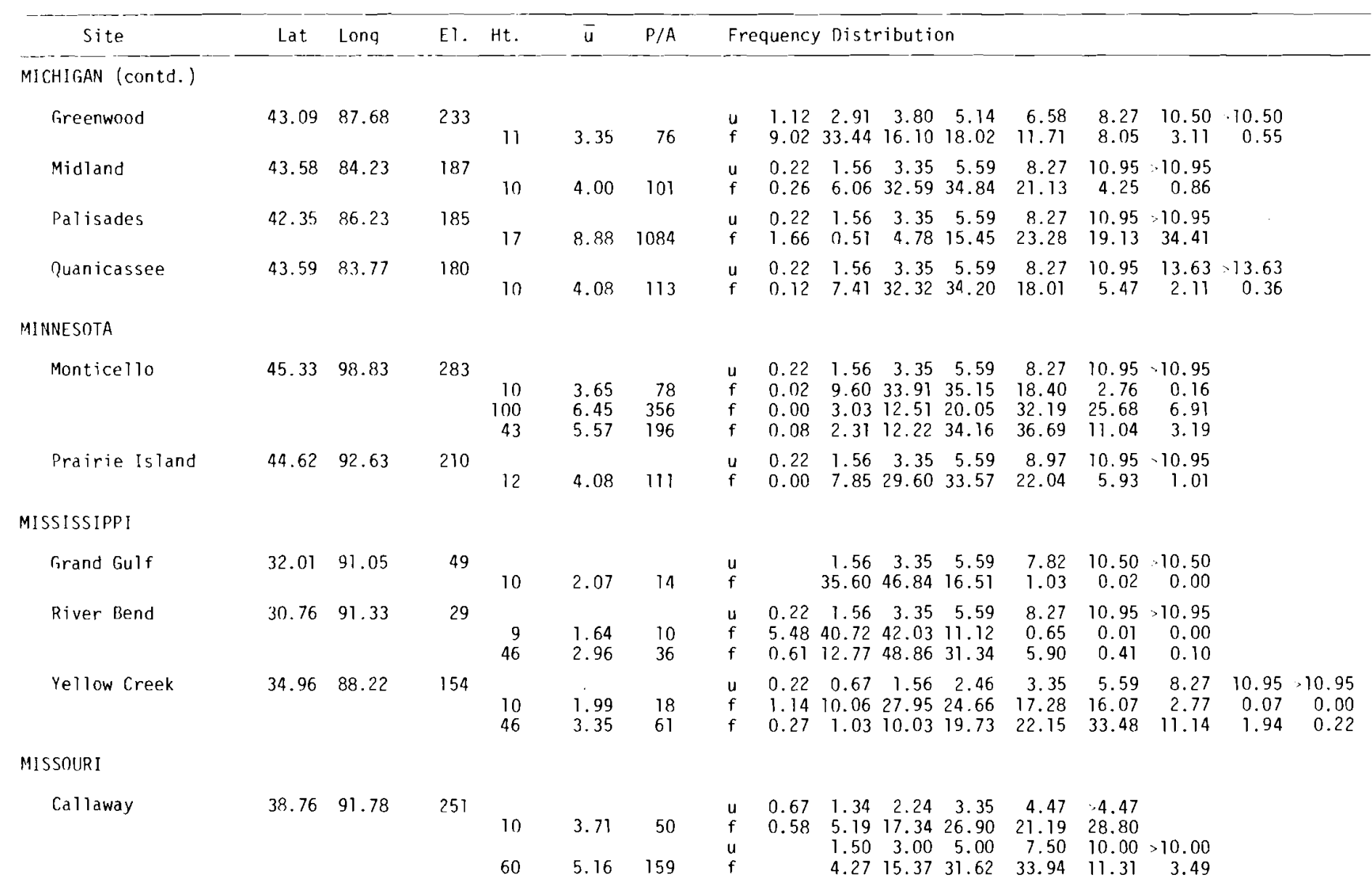




\begin{tabular}{|c|c|c|c|c|c|c|c|c|c|c|c|c|c|c|c|}
\hline Site & Lat & Long & E1. & Ht. & $\bar{u}$ & $P / A$ & \multicolumn{5}{|c|}{ Frequency Distribution } & & & & \\
\hline \multicolumn{14}{|l|}{ NEBRASKA } & & \\
\hline Cooper & 40.33 & 95.63 & 270 & 97 & 6.15 & 289 & $\stackrel{u}{f}$ & $\begin{array}{l}0.22 \\
0.03\end{array}$ & $\begin{array}{l}1.56 \\
1.42\end{array}$ & $\begin{array}{r}3.35 \\
12.23\end{array}$ & $\begin{array}{lr}5 & 5.59 \\
3 & 27.67\end{array}$ & $\begin{array}{r}8.27 \\
34.87\end{array}$ & $\begin{array}{l}10.95 \\
15.18\end{array}$ & $\begin{array}{r}>70.95 \\
8.56\end{array}$ & \\
\hline Fort Calhoun & 41.52 & 96.08 & 300 & 11 & 4.04 & 172 & u & & $\begin{array}{r}1.40 \\
12.88\end{array}$ & $\begin{array}{r}2.90 \\
22.58\end{array}$ & $\begin{array}{rr}0 & 4.40 \\
8 & 16.71\end{array}$ & $\begin{array}{r}5.90 \\
19.04\end{array}$ & $\begin{array}{r}8.90 \\
19.72\end{array}$ & $\begin{array}{r}>8.90 \\
9.07\end{array}$ & \\
\hline \multicolumn{16}{|l|}{ NEW HAMPSHIRE } \\
\hline Seabrook & 42.90 & 70.85 & 3 & 9 & 2.25 & 44 & $\stackrel{u}{f}$ & & $\begin{array}{r}1.50 \\
31.60\end{array}$ & $\begin{array}{r}4.00 \\
48.30\end{array}$ & $\begin{array}{lr}0 & 6.00 \\
0 & 13.40\end{array}$ & $\begin{array}{l}8.00 \\
4.60\end{array}$ & $\begin{array}{r}>8.00 \\
2.10\end{array}$ & & \\
\hline \multicolumn{16}{|l|}{ NEW JERSEY } \\
\hline Atlantic & 38.47 & 74.26 & 0 & 11 & 5.75 & 266 & $\begin{array}{l}u \\
f\end{array}$ & $\begin{array}{l}0.40 \\
0.10\end{array}$ & $\begin{array}{l}1.56 \\
1.90\end{array}$ & $\begin{array}{r}3.35 \\
14.60\end{array}$ & $\begin{array}{rr}5 & 5.59 \\
0 & 34.30\end{array}$ & $\begin{array}{r}8.27 \\
29.30\end{array}$ & $\begin{array}{l}10.73 \\
12.50\end{array}$ & $\begin{array}{r}>10.73 \\
7.30\end{array}$ & \\
\hline $\begin{array}{l}\text { Forked River } \\
\text { Oyster Creek }\end{array}$ & 39.81 & 74.21 & 3 & 23 & 3.39 & 96 & $\mathrm{u}$ & & $\begin{array}{r}1.56 \\
13.54\end{array}$ & $\begin{array}{r}3.35 \\
35.89\end{array}$ & $\begin{array}{r}5.59 \\
9 \quad 32.40\end{array}$ & $\begin{array}{r}8.27 \\
13.52\end{array}$ & $\begin{array}{r}11.40 \\
4.09\end{array}$ & $\begin{array}{r}14.53 \\
0.49\end{array}$ & $\begin{array}{rr}18.10 & >18.10 \\
0.04 & 0.03\end{array}$ \\
\hline Hope Creek/Salem & 39.46 & 75.53 & 3 & $\begin{array}{r}9 \\
91\end{array}$ & $\begin{array}{l}3.35 \\
5.76\end{array}$ & $\begin{array}{r}66 \\
308\end{array}$ & $\begin{array}{l}u \\
f \\
f\end{array}$ & $\begin{array}{l}0.22 \\
0.28 \\
0.12\end{array}$ & $\begin{array}{r}1.56 \\
13.61 \\
4.71\end{array}$ & $\begin{array}{r}3.35 \\
40.50 \\
14.08\end{array}$ & $\begin{array}{rr}5 & 5.59 \\
0 & 31.39 \\
8 & 26.67\end{array}$ & $\begin{array}{r}8.27 \\
11.24 \\
30.26\end{array}$ & $\begin{array}{r}>8.27 \\
2.98 \\
24.17\end{array}$ & & \\
\hline \multicolumn{16}{|l|}{ NEW YORK } \\
\hline $\begin{array}{l}\text { James A. } \\
\text { Fitzpatrick/Nine } \\
\text { Mile Point }\end{array}$ & 43.47 & 76.50 & 80 & $\begin{array}{l}10 \\
62\end{array}$ & $\begin{array}{l}3.61 \\
7.08\end{array}$ & $\begin{array}{l}239 \\
640\end{array}$ & $\begin{array}{l}u \\
f \\
u \\
f\end{array}$ & $\begin{array}{l}0.22 \\
6.55 \\
0.22 \\
1.73\end{array}$ & $\begin{array}{r}1.56 \\
14.39 \\
1.80 \\
3.25\end{array}$ & $\begin{array}{r}3.35 \\
30.11 \\
3.86 \\
13.99\end{array}$ & $\begin{array}{rr}5 & 5.59 \\
1 & 19.20 \\
6 & 6.43 \\
9 & 25.27\end{array}$ & $\begin{array}{r}8.27 \\
14.97 \\
9.52 \\
28.76\end{array}$ & $\begin{array}{r}10.95 \\
7.15 \\
12.61 \\
12.67\end{array}$ & $\begin{array}{r}>10.95 \\
7.63 \\
>12.61 \\
14.33\end{array}$ & \\
\hline Q.E. Ginna & 43.28 & 77.31 & 84 & $\begin{array}{l}15 \\
10\end{array}$ & $\begin{array}{l}3.61 \\
4.71\end{array}$ & $\begin{array}{l}100 \\
179\end{array}$ & $\begin{array}{l}u \\
f \\
u \\
f\end{array}$ & $\begin{array}{l}0.22 \\
1.87 \\
0.67 \\
0.13\end{array}$ & $\begin{array}{r}1.56 \\
10.13 \\
0.89 \\
1.50\end{array}$ & $\begin{array}{r}3.35 \\
33.61 \\
1.56 \\
5.97\end{array}$ & $\begin{array}{rr}5 & 5.59 \\
1 & 31.41 \\
6 & 3.35 \\
7 & 27.98\end{array}$ & $\begin{array}{r}>5.59 \\
22.98 \\
5.59 \\
31.39\end{array}$ & $\begin{array}{r}8.27 \\
20.52\end{array}$ & $\begin{array}{r}10.95 \\
8.44\end{array}$ & $\begin{array}{r}>10.95 \\
4.07\end{array}$ \\
\hline Greene & 42.15 & 73.91 & 9 & $\begin{array}{l}10 \\
60\end{array}$ & $\begin{array}{l}2.56 \\
4.12\end{array}$ & $\begin{array}{r}33 \\
135\end{array}$ & $\begin{array}{l}u \\
f \\
f\end{array}$ & $\begin{array}{l}0.22 \\
1.20 \\
0.47\end{array}$ & $\begin{array}{r}1.56 \\
23.18 \\
12.22\end{array}$ & $\begin{array}{r}3.35 \\
41.37 \\
28.17\end{array}$ & $\begin{array}{rr}5 & 5.59 \\
7 & 27.71 \\
7 & 27.75\end{array}$ & $\begin{array}{r}8.27 \\
6.15 \\
22.17\end{array}$ & $\begin{array}{r}10.95 \\
0.39 \\
7.35\end{array}$ & $\begin{array}{r}>10.95 \\
0.00 \\
1.89\end{array}$ & \\
\hline
\end{tabular}




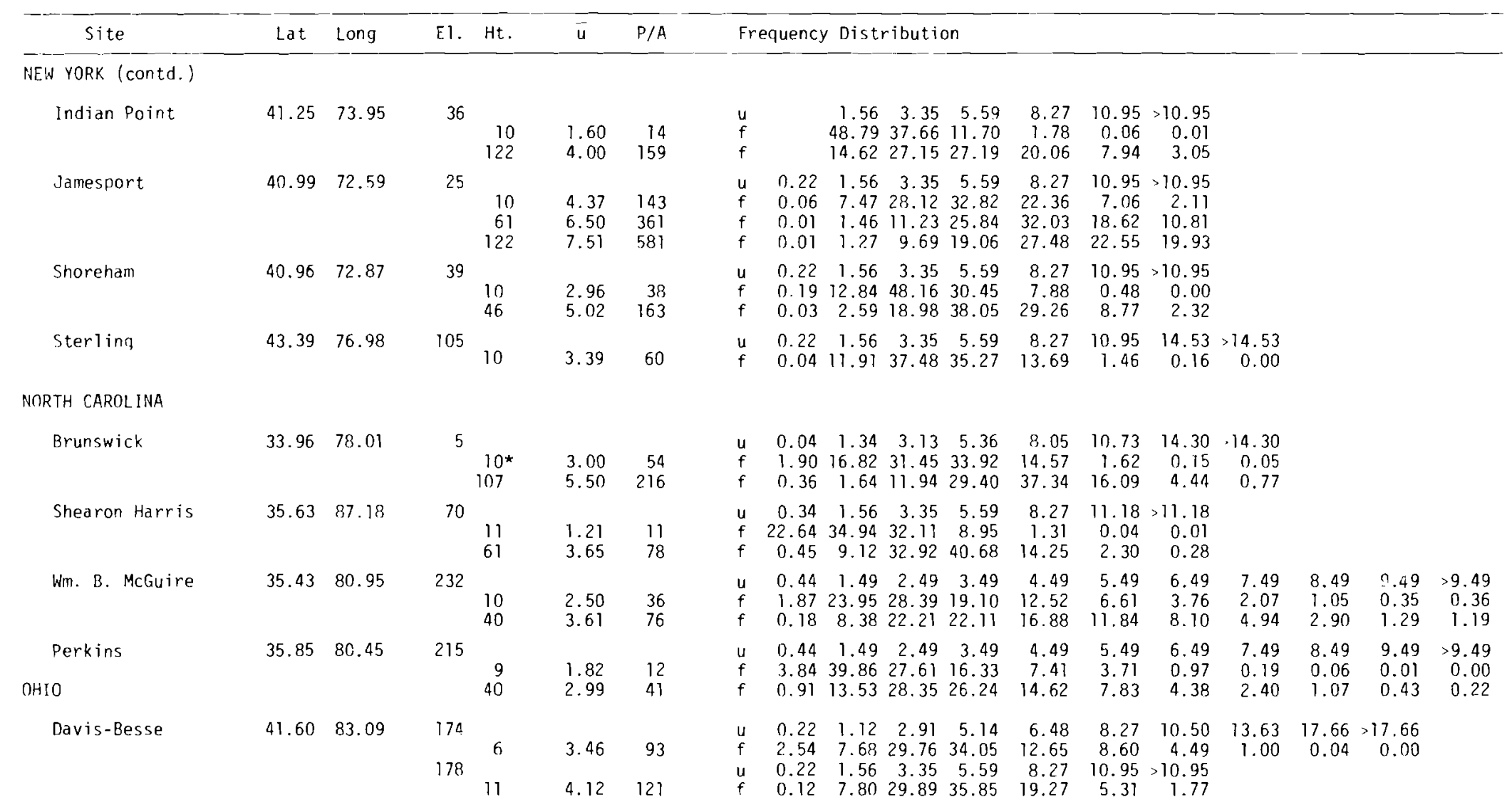




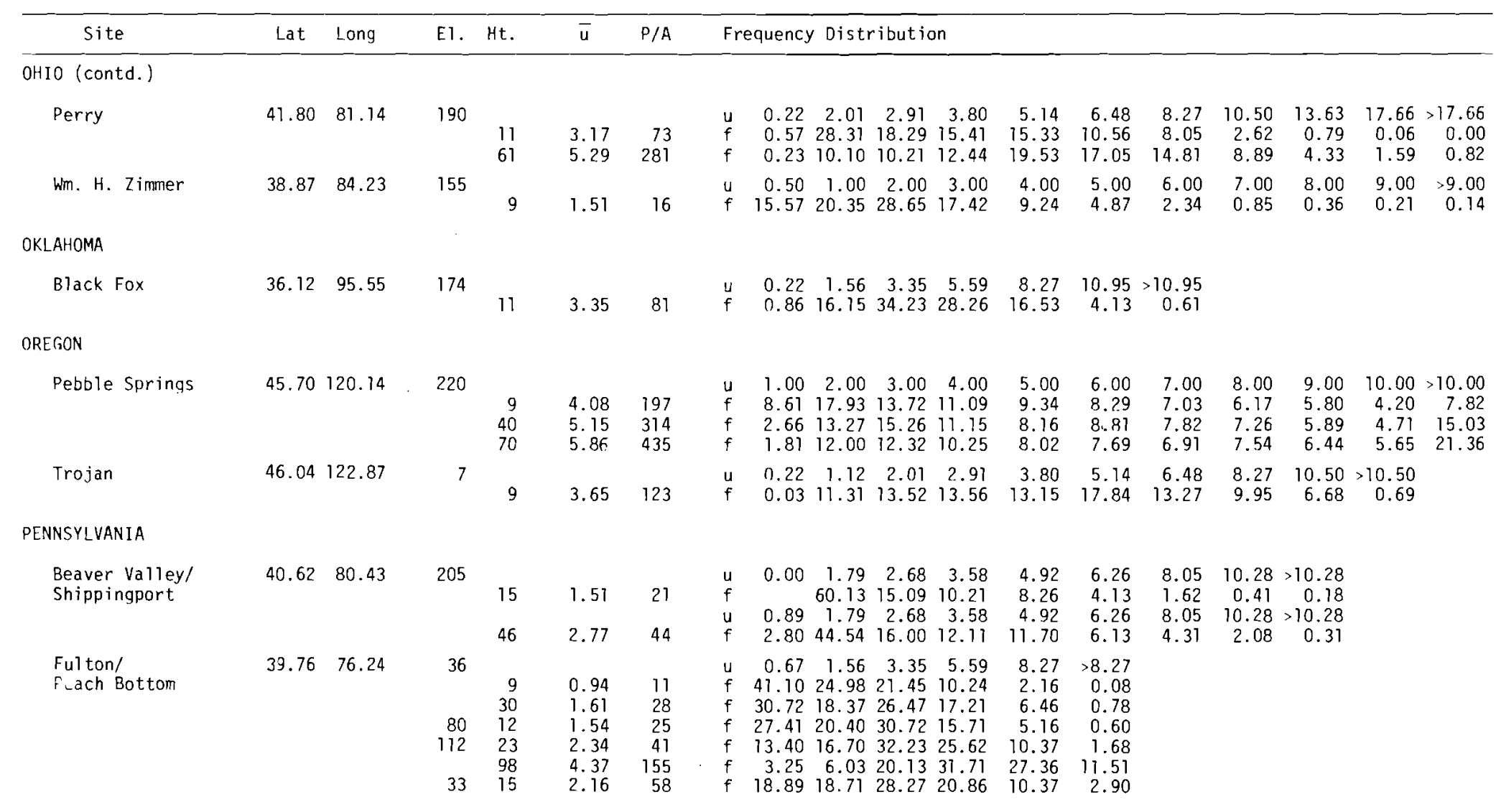




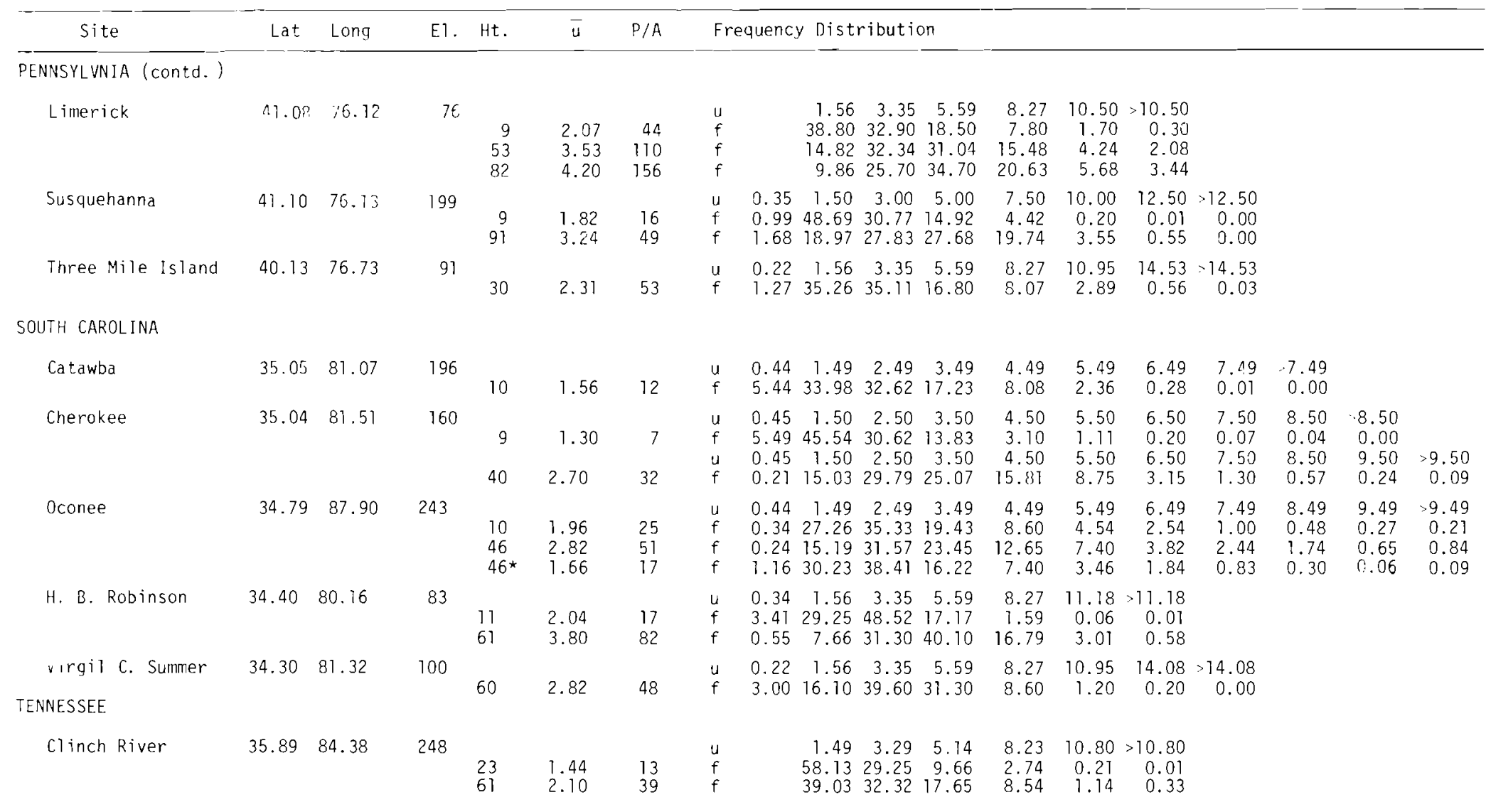




\begin{tabular}{|c|c|c|c|c|c|c|c|c|c|c|c|c|c|c|c|c|}
\hline Site & Lat & Long & $\mathrm{E} 1$ & $\mathrm{Ht}$. & $\vec{u}$ & $P / A$ & \multicolumn{10}{|c|}{ Frequency Distribution } \\
\hline Hartsville & 36.35 & 78.95 & 165 & 10 & 2.19 & 30 & $\begin{array}{l}u \\
f\end{array}$ & $\begin{array}{l}0.22 \\
1.88\end{array}$ & $\begin{array}{r}1.52 \\
37.71\end{array}$ & $\begin{array}{r}3.31 \\
35.36\end{array}$ & $\begin{array}{r}5.54 \\
17.63\end{array}$ & $\begin{array}{l}8.22 \\
6.21\end{array}$ & $\begin{array}{r}10.91 \\
1.18\end{array}$ & $\begin{array}{r}>10.91 \\
0.04\end{array}$ & & \\
\hline Phipps Bend & 36.46 & 82.81 & 362 & $\begin{array}{l}10 \\
46\end{array}$ & $\begin{array}{l}1.49 \\
2.40\end{array}$ & $\begin{array}{l}11 \\
37\end{array}$ & $\begin{array}{l}u \\
f \\
f\end{array}$ & $\begin{array}{l}0.22 \\
5.82 \\
1.21\end{array}$ & $\begin{array}{r}0.67 \\
13.76 \\
8.25\end{array}$ & $\begin{array}{r}1.56 \\
36.13 \\
31.27\end{array}$ & $\begin{array}{r}2.46 \\
21.41 \\
22.09\end{array}$ & $\begin{array}{r}3.35 \\
11.61 \\
12.94\end{array}$ & $\begin{array}{r}5.59 \\
10.08 \\
17.82\end{array}$ & $\begin{array}{l}8.27 \\
1.15 \\
5.33\end{array}$ & $\begin{array}{r}11.85 \\
0.08 \\
0.94\end{array}$ & $\begin{array}{r}>11.85 \\
0.00 \\
0.18\end{array}$ \\
\hline Watts Bar & 35.63 & 84.79 & 220 & $\begin{array}{l}10 \\
40 \\
10 \\
91\end{array}$ & $\begin{array}{l}1.37 \\
1.78 \\
1.69 \\
3.28\end{array}$ & $\begin{array}{r}8 \\
27 \\
22 \\
77\end{array}$ & $\begin{array}{l}u \\
f \\
u \\
f \\
u \\
f \\
f\end{array}$ & $\begin{array}{r}0.22 \\
11.64 \\
0.22 \\
7.91 \\
0.22 \\
0.38 \\
0.04\end{array}$ & $\begin{array}{r}1.56 \\
49.72 \\
1.56 \\
35.97 \\
0.67 \\
14.72 \\
1.66\end{array}$ & $\begin{array}{r}3.35 \\
29.65 \\
3.35 \\
34.23 \\
1.56 \\
32.59 \\
15.31\end{array}$ & $\begin{array}{r}5.59 \\
8.17 \\
5.59 \\
17.68 \\
2.46 \\
19.33 \\
19.94\end{array}$ & $\begin{array}{r}8.27 \\
0.81 \\
8.27 \\
3.48 \\
3.35 \\
13.41 \\
16.39\end{array}$ & $\begin{array}{r}>8.27 \\
0.00 \\
10.95 \\
0.62 \\
5.59 \\
15.81 \\
28.51\end{array}$ & $\begin{array}{r} \\
>10.95 \\
0.08 \\
8.27 \\
3.33 \\
13.85\end{array}$ & $\begin{array}{r}10.95 \\
0.35 \\
3.55\end{array}$ & $\begin{array}{r}>10.95 \\
0.03 \\
0.75\end{array}$ \\
\hline Blue Hills & 31.14 & 93.69 & 82 & $\begin{array}{l}10 \\
55\end{array}$ & $\begin{array}{l}2.01 \\
3.84\end{array}$ & $\begin{array}{l}18 \\
75\end{array}$ & $\begin{array}{l}u \\
f \\
f\end{array}$ & $\begin{array}{l}0.25 \\
0.19 \\
0.01\end{array}$ & $\begin{array}{r}1.50 \\
34.43 \\
5.72\end{array}$ & $\begin{array}{r}3.00 \\
40.60 \\
26.66\end{array}$ & $\begin{array}{r}5.00 \\
21.51 \\
40.99\end{array}$ & $\begin{array}{r}8.00 \\
3.25 \\
23.85\end{array}$ & $\begin{array}{r}10.00 \\
0.04 \\
2.08\end{array}$ & $\begin{array}{r}>10.00 \\
0.00 \\
0.68\end{array}$ & & \\
\hline Comanche Peak & 32.30 & 97.79 & 250 & 9 & 3.46 & 65 & $\begin{array}{l}u \\
f\end{array}$ & $\begin{array}{l}0.50 \\
2.81\end{array}$ & $\begin{array}{r}1.50 \\
12.70\end{array}$ & $\begin{array}{r}3.00 \\
32.52\end{array}$ & $\begin{array}{r}5.00 \\
31.82\end{array}$ & $\begin{array}{r}7.50 \\
15.69\end{array}$ & $\begin{array}{r}10.00 \\
3.87\end{array}$ & $\begin{array}{r}>10.00 \\
0.59\end{array}$ & & \\
\hline South Texas & 28.80 & 96.05 & 7 & $\begin{array}{l}10 \\
60\end{array}$ & $\begin{array}{l}4.41 \\
6.66\end{array}$ & $\begin{array}{l}146 \\
358\end{array}$ & $\begin{array}{l}u \\
f \\
f\end{array}$ & $\begin{array}{l}0.22 \\
1.04 \\
0.08\end{array}$ & $\begin{array}{l}1.56 \\
5.92 \\
1.68\end{array}$ & $\begin{array}{r}3.35 \\
27.43 \\
7.94\end{array}$ & $\begin{array}{r}5.59 \\
31.54 \\
+23.08\end{array}$ & $\begin{array}{r}8.27 \\
23.79 \\
37.69\end{array}$ & $\begin{array}{r}10.95 \\
8.04 \\
20.16\end{array}$ & $\begin{array}{r}>10.95 \\
2.22 \\
9.38\end{array}$ & & \\
\hline \multicolumn{17}{|l|}{ VERMONT } \\
\hline Vermont Yankee & 42.78 & 72.52 & 84 & 43 & 2.66 & 89 & $\begin{array}{l}u \\
f\end{array}$ & $\begin{array}{l}0.22 \\
4.98\end{array}$ & $\begin{array}{r}1.56 \\
26.76\end{array}$ & $\begin{array}{r}3.35 \\
28.09\end{array}$ & $\begin{array}{r}5.59 \\
20.88\end{array}$ & $\begin{array}{r}8.27 \\
13.52\end{array}$ & $\begin{array}{r}>8.27 \\
5.28\end{array}$ & & & \\
\hline
\end{tabular}




\begin{tabular}{|c|c|c|c|c|c|c|c|c|c|c|c|c|c|c|c|c|c|}
\hline Site & Lat & Long & El. & Ht. & $\bar{u}$ & $P / A$ & \multicolumn{11}{|c|}{ Frequency Distribution } \\
\hline \multicolumn{18}{|l|}{ VIRGINIA } \\
\hline North Anna & 38.06 & 77.79 & 81 & $\begin{array}{l}11 \\
46\end{array}$ & $\begin{array}{l}3.06 \\
2.79\end{array}$ & $\begin{array}{l}71 \\
43\end{array}$ & $\begin{array}{l}u \\
f \\
f\end{array}$ & $\begin{array}{l}0.22 \\
0.82 \\
2.12\end{array}$ & $\begin{array}{r}2.01 \\
29.72 \\
29.35\end{array}$ & $\begin{array}{r}3.80 \\
31.98 \\
37.83\end{array}$ & $\begin{array}{r}5.14 \\
18.39 \\
18.45\end{array}$ & $\begin{array}{l}6.48 \\
9.43 \\
7.31\end{array}$ & $\begin{array}{l}8.27 \\
6.16 \\
3.71\end{array}$ & $\begin{array}{r}10.50 \\
2.72 \\
1.10\end{array}$ & $\begin{array}{r}r 0.50 \\
0.78 \\
0.12\end{array}$ & & \\
\hline Surry & 37.17 & 76.70 & $\begin{array}{l}1 \\
8\end{array}$ & $\begin{array}{r}6 \\
46\end{array}$ & $\begin{array}{l}2.53 \\
3.31\end{array}$ & $\begin{array}{l}39 \\
61\end{array}$ & $\begin{array}{l}u \\
f \\
f\end{array}$ & $\begin{array}{l}0.22 \\
3.52 \\
0.73\end{array}$ & $\begin{array}{r}1.12 \\
14.25 \\
4.66\end{array}$ & $\begin{array}{r}2.01 \\
19.54 \\
13.07\end{array}$ & $\begin{array}{r}2.91 \\
19.78 \\
21.73\end{array}$ & $\begin{array}{r}3.80 \\
19.13 \\
26.14\end{array}$ & $\begin{array}{r}5.14 \\
14.36 \\
18.93\end{array}$ & $\begin{array}{l}6.48 \\
5.91 \\
8.15\end{array}$ & $\begin{array}{l}8.27 \\
2.42 \\
4.59\end{array}$ & $\begin{array}{r}10.50 \\
0.64 \\
1.52\end{array}$ & $\begin{array}{r}>10.50 \\
0.44 \\
0.48\end{array}$ \\
\hline \multicolumn{18}{|l|}{ WASHINGTON } \\
\hline Skagit & 48.53 & 122.09 & 128 & $\begin{array}{l}10 \\
60\end{array}$ & $\begin{array}{l}2.50 \\
3.80\end{array}$ & $\begin{array}{r}25 \\
118\end{array}$ & $\begin{array}{l}u \\
f \\
f\end{array}$ & $\begin{array}{l}0.22 \\
0.26 \\
0.05\end{array}$ & $\begin{array}{r}1.56 \\
29.89 \\
14.78\end{array}$ & $\begin{array}{r}3.35 \\
36.30 \\
26.65\end{array}$ & $\begin{array}{r}5.59 \\
28.31 \\
32.13\end{array}$ & $\begin{array}{r}8.29 \\
5.16 \\
18.56\end{array}$ & $\begin{array}{r}10.50 \\
0.07 \\
5.87\end{array}$ & $\begin{array}{r}>10.50 \\
0.07 \\
1.97\end{array}$ & & & \\
\hline WPPSS - Hanford & 46.47 & 119.32 & 134 & $\begin{array}{r}2 \\
10 \\
75\end{array}$ & $\begin{array}{l}1.99 \\
2.89 \\
4.28\end{array}$ & $\begin{array}{r}37 \\
83 \\
197\end{array}$ & $\begin{array}{l}u \\
f \\
f \\
f\end{array}$ & $\begin{array}{l}0.22 \\
0.00 \\
0.01 \\
0.00\end{array}$ & $\begin{array}{r}1.56 \\
38.70 \\
22.49 \\
11.15\end{array}$ & $\begin{array}{r}3.35 \\
36.09 \\
39.37 \\
30.68\end{array}$ & $\begin{array}{r}5.59 \\
17.30 \\
23.11 \\
26.04\end{array}$ & $\begin{array}{r}8.27 \\
6.30 \\
10.29 \\
18.07\end{array}$ & $\begin{array}{r}10.95 \\
1.48 \\
3.43 \\
8.59\end{array}$ & $\begin{array}{r}>10.95 \\
0.13 \\
1.31 \\
5.47\end{array}$ & & & \\
\hline HMS & & & 223 & $\begin{array}{r}15 \\
61 \\
122\end{array}$ & $\begin{array}{l}2.92 \\
3.88 \\
4.24\end{array}$ & $\begin{array}{r}80 \\
198 \\
301\end{array}$ & $\begin{array}{l}u \\
f \\
f \\
f\end{array}$ & $\begin{array}{l}0.22 \\
0.22 \\
1.50 \\
2.20\end{array}$ & $\begin{array}{r}1.56 \\
23.20 \\
17.60 \\
16.10\end{array}$ & $\begin{array}{r}3.35 \\
33.40 \\
25.30 \\
22.90\end{array}$ & $\begin{array}{r}5.59 \\
23.80 \\
22.90 \\
20.80\end{array}$ & $\begin{array}{r}8.27 \\
11.50 \\
19.10 \\
19.10\end{array}$ & $\begin{array}{r}10.95 \\
4.20 \\
8.50 \\
10.30\end{array}$ & $\begin{array}{r}14.08 \\
1.20 \\
3.90 \\
5.80\end{array}$ & $\begin{array}{r}17.21 \\
0.20 \\
0.80 \\
2.20\end{array}$ & $\begin{array}{r}20.79 \\
0.10 \\
0.30 \\
0.50\end{array}$ & $\begin{array}{r}>20.79 \\
0.00 \\
0.10 \\
0.10\end{array}$ \\
\hline WPPSS - Satsop & 45.96 & 123.47 & 90 & $\begin{array}{l}10 \\
60\end{array}$ & $\begin{array}{l}1.77 \\
3.17\end{array}$ & $\begin{array}{l}14 \\
59\end{array}$ & $\begin{array}{l}u \\
f \\
f\end{array}$ & $\begin{array}{l}0.31 \\
9.88 \\
3.38\end{array}$ & $\begin{array}{r}1.34 \\
25.49 \\
12.16\end{array}$ & $\begin{array}{r}3.13 \\
46.77 \\
31.76\end{array}$ & $\begin{array}{r}5.36 \\
16.26 \\
37.18\end{array}$ & $\begin{array}{r}8.05 \\
1.46 \\
13.48\end{array}$ & $\begin{array}{r}10.73 \\
0.15 \\
1.68\end{array}$ & $\begin{array}{r}14.30 \\
0.00 \\
0.36\end{array}$ & $\begin{array}{r}14.30 \\
0.00 \\
0.00\end{array}$ & & \\
\hline \multicolumn{18}{|l|}{ WISCONSIN } \\
\hline Ke:launee & 44.34 & 87.54 & 194 & 46 & 5.29 & 228 & $\begin{array}{l}u \\
f\end{array}$ & $\begin{array}{l}0.22 \\
0.86\end{array}$ & $\begin{array}{l}2.01 \\
7.85\end{array}$ & $\begin{array}{r}3.80 \\
20.02\end{array}$ & $\begin{array}{r}6.48 \\
35.32\end{array}$ & $\begin{array}{r}8.27 \\
20.42\end{array}$ & $\begin{array}{l}10.50 \\
10.25\end{array}$ & $\begin{array}{r}>10.50 \\
5.28\end{array}$ & & & \\
\hline Koshkonong & 42.86 & 88.89 & 260 & $\begin{array}{l}10 \\
60\end{array}$ & $\begin{array}{l}3.72 \\
5.62\end{array}$ & $\begin{array}{r}84 \\
273\end{array}$ & $\begin{array}{l}u \\
f \\
f\end{array}$ & $\begin{array}{l}0.22 \\
0.84 \\
0.12\end{array}$ & $\begin{array}{r}1.56 \\
10.16 \\
2.28\end{array}$ & $\begin{array}{r}3.35 \\
30.99 \\
12.23\end{array}$ & $\begin{array}{r}5.59 \\
36.21 \\
34.92\end{array}$ & $\begin{array}{r}8.27 \\
18.26 \\
35.10\end{array}$ & $\begin{array}{r}10.95 \\
3.09 \\
12.05\end{array}$ & $\begin{array}{r}>10.95 \\
0.44 \\
3.30\end{array}$ & & & \\
\hline La Crosse & 45.34 & 91.21 & 366 & 30 & 4.41 & 123 & $\begin{array}{l}u \\
f\end{array}$ & $\begin{array}{l}0.22 \\
0.08\end{array}$ & $\begin{array}{l}1.56 \\
6.38\end{array}$ & $\begin{array}{r}3.35 \\
24.15\end{array}$ & $\begin{array}{r}5.59 \\
39.77\end{array}$ & $\begin{array}{r}8.37 \\
22.29\end{array}$ & $\begin{array}{r}10.95 \\
5.68\end{array}$ & $\begin{array}{r}>10.95 \\
1.64\end{array}$ & & & \\
\hline
\end{tabular}




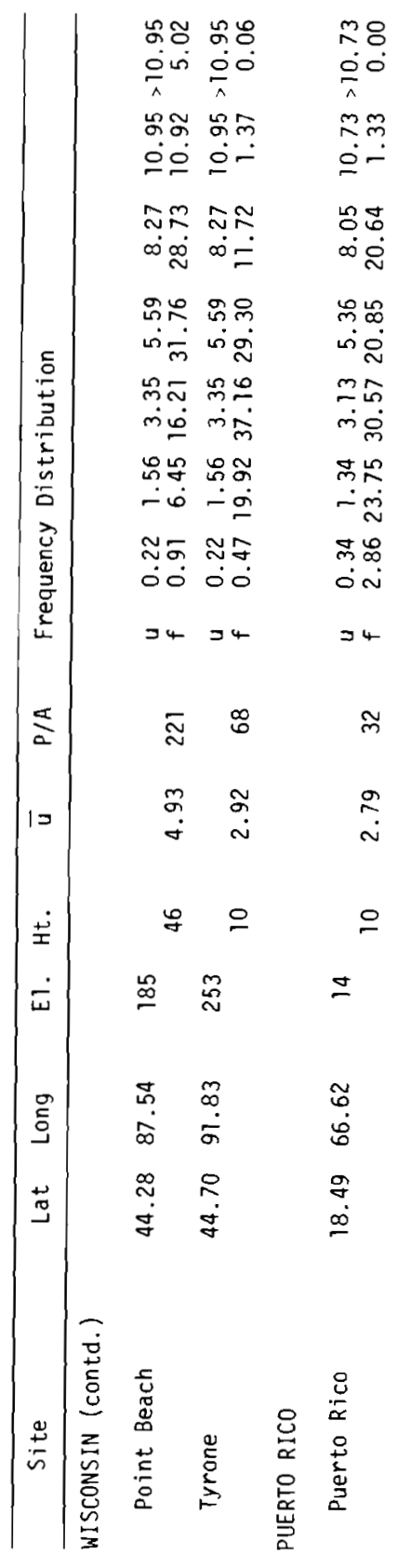

$A-13$ 

APPENDIX B

\author{
Alphabetical Tabulation \\ of \\ Nuclear Power Plant Sites \\ and \\ Selected wind Energy Related Sites
}

Legend

El. (Base Elevation, MSL) . . . . . . . . . . . . m

Ht. (Sensor Height, AGL). . . . . . . . . . . . . m

$\overline{\mathrm{u}}$ (Mean Wind Speed). . . . . . . . . . . . . . . . m/s

$\mathrm{P} / \mathrm{A}$ (Power per Unit Area). . . . . . . . . . . . . . $\mathrm{W} / \mathrm{m}^{2}$ Frequency Distribution

u (Categorical Upper Limit of Wind Speed) . . . . . m/s

f (Categorical Frequency) . . . . . . . . . . . 



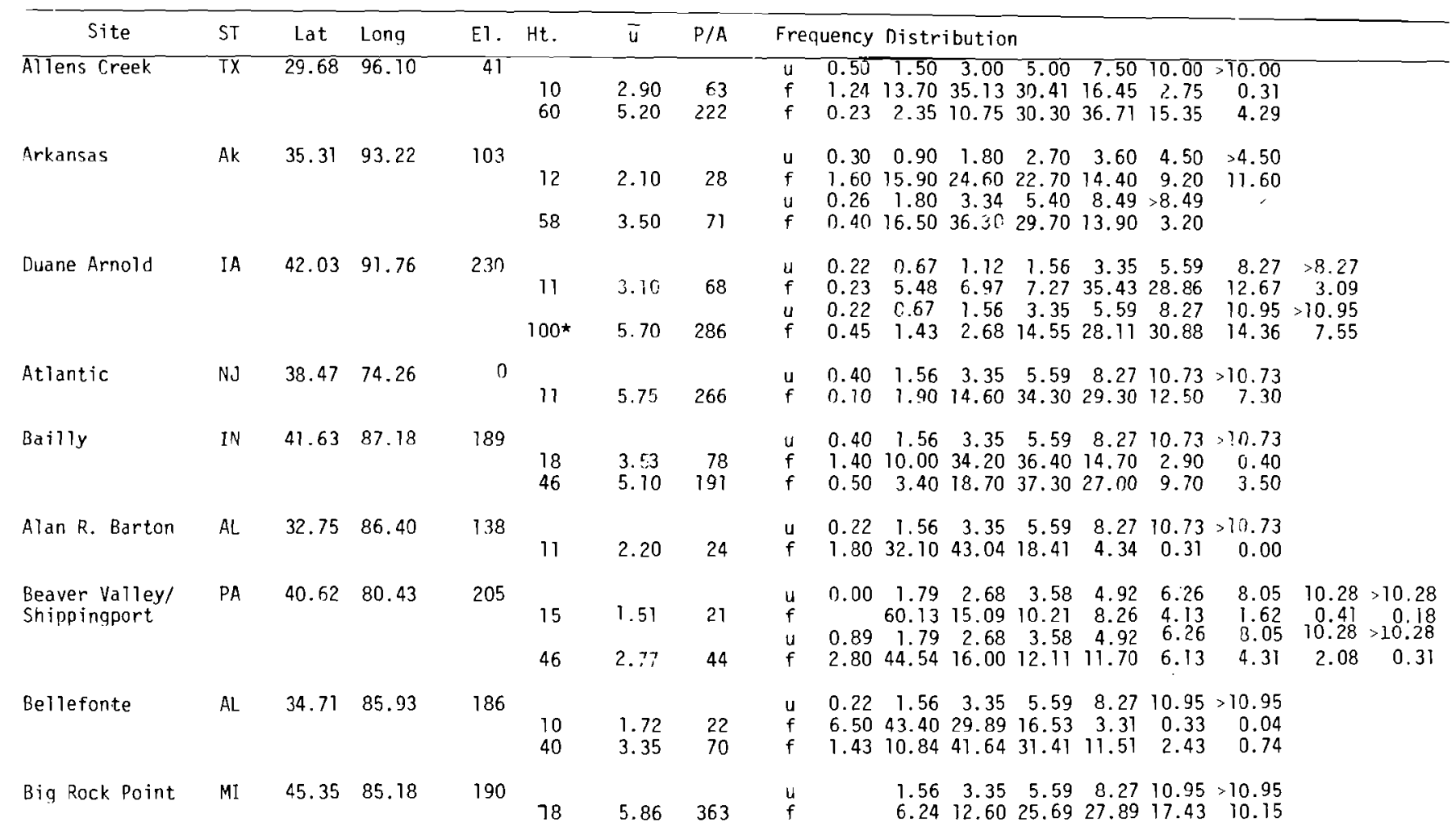




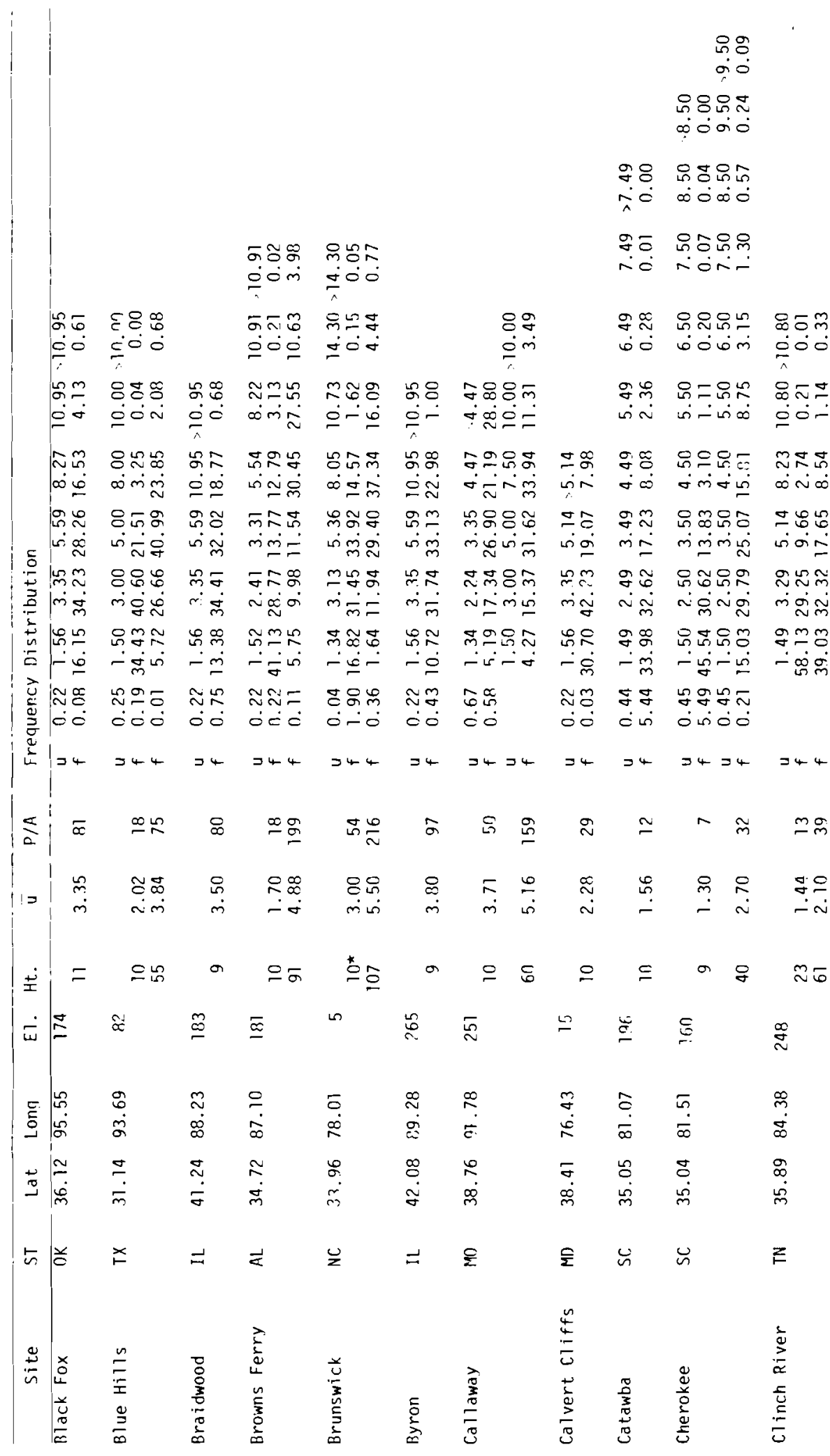




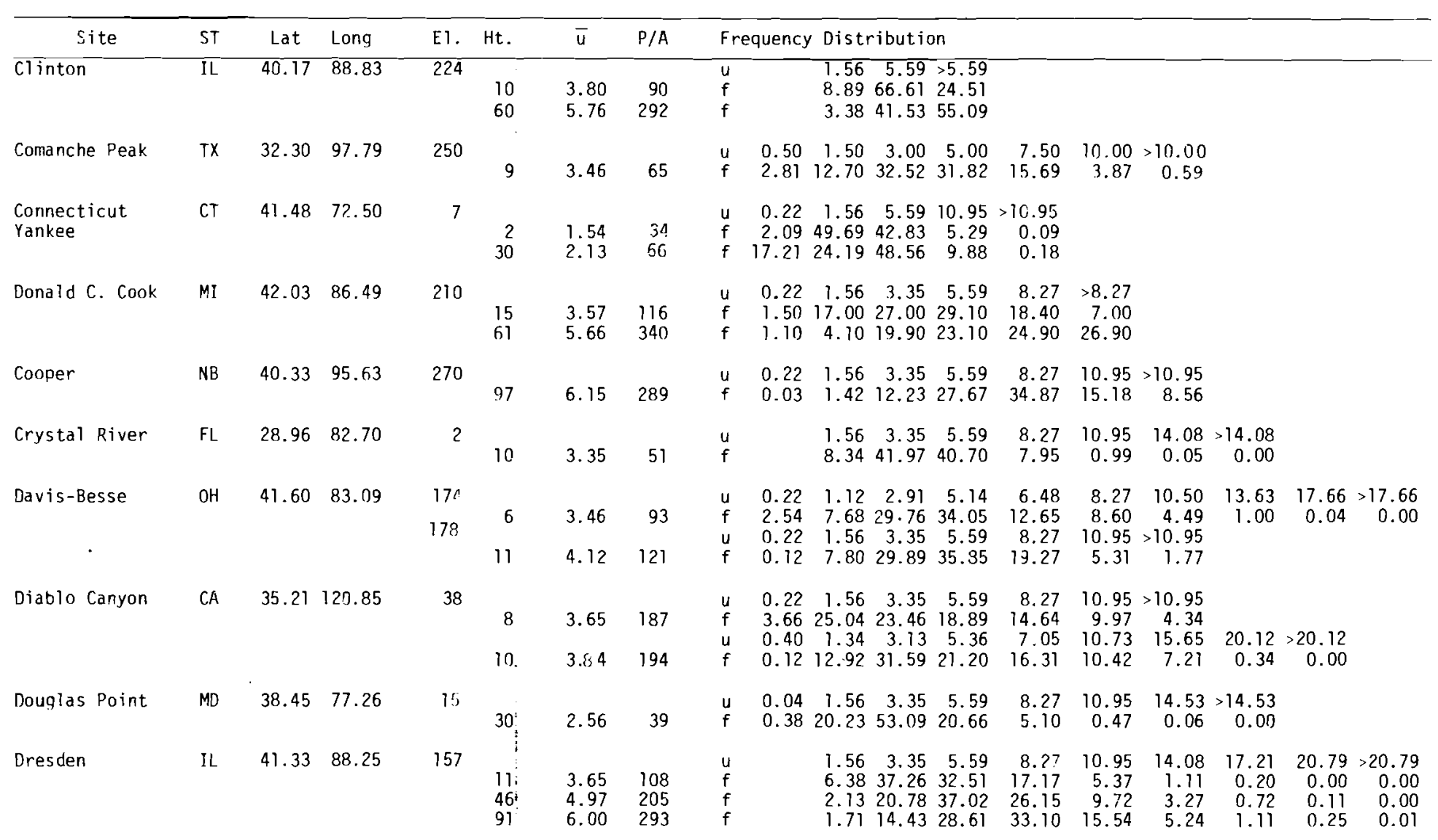




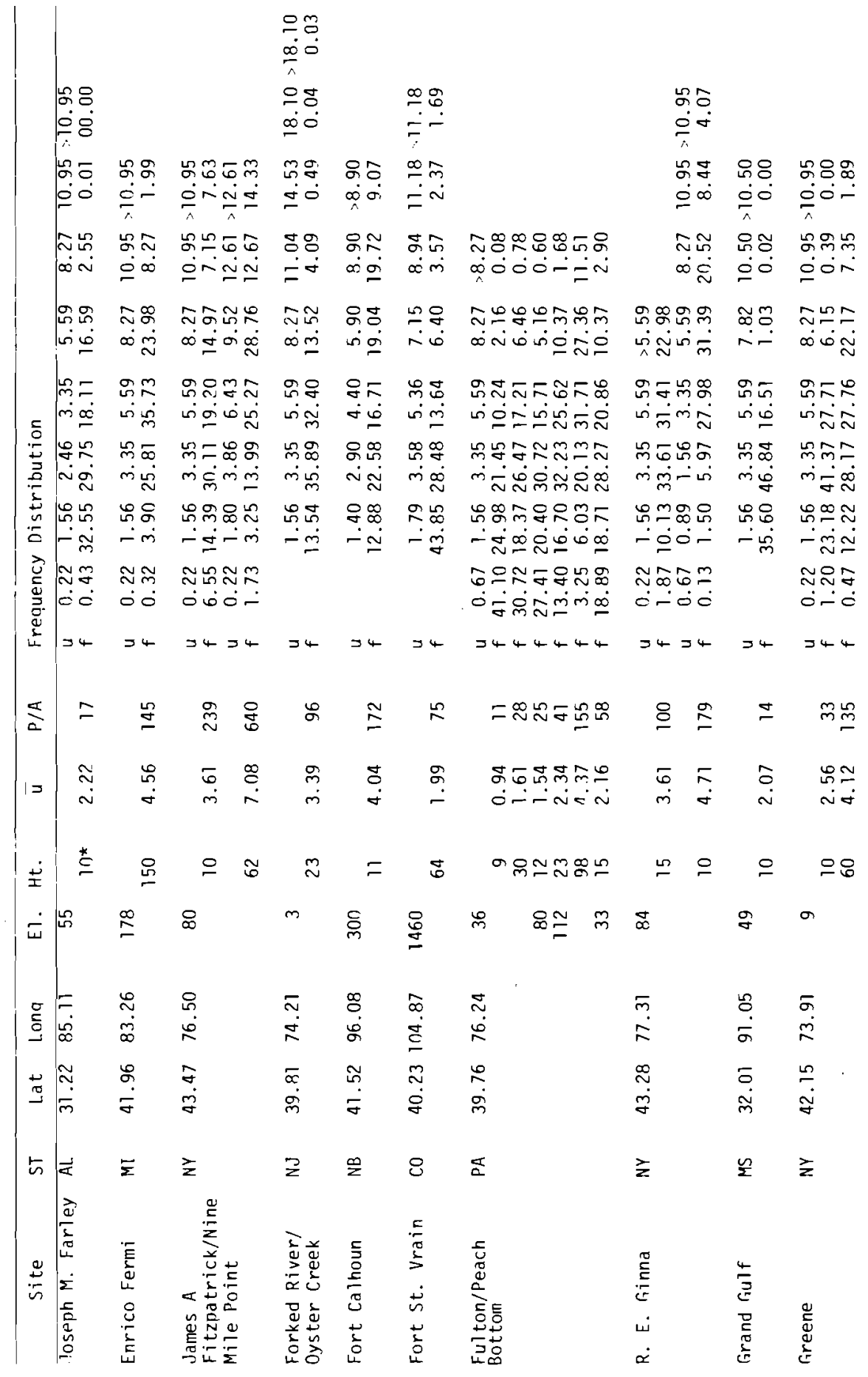




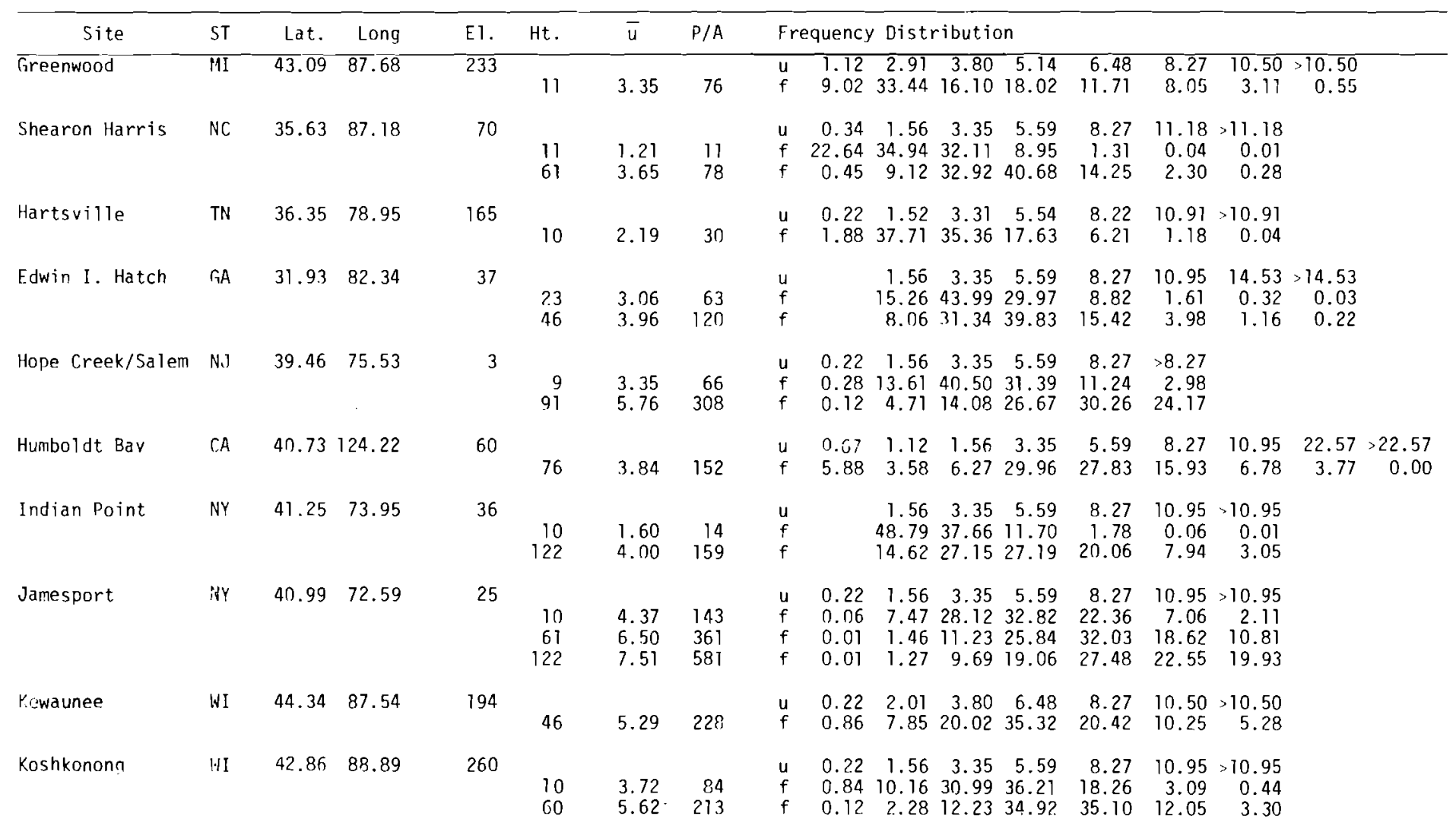




\begin{tabular}{|c|c|c|c|c|c|c|c|c|c|c|c|c|c|c|c|c|c|}
\hline Site & ST & Lat & Long & El. & $\mathrm{Ht}$ & $\bar{u}$ & $P / A$ & & equency & y Distribution & & & & & & & \\
\hline La Crosse & $W^{-}$ & $45 . \overline{34}$ & 91.21 & 366 & 30 & 4.41 & 123 & $\begin{array}{l}u \\
f\end{array}$ & $\begin{array}{l}\overline{0.22} \\
0.08\end{array}$ & $\begin{array}{rrr}1.56 & 3.35 & 5.59 \\
6.38 & 24.15 & 39.77\end{array}$ & $\begin{array}{r}8 . \overline{37} \\
22.29\end{array}$ & $\begin{array}{r}10.95 \\
5.68\end{array}$ & $\begin{array}{r}70.95 \\
1.64\end{array}$ & & & & \\
\hline Limerick & $P A$ & 41.08 & 76.12 & 76 & $\begin{array}{r}9 \\
53 \\
82\end{array}$ & $\begin{array}{l}2.07 \\
3.53 \\
4.20\end{array}$ & $\begin{array}{r}44 \\
110 \\
156\end{array}$ & $\begin{array}{l}u \\
f \\
f \\
f\end{array}$ & & $\begin{array}{rrr}1.56 & 3.35 & 5.59 \\
38.80 & 32.90 & 18.50 \\
14.82 & 32.34 & 31.04 \\
9.86 & 25.70 & 34.70\end{array}$ & $\begin{array}{r}8.27 \\
7.80 \\
15.48 \\
20.63\end{array}$ & $\begin{array}{r}10.50 \\
1.70 \\
4.24 \\
5.68\end{array}$ & $\begin{array}{r}>10.50 \\
0.30 \\
2.08 \\
3.44\end{array}$ & & & & \\
\hline Ma ine Yankee & ME & 43.95 & 69.70 & 14 & 45 & 3.61 & 111 & $\begin{array}{l}u \\
f\end{array}$ & $\begin{array}{l}0.22 \\
1.54\end{array}$ & $\begin{array}{rrr}1.56 & 3.35 & 5.59 \\
12.17 & 33.03 & 28.24\end{array}$ & $\begin{array}{r}8.27 \\
18.40\end{array}$ & $\begin{array}{r}8.27 \\
6.64\end{array}$ & & & & & \\
\hline Marble Hill & IN & 38.60 & 85.45 & 240 & 10 & 2.69 & 41 & $\mathrm{u}$ & $\begin{array}{l}0.25 \\
2.19\end{array}$ & $\begin{array}{rrr}1.50 & 3.00 & 5.00 \\
17.41 & 34.44 & 31.56\end{array}$ & $\begin{array}{r}8.00 \\
12.70\end{array}$ & $\begin{array}{r}10.00 \\
1.56\end{array}$ & $\begin{array}{r}70.00 \\
0.18\end{array}$ & & & & \\
\hline Wm. B. Mcfuire & NC. & 35.43 & 80.95 & 232 & $\begin{array}{l}10 \\
40\end{array}$ & $\begin{array}{l}2.50 \\
3.61\end{array}$ & $\begin{array}{l}36 \\
76\end{array}$ & $\begin{array}{l}u \\
f \\
f\end{array}$ & $\begin{array}{l}0.44 \\
1.87 \\
0.18\end{array}$ & $\begin{array}{rrr}1.49 & 2.49 & 3.49 \\
23.95 & 28.39 & 19.10 \\
8.38 & 22.21 & 22.11\end{array}$ & $\begin{array}{r}4.49 \\
12.52 \\
16.88\end{array}$ & $\begin{array}{r}5.49 \\
6.61 \\
11.84\end{array}$ & $\begin{array}{l}6.49 \\
3.76 \\
8.10\end{array}$ & $\begin{array}{l}7.49 \\
2.07 \\
4.94\end{array}$ & $\begin{array}{l}8.49 \\
1.05 \\
2.90\end{array}$ & $\begin{array}{l}9.49 \\
0.35 \\
1.29\end{array}$ & $\begin{array}{r}9.49 \\
0.36 \\
1.19\end{array}$ \\
\hline Midland & MI & 43.58 & 84.23 & 187 & 10 & 4.00 & 101 & $\begin{array}{l}u \\
f\end{array}$ & $\begin{array}{l}0.22 \\
0.26\end{array}$ & $\begin{array}{rrr}1.56 & 3.35 & 5.59 \\
6.06 & 32.59 & 34.84\end{array}$ & $\begin{array}{r}8.27 \\
21.13\end{array}$ & $\begin{array}{r}10.95 \\
4.25\end{array}$ & $\begin{array}{r}>10.95 \\
0.86\end{array}$ & & & & \\
\hline Millstone Point & $C T$ & 41.31 & 72.17 & $\begin{array}{l}0 \\
4\end{array}$ & $\begin{array}{r}10 \\
46 \\
10 \\
43 \\
114 \\
136\end{array}$ & $\begin{array}{l}2.86 \\
4.2 .8 \\
3.69 \\
4.93 \\
6.30 \\
6.66\end{array}$ & $\begin{array}{r}86 \\
200 \\
103 \\
196 \\
379 \\
422\end{array}$ & $\begin{array}{l}u \\
f \\
f \\
u \\
f \\
f \\
f \\
f\end{array}$ & $\begin{array}{l}0.22 \\
5.11 \\
2.08 \\
0.50 \\
1.33 \\
0.66 \\
0.10 \\
0.10\end{array}$ & $\begin{array}{rrr}1.56 & 3.35 & 5.59 \\
23.56 & 28.49 & 25.51 \\
10.65 & 23.11 & 30.02 \\
1.50 & 3.30 & 5.50 \\
11.48 & 30.24 & 33.38 \\
4.47 & 19.51 & 33.99 \\
2.31 & 10.36 & 25.40 \\
2.26 & 10.19 & 23.61\end{array}$ & $\begin{array}{r}8.27 \\
13.13 \\
19.90 \\
8.20 \\
16.81 \\
26.42 \\
32.90 \\
30.36\end{array}$ & $\begin{array}{r}10.95 \\
4.21 \\
14.24 \\
10.80 \\
5.26 \\
10.43 \\
18.46 \\
20.47\end{array}$ & $\begin{array}{r}>10.95 \\
0.00 \\
0.00 \\
15.00 \\
1.43 \\
3.95 \\
8.43 \\
10.42\end{array}$ & $\begin{array}{r}20.00 \\
0.07 \\
0.57 \\
1.84 \\
2.22\end{array}$ & $\begin{array}{r}20.00 \\
0.00 \\
0.01 \\
0.21 \\
0.37\end{array}$ & & \\
\hline Montaque & MA & 42.58 & 72.53 & 95 & $\begin{array}{r}10 \\
46 \\
99 \\
151\end{array}$ & $\begin{array}{l}1.17 \\
2.89 \\
3.84 \\
4.67\end{array}$ & $\begin{array}{r}10 \\
54 \\
124 \\
184\end{array}$ & $\begin{array}{l}u \\
f \\
f \\
f \\
f\end{array}$ & $\begin{array}{r}0.40 \\
79.53 \\
1.99 \\
2.11 \\
0.76\end{array}$ & $\begin{array}{rrr}1.50 & 3.30 & 5.50 \\
42.59 & 29.41 & 7.47 \\
18.89 & 36.42 & 30.00 \\
13.04 & 27.34 & 29.55 \\
8.11 & 22.98 & 28.78\end{array}$ & $\begin{array}{r}8.20 \\
0.92 \\
10.47 \\
19.89 \\
25.34\end{array}$ & $\begin{array}{r}10.80 \\
0.07 \\
2.07 \\
5.91 \\
9.88\end{array}$ & $\begin{array}{r}15.00 \\
0.00 \\
0.75 \\
2.04 \\
3.71\end{array}$ & $\begin{array}{l}20.00 \\
0.00 \\
0.17 \\
0.47\end{array}$ & $\begin{array}{l}20.00 \\
0.00 \\
0.01\end{array}$ & & \\
\hline Monticello & MN & 45.33 & 93.83 & 283 & $\begin{array}{r}10 \\
100 \\
43\end{array}$ & $\begin{array}{l}3.65 \\
6.45 \\
5.57\end{array}$ & $\begin{array}{r}78 \\
356 \\
196\end{array}$ & $\begin{array}{l}u \\
f \\
f \\
f\end{array}$ & $\begin{array}{l}0.22 \\
0.02 \\
0.00 \\
0.08\end{array}$ & $\begin{array}{rrr}1.56 & 3.35 & 5.59 \\
9.60 & 33.91 & 35.15 \\
3.03 & 12.15 & 20.05 \\
2.31 & 12.22 & 34.16\end{array}$ & $\begin{array}{r}8.27 \\
18.40 \\
32.19 \\
36.69\end{array}$ & $\begin{array}{r}10.95 \\
2.76 \\
25.58 \\
11.04\end{array}$ & $\begin{array}{r}>10.95 \\
0.76 \\
6.91 \\
3.19\end{array}$ & & & & \\
\hline
\end{tabular}




\begin{tabular}{|c|c|c|c|c|c|c|c|c|c|c|c|c|c|c|c|c|c|c|}
\hline Site & ST & Lat & Long & El. & $\mathrm{Ht}$. & $\bar{u}$ & $P / A$ & & quency & $y$ Dist & ribution & & & & & & & \\
\hline North Anna & VA & 38.06 & 77.79 & 81 & $\begin{array}{l}11 \\
46\end{array}$ & $\begin{array}{l}3.06 \\
2.79\end{array}$ & $\begin{array}{l}71 \\
43\end{array}$ & $\begin{array}{l}u \\
f \\
f\end{array}$ & $\begin{array}{l}0.22 \\
0.82 \\
2.12\end{array}$ & $\begin{array}{r}2.01 \\
29.72 \\
29.35\end{array}$ & $\begin{array}{rr}3.80 & 5.14 \\
31.98 & 18.39 \\
37.83 & 18.45\end{array}$ & $\begin{array}{l}6.48 \\
9.43 \\
7.31\end{array}$ & $\begin{array}{l}8.27 \\
6.16 \\
3.71\end{array}$ & $\begin{array}{r}10.50 \\
2.72 \\
1.10\end{array}$ & $\begin{array}{r}>10.50 \\
0.78 \\
0.12\end{array}$ & & & \\
\hline Oconee & SC & 34.79 & 87.90 & 243 & $\begin{array}{l}10 \\
46 \\
46^{\star}\end{array}$ & $\begin{array}{l}1.96 \\
2.82 \\
1.66\end{array}$ & $\begin{array}{l}25 \\
51 \\
17\end{array}$ & $\begin{array}{l}u \\
f \\
f \\
f\end{array}$ & $\begin{array}{l}0.44 \\
0.34 \\
0.24 \\
1.16\end{array}$ & $\begin{array}{r}1.49 \\
27.26 \\
15.19 \\
30.23\end{array}$ & $\begin{array}{rr}2.49 & 3.49 \\
35.33 & 19.43 \\
31.57 & 23.45 \\
38.41 & 16.22\end{array}$ & $\begin{array}{r}4.49 \\
8.60 \\
12.65 \\
7.40\end{array}$ & $\begin{array}{l}5.49 \\
4.54 \\
7.40 \\
3.46\end{array}$ & $\begin{array}{l}6.49 \\
2.54 \\
3.82 \\
1.84\end{array}$ & $\begin{array}{l}7.49 \\
1.00 \\
2.44 \\
0.83\end{array}$ & $\begin{array}{l}8.49 \\
0.48 \\
1.74 \\
0.30\end{array}$ & $\begin{array}{l}9.49 \\
0.27 \\
0.65 \\
0.06\end{array}$ & $\begin{array}{r}>9.49 \\
0.21 \\
0.84 \\
0.09\end{array}$ \\
\hline Palisades & MI & 42.35 & 86.23 & 185 & 17 & 8.88 & 1084 & $\begin{array}{l}u \\
f\end{array}$ & $\begin{array}{l}0.22 \\
1.66\end{array}$ & $\begin{array}{l}1.56 \\
0.51\end{array}$ & $\begin{array}{rr}3.35 & 5.59 \\
4.78 & 15.45\end{array}$ & $\begin{array}{r}8.27 \\
23.28\end{array}$ & $\begin{array}{l}10.95 \\
19.13\end{array}$ & $\begin{array}{r}>10.95 \\
34.41\end{array}$ & & & & \\
\hline Palo Verde & $A Z$ & 33.39 & 112.86 & 290 & $\begin{array}{l}11 \\
61\end{array}$ & $\begin{array}{l}2.28 \\
3.31\end{array}$ & $\begin{array}{r}46 \\
107\end{array}$ & $\begin{array}{l}u \\
f \\
f\end{array}$ & $\begin{array}{l}0.22 \\
0.51 \\
0.17\end{array}$ & $\begin{array}{l}0.67 \\
6.03 \\
3.18\end{array}$ & $\begin{array}{rr}1.56 & 2.46 \\
25.79 & 23.94 \\
16.54 & 18.49\end{array}$ & $\begin{array}{r}3.80 \\
19.64 \\
21.26\end{array}$ & $\begin{array}{r}6.48 \\
17.95 \\
24.45\end{array}$ & $\begin{array}{r}9.16 \\
5.05 \\
11.22\end{array}$ & $\begin{array}{r}>9.16 \\
1.09 \\
4.69\end{array}$ & & & \\
\hline Pebble Springs & OR & 45.70 & 120.14 & 220 & $\begin{array}{r}9 \\
40 \\
70\end{array}$ & $\begin{array}{l}4.08 \\
5.15 \\
5.86\end{array}$ & $\begin{array}{l}197 \\
314 \\
435\end{array}$ & $\begin{array}{l}u \\
f \\
f \\
f\end{array}$ & $\begin{array}{l}1.00 \\
8.61 \\
2.66 \\
1.81\end{array}$ & $\begin{array}{r}2.00 \\
17.93 \\
13.27 \\
12.00\end{array}$ & $\begin{array}{rr}3.00 & 4.00 \\
13.72 & 11.09 \\
15.26 & 11.15 \\
12.32 & 10.25\end{array}$ & $\begin{array}{l}5.00 \\
9.34 \\
8.16 \\
8.02\end{array}$ & $\begin{array}{l}6.00 \\
8.29 \\
8.81 \\
7.69\end{array}$ & $\begin{array}{l}7.00 \\
7.03 \\
7.82 \\
6.91\end{array}$ & $\begin{array}{l}8.00 \\
6.17 \\
7.26 \\
7.54\end{array}$ & $\begin{array}{l}9.00 \\
5.80 \\
5.89 \\
6.44\end{array}$ & $\begin{array}{r}10.00 \\
4.20 \\
4.71 \\
5.65\end{array}$ & $\begin{array}{r}>10.00 \\
7.82 \\
15.03 \\
21.36\end{array}$ \\
\hline Perkins & NC & 35.85 & 80.45 & 215 & $\begin{array}{r}9 \\
40\end{array}$ & $\begin{array}{l}1.82 \\
2.99\end{array}$ & $\begin{array}{l}12 \\
41\end{array}$ & $\begin{array}{l}u \\
f \\
f\end{array}$ & $\begin{array}{l}0.44 \\
3.84 \\
0.91\end{array}$ & $\begin{array}{r}1.49 \\
39.86 \\
13.53\end{array}$ & $\begin{array}{rr}2.49 & 3.49 \\
27.61 & 16.33 \\
28.35 & 26.24\end{array}$ & $\begin{array}{r}4.49 \\
7.41 \\
14.62\end{array}$ & $\begin{array}{l}5.49 \\
3.71 \\
7.83\end{array}$ & $\begin{array}{l}6.49 \\
0.97 \\
4.38\end{array}$ & $\begin{array}{l}7.49 \\
0.19 \\
2.40\end{array}$ & $\begin{array}{l}8.49 \\
0.06 \\
1.07\end{array}$ & $\begin{array}{l}9.49 \\
0.01 \\
0.43\end{array}$ & $\begin{array}{r}>9.49 \\
0.00 \\
0.22\end{array}$ \\
\hline Perry & $\mathrm{OH}$ & 41.80 & 81.14 & 190 & $\begin{array}{l}11 \\
61\end{array}$ & $\begin{array}{l}3.17 \\
5.29\end{array}$ & $\begin{array}{r}73 \\
281\end{array}$ & $\begin{array}{l}u \\
f \\
f\end{array}$ & $\begin{array}{l}0.22 \\
0.57 \\
0.23\end{array}$ & $\begin{array}{r}2.01 \\
28.31 \\
10.10\end{array}$ & $\begin{array}{rr}2.91 & 3.80 \\
18.29 & 15.41 \\
10.21 & 12.44\end{array}$ & $\begin{array}{r}5.14 \\
15.33 \\
19.53\end{array}$ & $\begin{array}{r}6.48 \\
10.56 \\
17.05\end{array}$ & $\begin{array}{r}8.27 \\
8.05 \\
14.81\end{array}$ & $\begin{array}{r}10.50 \\
2.62 \\
8.89\end{array}$ & $\begin{array}{r}13.63 \\
0.79 \\
4.33\end{array}$ & $\begin{array}{r}17.66 \\
0.06 \\
1.59\end{array}$ & $\begin{array}{r}>17 \quad 66 \\
0.00 \\
0.82\end{array}$ \\
\hline Phipps Ecnd & $\mathrm{TN}$ & 36.46 & 82.81 & 362 & $\begin{array}{l}10 \\
46\end{array}$ & $\begin{array}{l}1.49 \\
2.40\end{array}$ & $\begin{array}{l}11 \\
37\end{array}$ & $\begin{array}{l}u \\
f \\
f\end{array}$ & $\begin{array}{l}0.22 \\
5.82 \\
1.21\end{array}$ & $\begin{array}{r}0.67 \\
13.76 \\
8.25\end{array}$ & $\begin{array}{rr}1.56 & 2.46 \\
36.13 & 21.41 \\
31.27 & 22.09\end{array}$ & $\begin{array}{r}3.35 \\
11.61 \\
12.94\end{array}$ & $\begin{array}{r}5.59 \\
10.08 \\
17.82\end{array}$ & $\begin{array}{l}8.27 \\
1.15 \\
5.33\end{array}$ & $\begin{array}{r}11.85 \\
0.08 \\
0.94\end{array}$ & $\begin{array}{r}>11.85 \\
0.00 \\
0.18\end{array}$ & & \\
\hline Pilgrim & MA & 41.94 & 70.58 & 7 & $\begin{array}{l}10 \\
49 \\
67\end{array}$ & $\begin{array}{l}3.80 \\
5.43 \\
6.30\end{array}$ & $\begin{array}{l}105 \\
239 \\
345\end{array}$ & $\begin{array}{l}u \\
f \\
f \\
f\end{array}$ & $\begin{array}{l}0.45 \\
0.17 \\
0.09 \\
0.07\end{array}$ & $\begin{array}{r}1.79 \\
12.63 \\
5.49 \\
3.00\end{array}$ & $\begin{array}{rr}3.35 & 5.36 \\
30.01 & 34.85 \\
14.59 & 29.63 \\
11.36 & 21.66\end{array}$ & $\begin{array}{r}8.49 \\
17.37 \\
35.35 \\
38.28\end{array}$ & $\begin{array}{r}10.95 \\
3.91 \\
9.83 \\
16.68\end{array}$ & $\begin{array}{r}>10.95 \\
1.12 \\
5.00 \\
8.92\end{array}$ & & & & \\
\hline
\end{tabular}




\begin{tabular}{|c|c|c|c|c|c|c|c|c|c|c|c|c|c|c|c|c|c|}
\hline Size & $\mathrm{ST}$ & Lat & Long & EI. & $\mathrm{Ht}$. & $\bar{u}$ & $P / A$ & & quency & y Distribution & & & & & & & \\
\hline Point Beach & $w 1$ & 44.28 & 87.54 & 185 & 46 & 4.93 & 221 & $\begin{array}{l}u \\
f\end{array}$ & $\begin{array}{l}0.22 \\
0.91\end{array}$ & $\begin{array}{rrr}1.56 & 3.35 & 5.59 \\
6.45 & 16.21 & 31.76\end{array}$ & $\begin{array}{r}8.27 \\
28.73\end{array}$ & $\begin{array}{l}10.95 \\
10.92\end{array}$ & $\begin{array}{r}>10.95 \\
5.02\end{array}$ & & & & \\
\hline Prairie Island & MN & 44.62 & 92.63 & 210 & 12 & 4.08 & 111 & u & $\begin{array}{l}0.22 \\
0.00\end{array}$ & $\begin{array}{rrr}1.56 & 3.35 & 5.59 \\
7.85 & 29.60 & 33.57\end{array}$ & $\begin{array}{r}8.27 \\
22.04\end{array}$ & $\begin{array}{r}10.95 \\
5.93\end{array}$ & $\begin{array}{r}>10.95 \\
1.01\end{array}$ & & & & \\
\hline Puerto Rico & PR & 18.49 & 66.62 & 14 & 10 & 2.79 & 32 & $\begin{array}{l}u \\
f\end{array}$ & $\begin{array}{l}0.34 \\
2.86\end{array}$ & $\begin{array}{rrr}1.34 & 3.13 & 5.36 \\
23.75 & 30.57 & 20.85\end{array}$ & $\begin{array}{r}8.05 \\
20.64\end{array}$ & $\begin{array}{r}10.73 \\
7.33\end{array}$ & $\begin{array}{r}>10.73 \\
0.00\end{array}$ & & & & \\
\hline Muad Cities & IL & 41.72 & 90.32 & 184 & $\begin{array}{l}17 \\
38 \\
97\end{array}$ & $\begin{array}{l}3.61 \\
4.49 \\
5.90\end{array}$ & $\begin{array}{r}71 \\
187 \\
287\end{array}$ & $\begin{array}{l}u \\
f \\
f \\
f\end{array}$ & $\begin{array}{l}0.22 \\
0.04 \\
0.03 \\
0.03\end{array}$ & $\begin{array}{rrr}1.56 & 3.35 & 5.59 \\
9.22 & 38.86 & 34.00 \\
4.38 & 29.03 & 39.07 \\
2.90 & 16.71 & 24.79\end{array}$ & $\begin{array}{r}8.27 \\
14.72 \\
21.35 \\
31.34\end{array}$ & $\begin{array}{r}10.95 \\
2.67 \\
5.13 \\
17.07\end{array}$ & $\begin{array}{r}14.08 \\
0.48 \\
0.94 \\
5.78\end{array}$ & $\begin{array}{r}17.21 \\
0.01 \\
0.07 \\
1.10\end{array}$ & $\begin{array}{r}20.34 \\
0.00 \\
0.00 \\
0.25\end{array}$ & $\begin{array}{r}>20.34 \\
0.03\end{array}$ & \\
\hline Quanicassee & MI & 43.59 & 83.77 & 180 & 10 & 4.08 & 113 & $\begin{array}{l}u \\
f\end{array}$ & $\begin{array}{l}0.22 \\
0.12\end{array}$ & $\begin{array}{rrr}1.56 & 3.35 & 5.59 \\
7.41 & 32.32 & 34.20\end{array}$ & $\begin{array}{r}8.27 \\
18.01\end{array}$ & $\begin{array}{r}10.95 \\
5.47\end{array}$ & $\begin{array}{r}13.63 \\
2.11\end{array}$ & $\begin{array}{r}>13.63 \\
0.36\end{array}$ & & & \\
\hline Rancho Seco & $C A$ & 38.30 & 121.14 & 61 & 15 & 2.56 & 55 & $\begin{array}{l}u \\
f\end{array}$ & $\begin{array}{l}0.50 \\
4.30\end{array}$ & $\begin{array}{rrr}1.00 & 2.00 & 3.00 \\
7.52 & 25.69 & 24.72\end{array}$ & $\begin{array}{r}4.00 \\
16.98\end{array}$ & $\begin{array}{l}5.00 \\
8.71\end{array}$ & $\begin{array}{l}6.00 \\
4.90\end{array}$ & $\begin{array}{l}7.00 \\
2.24\end{array}$ & $\begin{array}{l}8.00 \\
1.40\end{array}$ & $\begin{array}{l}9.00 \\
0.99\end{array}$ & $\begin{array}{r}>9.00 \\
2.55\end{array}$ \\
\hline River Bend & MS & 30.76 & 91.33 & 29 & $\begin{array}{r}9 \\
46\end{array}$ & $\begin{array}{l}1.64 \\
2.96\end{array}$ & $\begin{array}{l}10 \\
36\end{array}$ & $\begin{array}{l}u \\
f \\
f\end{array}$ & $\begin{array}{l}0.22 \\
5.48 \\
0.61\end{array}$ & $\begin{array}{rrr}1.56 & 3.35 & 5.59 \\
40.72 & 42.03 & 11.12 \\
12.77 & 48.86 & 31.34\end{array}$ & $\begin{array}{l}8.27 \\
0.65 \\
5.90\end{array}$ & $\begin{array}{r}10.95 \\
0.01 \\
0.41\end{array}$ & $\begin{array}{r}70.95 \\
0.00 \\
0.10\end{array}$ & & & & \\
\hline H.B. Robinson & SC & 34.40 & 80.16 & 83 & $\begin{array}{l}11 \\
61\end{array}$ & $\begin{array}{l}2.04 \\
3.80\end{array}$ & $\begin{array}{l}17 \\
82\end{array}$ & $\begin{array}{l}u \\
f \\
f\end{array}$ & $\begin{array}{l}0.34 \\
3.41 \\
0.55\end{array}$ & $\begin{array}{rrr}1.56 & 3.35 & 5.59 \\
29.25 & 48.52 & 17.17 \\
7.66 & 31.30 & 40.70\end{array}$ & $\begin{array}{r}8.27 \\
1.59 \\
16.79\end{array}$ & $\begin{array}{r}11.18 \\
0.06 \\
3.01\end{array}$ & $\begin{array}{r}71.18 \\
0.01 \\
0.58\end{array}$ & & & & \\
\hline St. Lucie & $\mathrm{FL}$ & 27.33 & 80.25 & 5 & $\begin{array}{l}10 * \\
15\end{array}$ & $\begin{array}{l}3.03 \\
3.37\end{array}$ & $\begin{array}{r}38 \\
-52\end{array}$ & $\begin{array}{l}u \\
f \\
u \\
f\end{array}$ & $\begin{array}{l}0.45 \\
1.78 \\
0.22 \\
3.22\end{array}$ & $\begin{array}{rrr}1.79 & 3.80 & 5.81 \\
17.78 & 46.87 & 30.03 \\
1.56 & 3.35 & 5.59 \\
7.58 & 39.82 & 38.59\end{array}$ & $\begin{array}{l}8.49 \\
3.41 \\
8.27 \\
9.64\end{array}$ & $\begin{array}{r}11.18 \\
0.13 \\
10.95 \\
1.10\end{array}$ & $\begin{array}{r}13.86 \\
0.00 \\
14.08 \\
0.05\end{array}$ & $\begin{array}{r}>13.86 \\
0.00 \\
>74.08 \\
0.00\end{array}$ & & & \\
\hline San Onofre & $C A$ & 32.37 & 117.56 & 45 & $\begin{array}{l}10 \\
40\end{array}$ & $\begin{array}{l}3.17 \\
3.03\end{array}$ & $\begin{array}{l}53 \\
59\end{array}$ & $\begin{array}{l}u \\
f \\
f\end{array}$ & $\begin{array}{l}0.25 \\
0.07 \\
0.72\end{array}$ & $\begin{array}{rrr}1.00 & 2.00 & 3.00 \\
4.53 & 21.50 & 25.34 \\
7.71 & 22.68 & 23.70\end{array}$ & $\begin{array}{r}4.00 \\
21.92 \\
19.65\end{array}$ & $\begin{array}{r}5.00 \\
13.32 \\
11.78\end{array}$ & $\begin{array}{l}6.00 \\
6.51 \\
6.12\end{array}$ & $\begin{array}{l}7.00 \\
3.41 \\
3.13\end{array}$ & $\begin{array}{l}8.00 \\
1.50 \\
1.68\end{array}$ & $\begin{array}{l}9.00 \\
0.86 \\
1.08\end{array}$ & $\begin{array}{r}>9.00 \\
1.05 \\
1.73\end{array}$ \\
\hline Seabrook & $\mathrm{NH}$ & 42.90 & 70.85 & 3 & 9 & 2.25 & 44 & $\begin{array}{l}u \\
f\end{array}$ & & $\begin{array}{rrr}1.50 & 4.00 & 6.00 \\
31.60 & 48.30 & 13.40\end{array}$ & $\begin{array}{l}8.00 \\
4.60\end{array}$ & $\begin{array}{r}>8.00 \\
2.10\end{array}$ & & & & & \\
\hline Sequoyah & TN & 35.23 & 85.09 & 230 & 10 & 1.82 & 13 & $\begin{array}{l}u \\
f\end{array}$ & $\begin{array}{l}0.22 \\
2.25\end{array}$ & $\begin{array}{rrr}0.67 & 1.56 & 2.46 \\
10.16 & 34.81 & 25.13\end{array}$ & $\begin{array}{r}3.35 \\
14.86\end{array}$ & $\begin{array}{r}5.59 \\
11.97\end{array}$ & $\begin{array}{l}8.27 \\
0.77\end{array}$ & $\begin{array}{r}10.95 \\
0.03\end{array}$ & $\begin{array}{r}>10.95 \\
0.02\end{array}$ & & \\
\hline
\end{tabular}




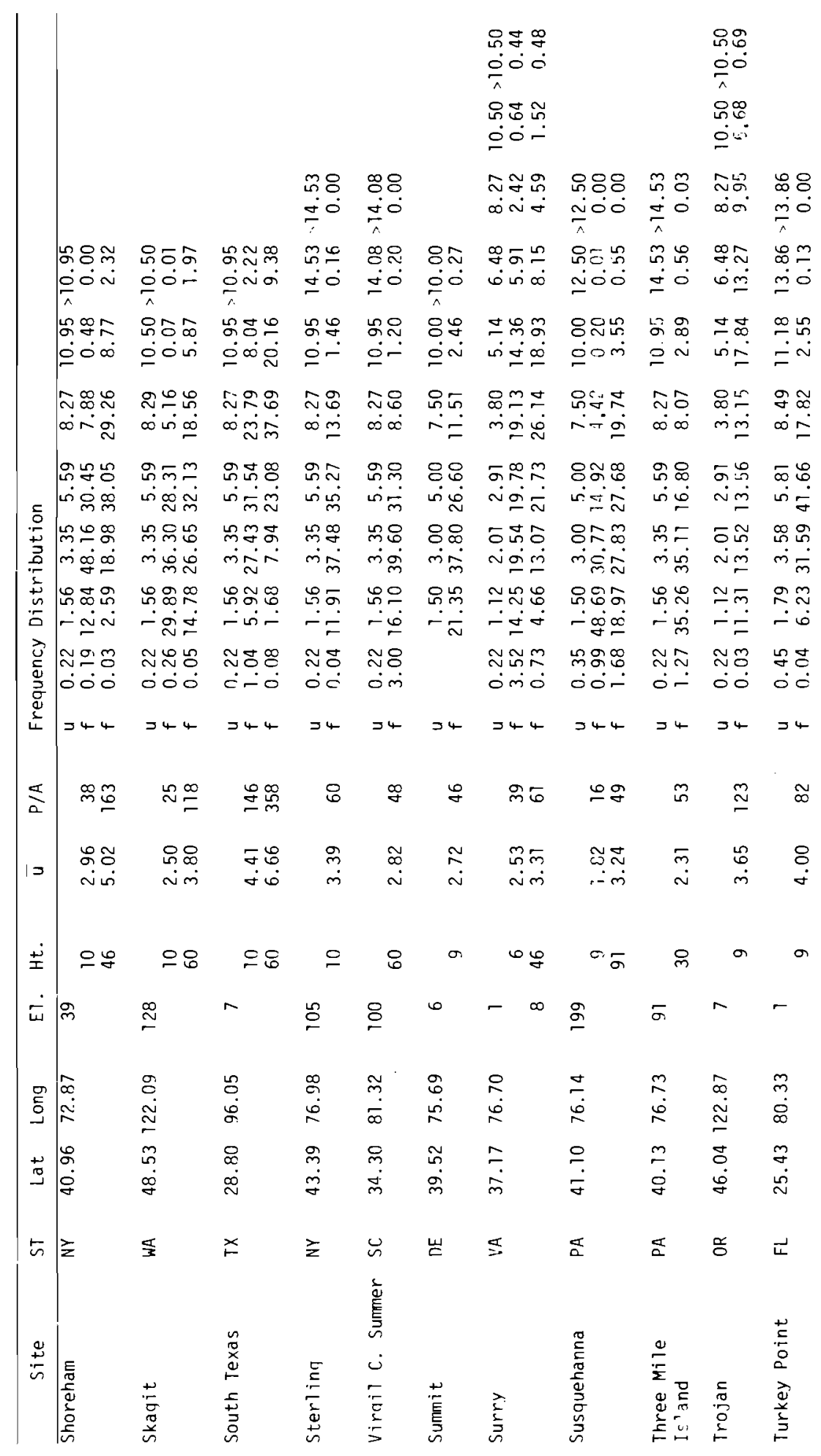




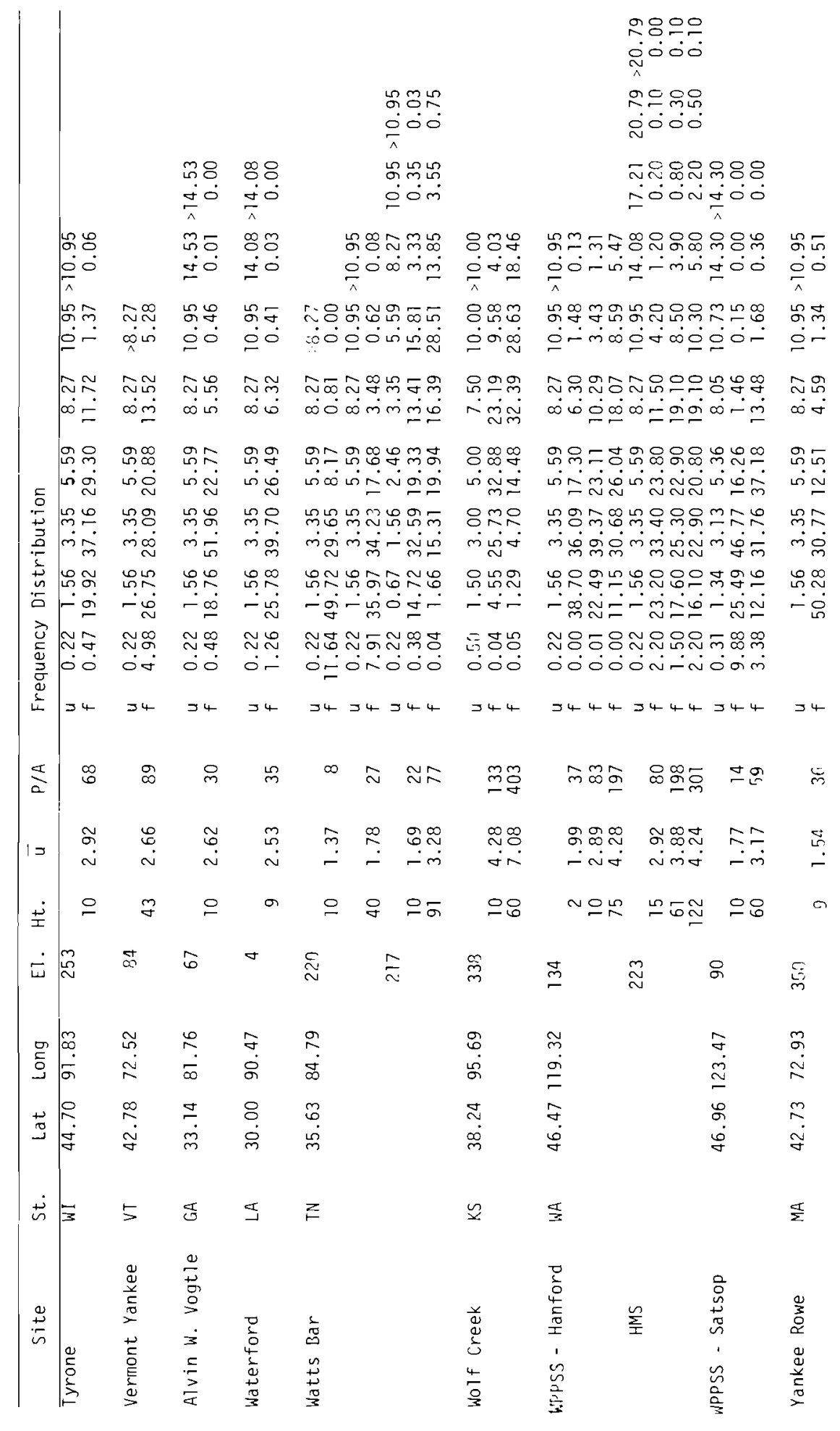




\begin{tabular}{|c|c|c|c|c|c|c|c|c|c|c|c|c|c|c|c|c|c|c|}
\hline Site & ST & Lat & Long & El. & $\mathrm{Ht}$. & $\vec{u}$ & $P / A$ & & quency & Distr & ribution & & & & & & & \\
\hline Yellow Creek & MS & 34.96 & 88.22 & 154 & $\begin{array}{l}10 \\
46\end{array}$ & $\begin{array}{l}1.99 \\
3.35\end{array}$ & $\begin{array}{l}18 \\
61\end{array}$ & $\begin{array}{l}u \\
f \\
f\end{array}$ & $\begin{array}{l}0.22 \\
1.14 \\
0.27\end{array}$ & $\begin{array}{r}0.67 \\
10.06 \\
1.03\end{array}$ & $\begin{array}{rr}1.56 & 2.46 \\
27.95 & 24.66 \\
10.03 & 19.73\end{array}$ & $\begin{array}{l}3.35 \\
17.28 \\
22.15\end{array}$ & $\begin{array}{r}5.59 \\
16.07 \\
33.48\end{array}$ & $\begin{array}{r}8.27 \\
2.77 \\
11.14\end{array}$ & $\begin{array}{r}10.95 \\
0.07 \\
1.94\end{array}$ & $\begin{array}{r}>10.95 \\
0.00 \\
0.22\end{array}$ & & \\
\hline Wm. H. Zimmer & $\mathrm{OH}$ & 38.87 & 84.23 & 155 & 9 & 1.51 & 16 & $\begin{array}{l}u \\
f\end{array}$ & $\begin{array}{r}0.5 ? \\
15.57\end{array}$ & $\begin{array}{r}1.00 \\
20.35\end{array}$ & $\begin{array}{rr}2.00 & 3.00 \\
28.65 & 17.42\end{array}$ & $\begin{array}{l}4.00 \\
9.24\end{array}$ & $\begin{array}{l}5.00 \\
4.87\end{array}$ & $\begin{array}{l}6.00 \\
2.34\end{array}$ & $\begin{array}{l}7.00 \\
0.85\end{array}$ & $\begin{array}{l}8.00 \\
0.36\end{array}$ & $\begin{array}{l}9.00 \\
0.21\end{array}$ & $\begin{array}{r}>9.00 \\
0.14\end{array}$ \\
\hline Zion & $I L$ & 42.45 & 87.80 & 180 & $\begin{array}{l}11 \\
76\end{array}$ & $\begin{array}{l}3.35 \\
6.40\end{array}$ & $\begin{array}{r}84 \\
371\end{array}$ & $\begin{array}{l}u \\
u \\
f\end{array}$ & $\begin{array}{l}0.22 \\
1.96 \\
0.22 \\
0.86\end{array}$ & $\begin{array}{r}1.56 \\
11.01 \\
1.56 \\
1.66\end{array}$ & $\begin{array}{rr}3.35 & 5.59 \\
37.27 & 30.69 \\
3.35 & 5.59 \\
10.71 & 25.49\end{array}$ & $\begin{array}{r}8.27 \\
14.40 \\
8.27 \\
32.85\end{array}$ & $\begin{array}{r}10.95 \\
3.83 \\
10.95 \\
18.68\end{array}$ & $\begin{array}{r}14.08 \\
0.77 \\
14.08 \\
7.11\end{array}$ & $\begin{array}{r}17.21 \\
0.07 \\
17.21 \\
2.07\end{array}$ & $\begin{array}{r}>17.21 \\
0.00 \\
20.79 \\
0.47\end{array}$ & $\begin{array}{r}20.79 \\
0.10\end{array}$ & \\
\hline
\end{tabular}



APPENDIX $C$

Alphabetical Compilation

of

Site Descriptions and Data 



\section{INDEX}

Allens Creek. . . . . . . . . . . . . . . . . C-1 Arkansas. . . . . . . . . . . . . . . . . . . C-4 Duane Arnold. . . . . . . . . . . . . . . . C-7 Atlantic. . . . . . . . . . . . . . . C-10 Bailly. . . . . . . . . . . . . . . . C-12 Alan R. Barton. . . . . . . . . . . . . . C-15 Beaver Valley/Shippingport. . . . . . . . . . . C-17 Bellefonte. . . . . . . . . . . . . . . . . C-20 Big Rock Point. . . . . . . . . . . . . . . C-23 Black Fox . . . . . . . . . . . . . . C-25 Blue Hills. . . . . . . . . . . . . . . . C-27 Braidwood . . . . . . . . . . . . . . . C-30 Browns Ferry. . . . . . . . . . . . . . . . . C-32 Brunswick . . . . . . . . . . . . . . . C-35 Byron . . . . . . . . . . . . . . . . C-38 Callaway. . . . . . . . . . . . . . . . . . C-40 Calvert Cliffs. . . . . . . . . . . . . C-43 Catawba .. . . . . . . . . . . . . . . C 45 Cherokee. . . . . . . . . . . . . . . . C 447 Clinch River. . . . . . . . . . . . . . . C-50 Clinton . . . . . . . . . . . . . . . . C-53 Comanche Peak . . . . . . . . . . . . . . . C-56 Connecticut Yankee. . . . . . . . . . . . . . C-58 Donald C. Cook. . . . . . . . . . . . . . . C-61 Cooper. . . . . . . . . . . . . . . . . . . C-64 Crystal River.................... C-66 Davis-Besse . . . . . . . . . . . . . . C-68 Diablo Canyon . . . . . . . . . . . . . . C-71 Douglas point... . . . . . . . . . . . . C-74 Dresden . . . . . . . . . . . . . . C C-76 Joseph M. Farley. . . . . . . . . . . . . . . C-80 
Enrico Fermi. . . . . . . . . . . . . . . . C-82 James A. Fitzpatrick/Nine Mile Pt. . . . . . . . . . . C-84 Forked River/Oyster Creek . . . . . . . . . . . . C-87 Fort Calhoun. . . . . . . . . . . . . . . . . C-89

Fort St. Vrain. . . . . . . . . . . . . . . . C-91 Fulton/Peach Bottom . . . . . . . . . . . . C-93 R. E. Ginna . . . . . . . . . . . . . . . . c -100 Grand Gulf. . . . . . . . . . . . . . . C-103 Greene. . . . . . . . . . . . . . . . . C-105 Greenwood . . . . . . . . . . . . . . . . C-108 Shearon Harris. . . . . . . . . . . . . . . C-110 Hartsville. . . . . . . . . . . . . . . . . C-113 Edwin I. Hatch. . . . . . . . . . . . . . . C-115 Hope Creek/Salem. . . . . . . . . . . . . . C-118 Humboldt Bay. . . . . . . . . . . . . . . . C-121 Indian Point. . . . . . . . . . . . . . . . . C-123 Jamesport . . . . . . . . . . . . . . . . C-126 Kewaunee. . . . . . . . . . . . . . . C C-130 Koshkonong. . . . . . . . . . . . . . . . . . . C-132 La Grosse . . . . . . . . . . . . . . . . C-135 LaSalle . . . . . . . . . . . . . . . C C-137 Limerick. . . . . . . . . . . . . . . . . . . . C-138 Maine Yankee. . . . . . . . . . . . . . . . C-142 Marble Hill . . . . . . . . . . . . . . . . . C-144 Wm. B. McGuire. . . . . . . . . . . . . . C C-146 Midland . . . . . . . . . . . . . . . . . . C-149 Millstone point. . . . . . . . . . . . . . . C-151 Montague. . . . . . . . . . . . . . . . . C-158 Monticello. . . . . . . . . . . . . . . . C-163 North Anna. . . . . . . . . . . . . . . . . C-167 Oconee. . . . . . . . . . . . . . . . . . . . . C-170 palisades................... . C-174 
Palo Verde. . . . . . . . . . . . . . . . . C-176

Pebble Springs. . . . . . . . . . . . . . . . . . . . C-179

Perkins . . . . . . . . . . . . . . . . . . . . . C-183

Perry • . . . . . . . . . . . . . . . . . . . . . C-186

Phipps Bend . • . . . . . . . . . • . . . . . . C-189

Pilgrim . . . • . • . . . . . . . . . . . . . . . C-192

Point Beach . . . . . . . . . . . . . . . . . . C-196

Prairie Island. . . . . . . . . . . . . . . . . C-198

Puerto Rico . . . . . . . . . . . . . . . . . . . C-200

Quad Cities . . . . . . . . . . . . . . . . . . . C-202

Quanicassee . • . . . . . . . . . . . . . . . C 206

Rancho Seco . . . . . . . . . . . . . . . . . . . C-208

River Bend. . . . . . . . . . . . . . . . . . . . c C-210

H. B. Robinson. . . . . . . . . . . . . . . . . . C-213

Saint Lucie . • . • . . . . . . . • . . . . . . . . C-216

San Onofre. . . . . . . . . . . . . . . . . . . . . C-219

Seabrook. . . . . . . . . . . . . . . . . . . . C -222

Sequoyah. . . . . . • . . . . . • • . . . . . . . C-224

shoreham. . . . . . . . . . . . . . . . . . . C-226

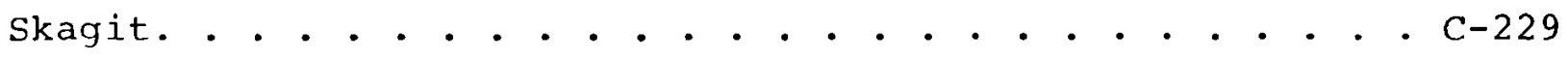

South Texas. . . . . . . . . . . . . . . . . C-232

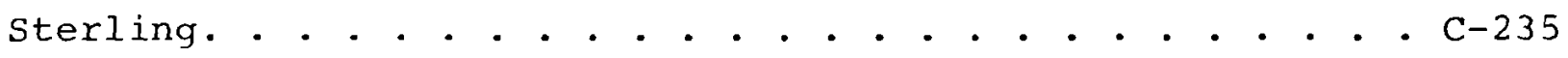

Virgil C. Summer. • • . . . . . . • . . . . . . . C-237

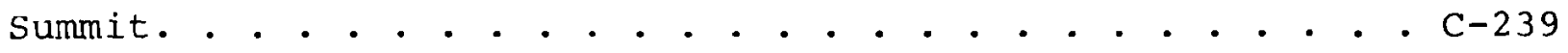

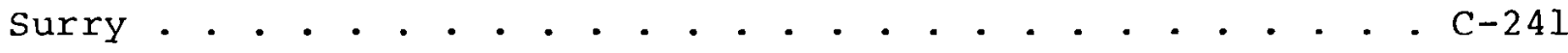

Susquehanna . • . • . . . . . • . . • . . . . • . . . C-244

Three Mile Island . . . . . . . . . . . . . . . . C-247

Trojan. . . • . . . . . . . . . . . . . . . . . c-249

Turkey Point. . . . . . . . . . . . . . . . . c c-251

Tyrone. • . . . . . . . . . . . . . . . . . . . c-253

Vermont Yankee. • . . . . . . . . . . . . . . . C-255

Alvin W. Vogtle. . . . . . . . . . . . . . . C-257 
waterford. . . . . . . . . . . . C-259

Watts Bar.................. . C-261

Wolf creek. . . . . . . . . . . . . C-266

WPPSS (Hanford)................ C-269

WPPSS (Satsop)................ . . C-276

Yankee Rowe. . . . . . . . . . . . . . . . . C-279

Yellow Creek.................. C-281

Wm. H. Zimmer. . . . . . . . . . . . . C-284

zion.................. . . C-286 


\section{SITE LOCATION:}

The site of the Allens Creek Nuclear Generating Station $\left(29.68^{\circ} \mathrm{N} / 96.10^{\circ} \mathrm{W}\right)$ is located in southern Austin County, Texas, $6 \mathrm{~km} \mathrm{NW}$ of Wallis, $11 \mathrm{~km}$ SSE of Sealy, and $72 \mathrm{~km} \mathrm{~W}$ of the center of Houston.

\section{TOPOGRAPHY :}

The site is located on uplands immediately $W$ of the Brazos River, between State Highway 36 and the Brazos River floodplain. Elevation on the 11,000-acre site is 37-45 $\mathrm{m}$ above Mean Sea Level (MSL). The topography of the region rises gradually from sea level in the SE to $150-250 \mathrm{~m}$ (MSL) in the NW.

ON-SITE WIND MEASUREMENTS:

Wind data are collected from a 60-m tower instrumented with Climet WS-011-1 (speed) and Climet WD-012-10 (direction) sensors at the $10 \mathrm{~m}$ and $60 \mathrm{~m}$ levels.

NRC Docket No. $50-466$ 


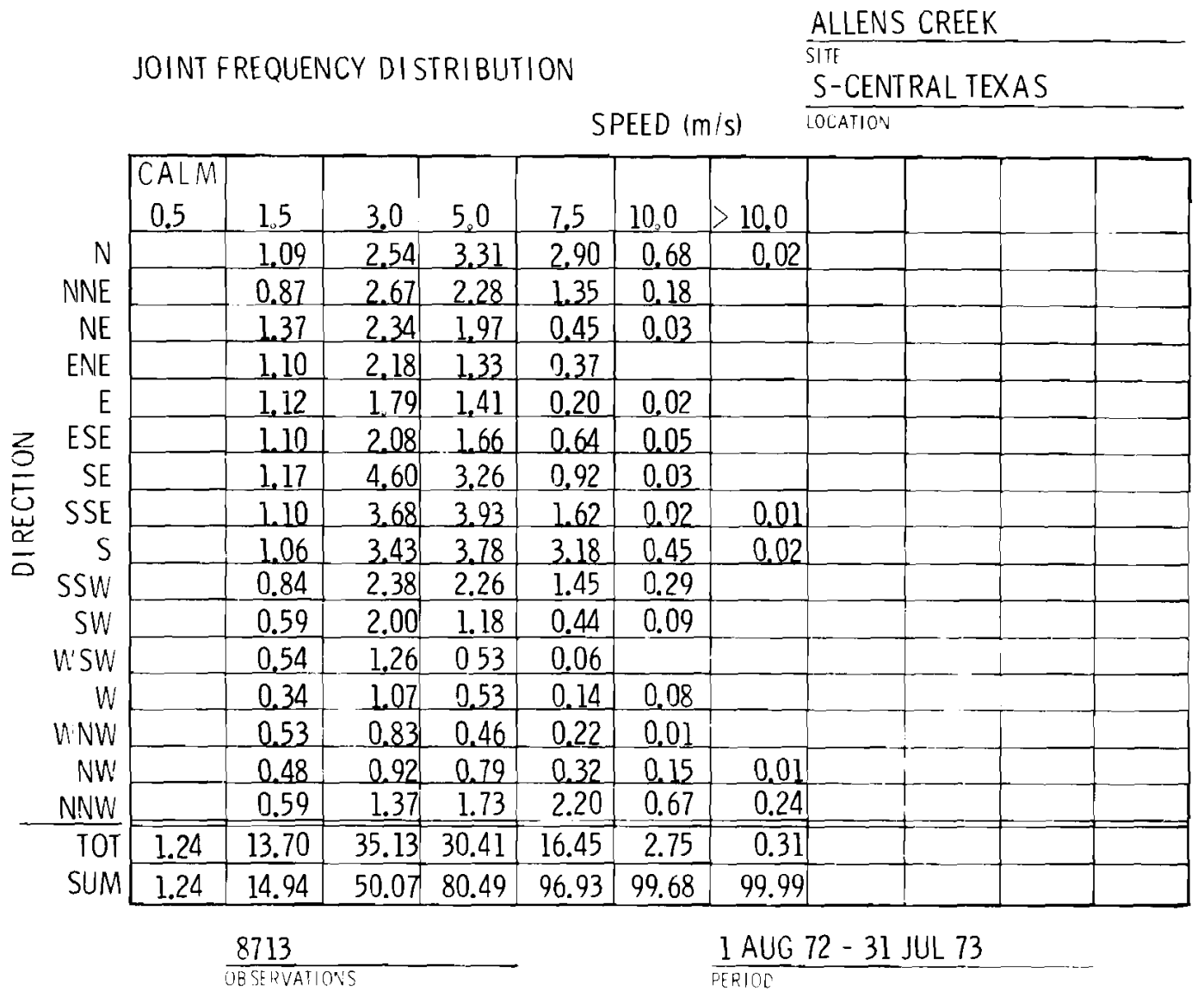

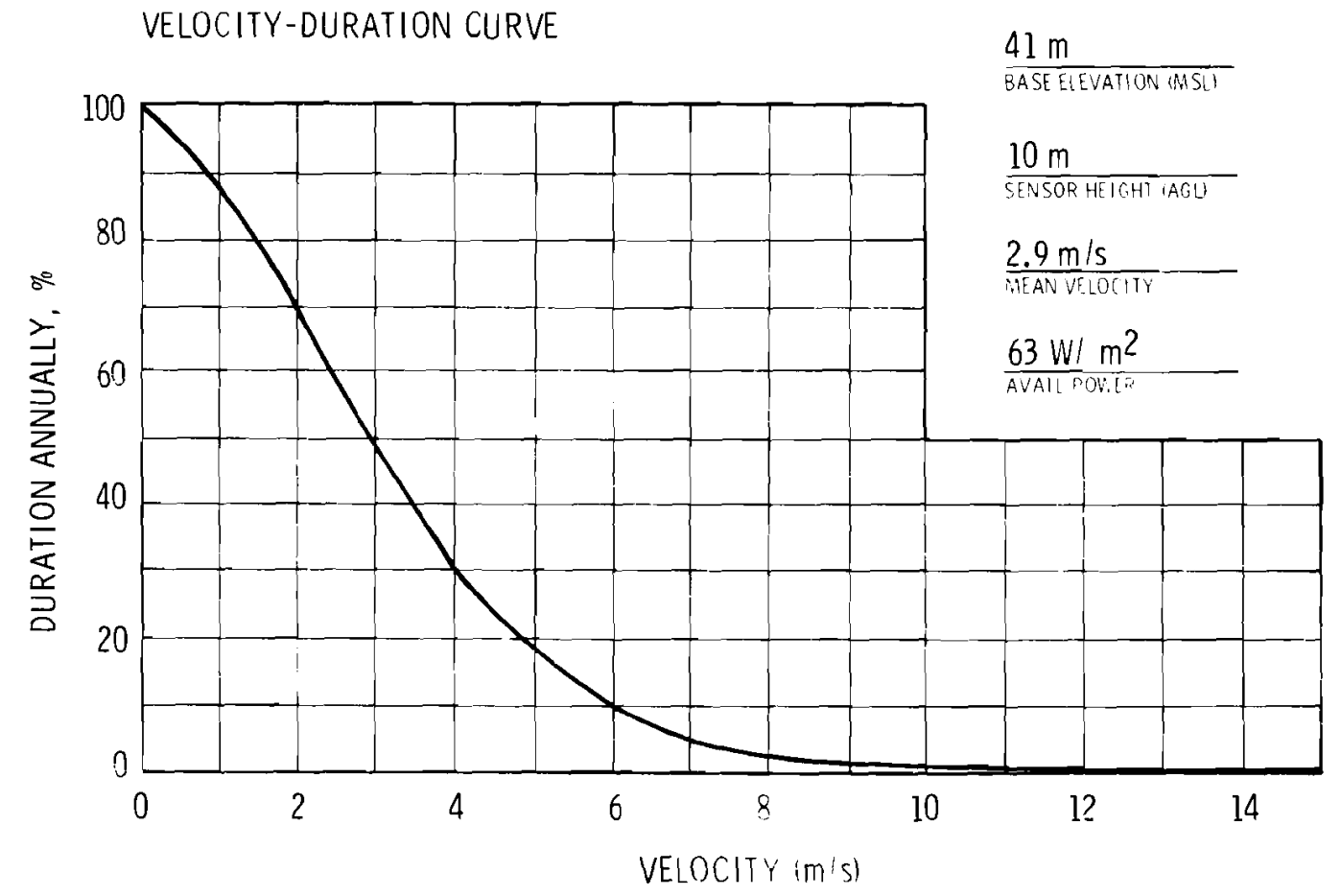




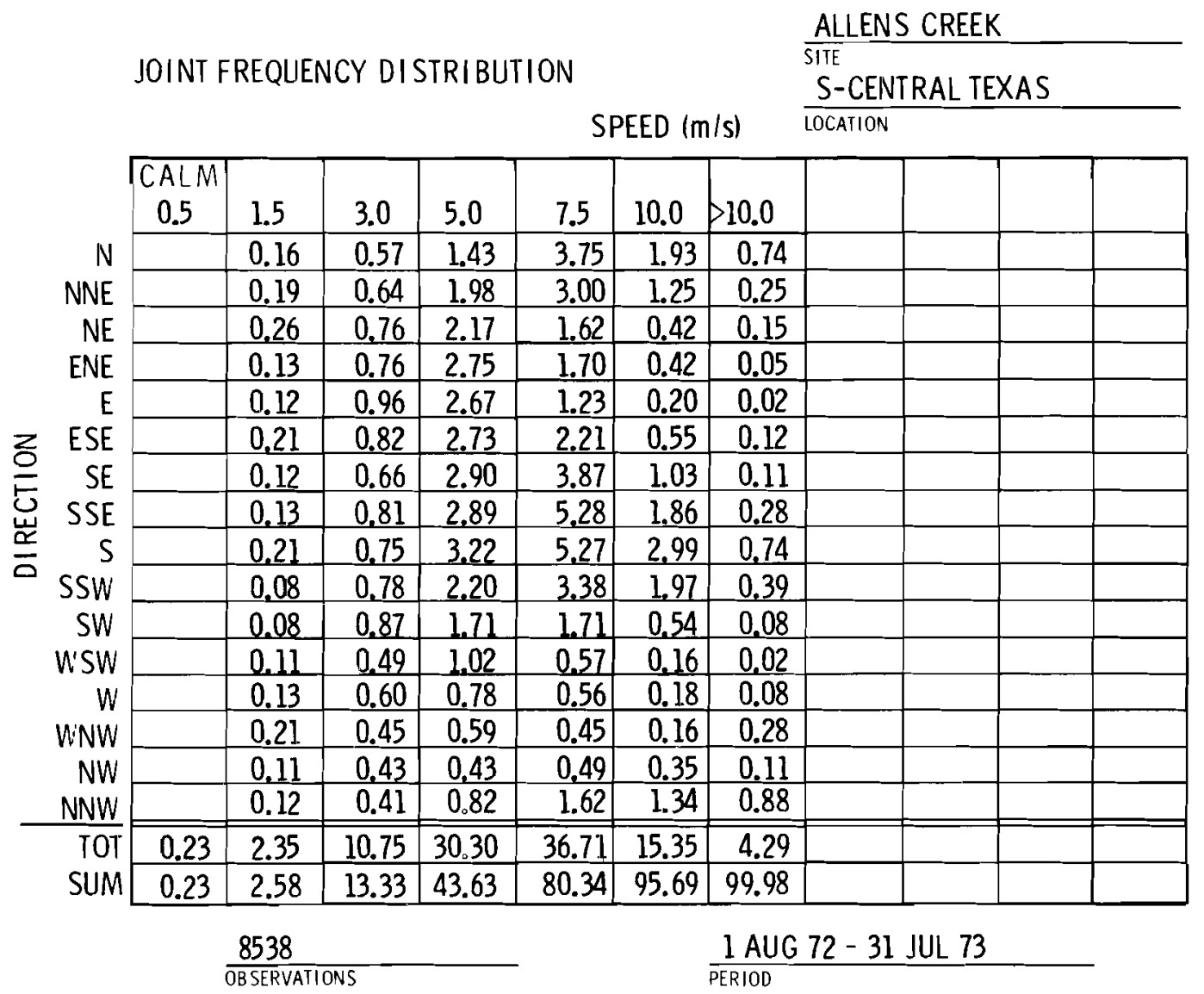

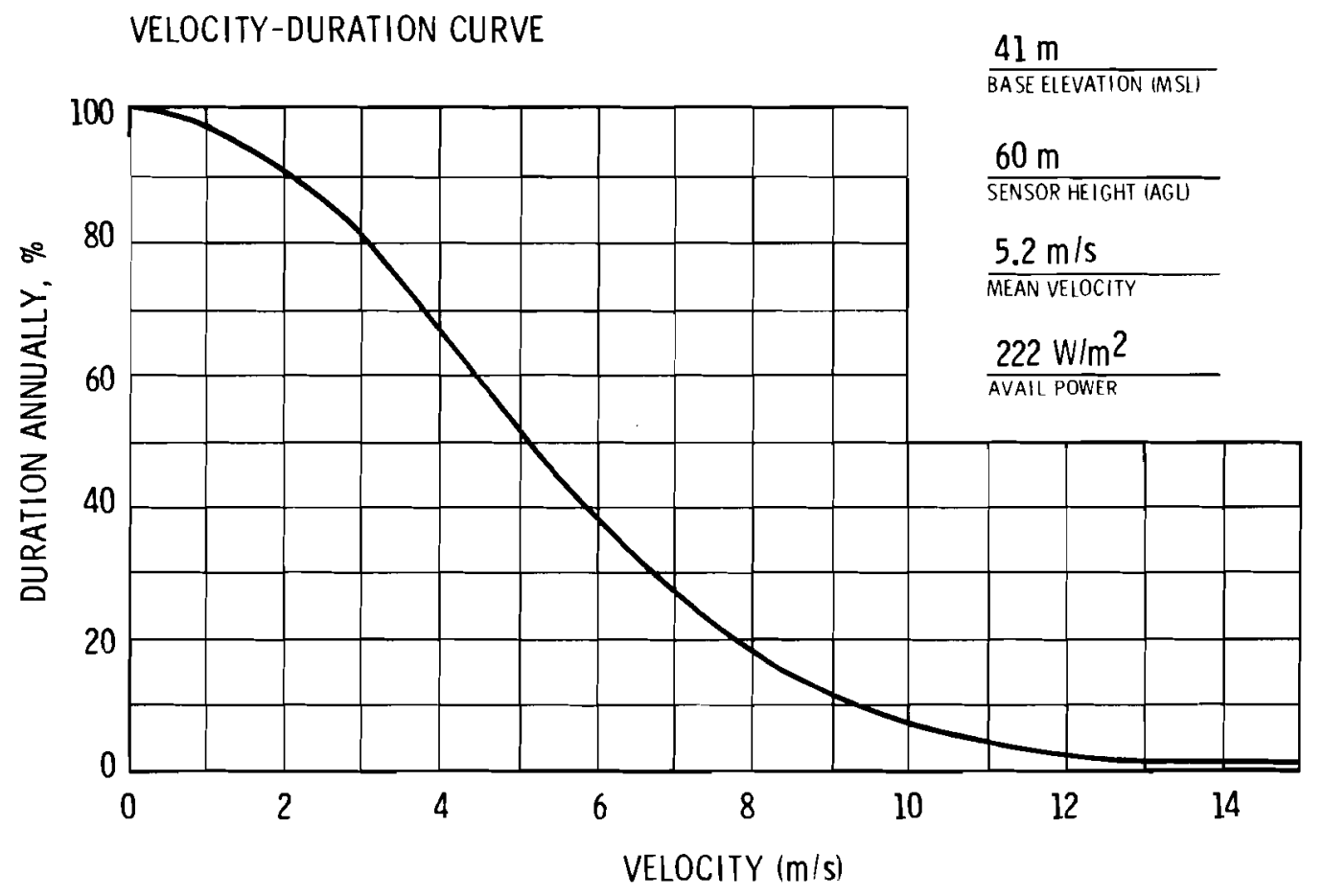


ARKANSAS

SITE LOCATION:

The Arkansas Nuclear site $\left(35.31^{\circ} \mathrm{N} / 93.22^{\circ} \mathrm{W}\right)$ is located in southwestern Pope County, Arkansas, about $92 \mathrm{~km} \mathrm{NW}$ of Little Rock and $110 \mathrm{~km} \mathrm{E}$ of Fort Smith, on a peninsula formed by the Dardanelle Reservoir. The town of Russellville is about $10 \mathrm{~km}$ ESE of the site and the village of London is about $3 \mathrm{~km} N W$ of the site.

\section{TOPOGRAPHY:}

The site is on a peninsula in the Dardanelle Reservoir, an impoundment on that portion of the Arkansas River lying between the Boston Mountains to the north and the Ouachita Mountains to the south. These mountains generally reach to $600 \mathrm{~m}$ and occasionally to $900 \mathrm{~m}$ (MSL). The regional topography within an $8 \mathrm{~km}$ radius can be best described as gently rolling. Site elevation is approximately $103 \mathrm{~m}$ (MSL).

ON-SITE WIND MFASURFMENTS:

In June 1969, a 58-m tower was installed and instrumented at the $12 \mathrm{~m}$ - and $58-\mathrm{m}$ levels using Litton $511 \mathrm{~s}-4$ sensors for wind speed and Litton 510D-2 sensors for direction.

NRC Docket Nos. $\overline{50-313,550-368}$ 


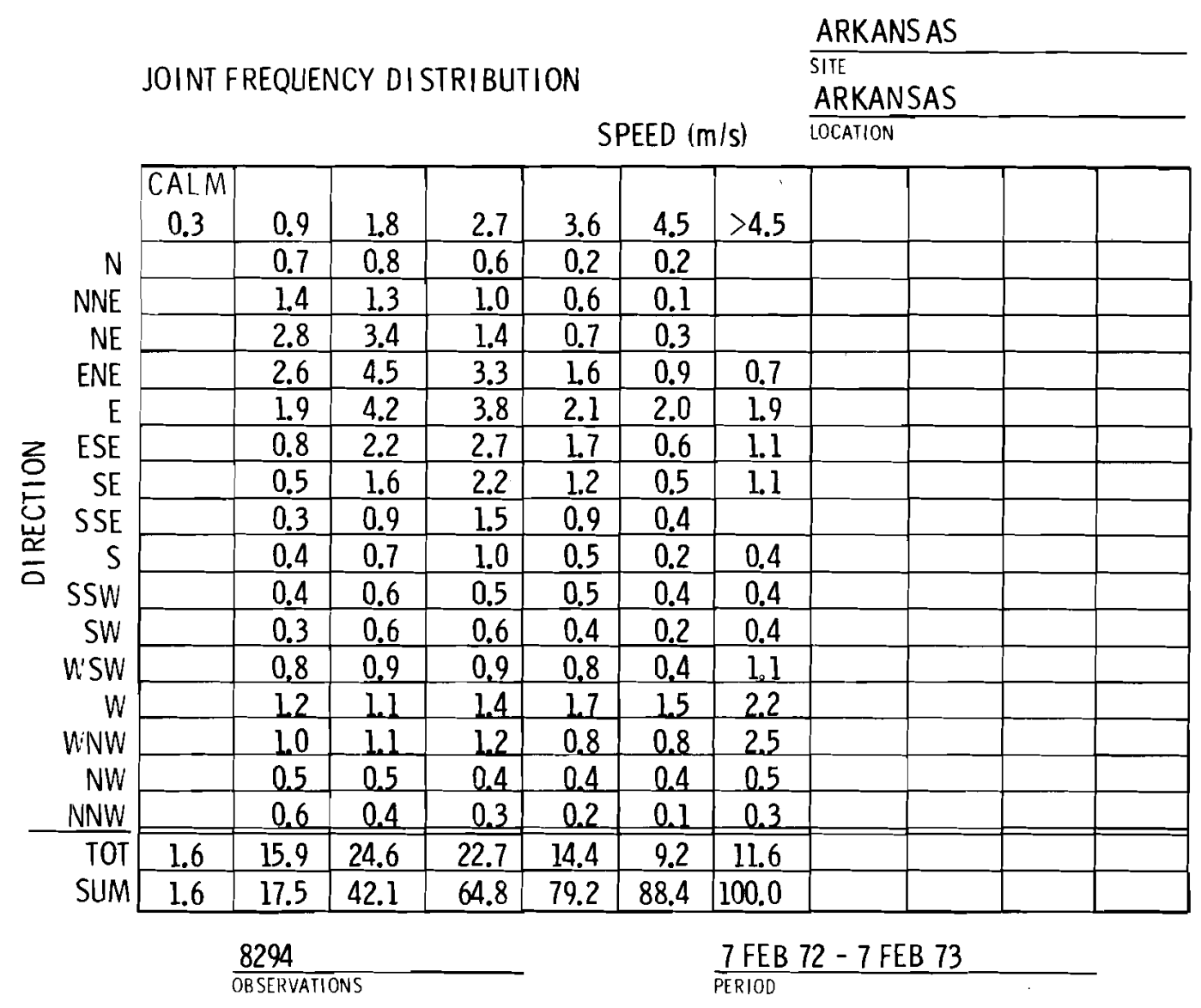

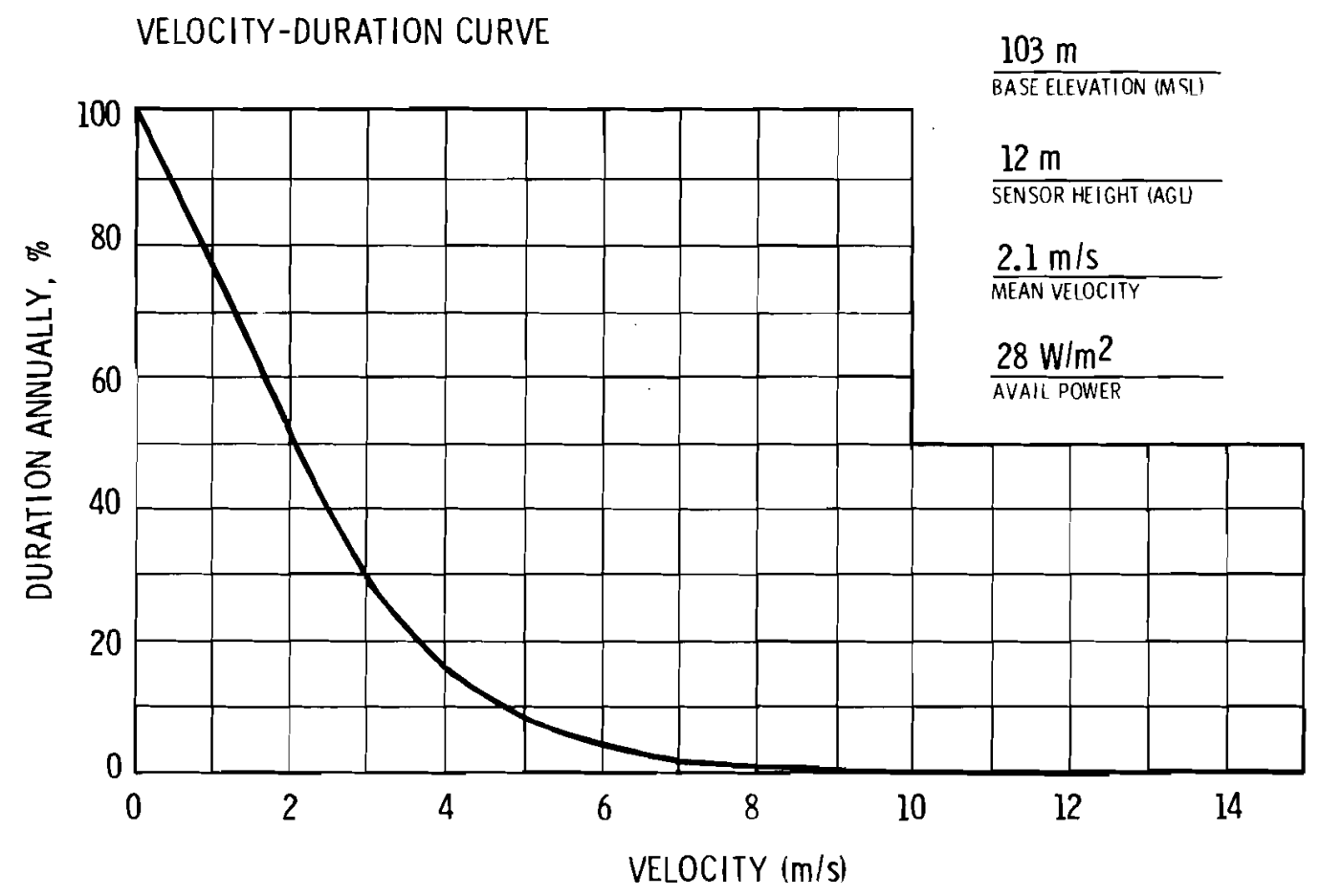



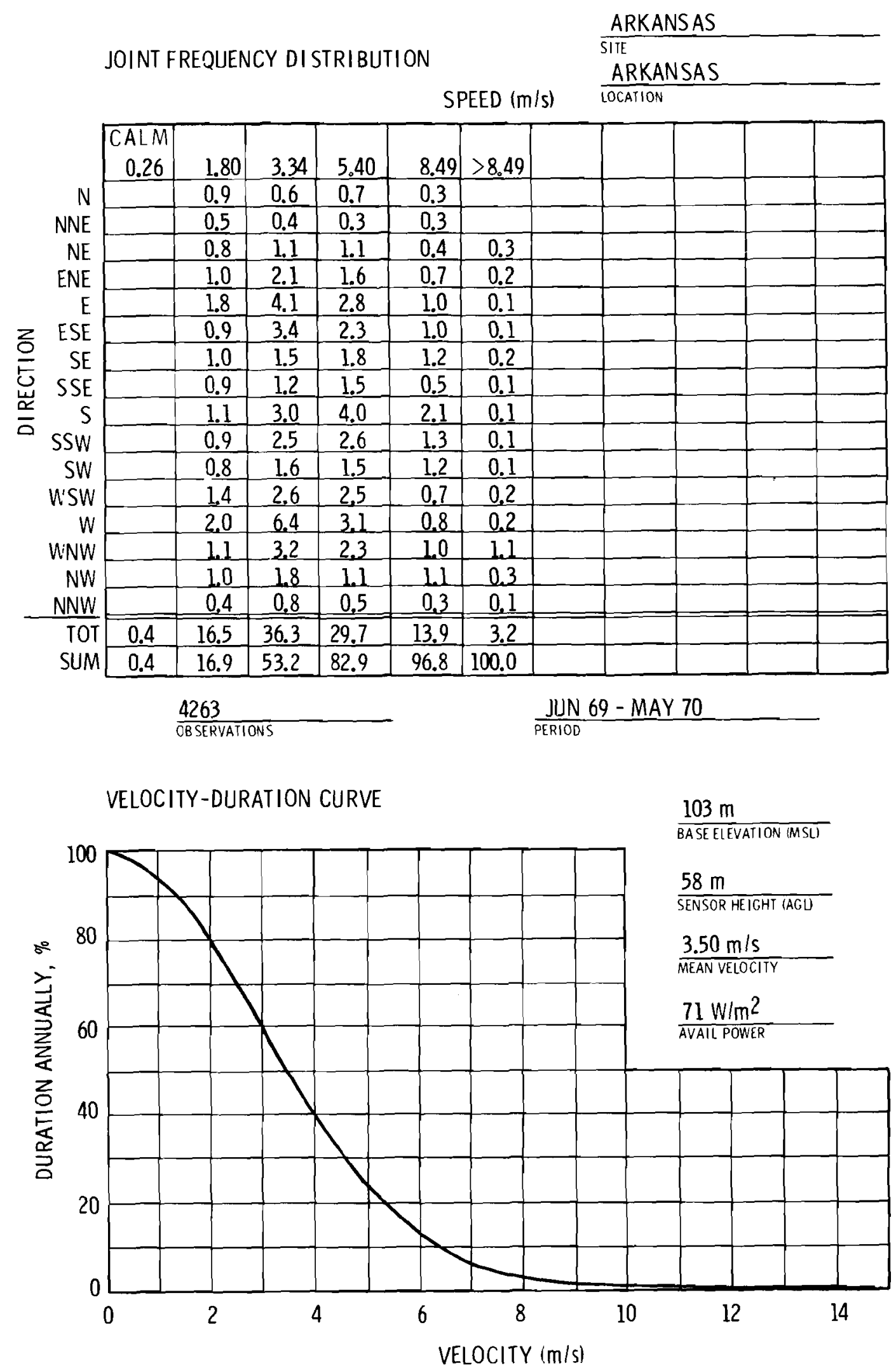
DUANE ARNOLD

\section{SITE LOCATION:}

The Duane Arnold site $\left(42.03^{\circ} \mathrm{N} / 91.76^{\circ} \mathrm{W}\right)$ is located on the western side of the $\mathrm{N}-\mathrm{S}$ reach of the Cedar River, about $4 \mathrm{~km}$ NNE of the village of Palo, Linn County, in east-central Iowa. The closest city is cedar Rapids, with its outer boundary being $13 \mathrm{~km}$ to the $\mathrm{SE}$.

\section{TOPOGRAPHY :}

A relatively flat plain at about $230 \mathrm{~m}$ (MSL) extends from the site towards Palo to the SW. Across the river from the site, the land rises from an elevation of $230 \mathrm{~m}$ to $275 \mathrm{~m}$ within approximately $0.6 \mathrm{~km}$. These slopes are rather heavily wooded with only an occasional field or pasture dotting the landscape. Beyond the rise, the land is gently rolling farmland. To the $\mathrm{NW}$, the land rises to an elevation of $260 \mathrm{~m}$. Immediately adjacent to the $\mathrm{E}$ is another heavily wooded low area that constitutes the current floodplain. This area is very flat and extends some $0.5 \mathrm{~km}$ to the $\mathrm{w}$ bank of the river. General topographical features in this portion of the Cedar River consist of broad valleys with relatively narrow floodplains. In many places, these broad valleys merge almost imperceptibly into the adjacent uplands. Away from the vicinity of the river, the land is gently rolling farmland.

\section{ON-SITE WIND MEASUREMENTS:}

A 50-m tower has been in operation since 10 January 1971. Wind data are collected at the 11 - and $50-\mathrm{m}$ levels using climet WS-011-1 instruments for wind speed and Climet WD-012-10 instruments for direction at the $11-\mathrm{m}$ level and a Bendix-Friez Aerovane 120 at $50 \mathrm{~m}$. Tower base is about $230 \mathrm{~m} \mathrm{(MSL).}$ 


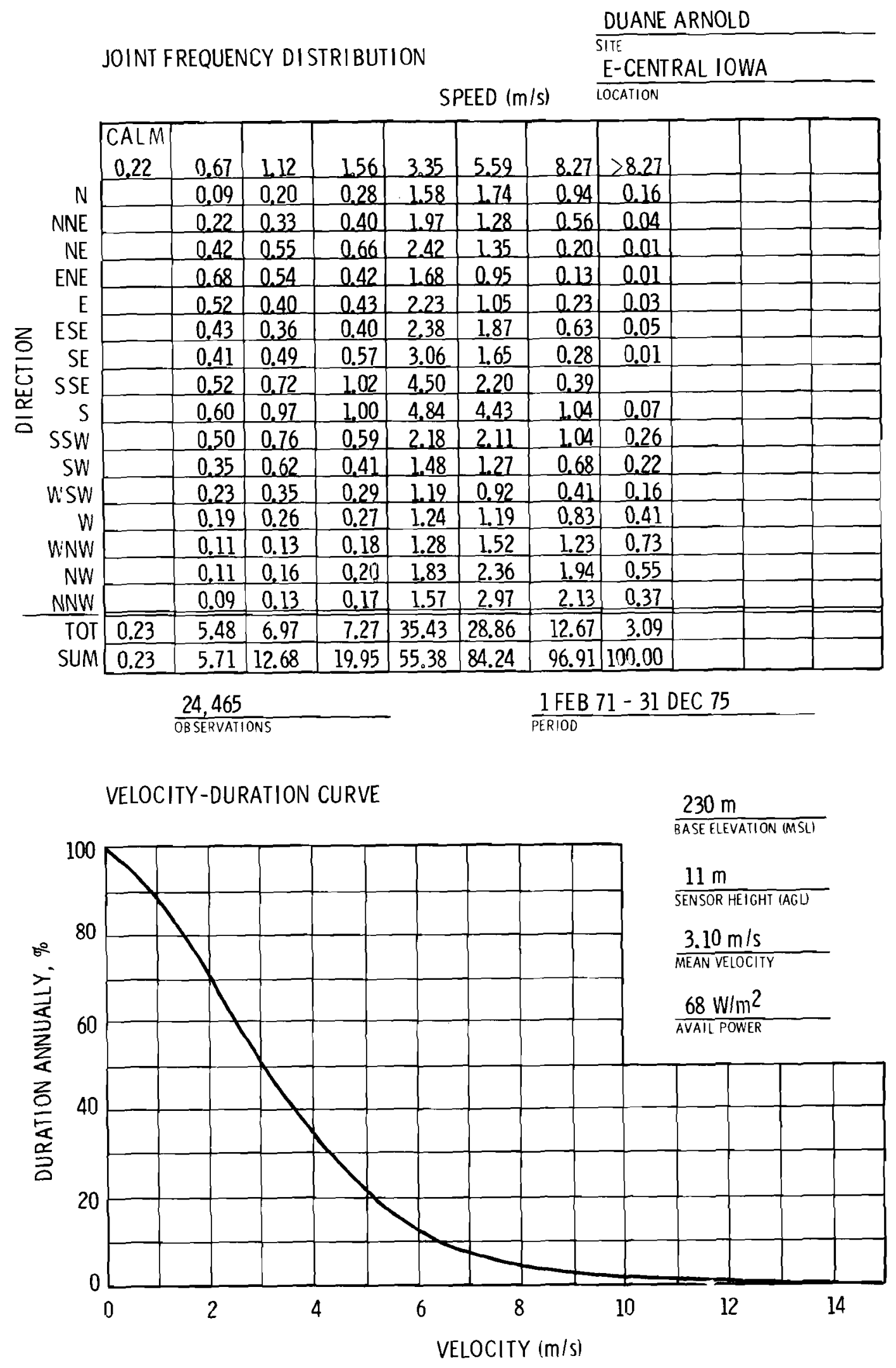




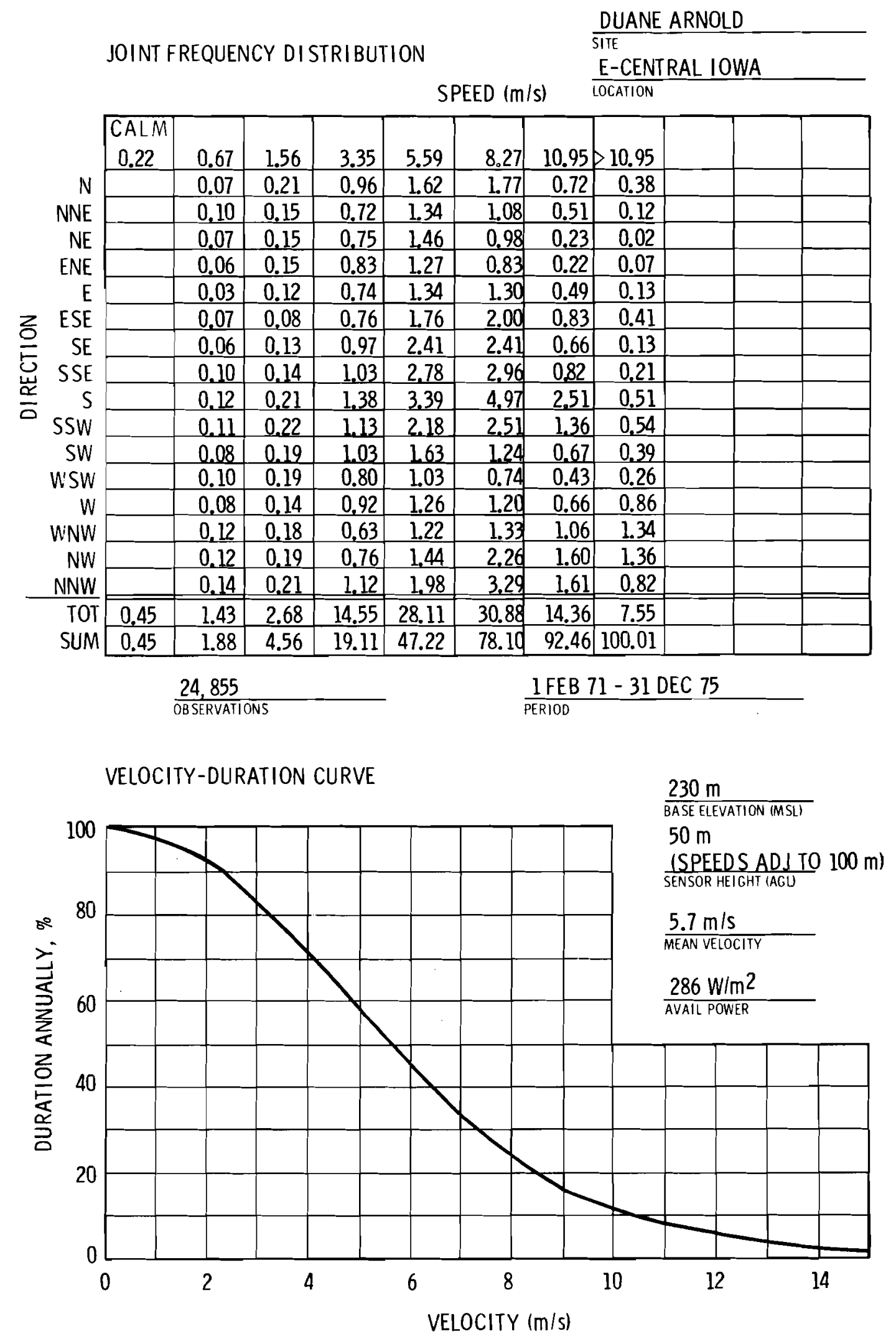




\section{SITE LOCATION:}

The proposed site of the Atlantic Generating Station $\left(39.47^{\circ} \mathrm{N} / 74.26^{\circ} \mathrm{W}\right)$ is located in the Atlantic Ocean about $4.5 \mathrm{~km}$ offshore from the SE coast of New Jersey. It is situated opposite Ocean and Atlantic counties on shore. Further, it is some $18 \mathrm{~km} \mathrm{NE}$ of Atlantic City, New Jersey, and opposite the Mullica River, which flows into the Atlantic Ocean via Great Bay and Little Egg Inlet.

\section{TOPOGRAPHY:}

The nearest land feature is the New Jersey coastline, some $5 \mathrm{~km}$ $W$ of the site. The coastal area is basically a series of elongated sandbars beyond which lies a maze of inland waterways and salt marshes. In general, the land is very flat.

ON-SITE WIND MEASUREMENTS:

A 10-m tower is instrumented at the top with climet ws-011-1 (speed) and Climet WD-012-10 (direction) sensors.

$\overline{\text { NRC Docket NO. STN50-477 }}$ 

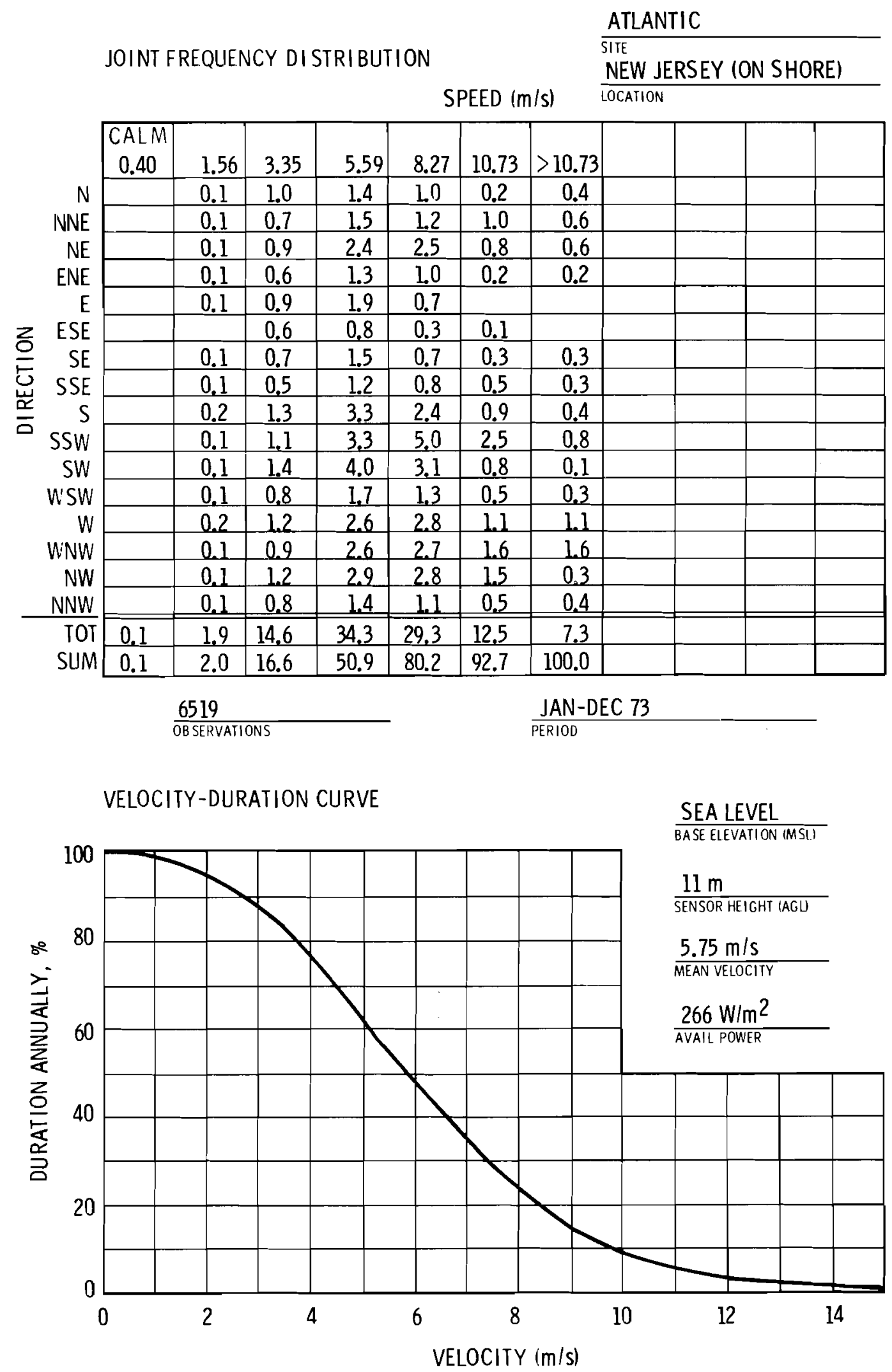


\section{SITE LOCATION :}

The site of the Bailly Generating Station $\left(41.63^{\circ} \mathrm{N} / 81.18^{\circ} \mathrm{W}\right)$ is located in Porter County, $19 \mathrm{~km} \mathrm{NE}$ of Gary, IN, at the S end of Lake Michigan, between the villages of Ogden Dunes to the $W$ and Dune Acres to the $E$.

\section{TOPOGRAPHY :}

The site is bordered by Lake Michigan from the $W$ through $N E$, by sand dunes to the $\mathrm{E}$, and by various industrial and/or residential areas throughout the remaining directions. Lake Michigan, whose elevation is $177 \mathrm{~m}$ (MSL), is $12 \mathrm{~m}$ below the site situation. Sand dunes paralleling the Lake Michigan shoreline to the NE vary considerably in slope, elevation and vegetative cover. At $230 \mathrm{~m}$ (MSL), Mt. Holden, $6.5 \mathrm{~km} \mathrm{NNE}$, is the highest feature of the region.

\section{ON-SITE WIND MEASUREMENTS:}

A 46-m tower based at $189 \mathrm{~m}$ (MSL) has been instrumented at the $18-\mathrm{m}$ and $46-\mathrm{m}$ levels. Wind speed and direction are measured with Bendix Aerovane Model 120 (6-bladed propeller) wind transmitters.

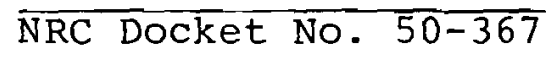




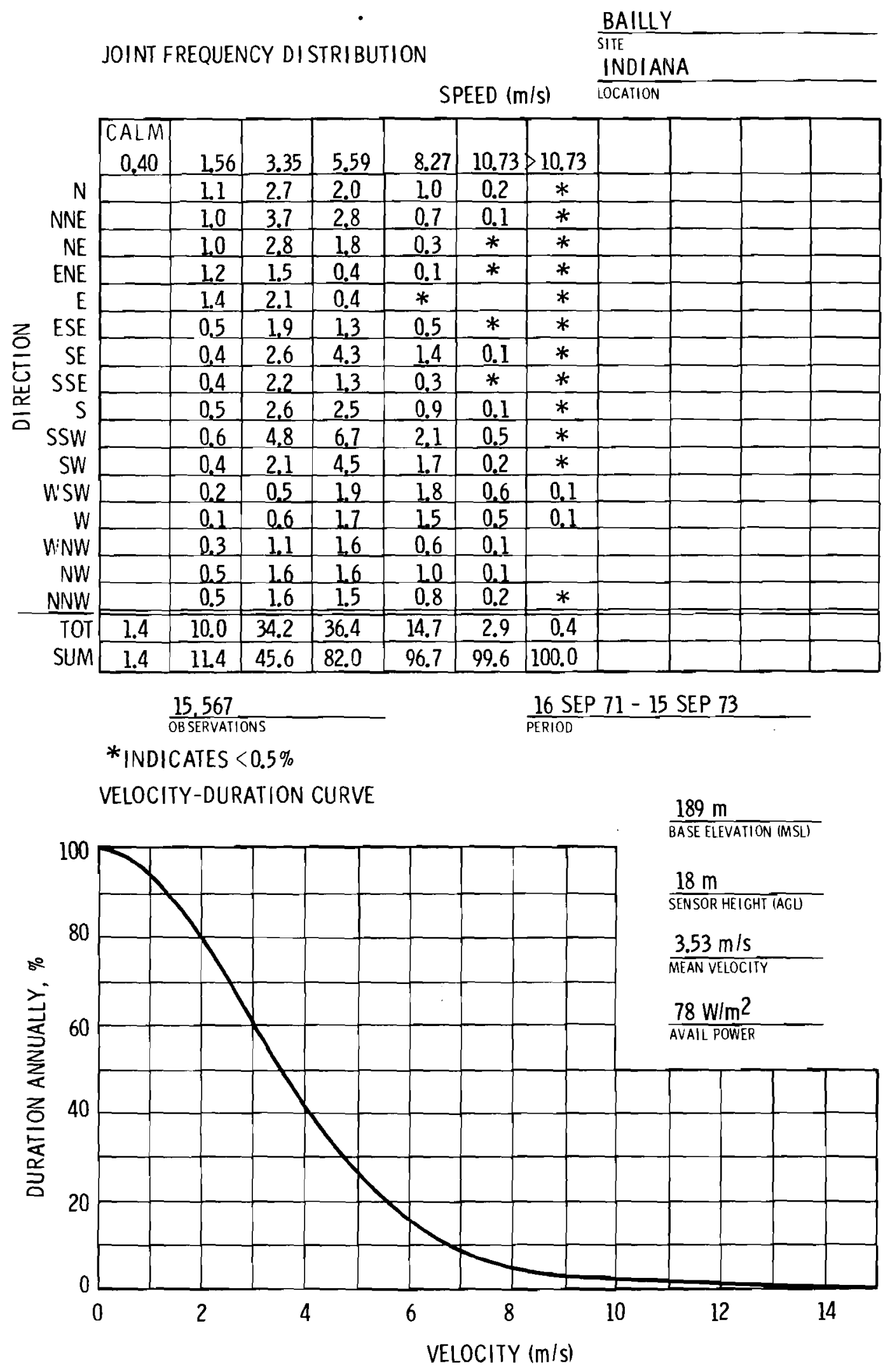



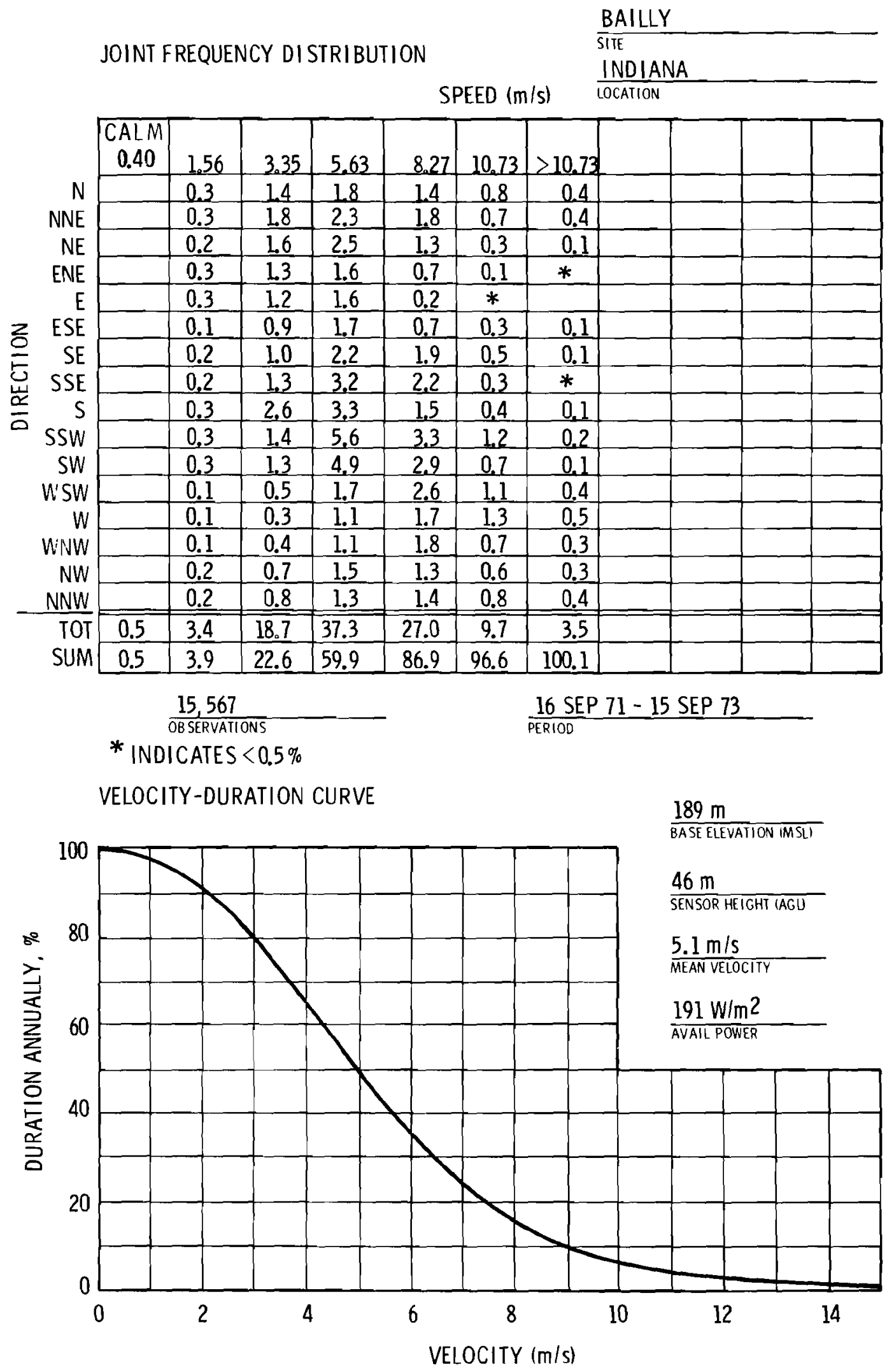
Alan R. BARTON

SITE LOCATION:

The Barton Nuclear Power Plant site $\left(32.75^{\circ} \mathrm{N} / 86.40^{\circ} \mathrm{W}\right)$ is located about $40 \mathrm{~km}$ NW of Montgomery, Alabama, and about 24 km ESE of Clanton.

TOPOGRAPHY :

The site is located in gently rolling, generally wooded country. Finished grade elevation at the site is approximately $135 \mathrm{~m}$ (MSL). The site is adjacent to the relatively narrow valley of the Coosa River, which has a water level of about $74 \mathrm{~m}$ near the site. The main topographical relief in the immediate area is attributable to the river valley and its tributary ravines.

ON-SITE WIND MEASUREMENTS:

A 61-m tower was installed in september 1973 at about $138 \mathrm{~m}$ (MSL). Wind speed and direction are measured by Climet WS-011-1 (speed) and Climet WD-012-10 (direction) instruments at $11 \mathrm{~m}, 30 \mathrm{~m}$ and $59 \mathrm{~m}$ elevation above ground level (AGL).

NRC Docket No. 50-254

$\mathrm{C}-15$ 


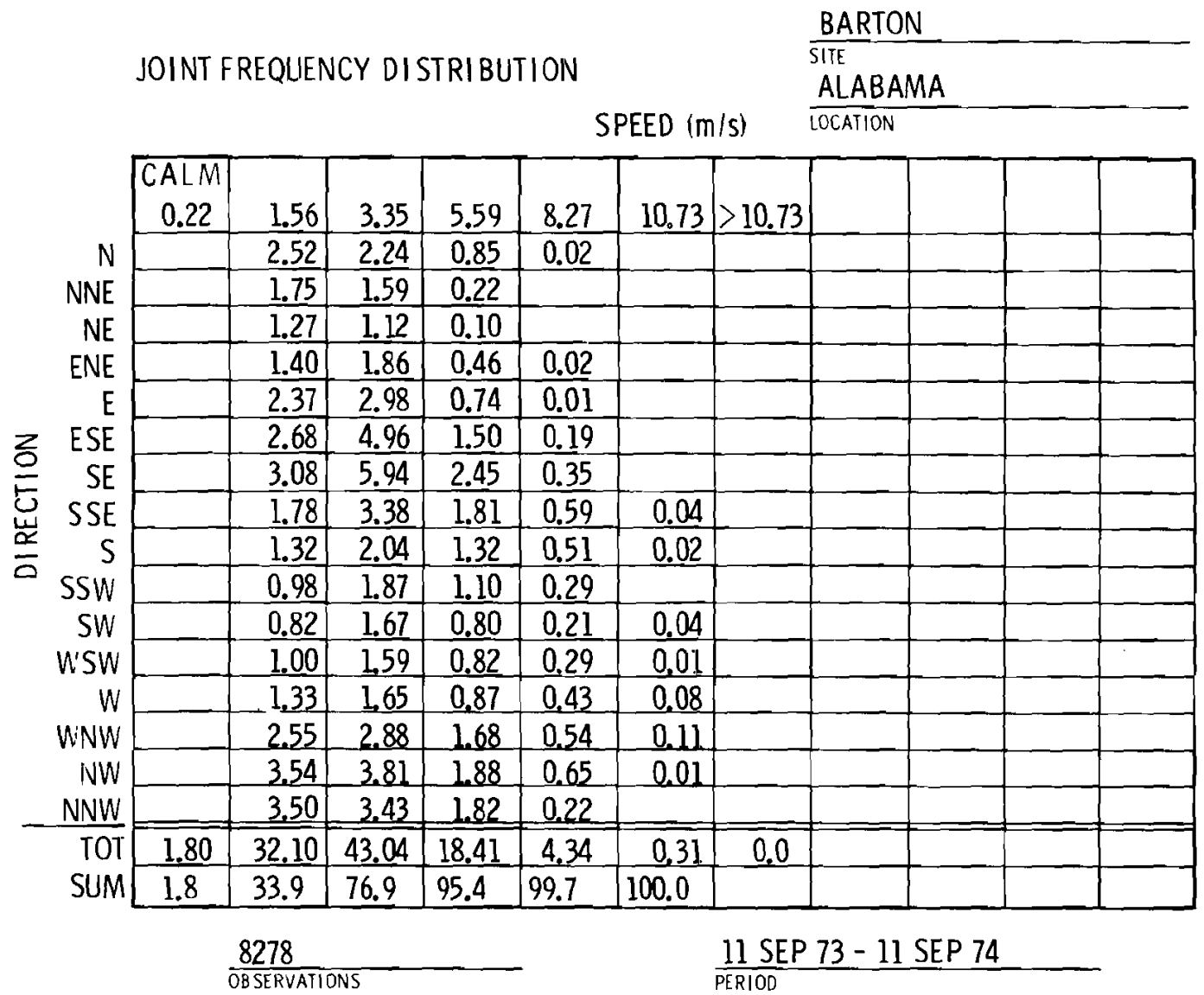

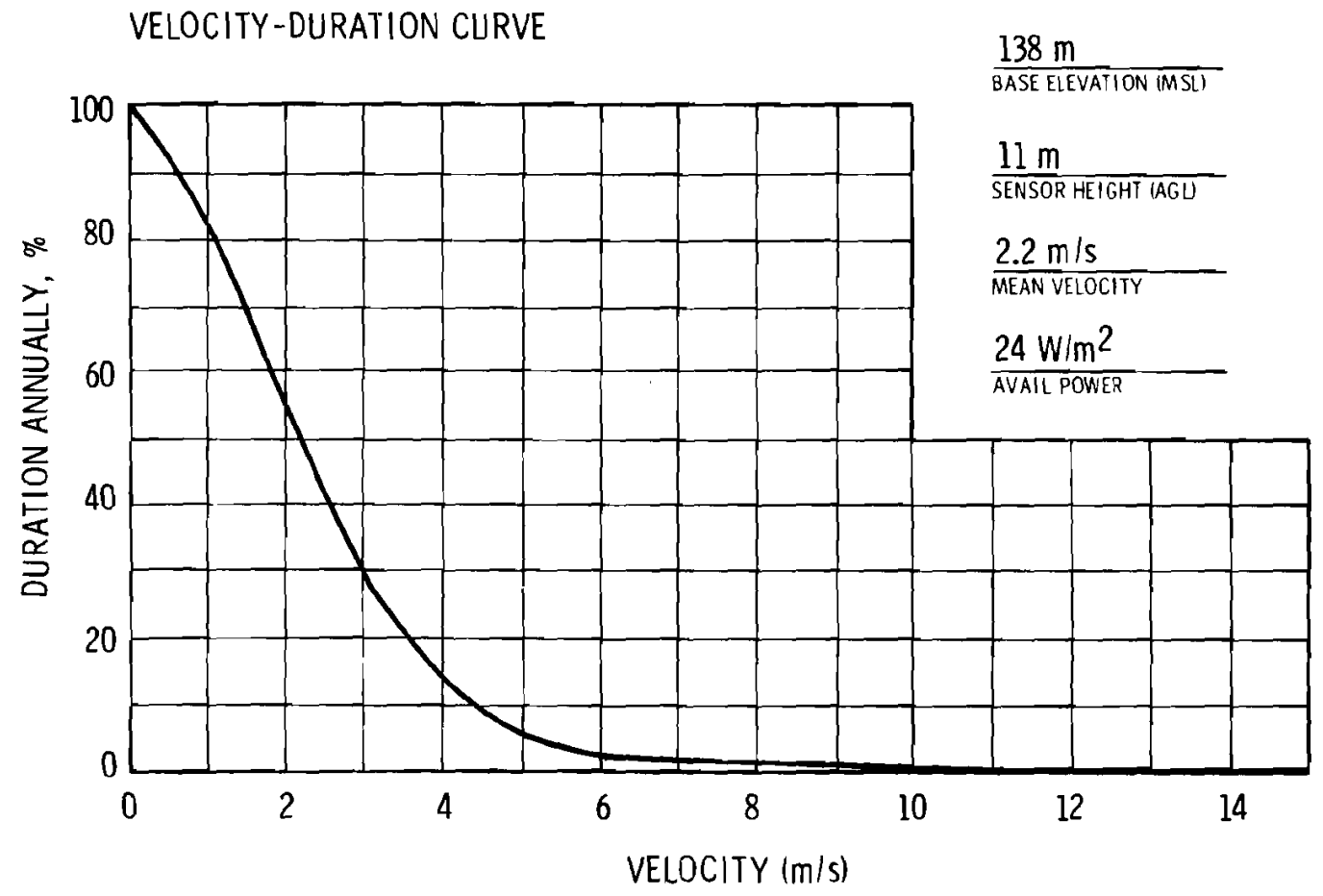


BEAVER VALLEY/SHIPPINGPORT

\section{SITE LOCATION:}

The Beaver Valley site $\left(40.62^{\circ} \mathrm{N} / 80.43^{\circ} \mathrm{W}\right)$ is located on the south bank of the Ohio River, about $50 \mathrm{~km}$ NW of Pittsburgh, Pennsylvania, and about $6.5 \mathrm{~km} \mathrm{E}$ of the Ohio-West Virginia state line, $7.5 \mathrm{~km}$ ESE of East Liverpool, Ohio. This is also the site of the Shippingport nuclear unit.

\section{TOPOGRAPHY:}

The west portion of Pennsylvania in the vicinity of the Beaver Valley Power Station site lies on the west slope of the Allegheny Mountains, $145 \mathrm{~km} \mathrm{SE}$ of Lake Erie and some $550 \mathrm{~km}$ across several mountain ranges to the Atlantic Ocean. The major topographical influence is the deep, enclosed ohio River valley. The valley is sharply defined by the hills and bluffs extending to an average height of $120 \mathrm{~m}$ to $155 \mathrm{~m}$ within short distance of the river banks. The average width of the ohio River valley in the vicinity of the site is approximately $1.6 \mathrm{~km}$. ON-SITE WIND MEASUREMENTS:

A 46-m tower was instrumented on 19 April 1969 with Bendix Friez Aerovanes (6-bladed propeller and vane) at the 15-m and 46-m levels. Tower base is at approximately $205 \mathrm{~m}$ (MSL).

NRC Docket Nos. $50-334,50-412$ 


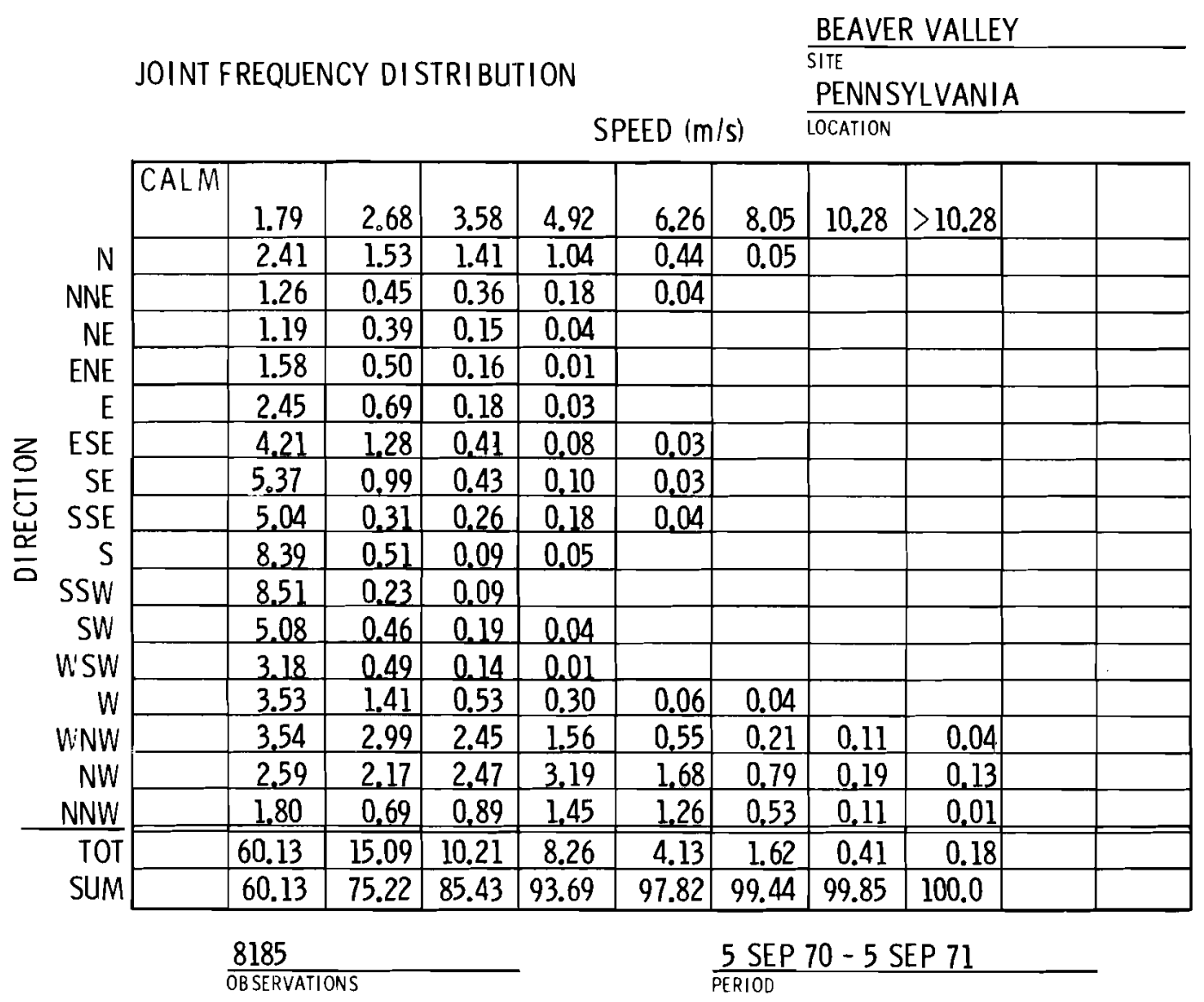

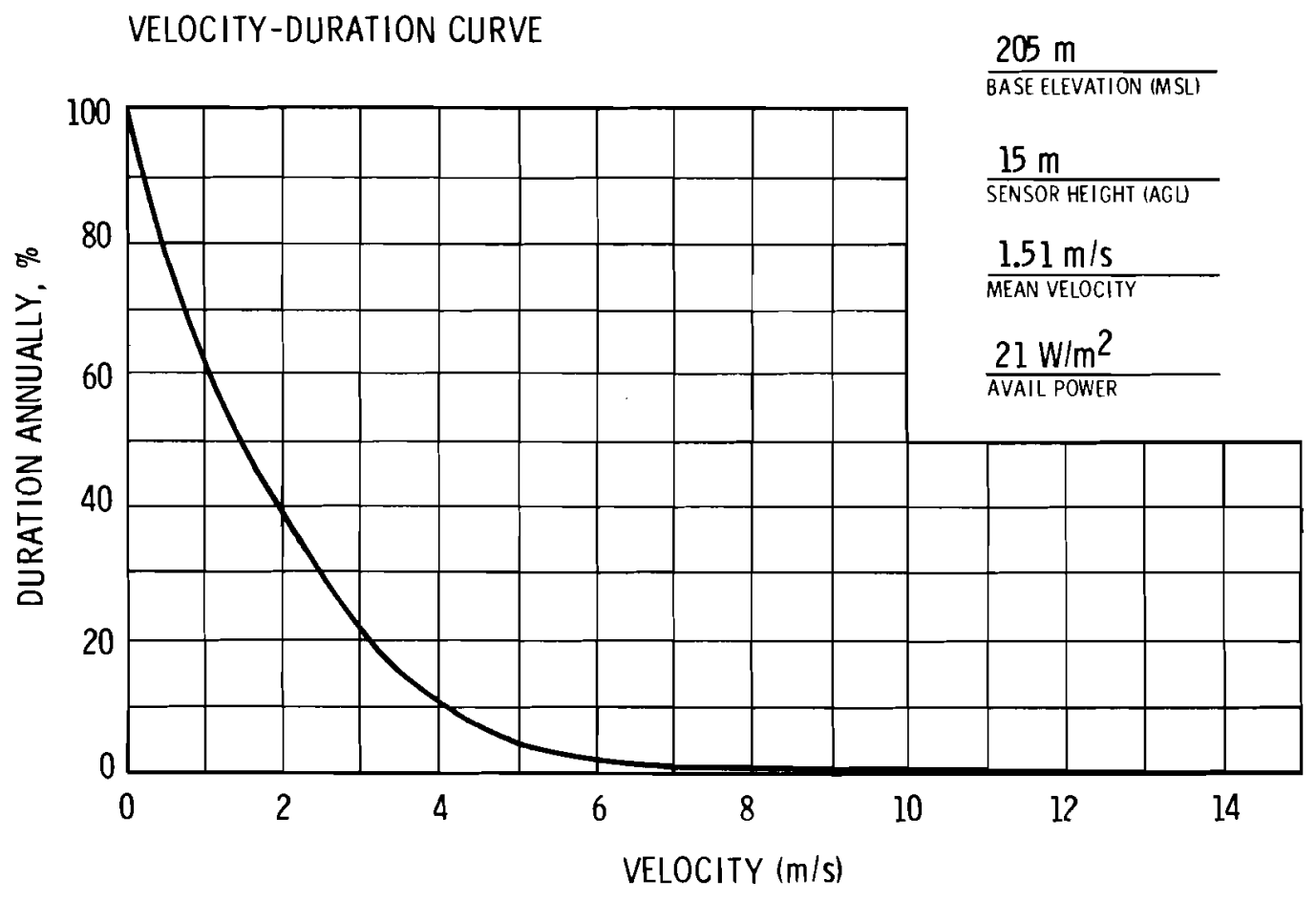




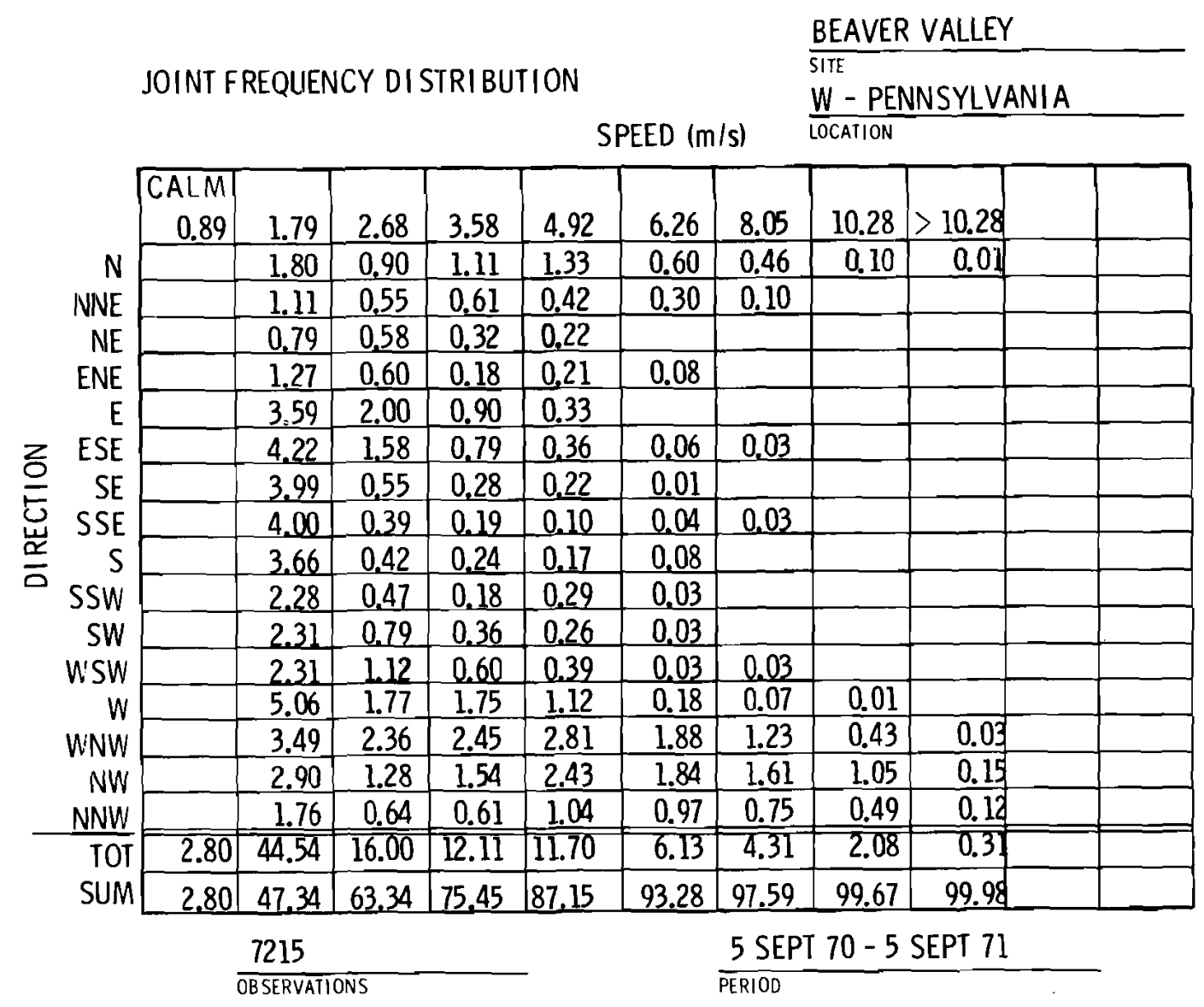

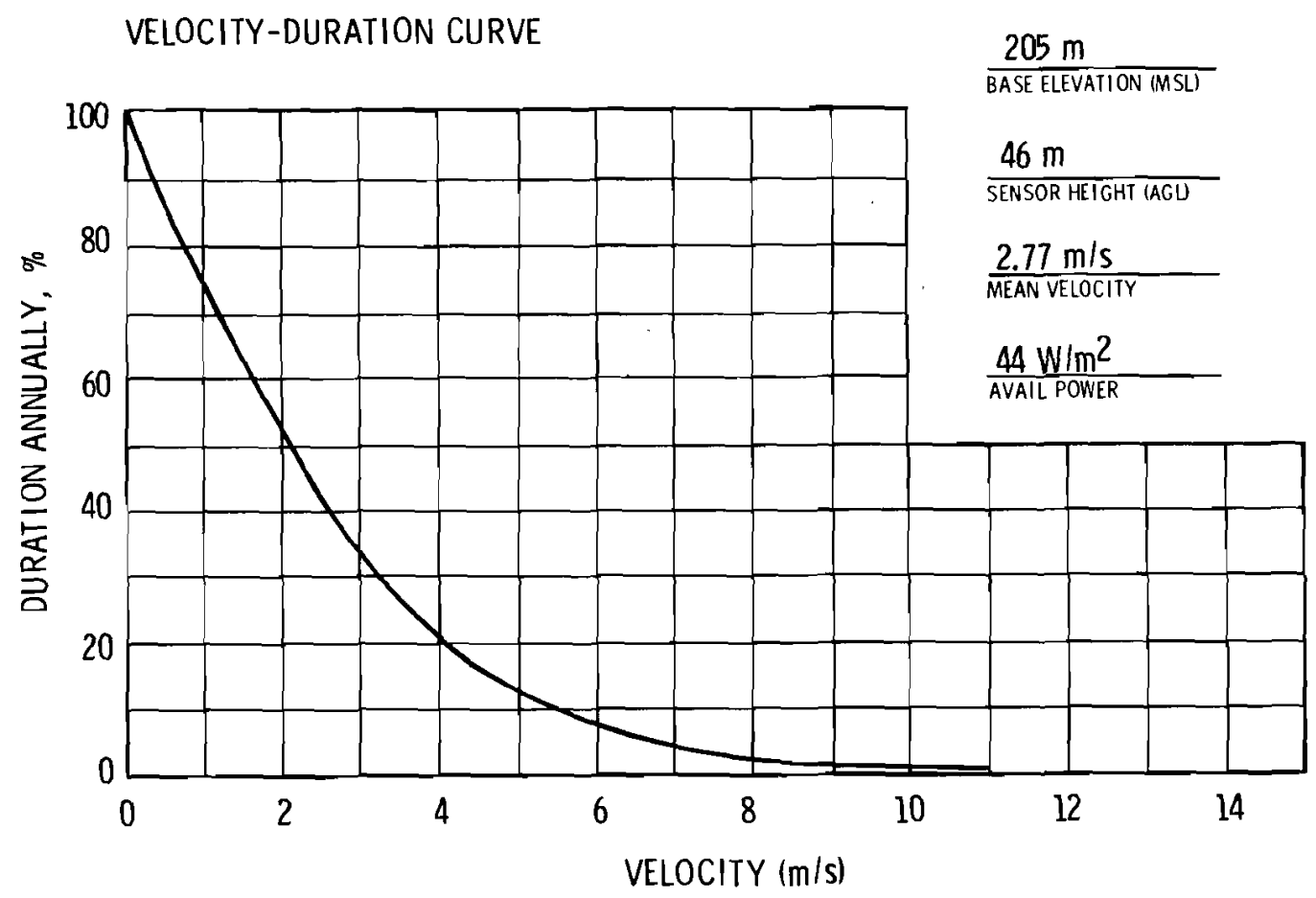


BELLEFONTE

\section{SITE LOCATION:}

The Bellefont Nuclear Power Plant site $\left(34.71^{\circ} \mathrm{N} / 85.93^{\circ} \mathrm{W}\right)$ is located in NE Alabama, $89 \mathrm{~km}$ E of Huntsville, $72 \mathrm{~km}$ WSW of Chattanooga, and $11 \mathrm{~km}$ ENE of Scottsboro, in Jackson County. The site is also $93 \mathrm{~km}$ SW of the Sequoyah Nuclear Plant.

\section{TOPOGRAPHY :}

The Bellefonte site lies in the sw end of the Appalachian Mountains, along the upper reaches of Guntersville Lake on the Tennessee River. The general terrain consists of wooded, rather rugged hills. The Tennessee River flows southsouthwestward, forming a relatively narrow valley some $245 \mathrm{~m}$ deep. The plant is located on the flat to gently rolling floor at $192 \mathrm{~m}$ (MSL) in close proximity to the river.

\section{ON-SITE WIND MEASUREMENTS:}

Data from Bellefonte's 91-m on-site tower were not yet available; however, a 40-m tower, located $3.5 \mathrm{~km}$ NNW of the site at about $186 \mathrm{~m}$ (MSL), approximately $6 \mathrm{~m}$ below plant grade, was established on 12 May 1972. Data are collected at $10 \mathrm{~m}$ and $40 \mathrm{~m}$ with Climet WS-01I-1I (speed) and Climet WD-012-11 (direction) instruments.

$\overline{\text { NRC Docket No. } 50-438}$ 


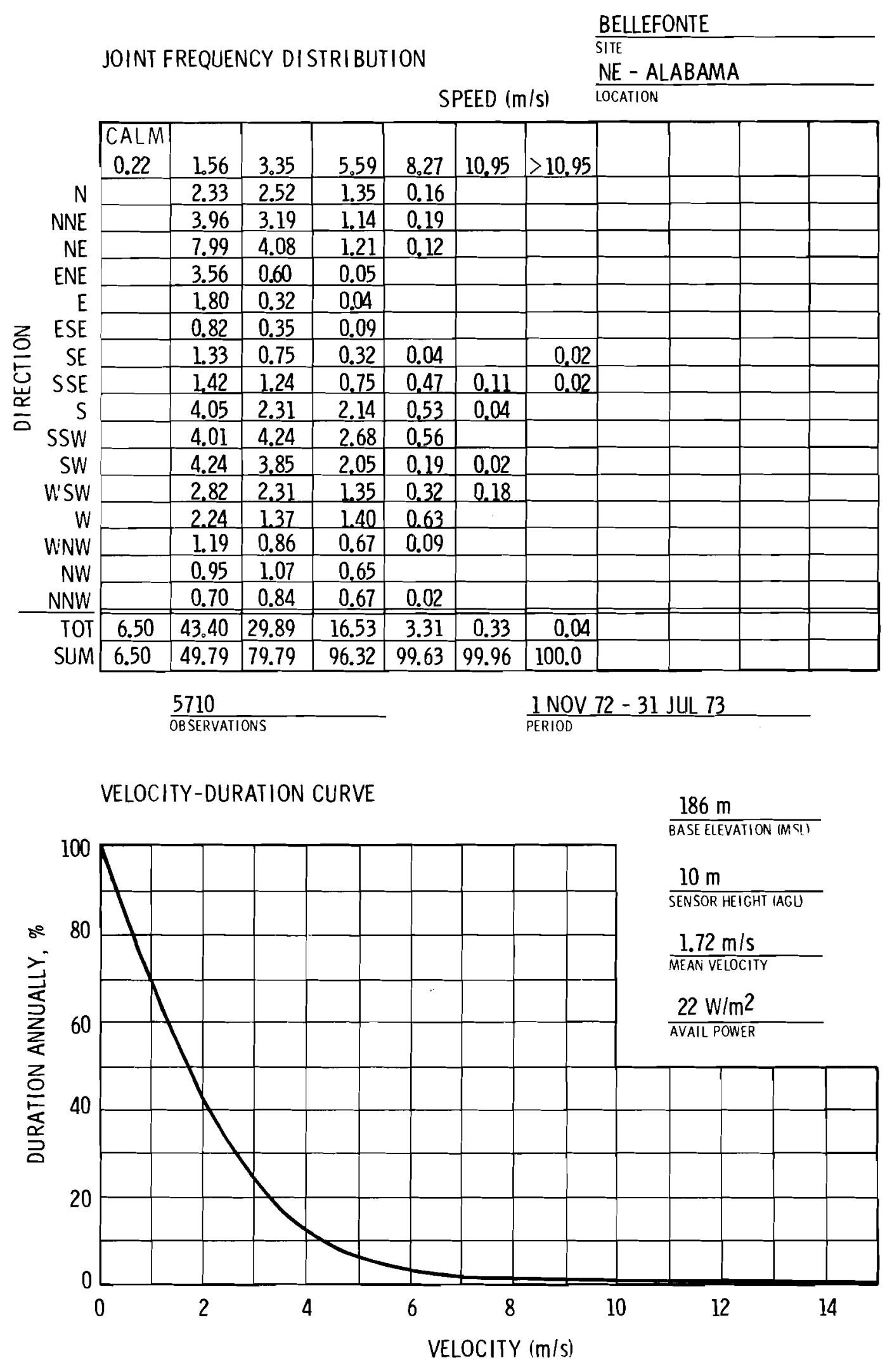




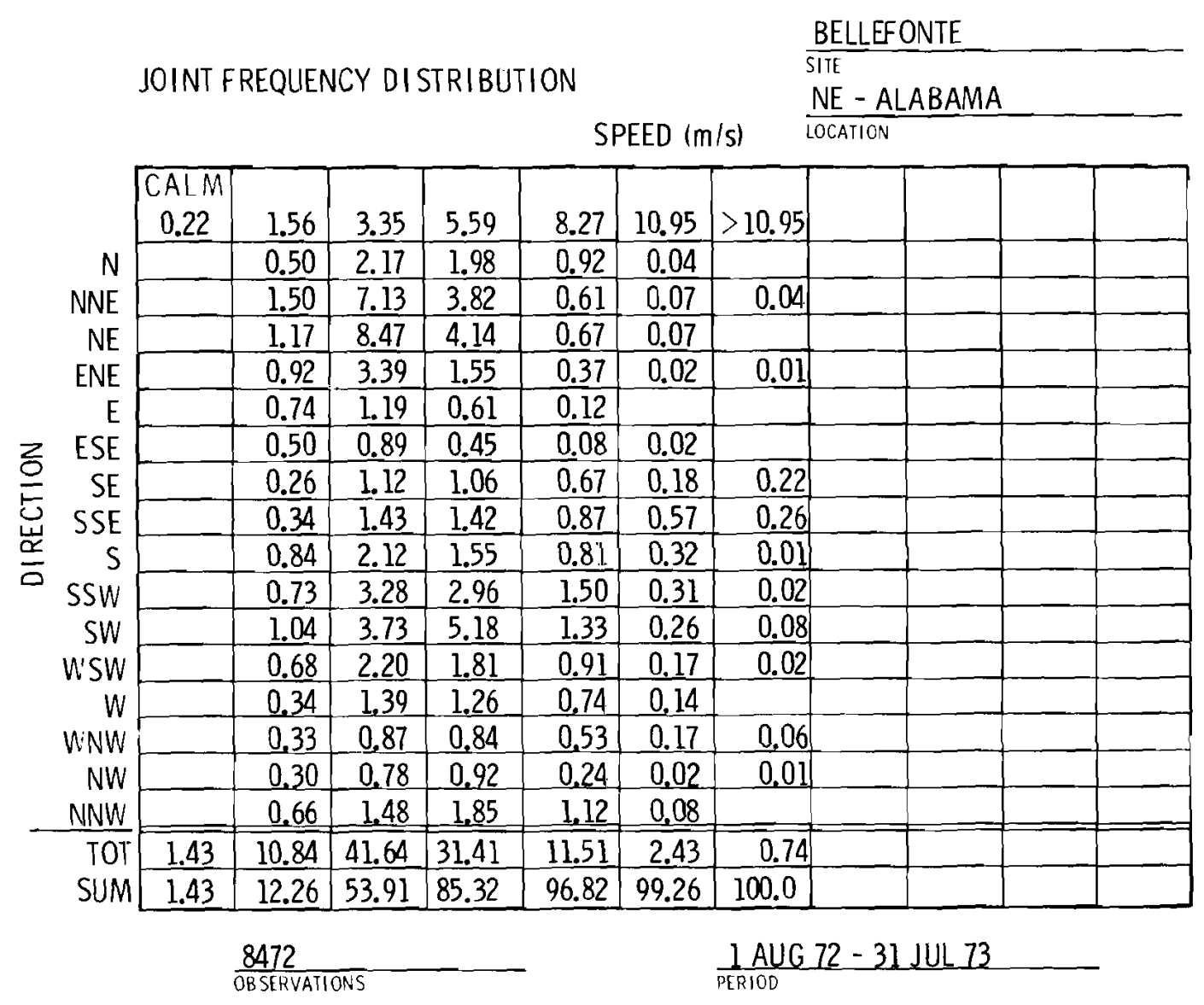

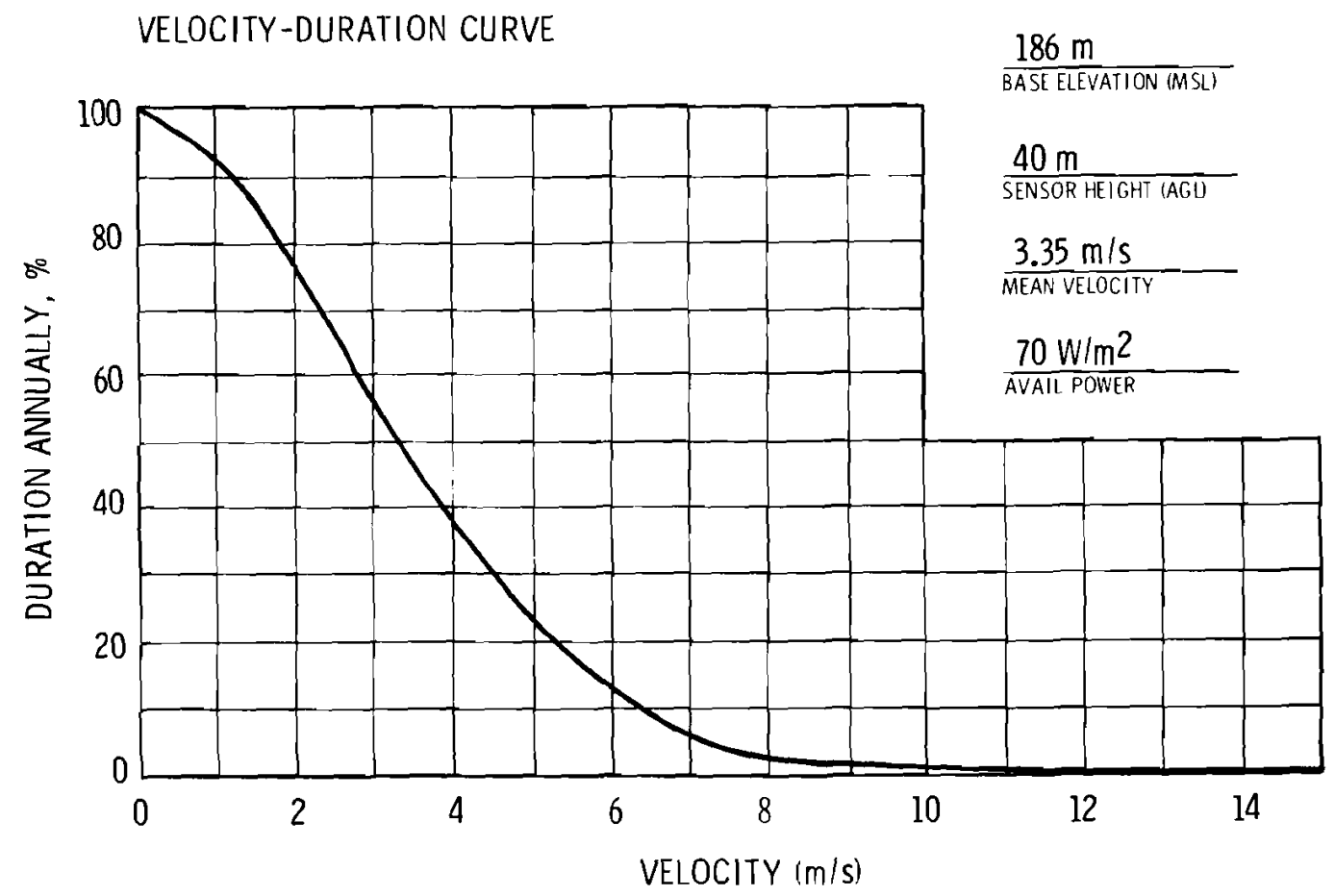




\section{SITE LOCATION:}

The Big Rock Point Nuclear Power Plant site $\left(45.35^{\circ} \mathrm{N} / 85.18^{\circ} \mathrm{W}\right)$ is located in Charlevoix County, Michigan, $6.5 \mathrm{~km} \mathrm{NE}$ of Charlevoix and $19.3 \mathrm{~km} \mathrm{~W}$ of Petoskey, on the north shore of Michigan's lower peninsula. The site consists of 600 acres on the $W$ extremity of the south shore of Little Traverse Bay. The site is $367 \mathrm{~km}$ NNW of Detroit and $422 \mathrm{~km} \mathrm{NNE}$ of Chicago.

\section{TOPOGRAPHY :}

The region for several kilometers around the site consists of gently sloping, partly wooded land. Lake Charlevoix, a significant inland extension of Lake Michigan, lies $5 \mathrm{~km}$ to the south, and Little Traverse Bay, which opens to Lake Michigan, lies immediately north.

ON-SITE WIND MEASURFMFNTS:

Wind data were collected using a 3-cup Electric speed Indicator Company instrument of unknown accuracy and a locally fabricated vane. Data were taken at the $78 \mathrm{~m}$ level. Base elevation was approximately $190 \mathrm{~m}$ (MSL).

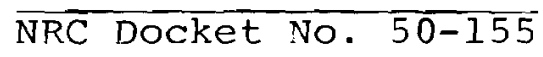



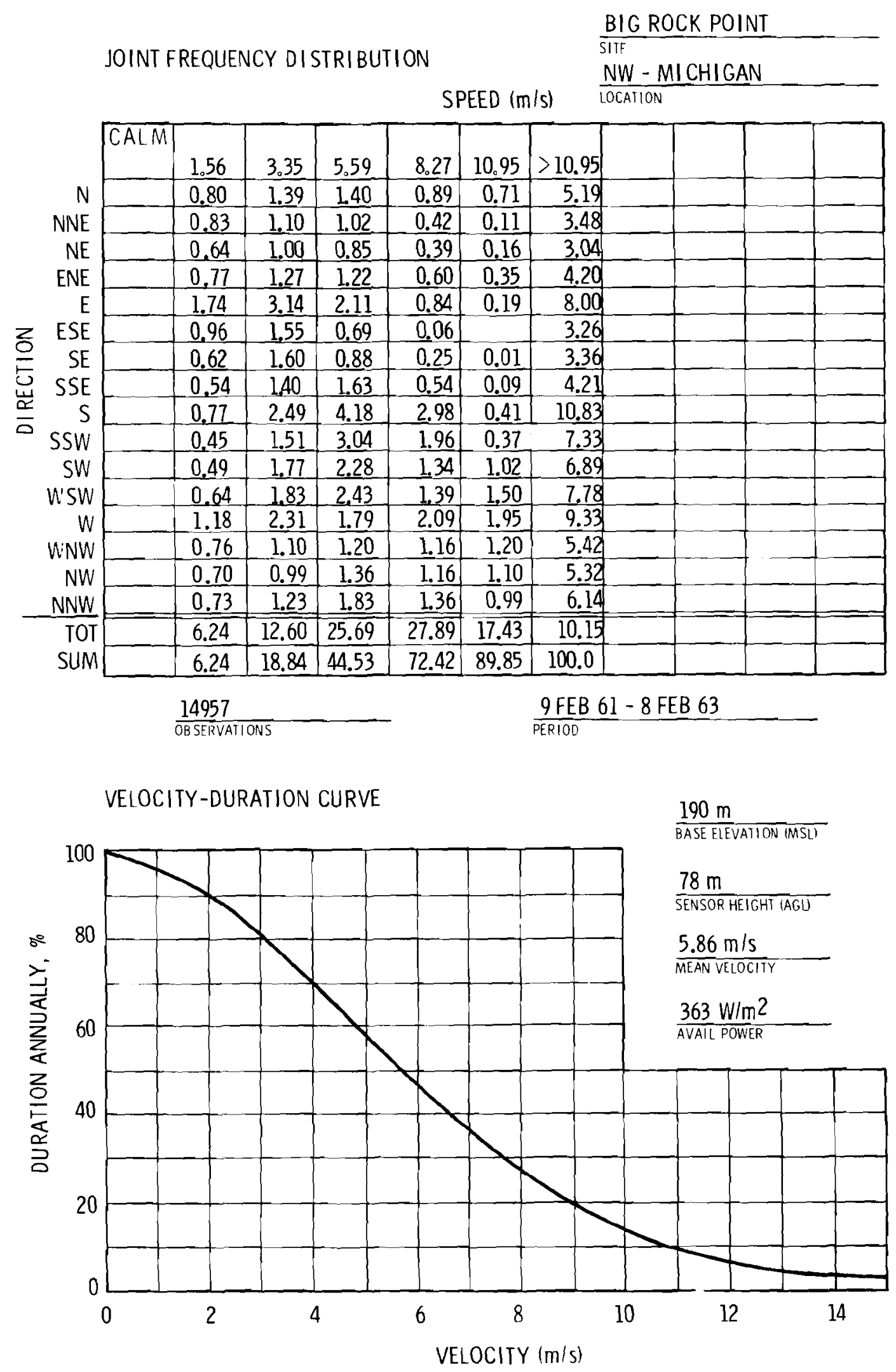
BLACK FOX

\section{SITE LOCATION:}

The plant site is located in Inola township of Rogers county, oklahoma $\left(36.12^{\circ} \mathrm{N} / 95.55^{\circ} \mathrm{W}\right)$ within the expanded city limits of Inola. Tiawah, a small unincorporated community, is $16 \mathrm{~km} \mathrm{~N}$; Fort Gibson Reservoir is about $19 \mathrm{~km} \mathrm{ESE;} \mathrm{and} \mathrm{Tulsa} \mathrm{is} 37 \mathrm{~km}$ W. The Tulsa NWS station is $31 \mathrm{~km}$ WNW of Balck Fox Station.

\section{TOPOGRAPHY :}

The 2006-acre site and its environs consist primarily of pastures and woodlands along the verdigris River. The surrounding terrain is generally gently rolling hills. Black Fox station is about $187 \mathrm{~m}$ (MSI) in elevation, and the maximum variations are a rise of $40 \mathrm{~m}, 8 \mathrm{~km}$ to the north and a drop of $15 \mathrm{~m}$ to the Verdigris River and Adams Creek on the west boundary.

ON-SITE WIND MEASUREMENTS:

A $100 \mathrm{~m}$ tower was erected in November 1973 at $174 \mathrm{~m}$ (MSL). The tower was instrumented at $10 \mathrm{~m}, 40 \mathrm{~m}$ and $98 \mathrm{~m}$ with MRI 1074-2 wind measurement systems.

$\overline{\text { NRC Docket No. STN50-556 }}$ 


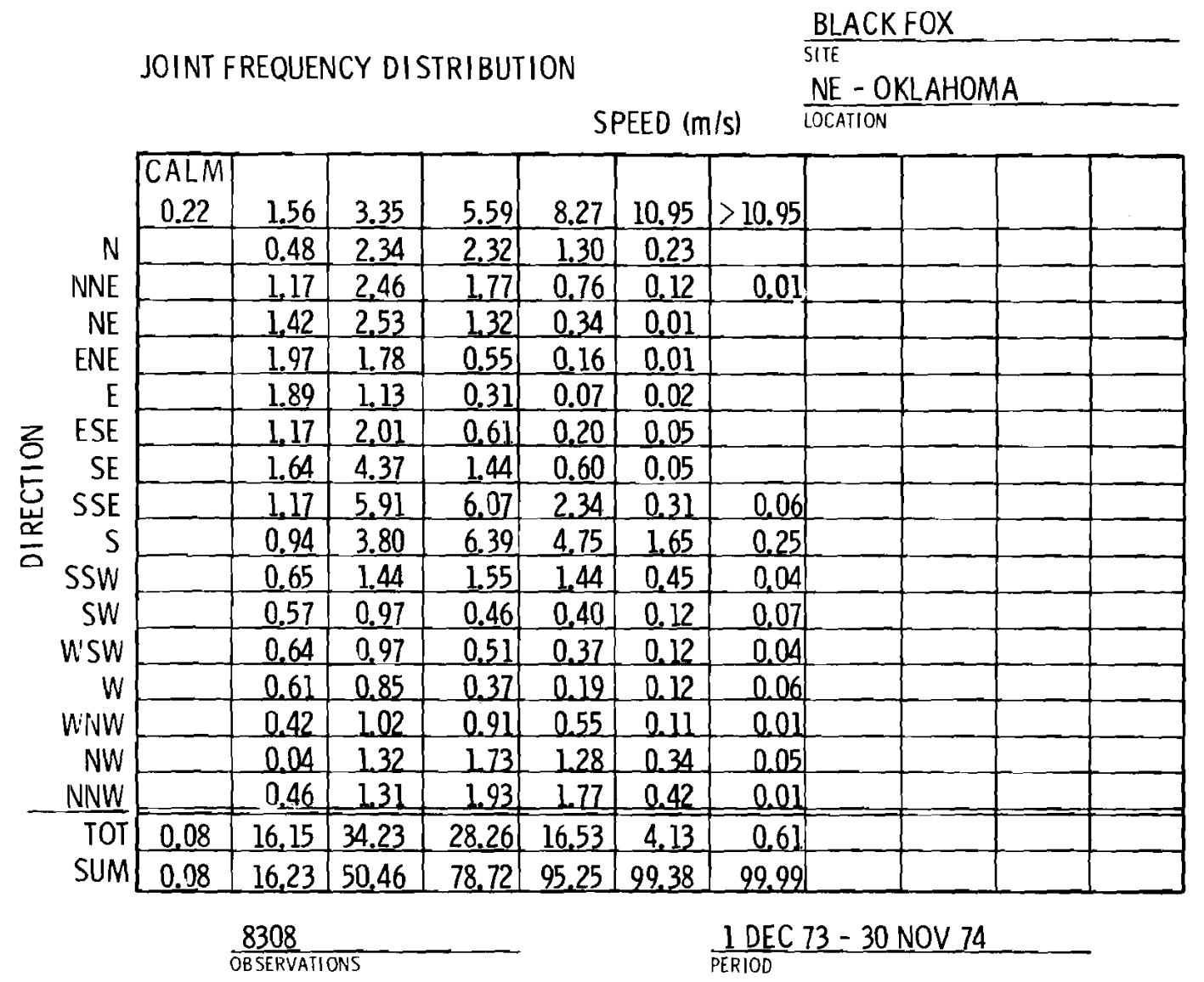

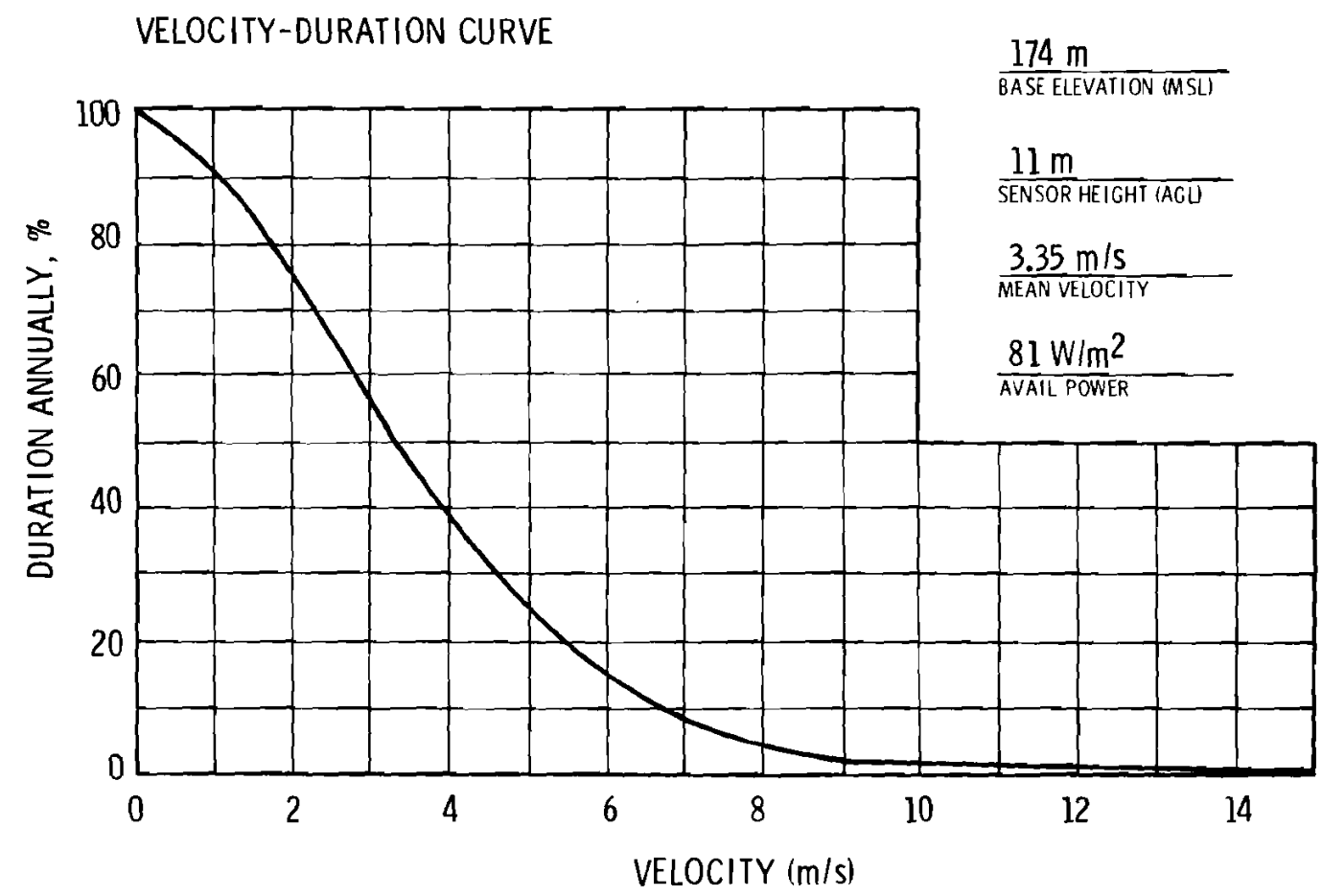


BLUE HILLS

\section{SITE LOCATION:}

Blue Hills station $\left(31.14^{\circ} \mathrm{N} / 93.69^{\circ} \mathrm{W}\right)$ is located in the $\mathrm{NE}$ corner of Newton County, Texas, $3.2 \mathrm{~km}$ SW of Toledo Bend Reservoir and $27 \mathrm{~km} \mathrm{E}$ of Sam Rayburn Reservoir. The site is about $40 \mathrm{~km}$ ENE of Jasper and $16 \mathrm{~km} \mathrm{~N}$ of Wiergate and Burkeville. The Texas-Louisiana border is $14.5 \mathrm{~km} \mathrm{E}$ of the site. The Gulf of Mexico is $153 \mathrm{~km}$ to the $\mathrm{S}$.

\section{TOPOGRAPHY:}

The site is composed of about 3016 acres at an elevation of about $82 \mathrm{~m}$ (MSL). The terrain is generally rolling or slightly hilly. The site and surrounding area are heavily wooded, primarily with long-needled pines rising 12 to $22 \mathrm{~m}$ in height. The rolling terrain characteristic of the site gives way near Newton, Texas, $43 \mathrm{~km} \mathrm{~S}$, and becomes almost flat the remaining $110 \mathrm{~km}$ to the gulf. Terrain in other directions is mostly rolling with no pronounced features.

\section{ON-SITE WIND MEASUREMFNTS:}

A 55-m tower was completed in october 1973. Wind speed and direction were measured at $10 \mathrm{~m}$ and $55 \mathrm{~m}$ with TeledyneGeotech 50.1 and 50.2 systems for speed and direction, respectively. Wind speed is also measured at $20 \mathrm{~m}$ and $30 \mathrm{~m}$, but not wind direction. Tower base is at approximately $82 \mathrm{~m}$ (MSL).

$\overparen{\text { NRC Docket No. STN50-5̄ }}$ 

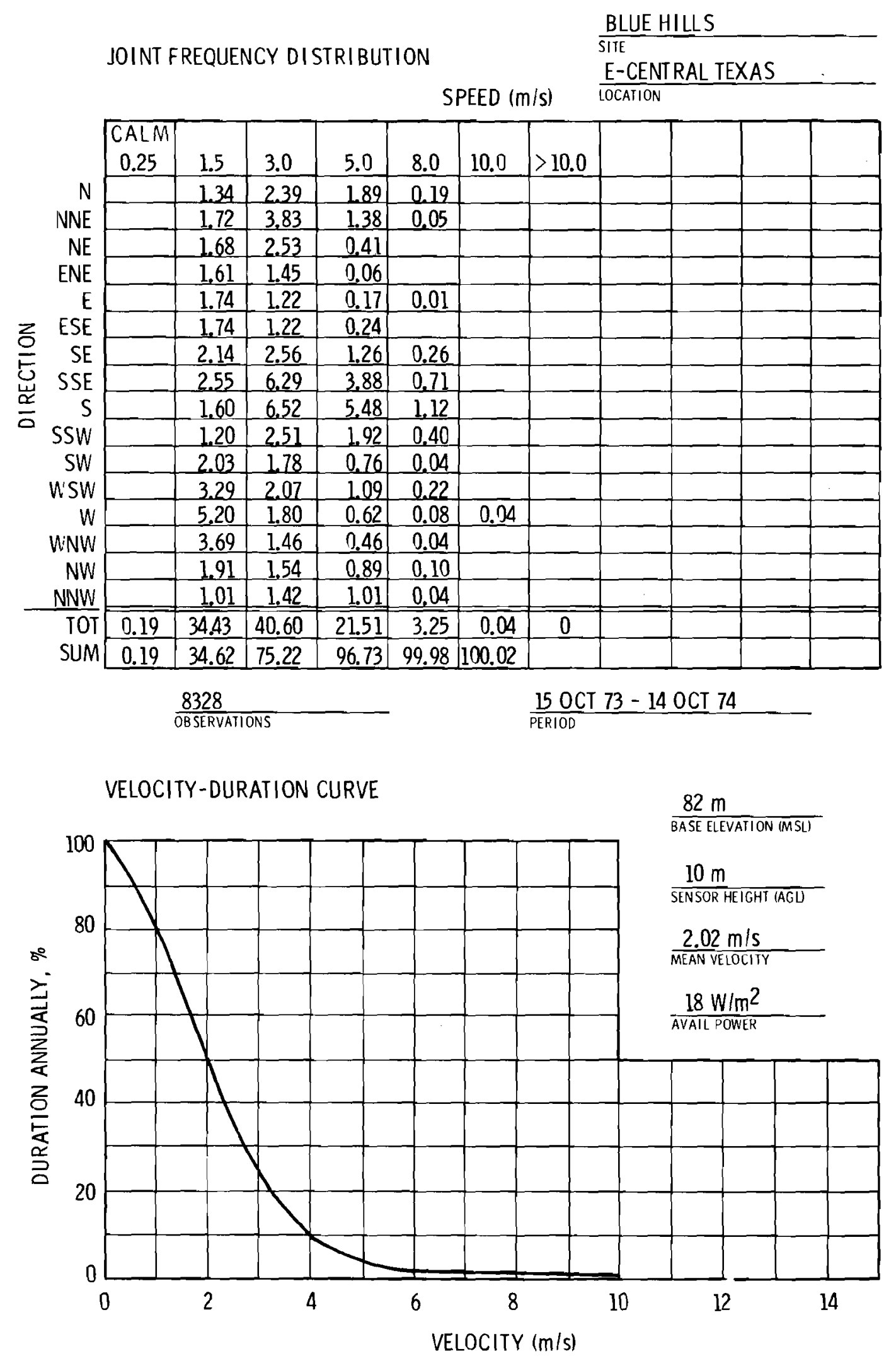

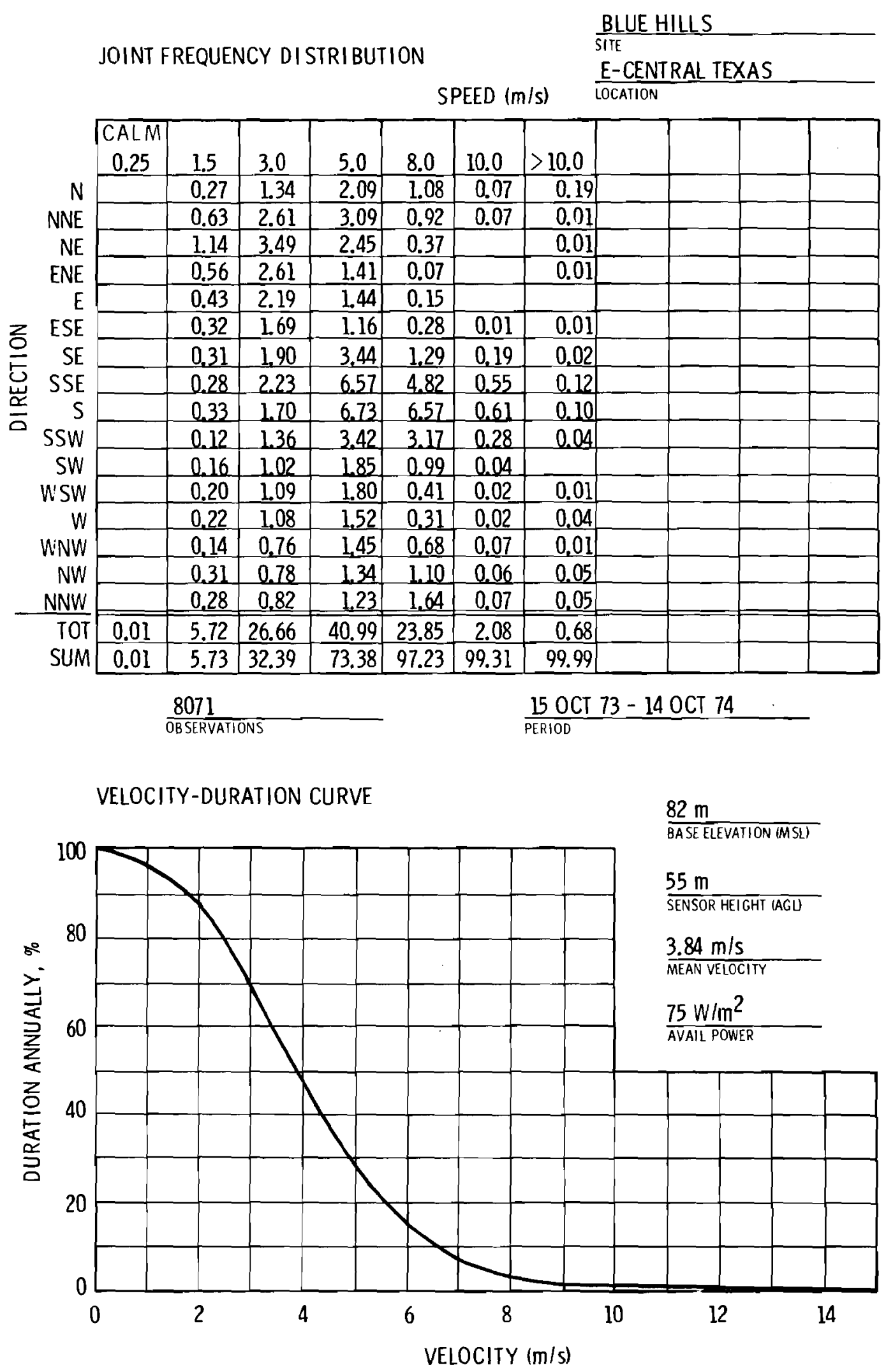
BRAIDWOOD

SITE LOCATION:

The Braidwood site $\left(41.24^{\circ} \mathrm{N} / 88.23^{\circ} \mathrm{W}\right)$ is in north central Illinois, in the SW corner of Will County, approximately $80 \mathrm{~km}$ SW of Chicago, and $32 \mathrm{~km}$ SSW of Joliet. The NW corner of the site is adjacent to the community of Godley and its south border lies along the Will-Kankakee County line.

TOPOGRAPHY :

The terrain in northern Illinois is generally flat. The site is located on the Kankakee plain in an area where farmlands have been displaced by strip coal mining. This specific area has already been mined to a great extent by Peabody coal Company. The 98-m meteorological tower, at an elevation of $183 \mathrm{~m}$, is at one of the highest points within an 8-km radius. The lowest points within $8 \mathrm{~km}$ are at about $168 \mathrm{~m}$ and the slope from the higher terrain to the lower points is generally gradual. The kankakee River lies $5 \mathrm{~km} \mathrm{E}$ of the $\mathrm{NE}$ site boundary. The meteorological tower is located in the center of a large open field with no other tall structures or trees in the vicinity.

ON-SITE WIND MEASUREMENTS:

The tower was completed in October, 1973. The 98-m tower is at an elevation of $183 \mathrm{~m}$ (MSL) and is some $670 \mathrm{~m} \mathrm{NE}$ of the nearest building. Wind speed and direction are measured at $9 \mathrm{~m}$ and $61 \mathrm{~m}$ with MRI 1074-1 combined cup and vane sensors.

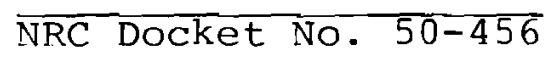



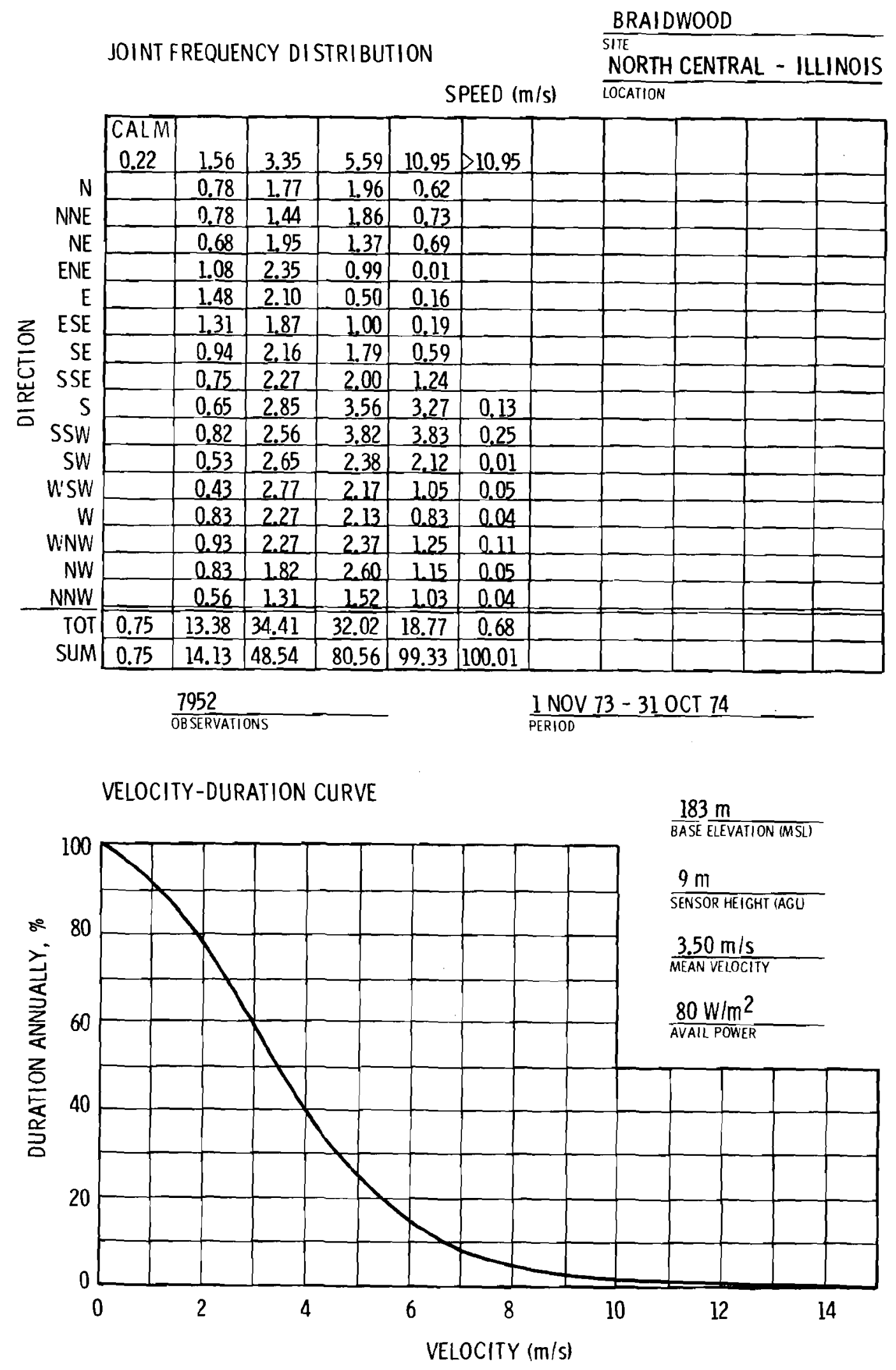
BROWNS FERRY

\section{SITE LOCATION:}

The site is located on the north shore of Wheeler Lake in Limestone County in northern Alabama $\left(34.72^{\circ} \mathrm{N} / 87.10^{\circ} \mathrm{W}\right)$. The site is approximately $16 \mathrm{~km} \mathrm{sw}$ of Athens, Alabama, and $16 \mathrm{~km}$ NW of Decatur, Alabama.

\section{TOPOGRAPHY:}

The Browns Ferry site is adjacent to the Tennessee River, which flows NW at this location. There are no significant physiographic features at the site as the immediate terrain is flat or slightly undulating with scattered 120 to $190 \mathrm{~m}$ foothills and ridges located 30 to $40 \mathrm{~km}$ to the $E$ through $\mathrm{S}$ and SW. Wheeler Lake adjoins the site and averages 1.5 to $2.5 \mathrm{~km}$ in width; however, there is little valley feature relief. Wheeler Lake is at $169 \mathrm{~m}$ (MSL).

\section{ON-SITE WIND MEASUREMENTS:}

A $91-m$ tower was erected in February 1967, then relocated twice. In March 1973, the tower was moved to its present location at about $9 \mathrm{~m}$ above plant grade, 172 (MSL). The tower is instrumented with Climet WS-011-1 (speed) and Climet WD-012-11 (direction) sensors at both the 10-m and the 91-m levels.

$\overline{\text { NRC }} \overline{\text { Docket }}$ Nos. $\overline{50-259, \overline{50-296}}$ 

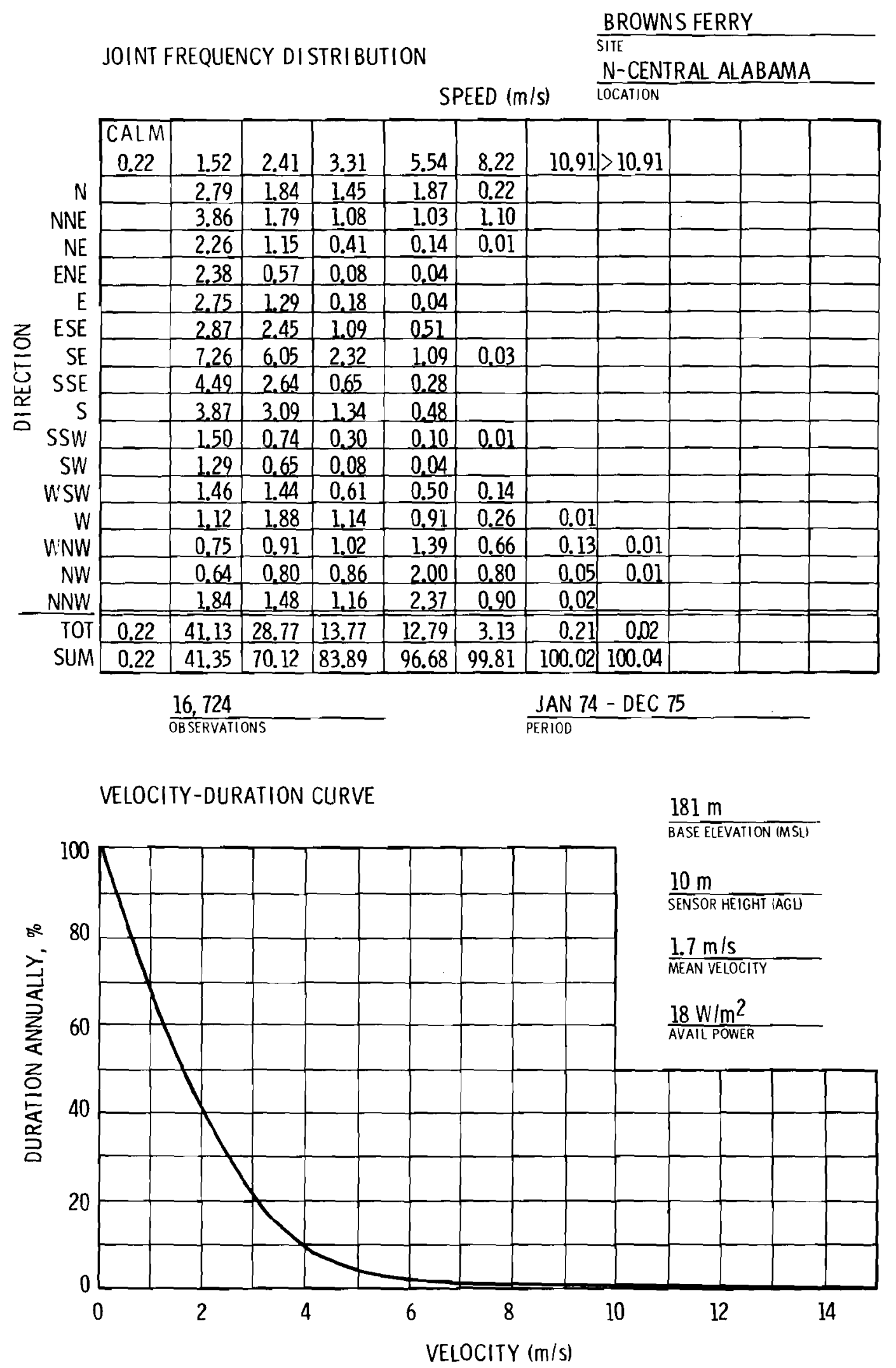


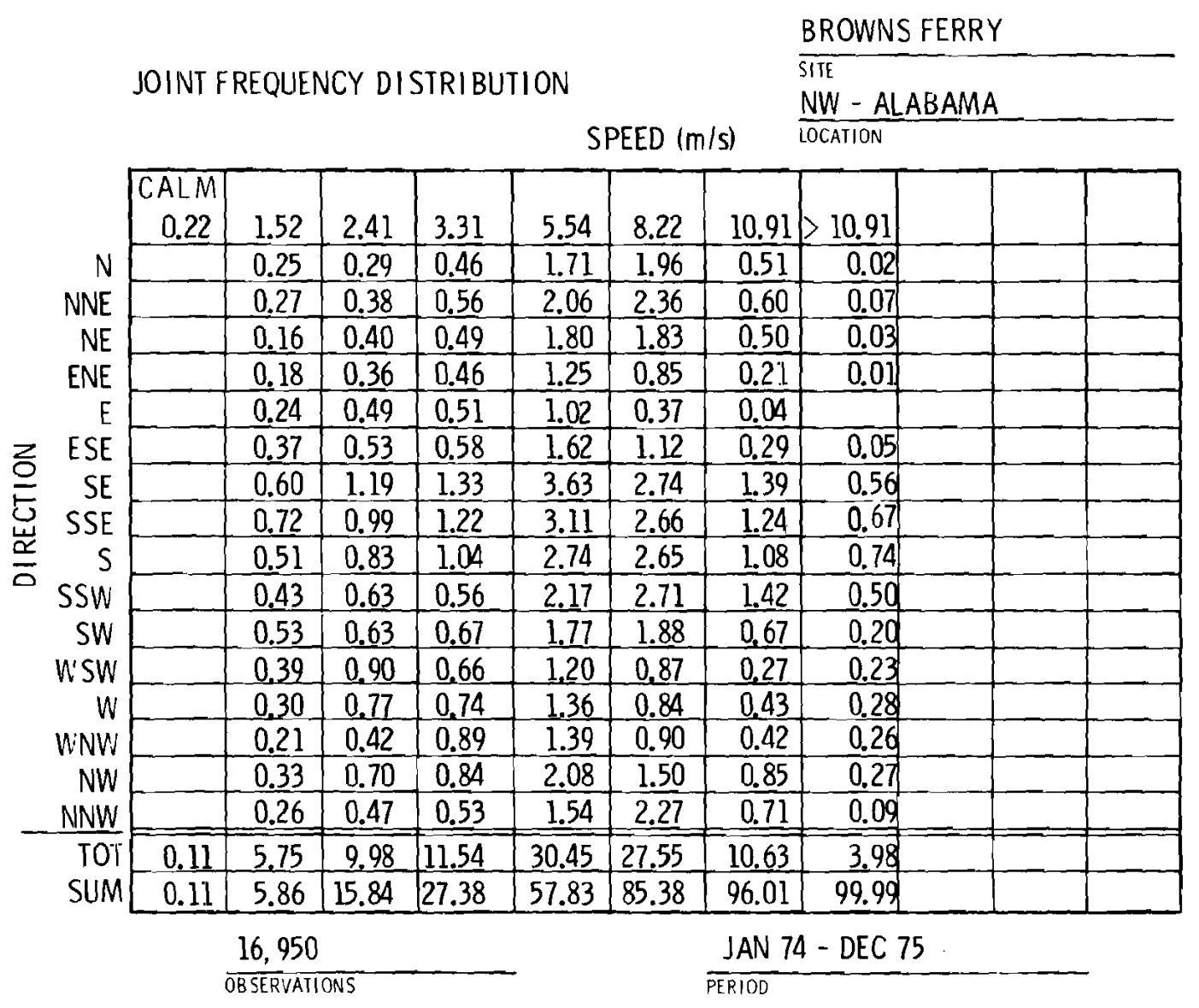

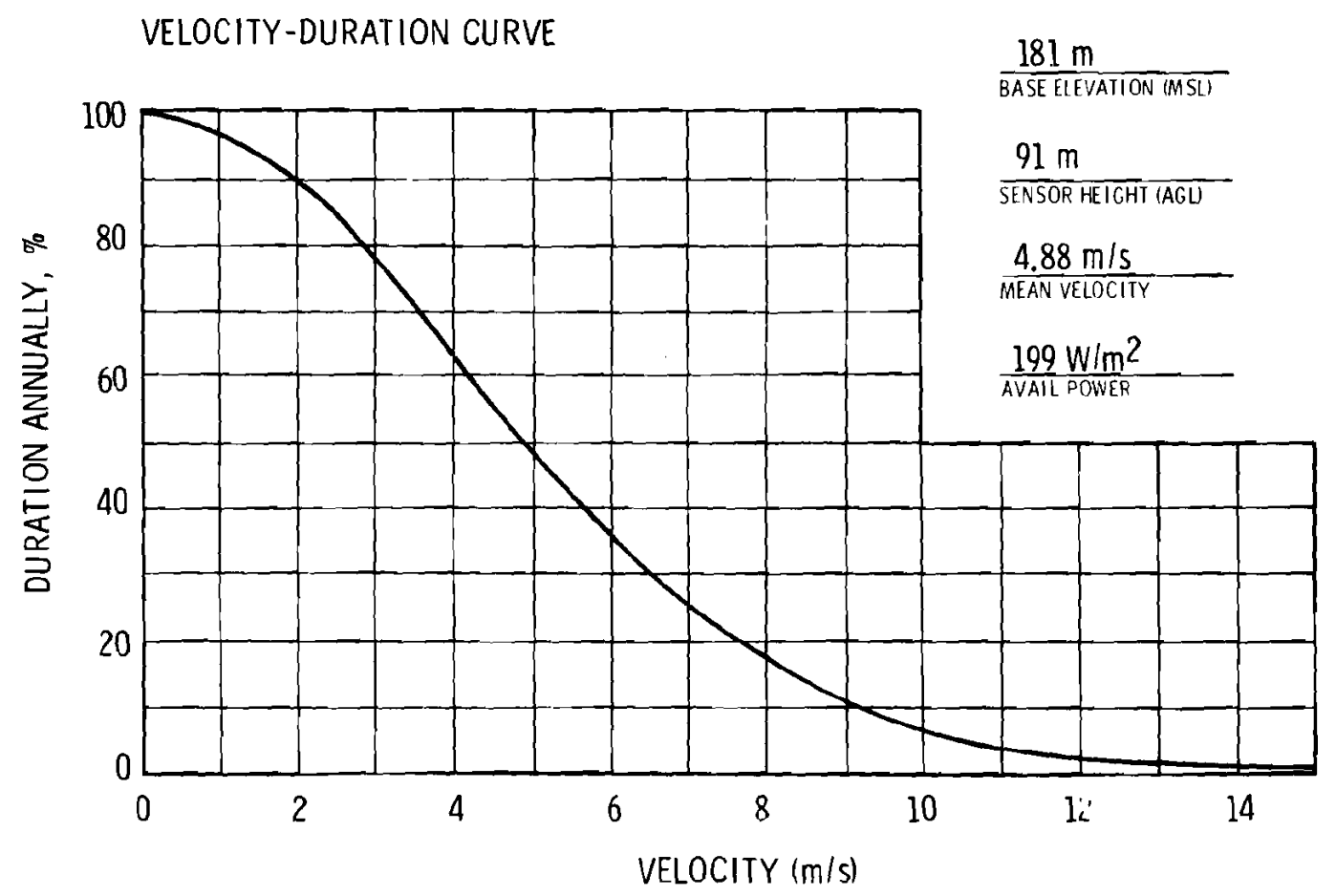


BRUNSWICK

\section{SITE LOCATION:}

The 1200-acre Brunswick site $\left(33.96^{\circ} \mathrm{N} / 78.01^{\circ} \mathrm{W}\right)$ is located in the SE portion of North Carolina in Brunswick County, $5 \mathrm{~km} \mathrm{~N}$ of Southport and $2.4 \mathrm{~km} \mathrm{~W}$ of Cape Fear River. Wilmington is $32 \mathrm{~km}$ NNE.

\section{TOPOGRAPHY :}

The site is located on the coastal plain, just inland from the island of Cape Fear. The area is generally flat with swamps to the $\mathrm{N}$ and $\mathrm{W}$ for some $65 \mathrm{~km}$. The swamps and marshes are laced with numerous small streams. The Cape Fear River lies $2.4 \mathrm{~km} \mathrm{E}$, beyond which is a low peninsula that separates the river from the Atlantic Ocean. Southward beyond Southport lies a small bay and then the Atlantic. There is very little relief in the vicinity of the site.

ON-SITE WIND MEASUREMENTS:

Since September 1970, data have been recorded continuously from instruments mounted on a $111-\mathrm{m}$ microwave tower. It is away from all structures and trees have been cleared to a radius of $183 \mathrm{~m}$. Wind speed and direction are recorded at two levels, at $13 \mathrm{~m}$ using a Climet WS-011-1/WD-012-11 system and at $107 \mathrm{~m}$ using a Bendix aerovane.

NRC Docket No. 50-324 

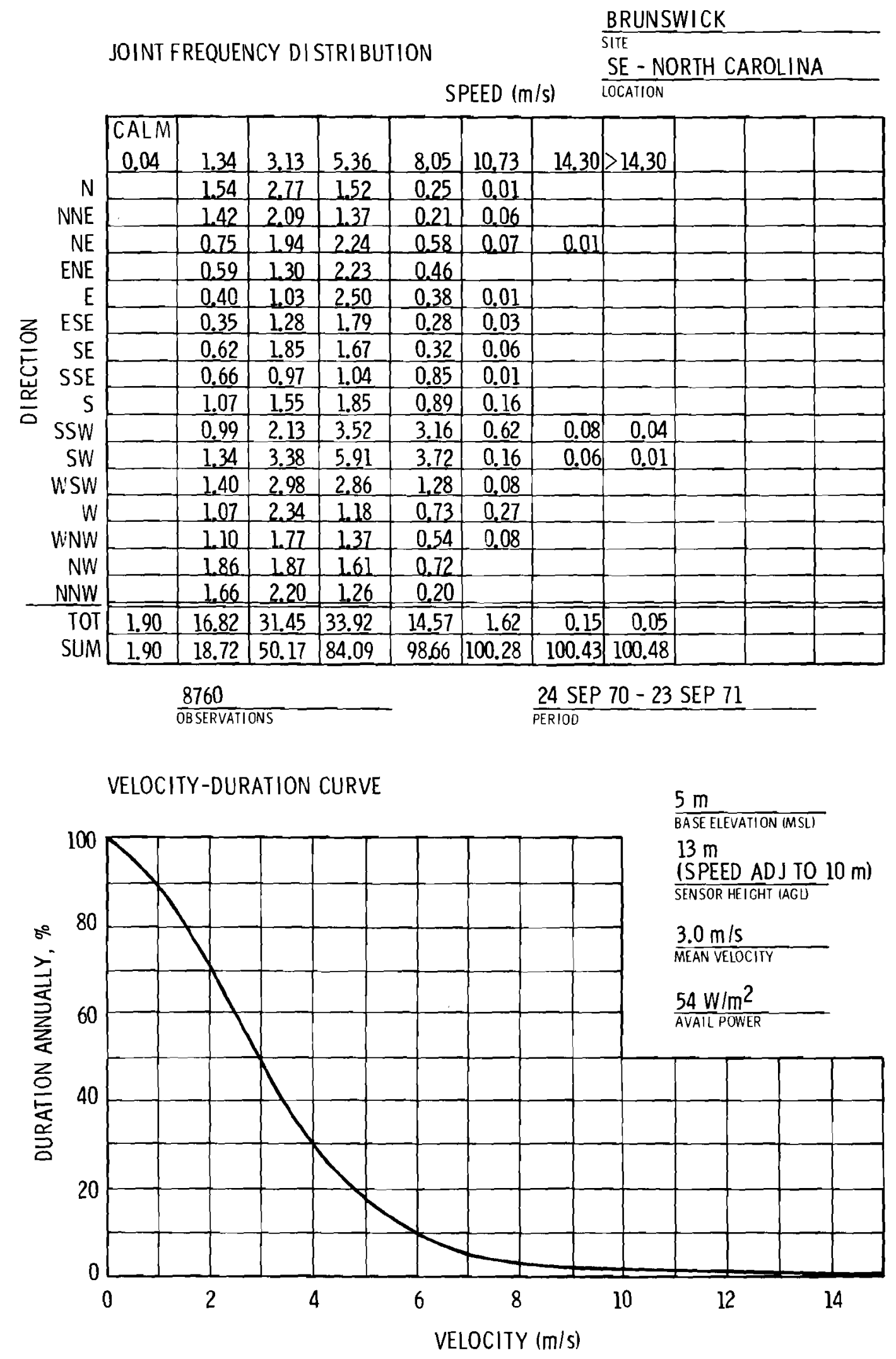


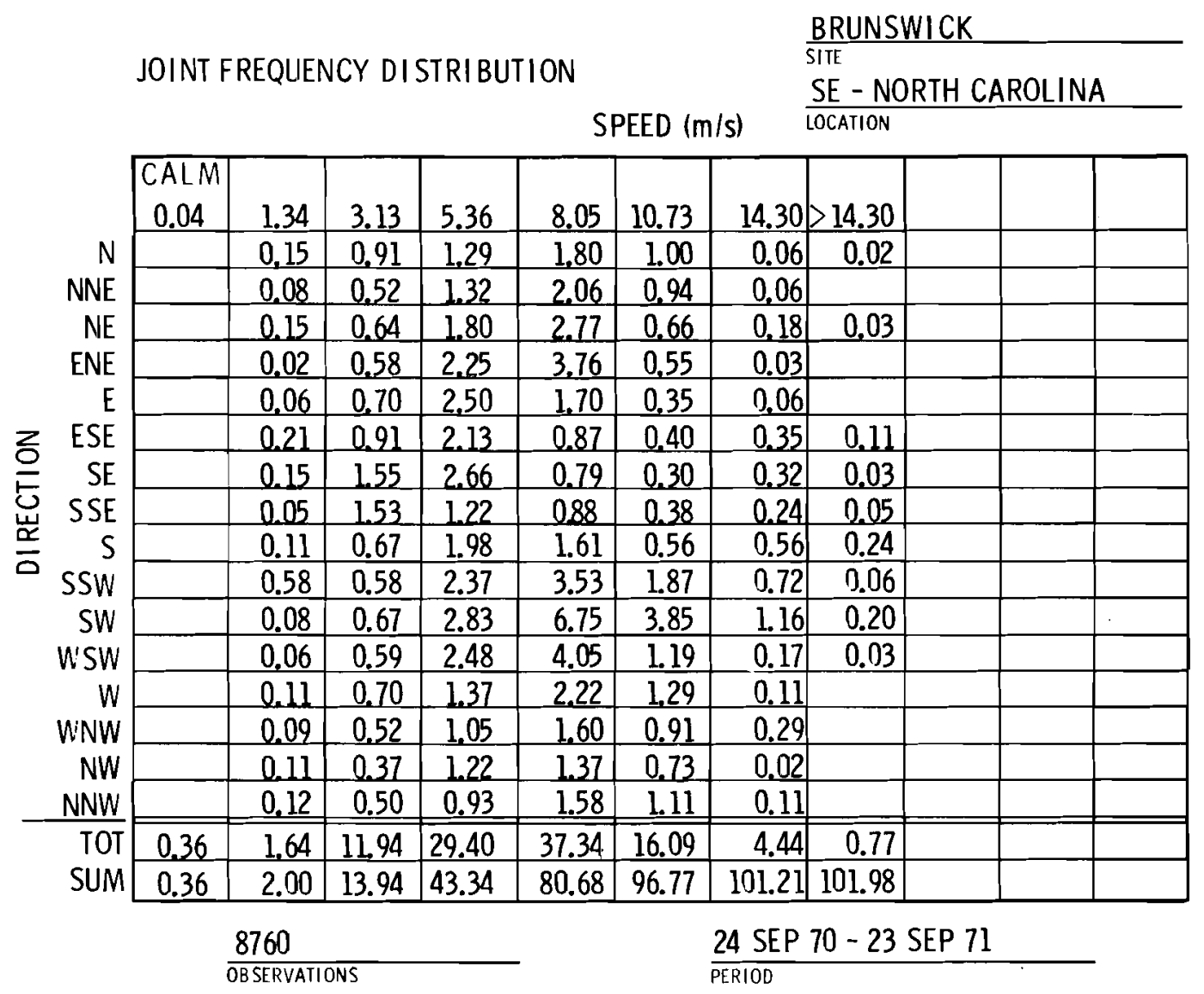

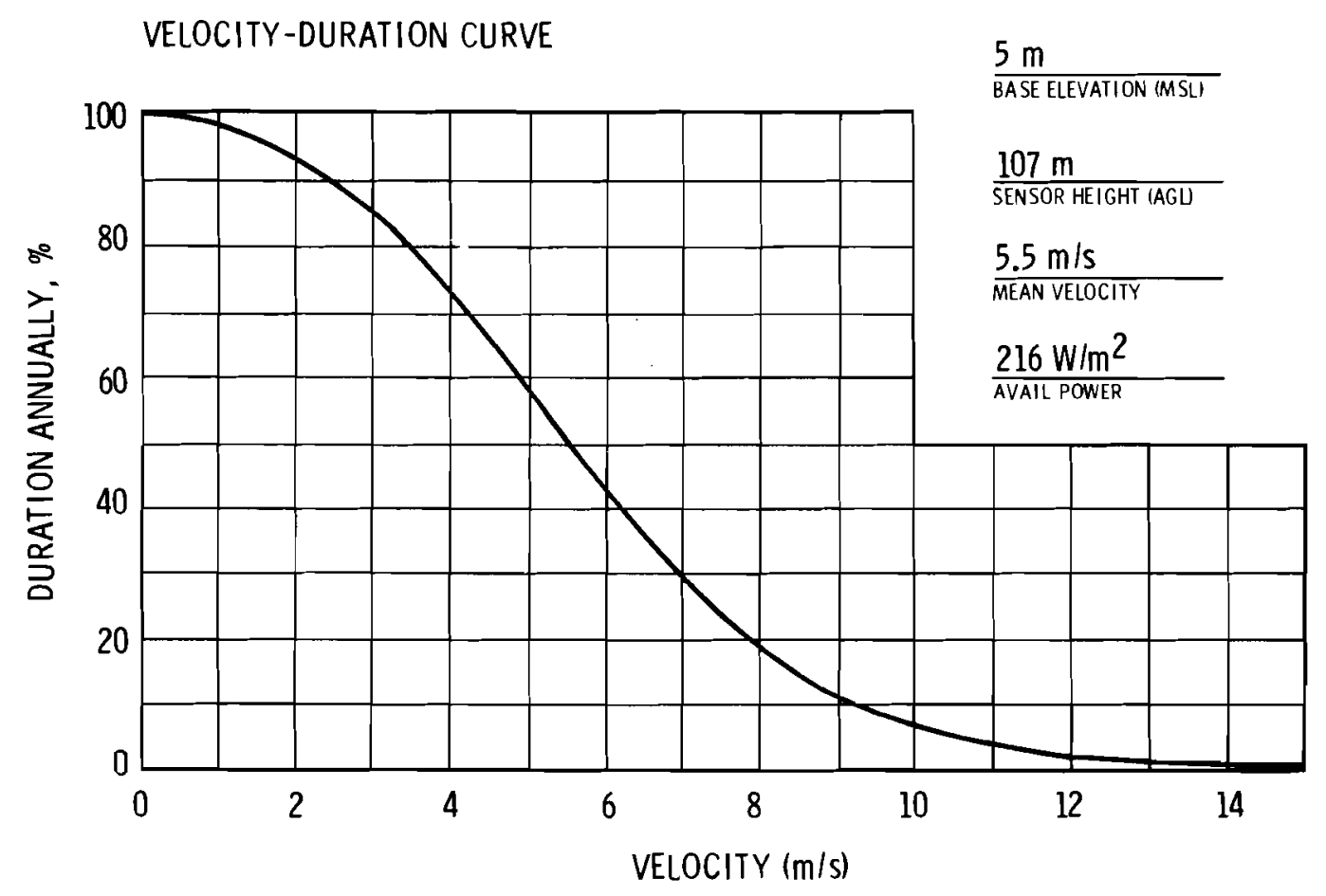


BYRON

\section{SITE LOCATION:}

The Byron site $\left(42.08^{\circ} \mathrm{N} / 89.28^{\circ} \mathrm{W}\right)$ is about $3 \mathrm{~km} \mathrm{E}$ of the Rock River and $5 \mathrm{~km}$ SW of Byron, Ogle County, north central Illinois. The site is also $27 \mathrm{~km}$ sw of Rockford and some 140 $\mathrm{km}$ WNW of Chciago.

\section{TOPOGRAPHY :}

Terrain in northern Illinois is relatively flat with only slight undulations. The site consists of 1000 acres. The northern half is dissected and slopes to the NE. In the southern half, the land slopes to the $S$ and is slightly dissected and rolling. Elevations range from $276 \mathrm{~m}$ (MSL) in the SE portion to about $223 \mathrm{~m}$ (MSL) in the NW corner nearest the river. Plant grade is at $265 \mathrm{~m}$ (MSL), as is the meteorological tower. This is one of the highest points within $8 \mathrm{~km}$ and terrain generally falls off gradually in all directions except $\mathrm{S}$ and SE. The Rock River runs NE-SW at an elevation of $213 \mathrm{~m}$ (MSL) about $3 \mathrm{~km} \mathrm{~W}$ and NW of the site.

\section{ON-SITE WIND MEASUREMENTS:}

A 76-m meteoroloqical tower was completed in May 1973 at an elevation of $265 \mathrm{~m}$ (MSL). Wind speed and direction are measured at $9 \mathrm{~m}$ and $76 \mathrm{~m}$ (AGL) with MRI model 1074-1 combined cup and vane sensor.

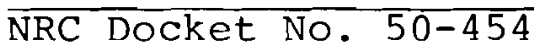




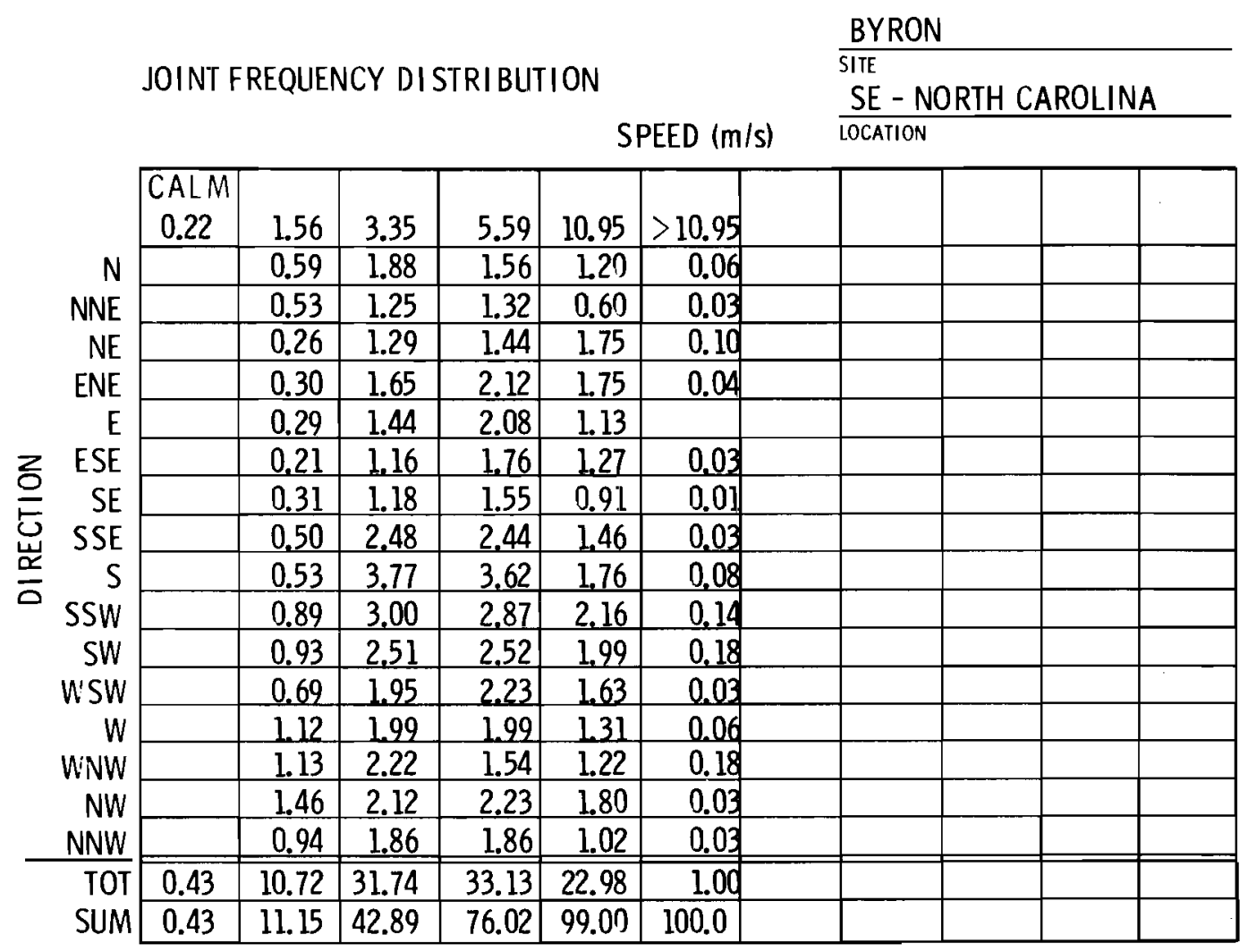

\section{7}

OB SERVATIONS
1 JLIN 73 - 31 MAY 74 PERIOD
VELOCITY-DURATION CURVE

כ。

100

80

60

40

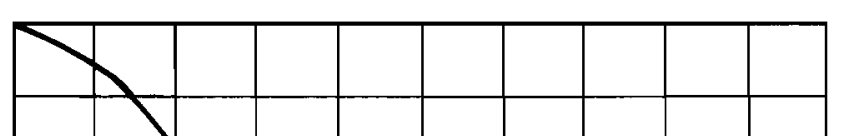

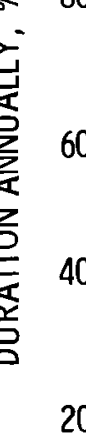
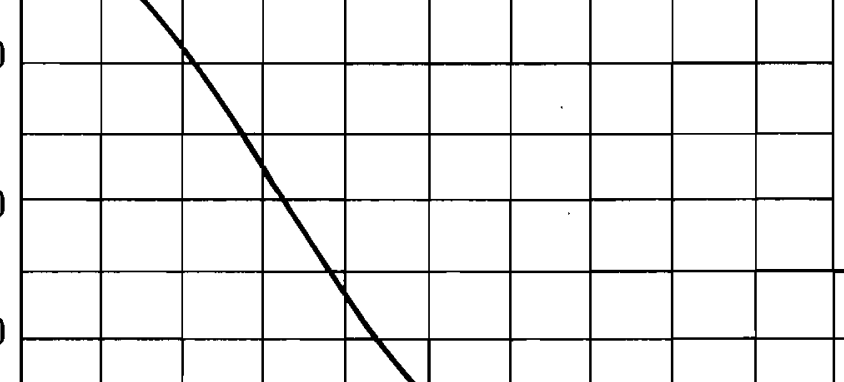

20
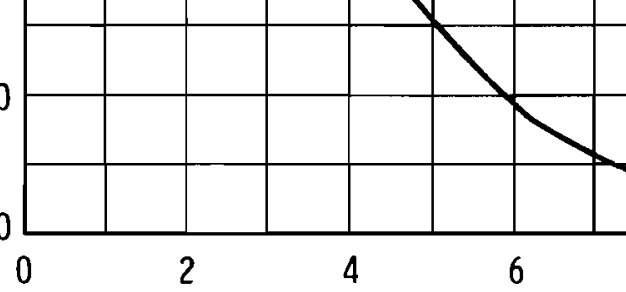

$265 \mathrm{~m}$

BASE ELEVATION (MSL)

$9 \mathrm{~m}$

SENSOR HEIGHT IAGU

$3.80 \mathrm{~m} / \mathrm{s}$

MEAN VELOCITY

$97 \mathrm{~W} / \mathrm{m}^{2}$

AVAIL POWER

VELOCITY $(\mathrm{m} / \mathrm{s})$ 


\section{SITE LOCATION:}

The Callaway site $\left(38.76^{\circ} \mathrm{N} / 91.78^{\circ} \mathrm{W}\right)$ is located in east central Missouri, $13 \mathrm{~km} \mathrm{SE}$ of Fulton and $49 \mathrm{~km}$ ESE of Columbia.

\section{TOPOGRAPHY :}

The 3,177-acre site is located on a plateau, $N$ of the Missouri River. It is about $100 \mathrm{~m}$ above the river's floodplain and the area between the plateau and the river is highly dissected. The southern flank of the plateau is deeply incised with steep stream gradients. Relief varies from $45 \mathrm{~m}$ to $100 \mathrm{~m}$ or more. The more gently rolling terrain of the plateaus and the floodplains of the streams and rivers are usually cultivated, while the predominant fraction of the land lies in slopes unsuitable for farming and consequently is occupied by forest growth.

\section{ON-SITE WIND MEASUREMENTS:}

A permanent tower, $93 \mathrm{~m}$ high, was completed in May 1973, at a base elevation of $251 \mathrm{~m}$ (MSL). The tower is in an open field $2.25 \mathrm{~km}$ ENE of the site, on a plateau that has a flat to undulating terrain. Wind speed and direction were measured at $10 \mathrm{~m}, 60 \mathrm{~m}$ and $90 \mathrm{~m}$ using $\mathrm{Climet} W \mathrm{~W}-01 \mathrm{l}-1$ and Climet WD-012-10, respectively.

$\overline{\mathrm{NRC}}$ Docket Nos. 50-483, 50-486 


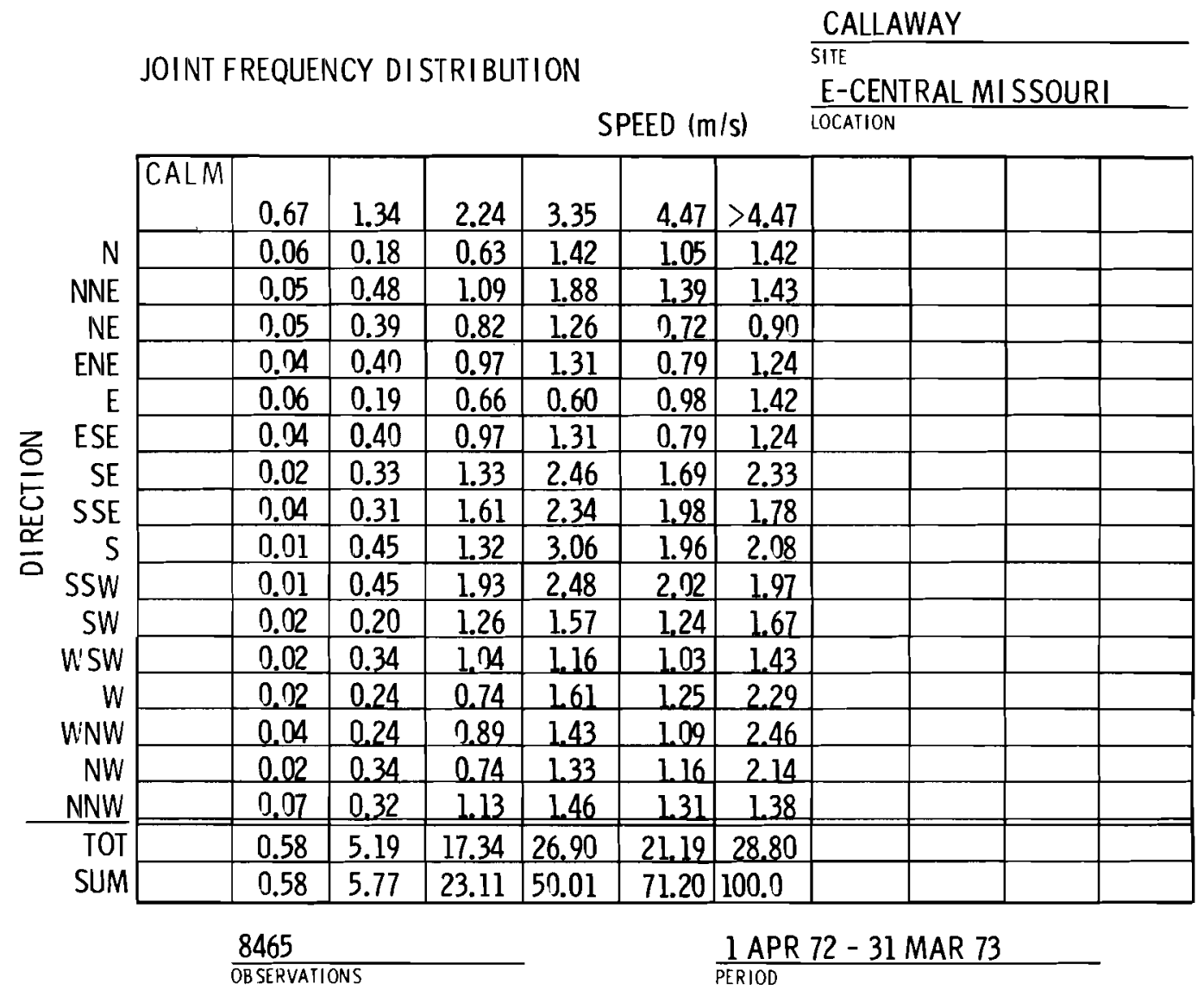

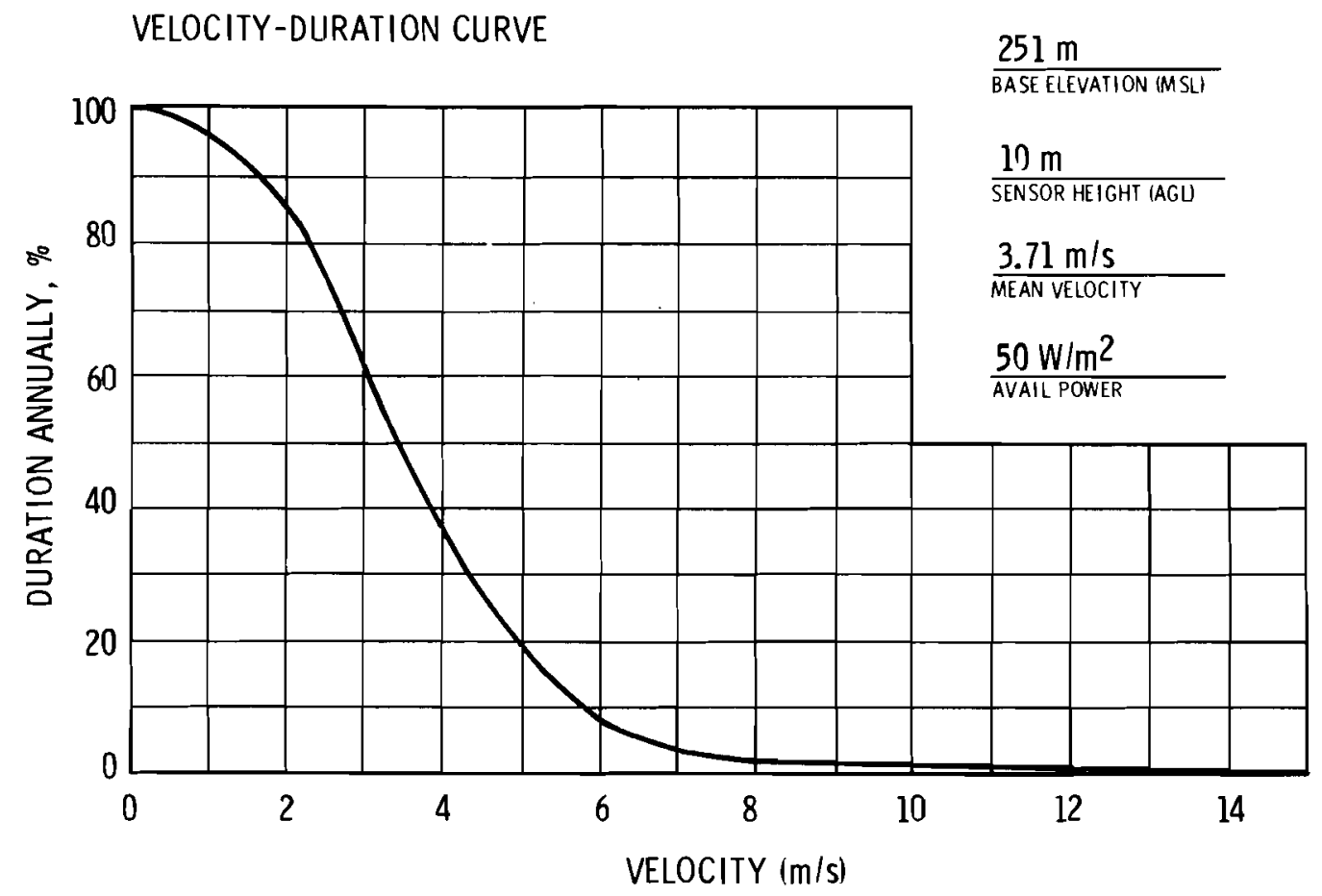




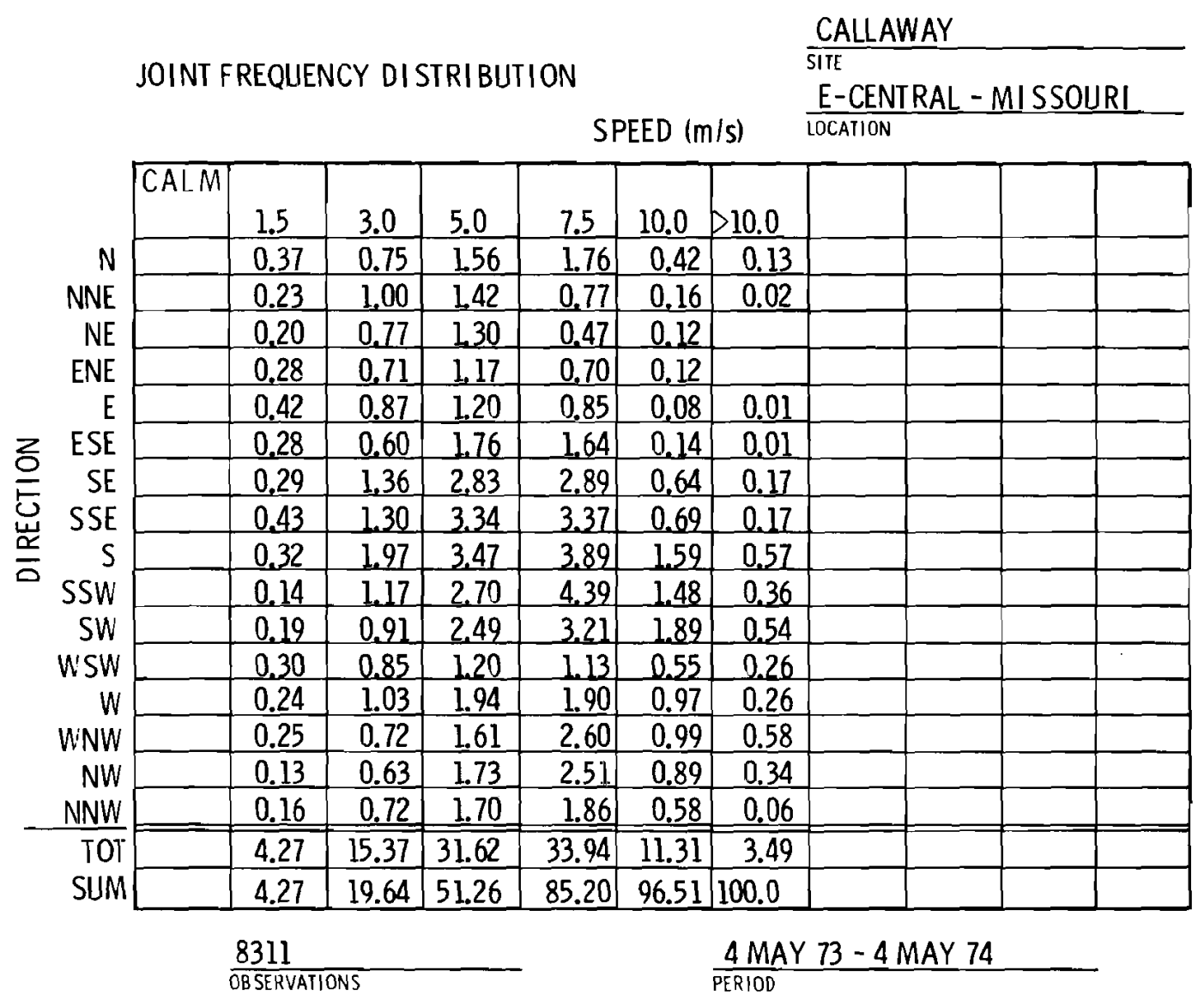

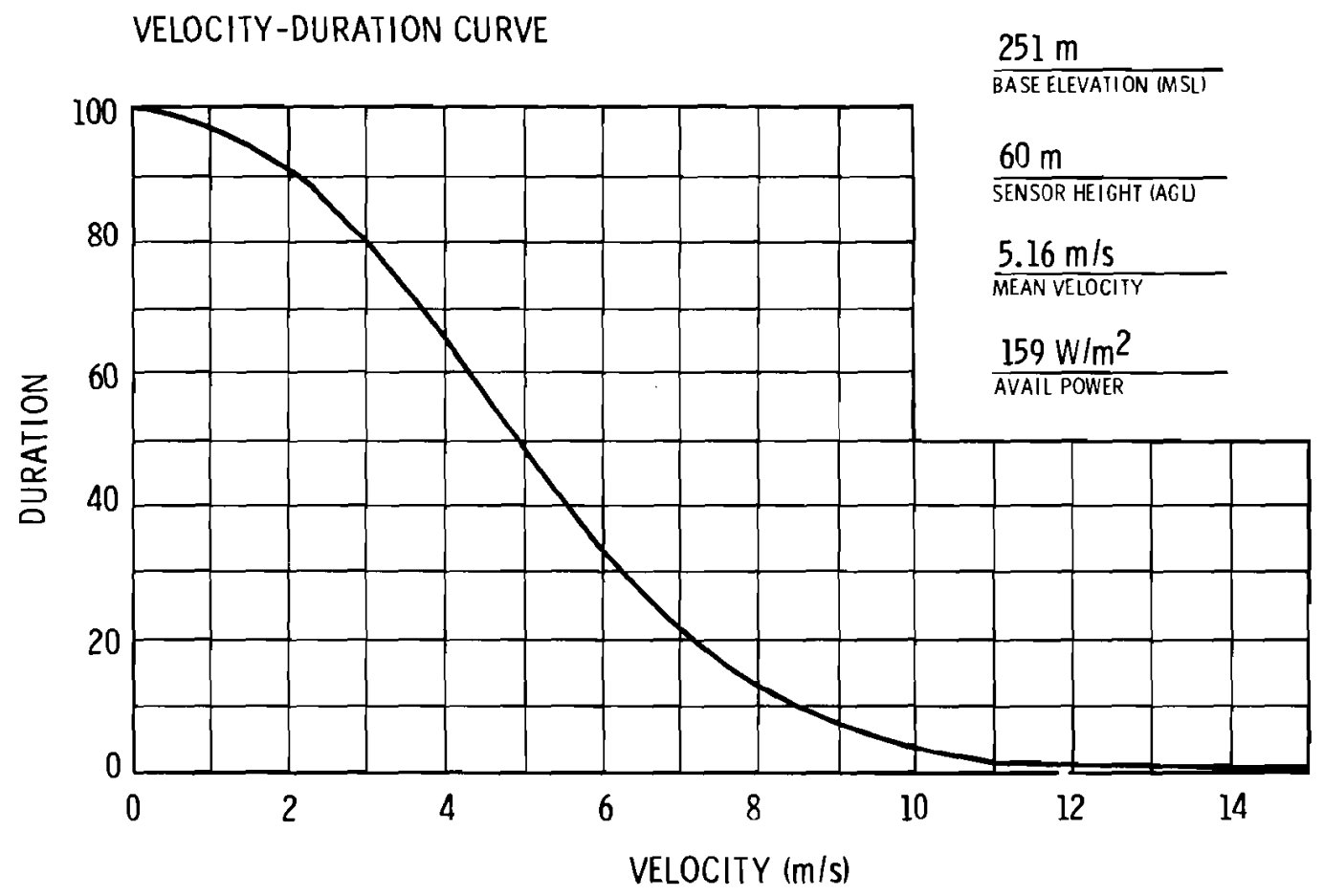


CALVERT CLIFFS

\section{SITE LOCATION:}

The Calvert Cliffs Nuclear Power Plant $\left(38.41^{\circ} \mathrm{N} / 76.43^{\circ} \mathrm{W}\right)$ is located in an excavated section of the Calvert cliffs in Calvert County, Maryland, on the western shore of Chesapeake Bay. It is about halfway between the mouth of the bay and its headwaters at the susquehanna River. It is located $17 \mathrm{~km} \mathrm{SE}$ of Prince Frederick and $7 \mathrm{~km} \mathrm{NW}$ of Cove Point, Maryland.

\section{TOPOGRAPHY :}

The 1.135-acre site is located on rolling land which is forested primarily with deciduous trees and an understory of various grasses, herbs and shrubs. There is some cultivation of tobacco and a little hay and corn. The site varies in elevation from sea level to $42 \mathrm{~m}$ (MSL). The bay frontage and several of the small interior streams are characterized by near-perpendicular walls caused by water, wind and frost action.

\section{ON-SITE WIND MEASUREMENTS:}

While several towers have been used at various times, the attached data were taken from a tower established in early 1969, known as the Inner South (IS) station. The tower was erected at $15 \mathrm{~m}$ (MSL) and records winds at $3.7 \mathrm{~m}$ and $10 \mathrm{~m}$ with an MRI Mechanical Weather Station, Model 1071, an MRI Vector Vane Sigma Meter Model 1053-Mark II and an MRI Model 2040 Wind Diffusion System.

NRC Docket No. $5 \overline{0-3 \overline{1} 7}$ 

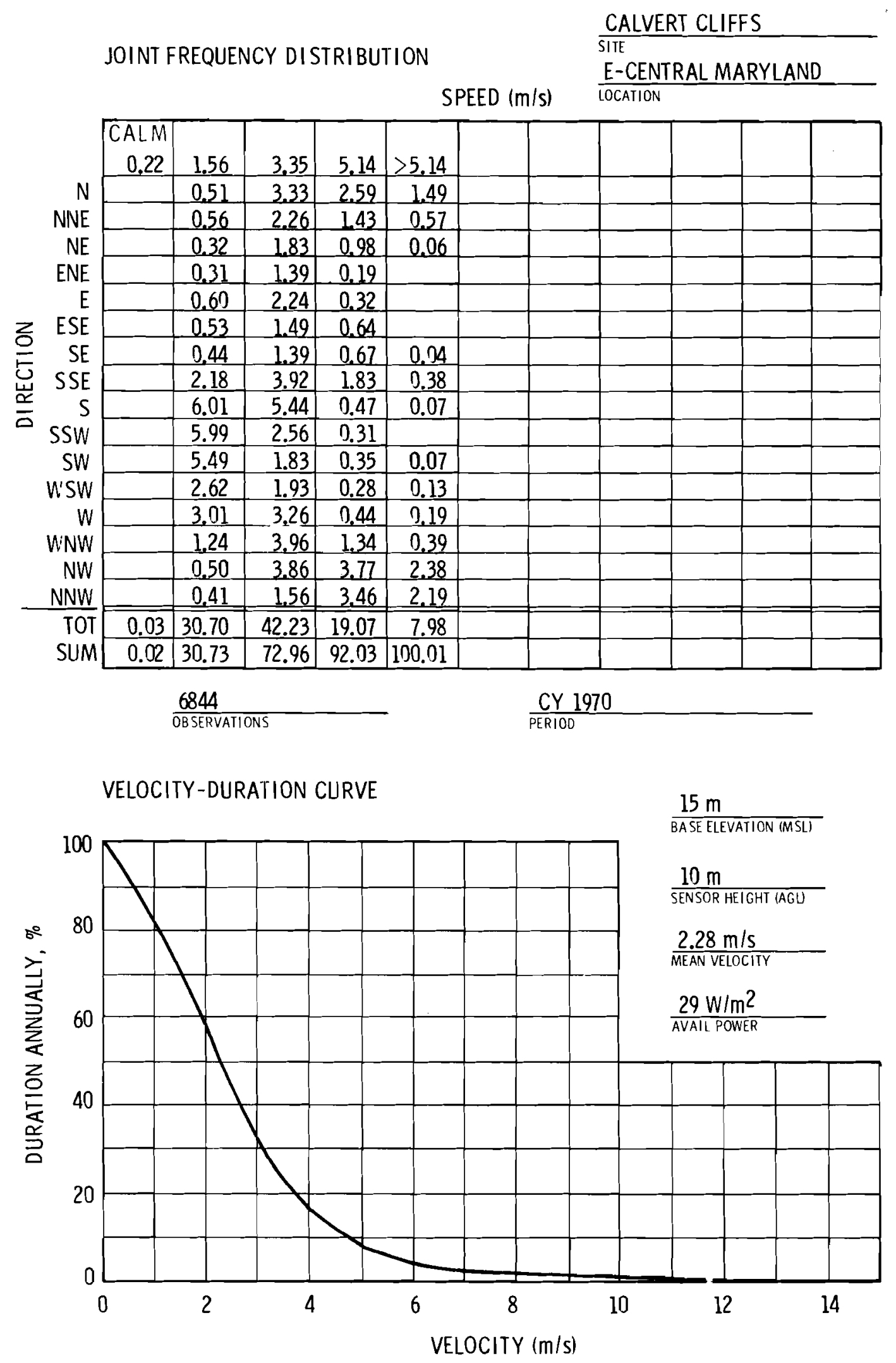
CATAWBA

\section{SITE LOCATION:}

The site is located in York County, South Carolina, on Lake Wylie $\left(35.05^{\circ} \mathrm{N} / 81.07^{\circ} \mathrm{W}\right)$. South of the site is Big Allison Creek and north is Beaver Dam Creek, which are arms of Lake Wylie. About $7 \mathrm{~km}$ SE of the site is Wylie Dam and hydroelectric station. The site is also $35 \mathrm{~km}$ E of Cherokee Nuclear station, $59 \mathrm{~km} \mathrm{~N}$ of Columbia, $40 \mathrm{~km}$ ENE of spartansburg and about $6 \mathrm{~km}$ NNW of Rock Hill.

\section{TOPOGRAPHY :}

The site is located in the rolling plains of the Appalachian piedmont. Within an $8 \mathrm{~km}$ radius, the terrain is generally rolling to rough with elevations ranging from $170 \mathrm{~m}$ to $220 \mathrm{~m}$ (MSL) with a knob of $290 \mathrm{~m}$ (MSL) at $4 \mathrm{~km}$ to the NW. Wylie Lake, at $174 \mathrm{~m}$ (MSL), extends somewhat $\mathrm{N}-\mathrm{S}$ just $\mathrm{E}$ of the site. The shoreline is very irregular with dendritic arms, such as Big Allison Creek to the south of the site and Beaver Dam Creek to the north. The width of main lake is generally 600-1000 m. The site itself varies in elevation from $170 \mathrm{~m}$ to $195 \mathrm{~m}$ (MSL) while the base of the meteorological tower is at $196 \mathrm{~m}$ (MSL), $450 \mathrm{~m} \mathrm{SE}$ of the site.

ON-SITE WIND MEASUREMENTS:

Wind measurements are made at $10 \mathrm{~m}$ (AGL) by a Packard-Bell Model W/S-101B Series wind Direction-Speed System. The tower has limited exposure being in a 107 x $107 \mathrm{~m}$ clearing in the surrounding pine forest.

$\overline{\mathrm{NRC}} \overline{\text { Docket No. }} \overline{5 \pi-413}$ 


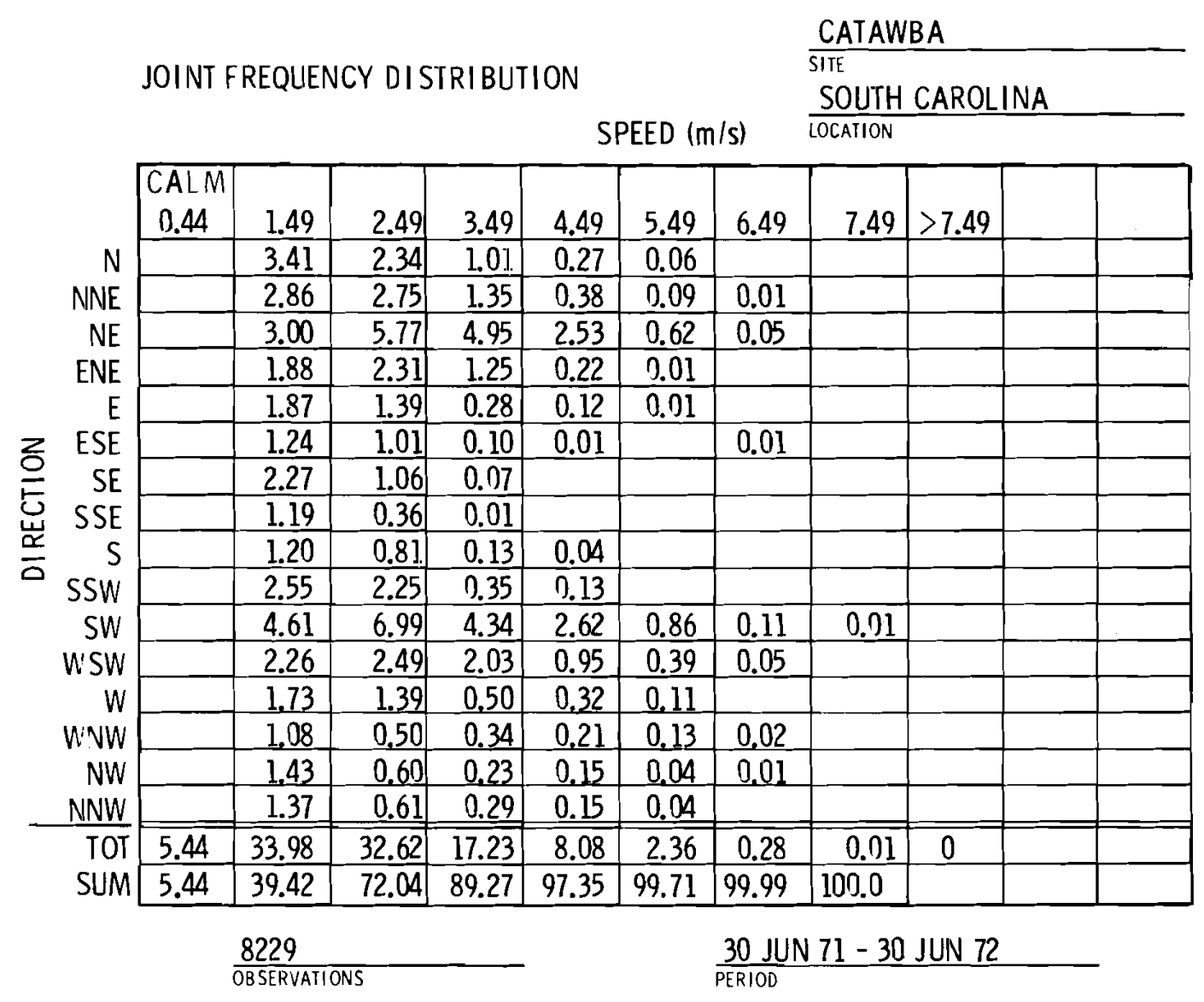

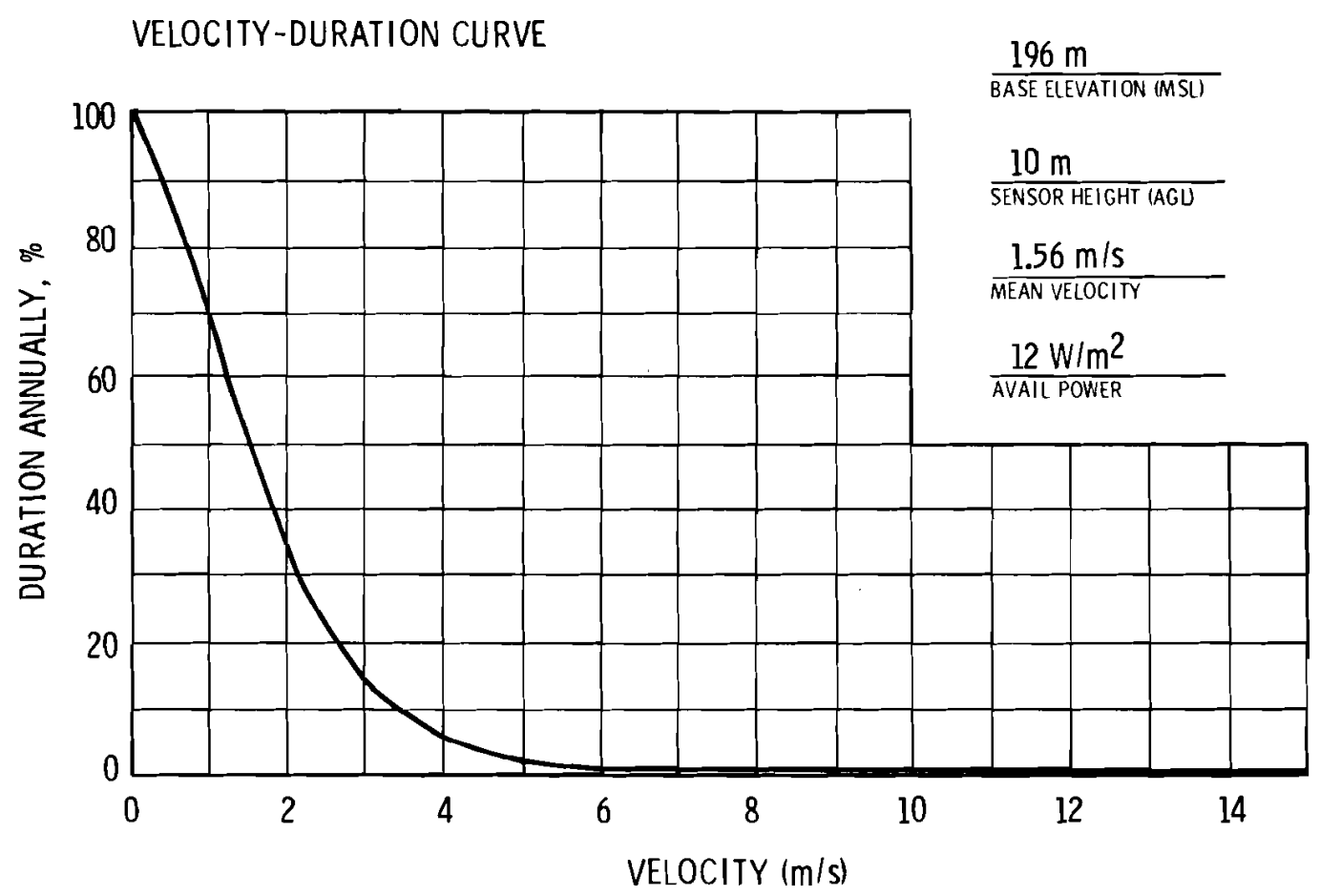


CHEROKEE

\section{SITE LOCATION:}

Cherokee Nuclear Station $\left(35.09^{\circ} \mathrm{N} / 81.51^{\circ} \mathrm{W}\right)$ is located in the E portion of Cherokee County, South Carolina, on the Broad River. The nearest towns are Gaffney, $13 \mathrm{~km} \mathrm{NW}$, and Blacksburg, $10 \mathrm{~km} \mathrm{~N}$. The site is also $27 \mathrm{~km}$ ENE of Greenville and $37 \mathrm{~km}$ NNW of Columbia.

\section{TOPOGRAPHY :}

The site is located in the rolling plans of the Appalachian piedmont. Terrain is generally rolling to rough with a small ridge rising to $245 \mathrm{~m}$ (MSL) $\mathrm{SW}$ of the plant and the Broad River at $155 \mathrm{~m}$ (MSL) on the $\mathrm{N}$ and $\mathrm{E}$ borders of the site.

ON-SITE WIND MEASUREMENTS:

On-site meteorological equipment became operational on 11 Sep 73. Wind measurements are made at $9 \mathrm{~m}$ and $40 \mathrm{~m}$ with PackardBell Model W/S I01B Series Wind Direction-Speed Systems. Wind direction and speed are averaged over 30-minute intervals preceding each hour and logged on the hour.

$\overline{\text { NRC Docket No. 50-491 }}$ 


\begin{tabular}{|c|c|c|c|c|c|c|c|c|c|c|c|}
\hline & & & & & & & & CHER & & & \\
\hline & JOINT & REQUEI & CY DIS & TRIBUTT & ION & & & & $L-N O R$ & TH O & \\
\hline & & & & & & $E D(m)$ & & LOCATION & & & \\
\hline & \begin{tabular}{|l} 
CALM \\
0.44 \\
\end{tabular} & 1.5 & 2.5 & 3.5 & 4.5 & 5.5 & 6.5 & 7.5 & 8.5 & $>8.5$ & \\
\hline$N$ & & 2.91 & 1.99 & 0.68 & 0.10 & & 0.01 & & & & \\
\hline NNE & & 1.83 & 2.47 & 0,87 & 0.11 & 0.01 & & 0.01 & & & \\
\hline $\mathrm{NE}$ & & 1.82 & 3.05 & 1.65 & 0.43 & 0.05 & & & & & \\
\hline ENE & & 1.63 & 1.88 & 1.27 & 0.10 & 0.02 & & & & & \\
\hline $\mathrm{E}$ & & 1.43 & 1.63 & 0.42 & 0.05 & & & & & & \\
\hline ESE & & 1.03 & 0.88 & 0.09 & 0.01 & & & & & & \\
\hline SE & & 1.71 & 1.20 & 0.29 & & 0.01 & & & & & \\
\hline SSE & & 1.09 & 0.45 & 0,09 & 0.05 & & & & & & \\
\hline$S$ & & 1.75 & 1.17 & 0.28 & 0.02 & & & & & & \\
\hline SSW & & 2.19 & 1.63 & 0,53 & 0.01 & 0,01 & & & & & \\
\hline SW & & 4.46 & 4.39 & 2.32 & 0.55 & 0.20 & & 0.01 & & & \\
\hline W'SW & & 3.42 & 2.90 & 2.22 & 0,72 & 0.28 & 0.10 & 0,04 & 0,04 & & \\
\hline$w$ & & 4.88 & 1.89 & 1.01 & 0.22 & 0.13 & 0.04 & 0.01 & & & \\
\hline WNWW & & 5.38 & 1.26 & 0.62 & 0.11 & 0.13 & 0.02 & & & & \\
\hline NW & & 7.00 & 2.24 & 1.03 & 0.49 & 0.24 & 0.02 & & & & \\
\hline NNW & & 3.01 & 1.60 & 0.46 & 0.13 & 0.01 & & & & & \\
\hline TOT & 5.49 & 45.54 & 30.62 & 13.83 & 3.10 & 1.11 & 0.20 & 0.07 & 0.04 & 0 & \\
\hline SUM & 5.49 & 51.03 & 81.65 & 95.48 & 98.58 & 99.69 & 99.89 & 99.96 & 100.0 & & \\
\hline & & 184 & & & & & ERIOD & $73-1$ & P 7 & & \\
\hline
\end{tabular}

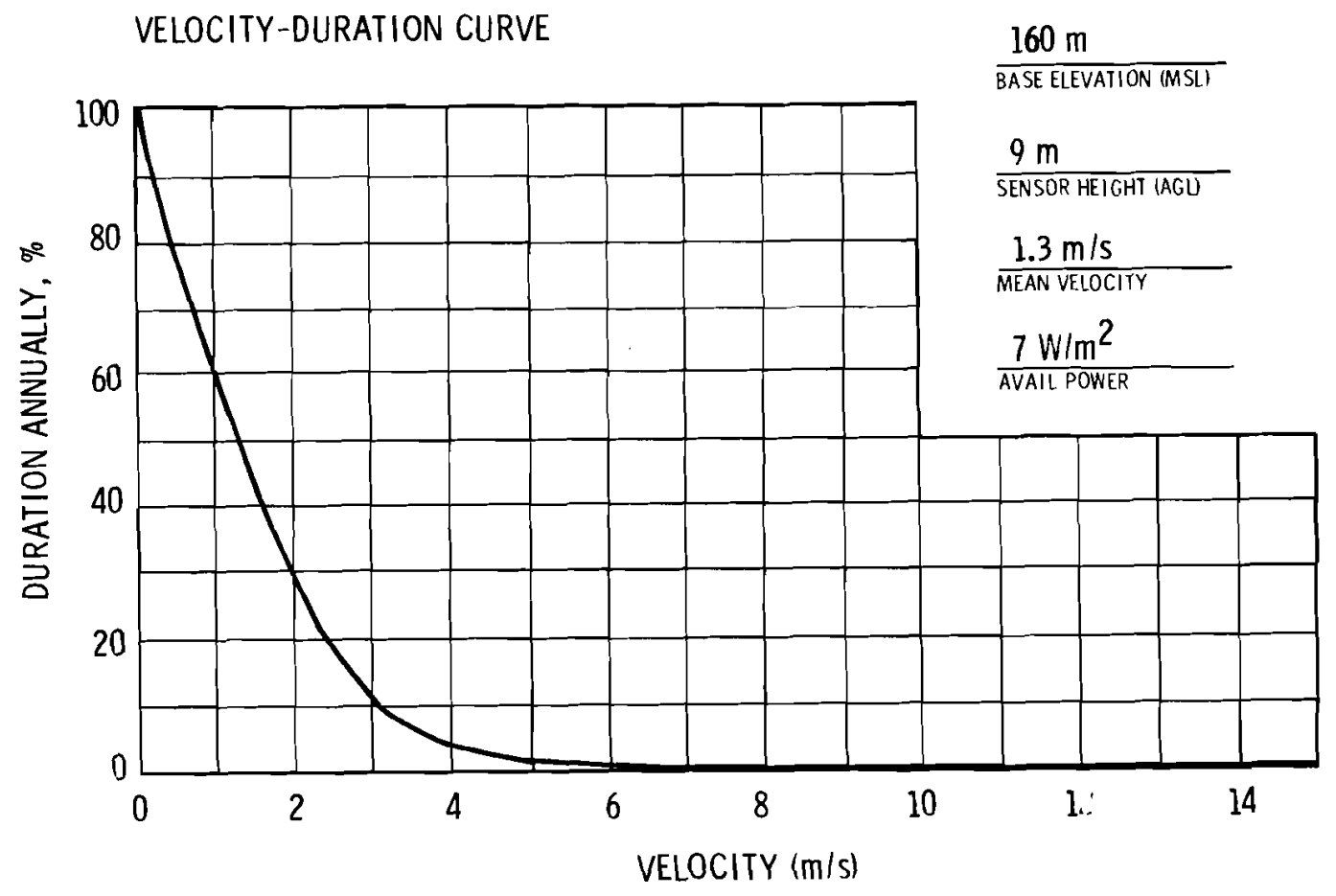




\begin{tabular}{|c|c|c|c|c|c|c|c|c|c|c|c|}
\hline & JOINT & REQUEN & CY DIS & STRIBU & ION & EED (m & & $\begin{array}{l}\text { CHEROI } \\
\text { SITE } \\
\text { CENTR/ } \\
\text { LOCATION }\end{array}$ & $\begin{array}{l}\mathrm{EE} \\
\mathrm{L}-\mathrm{NOF}\end{array}$ & TH CAF & OLINA \\
\hline & $\longdiv { C A L M }$ & & & & & & & & & & \\
\hline & 0.45 & 1.5 & 2.5 & 3.5 & 4.5 & 5.5 & 6.5 & 7.5 & 8.5 & 9.5 & $>9.5$ \\
\hline $\mathrm{N}$ & & 1.03 & 2.13 & 2.38 & 1.10 & 0.47 & 0.04 & 0.01 & & 0.01 & \\
\hline NNE & & 0.98 & 1.89 & 2.16 & 1.42 & 0.49 & 0.12 & & & 0.01 & \\
\hline NE & & 1.29 & 2.60 & 2.28 & 1.48 & 0.62 & 0.13 & 0.01 & 0.01 & 0.01 & \\
\hline ENE & & 0.85 & 1.63 & 1.00 & 0.69 & 0.35 & 0.14 & 0.01 & & & \\
\hline$E$ & & 0.93 & 1.77 & 0.75 & 0.30 & 0.16 & 0.02 & 0.01 & & & \\
\hline ESE & & 0.96 & 1.26 & 0.48 & 0.17 & 0.04 & & & & & \\
\hline SE & & 1.14 & 1.61 & 0.61 & 0.52 & 0.15 & 0.02 & 0.02 & 0.01 & & \\
\hline SSE & & 1.08 & 1.53 & 0.64 & 0,33 & 0.22 & 0.14 & 0,02 & 0.01 & & \\
\hline$S$ & & 0.99 & 1.95 & 1.60 & 0.66 & 0.31 & 0.11 & & 0.04 & & \\
\hline SSW & & 0.84 & 239 & 2.29 & 1.48 & 1,04 & 0,31 & 0.02 & 0,01 & & \\
\hline SW & & 1.01 & 2.31 & 3.43 & 2.96 & 1.89 & 0.99 & 0.40 & 0,20 & 0.20 & 0,04 \\
\hline W'SW & & 0,62 & 1.29 & 1.45 & 1.39 & 0.92 & 0.43 & 0.25 & 0.10 & 0.05 & 0.04 \\
\hline W & & 0.74 & 1.45 & 104 & 0.61 & 0.48 & 0.11 & 0.10 & 0.04 & 0.02 & \\
\hline WNW & & 0.77 & 1.30 & 0.90 & 0.79 & 0.57 & 0.22 & 0.15 & 0.10 & 0.02 & 0.01 \\
\hline NW & & 0,96 & 2.51 & 2,34 & 1.13 & 0.66 & 0.24 & 0.28 & 0.06 & 0.02 & \\
\hline NNW & & 0.84 & 2.16 & 1.73 & 0.78 & 0.38 & 0.10 & & & & \\
\hline TOT & $\overline{0.21}$ & 15.03 & 29.79 & 25.07 & 15.81 & 8.75 & 3.15 & 1.30 & 0.57 & 0.24 & 0.09 \\
\hline SUM & 0.21 & 5.24 & 45.03 & 70.10 & 85.91 & 94.66 & 97.81 & 99.11 & 99.68 & 99.92 & 100.0 \\
\hline
\end{tabular}

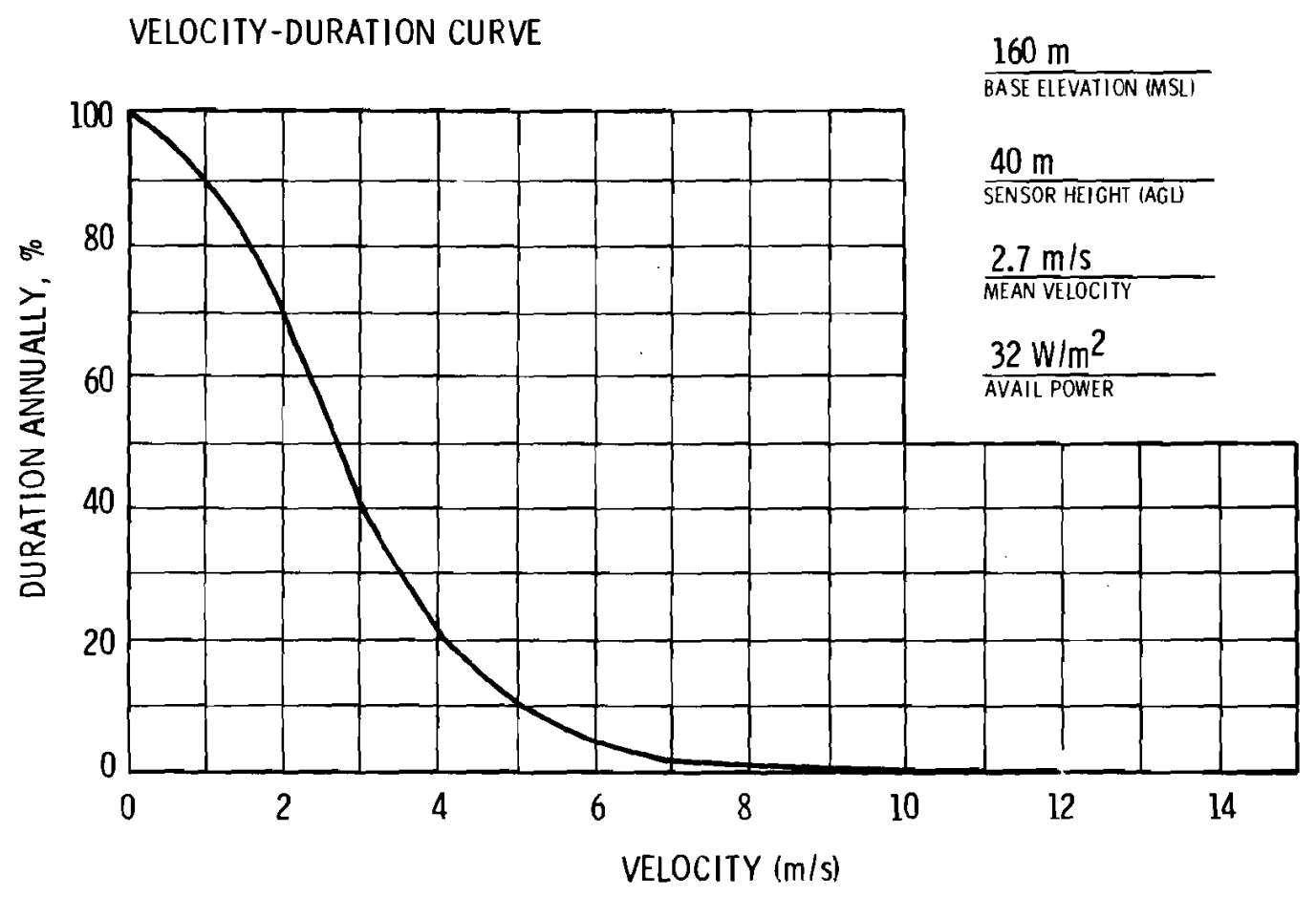


CLINCH RIVER

\section{SITE LOCATION:}

The Clinch River site $\left(35.89^{\circ} \mathrm{N} / 84.38^{\circ} \mathrm{W}\right)$ is in east central Tennessee in the eastern part of Roane County and within the city limits of Oak Ridge, about $40 \mathrm{~km} \mathrm{~W}$ of Knoxville.

\section{TOPOGRAPHY :}

The site is on a peninsula on the $\mathrm{N}$ bank of Watts Bar Lake on the Clinch River. The area is a broad valley between the Cumberland Mountains, which lies to the NW, and the Great smokey Mountains to the SE, both of which are a part of the southern Appalachian mountains. General terrain of the region is heavily wooded rolling hills with intervening valleys. Elevations of the ridge crests range between $275 \mathrm{~m}$ and $375 \mathrm{~m}$ (MSI), compared to a site elevation of $248 \mathrm{~m}$ and normal reservoir pool elevation of $225 \mathrm{~m}$. The highest point within $8 \mathrm{~km}$ of the site is Melton Hill, $413 \mathrm{~m}$ (MSI), about $7.6 \mathrm{~km}$ ENE. The broad valley in which the site lies is set off by a series of parallel ridges extending on a $\mathrm{NE}-\mathrm{SW}$ direction. The site lies along a flank of one of these ridges. Terrain south of the site just beyond Watts Bar Lake (1.1 km S) rises abruptly to $325 \mathrm{~m}$ (MSI). Hills or ridges similar in elevation are found within $3 \mathrm{~km}$ of the site in every direction except $\mathrm{NE}$.

\section{ON-SITE WIND MEASUREMENTS:}

An on-site meteorological program was initiated on 11 Apr 73 . Wind measurements are made at 23 and $61 \mathrm{~m}$ using climet 011-11 instruments for wind speed and climet 012-11 instruments for wind direction.

$\overline{\mathrm{NRC}}$ Docket No. $50-53 \overline{7}$ 

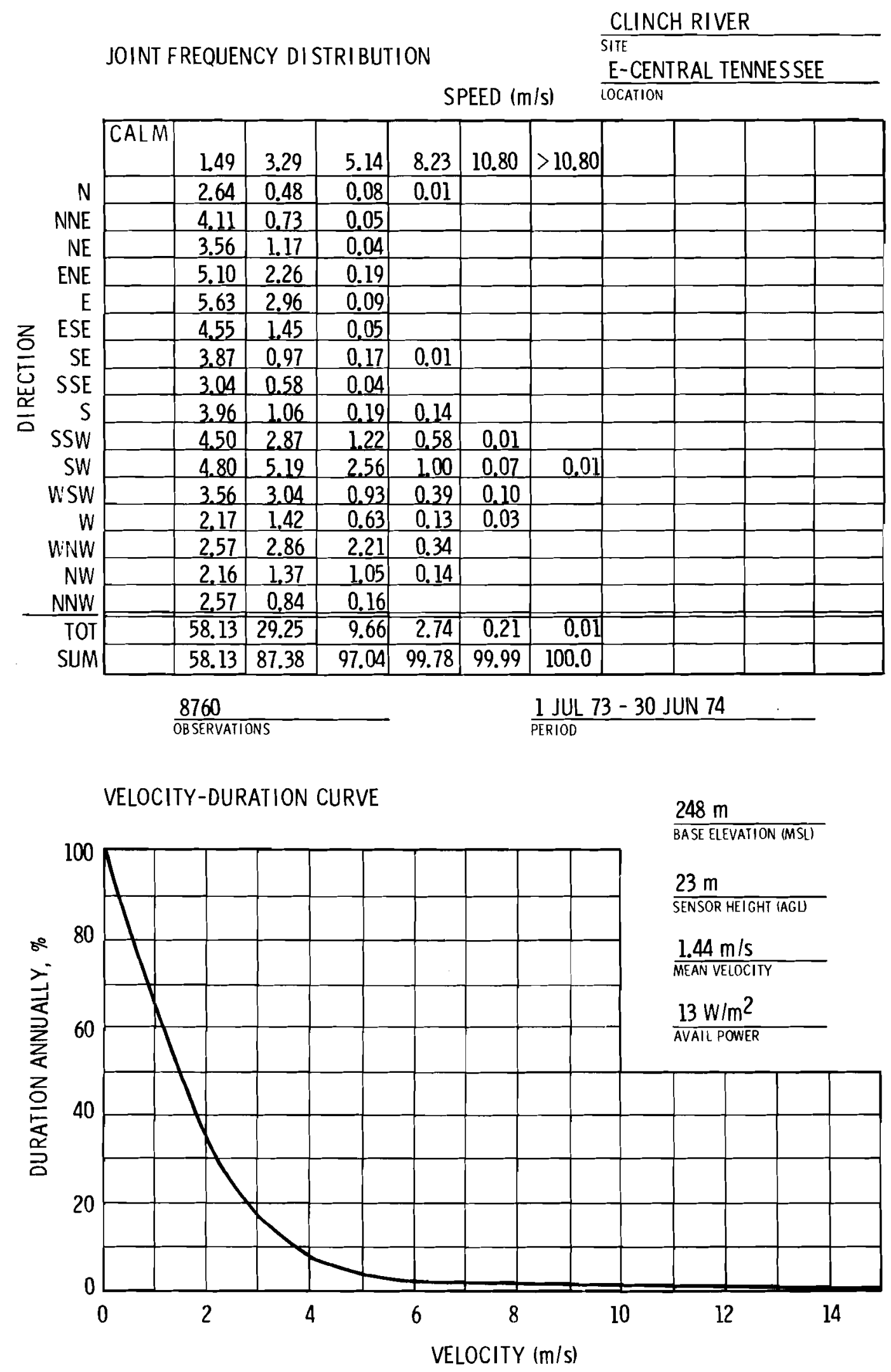


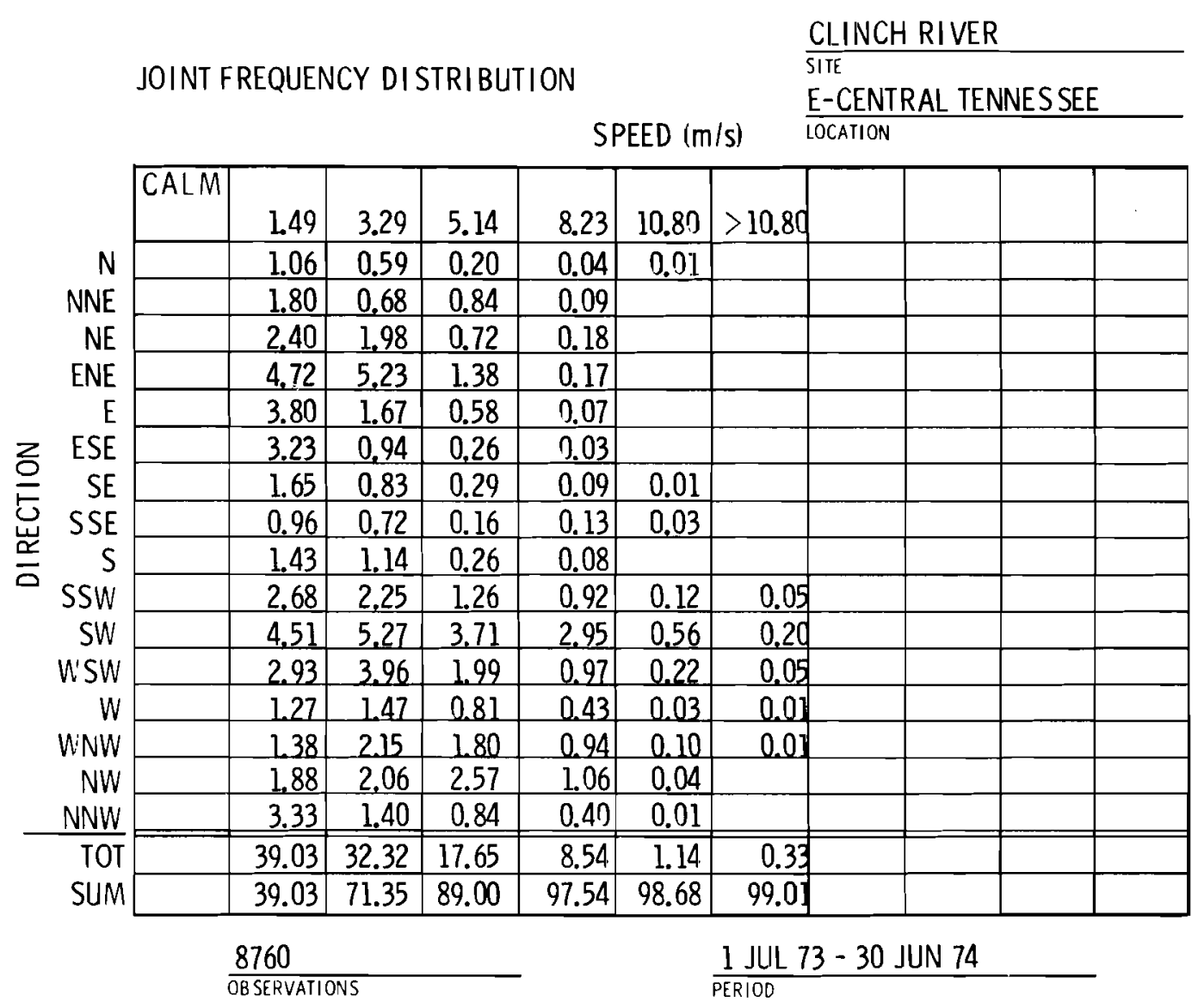

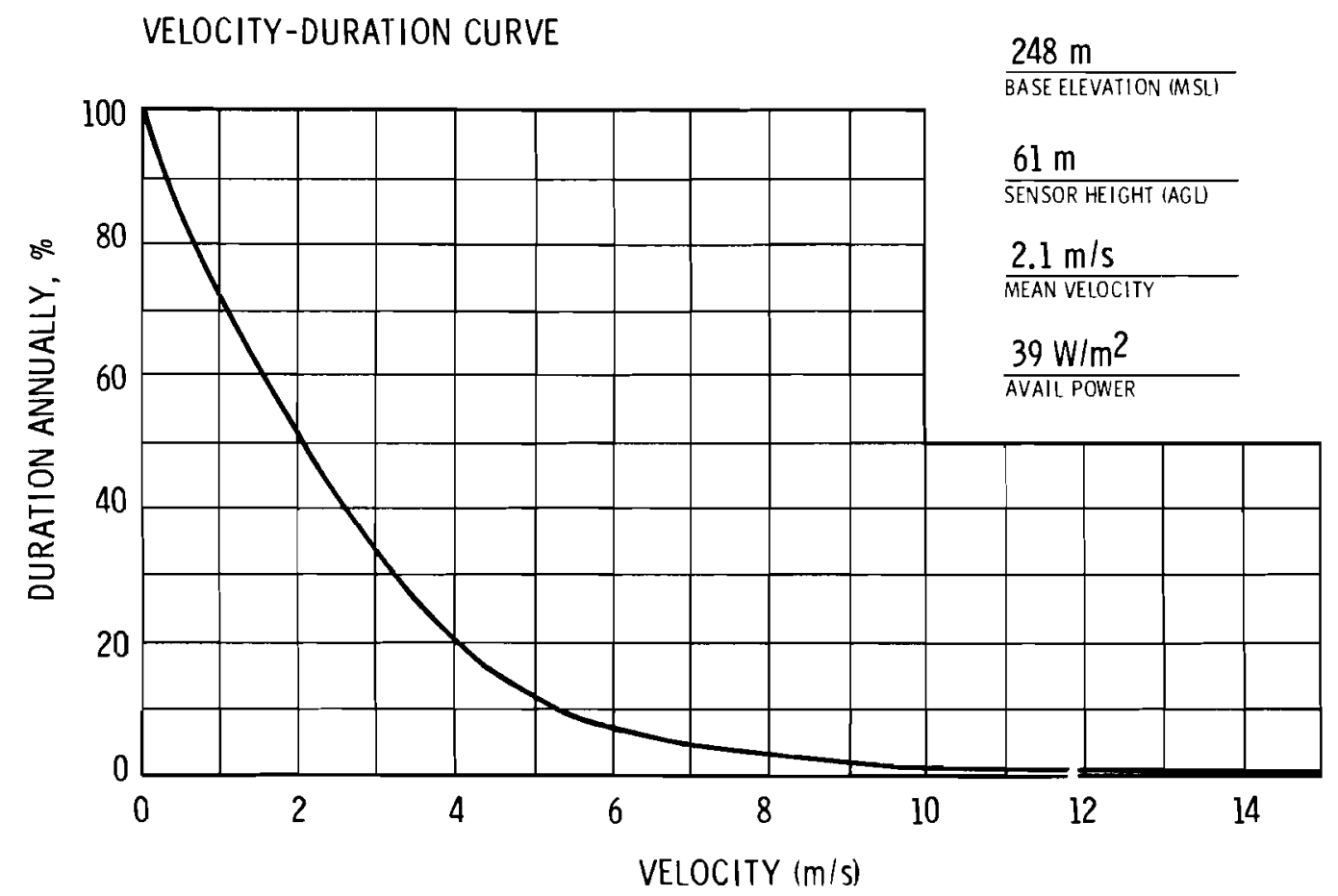


CLIN'TON

SITE LOCATION:

The Clinton Power Station site $\left(40.17^{\circ} \mathrm{N} / 88.83^{\circ} \mathrm{W}\right)$ is at the confluence of the North Fork of Salt Creek and Salt Creek, about $10 \mathrm{~km} \mathrm{E}$ of Clinton in Dewitt County, east central Illinois. Chicago is $215 \mathrm{~km} \mathrm{NE}$ and Springfield is $75 \mathrm{~km}$ WSW.

TOPOGRAPHY :

The topography surrounding the site is exceptionally level. The nearest large body of water (28 acres) is $16 \mathrm{~km}$ away. Plant elevation is $225 \mathrm{~m}$ (MSL) and within $8 \mathrm{~km}$, elevations range from $195 \mathrm{~m}$ to $232 \mathrm{~m}$ (MSL). Most of this relief is due to the shallow valleys surrounding the North Fork Salt Creek and Salt Creek. A large portion of this relief will be filled by the cooling lake formed in these valleys at $210 \mathrm{~m}$ (MSL).

\section{ON-SITE WIND MEASUREMENTS:}

An instrumented meteorological tower was completed in April 1972. The tower is $61 \mathrm{~m}$ high with a base at $224 \mathrm{~m}$ (MSI). Beyond the 113-by-87 $\mathrm{m}$ plot that contains the tower, the land is used to raise soybeans, and, therefore, is quite unsheltered. Wind measurements are made at the $10-\mathrm{m}$ and $60-\mathrm{m}$ levels. At $10 \mathrm{~m}$, the speed is taken by a Teledyne Geotech staggered sixcup anemometer and the wind direction by the guick one vane. The $60 \mathrm{~m}$ winds are measured by a six-bladed Bendix Aerovane. For hourly data values, the average value for the 30 minutes preceding the hour is determined directly from strip charts.

NRC Docket No. $\overline{50-461}$ 


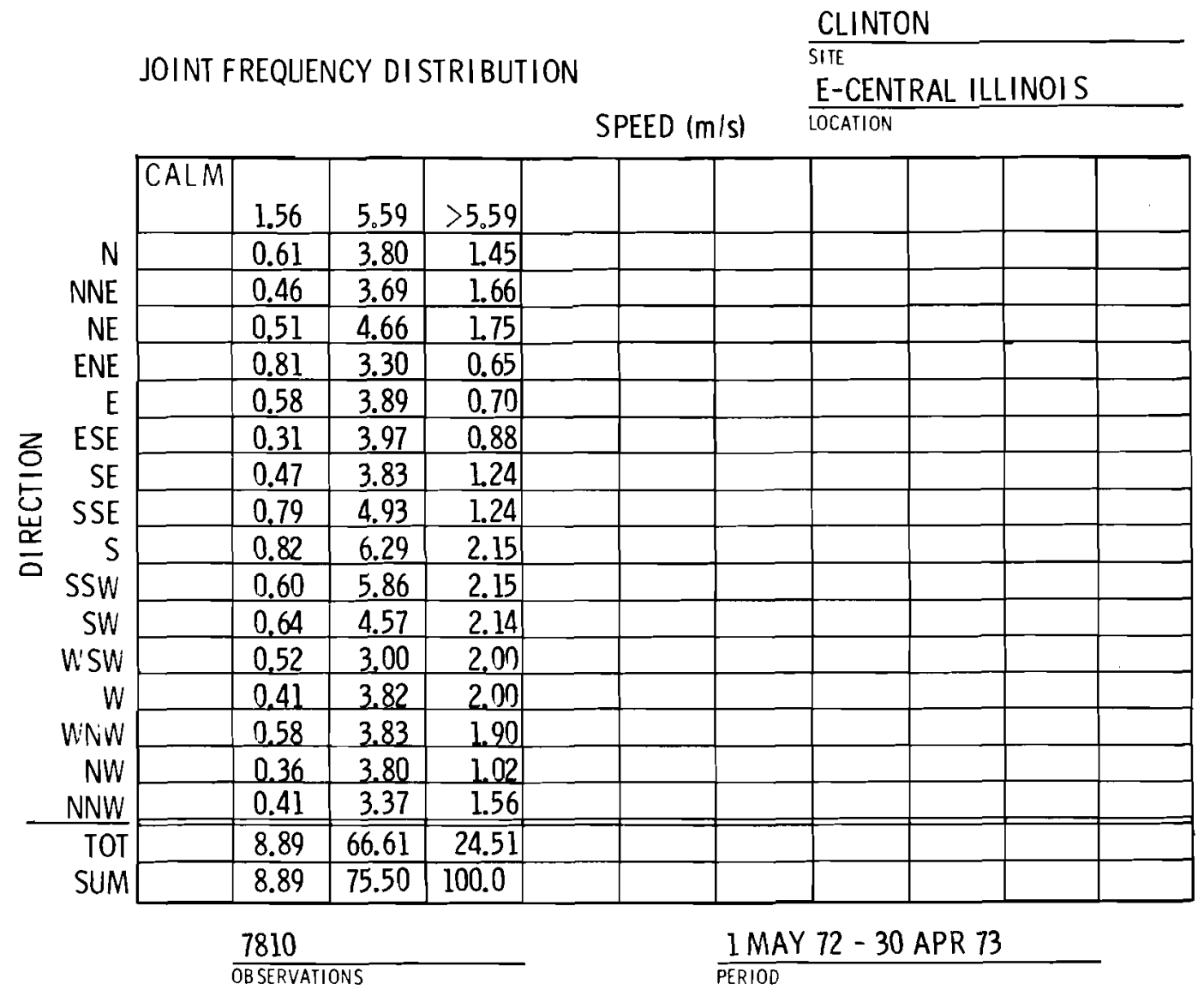

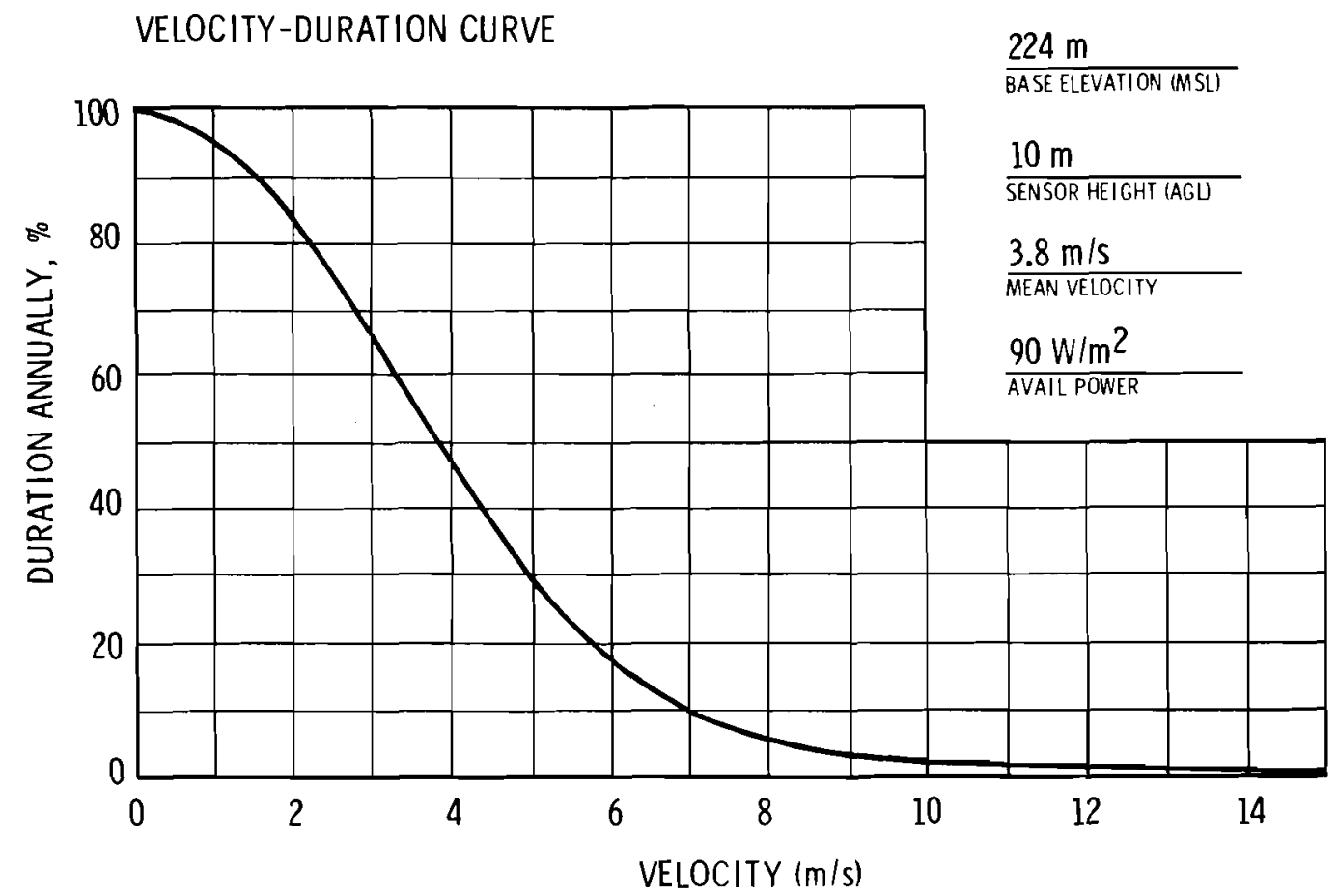




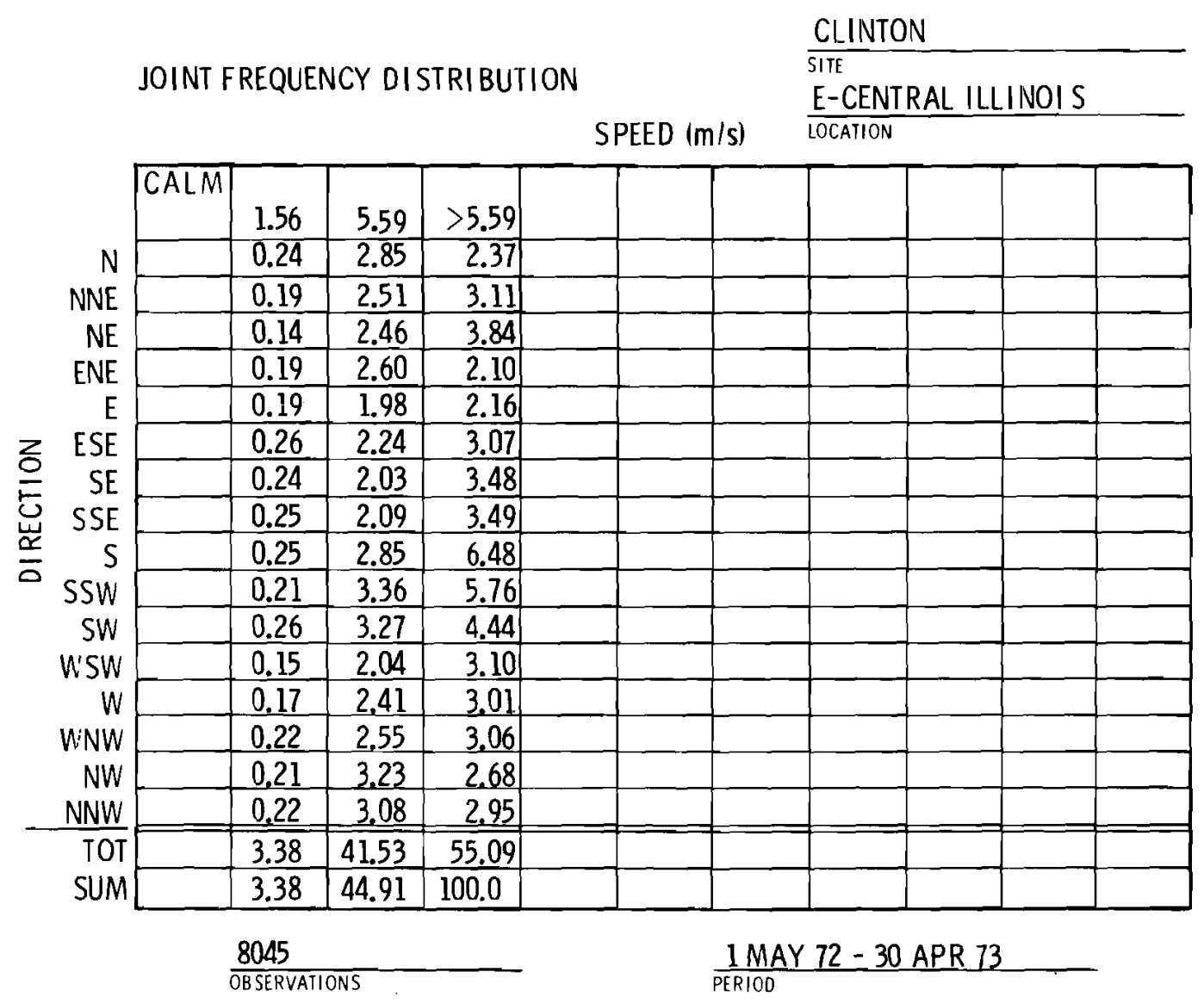

VELOCITY-DURATION CURVE

$224 \mathrm{~m}$

BASE ELEVATION (MSL!

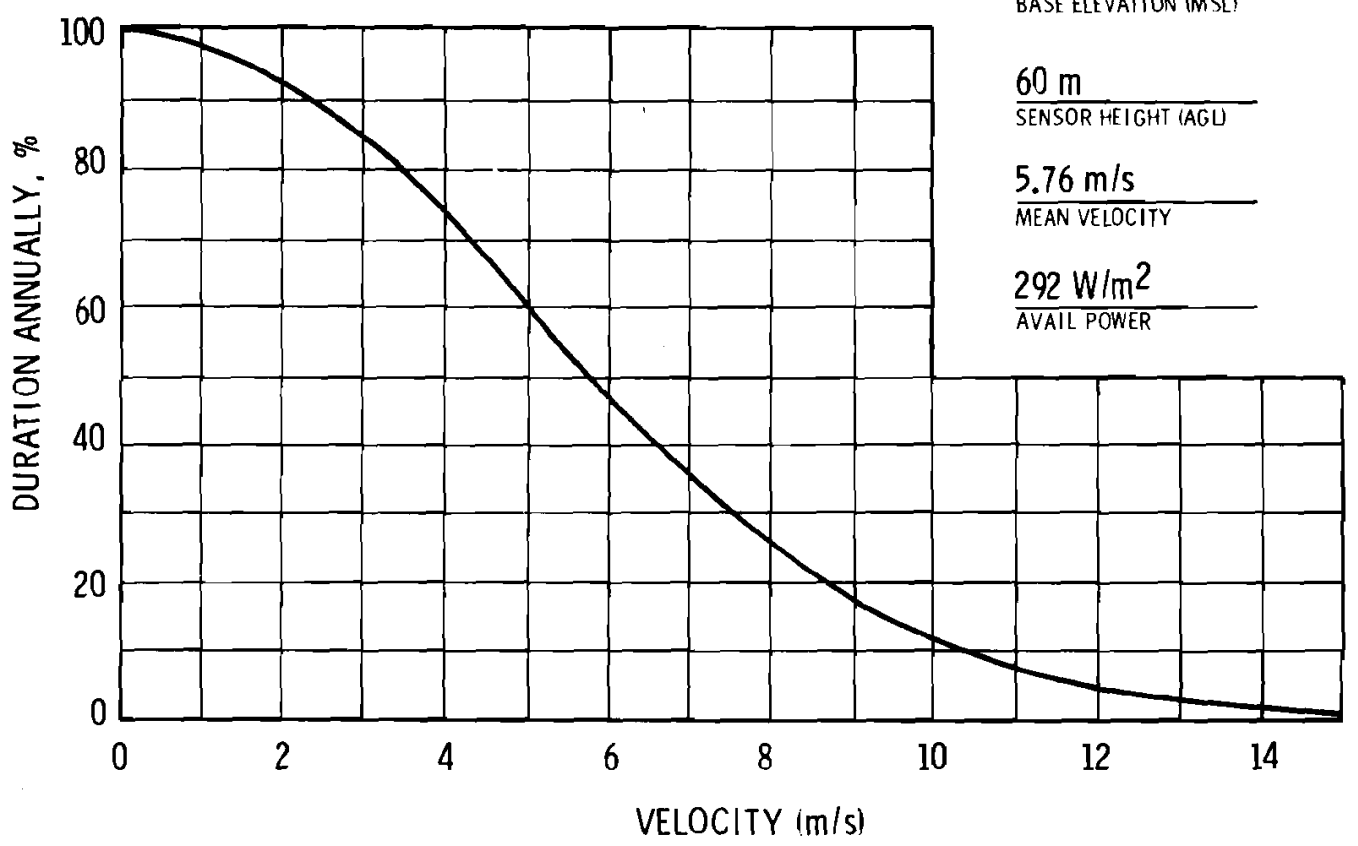

$C-55$ 


\section{SITE LOCATION:}

The Comanche Peak site $\left(32.30^{\circ} \mathrm{N} / 97.79^{\circ} \mathrm{W}\right)$ is located approximately equidistant between Cleburne and stephenville, Texas, W of the Brazos River. Fort Worth is $62 \mathrm{~km}$ to the NNE and Dallas is $101 \mathrm{~km}$ to the $\mathrm{NE}$.

\section{TOPOGRAPHY :}

The site is located on the gently rolling plains of north central Texas. Terrain in the region slopes gradually from about 100 to $200 \mathrm{~m}$ (MSI) in the SE to about 350 to $550 \mathrm{~m}$ (MSI) in the NW. Site elevation is about $250 \mathrm{~m}$ (MSI), and the terrain within $8 \mathrm{~km}$ varies from 175 to $300 \mathrm{~m}$ (MSI). Though locally variable, the terrain is generally sloping upward from SE to NW. The terrain surrounding the meteorological tower is relatively hilly and is covered by widely scattered scrub brush, small mesquite and cedar.

\section{ON-SITE WIND MEASUREMENTS:}

Wind measurements are made at 9 and $60 \mathrm{~m}$ on a $61-\mathrm{m}$ tower. Both levels are instrumented with Weathermeasure W 103/6L/A 6-cup anemometers and Weathermeasure $\mathrm{w}-104-2$ vanes.

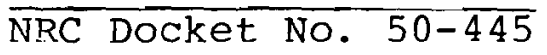


COMANCHE PEAK

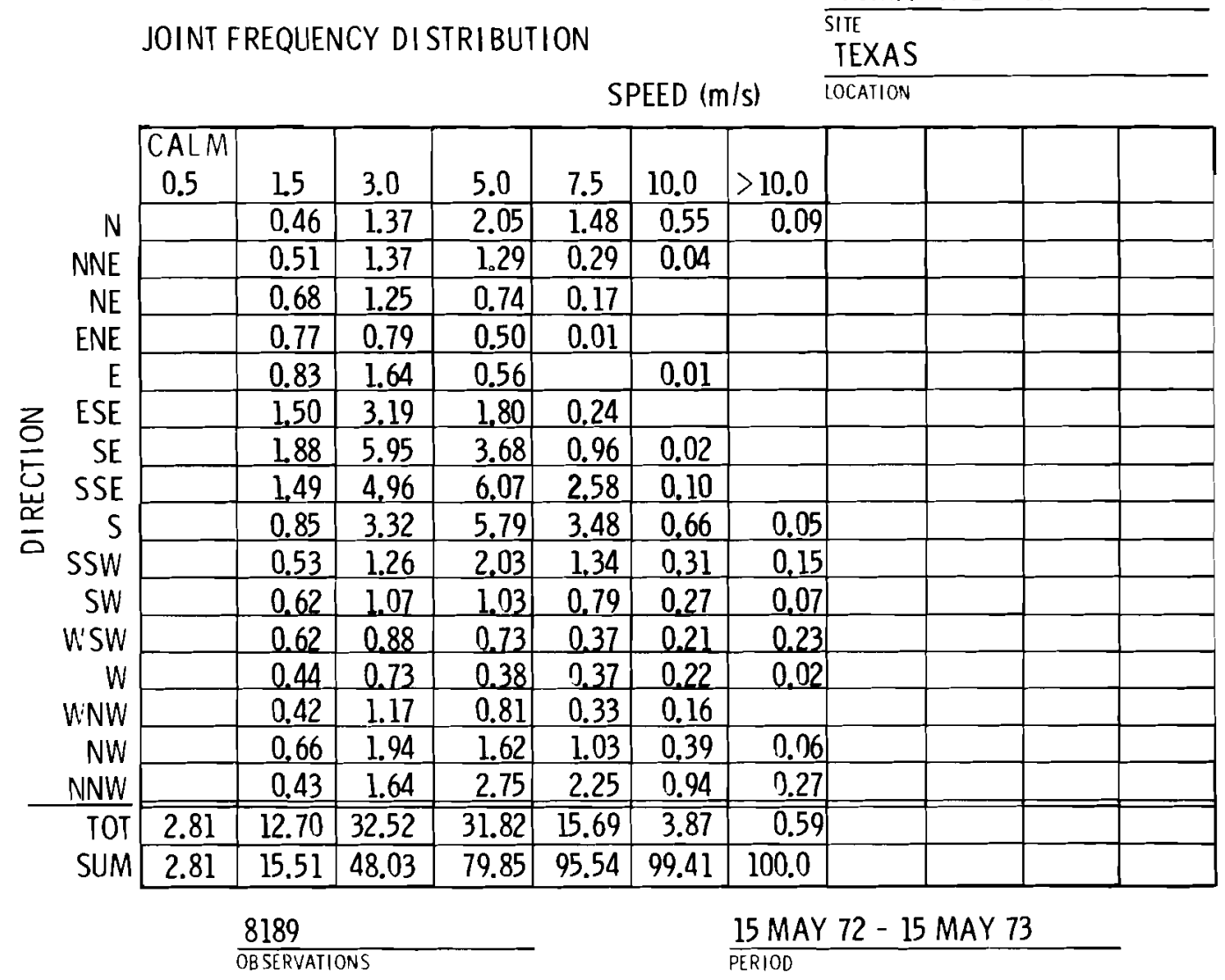

VELOCITY-DURATION CURVE

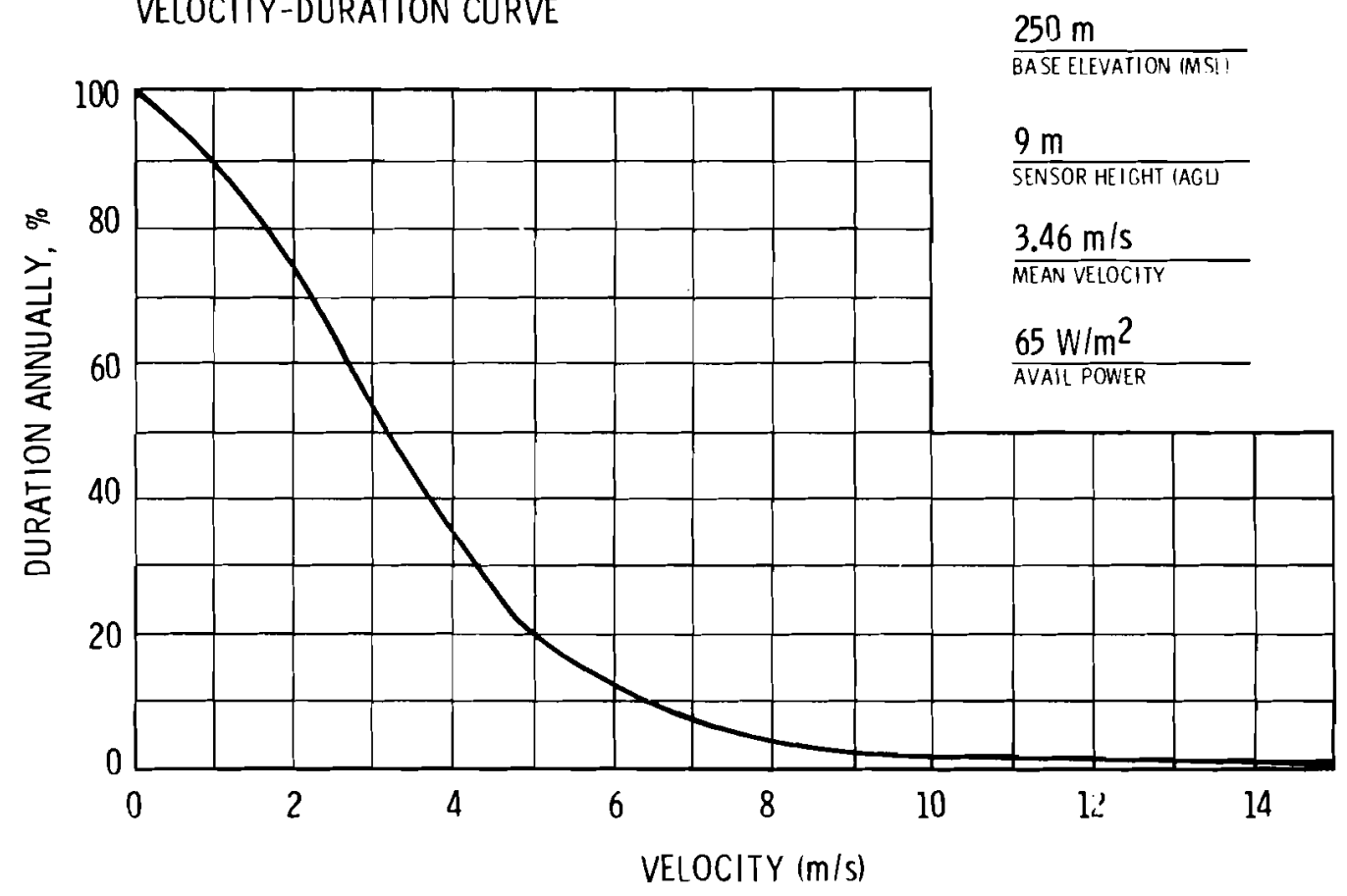


CONNECTICUT YANKEE

\section{SITE LOCATION:}

The site is located in the town of Haddam, Middlesex county, Connecticut $\left(41.48^{\circ} \mathrm{N} / 72.50^{\circ} \mathrm{W}\right)$ on the east bank of the Connecticut River. Hartford is $35 \mathrm{~km}$ to the NNW and New Haven is $40 \mathrm{~km} \mathrm{SW}$.

\section{TOPOGRAPHY :}

The 525-acre site is located on a peninsula land form on the east bank of the Connecticut River. This is the rather hilly region of the southern New England coast. The river flows in a NW-SE direction just $\mathrm{W}$ of the site and also forms the southern boundary of the site at the end of the peninsula, about $2 \mathrm{~km}$ from the plant. North of the plant, there are hills rising to $175 \mathrm{~m}$ (MSL) within $6 \mathrm{~km}$ and to the east, wooded hillsides rise steeply above a perpendicular rock cut to a 90 to $125 \mathrm{~m}$ ridge. Plant elevation is $6.5 \mathrm{~m}$ (MSL).

ON-SITE WIND MEASUREMENTS:

The meteorological program was initiated in 1962 and includes a $31-m$ tower on-site. Wind measurements are taken at 2 and $31 \mathrm{~m}$ with Bendix Aerovanes.

$\overline{\text { NRC Docket No. 50-213 }}$ 

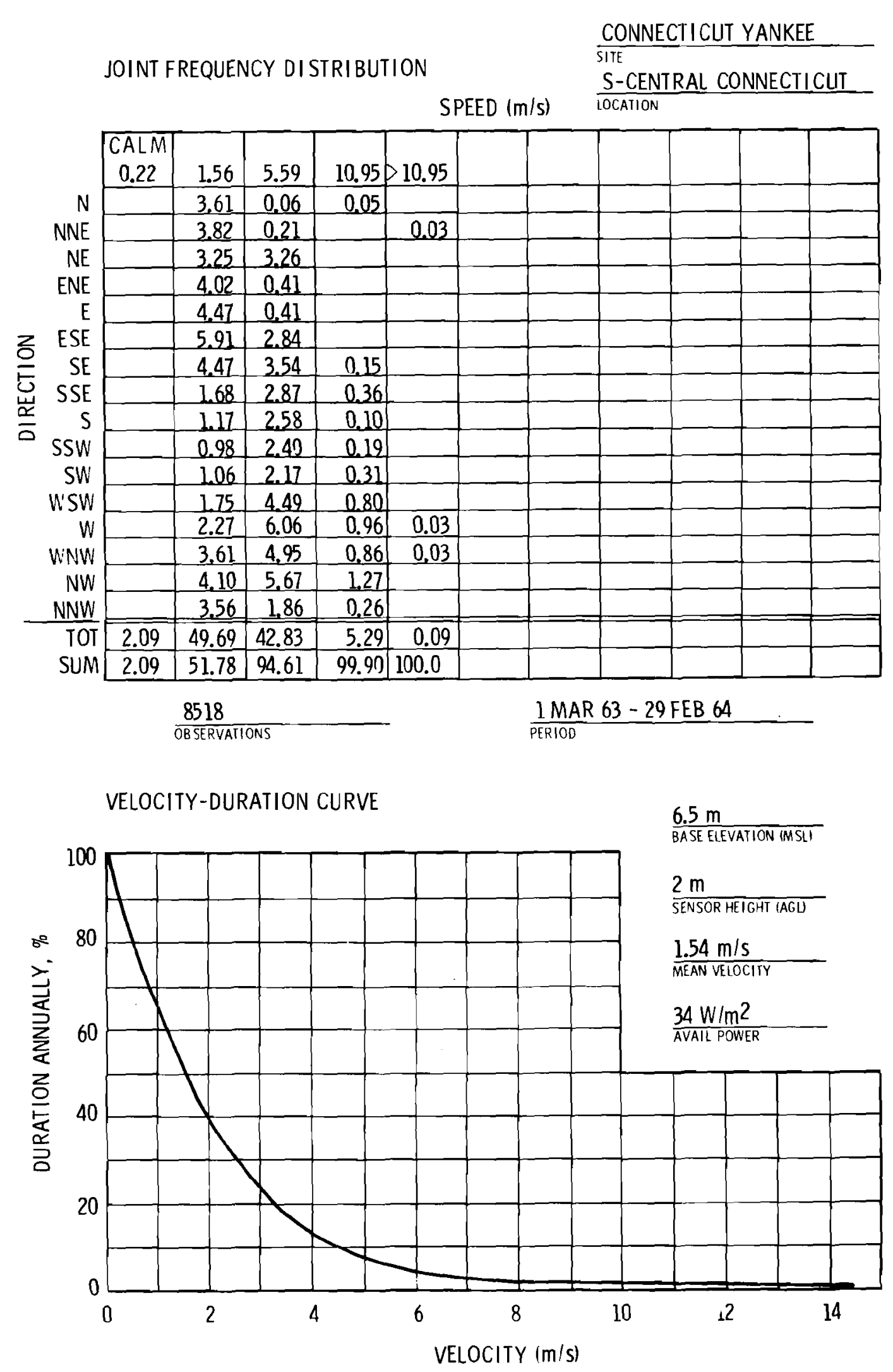


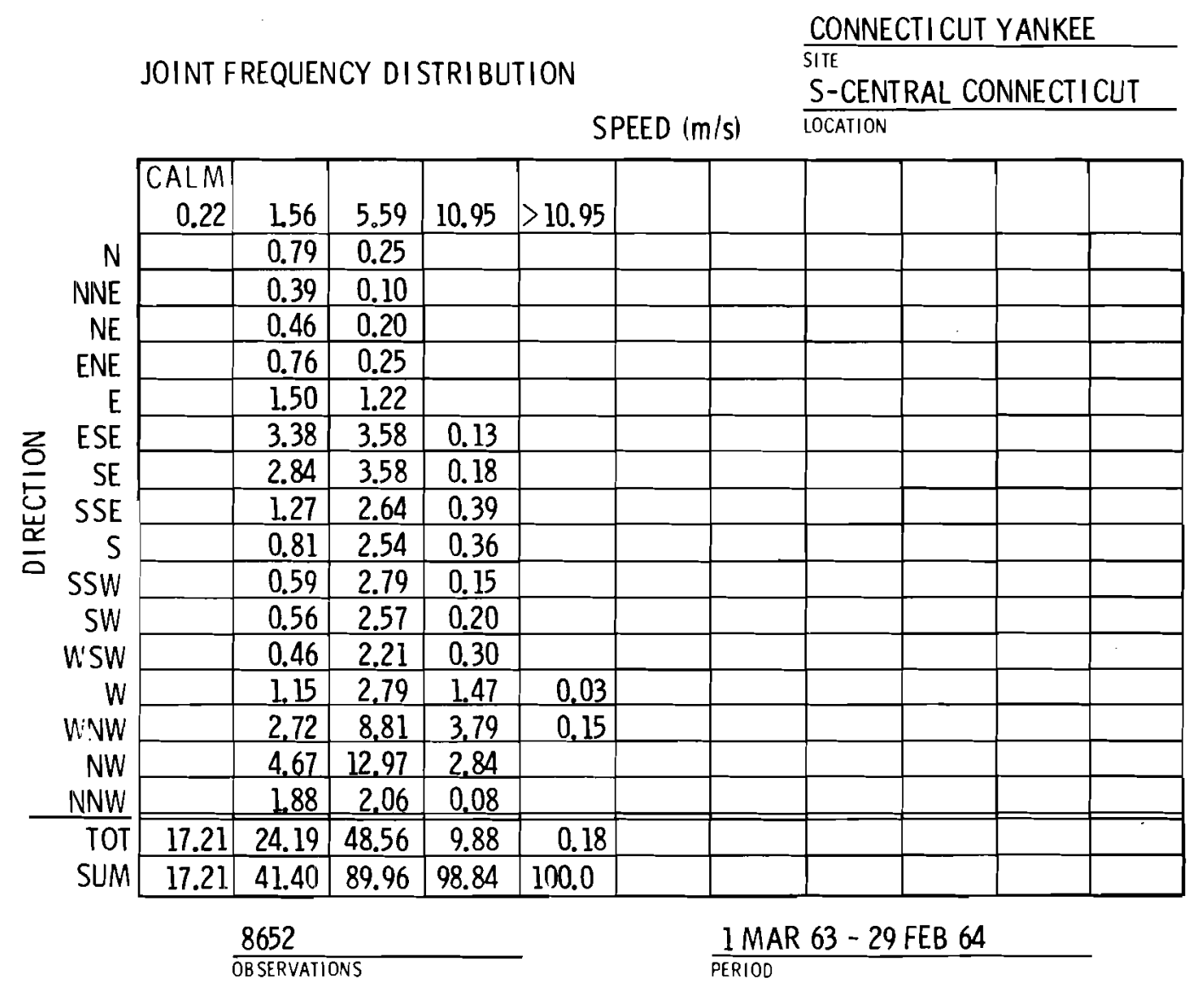

VELOCITY-DURATION CURVE

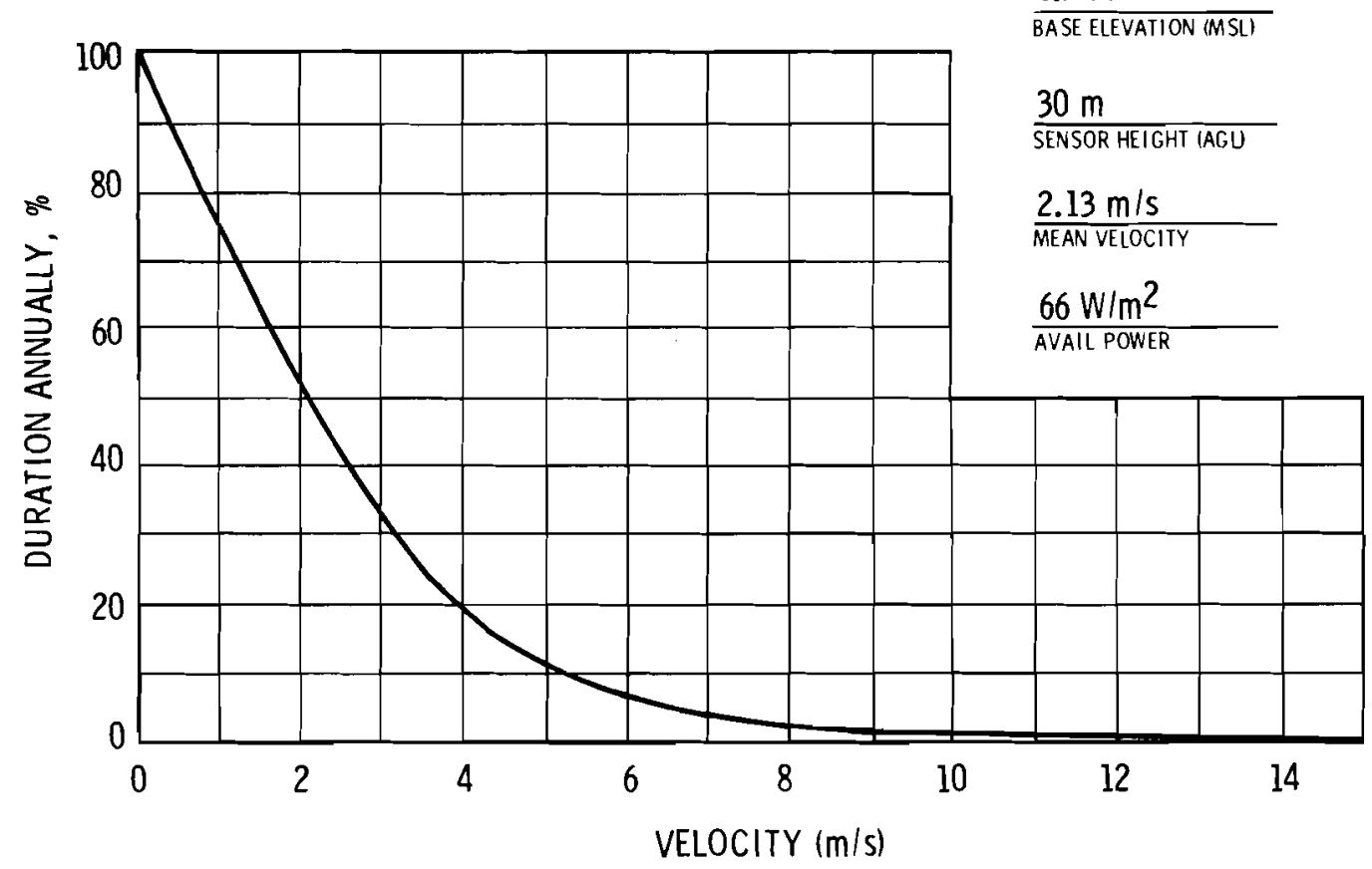

$6.5 \mathrm{~m}$

BASE ELEVATION (MSLI

$30 \mathrm{~m}$

$2.13 \mathrm{~m} / \mathrm{s}$

MEAN VELOCITY

$66 \mathrm{~W} / \mathrm{m}^{2}$

AVAIL POWER 
Donald C. COOK

\section{SITE LOCATION:}

The site is located in Berrien County $\left(42.03^{\circ} \mathrm{N} / 86.49^{\circ} \mathrm{W}\right)$, in the SW corner of Michigan, about $18 \mathrm{~km}$ SSW of Benton Harbor, on the eastern shore of Lake Michigan.

\section{TOPOGRAPHY :}

The 650-acre site along the eastern shore of Lake Michigan consists primarily of heavily wooded, rugged sand dunes. A sandy beach slopes gently upwards for about $60 \mathrm{~m}$ from the lake before rising sharply into the dunes. The peaks of the highest dunes reach elevations of about $55 \mathrm{~m}$ above the lake surface, while depressions between dunes are as low as $3 \mathrm{~m}$. The site is open to the lake from SSW through NNE. Lake elevation is $177 \mathrm{~m} \mathrm{(MSL);} \mathrm{plant} \mathrm{grade} \mathrm{is} 185 \mathrm{~m}$ (MSL).

ON-SITE WIND MEASUREMENTS:

A 61-m tower was installed in the summer of 1966 and equipped with Bendix-Friez "Aerovane" systems at $15 \mathrm{~m}$ and $6.1 \mathrm{~m}$. The base of the tower is at about $210 \mathrm{~m}$ (MSL).

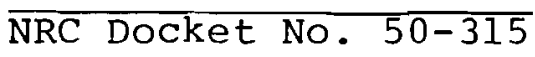



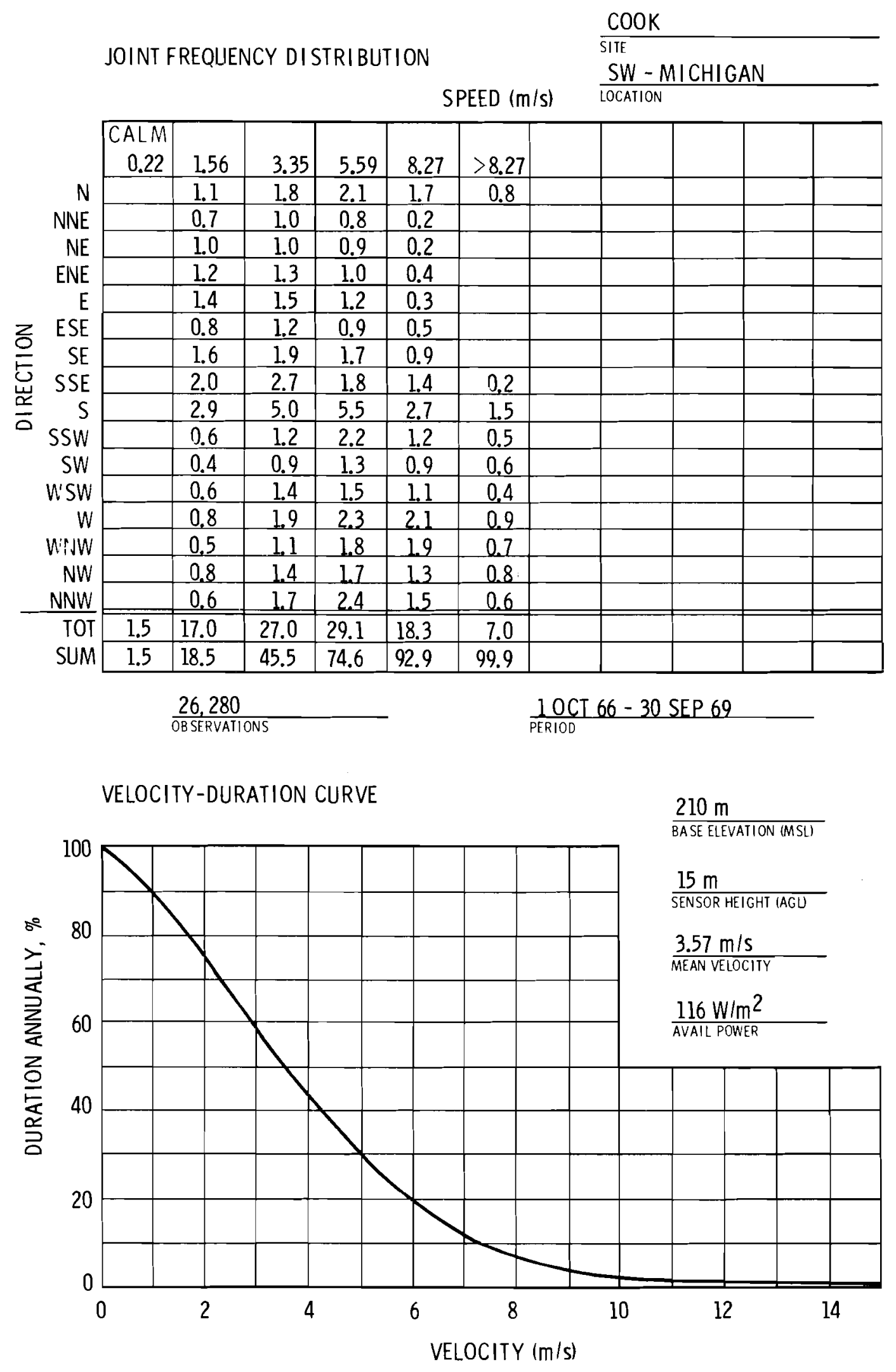

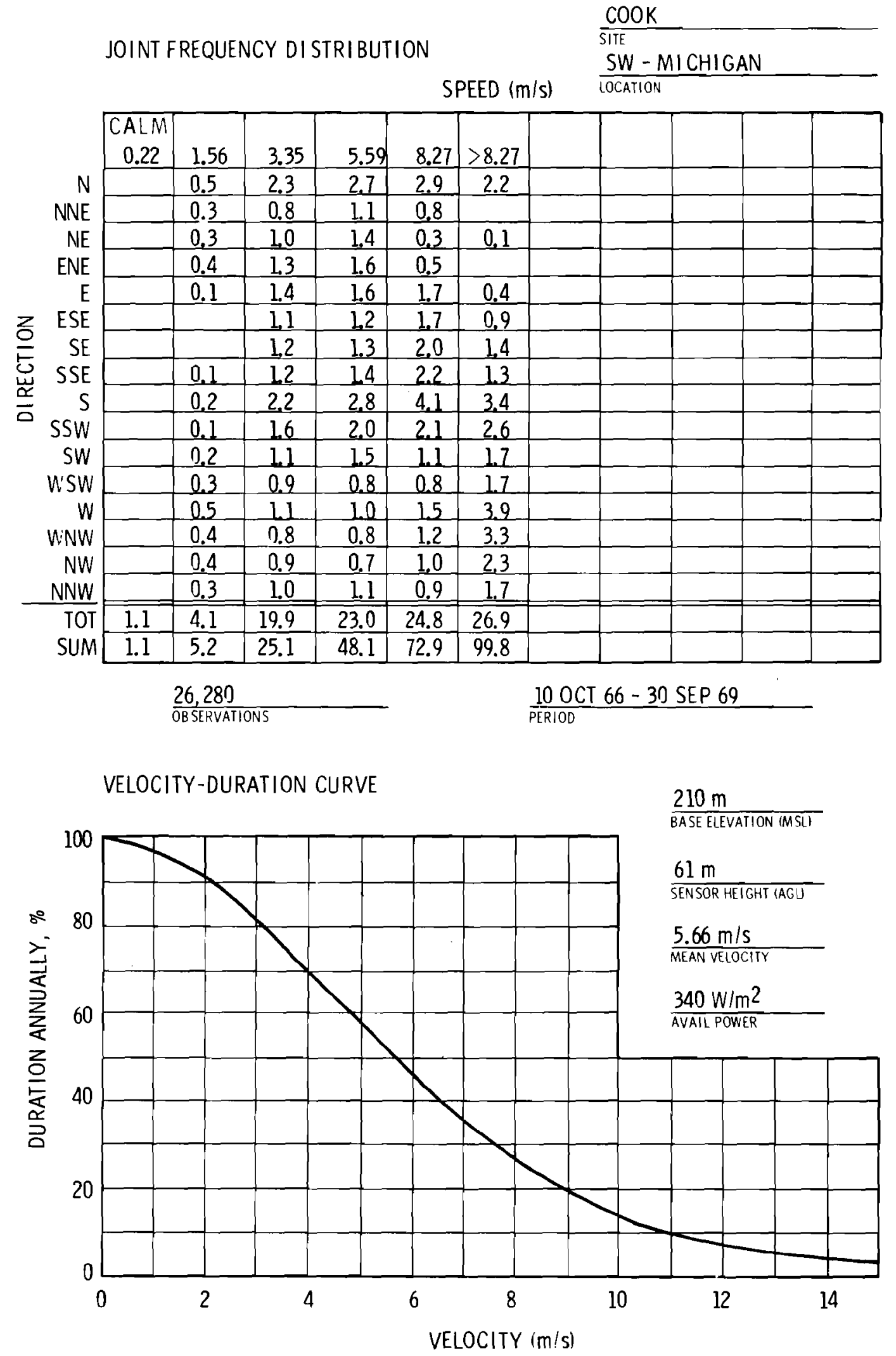
COOPER

\section{SITE LOCATION:}

The site is located $3 \mathrm{~km} \mathrm{~N}$ of Brownville, Nemaha County, Nebraska $\left(40.33^{\circ} \mathrm{N} / 95.63^{\circ} \mathrm{W}\right)$, on the west bank of the Missouri River. Lincoln is $96 \mathrm{~km}$ NW and Omaha is $94 \mathrm{~km}$ NNW.

TOPOGRAPHY :

The site is in a region of rolling hills in SE Nebraska. To the west, the land begins a gradual rise to the large plains of western Nebraska. Locally, the rolling terrain is cut by the broad, generally N-S valley of the Missouri River some 30 to $50 \mathrm{~m}$ deep. The site is at about $270 \mathrm{~m}$ (MSL) on the west bank of the river.

ON-SITE WIND MEASUREMENTS:

A 97-m tower was erected at plant grade (270 m (MSL)) and data collection initiated on 8 Jan 1970. Wind speed and direction measurements are made at the 97-m level using a Bendix Aerovane.

NRC Docket No. $50-298$ 


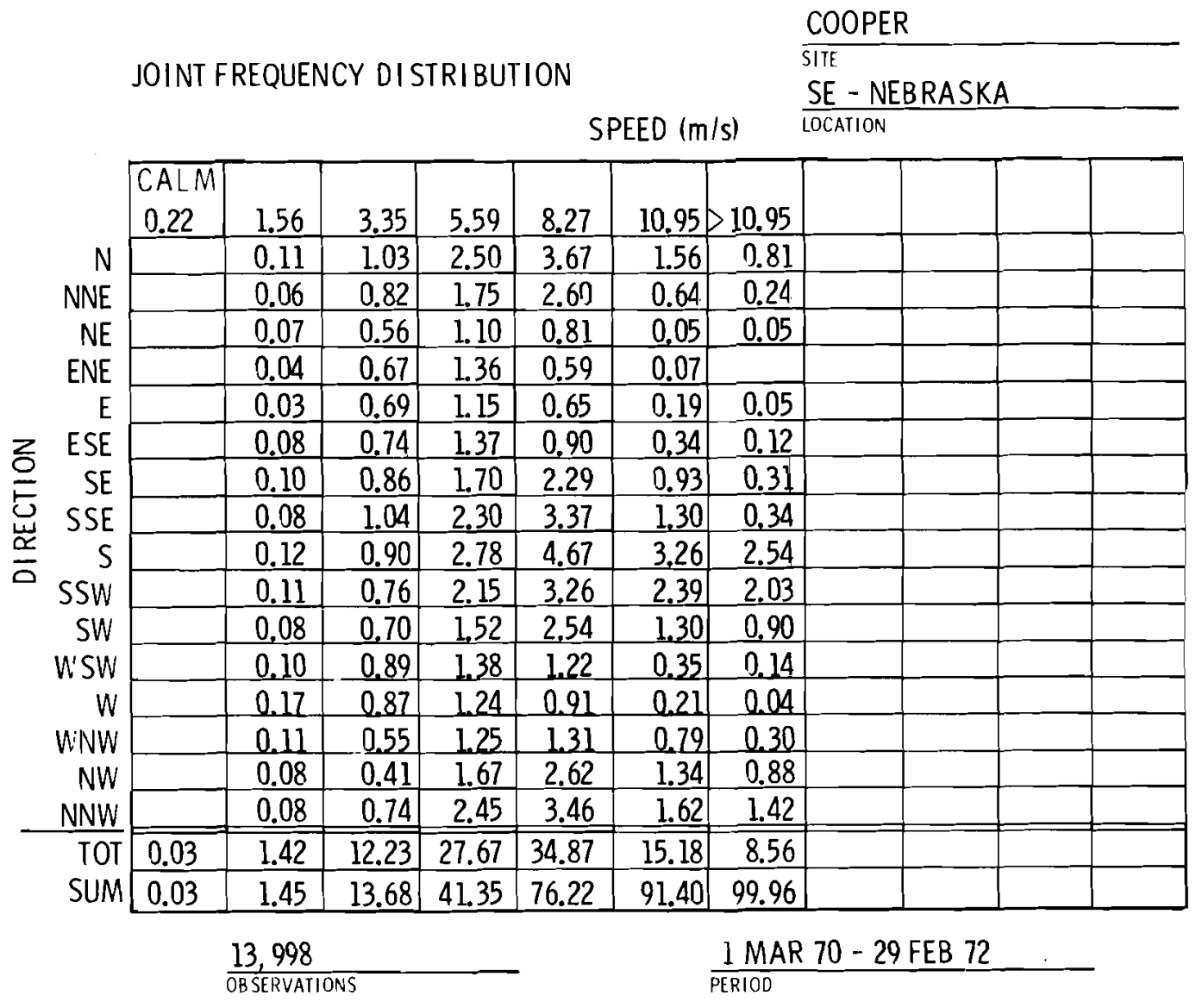

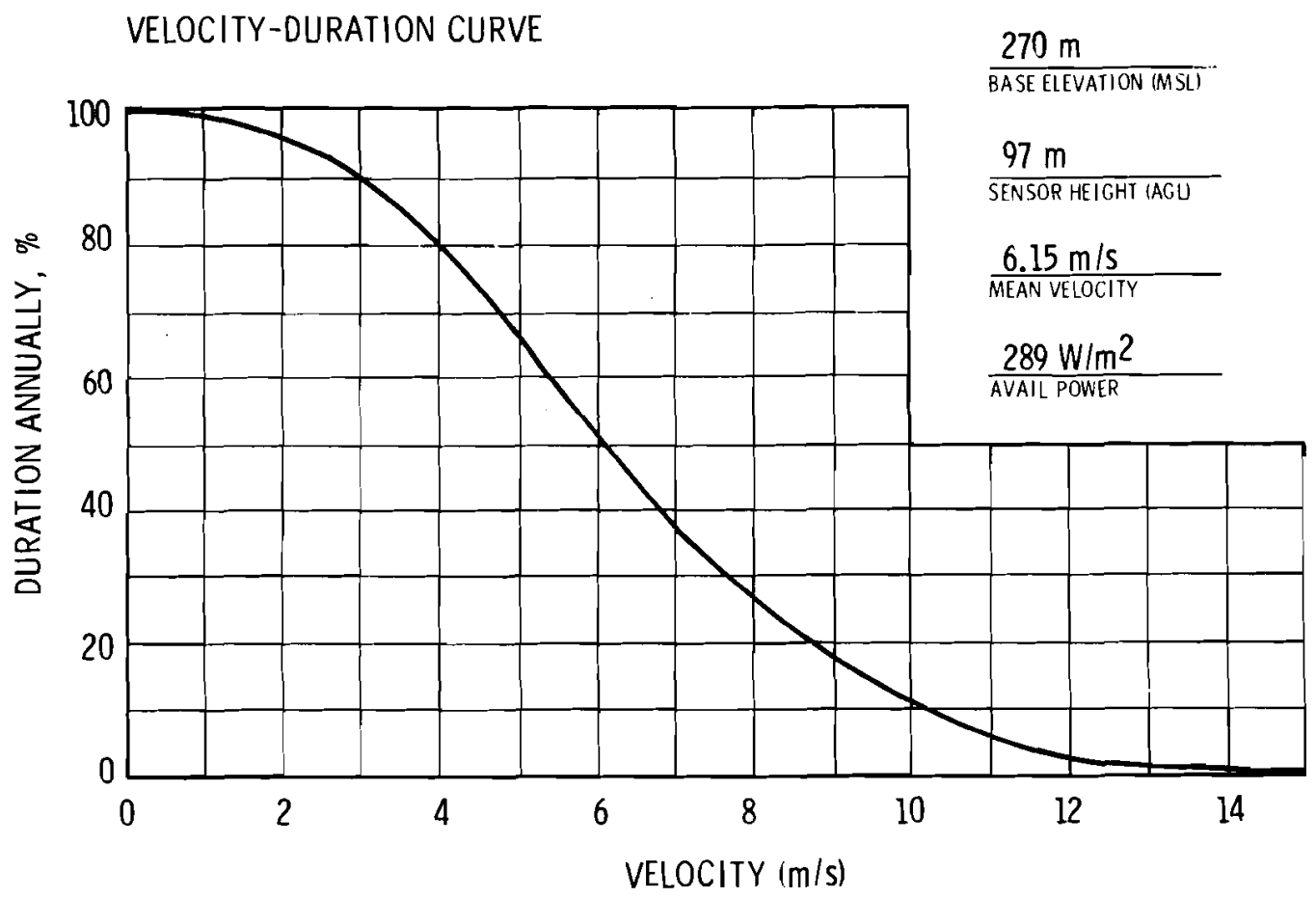


CRYSTAL RIVER

\section{SITE LOCATION:}

The site is located $12 \mathrm{~km}$ NW of Crystal River and $113 \mathrm{~km} \mathrm{~N}$ of Tampa, Florida $\left(28.96^{\circ} \mathrm{N} / 82.70^{\circ} \mathrm{W}\right)$.

\section{TOPOGRAPHY:}

The 4,738-acre site is on the west coast of Florida, a region characterized by the Gulf of Mexico on the west with gradually rising terrain from the mangrove swamps and marshlands in the coastal areas to gently rolling hills about $25 \mathrm{~km}$ to the east. The area around the site is extremely flat and featureless. There is a maximum of $6 \mathrm{~m}$ difference in relief within $8-\mathrm{km}$ radius. The Gulf of Mexico on the west extends from the NNW counterclockwise through the SE.

\section{ON-SITE WIND MEASUREMENTS:}

Wind measurements are made at the $10 \mathrm{~m}$ and $46 \mathrm{~m}$ levels of a 46-m tower using model 120 Bendix Aerovanes. Data are manually reduced for 15-minute average values on an hourly basis.

$\overline{\text { NRC Docket No. } 50-302}$ 


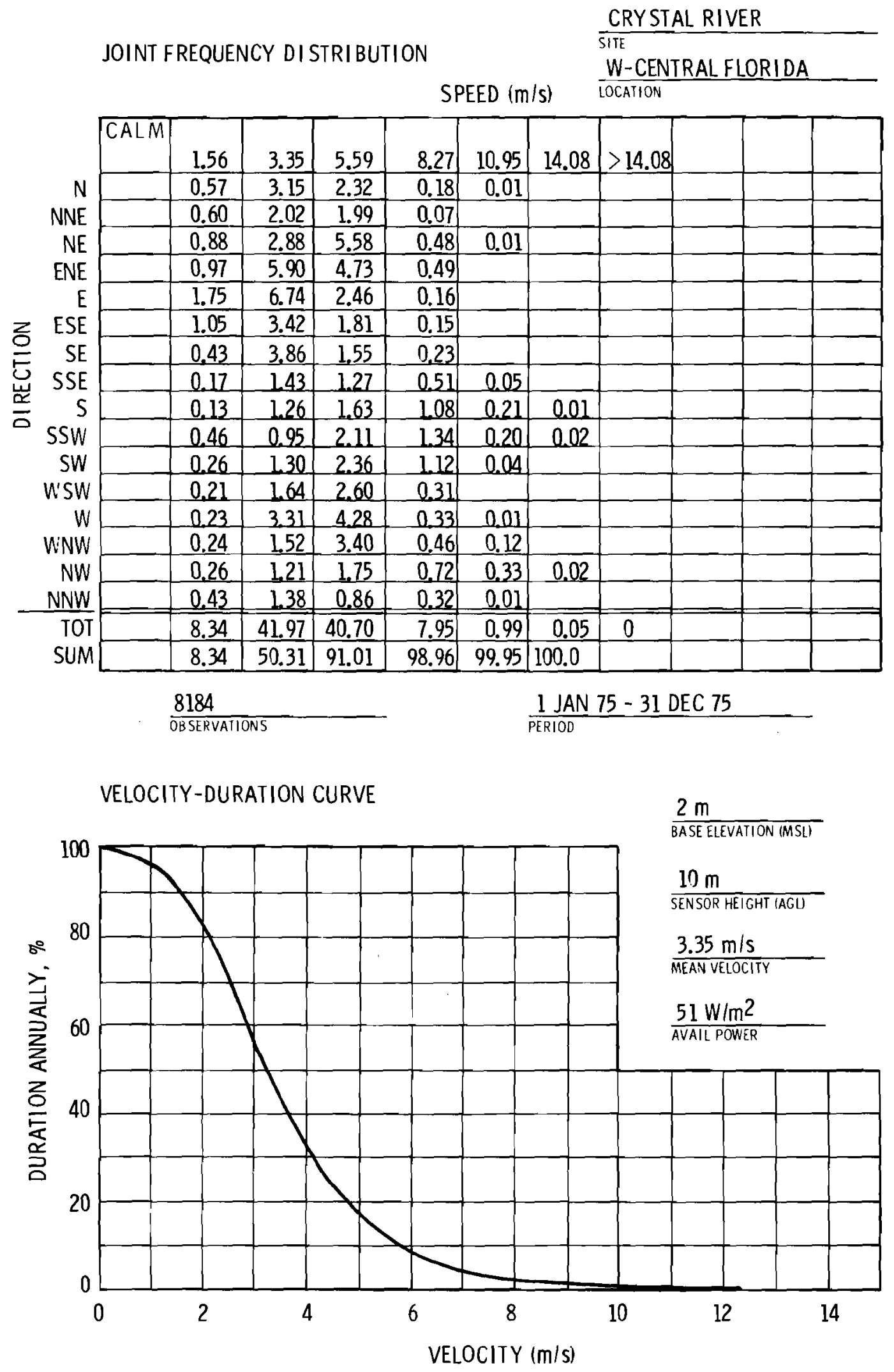


DAVIS-BESSE

\section{SITE LOCATION:}

The Davis-Besse site $\left(41.60^{\circ} \mathrm{N} / 83.09^{\circ} \mathrm{W}\right)$ is on the southwest shore of Lake Erie and the north bank of the mouth of the Toussaint River in ottawa county in northwest Ohio. Toledo is $40 \mathrm{~km} \mathrm{~W}$ and Cleveland is $115 \mathrm{~km}$ ESE.

\section{TOPOGRAPHY :}

The region around the SW shore of Lake Erie is very flat uplands. Bordering the lake in the vicinity of the site and on the site itself are marshlands, including some 600 acres on the 954-acre site. Site elevation is $178 \mathrm{~m}$ (MSL). The site is on the southwest shore of Lake Erie and the north bank of the Toussaint River, and has been built up almost $2.5 \mathrm{~m}$ to its present elevation. Elevations within $8 \mathrm{~km}$ are between $175 \mathrm{~m}$ and $180 \mathrm{~m}$ (MSL).

\section{ON-SITE WIND MEASUREMENTS:}

From October 1968 to November 1970, wind measurements were made at $6 \mathrm{~m}, 30 \mathrm{~m}$, and $91 \mathrm{~m}$ on a 91-m tower at $174 \mathrm{~m}$ (MSL), using Bendix-Friez Model 120 "Aerovane" six-bladed wind systems. With the addition of more than 4-m of fill, the tower did not conform to Safety Guide 23 and a new 104-m tower was installed at $178 \mathrm{~m}$ (MSL). Wind measurements on the new tower are made at $11 \mathrm{~m}$, $76 \mathrm{~m}$, and $104 \mathrm{~m}$ using $\mathrm{Climet} \mathrm{WS}-011-1$ speed instruments and Climet WD-012-10 wind direction instruments. The attached sample data reflect the change in instruments and elevation.

NRC Docket Nos. 50-346, 50-500 


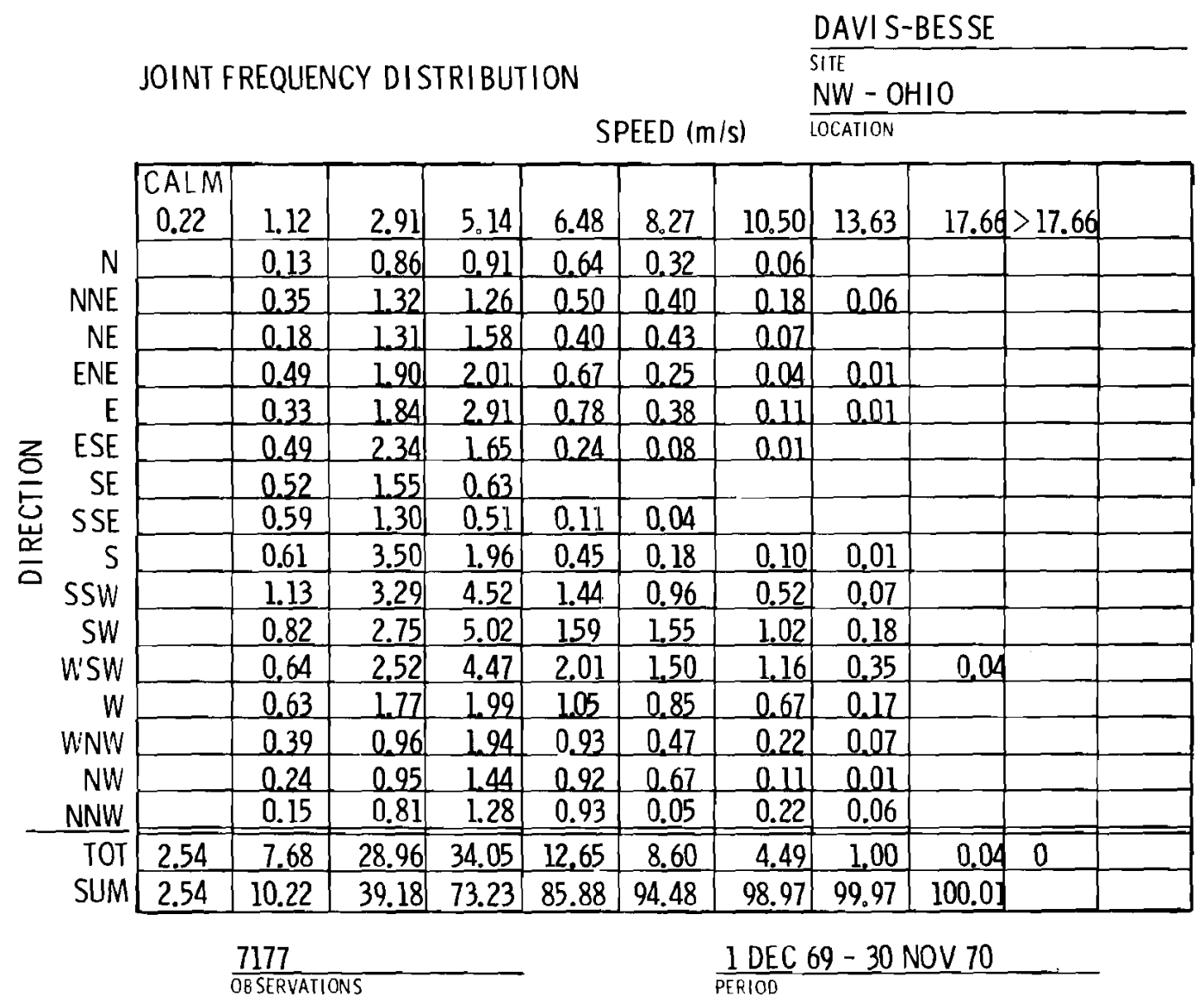

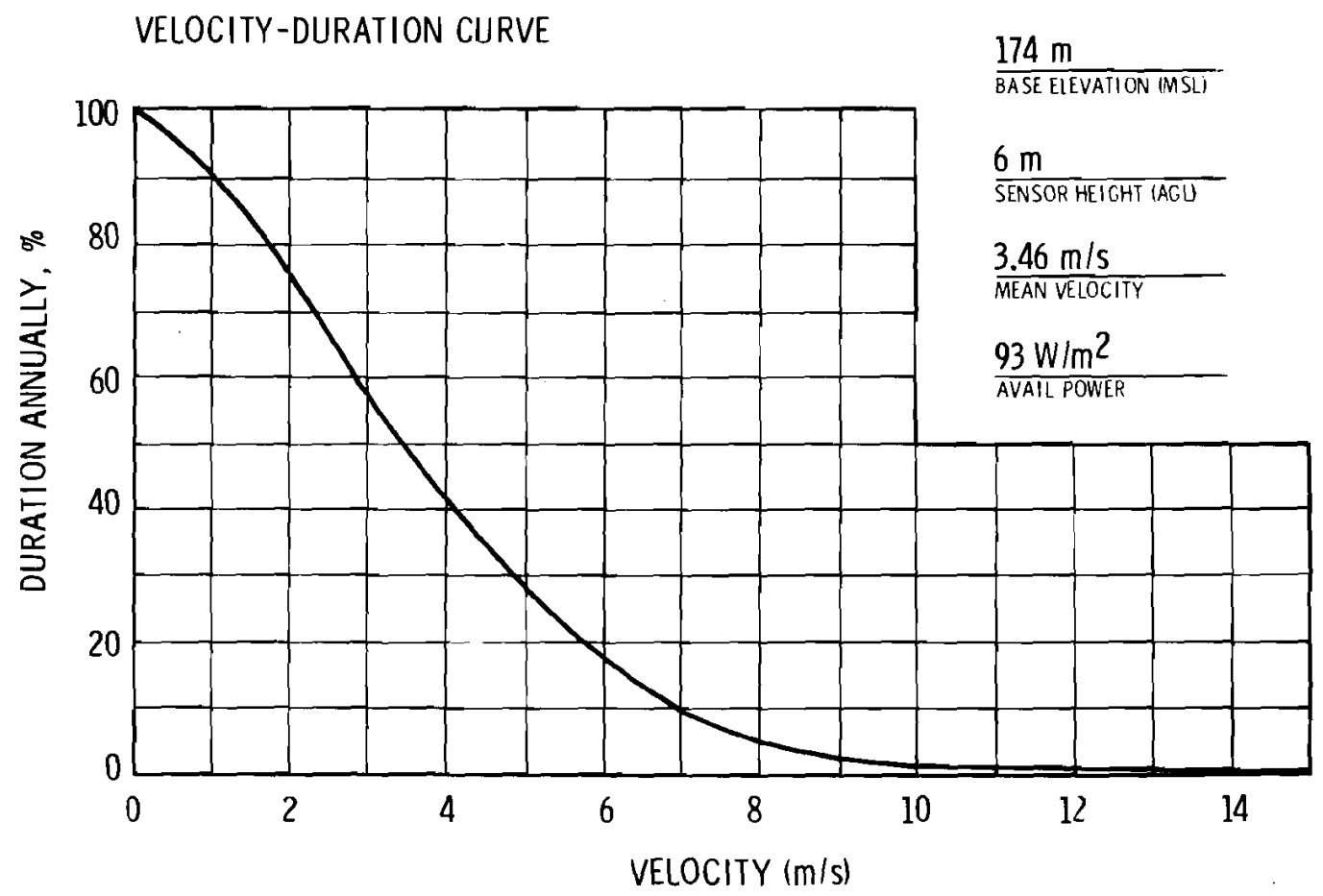




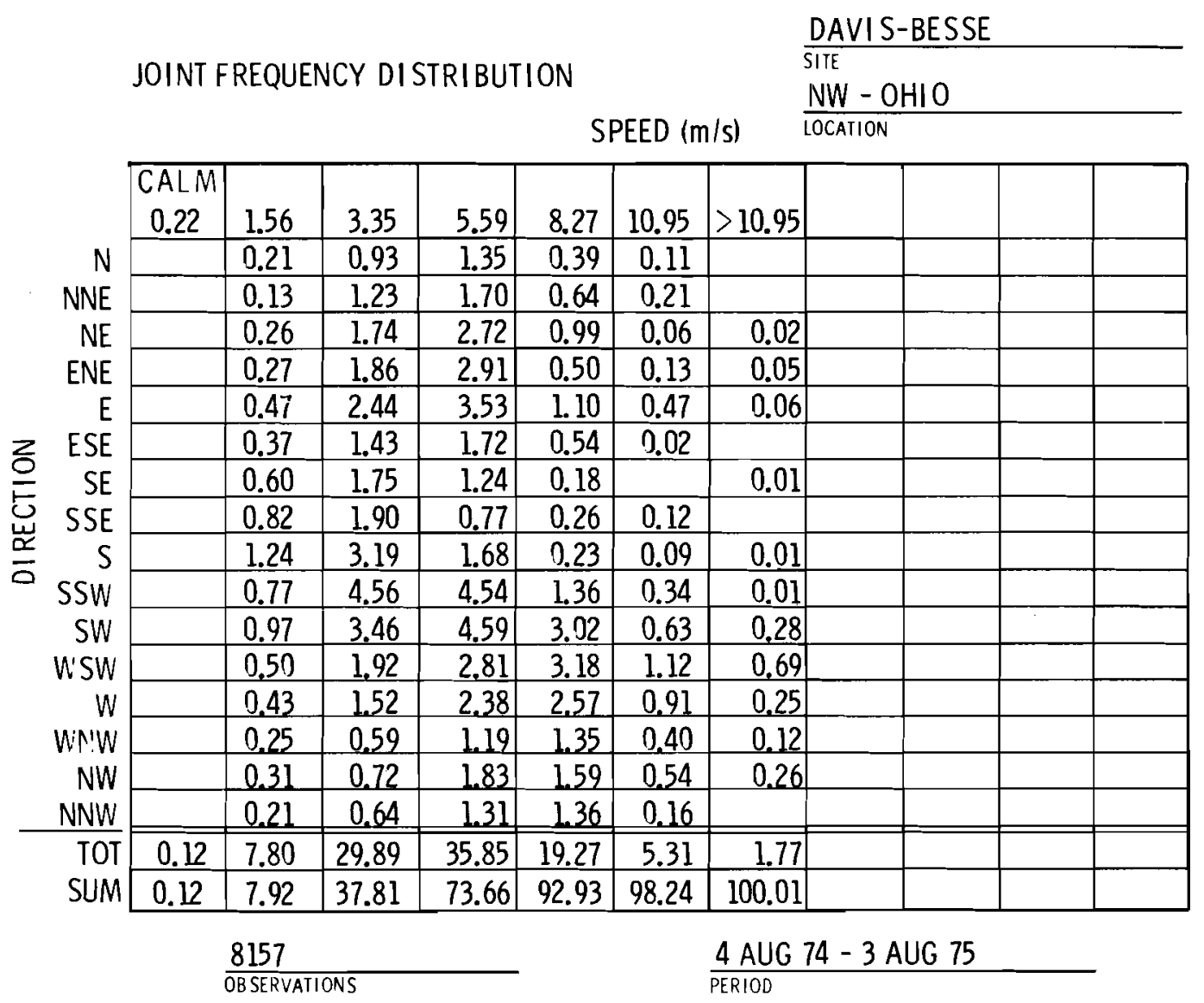

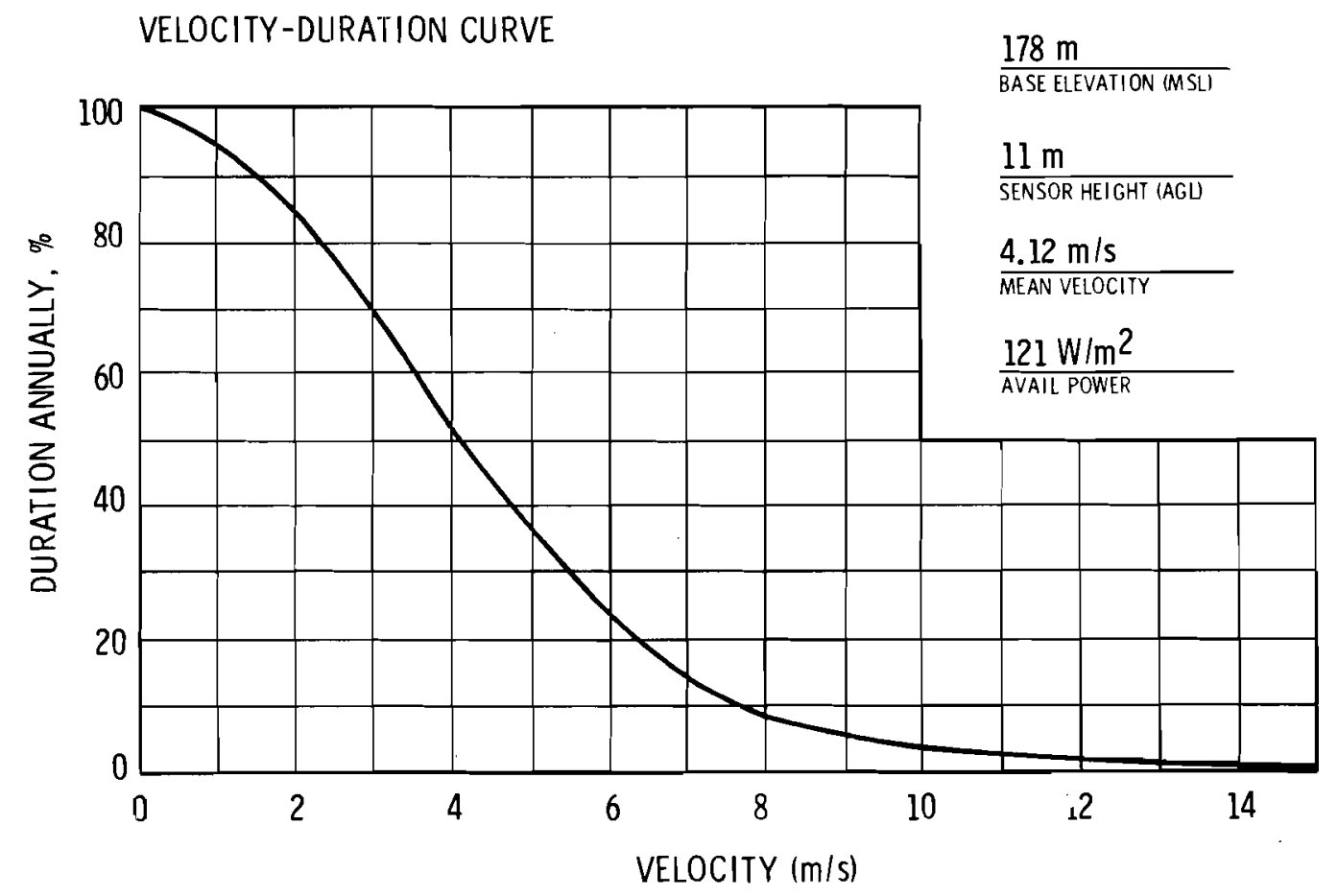




\section{DIABLO CANYON}

\section{SITE LOCATION:}

The Diablo Canyon site $\left(35.21^{\circ} \mathrm{N} / 120.85^{\circ} \mathrm{W}\right)$ is located on the Pacific Ocean, in San Luis obispo County, California about $16 \mathrm{~km}$ SW of the city of San Luis obispo. Los Angeles is about $250 \mathrm{~km} \mathrm{SE}$ and San Francisco is $325 \mathrm{~km} \mathrm{~N}$.

\section{TOPOGRAPHY :}

The site is located in the rugged coastal region of California. The site occupies a coastal terrace that ranges in elevation from $15 \mathrm{~m}$ to $50 \mathrm{~m} \mathrm{(MSL)} \mathrm{and} \mathrm{is} \mathrm{approximately} 300 \mathrm{~m}$ wide. Plant grade is at $26 \mathrm{~m}$. The seaward edge of the terrace is a nearvertical cliff. Back from the terrace and extending many kilometers inland are the rugged Irisis Hills, an area of steep brush-covered hillsides and deep canyons, which are part of the San Luis Mountains and which attain an elevation of 450 $m$ within a little over a kilometer of the site.

\section{ON-SITE WIND MEASUREMENTS:}

Wind data have been collected from a comprehensive network of six stations $(A-F)$ at various times. Stations $A$ and $B$ are $900 \mathrm{~m} \mathrm{SE}$ of the plant at $38 \mathrm{~m}$ (MSL) and $183 \mathrm{~m} \mathrm{(MSL),} \mathrm{respec-}$ tively. Stations $C$ and $D$ are in Diablo Canyon at $23 \mathrm{~m}$ (MSL) and $107 \mathrm{~m}$ (MSL). The wind instruments at each of these four stations consisted of Climet CI-26 cup and vane assemblies at a height of $11 \mathrm{~m}$. Station $\mathrm{E}$ is an $80-\mathrm{m}$ tower at $38-\mathrm{m}$ (MSL) near the plant location with Bendix-Friez Model 120 Aerovanes at the $8-\mathrm{m}$ and $76-\mathrm{m}$ level. The $8-\mathrm{m}$ sensor was later moved to $10 \mathrm{~m}$. Data samples in this report are from station $E$ at the 8-m and 10-m levels. Station $\mathrm{F}$ was $900 \mathrm{~m} \mathrm{E}$ of the plant and consisted of a 30-m tower at 280-m (MSL), instrumented with a Bendix-Friez Model 120 Aerovane on the top of the tower. 

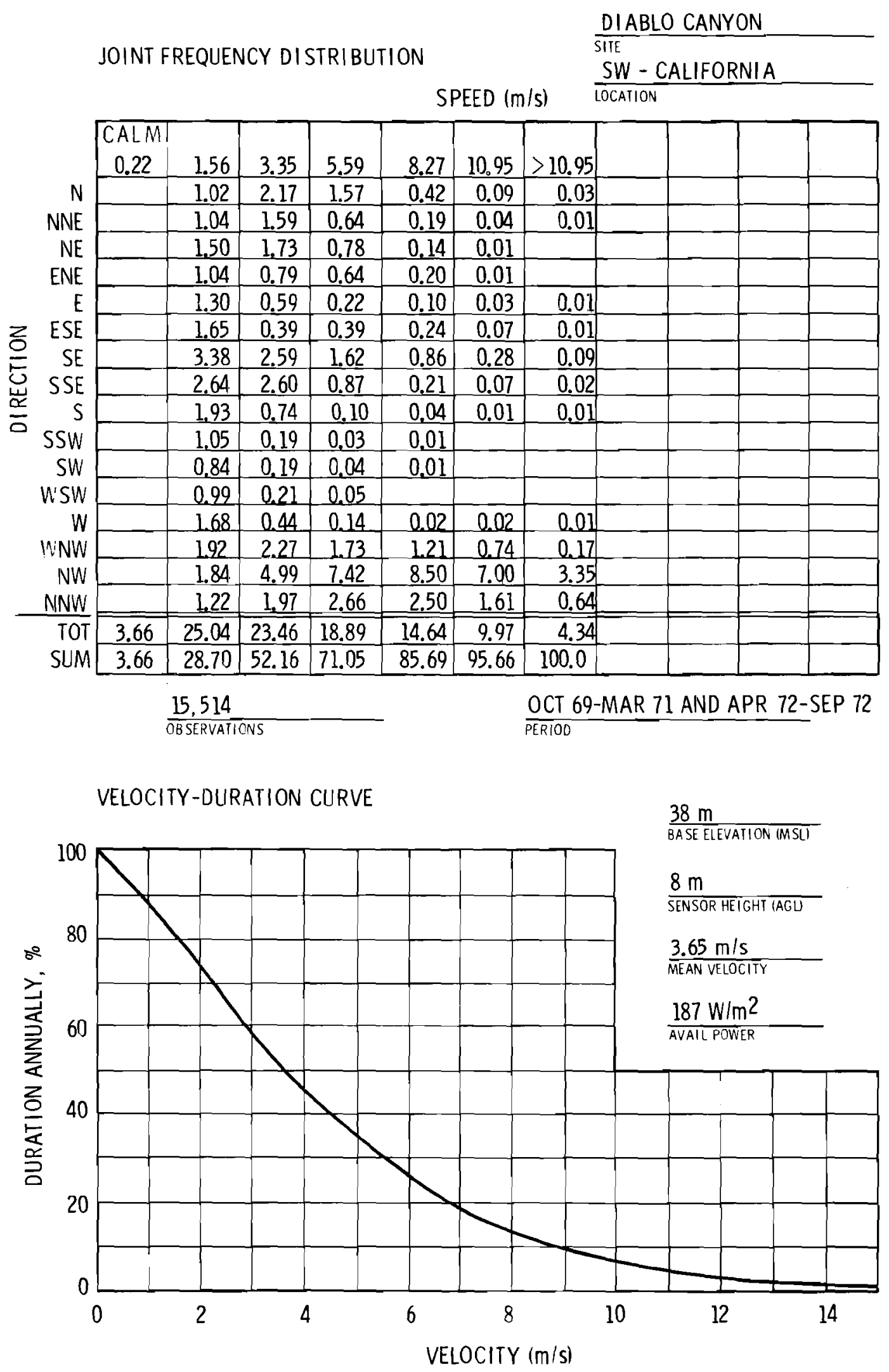


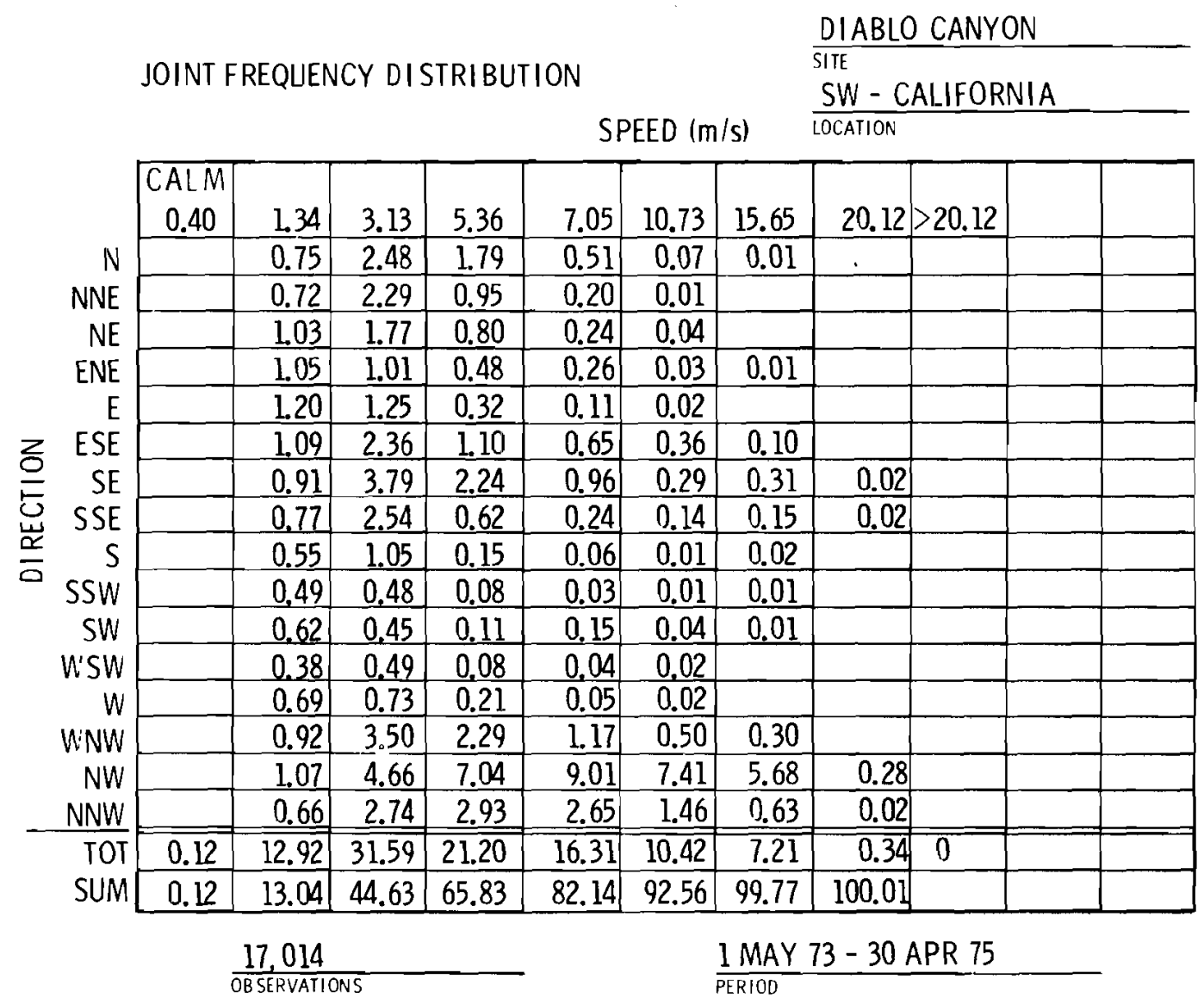

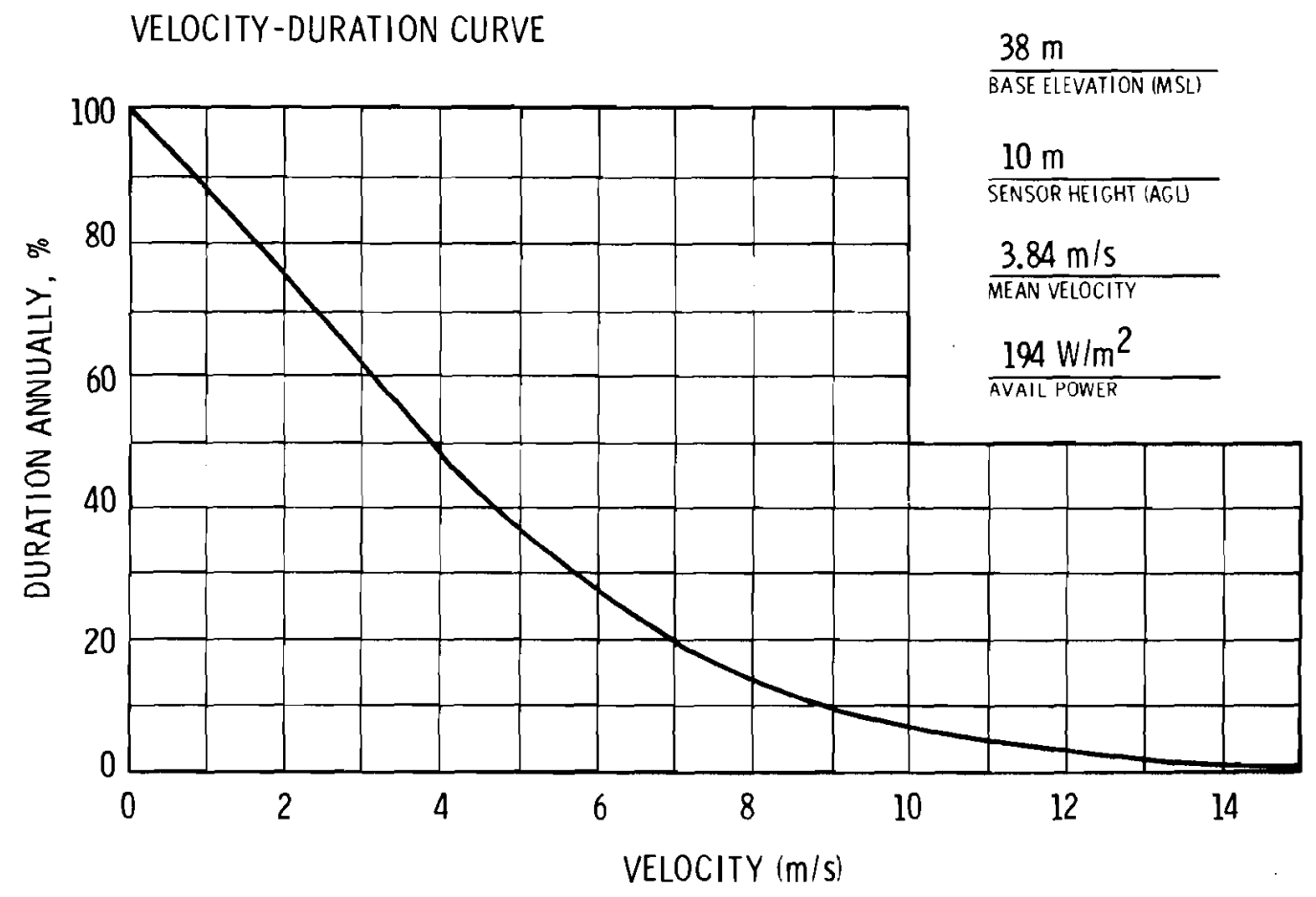


DOUGLAS POINT

\section{SITE LOCATION:}

The site is located in Charles County, Maryland

$\left(38.45^{\circ} \mathrm{N} / 77.26^{\circ} \mathrm{W}\right)$, on the east bank of the Potomac River, $55 \mathrm{~km}$ SSW of Washington, D.C. and $101 \mathrm{~km}$ SSW of Baltimore. The town of Quantico, Virginia is about $9 \mathrm{~km}$ NNW; Fredricksburg, $\mathrm{VA}$, is $26 \mathrm{~km}$ SSW and Nanjecmoy, MD, is $5 \mathrm{~km} \mathrm{E}$.

\section{TOPOGRAPHY :}

The terrain in this region is relatively flat. This region is near the western edge of the Middle Atlantic Coastal Plain, about $80 \mathrm{~km} \mathrm{E}$ of the Blue Ridge Mountains and about $60 \mathrm{~km} \mathrm{~W}$ of the Chesapeake Bay. The topographical relief of the region is low, ranging from near sea level at the shore to about $30 \mathrm{~m}$ to the east. To the west, the rise is gradual at first, becoming more pronounced toward the foothills of the Appalachian Mountains. The river valley is over $5 \mathrm{~km}$ wide, generally heavily wooded.

\section{ON-SITE WIND MEASUREMENTS:}

The entire Douglas Point site is thickly wooded, and it was desirable to cut as few trees as possible, therefore the 104-m tower was placed in an area cleared to a radius of $75 \mathrm{~m}$. Winds are measured at $10-\mathrm{m}, 30-\mathrm{m}, 60-\mathrm{m}$, and 104-m levels. Wind speed is measured by a Teledyne Model 50.1 with lexan cups. Anemometers have six staggered cups at $10 \mathrm{~m}$ and $30 \mathrm{~m}$, and 3 cups at $60 \mathrm{~m}$ and $104 \mathrm{~m}$. Wind direction is measured by Quick-2 Vanes at all levels. Only data at the $30-\mathrm{m}$ level were available.

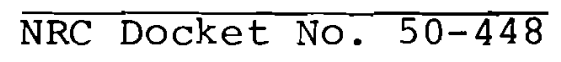




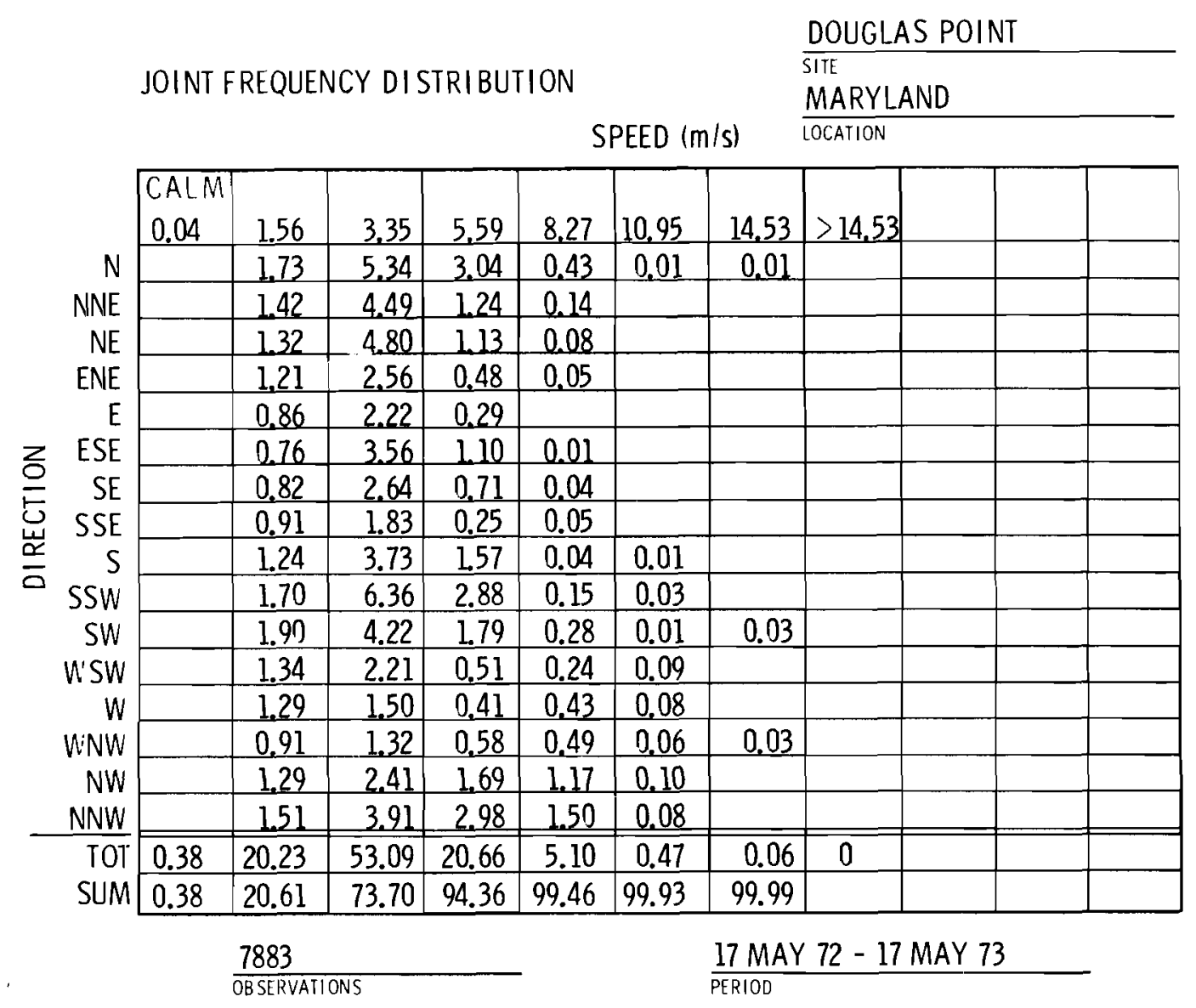

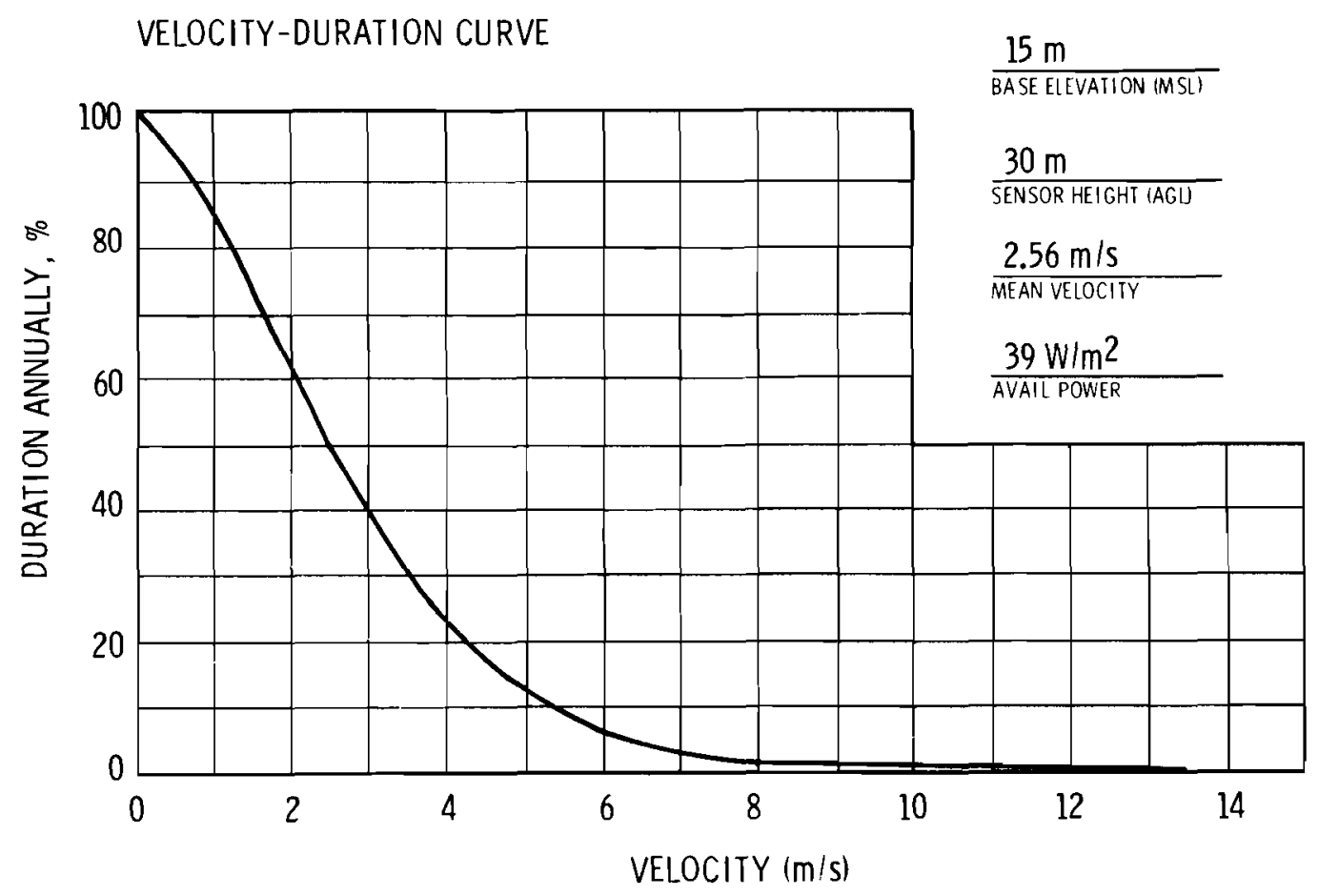


DRESDEN

SITE LOCATION:

The site for Dresden Nuclear Power Station $\left(41.33^{\circ} \mathrm{N} / 88.25^{\circ} \mathrm{W}\right)$ consists of 953 acres located in Grundy County, in NE Illinois, about $22 \mathrm{~km} \mathrm{SW}$ of Joliet and $74 \mathrm{~km} \mathrm{SW}$ of the Chicago shoreline of Lake Michigan. The site is bounded on the north by the Illinois River and on the east by the Kankakee River.

TOPOGRAPHY :

The site is located in rolling prairie terrain typical of much of Illinois. The broad valley formed by the confluence of the Kankakee and Illinois Rivers affords little topographical relief. Elevations vary from 155 to $160 \mathrm{~m}$ (MSL).

ON-SITE WIND MEASUREMENTS:

A new 122-m tower became operational on 1 Jan 1974. The tower is instrumented at $11 \mathrm{~m}, 46 \mathrm{~m}$, and $91 \mathrm{~m}$ with Teledyne-Geotech Series 50 wind sensors. Base elevation is $157 \mathrm{~m}$ (MSL).

$\overline{\text { NRC }}$ Docket Nos. 50-010, 50-237, 50-249 


\begin{tabular}{|c|c|c|c|c|c|c|c|c|c|c|c|}
\hline & & & & & & & & DRESD & & & \\
\hline & JOINT & REQU & ICY DI & STRIBU & ION & & & $\begin{array}{l}\text { SITE } \\
\text { NE - IL }\end{array}$ & INOIS & & \\
\hline & & & & & & EED $(m$ & & LOCATION & & & \\
\hline & CALM & & & & & & & & & & \\
\hline & & 1.56 & 3.35 & 5.59 & 8.27 & 10.95 & 14.08 & 17.21 & 20.79 & 20.79 & \\
\hline$N$ & & 0.22 & 1.72 & 1.72 & 0.43 & 0.02 & & & & & \\
\hline NNE & & 0.27 & 1.49 & 1.20 & 0,65 & 0.13 & & & & & \\
\hline $\mathrm{NE}$ & & 0.30 & 2.07 & 1.45 & 0.30 & 0.05 & & & & & \\
\hline ENE & & 0.25 & 1.95 & 1.75 & 0.35 & 0.01 & & & & & \\
\hline$E$ & & 0.20 & 2.73 & 2.55 & 1.01 & 0.16 & & & & & \\
\hline ESE & & 0.33 & 3.25 & 1.98 & 0.67 & 0.19 & & & & & \\
\hline SE & & 0.29 & 2.27 & 1.89 & 0.80 & 0.25 & 0.01 & & & & \\
\hline SSE & & 0.40 & 2.94 & 1.90 & 1.38 & 0.65 & 0,07 & 0,01 & & & \\
\hline$S$ & & 0.46 & 3.19 & 2.85 & 2.00 & 1.00 & 0.19 & 0.06 & & & \\
\hline SSW & & 0.68 & 2.92 & 2.54 & 1.84 & 0.58 & 0.14 & 0,04 & & & \\
\hline SW & & 0.81 & 2.70 & 2.32 & 1.15 & 0.43 & 0.20 & 0.05 & & & \\
\hline U'SW & & 0.44 & 1.84 & 1.48 & 1.15 & 0.36 & 0.09 & 0.01 & & & \\
\hline W & & 0.39 & 2.24 & 2.35 & 1.47 & 0.78 & 0.34 & 0.03 & & & \\
\hline WiNW & & 0.34 & 1.84 & 2.40 & 1.44 & 0.47 & 0.04 & & & & \\
\hline NW & & 0.40 & 2.02 & 2.30 & 1.66 & 0.14 & & & & & \\
\hline NNW & & 0.38 & 2.09 & 1.83 & 0.87 & 0.15 & & & & & \\
\hline$\overline{T O T}$ & & 6.38 & 37.26 & 32.51 & 17.17 & 5.37 & 1.11 & 0.20 & 0 & 0 & \\
\hline SUM & & 6.38 & 43.64 & 76.15 & 93.32 & 98.69 & 99.80 & 100.0 & & & \\
\hline & & & & & & & $J A I$ & -3 & EC 75 & & \\
\hline
\end{tabular}

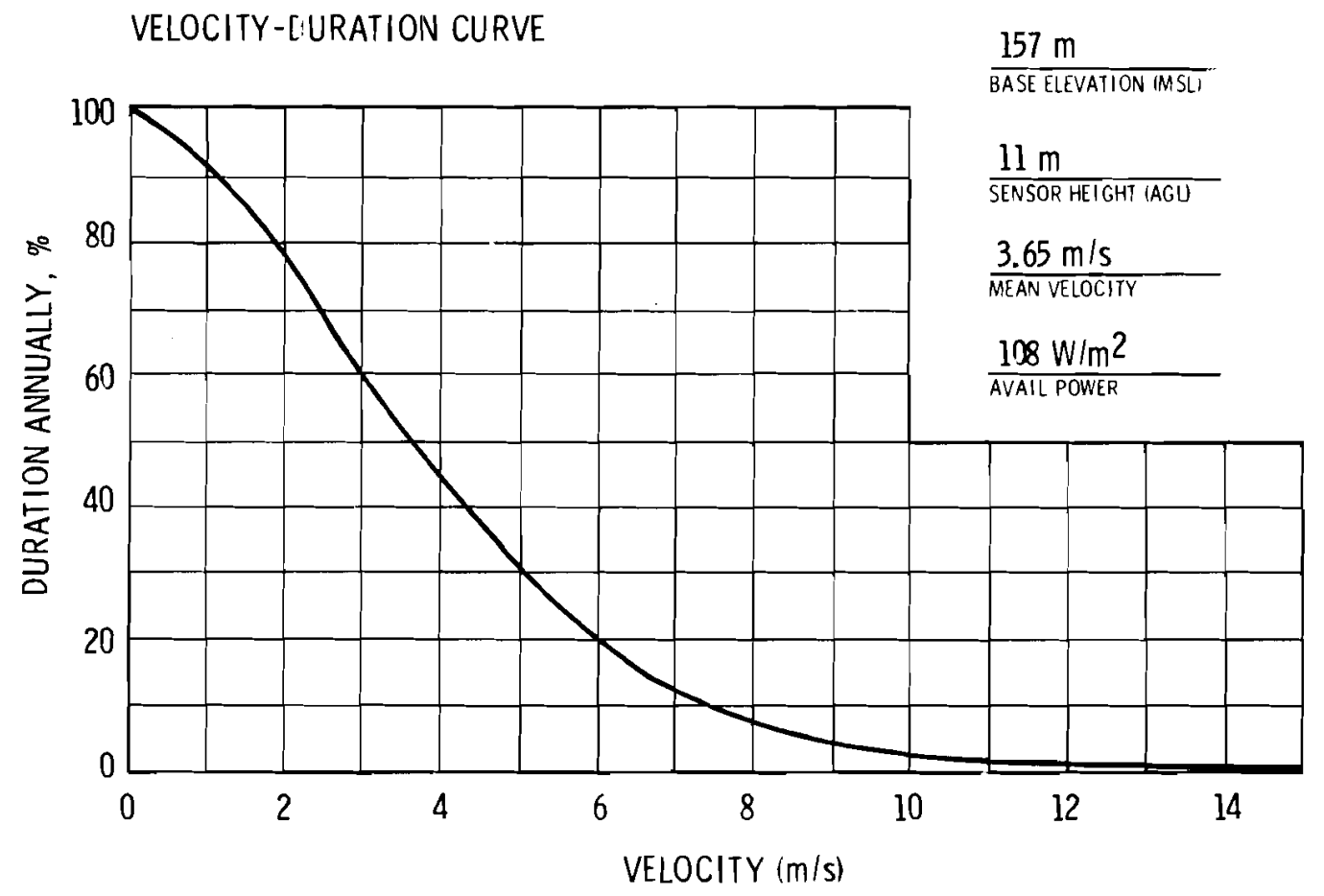




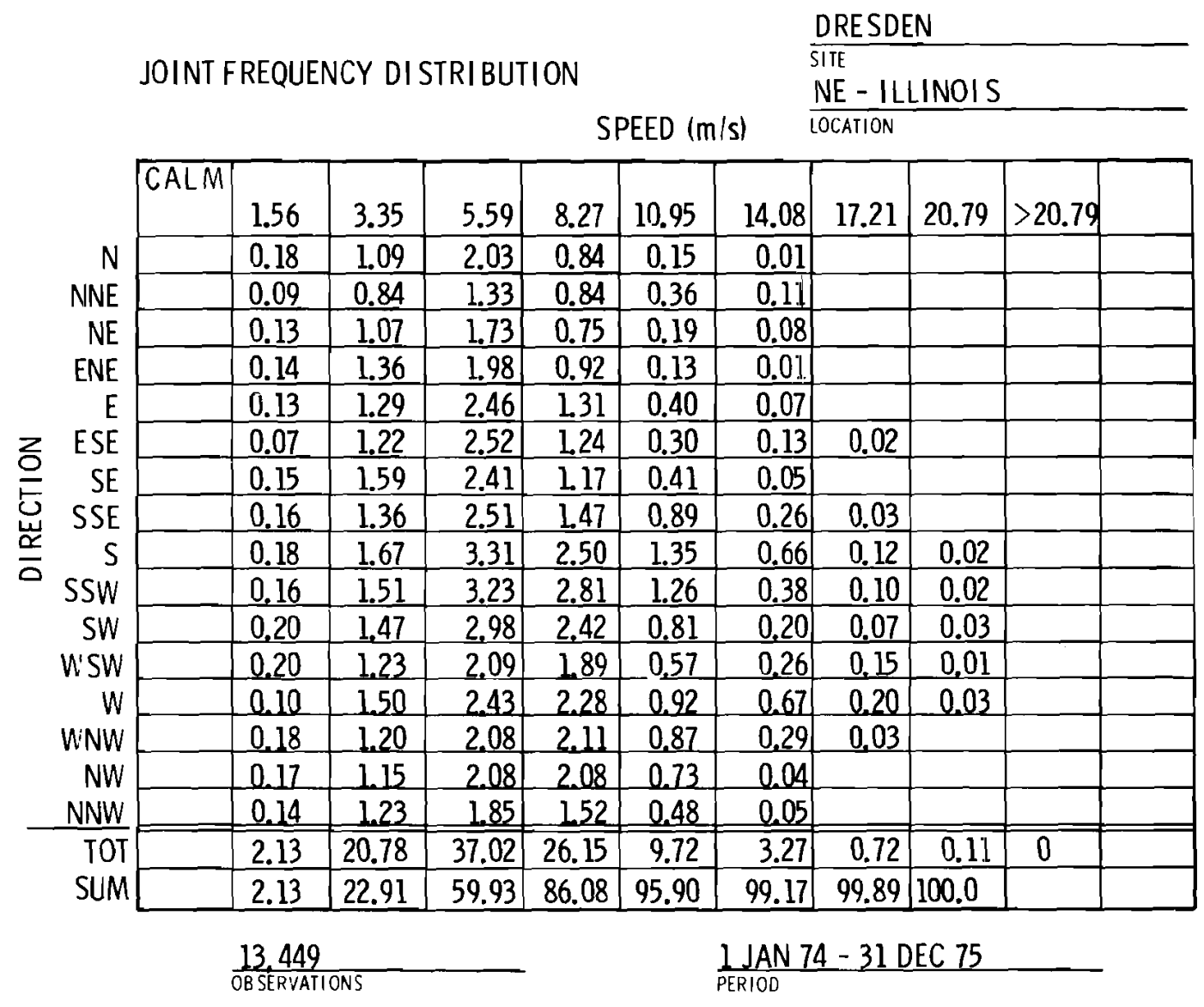

VELOCITY-DURATION CURVE

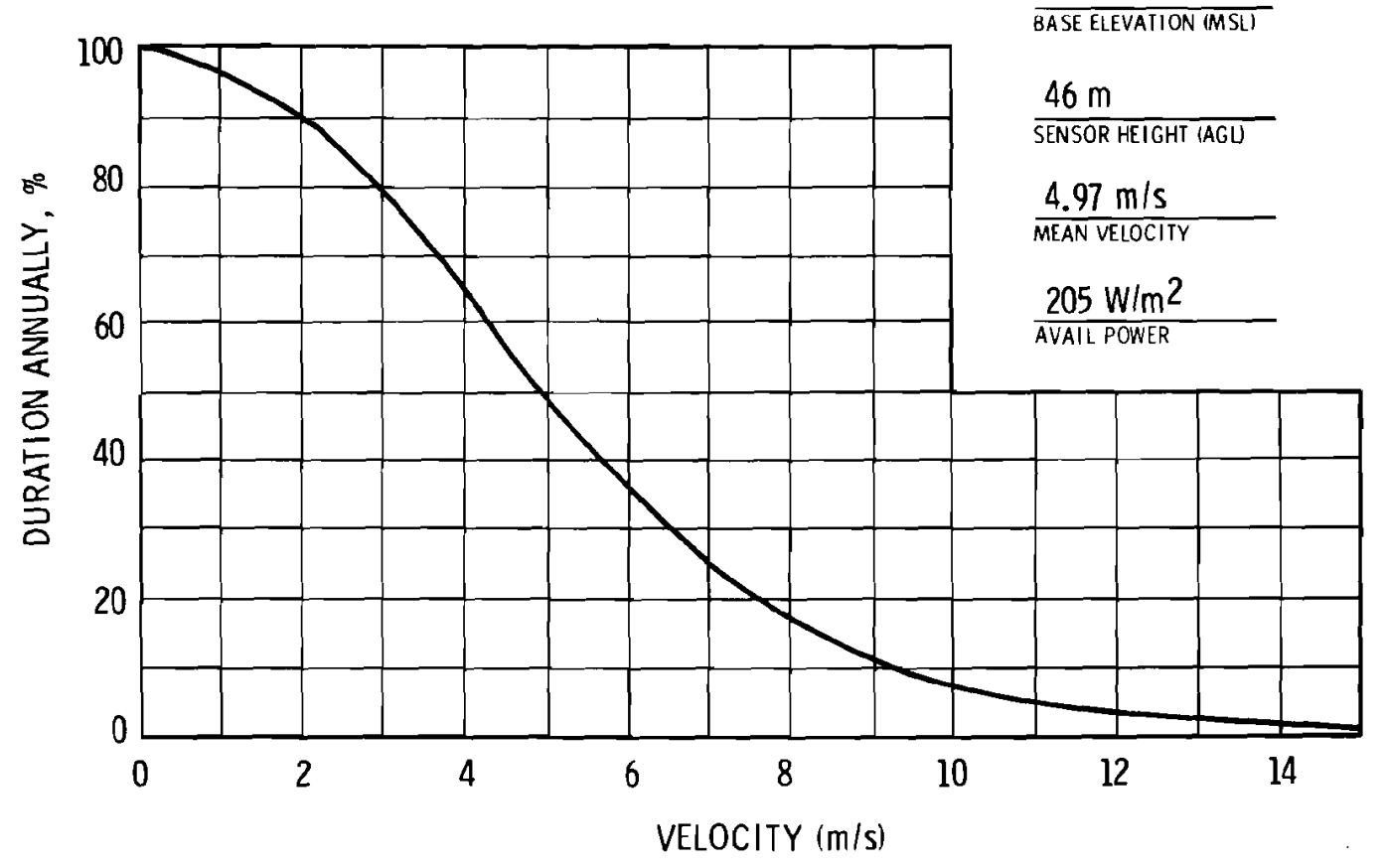




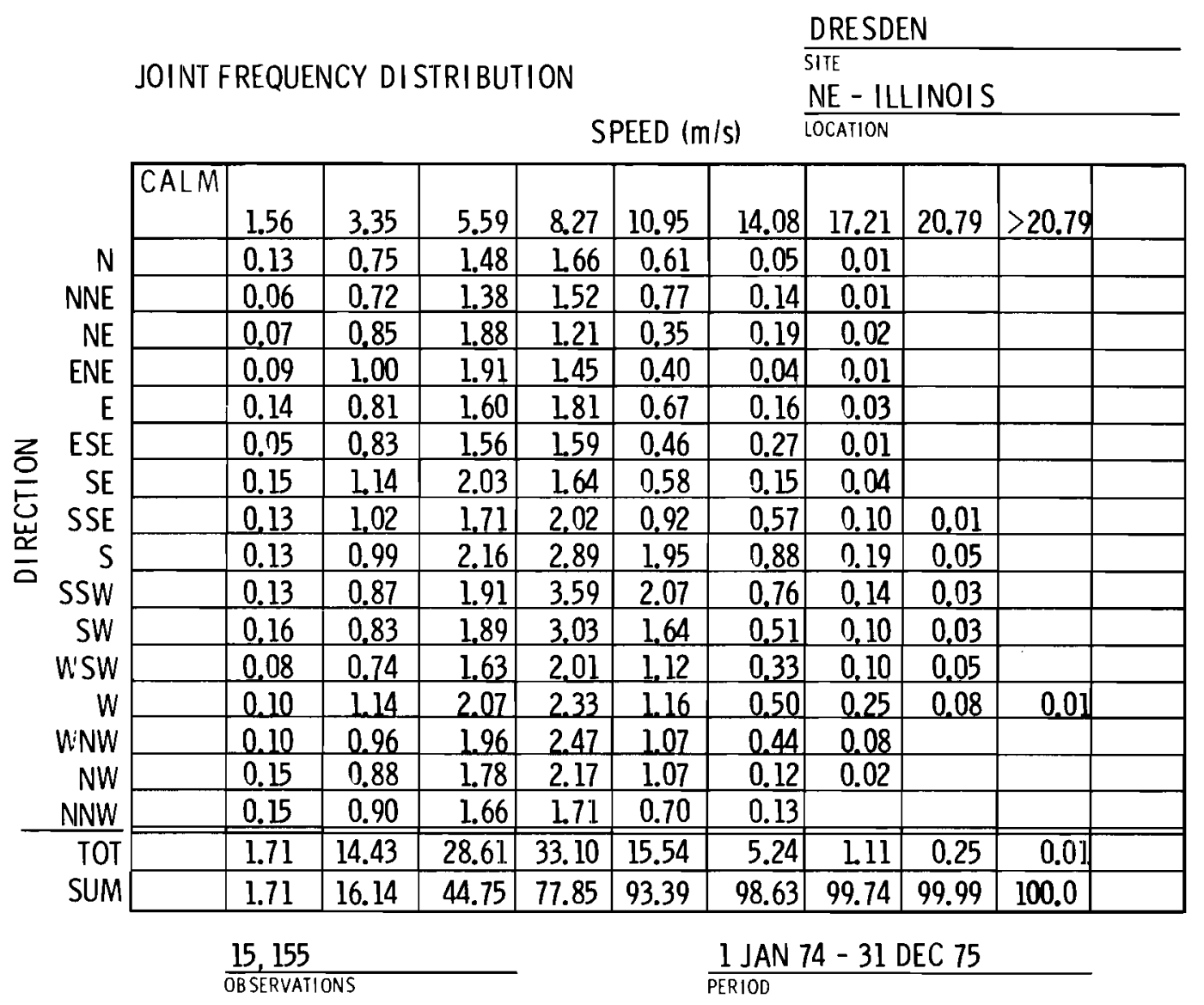

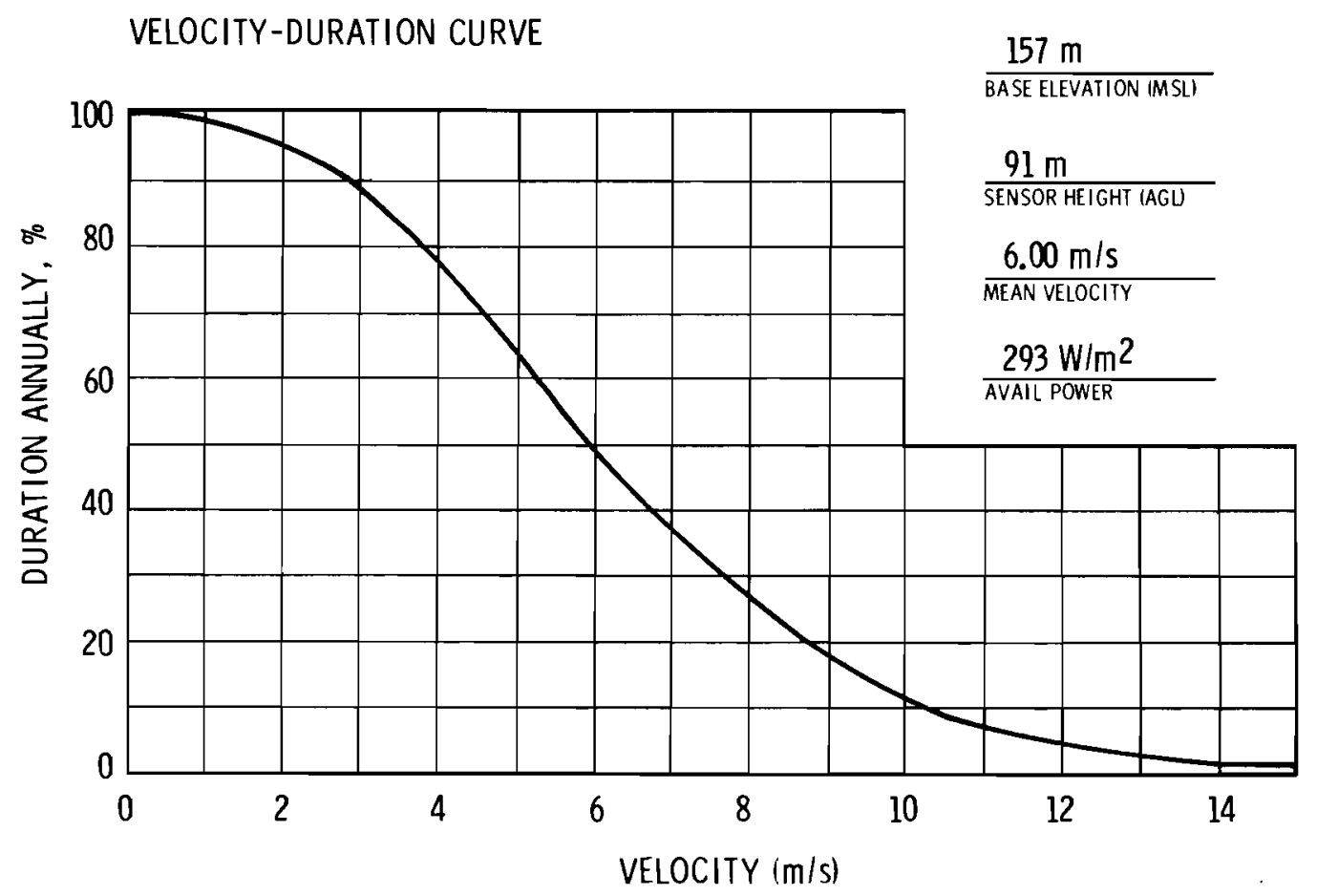


JOSEPH M. FARLEY

\section{SITE LOCATION:}

The site $\left(31.22^{\circ} \mathrm{N} / 85.11^{\circ} \mathrm{W}\right)$ is located in southeast Alabama on the west side of the Chattahoochee River, in Houston County. Dothan is $26 \mathrm{~km} \mathrm{~W}$; Blakely, $24 \mathrm{~km} \mathrm{NE}$; Montgomery, $160 \mathrm{~km} \mathrm{NW}$; and Atlanta, $290 \mathrm{~km} \mathrm{NNE.}$

\section{TOPOGRAPHY :}

The site is in the inland portion of the coastal plain on rolling terrain with variations of 15 to $30 \mathrm{~m}$ to the west. To the east, the terrain is flatter and lower with variations of 5 to $15 \mathrm{~m}$. The river to the east of the site lies in a depression of 15 to $30 \mathrm{~m}$, running $\mathrm{N}-\mathrm{S}$.

ON-SITE WIND MEASUREMENTS:

The on-site meteorological measurement program began in March 1971. A 73-m tower is located in a relatively flat, cleared field which is surrounded by trees, about 12-15 $\mathrm{m} \mathrm{high} \mathrm{at} \mathrm{a}$ distance greater than $180 \mathrm{~m}$ in all directions. Climet wS-011-1 (speed) and WD-012-10 (direction) sensors are installed at $15 \mathrm{~m}$ and $46 \mathrm{~m}$. Base elevation is $55 \mathrm{~m}$ (MSL).

NRC Docket Nos. $50-348, \overline{50-364}$ 


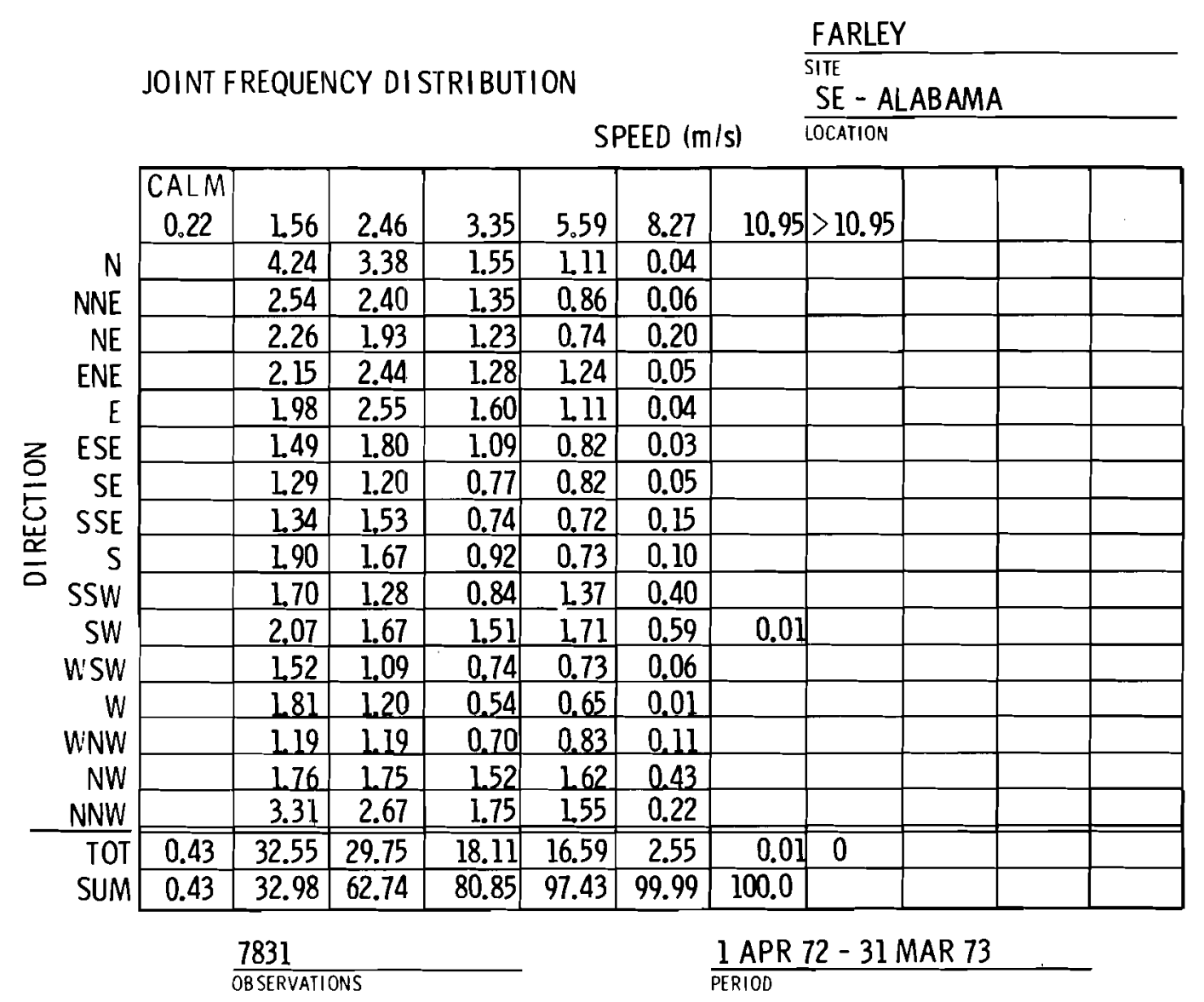

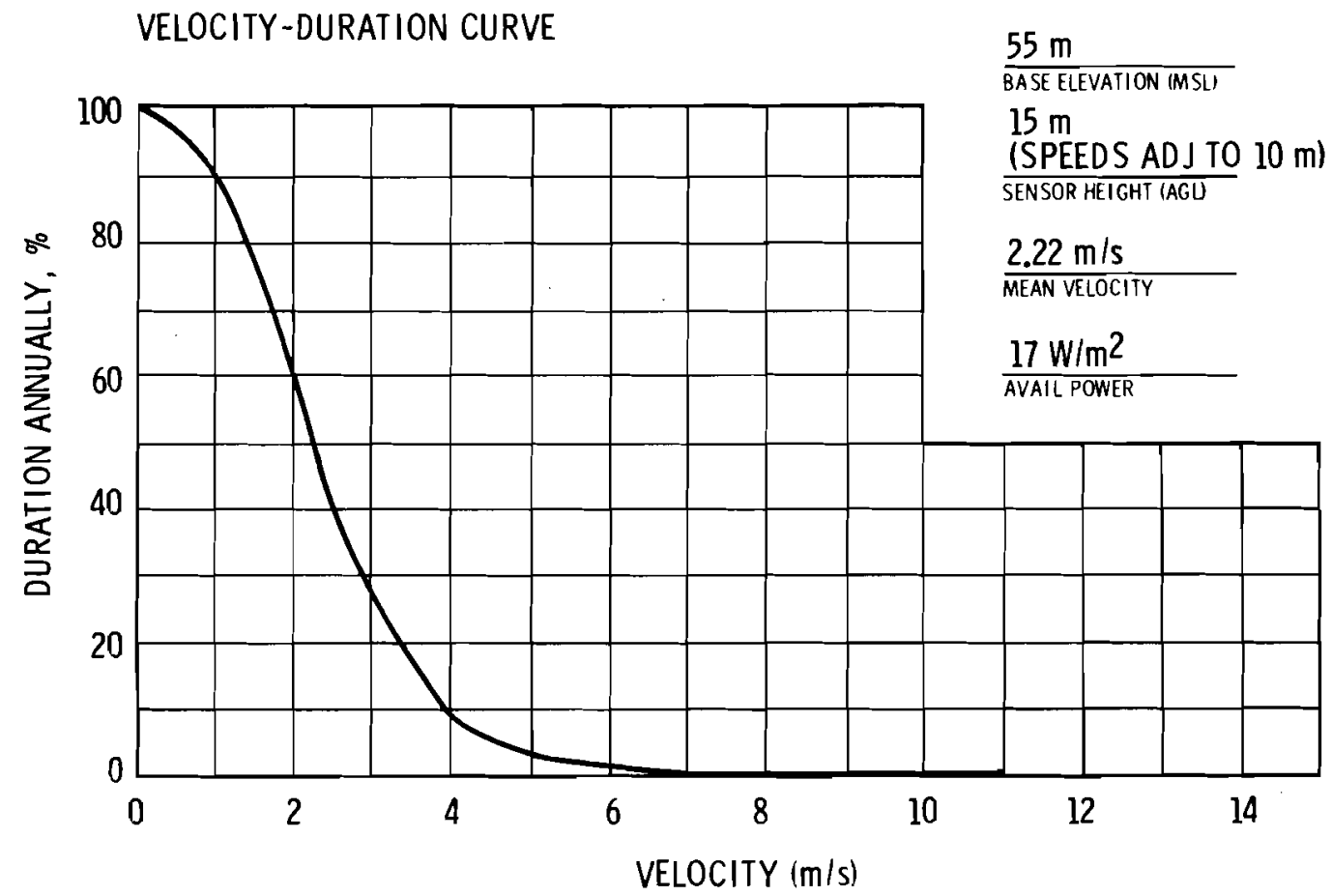


ENRICO FERMI

SITE LOCATION:

The Enrico Fermi Atomic Power Plant site $\left(41.96^{\circ} \mathrm{N} / 83.26^{\circ} \mathrm{W}\right)$ is located on the western shore of Lake Erie at Lagoona Beach, Monroe County, Michigan. The site is $13 \mathrm{~km}$ ENE of Monroe; $48 \mathrm{~km} \mathrm{SW}$ of downtown Detroit; and $40 \mathrm{~km} \mathrm{NE}$ of Toledo, Ohio.

\section{TOPOGRAPHY :}

The 1,120-acre site is located in the relatively flat coastal plain of the southern and western shore of Lake Erie. The terrain is flat to gently sloping with maximum elevations to $30 \mathrm{~m}$ above the lake level, which is about $174 \mathrm{~m}$ (MSL). The immediate area is characterized by large lagoons and marshlands in the northern and southern sections. To the east is Lake Erie and the western section is dominated by several woodlots and Quarry Lake. The site elevation ranges from lake level in the east to $8 \mathrm{~m}$ above lake level on the western edge of the site.

\section{ON-SITE WIND MEASUREMENTS:}

Wind data have been collected from three towers on the site: a 150-m tower $365 \mathrm{~m} \mathrm{~S}$ of Fermi I (1 Sep 73-31 Aug 74); a 30-m tower located $150 \mathrm{~m}$ SSE of Fermi I (1 Dec 56-30 Mar 59); and from a 10-m tower located near Langton Rd (1 Jan 72-31 Dec 72). The data from the 150-m tower are the only data available. The $150-\mathrm{m}$ tower was instrumented at $10 \mathrm{~m}, 57 \mathrm{~m}$ and $150 \mathrm{~m}$ using Climet WS-011-1 and Climet WD-012-30 sensor systems.

$\overline{\text { NRC Docket No. } 50-341}$ 


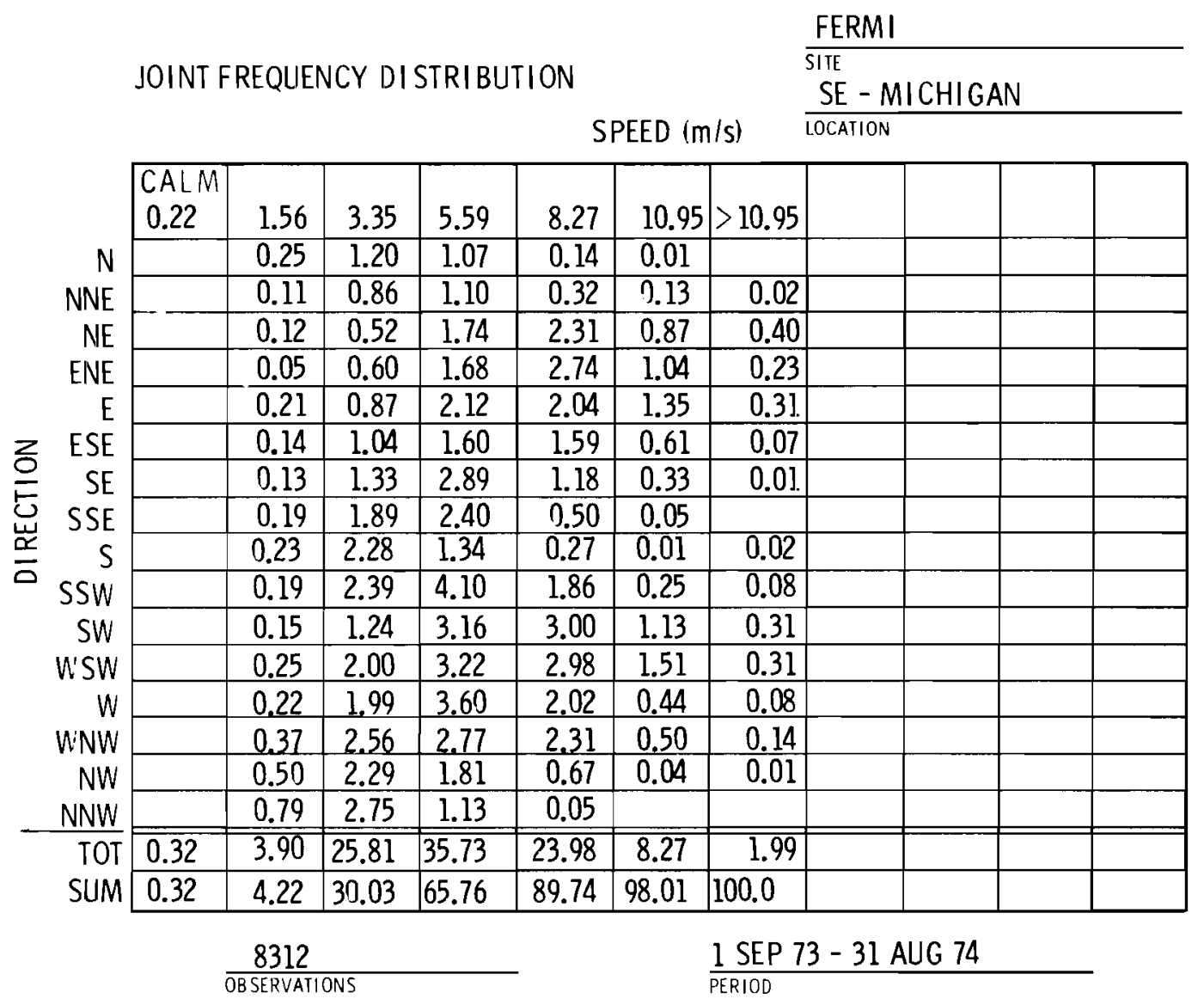

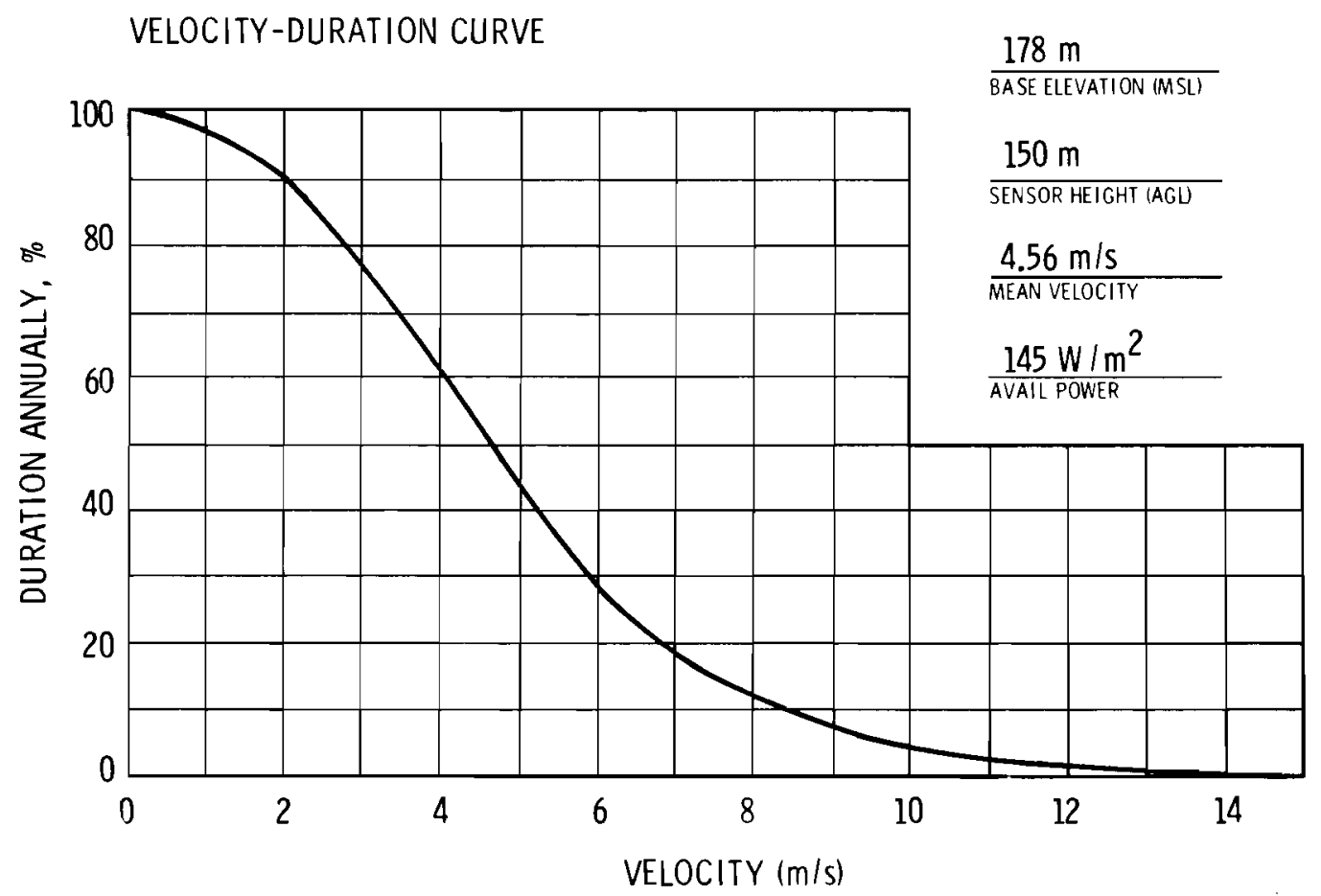


JAMES A. FITZPATRICK/NINE MILE PT.

SITE LOCATION:

The Nine-Mile Point Nuclear Station $\left(43.47^{\circ} \mathrm{N} / 76.50^{\circ} \mathrm{W}\right)$ shares a common boundary with the James A. Fitzpatrick Nuclear Power Plant. The site, often referred to as NMP-JAF, is located on the south shore of Lake ontario, in the SE corner of the lake. The site is in Oswego County, in central New York, in the town of Scriba. It is also $11 \mathrm{~km} \mathrm{NE}$ of Oswego, $58 \mathrm{~km} \mathrm{NW}$ of Syracuse and $220 \mathrm{~km}$ E of Buffalo.

TOPOGRAPHY :

The site is on the slightly elevated south shore of Lake Ontario. The region is characterized as a flat featureless plain, partially wooded. For many kilometers to the west, east and south, the terrain is gently rolling, rising gently up from the lake. Maximum elevation of the site is about $95 \mathrm{~m}$ (MSL) at the southern extremity. Plant grade is at $80 \mathrm{~m}$ (MSL).

ON-SITE WIND MEASUREMENTS:

wind data were obtained from a 62-m tower instrumented at $9 \mathrm{~m}$ and $62 \mathrm{~m}$, using Brookhaven-type aerovanes.

NRC Docket Nos. $50-33 \overline{3 / 50-241,50-410}$ 


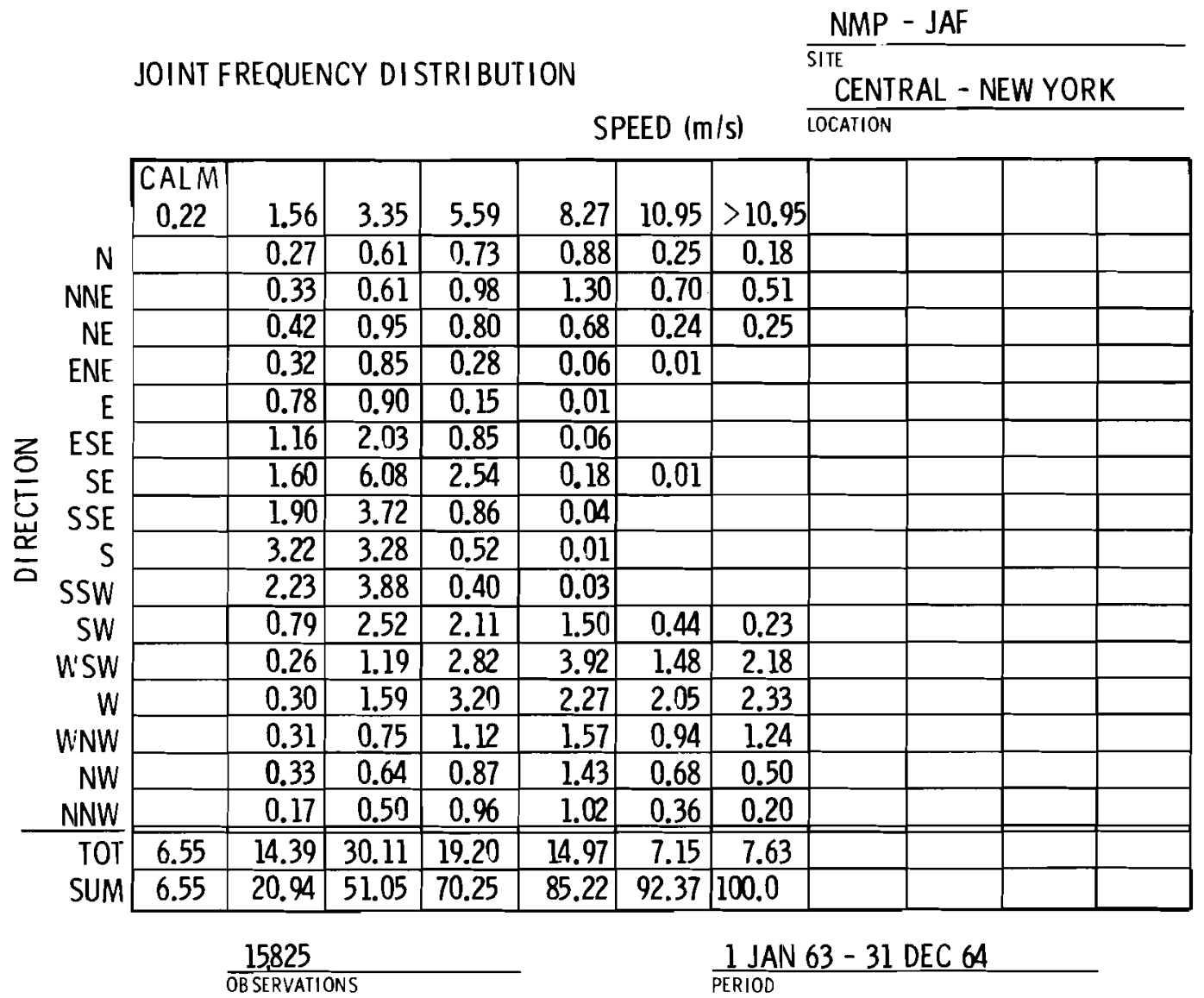

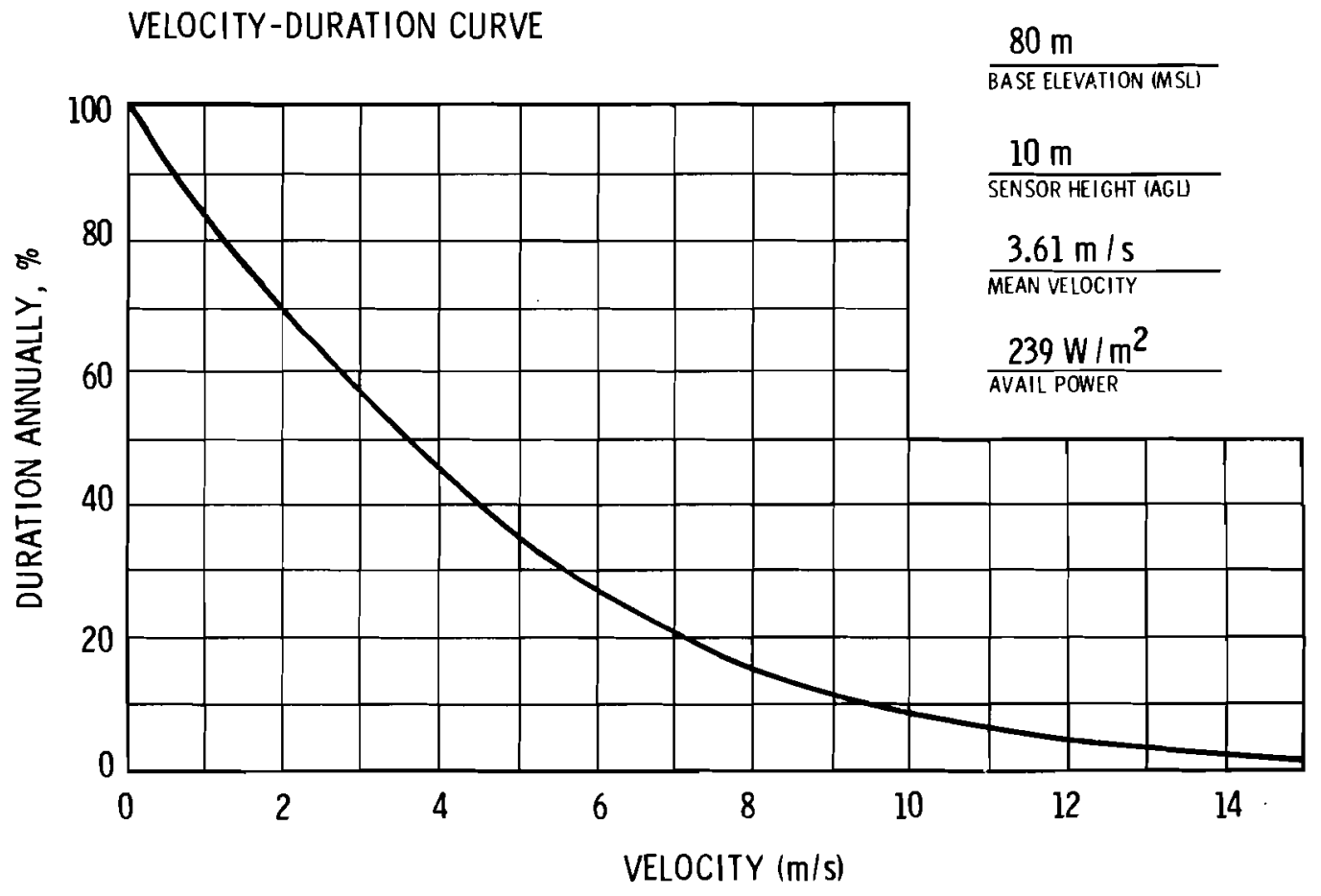




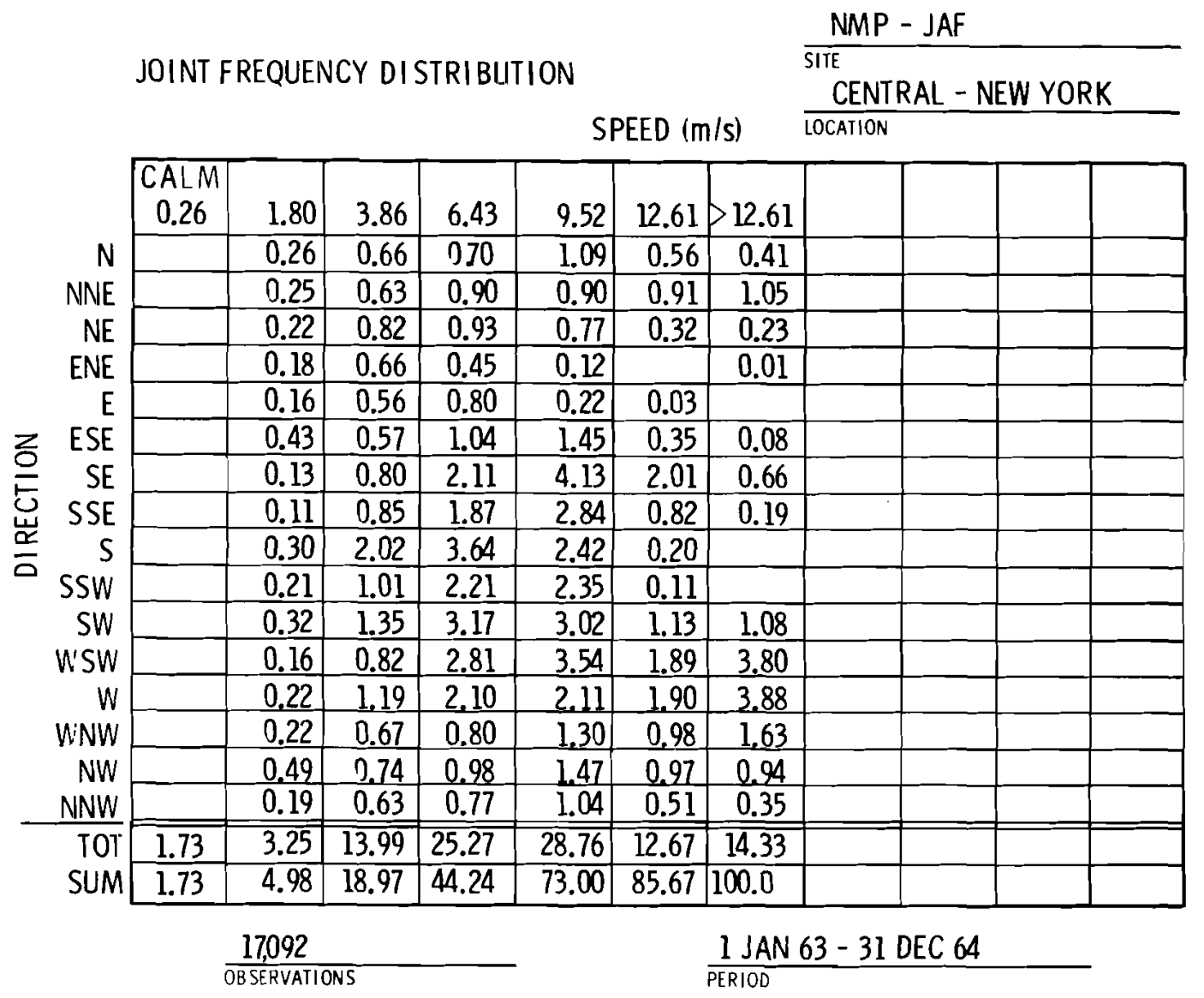

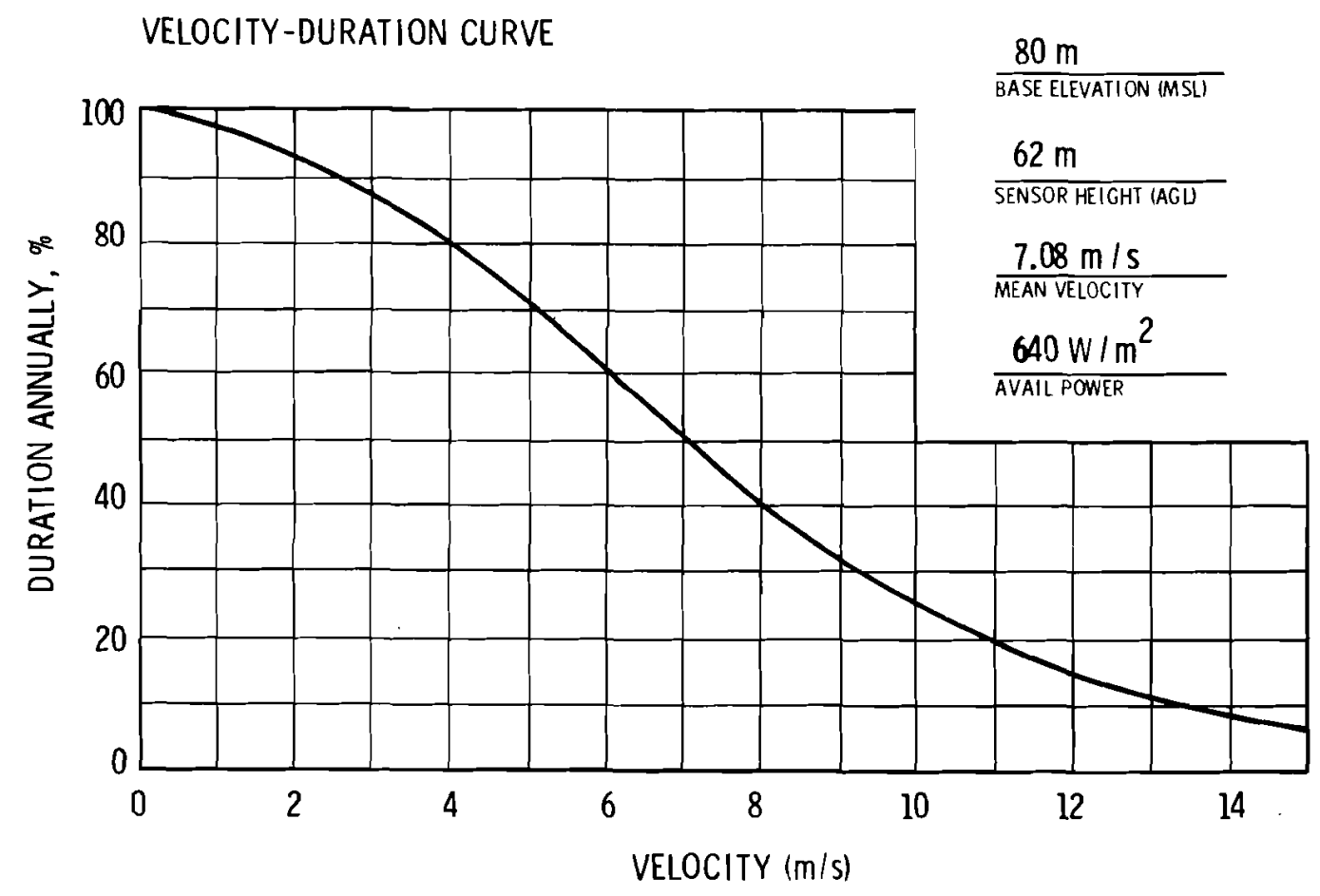


FORKED RIVER/OYSTER CREEK

\section{SITE LOCATION:}

The Forked River site $\left(39.81^{\circ} \mathrm{N} / 74.21^{\circ} \mathrm{W}\right)$ is located on the Atlantic coast, $3 \mathrm{~km} S$ of the community of Forked River, partly in Lacey County and partly in Ocean County, New Jersey. It is located about $2.5 \mathrm{~km}$ inland from the shore of Barnegat Bay and about $11 \mathrm{~km}$ WNW of Barnegat Light. The 1,425-acre site is also the location of the Oyster Creek Nuclear Plant (Oyster Creek I). The site is also $15 \mathrm{~km} \mathrm{~S}$ of Toms River; $56 \mathrm{~km} \mathrm{~N}$ of Atlantic City; $72 \mathrm{~km}$ E of Philadelphia, PA; and $97 \mathrm{~km} \mathrm{~S}$ of Newark, NJ.

TOPOGRAPHY :

The site is located in the low, relatively flat coastal plain typical of the New Jersey coast. To the west, the terrain rises gently to $62 \mathrm{~m}$ wizhin $15 \mathrm{~km}$.

ON-SITE WIND MEASUREMENTS:

The on-site meteorological data collection nrogram has been in operation since Feb. 1966. Wind speed and direction have been recorded at $23 \mathrm{~m}$ and $122 \mathrm{~m}$ above site grade, Ising Bendix-Fr.er: Model 120 Aerovanes.

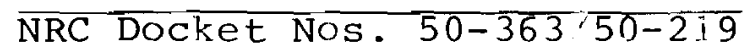


JOINT FREQUENCY DISTRIBUTION

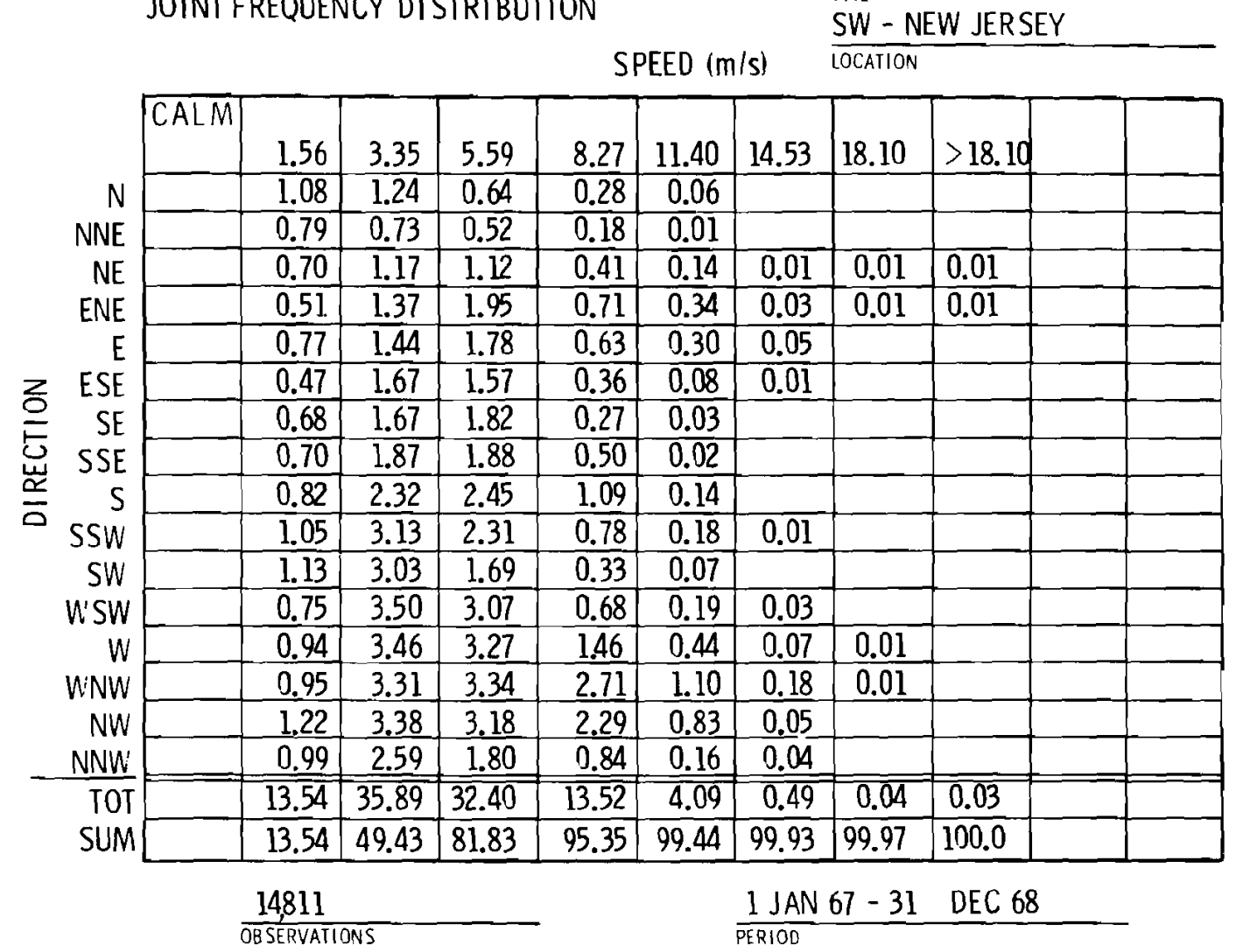

VELOCITY-DURATION CURVE

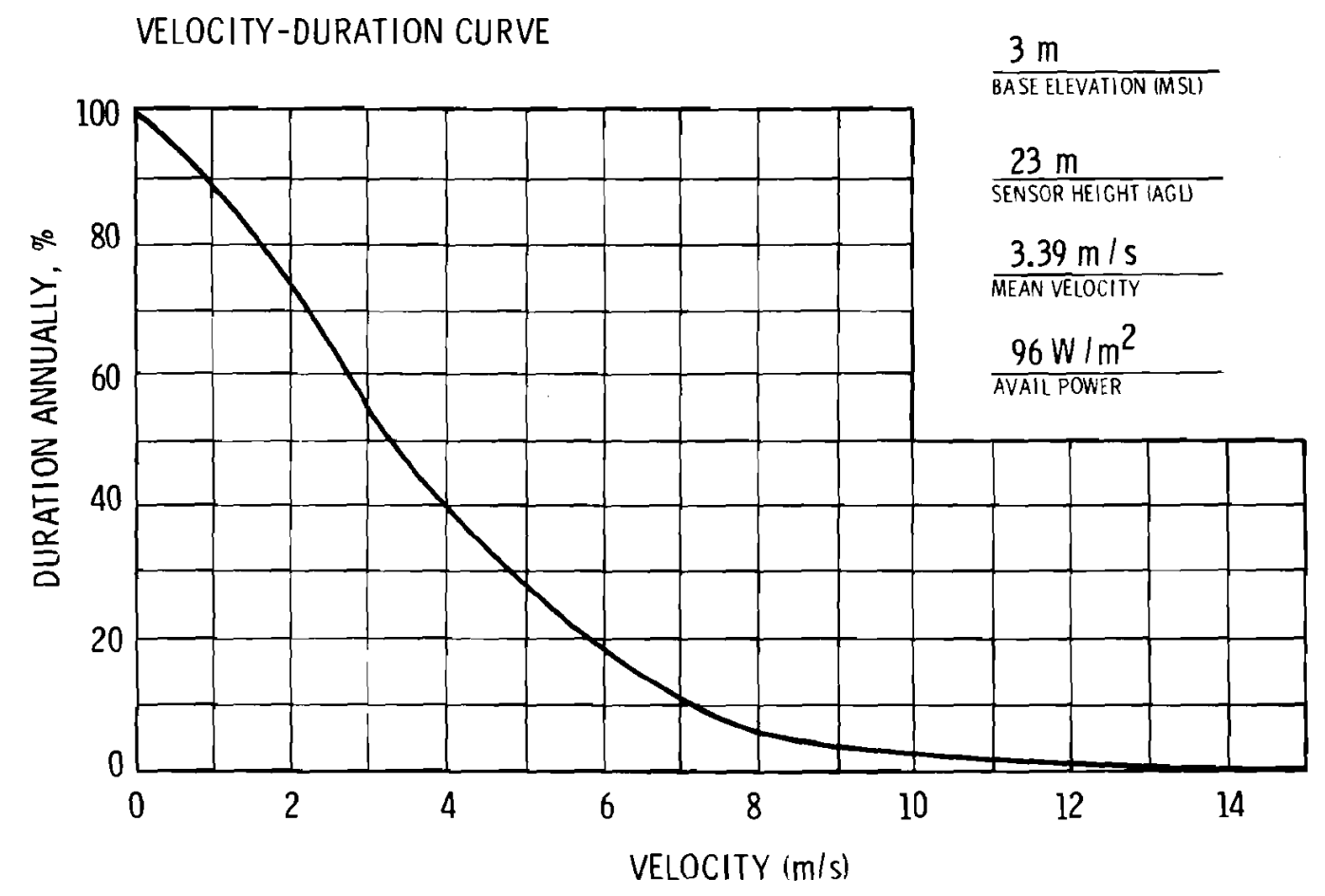

FORKED RIVER / OY STER CREEK

SITE

SW - NEW JERSEY 
FORT CALHOUN

SITE LOCATION:

The Fort Calhoun site $\left(41.52^{\circ} \mathrm{N} / 96.08^{\circ} \mathrm{W}\right)$ is in Washington

County, Nebraska, on the southwest bank of the Missouri River, about $4 \mathrm{~km} \mathrm{SE}$ of Blair and about $31 \mathrm{~km}$ NNW of Omaha, NB.

\section{TOPOGRAPHY :}

The site location is in SE Nebraska. The land rises from 250 $\mathrm{m}$ (MSL) in the SE corner of the state, to about $375 \mathrm{~m}$ in the NE. The land elevation also increases westward to over $900 \mathrm{~m}$ in the SW and to more than $1500 \mathrm{~m}$ in the NW. The terrain changes from level to gently rolling prairie in the east, to rounded sandhills in the north central portion, and to high plains in the west. Fort Calhoun station is at an elevation of about $300 \mathrm{~m}$ (MSL). The topography of the site within $16 \mathrm{~km}$ is governed primarily by the floodplain of the Missouri River. There is little relief from north to south along the river, but to the east and west there are low lying benches (bluffs) with elevations of about $400 \mathrm{~m}$ (MSL), cut by ravines. These bluffs extend along the western bank of the river, which runs generally from the NW to the SE, and come within about one to two kilometers of the site in the $S$ through wSW sectors. The Missouri River in this area has a depth of about $60 \mathrm{~m}$ to $90 \mathrm{~m}$ and a width of about $20 \mathrm{~km}$.

ON-SITE WIND MEASUREMENTS:

The on-site meteorological measurement program was initiated in May 1967 using an MRI Mechanical weather station on top of a 13-m tower, located next to the Missouri River. During 1970 , a 49-m Rohn tower was installed at plant elevation, $300 \mathrm{~m}$ (MSL), with MRI 1074 wind systems at $11 \mathrm{~m}$ and $36 \mathrm{~m}$ (AGL).

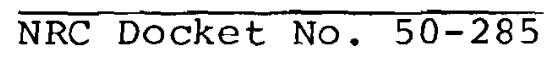




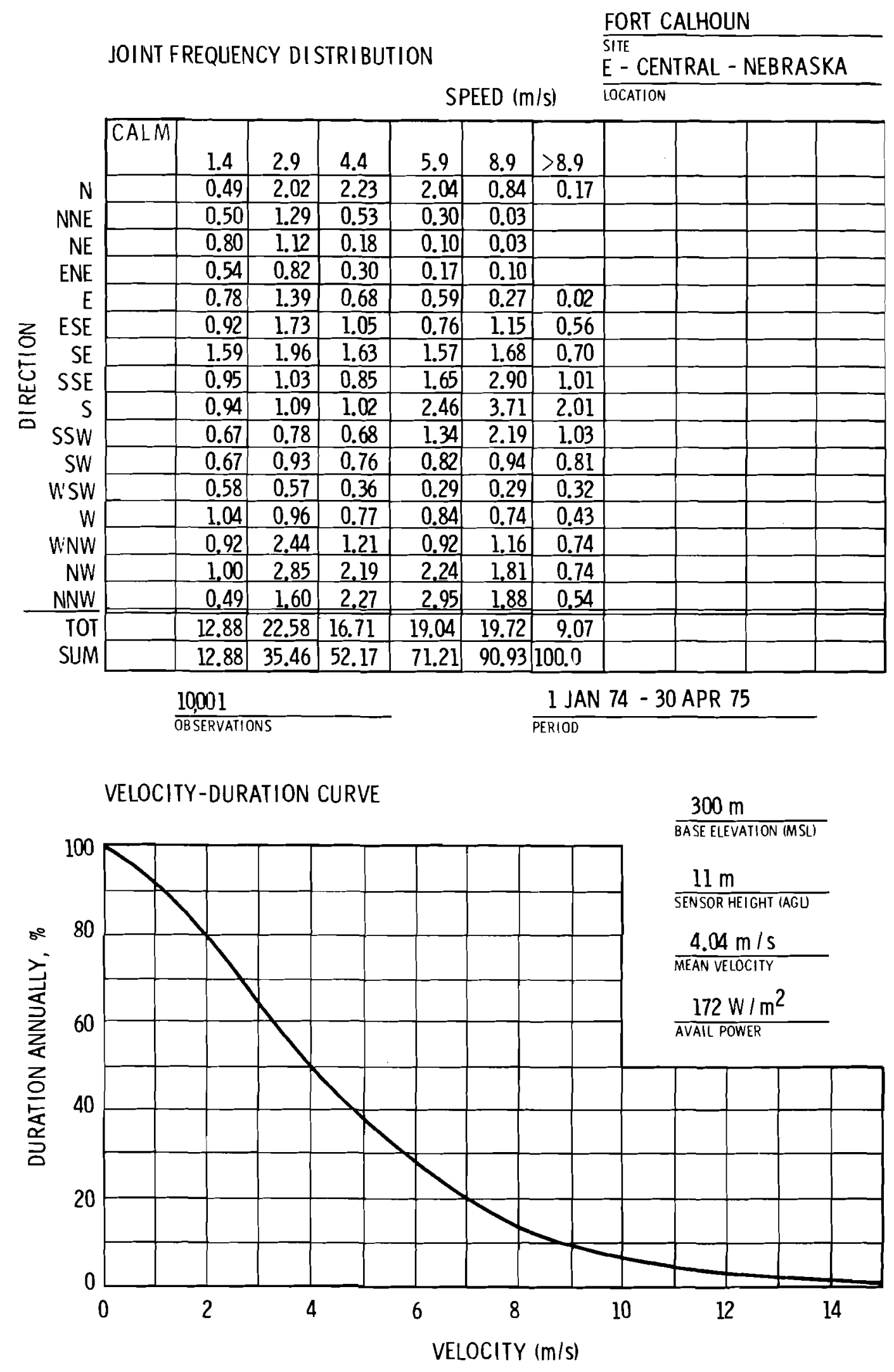


FORT ST. VRAIN

\section{SITE LOCATION :}

The site $\left(40.22^{\circ} \mathrm{N} / 104.89^{\circ} \mathrm{W}\right)$ is located in weld County, northeast Colorado, about $6 \mathrm{~km} \mathrm{NW}$ of the town of Platteville, and about $55 \mathrm{~km} \mathrm{~N}$ of Denver.

\section{TOPOGRAPHY :}

The Fort st. Vrain Generating station lies in a shallow valley formed by the st. Vrain creek and the South Platte River. This is an agricultural area with gently rolling hills. Site elevation is $1,460 \mathrm{~m}$. The foothills of the Rocky Mountains start to rise about $30 \mathrm{~km} \mathrm{~W}$ of the site, and the Continental Divide is prominently identified by Long's Peak at $4,345 \mathrm{~m}$, which is $65 \mathrm{~km}$ $W^{*}$ of the site.

ON-SITE WIND MEASUREMENTS:

The meteorological tower is $300 \mathrm{~m}$ south of the plant and is equipped with a Gill u-v-w anemometer mounted at $64 \mathrm{~m}$. Measurements began on 22 Nov 1966.

NRC Docket No. 50-267 


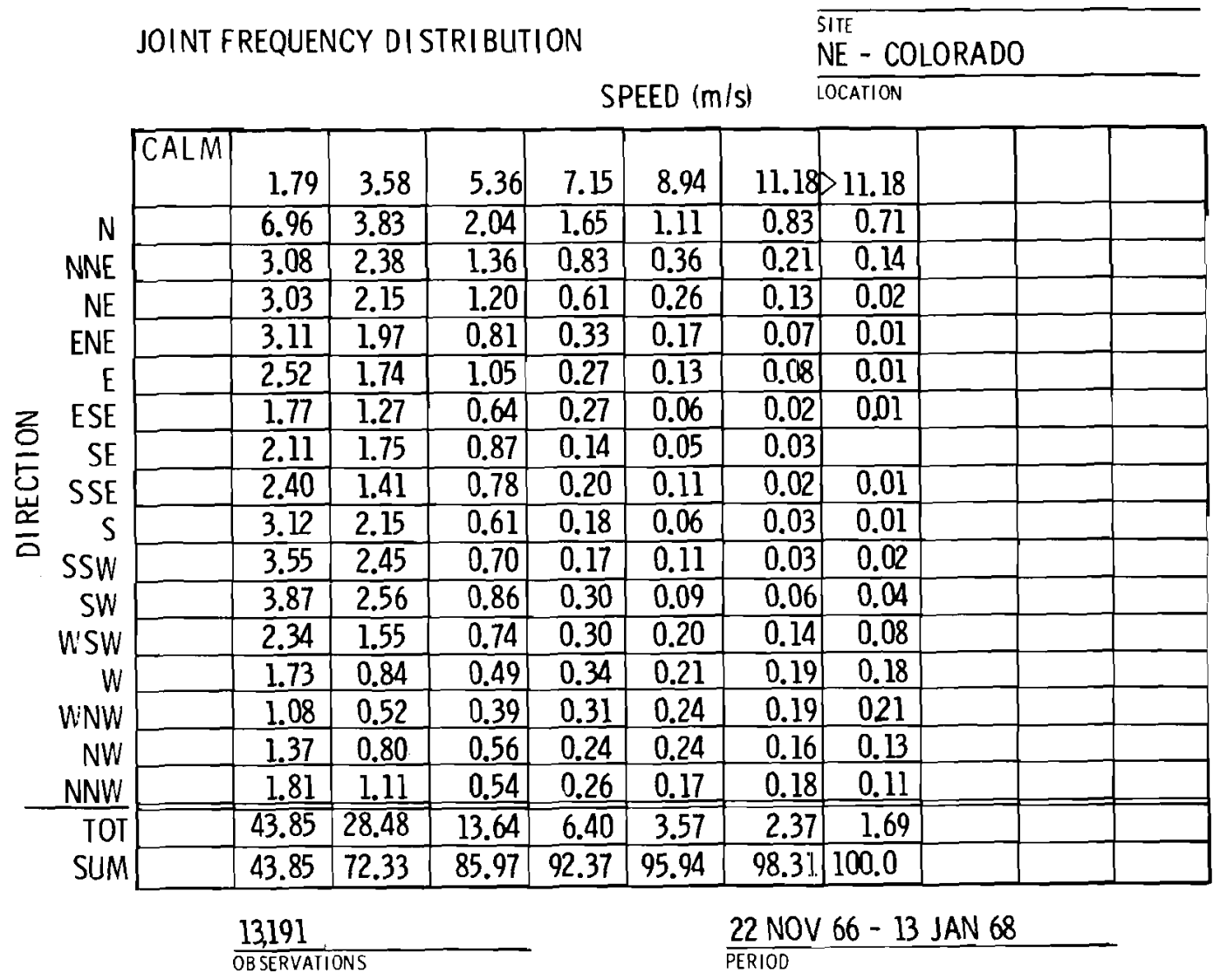

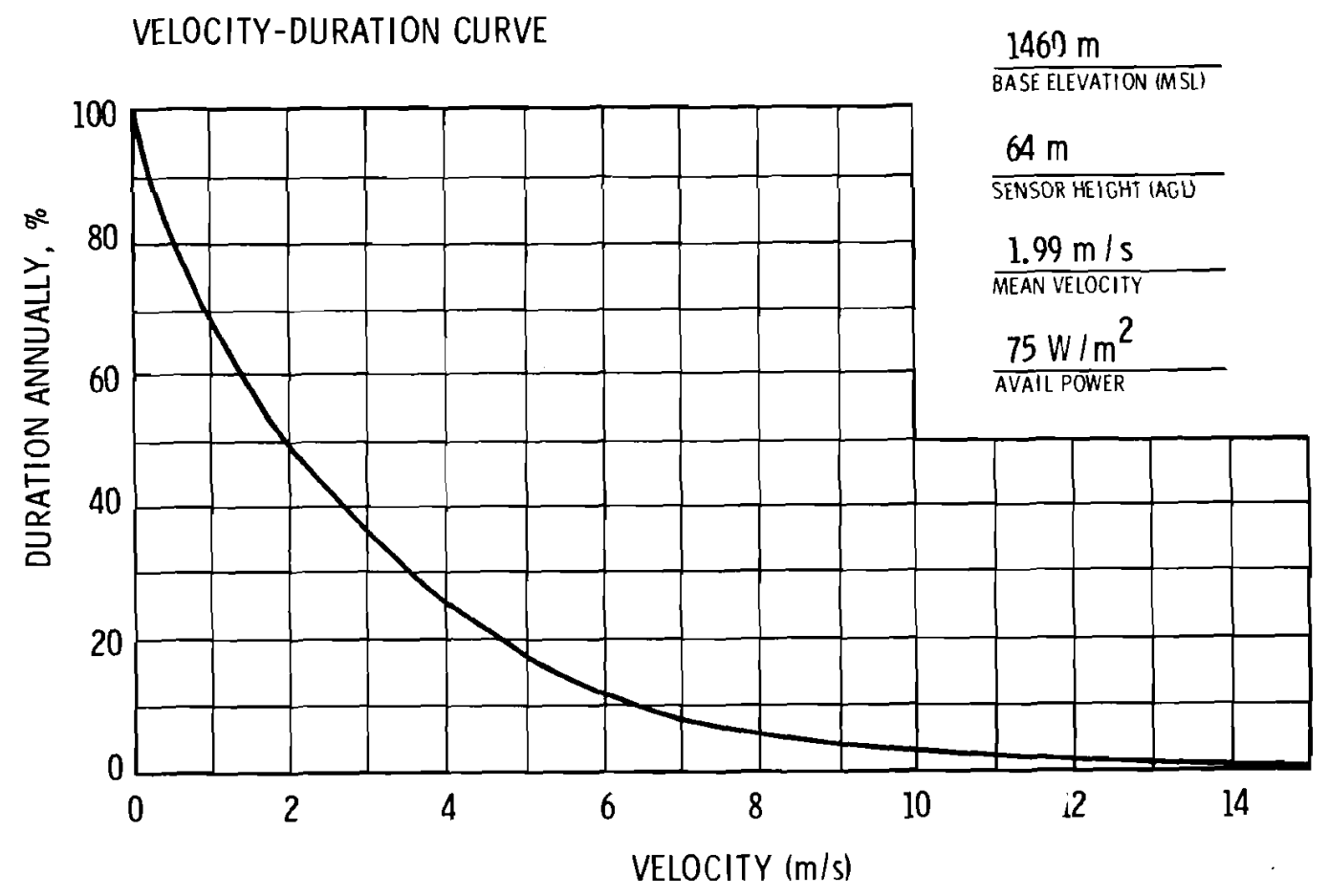




\section{FULTON/PEACH BOTTOM}

SITE LOCATION:

The Fulton Generating Station and the Peach Bottom Atomic Power Station $\left(39.76^{\circ} \mathrm{N} / 76.24^{\circ} \mathrm{W}\right)$ are located in Lancaster County, in SE Pennsylvania. The Fulton site is on the bank NE of Conowingo Pond on the Susquehanna River, and just opposite Peach Bottom $2.75 \mathrm{~km}$ W. Delta, PA and Cardiff, MD are $6 \mathrm{~km} \mathrm{SW}$; Lancaster is $27 \mathrm{~km} \mathrm{~N}$; Baltimore is $60 \mathrm{~km} \mathrm{SW}$; and Philadelphia is $98 \mathrm{~km} \mathrm{ENE}$. TOPOGRAPHY :

The area is characterized by the well defined Susquehanna River valley. Conowingo Pond is at $35 \mathrm{~m} \mathrm{(MSL)} \mathrm{and} \mathrm{lies} \mathrm{NW-SE.} \mathrm{The}$ Fulton site is on high ground at $118 \mathrm{~m}$ (MSL) NE of the river; Peach Bottom (at $36 \mathrm{~m} \mathrm{(MSL))} \mathrm{is} \mathrm{located} \mathrm{between} \mathrm{the} \mathrm{river} \mathrm{and} \mathrm{the}$ foot of a low hill near the point where Rock Run Creek discharges into the pond. On both sides of the pond, steep sloping hills rise directly up to about $90 \mathrm{~m}$ above the water with outcroppings of rock apparent at many locations. Because of the relatively rough terrain, much of the land has scattered woods with the more gently sloping areas cleared and cultivated. The terrain rises to $160 \mathrm{~m}$ (MSL) within $3 \mathrm{~km}$ and $210 \mathrm{~m}$ within $8 \mathrm{~km}$. From 8 to 16 $\mathrm{km}$, there are some hills about $270 \mathrm{~m}$ (MSL) to the $\mathrm{W}-\mathrm{NW}-\mathrm{N}$ sectors. This rather hilly relief persists for $20-25 \mathrm{~km}$, thereafter becoming low rolling hills.

\section{ON-SITE WIND MEASUREMENTS:}

Data from Fulton have not been published yet, but the Peach Bottom facility has been functioning since the summer of 1967 and data are available. Peach Bottom has two towers and two satellite locations, all instrumented with Bendix-Friez "Aerovanes". Tower 1 , at $36 \mathrm{~m}$ (MSL), is instrumented at $9 \mathrm{~m}$ and $30 \mathrm{~m}$; Hill Pole, at $80 \mathrm{~m}$ (MSL), is instrumented at $12 \mathrm{~m}$; the Microwave Tower, at $112 \mathrm{~m}$ (MSL), is instrumented at $23 \mathrm{~m}$ and $98 \mathrm{~m}$; and River Pole, at $33 \mathrm{~m}$ (MSL), is instrumented at $15 \mathrm{~m}$.

NRC Docket Nos. 50-463/50-277 

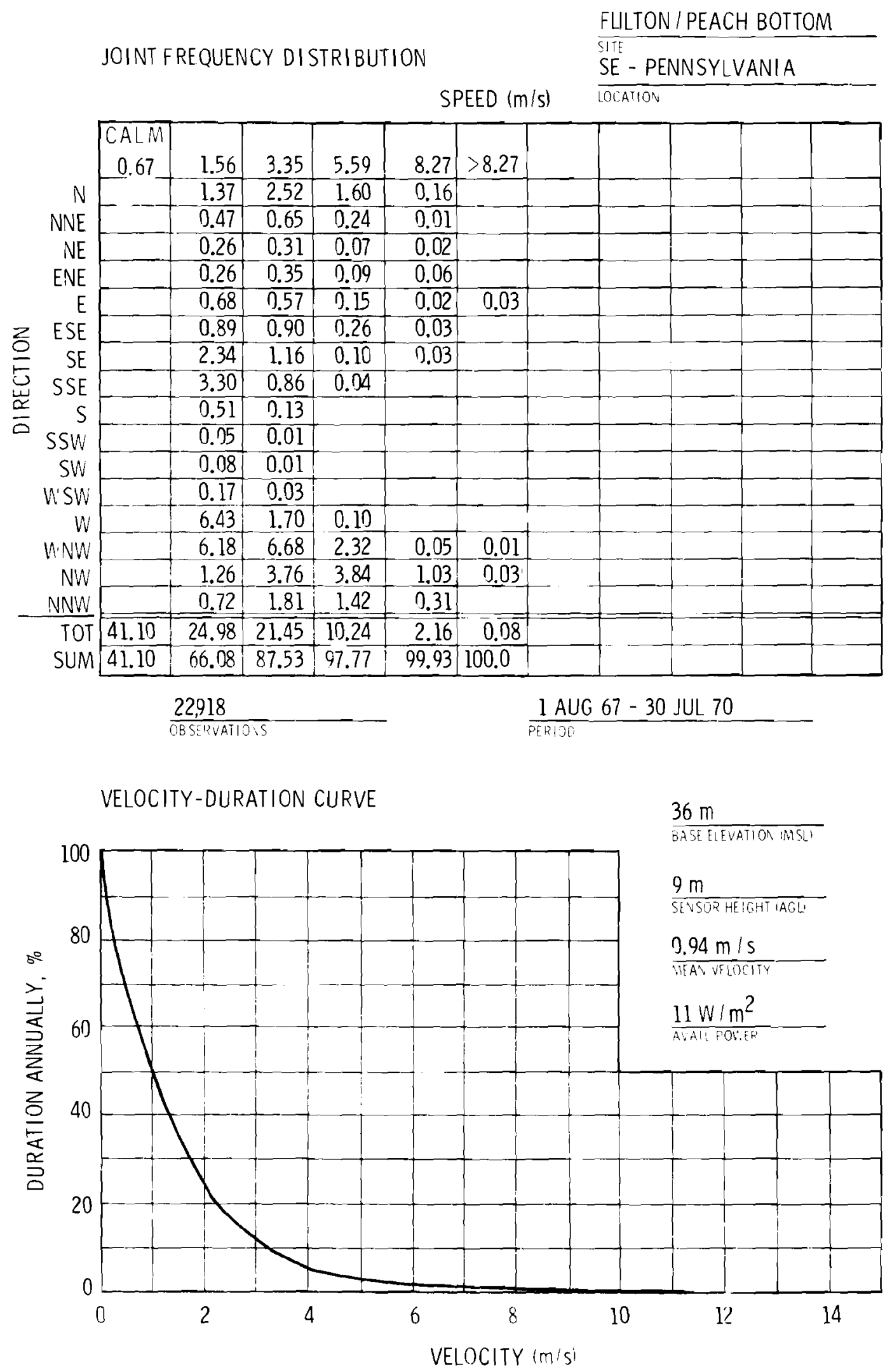


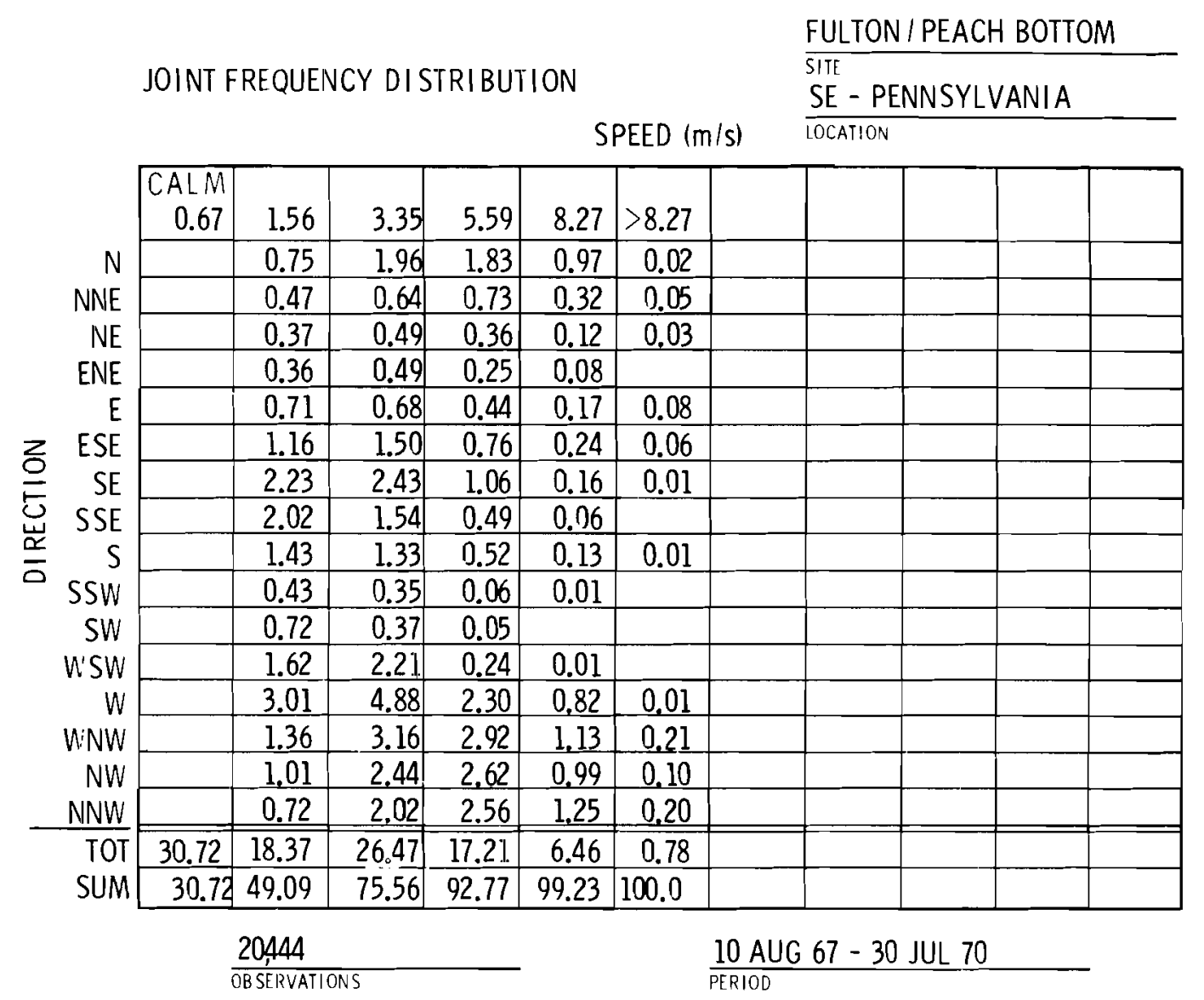

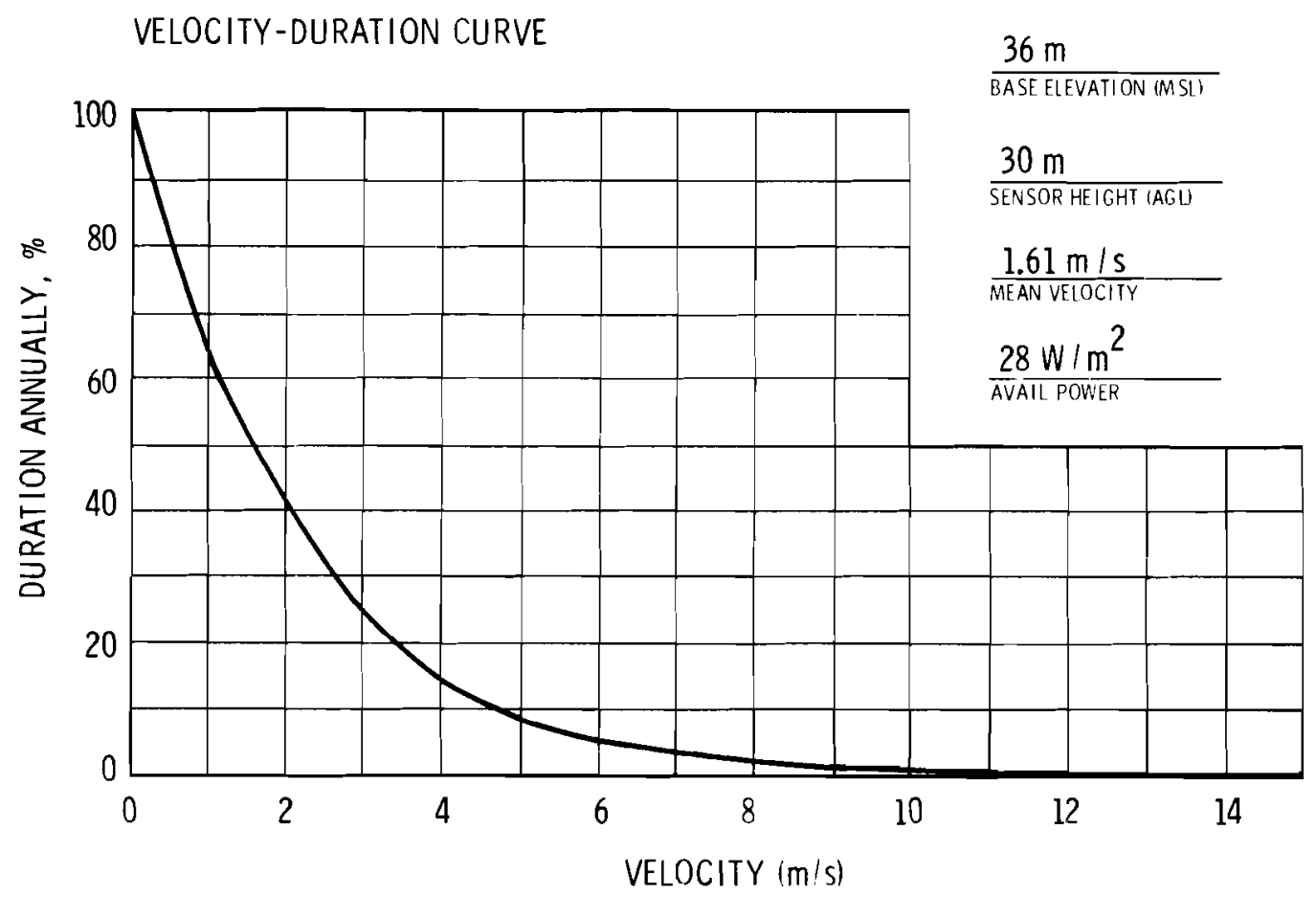




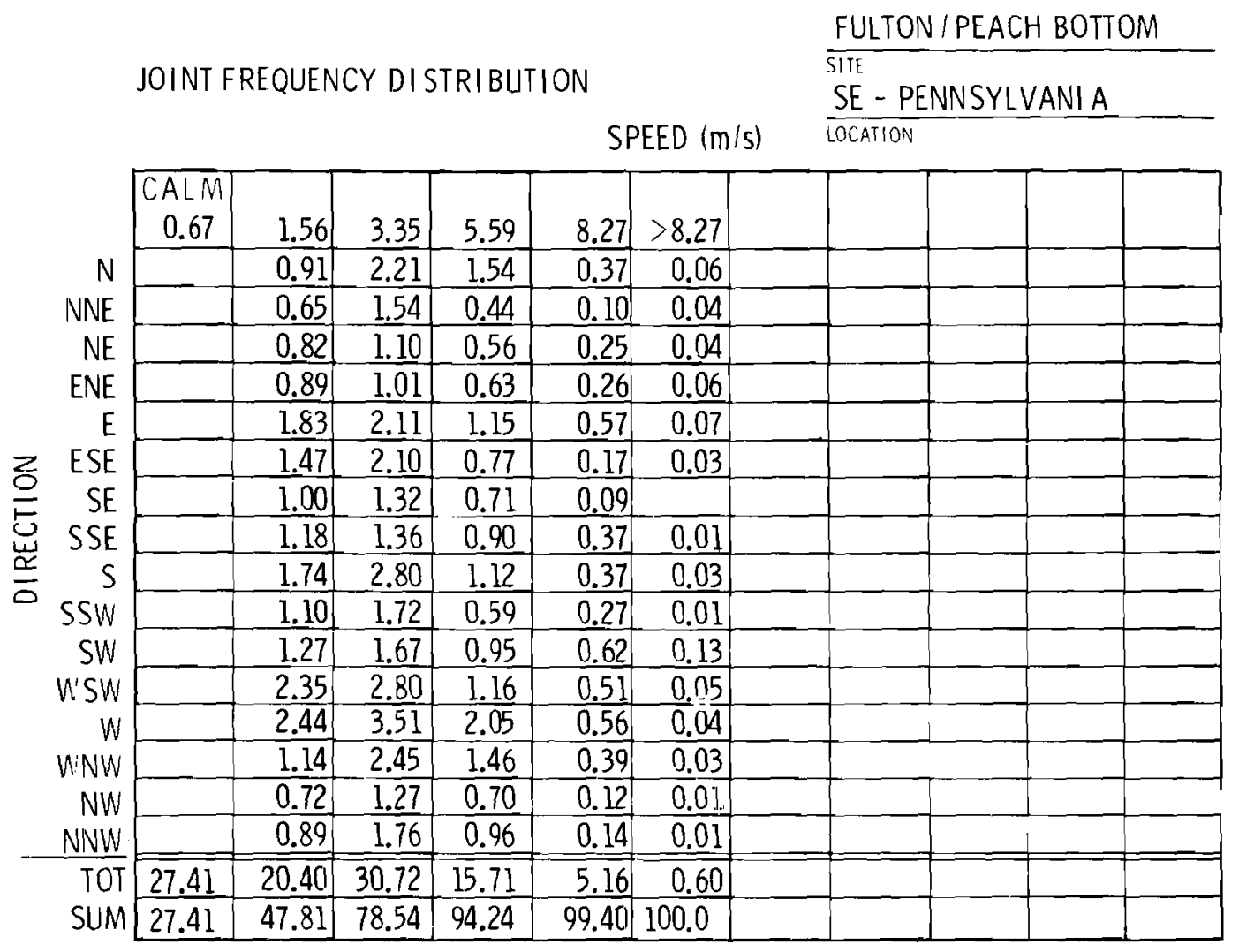

\section{4}

OBSERVATION'S

$\frac{1 \text { AUG }}{\text { PFPIOD }} 67=30$ JUL 70

VELOCITY-DURATION CURVE

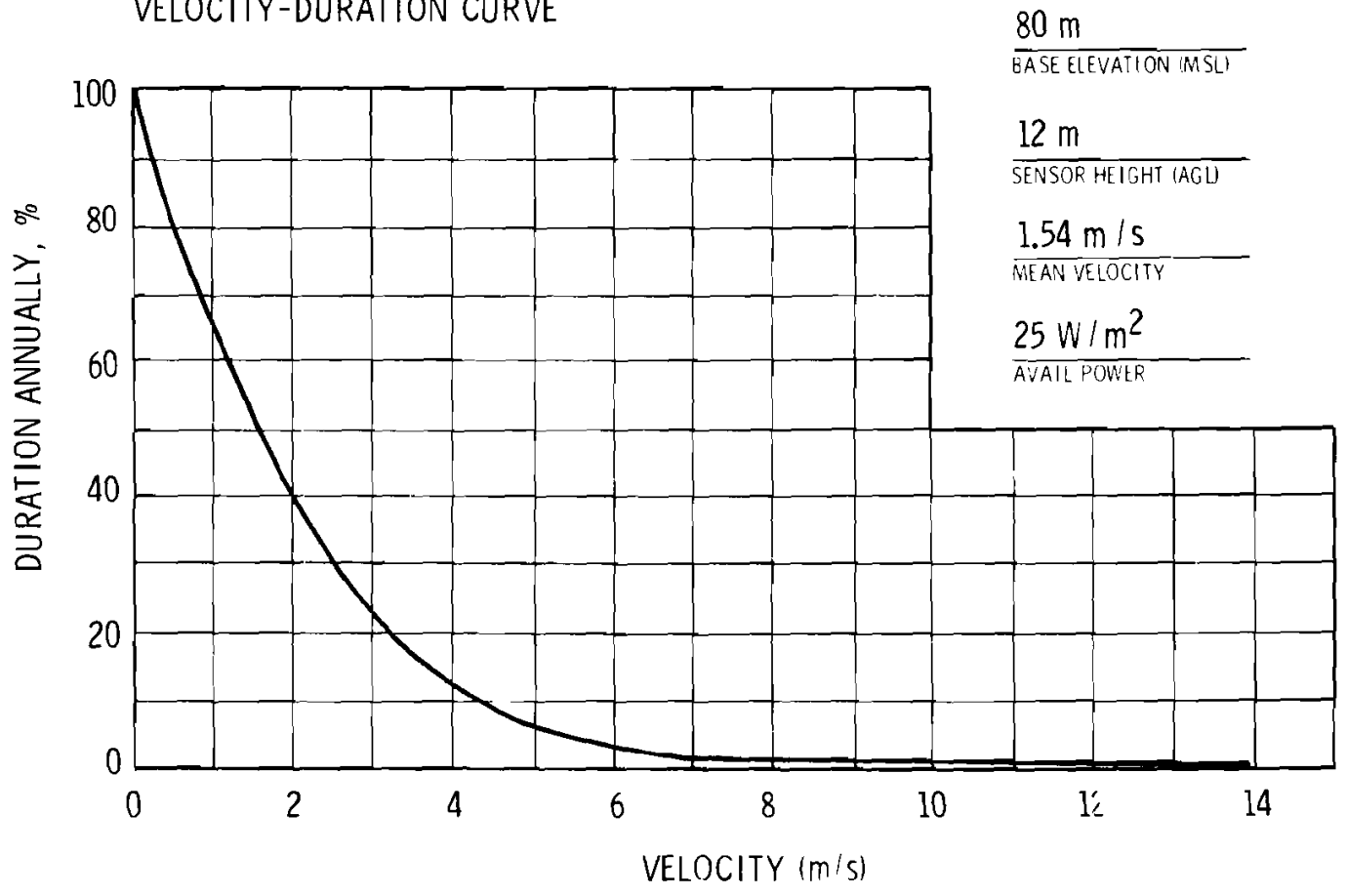




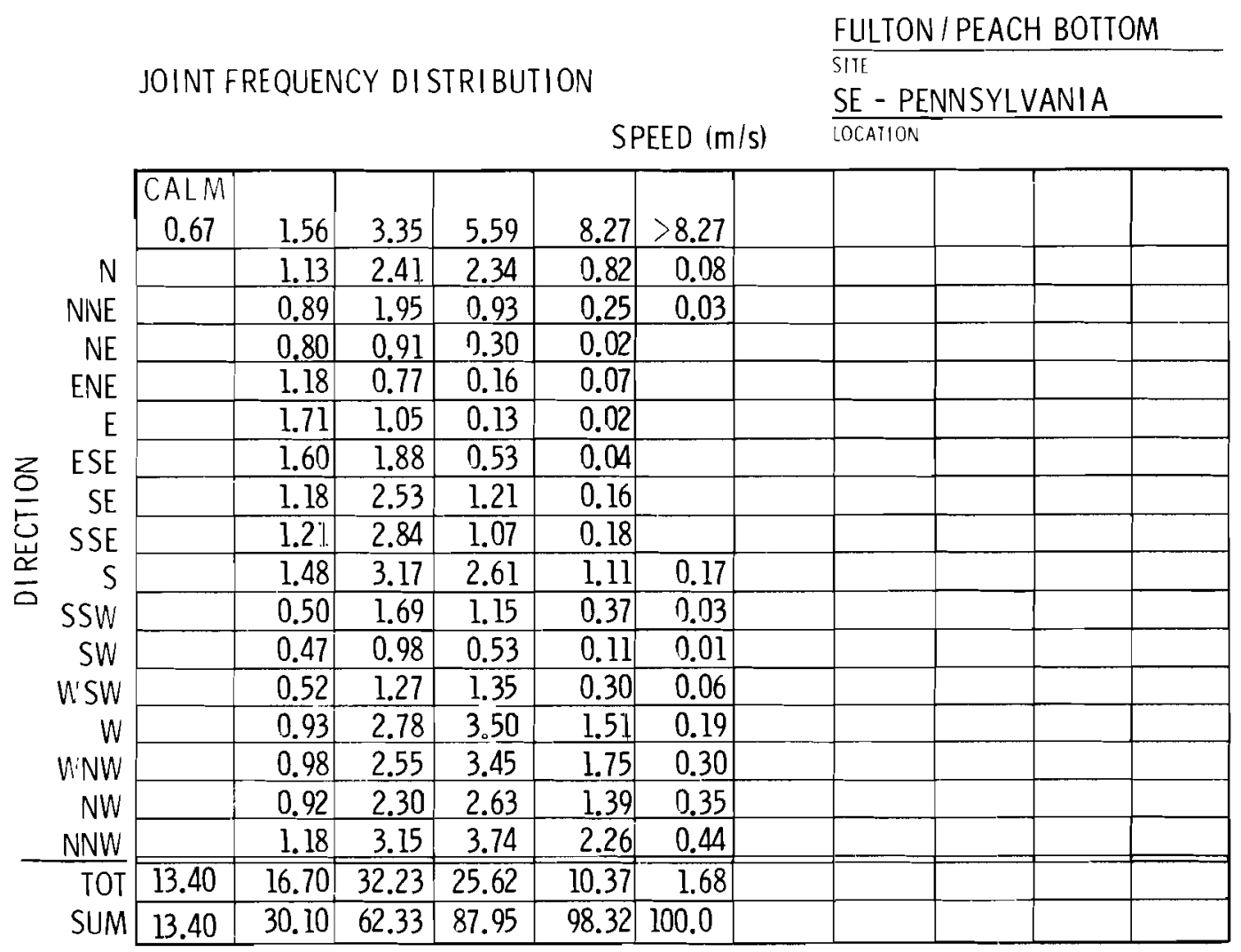

\section{1}

OB SERVAIIONS

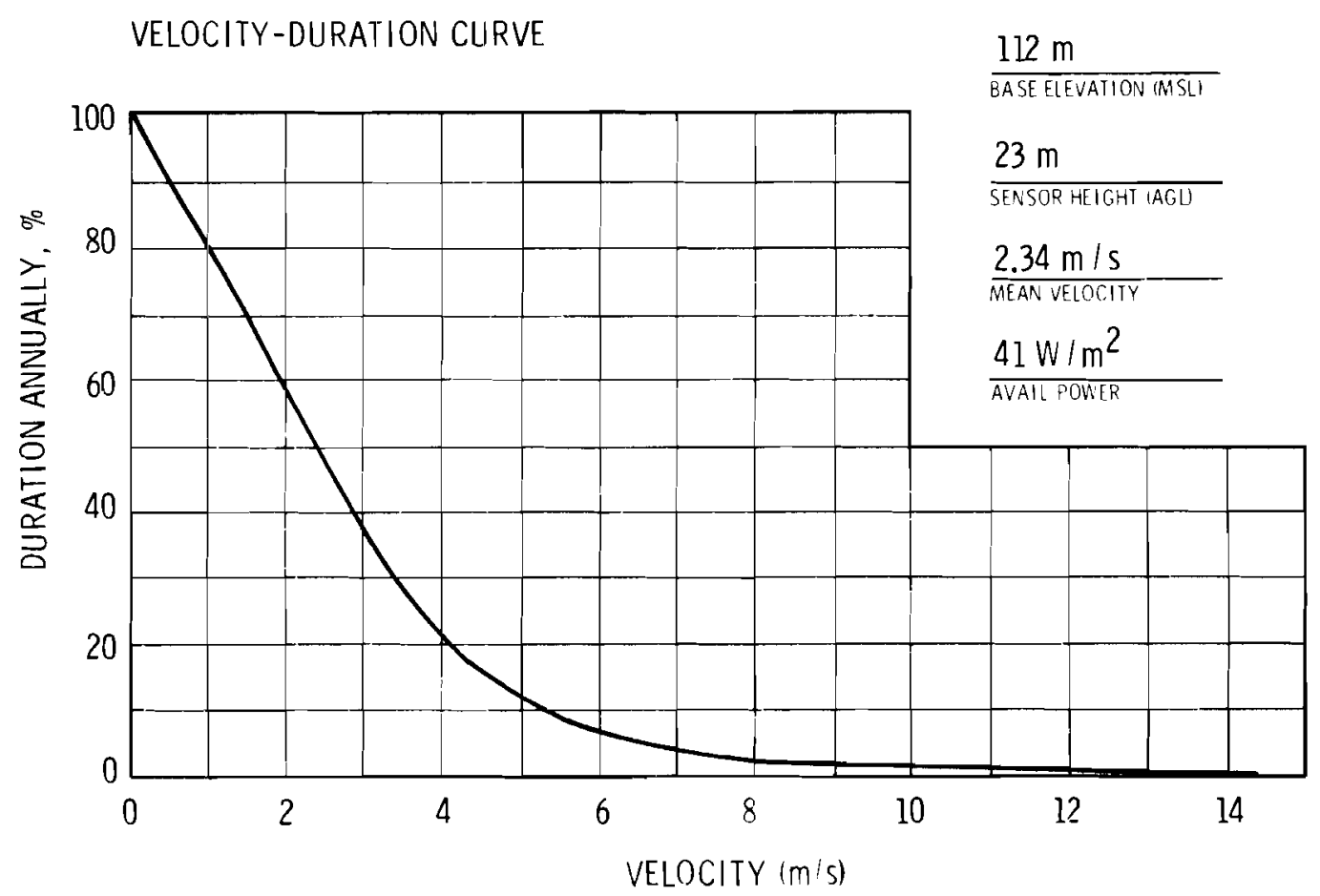



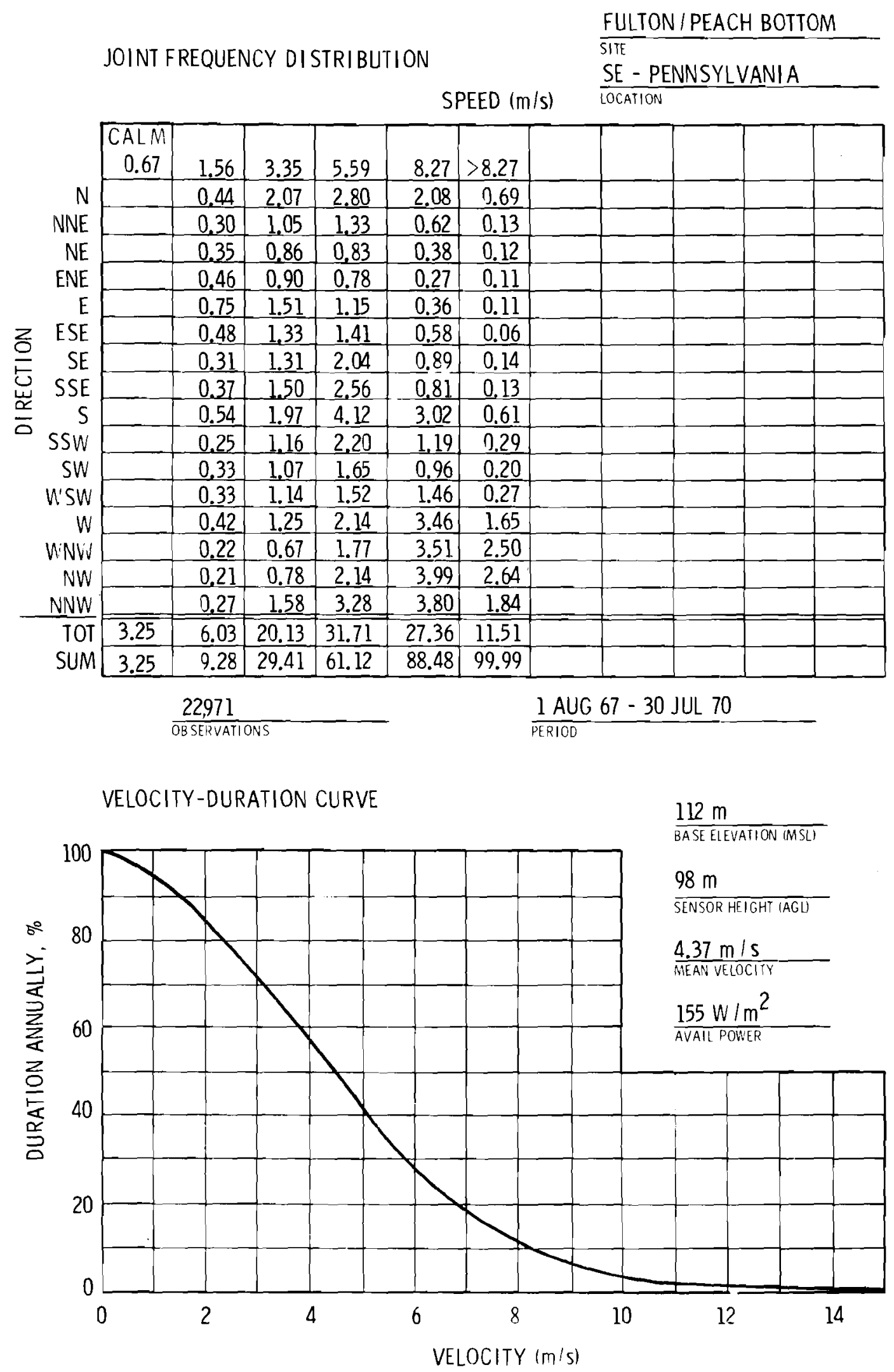


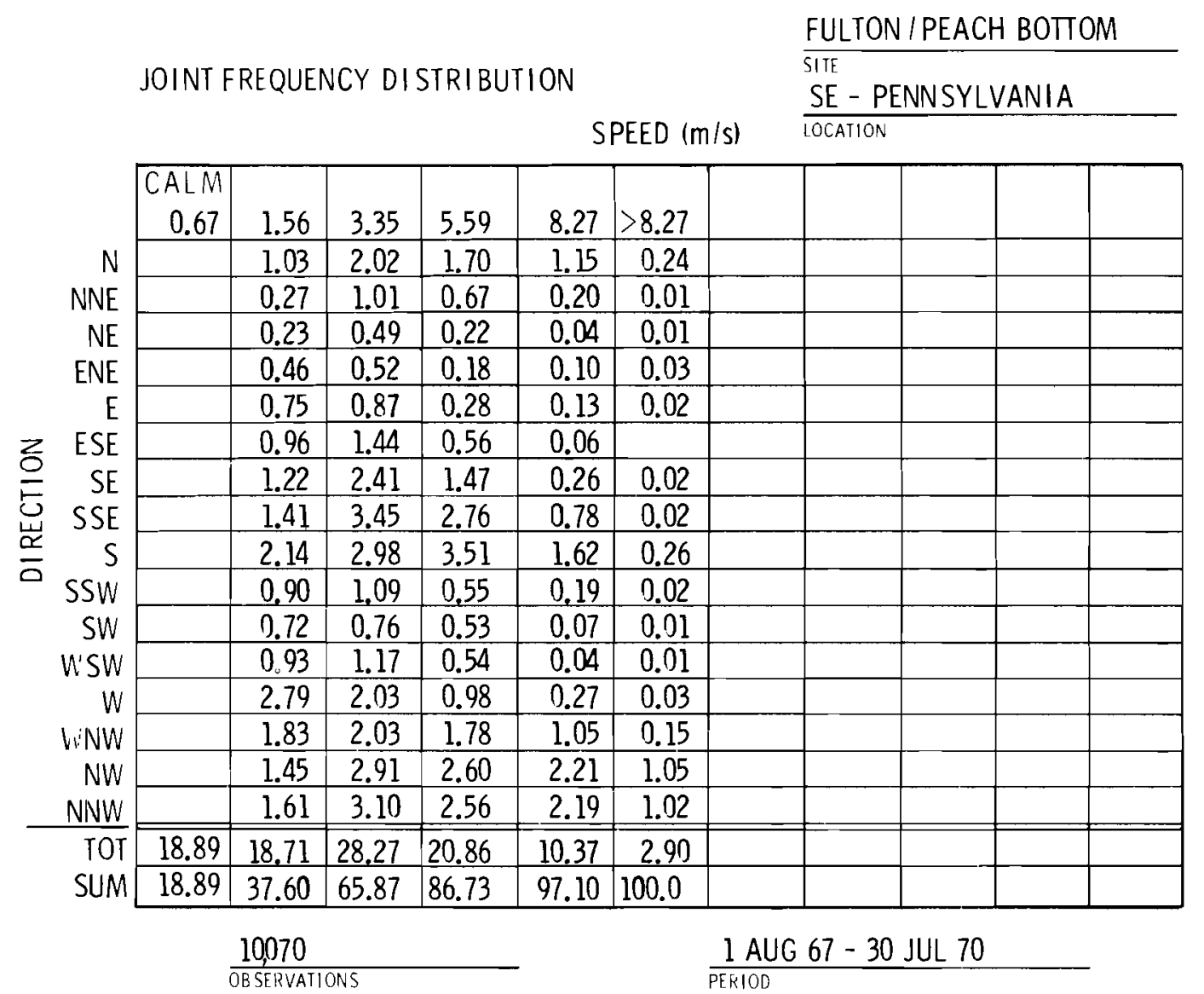

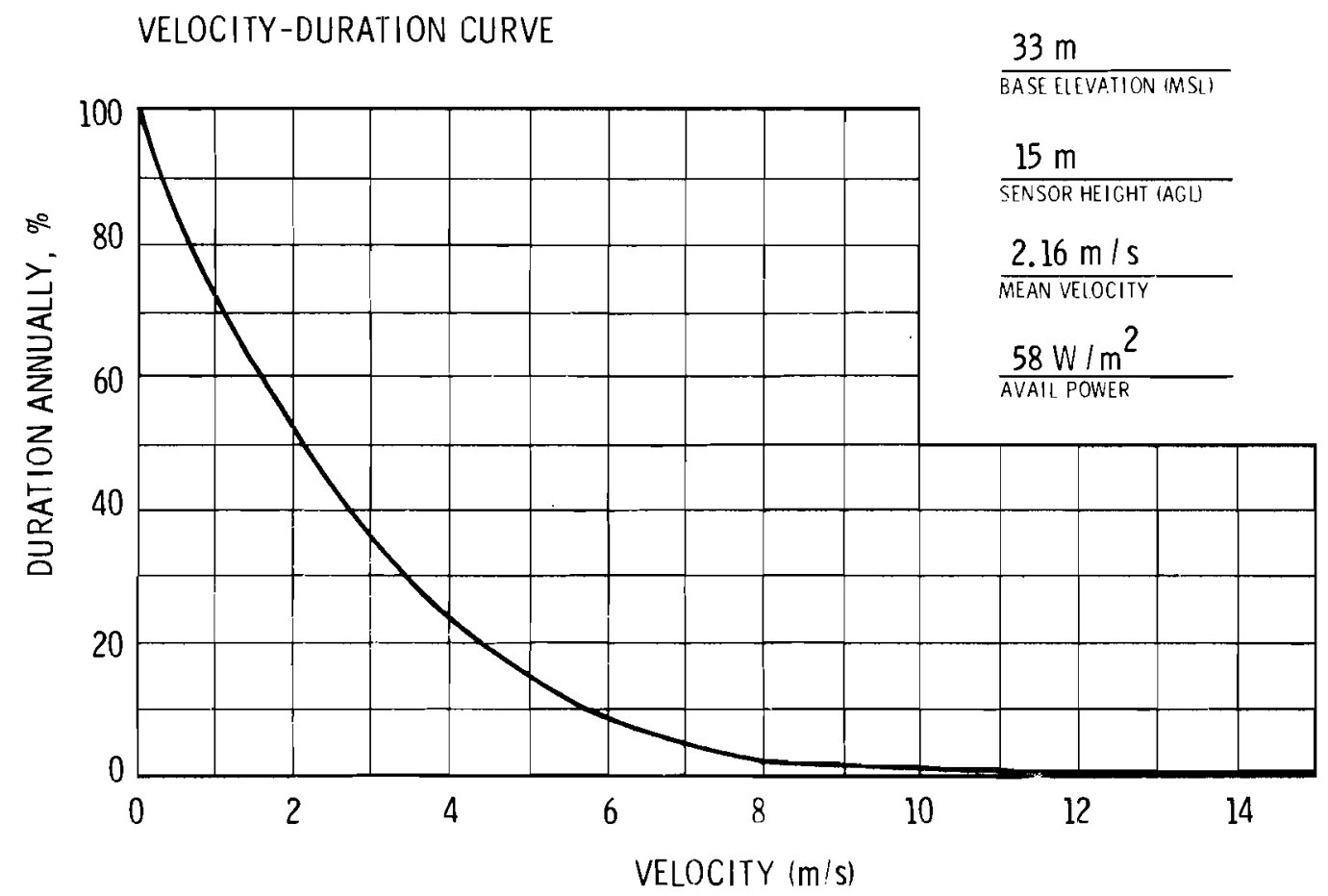


R. E. GINNA

\section{SITE LOCATION:}

The site $\left(43.28^{\circ} \mathrm{N} / 77.31^{\circ} \mathrm{W}\right)$ is in the $\mathrm{NW}$ corner of wayne County, New York, on the south shore of Lake Ontario about $32 \mathrm{~km}$ ENE or Rochester and $64 \mathrm{~km} \mathrm{WSW}$ of Oswego.

\section{TOPOGRAPHY :}

The site is on the slightly $(2.5 \mathrm{~m})$ elevated south shore of Lake ontario. The terrain around the site is gently rolling. ON-SITE WIND MEASUREMENTS:

A 56-m tower was used to collect wind data using a BendixFriez Model 120 Aerovane at $15 \mathrm{~m}$ elevation. The instrument was moved to $10 \mathrm{~m}$ in late 1974 . Tower base elevation is $84 \mathrm{~m}$ (MSL) .

$\overline{\text { NRC Docket No. 50-244 }}$ 

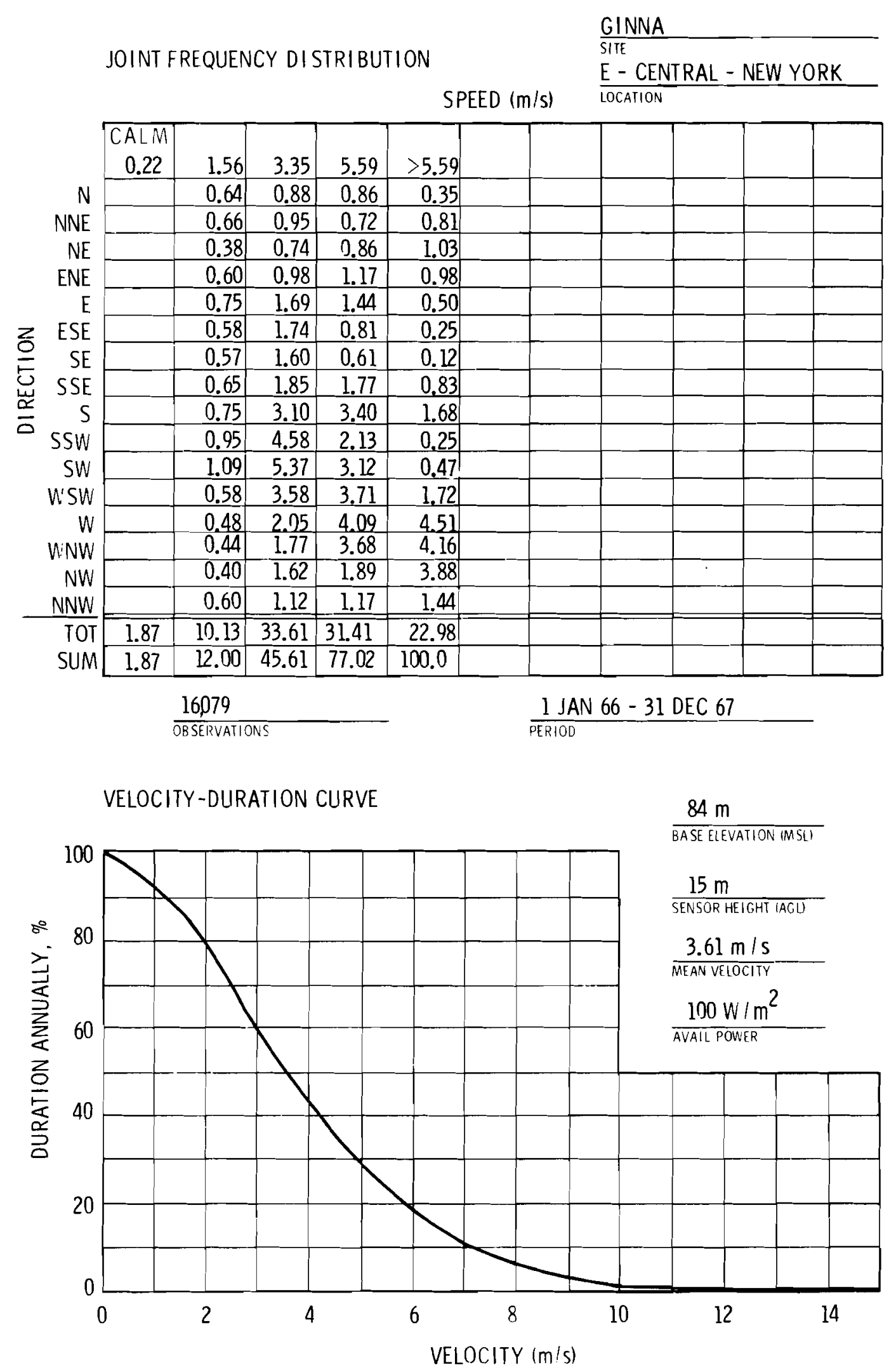

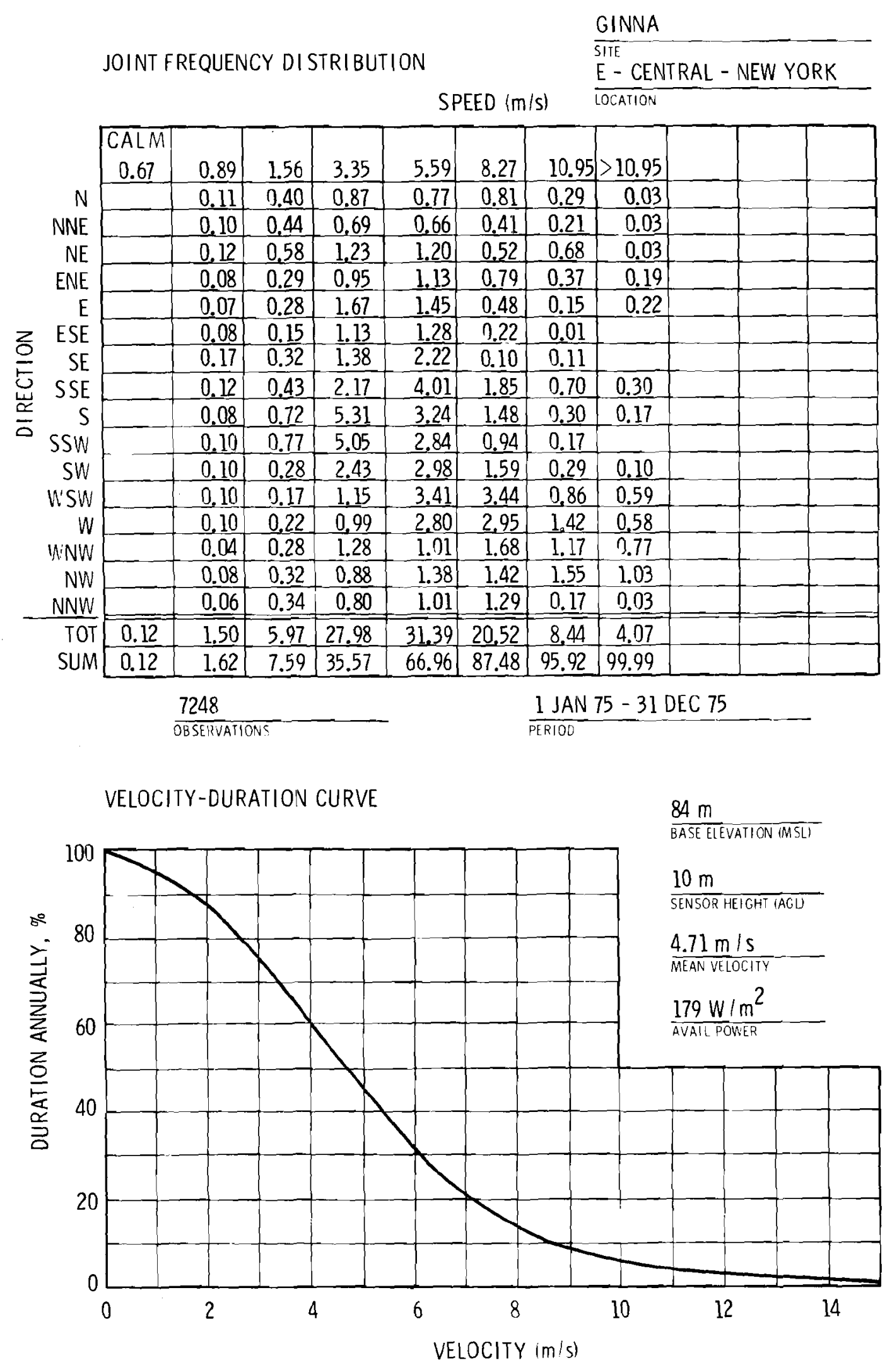
GRAND GULF

\section{SITE LOCATION:}

The site $\left(32.01^{\circ} \mathrm{N} / 91.05^{\circ} \mathrm{W}\right)$ is in clairborne County, sw Mississippi. It is on the east bank of the Mississippi River, $2.5 \mathrm{~km} \mathrm{~S}$ of the community of Grand Gulf, $40 \mathrm{~km} \mathrm{~S}$ of Vicksburg and $60 \mathrm{~km}$ NNE of Natchez. The town of Port Gibson is about $10 \mathrm{~km} \mathrm{SE}$ of the site.

\section{TOPOGRAPHY:}

The site lies about $2.5 \mathrm{~km} \mathrm{E}$ of the Mississippi River, at about $40 \mathrm{~m}$ (MSL). The site region consists primarily of woodlands and farms, and is about equally divided between two physiographic sections. To the south and east, the terrain is generally hilly and wooded with several hilltops peaking over $100 \mathrm{~m} \mathrm{(MSL)} \mathrm{to} \mathrm{the} \mathrm{S}$. To the north and west lies the alluvial plain of the Mississippi River where the terrain is generally flat and wooded, ranging between 20 and $30 \mathrm{~m}$ (MSL). Numerous lakes formed by the meandering river and isolated marshes dot the landscape. There is a rather abrupt (irregular) 30-m to 60-m rise in terrain about $2 \mathrm{~km}$ east of the riverbank.

ON-SITE WIND MEASUREMENTS:

A permanent tower, located in an open field at about $49 \mathrm{~m}$ (MSL), became operational in Aug. 1972. It is equipped with an MRI 1074-2 wind system at its top $(10 \mathrm{~m})$.

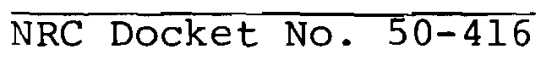



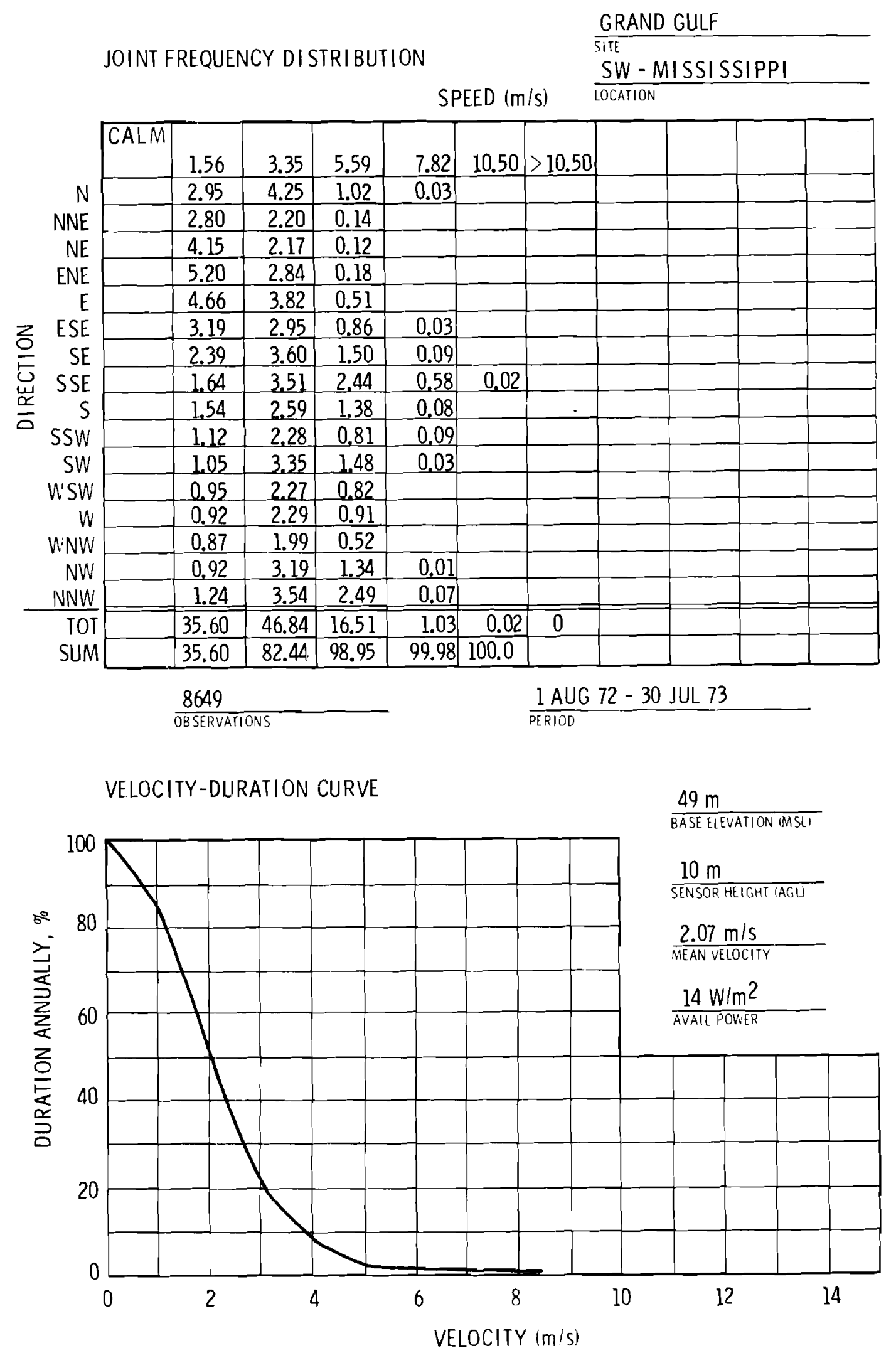
GREENE

SITE LOCATION:

The Greene County Nuclear Power Plant site $\left(42.15^{\circ} \mathrm{N} / 73.91^{\circ} \mathrm{W}\right)$ is located on the west bank of the Hudson River, $21 \mathrm{~km} \mathrm{~N}$ of Kingston, in Greene County, SE New York. It is about $2 \mathrm{~km} \mathrm{~N}$ of the hamlet of cementon, about $25 \mathrm{~km}$ SSW of Albany and about $65 \mathrm{~km} \mathrm{~N}$ of New York City.

\section{TOPOGRAPHY :}

The site is located in the Hudson River Valley between the Catskill Mountains to the west and the Berkshire Mountains to the east. The topography in the vicinity of the site $(9 \mathrm{~m}$ (MSL)) is characterized by the Hudson River Valley, which is oriented NNE-SSW. To the west of the site, two ridges parallel the river. The nearest ridge, about $1 \mathrm{~km} W$ rises from $60 \mathrm{~m}$ to $90 \mathrm{~m}$ (MSL). The second ridge lies about $5 \mathrm{~km}$ to $7 \mathrm{~km} \mathrm{~W}$ and rises to heights of $120 \mathrm{~m}$ to $150 \mathrm{~m}$ (MSL). Three kilometers to the east, across the river, a series of rolling hills rise to the heights of 60 to $90 \mathrm{~m}$ (MSL). To the north and south in the vicinity of the river, the terrain is relatively flat.

ON-SITE WIND MEASUREMENTS:

The meteorological monitoring program was initiated on 1 Jun 1973. Wind direction and speed are measured at the $10 \mathrm{~m}, 60 \mathrm{~m}$, and $122 \mathrm{~m}$ levels using Climatronics Corporation, F-460 wind sets (3-cup anemometers and direction vanes).

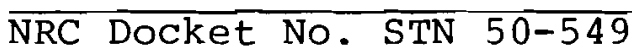



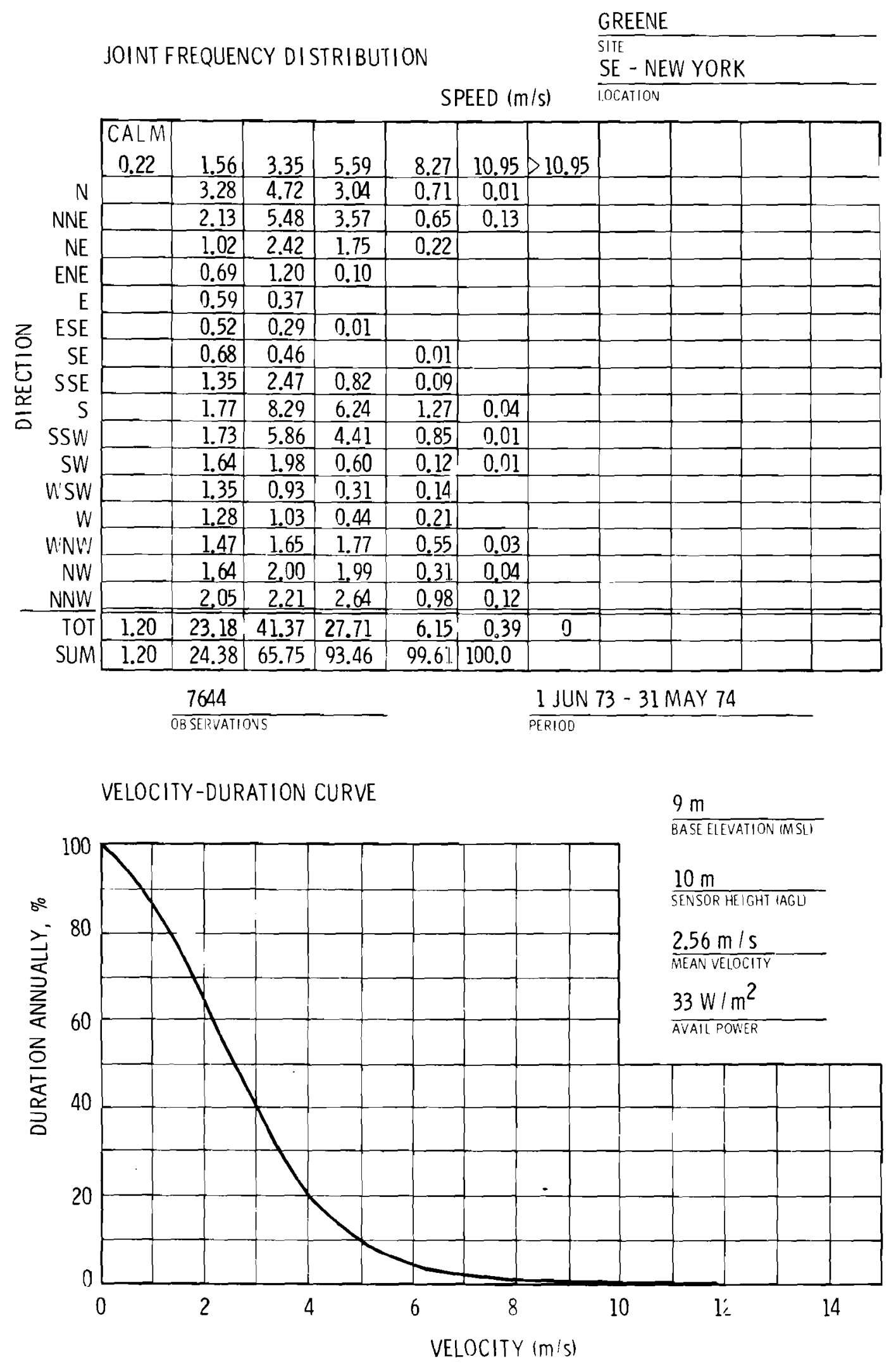

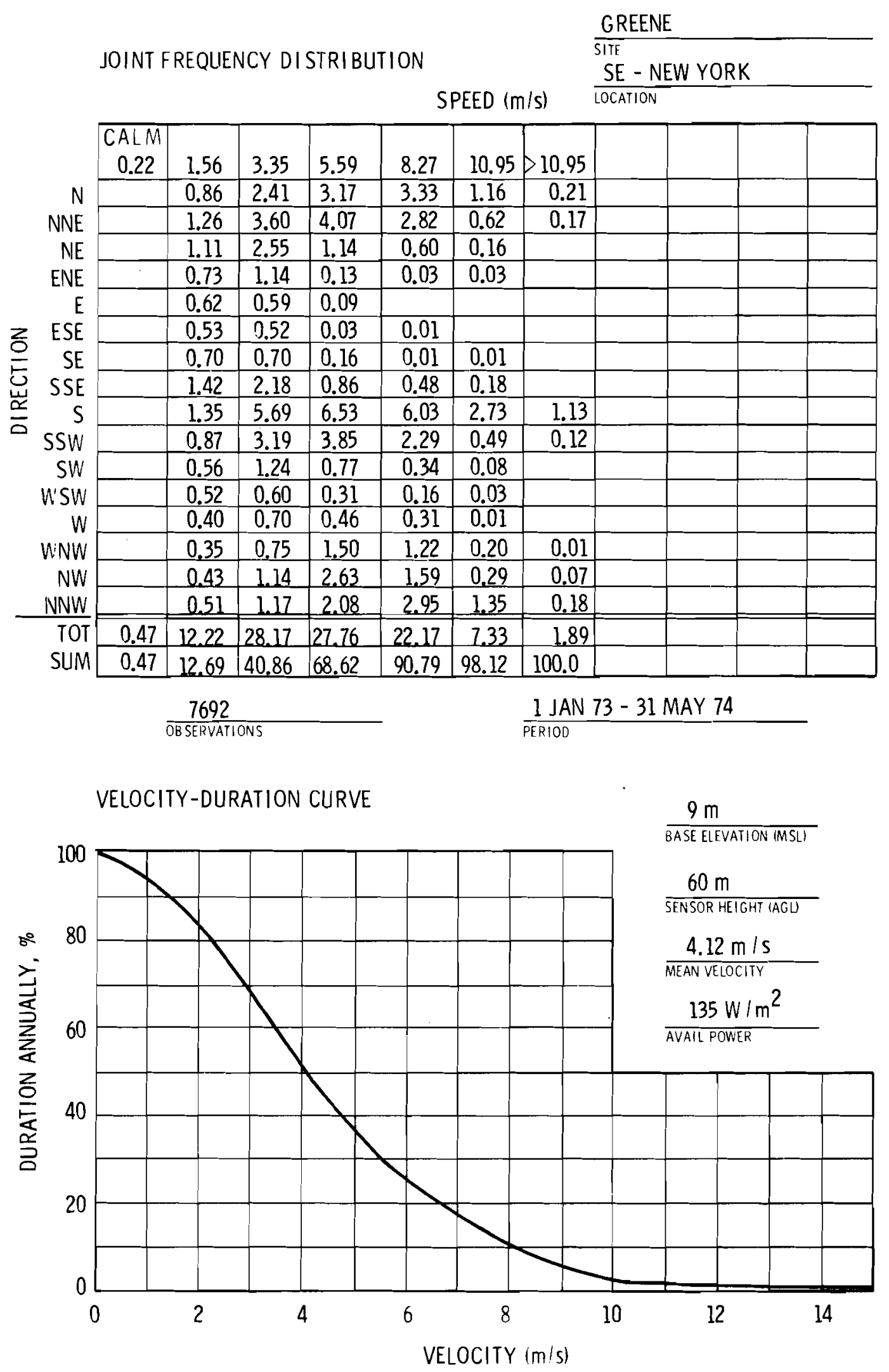
GREENWOOD

\section{SITE LOCATION:}

The Greenwood Energy Center $\left(43.09^{\circ} \mathrm{N} / 82.68^{\circ} \mathrm{W}\right)$ is situated in the "thumb" region of SE Michigan. The site is in St. Clair county, $80 \mathrm{~km}$ NNE of Detroit, $18 \mathrm{KM}$ inland from Lake Huron and $26 \mathrm{Km}$ WNW of Port Huron.

TOPOGRAPHY:

The terrain in the region is characterized by smooth gently rolling plains with relief varying from $30 \mathrm{~m}$ to $90 \mathrm{~m}$. Site elevation is between 230 and $235 \mathrm{~m}$ (MSL).

ON-SITE WIND MEASUREMENTS:

The on-site meteorological program began on 25 sept 1972 . The system includes a 61-m tower instrumented with Climet WS-011-10 and $\mathrm{Cl}$ imet WD-012-11 sensor systems at $11 \mathrm{~m}$ and $61 \mathrm{~m}$. Tower base elevation is $233 \mathrm{~m}$ (MSL).

$\overline{\text { NRC Docket No. } 50-4 \overline{52}}$ 


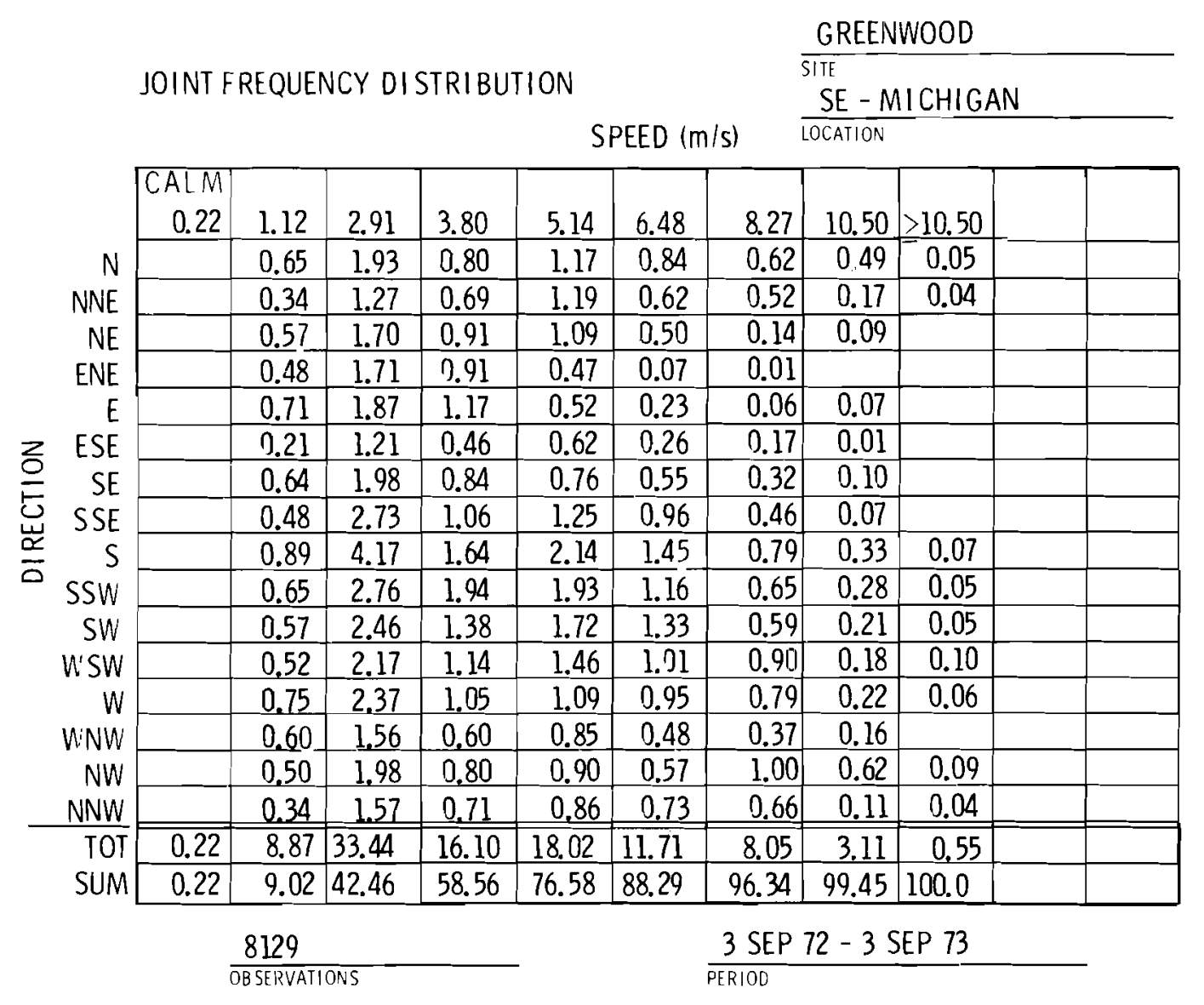

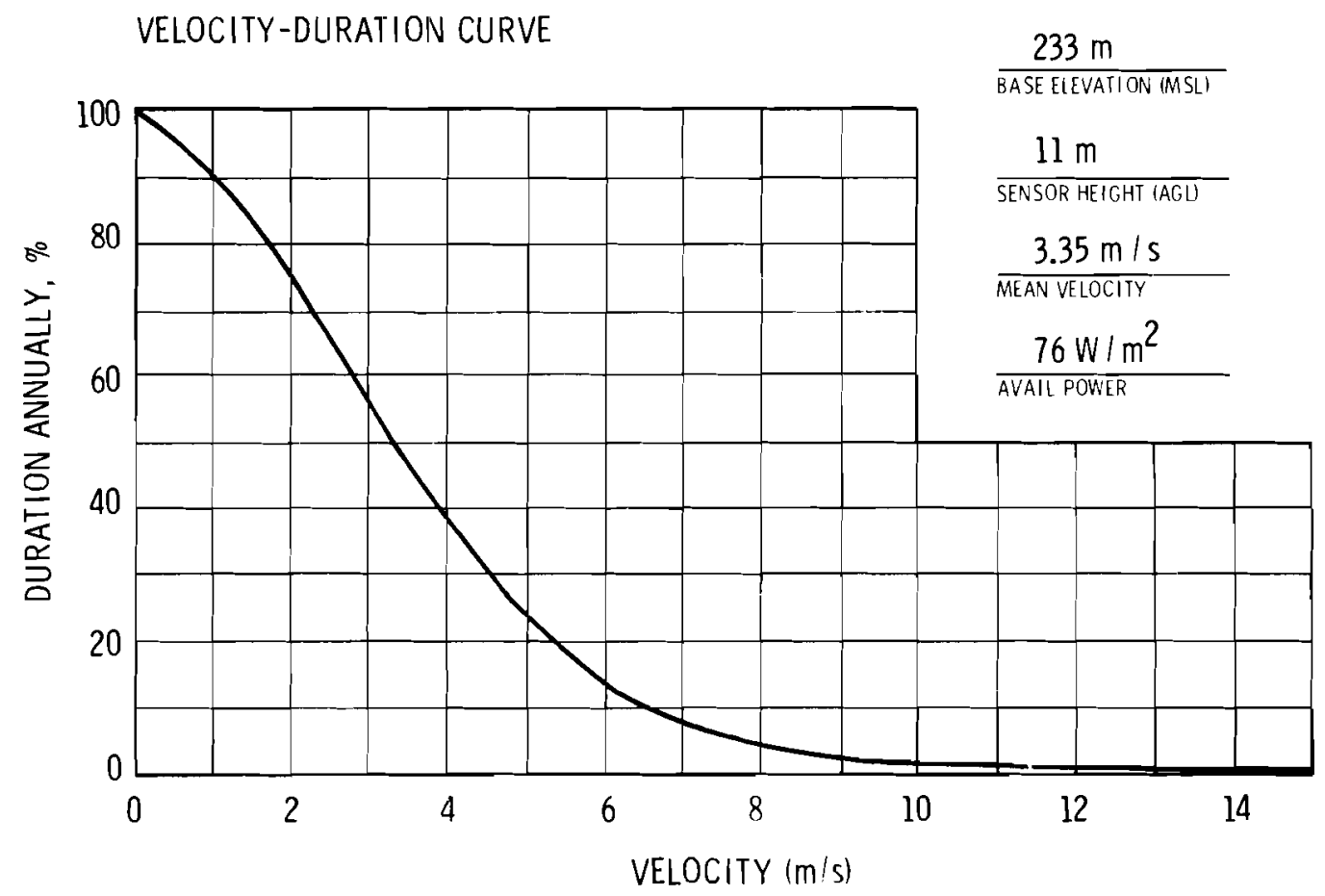




\section{SITE LOCATION:}

The site $\left(35.63^{\circ} \mathrm{N} / 78.95^{\circ} \mathrm{W}\right)$ is in the extreme SW corner of $7 a h e$ County, and the SE corner of Chatham County, North Carolina. Raleigh is $32 \mathrm{Km} \mathrm{NE}$ and sanford is $16 \mathrm{Km} \mathrm{SW}$.

\section{TOPOGRAPHY :}

The site is in the leading edge of the Appalachian Piedmont region. The land is rolling and heavily wooded. Plant grade is at $70 \mathrm{~m}$ (MSL).

ON-SITE WIND MEASUREMENTS:

Wind measurements are made at $11 \mathrm{~m}$ and $61 \mathrm{~m}$ (AGL) using MRI 1074-22 sensors.

$\overline{\text { NRC Docket No. } 50-400}$ 


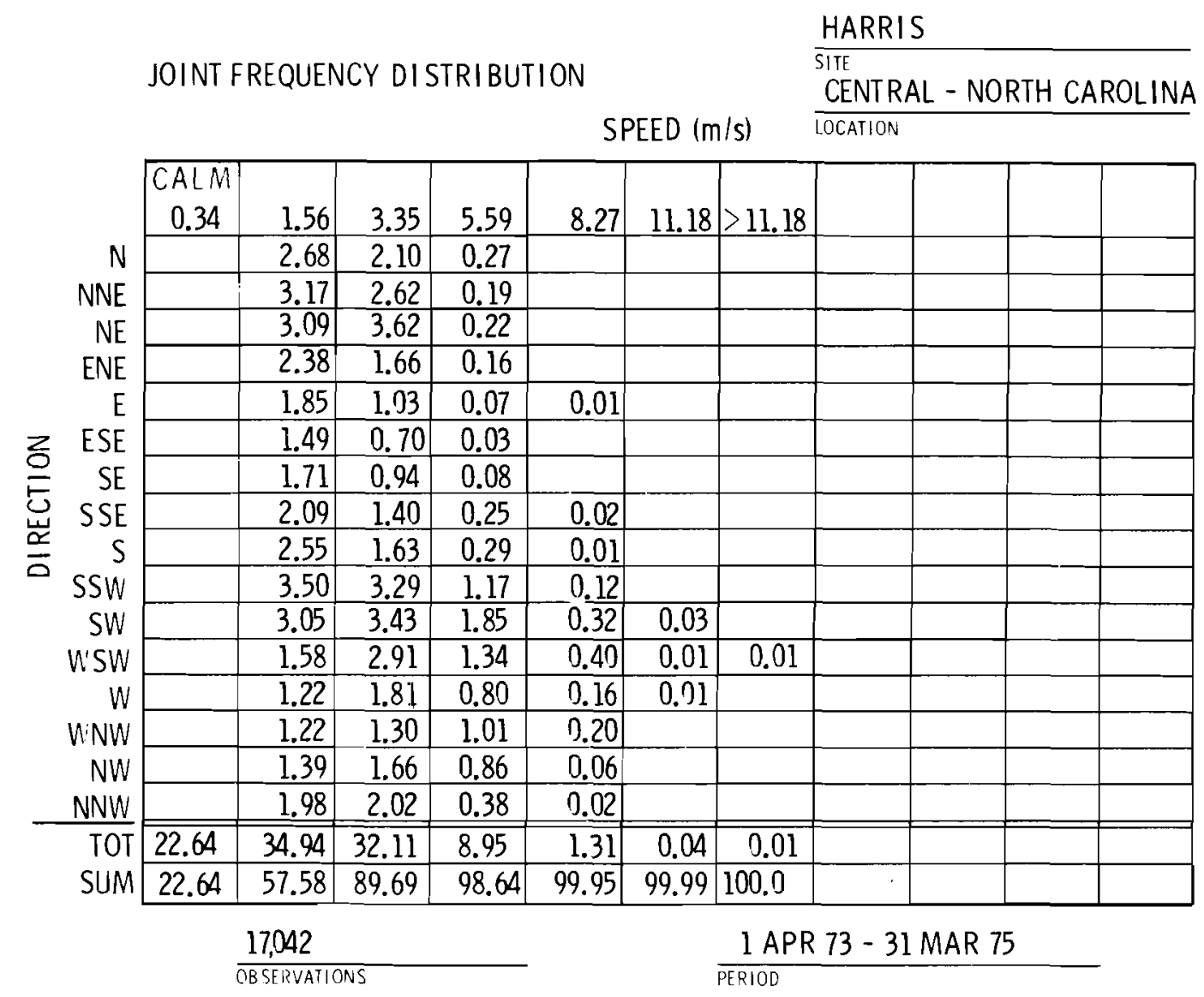

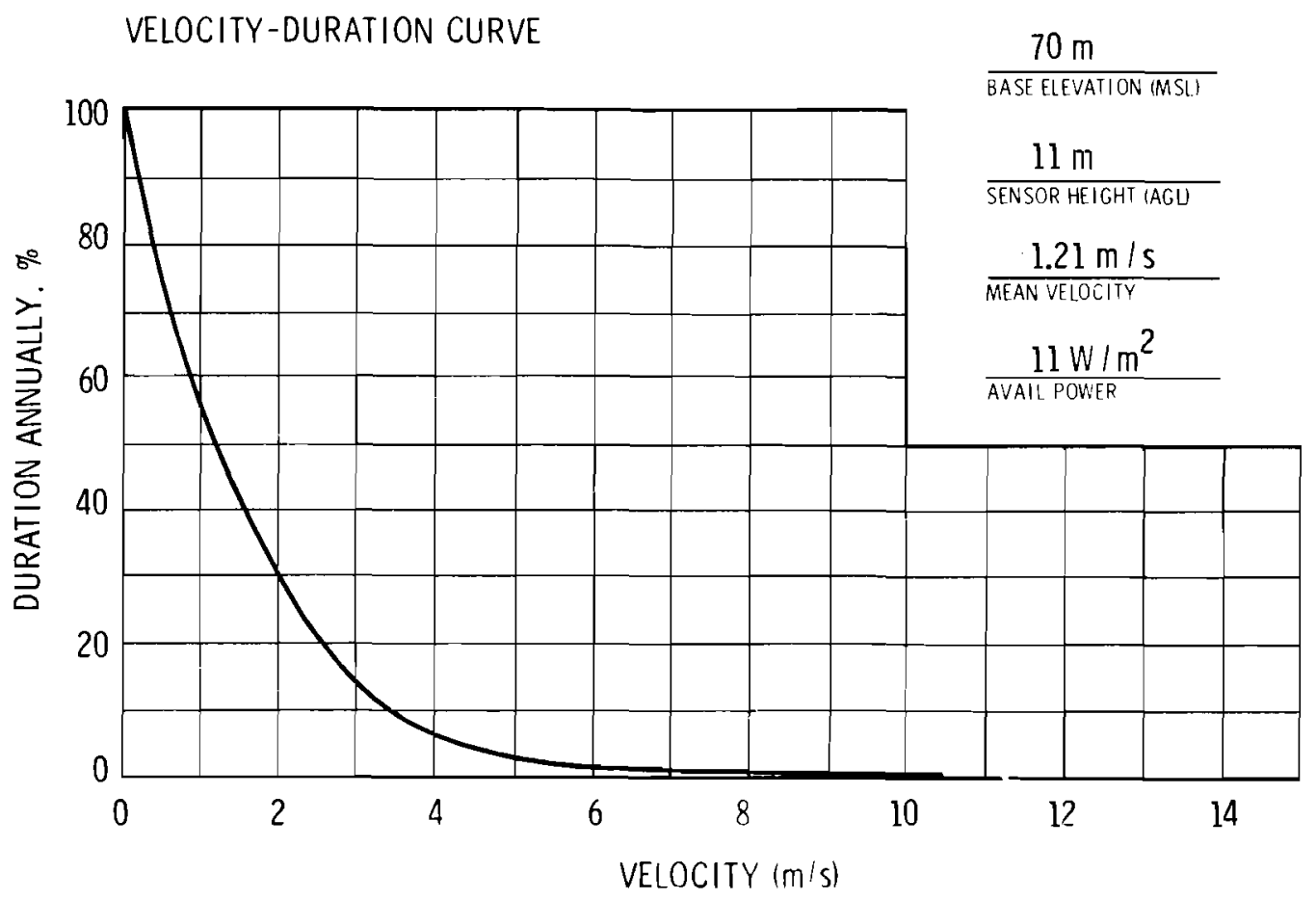



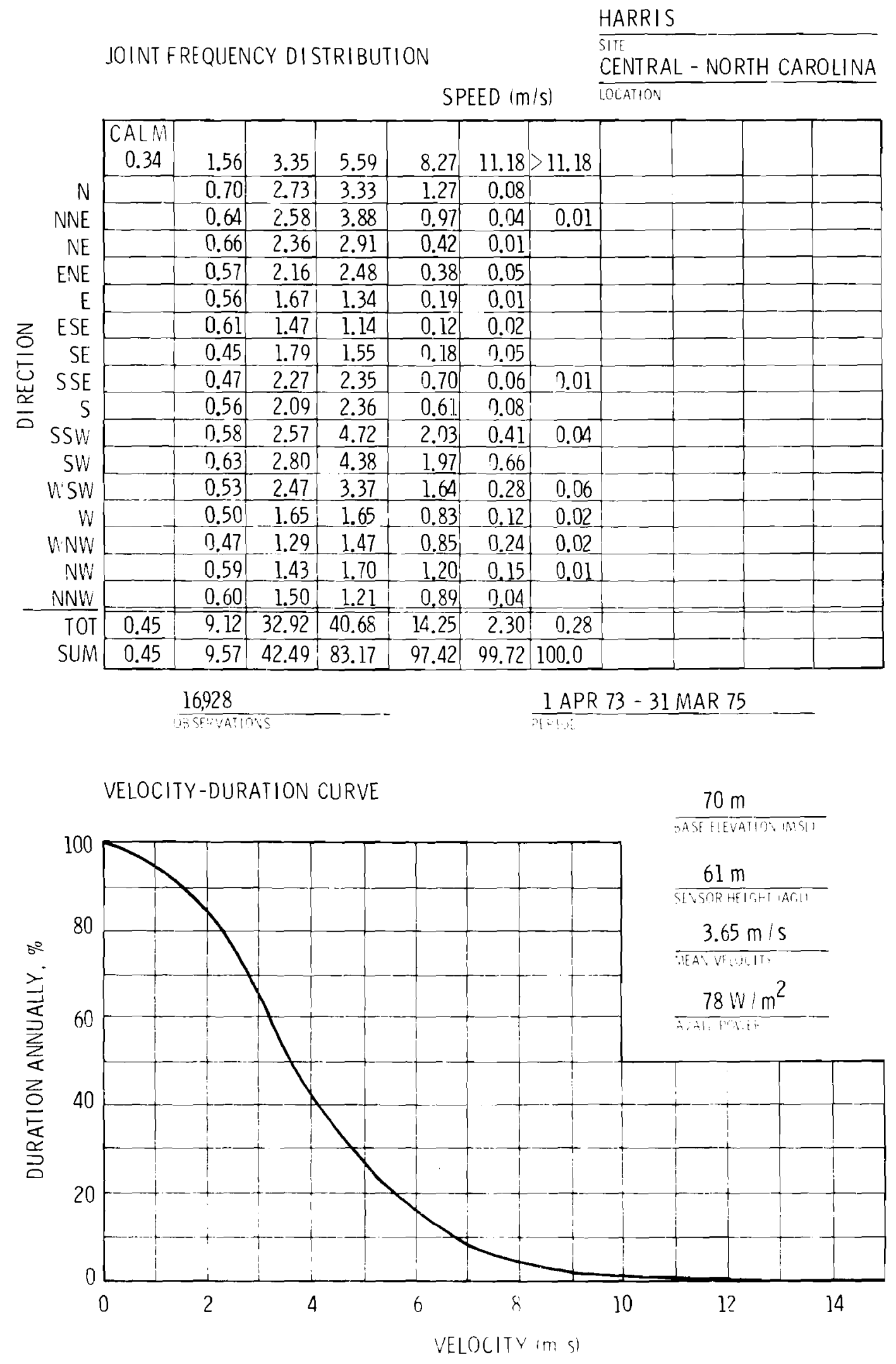
HARTSVILLE

\section{SITE LOCATION:}

The Hartsville site $\left(36.35^{\circ} \mathrm{N} / 86.09^{\circ} \mathrm{W}\right)$ consists of 1,940 acres, and straddles the Trousdale and Smith county line. It is about $8 \mathrm{~km}$ SE of Hartsville, Tennessee, and about $40 \mathrm{~km} \mathrm{ENE}$ of Nashville.

\section{TOPOGRAPHY :}

The regional topography is one of irregular rolling hills, : with mixed woods and cultivation. The highest close-in terrain features are a ridge about $3 \mathrm{~km} \mathrm{NNW}$ and $\mathrm{N}$ and a small ridge about $3 \mathrm{~km}$ to the $\mathrm{NW}$ which rise to about $150 \mathrm{~m}$ above plant grade of $165 \mathrm{~m}$ (MSL). The highest sector-wide ridges are located to the WNW through ESE and have elevations ranging from $60 \mathrm{~m}$ to $150 \mathrm{~m}$ above plant grade. This higher terrain has a shallow ridge-valley configuration. There is a narrow valley extending SE for about $16 \mathrm{~km}$, otherwise the terrain is mostly low, irregular rolling hills.

\section{ON-SITE WIND MEASUREMENTS:}

The on-site meteorological facility began collecting data on 1 Feb 1973. A 46-m tower is located at $165 \mathrm{~m}$ (MSL) and is instrumented at $10 \mathrm{~m}$ and $46 \mathrm{~m}$, with a Climet wS-012-11 and Climet WD-011-10 for wind direction and speed, respectively, at each level

NRC Docket No. $50-\overline{518}$ 


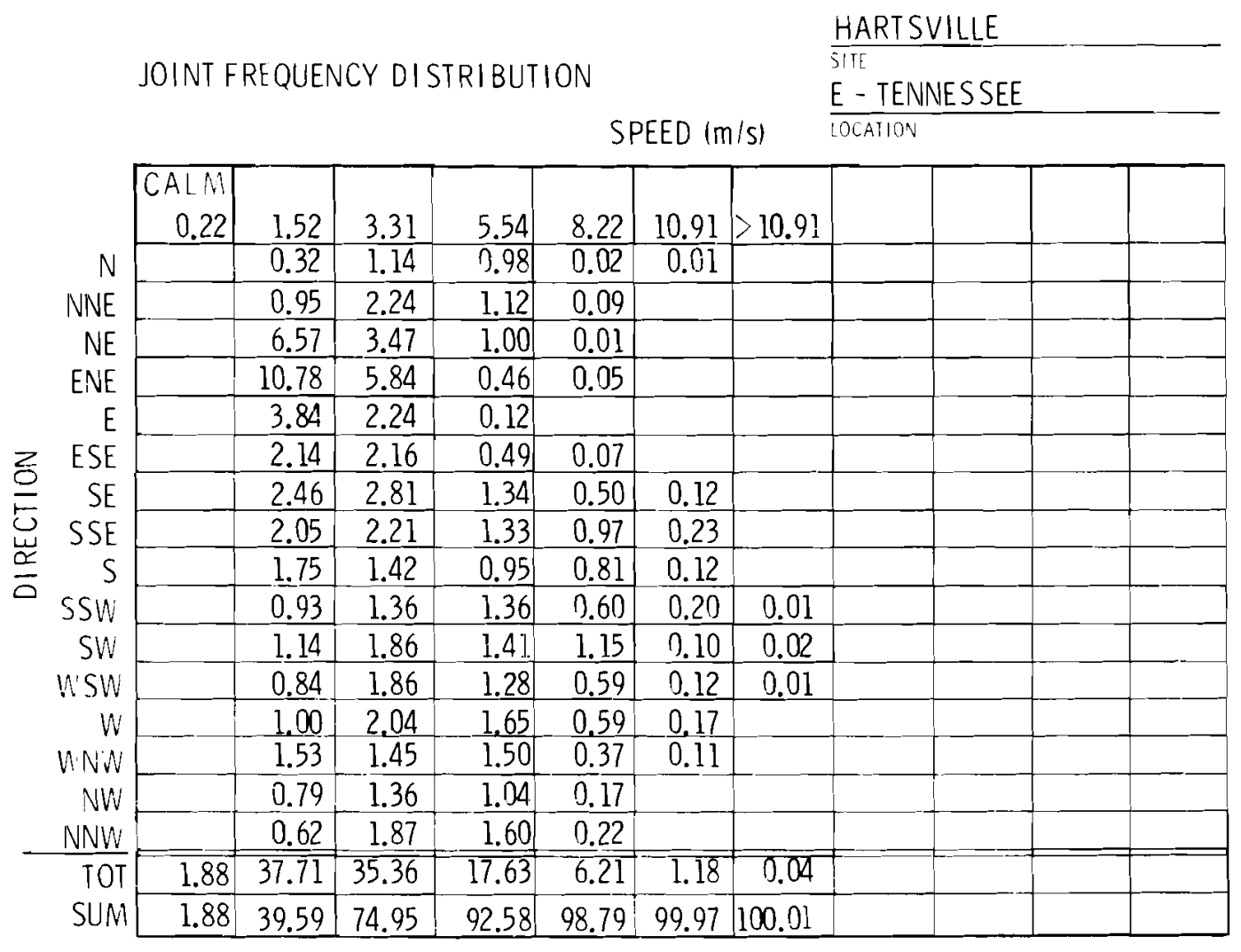

$$
\frac{7802}{\text { OB SERVATIONS }}
$$

1 FEB 73 - 31 JAN 74

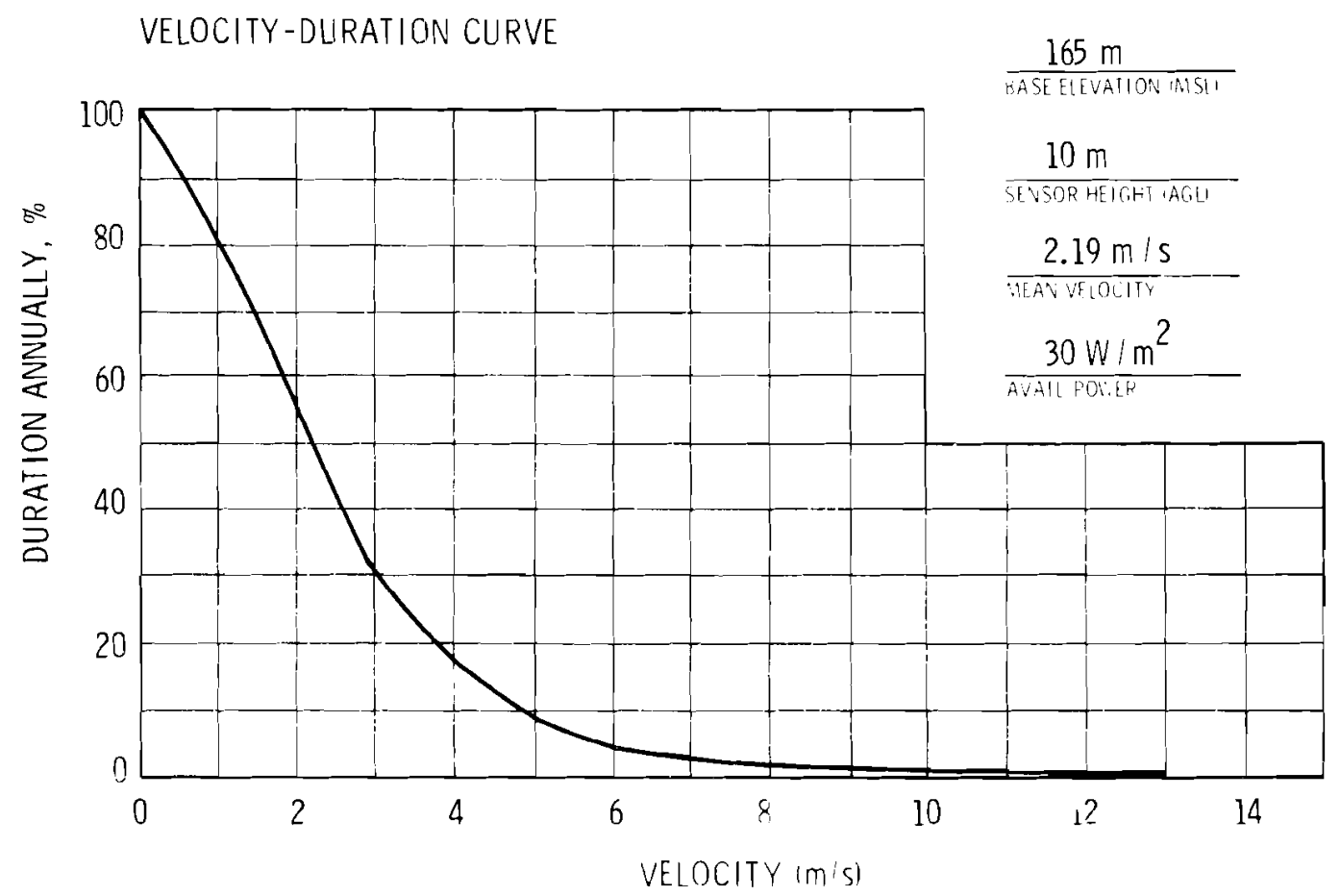


EDWIN I. HATCH

\section{SITE LOCATION:}

The site $\left(31.93^{\circ} \mathrm{N} / 82.34^{\circ} \mathrm{W}\right)$ is located in Appling County, Georgia; $18 \mathrm{~km} \mathrm{~N}$ of Baxley, $77 \mathrm{~km} \mathrm{~N}$ of Waycross, and about $125 \mathrm{~km}$ WSW of Savannah. The location is also $117 \mathrm{~km} \mathrm{NW}$ of Brunswick and $158 \mathrm{~km} \mathrm{SE}$ of Macon.

\section{TOPOGRAPHY :}

The site is within the Atlantic Coastal plain, which has a slight rise from the $\mathrm{SE}$ to the NW. The local terrain is gently rolling with the natural grade varying between $22 \mathrm{~m}$ (MSL) at the Altamaha River floodplain to $45 \mathrm{~m}$ at the southern border.

\section{ON-SITE WIND MEASUREMENTS:}

Wind speed and direction are measured on a 46-m tower based at about $37 \mathrm{~m} \mathrm{(MSL).} \mathrm{Measurements} \mathrm{are} \mathrm{made} \mathrm{at} 23 \mathrm{~m}$ and $46 \mathrm{~m}$ heights, using Climet Model WS-011-1 (speed) and Climet Model WD-012-10 (direction) instruments at each level.

NRC Docket Nos. 50-321, 50-366 

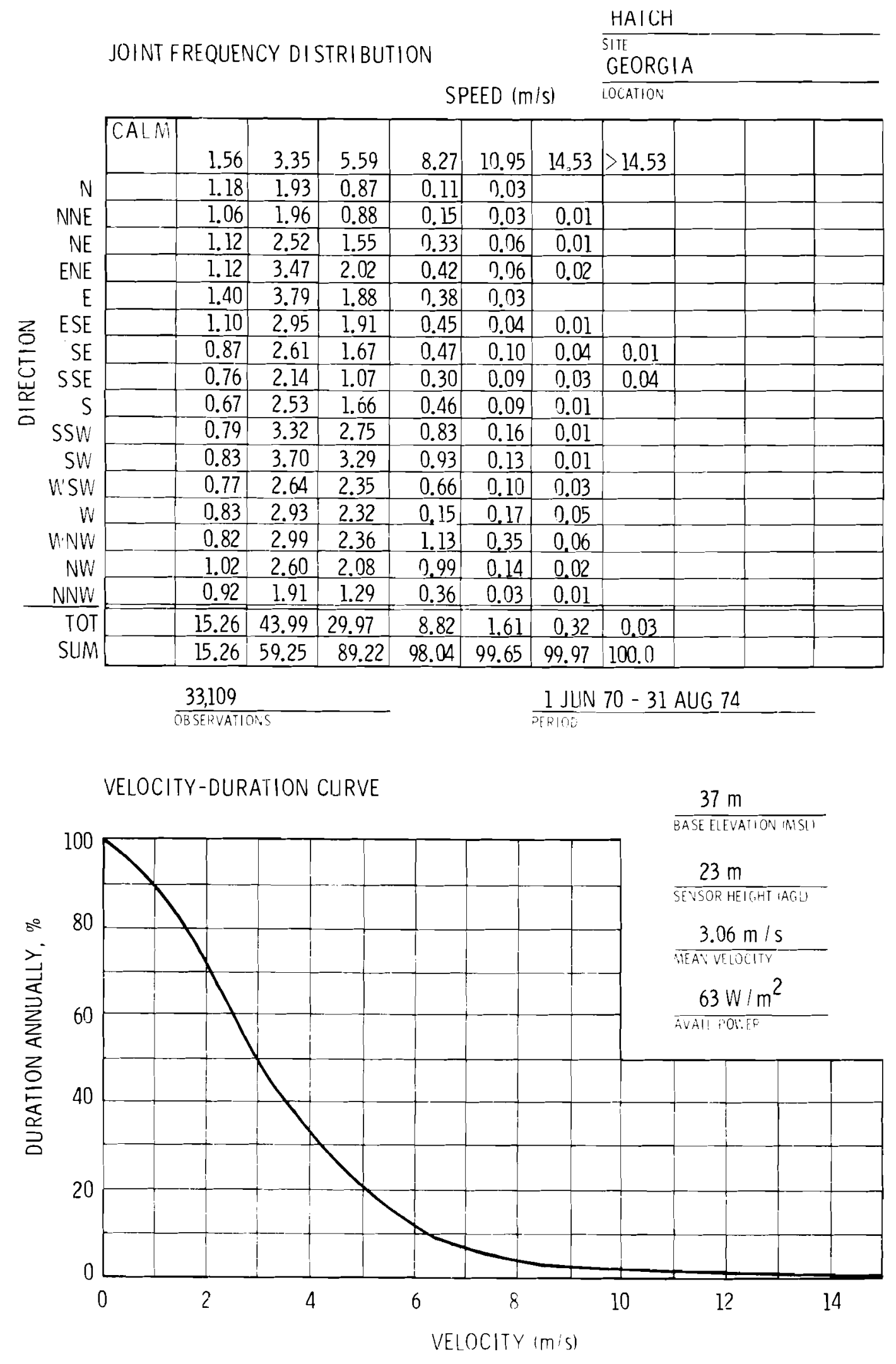


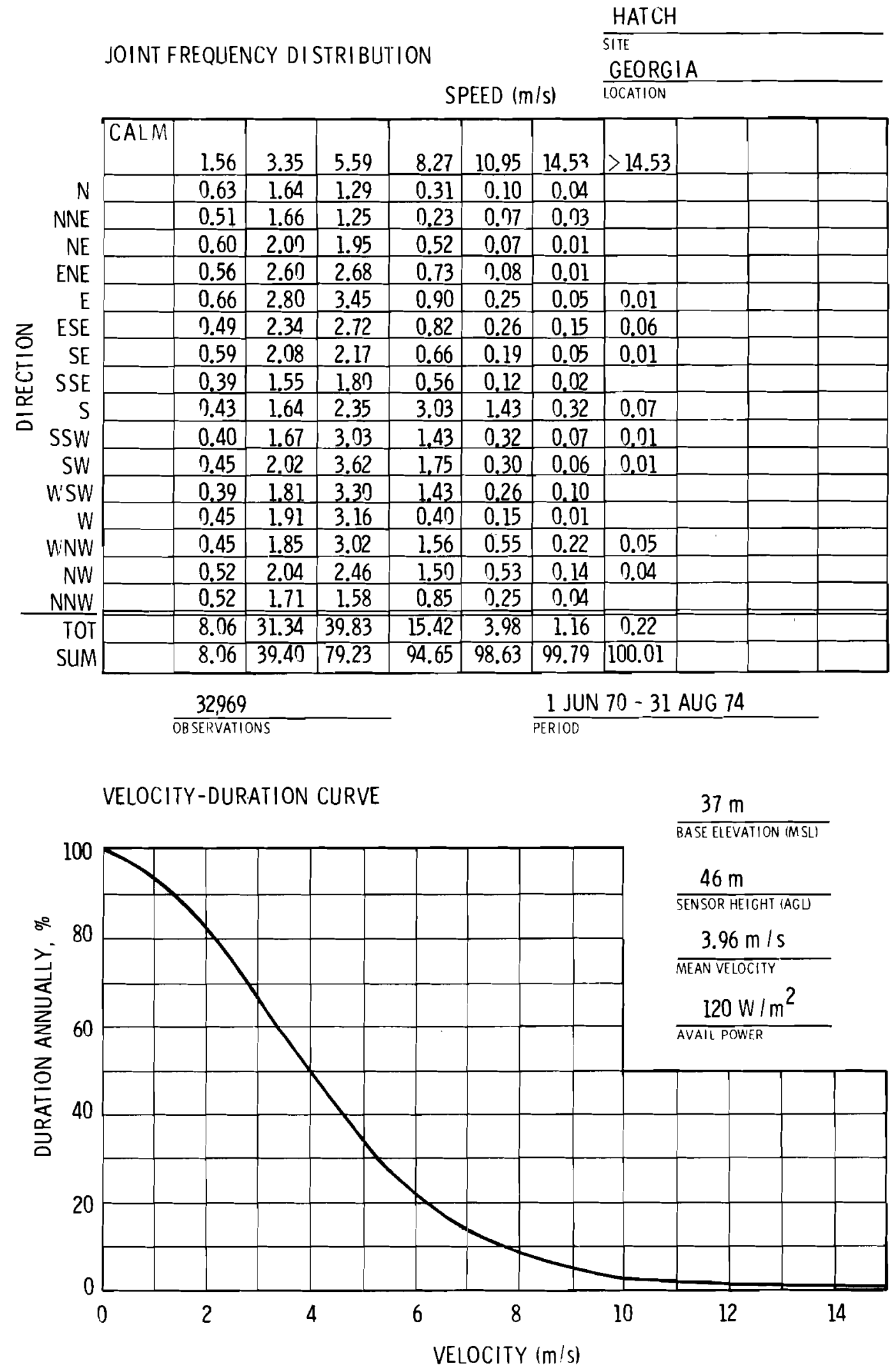


HOPE CREEK/SALLEM

\section{SITE LOCATION:}

Hope Creek and Salem $\left(39.46^{\circ} \mathrm{N} / 75.53^{\circ} \mathrm{W}\right)$ are co-located on the southern part of Artificial Island on the $E$ bank of the Delaware River in Salem County, SW New Jersey. The site is $24 \mathrm{~km} \mathrm{~S}$ of the Delaware Memorial Bridges; $29 \mathrm{~km} \mathrm{~S}$ of Wilmington, DE; $48 \mathrm{~km} \mathrm{SW}$ of Philadelphia; and $12 \mathrm{~km} \mathrm{SW}$ of Salem, NJ.

\section{TOPOGRAPHY :}

The area is part of the Coastal Plain region of New Jersey, a low lying, gently rolling plain area. Maximum elevation in the Coastal Plain region is about $60 \mathrm{~m}$ (MSL), sloping gently toward the Delaware River and the Atlantic Ocean. Much of the area is lower and there are large areas of tidal marshes adjacent to the rivers and larger streams. Artificial Island was once a natural bar in the Delaware River, adjacent to the western shore of NJ. The island is very flat, with a mean elevation of about $3 \mathrm{~m}$ (MSL) and a maximum elevation of $6 \mathrm{~m}$ (MSL) at the southern extremity. A 3-m high levee has been constructed around most of the island. The river is more than $3 \mathrm{~km}$ wide at the site and the area immediately surrounding the site consists almost entirely of the tidal marshes and grasslands with a maximum rise of $5 \mathrm{~m}$ in the first $5 \mathrm{~km}$ inland from the river.

\section{ON-SITE WIND MEASUREMENTS:}

A 95-m tower at $3 \mathrm{~m}$ (MSL) is instrumented with Bendix-Friez Aerovanes at $9 \mathrm{~m}, 46 \mathrm{~m}$, and $91 \mathrm{~m}$ (AGL). The $46-\mathrm{m}$ level is used only intermittently.

$\overline{\text { NRC Docket Nos. 50-354/50-272, 50-311 }}$ 


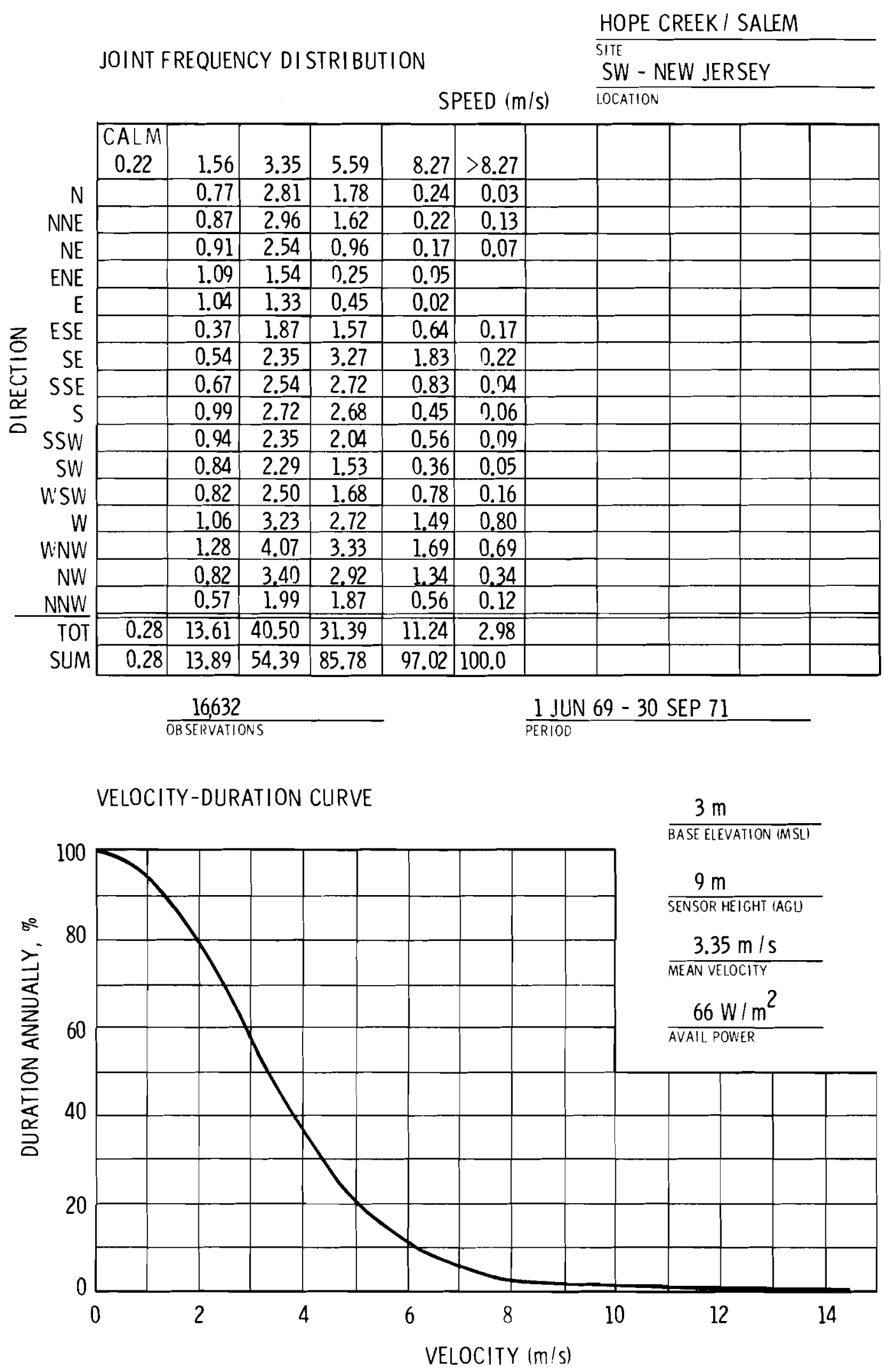




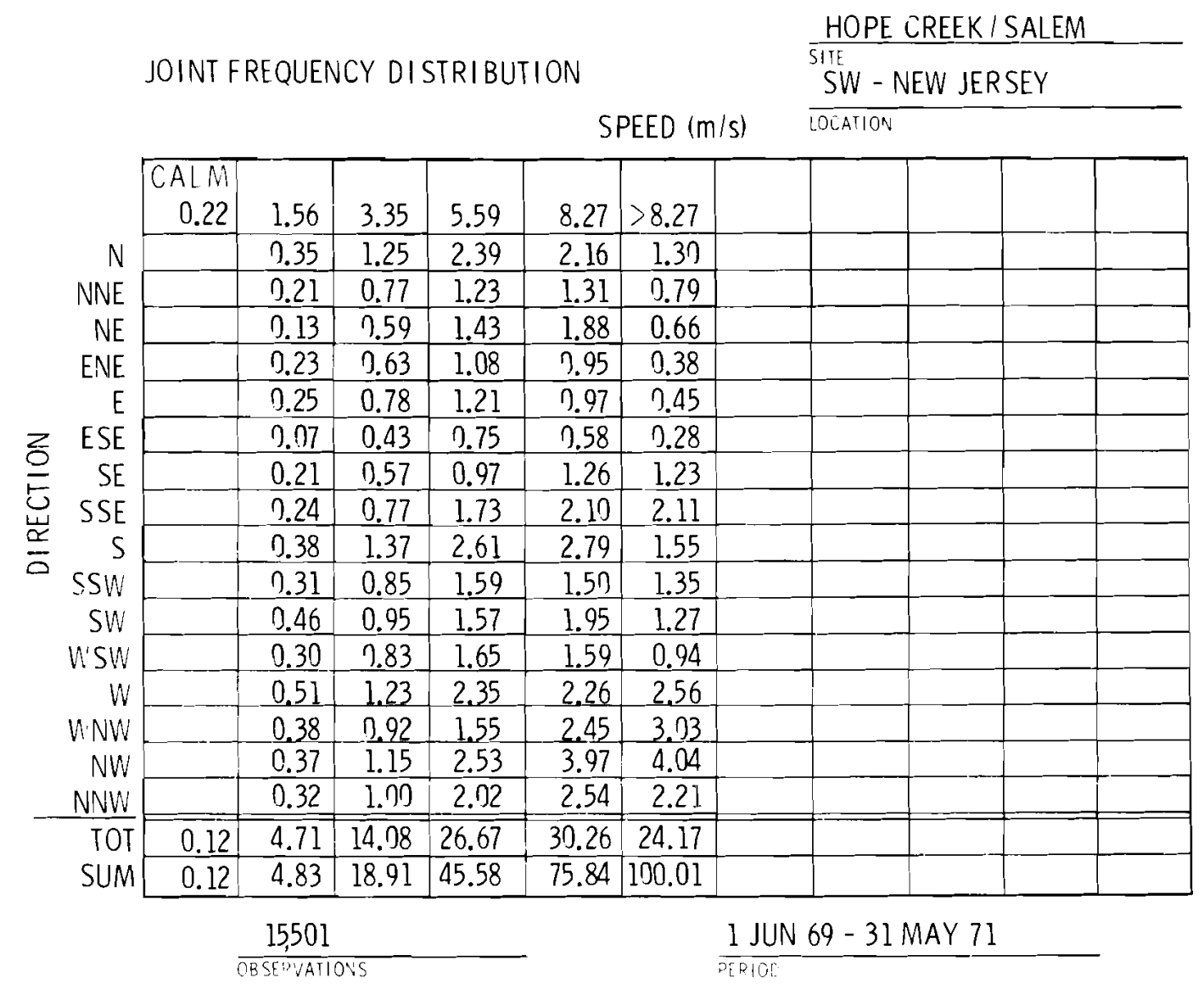

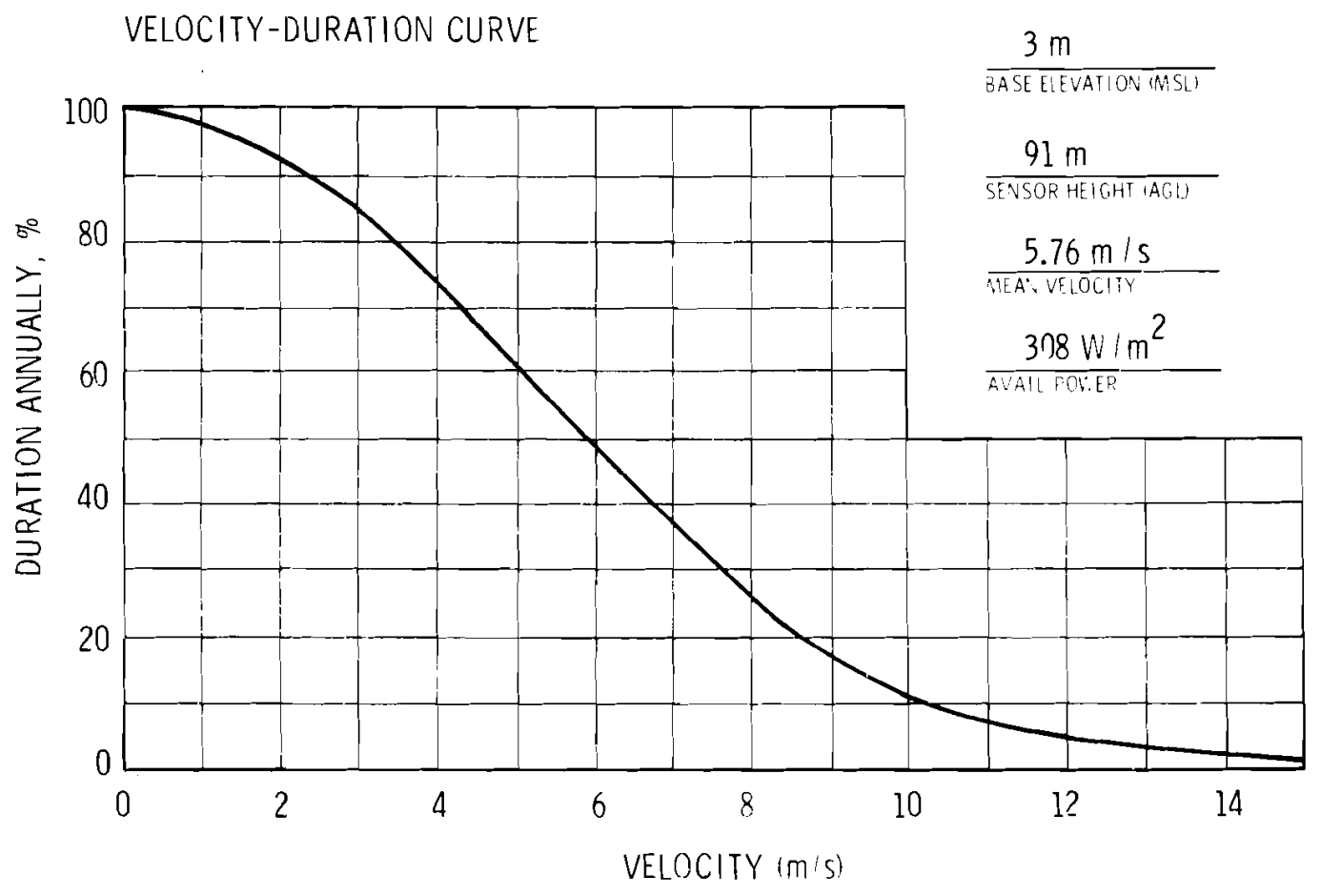


HUMBOLDT BAY

\section{SITE LOCATION:}

The Humboldt Bay site $\left(40.73^{\circ} \mathrm{N} / 124.22^{\circ} \mathrm{W}\right)$ is $6 \mathrm{~km} \mathrm{sw}$ of Eureka, California, in Humboldt County. The location is about $140 \mathrm{~km} \mathrm{~S}$ of the Oregon-California border and $395 \mathrm{~km}$ NNW of San Francisco.

\section{TOPOGRAPHY :}

The terrain of Humboldt County is mostly mountainous with rather narrow coastal plains in the Eureka region and narrow river valleys extending inland. The mountains are quite rugged with several peaks just over $1800 \mathrm{~m}$ (MSL) and result in very limited access to the interior of the county, except along the major river valleys. The mountains are heavily forested with Douglas fir and redwood, as are some of the river valleys inland. The coastal plains are covered mostly with short grass. The topography in the immediate vicinity of the site is relatively flat but gives way quickly to low wooded rolling hills, $60 \mathrm{~m}$ to $120 \mathrm{~m}$ high. The terrain continues to slope upward until a ridge, $600 \mathrm{~m}$ to $900 \mathrm{~m}$ (MSL) is reached about $20 \mathrm{~km} E$ of the site. This ridge extends in a semicircle from a point $30 \mathrm{~km} \mathrm{~N}$ of Eureka to a point $40 \mathrm{~km}$ south.

ON-SITE WIND MEASUREMENTS:

The wind data collection system consists of Beckman and Whitley wind sensors installed at the top of a 76-m tower.

$\widehat{\text { NRC Docket No. } 50-1 \overline{33}}$ 


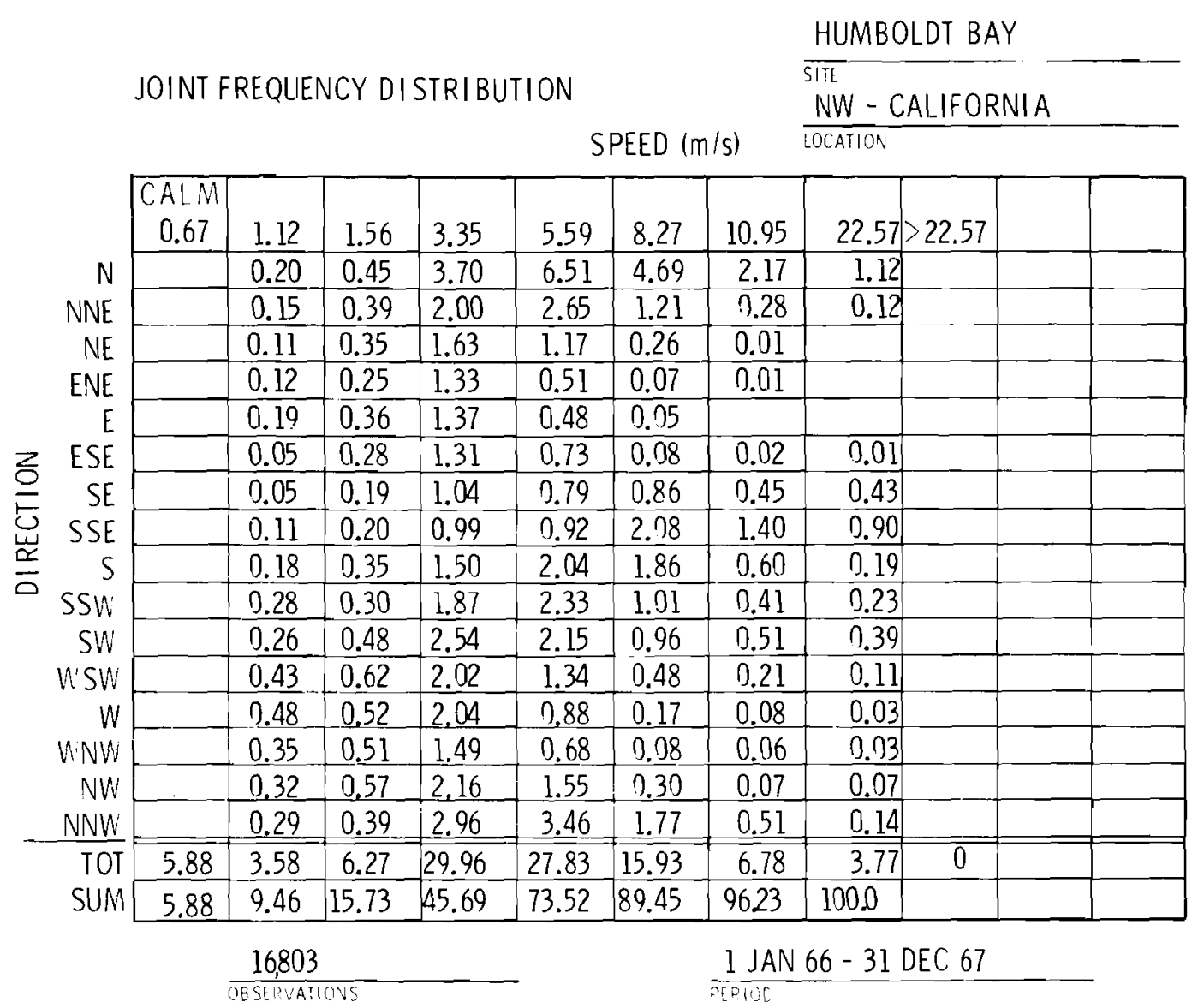

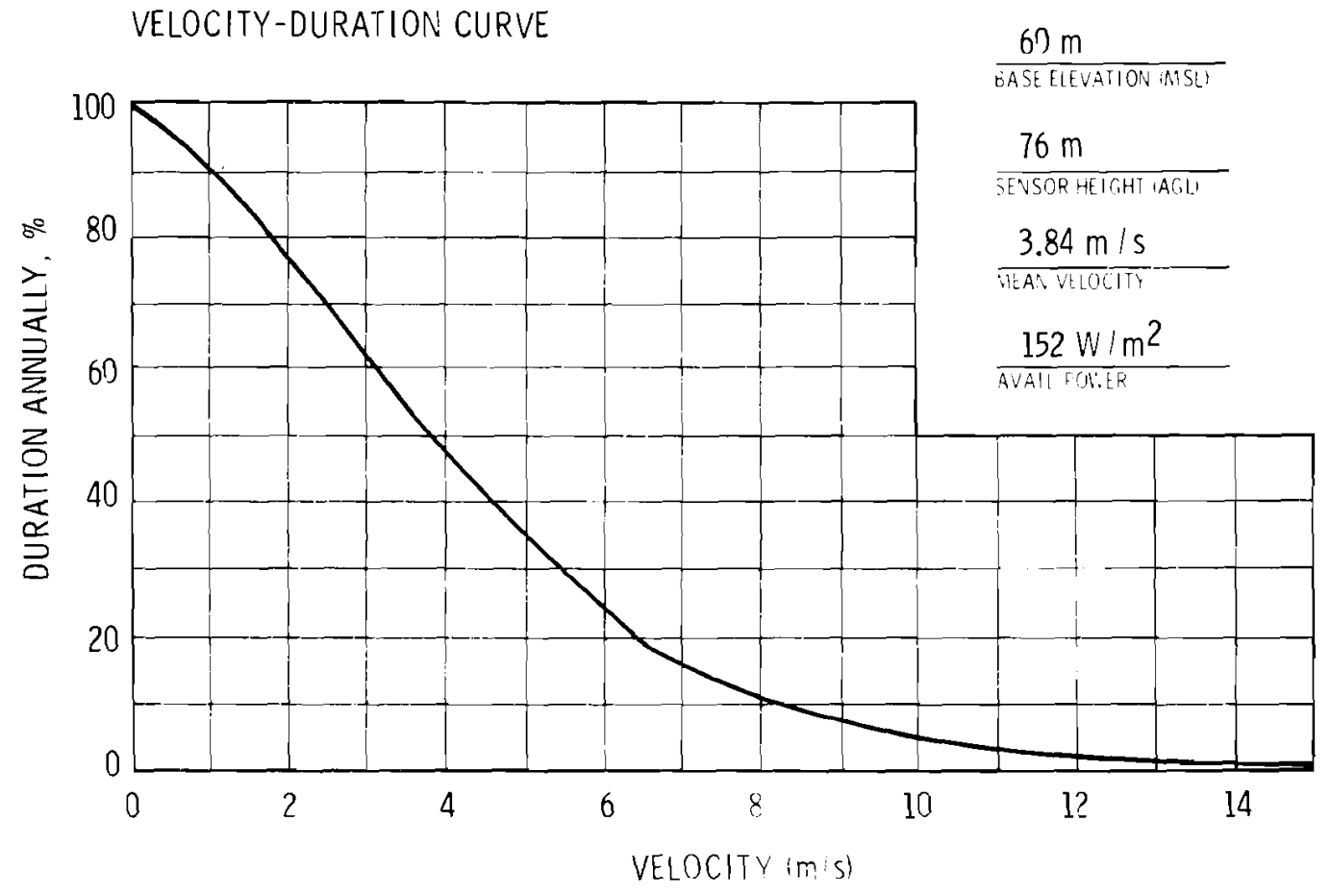


INDIAN POINT

SITE LOCATION:

The Indian Point site $\left(41.25^{\circ} \mathrm{N} / 73.95^{\circ} \mathrm{W}\right)$ is on the east bank of the Hudson River, in the town of Buchanan, Westchester County, New York. This location is $4 \mathrm{~km} \mathrm{SW}$ of Peekskill and about 50 $\mathrm{km}$ upriver from New York City.

TOPOGRAPHY :

The site meteorology is influenced by its location in the Hudson River valley. The valley here is rather deep in the rolling hills along the river and ridges above, all running in a north-south direction paralleling the river valley.

ON-SITE WIND MEASUREMENTS:

Wind data have been collected at Indian Point since 1955 during varying intervals. The two years of data presented here were collected during 1974 and 1975, using climet instruments on a 122-m tower, based at an elevation of approximately $37 \mathrm{~m}$ (MSL).

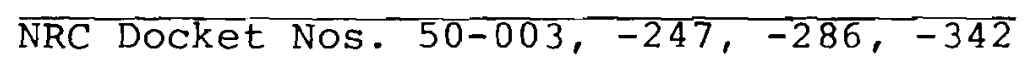




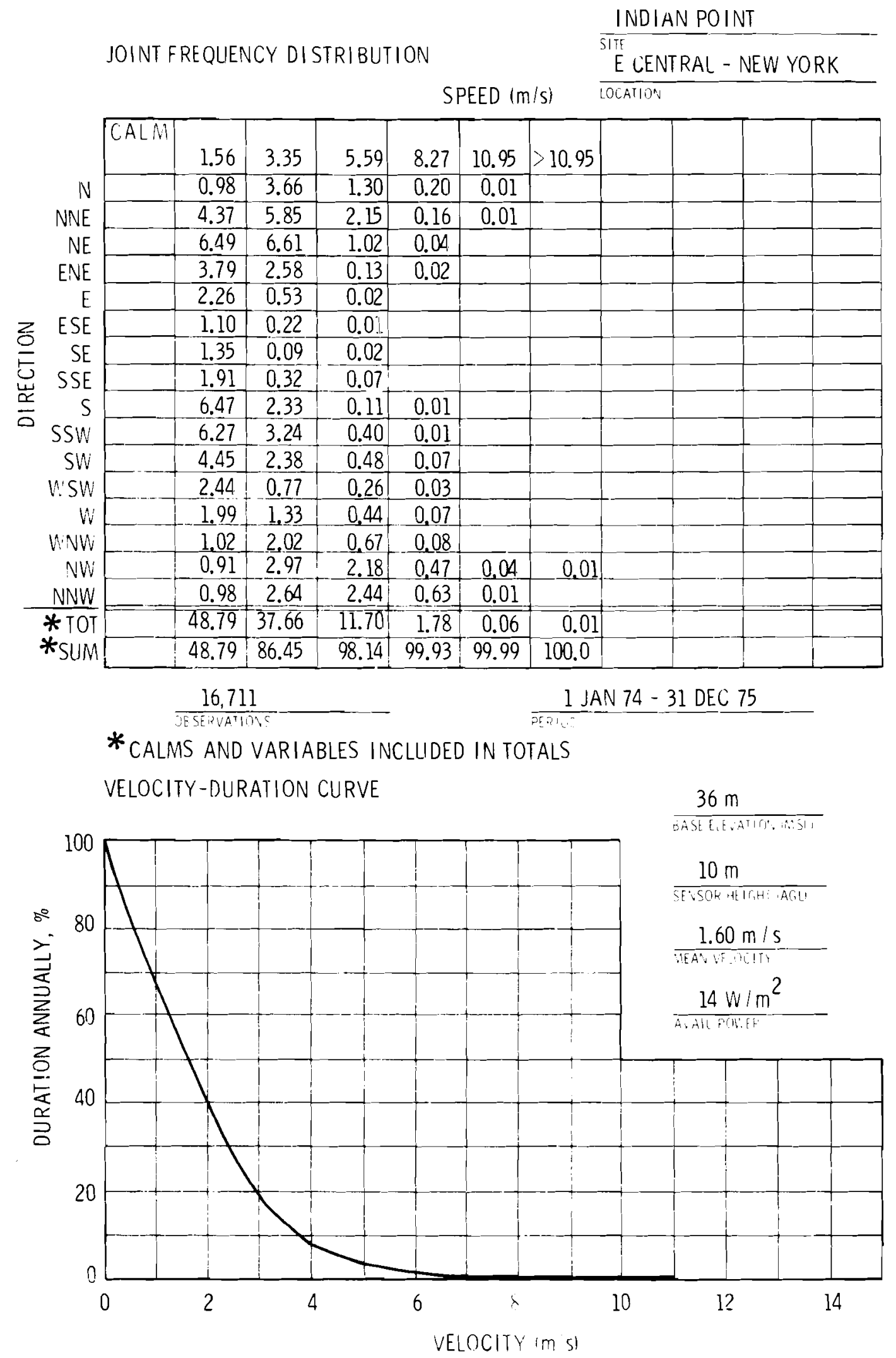


JOINT FREQUENCY DISTRIBUTION

INDIAN POINT

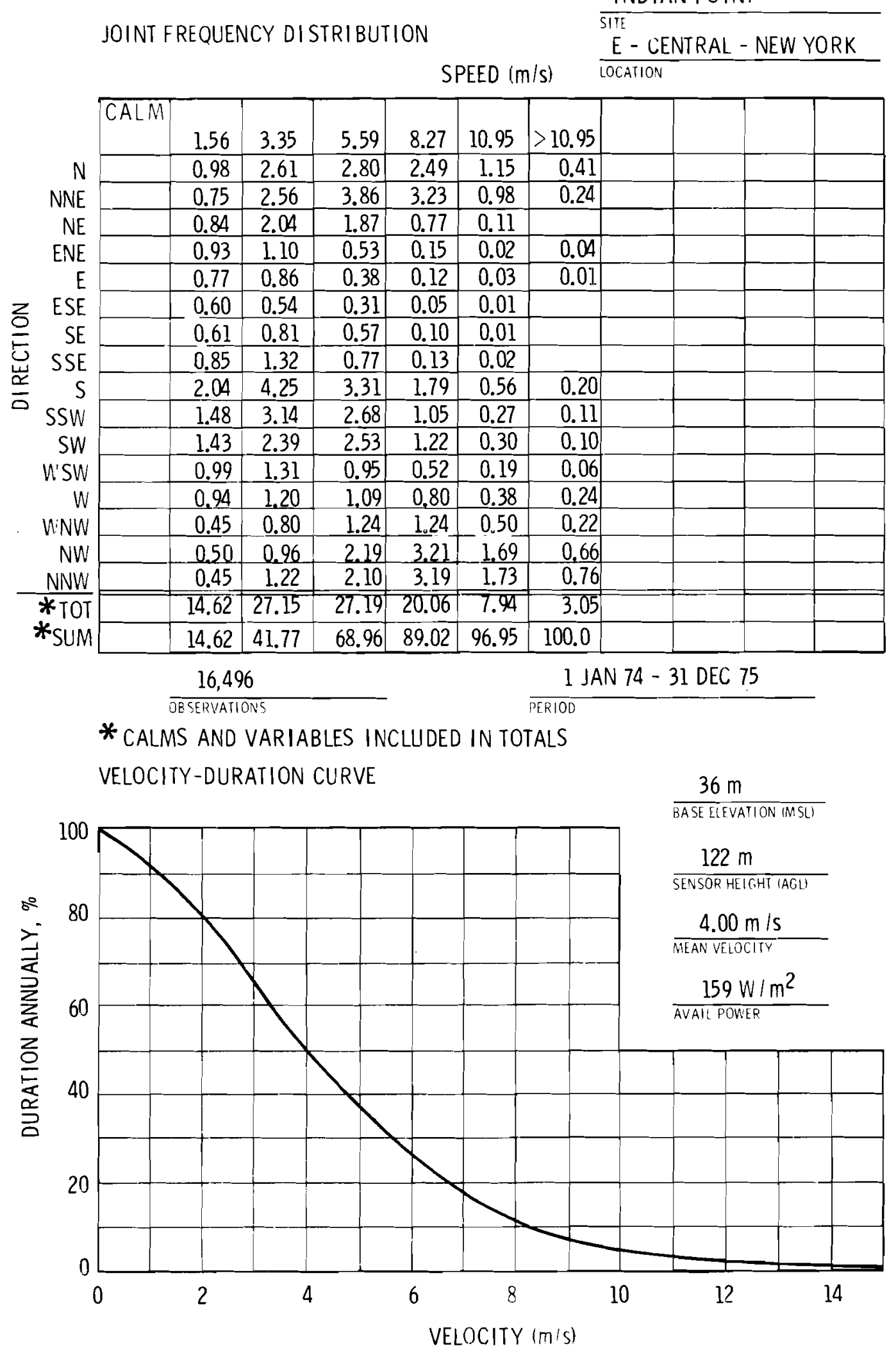


JAMESPORT

\section{SITE LOCATION:}

The 525 -acre site $\left(40.99^{\circ} \mathrm{N} / 72.59^{\circ} \mathrm{W}\right)$ is located on the north shore of Long Island, in the town of Riverhead, Suffolk County, New York. The site is about $10 \mathrm{~km} \mathrm{NE}$ of Riverhead and about $105 \mathrm{Km} \mathrm{E}$ of New York City.

TOPOGRAPHY :

The terrain in this section of Long Island is generally flat. At the northern site boundary, the elevation drops off abruptly from $25 \mathrm{~m}$ to $30 \mathrm{~m}$ (MSL) down to sea level at Long Island Sound.

ON-SITE WIND MEASUREMENTS:

The meteorological monitoring program began on 19 sep 1973 . A 122-m tower is instrumented with Climatronics F460 wind sets (3-cup anemometers and vanes) at $10 \mathrm{~m}, 61 \mathrm{~m}$ and $122 \mathrm{~m}$. $\overline{\text { NRC Docket No. } 50-516}$ 

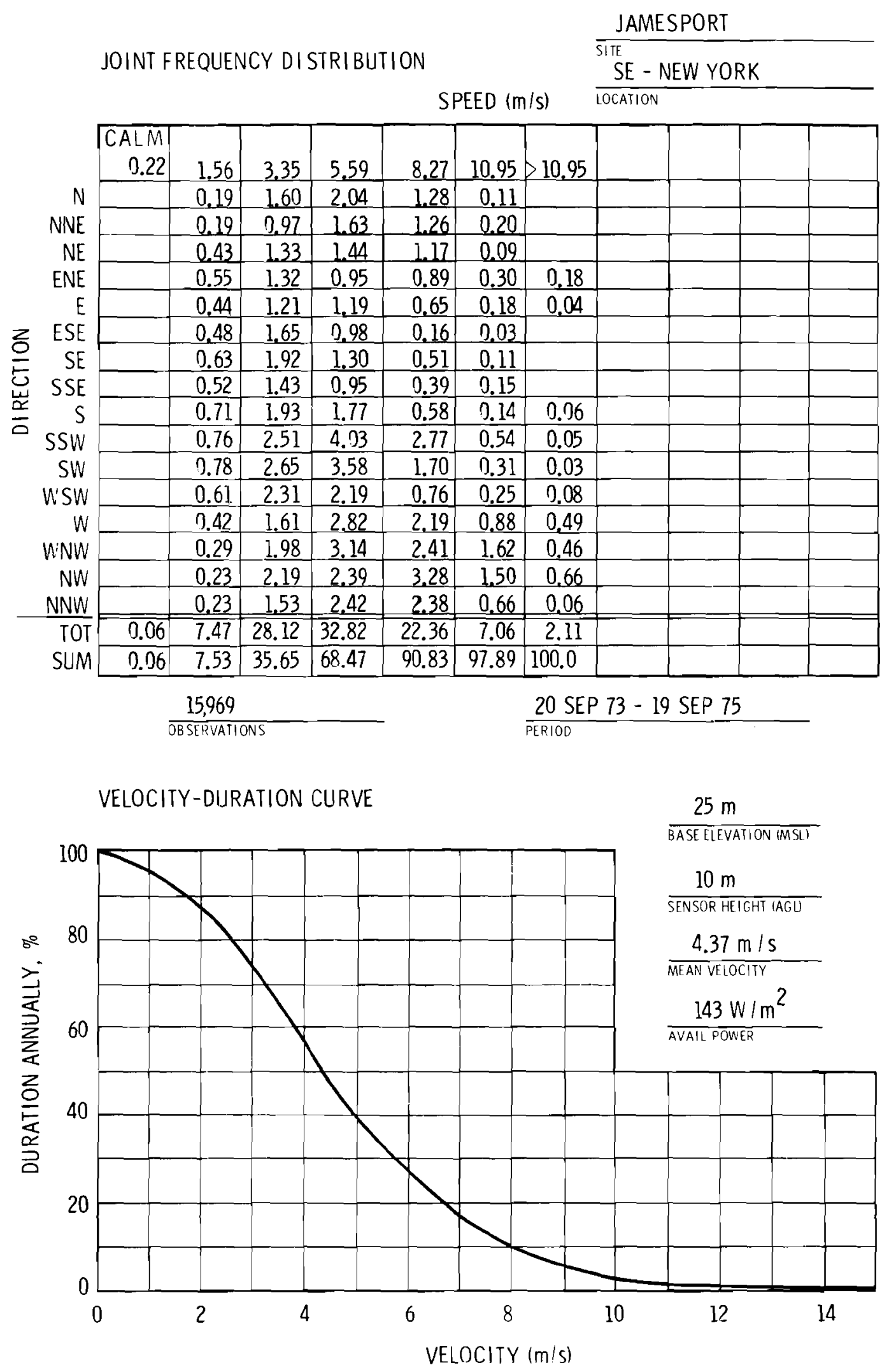


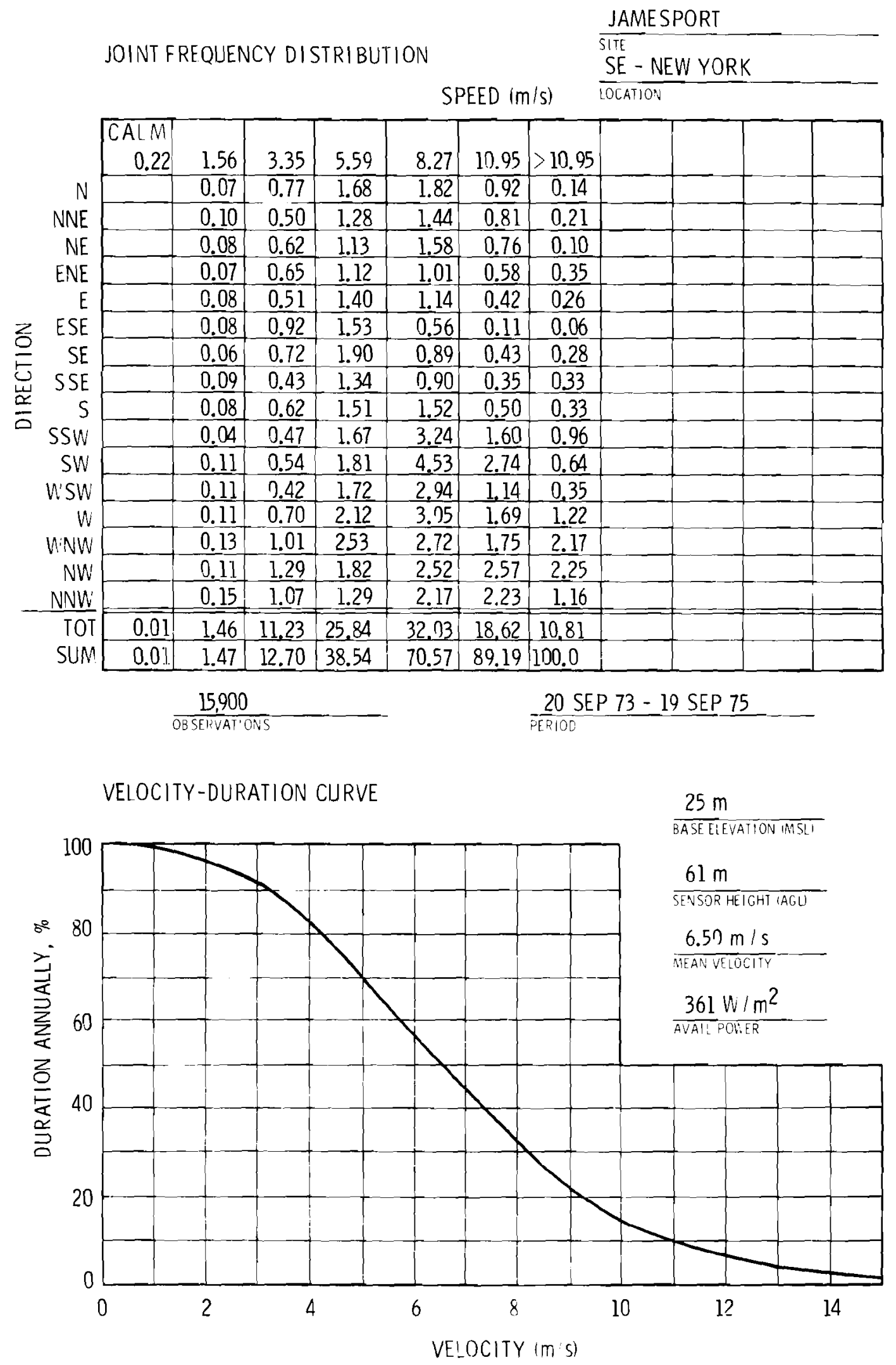



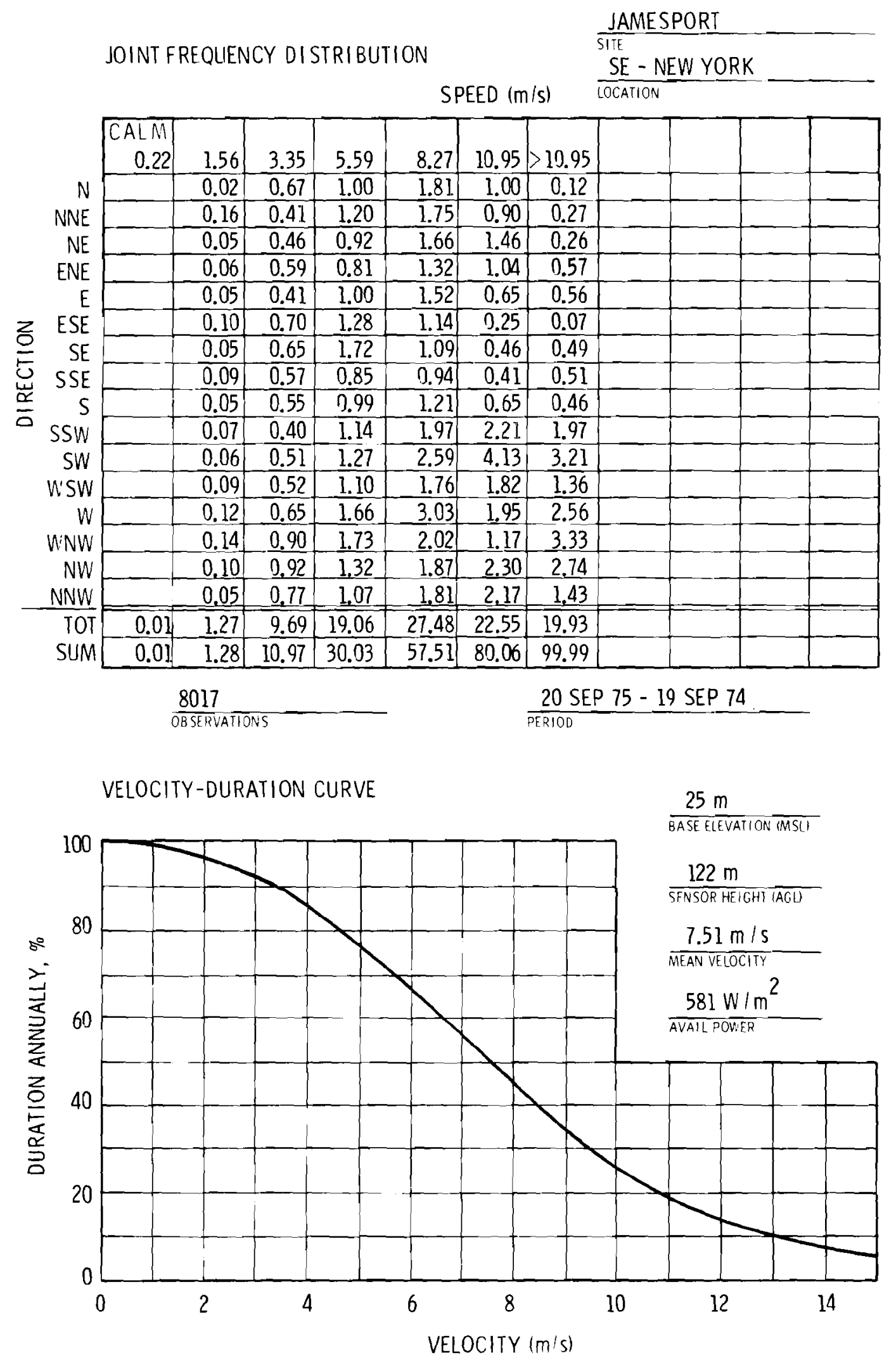
KEWAUNEE

\section{SITE LOCATION:}

The site $\left(44.34^{\circ} \mathrm{N} / 87.54^{\circ} \mathrm{W}\right)$ is in the township of Carlton in the southeast corner of Kewaunee County, Wisconsin, on the west shore of Lake Michigan. The location is about $43 \mathrm{~km}$ ESE of Green Bay and about $145 \mathrm{~km}$ NNE of Milwaukee.

\section{TOPOGRAPHY:}

The terrain around the site is gently rolling to flat, with elevations varying from $3 \mathrm{~m}$ to $30 \mathrm{~m}$ above the level of Lake Michigan (176 $\mathrm{m}$ (MSI)). The land surface slopes gradually toward the lake from the higher glacial moraine areas west of the site. At the northern and southern edges of the site, bluffs face Lake Michigan; near the center of the site, the land slopes to a sandy beach.

ON-SITE WIND MEASUREMENTS:

Wind data are collected from a 46-m tower, using a Belfort Type "M" wind transmitter.

NRC Docket No. $50-305$ 


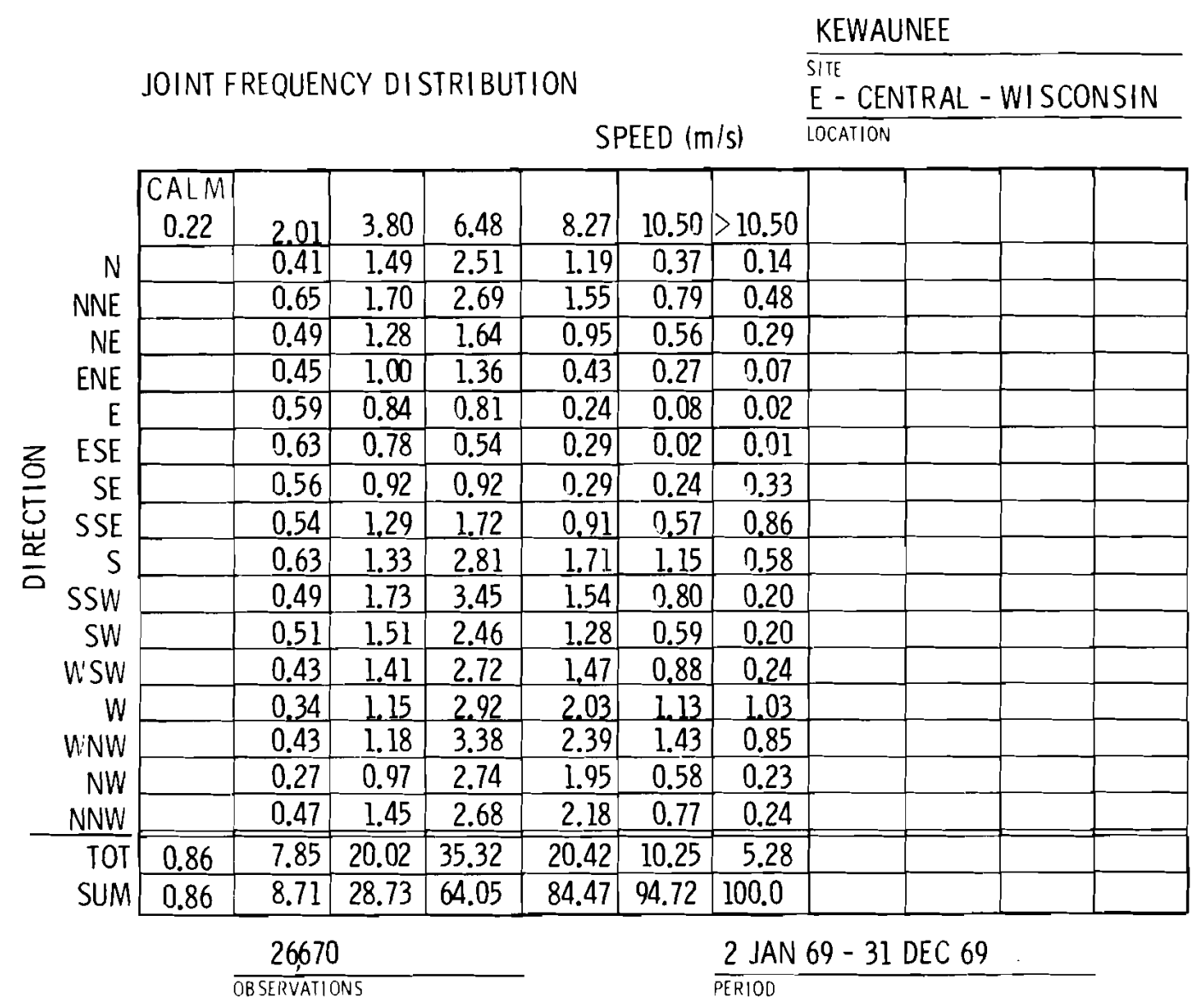

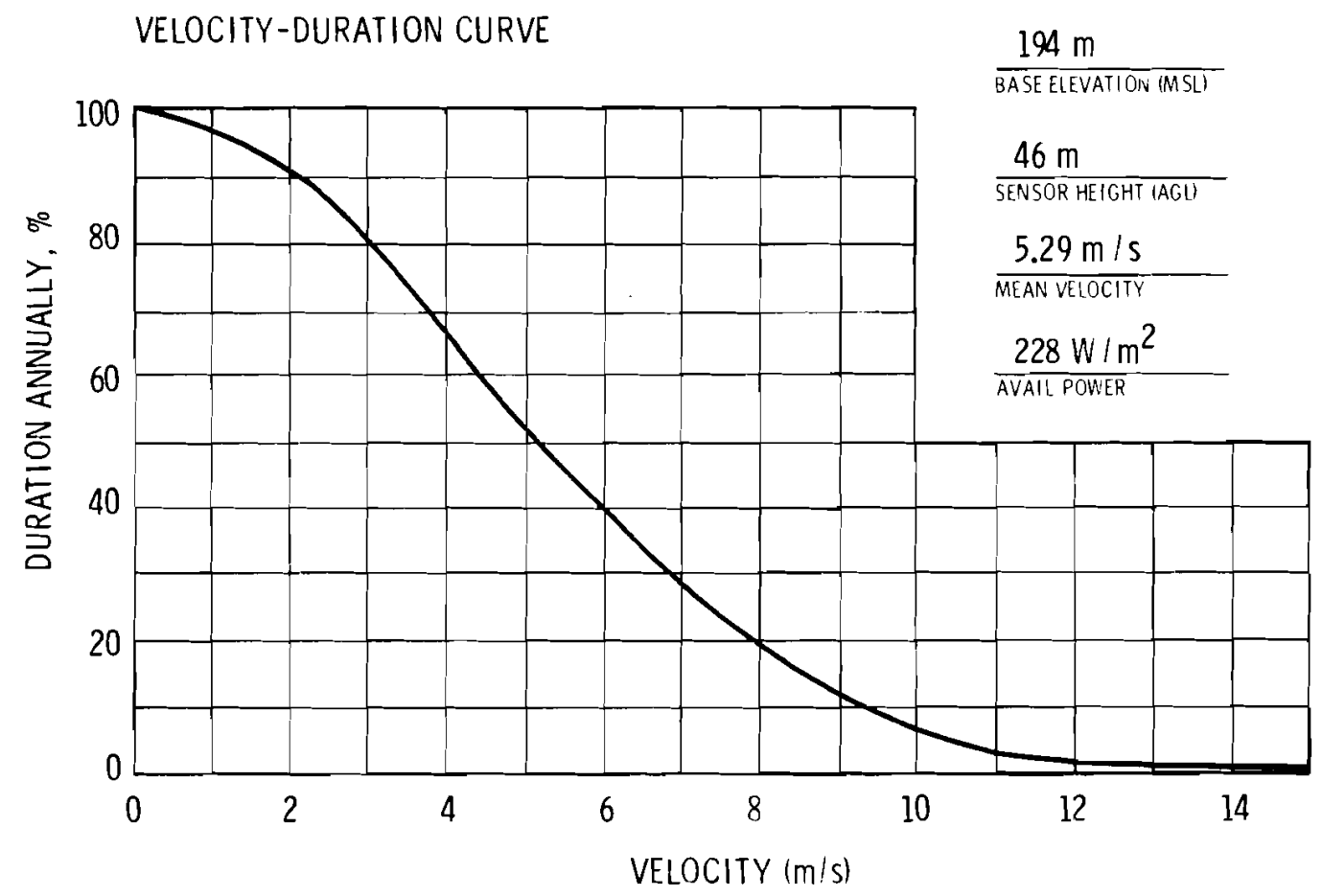


KOSHKONOING

SITE LOCATION:

The Koshkonong Nuclear Plant $\left(42.86^{\circ} \mathrm{N} / 88.89^{\circ} \mathrm{W}\right)$ is located in SW Jefferson County, Wisconsin, about $10 \mathrm{~km} \mathrm{SSW} \mathrm{of}$ Fort Atkinson and $84 \mathrm{KM}$ SW of Milwaukee.

\section{TOPOGRAPHY :}

The location of the site in SE Wisconsin can be characterized as relatively smooth with some small rolling hills. Terrain relief within $8 \mathrm{~km}$ of the site ranges from $240 \mathrm{~m}$ to $295 \mathrm{~m}$ (MSL). Plant grade is at about $260 \mathrm{~m}$ (MSL). Lake Koshkonong is located about $2 \mathrm{~km} E$ of the site and has an areal dimension of 10,893 acres and an average depth of $1.5 \mathrm{~m}$.

ON-SITE WIND MEASUREMENTS:

On-site wind data have been collected since 19 July 1973. A 61-m tower is equipped with Climet wS-011-1 (speed) and Climet WD-012-10 (direction) sensors at the 10-m and 60-m levels.

$\overline{\text { NRC Docket } 50-502}$ 


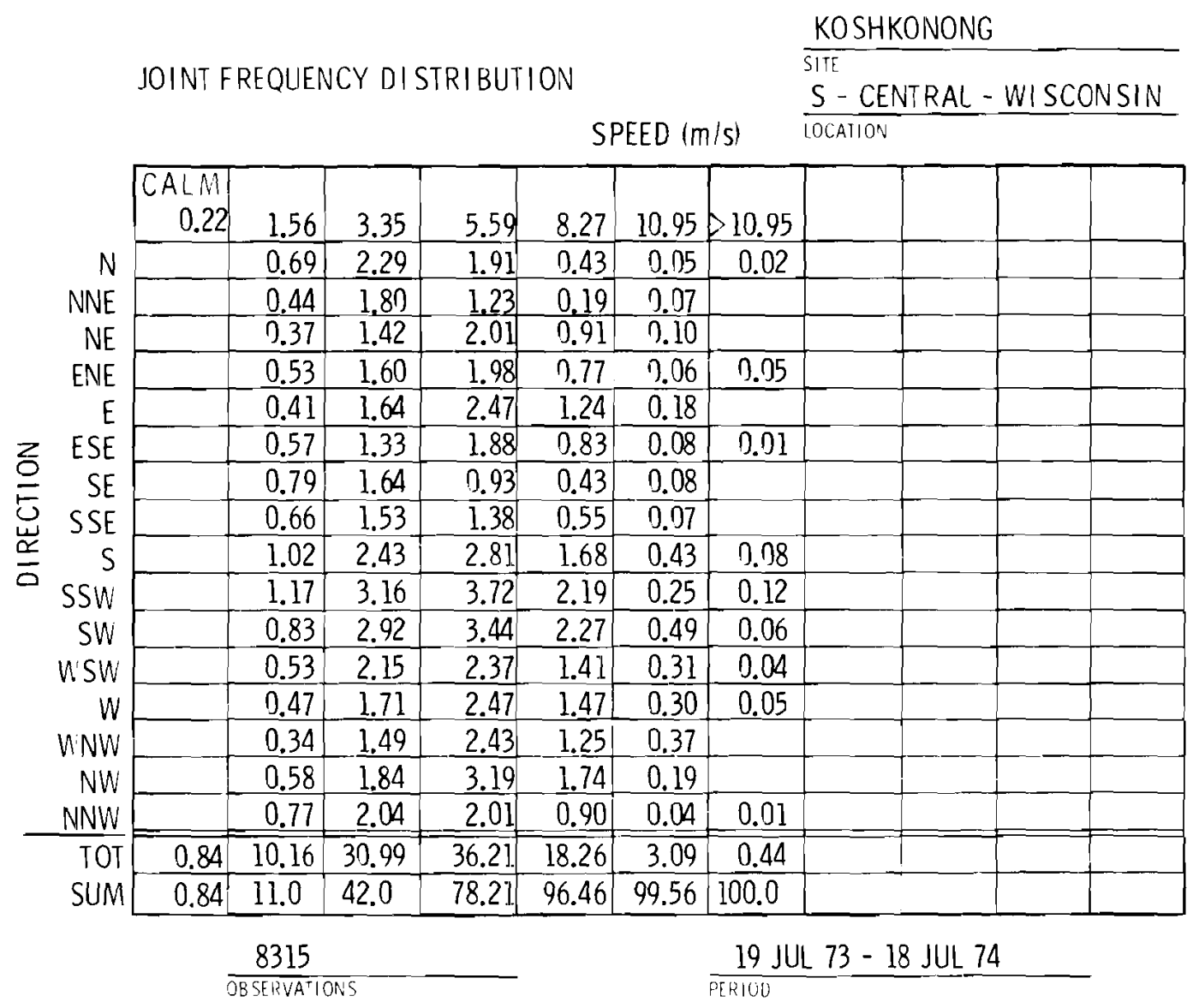

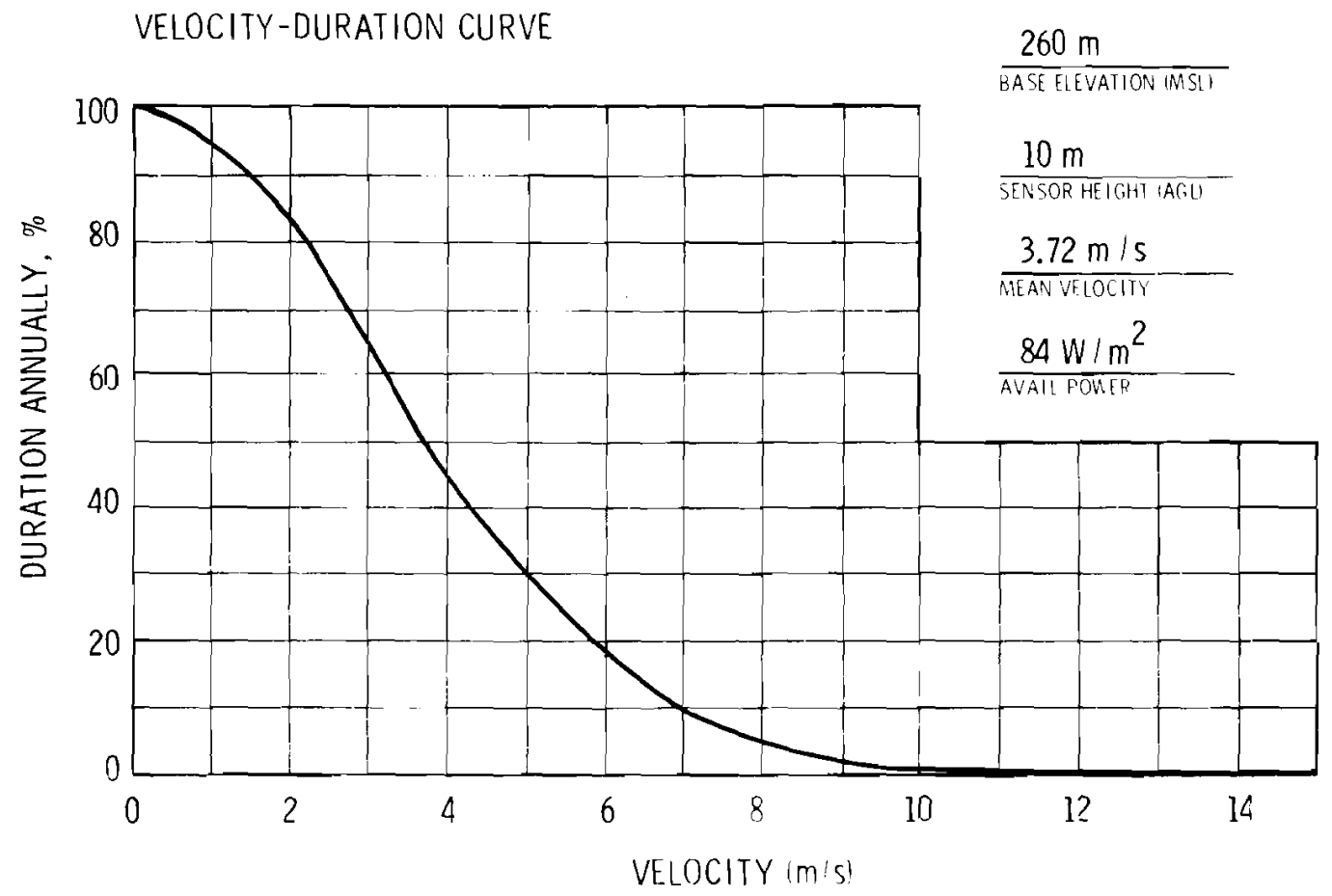




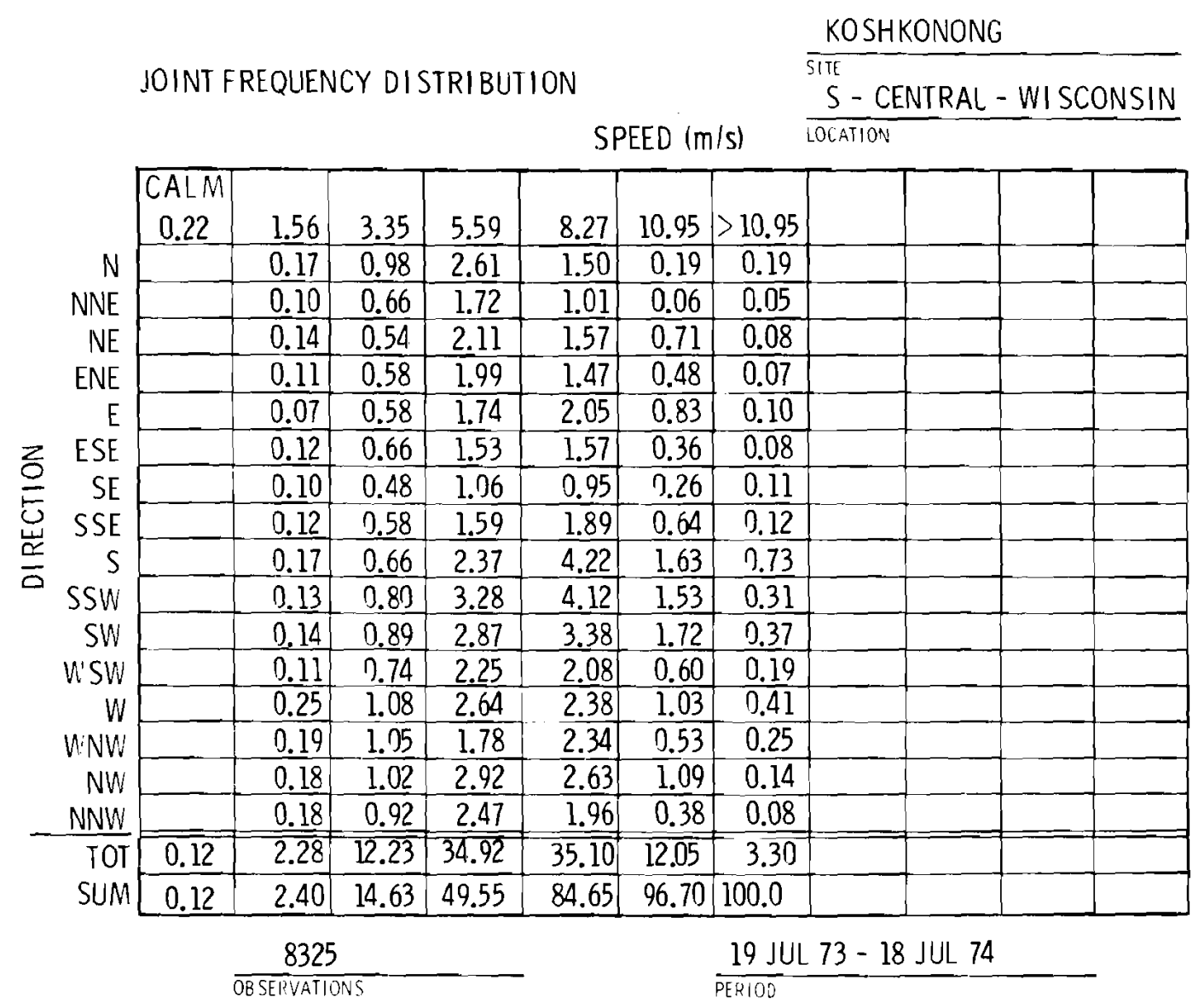

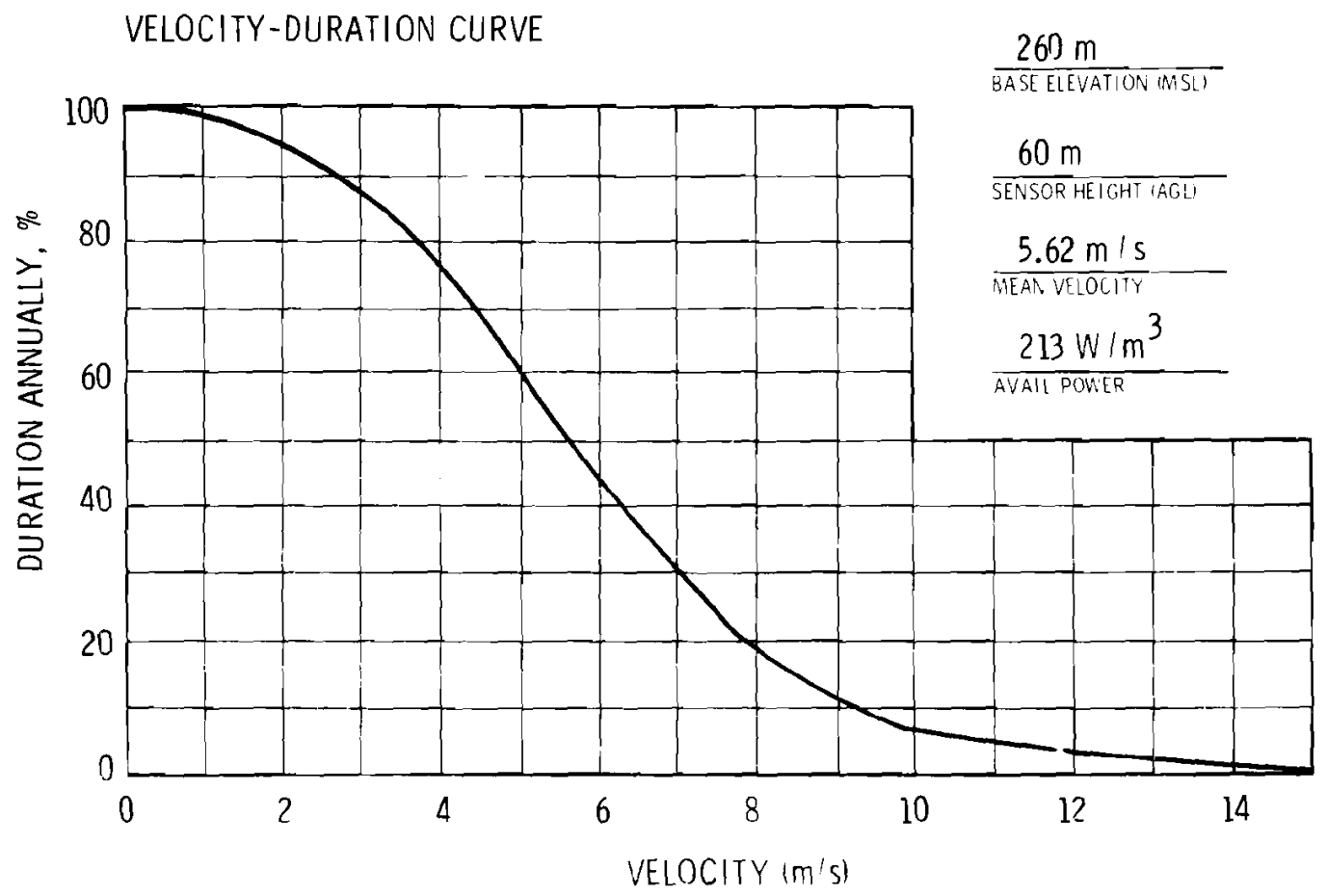


LA CROSSE

\section{SITE LOCATION:}

The La Crosse Boiling water Reactor site $\left(43.54^{\circ} \mathrm{N} / 91.21^{\circ} \mathrm{W}\right)$ is located on the east bank of the Mississippi River in SE Wisconsin. The site is in Vernon county, about $1 \mathrm{~km} \mathrm{~s}$ of Genoa, $27 \mathrm{~km} \mathrm{~S}$ of La Crosse and $160 \mathrm{~km} \mathrm{NW}$ of Madison.

\section{TOPOGRAPHY :}

The valley of the Mississippi River in this area is cut deeply into highly dissected upland. North and south of the site, from La Crosse to Lansing, IA, the valley is relatively straight, almost due N-S, and ranges in width from $4 \mathrm{~km}$ to 7 $\mathrm{km}$. The valley walls rise sharply to the upland, $150 \mathrm{~m}$ to $180 \mathrm{~m}$ above the river $(189 \mathrm{~m}$ (MSL)). The action of tributary streams has cut the walls into a series of distinct bluffs, looming above the highways on either side of the river. Beyond the bluffs, tributary streams have cut numerous short, steepwalled valleys, known as coulees, into the gently rolling upland surface. The upland areas, as well as the more level coulee floors are cultivated and grazed. A few kilometers north of the plant, the Mississippi River presents an almost unbroken expanse of water, some $4 \mathrm{~km}$ wide. At the plant site, however, the river's main channel is less than $200 \mathrm{~m}$ wide. The rest of the valley floor is mostly marshy islands and lowlying bottomland cut by a maze of side channels, sloughs, ponds and backwaters.

ON-SITE WIND MEASUREMENTS:

Wind measurements are made from the top of a 30-m radio tower located on a bluff about $3 \mathrm{~km}$ ESE of the plant site. Grade elevation of the tower is $366 \mathrm{~m}$ (MSL), while the reactor site is at $195 \mathrm{~m}$ (MSL). Instrumentation was an MRI Mociel 1074-22 anemometer and vane. 


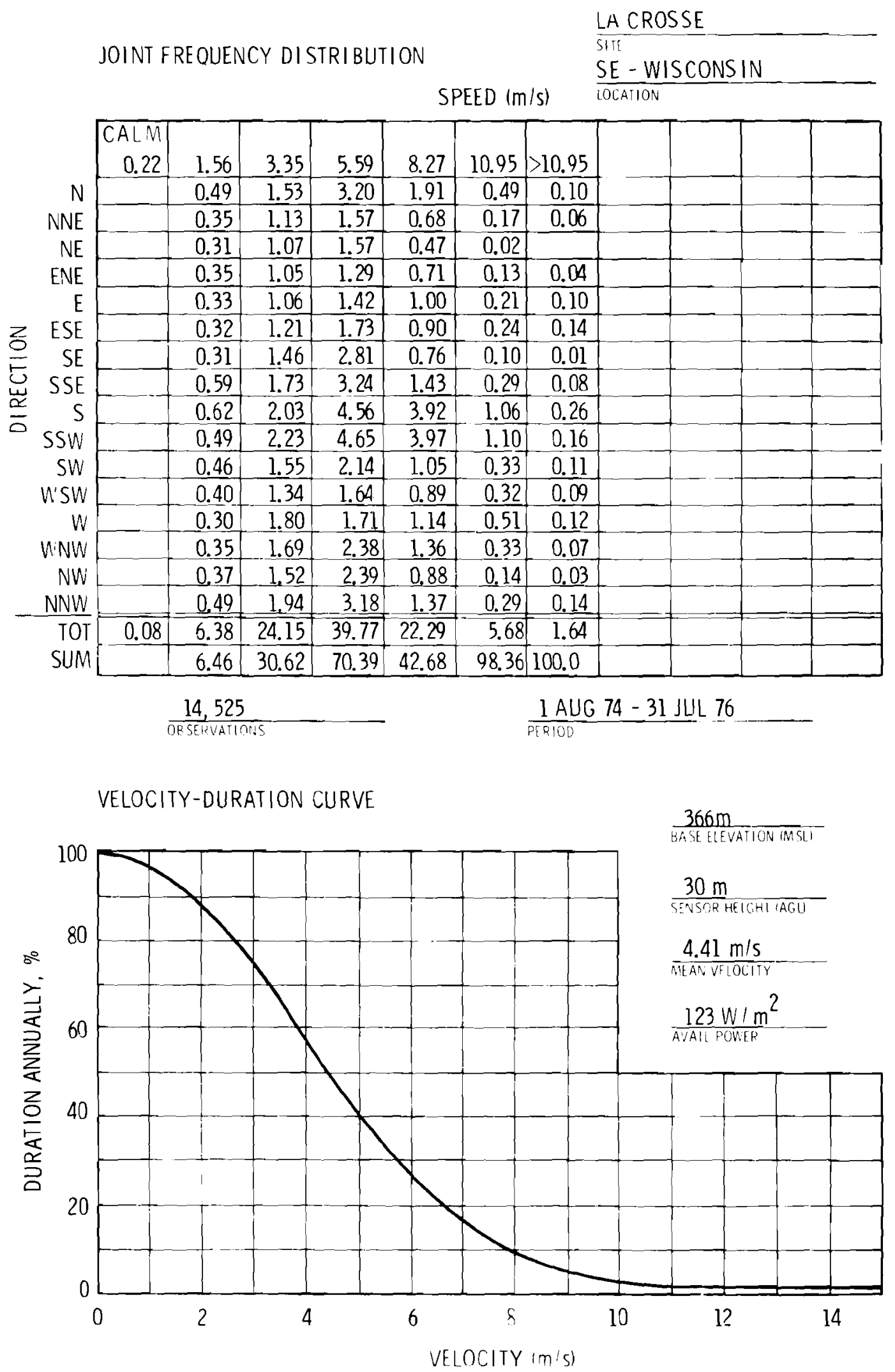




\section{SITE LOCATION:}

The Lasalle site $\left(41.23^{\circ} \mathrm{N} / 88.65^{\circ} \mathrm{W}\right)$ is in the $\mathrm{SE}$ corner of LaSalle County, Illinois, about $18 \mathrm{~km} \mathrm{SE}$ of ottawa, $18 \mathrm{~km} \mathrm{NE}$ of Streator, and $8 \mathrm{~km}$ from both Seneca and Marseilles. Peoria is $97 \mathrm{~km} \mathrm{SW}$, Joliet is $64 \mathrm{~km} \mathrm{NE}$ and the Dresden site is $40 \mathrm{~km} \mathrm{NE}$.

TOPOGRAPHY :

The terrain is typical of northern Illinois, being flat to slightly rolling. Site elevation is $216 \mathrm{~m}$ (MSL).

ON-SITE WIND MEASUREMENTS:

A full year's data are not available yet.

NRC Docket No. $50-\overline{373}$ 
LIMERTCK

\section{SITE LOCATION:}

The Limerick Station $\left(41.08^{\circ} \mathrm{N} / 76.12^{\circ} \mathrm{W}\right)$ is located in SE Pennsylvania on the Schuylkill River about $3 \mathrm{~km} \mathrm{SE}$ of Pottstown and about $33 \mathrm{~km} \mathrm{NW}$ of Phildadelphia. The Schuylkill River runs through the site, separating the western portion which is in Chester county from the eastern portion, which is in Montgomery county.

\section{TOPOGRAPHY :}

The plant is located in gently rolling countryside, traversed by numerous valleys containing small creeks or streams which empty into the Schuylkill River. On the east bank of the schuylkill River, the terrain rises from just under $34 \mathrm{~m}$ (MSI) at the river to about $85 \mathrm{~m}$ to the $\mathrm{E}$, which is the highest point on the site. Two prallel streams, Possum Hollow Run and Brook Evans creek, cut through the site in wooded valleys running $S W$ into the Schuylkill River. Site grade is at $67 \mathrm{~m}$ (MSL) on the west bank of the schuylkill; the terrain is relatively flat, rising only about $15 \mathrm{~m}$ from the river to the western boundary. Within $8 \mathrm{~km}$ of the site, elevations are generally below $122 \mathrm{~m}$ (MSI) with six isolated hills over $150 \mathrm{~m}$ (MSL) (four to the $\mathrm{N}$, the highest about $171 \mathrm{~m}$ (MSL); one to the $\mathrm{W}$ at $157 \mathrm{~m} \mathrm{(MSL);} \mathrm{and} \mathrm{one}$ to the $\mathrm{SW}$ at $155 \mathrm{~m}$ (MSL)). Higher ground (between $150 \mathrm{~m}$ and 300 $m$ (MSL)) exists to the $N W$ and the $W$ between $8 \mathrm{~km}$ and $16 \mathrm{~km}$ to the $\mathrm{W}$, one hill reaches $305 \mathrm{~m}$ (MSL) and to the NW, four hills exceed $300 \mathrm{~m}$, the highest being $335 \mathrm{~m}$ (MSL).

ON-SITE WIND MEASUREMENTS:

There are three (3) on-site towers. The attached data are from the 86-m tower, based at $76 \mathrm{~m}$ (MSL). The tower is equipped with Bendix-Friez Aerovanes at $9 \mathrm{~m}, 46 \mathrm{~m}, 53, \mathrm{~m}$ and $82 \mathrm{~m}$ (AGL).

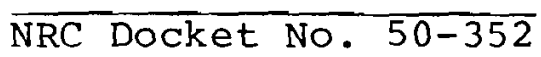




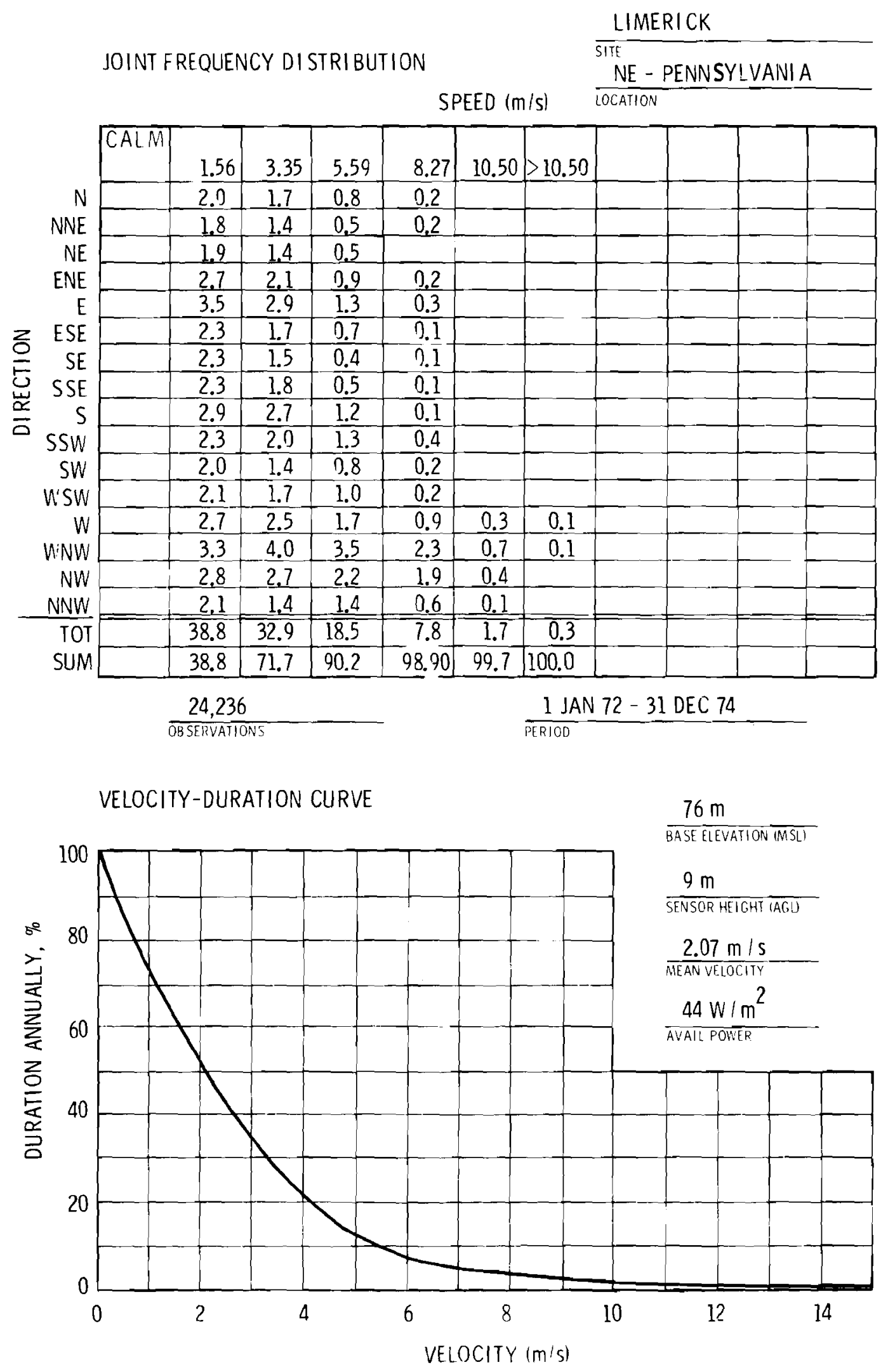



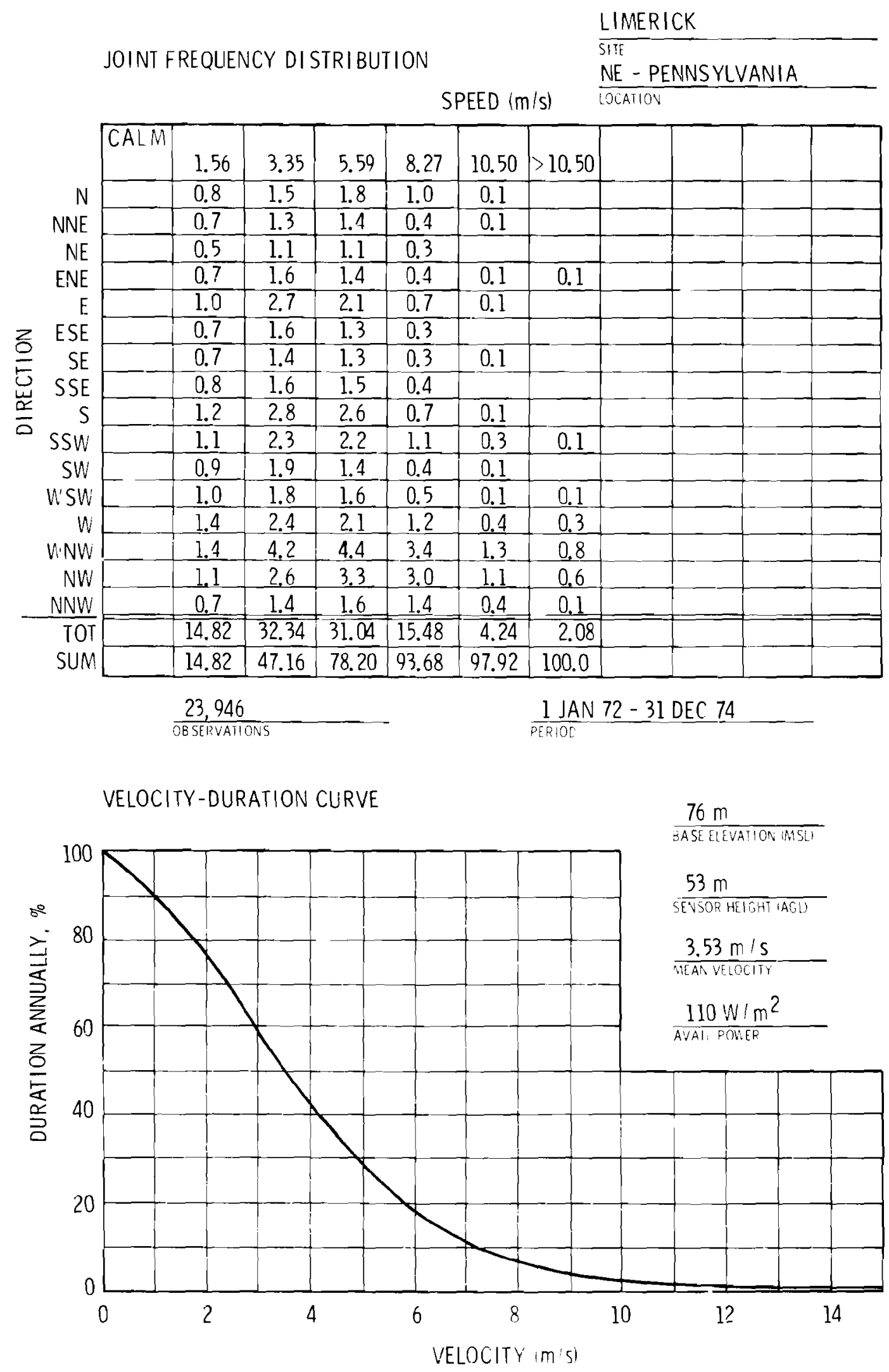


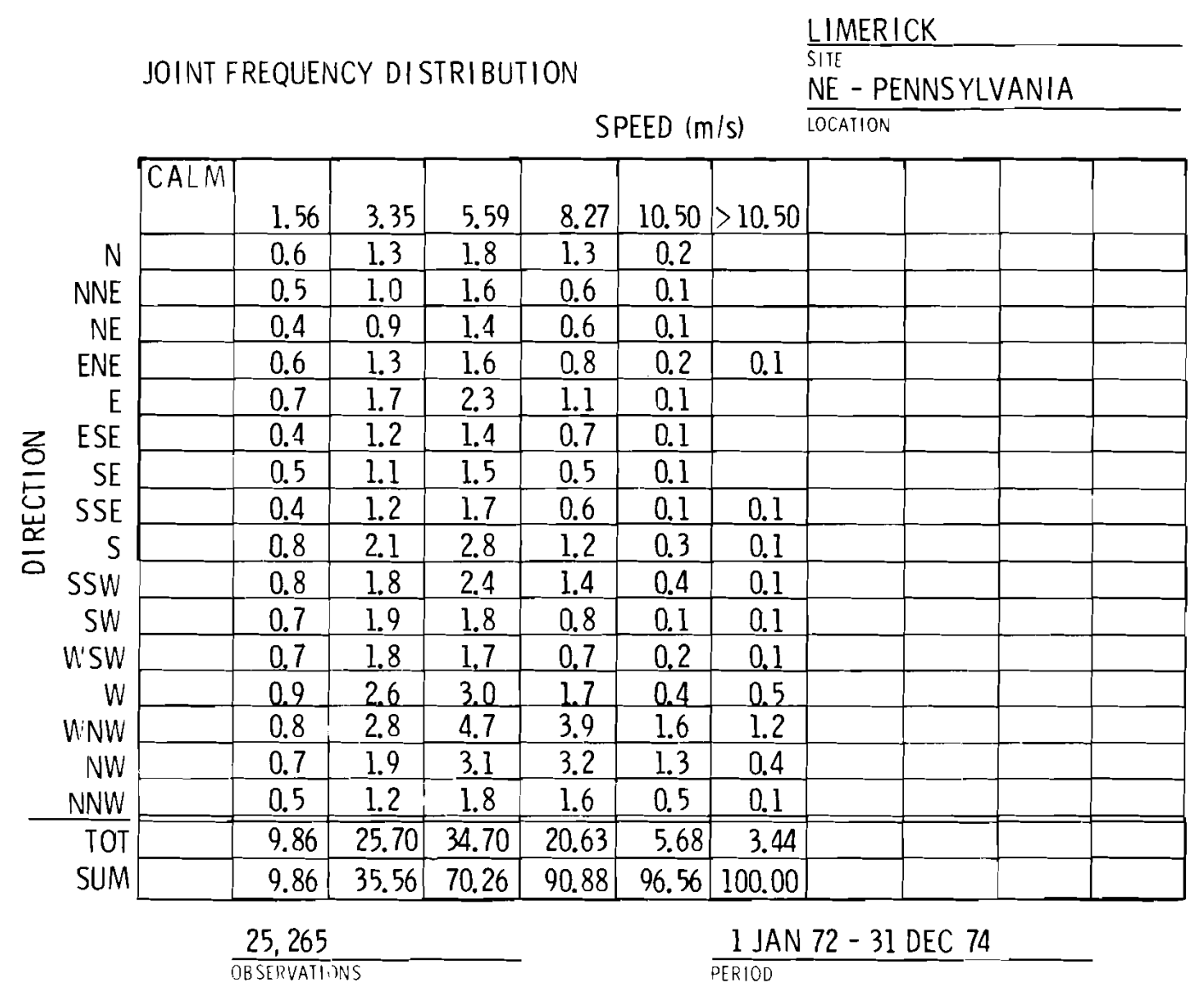

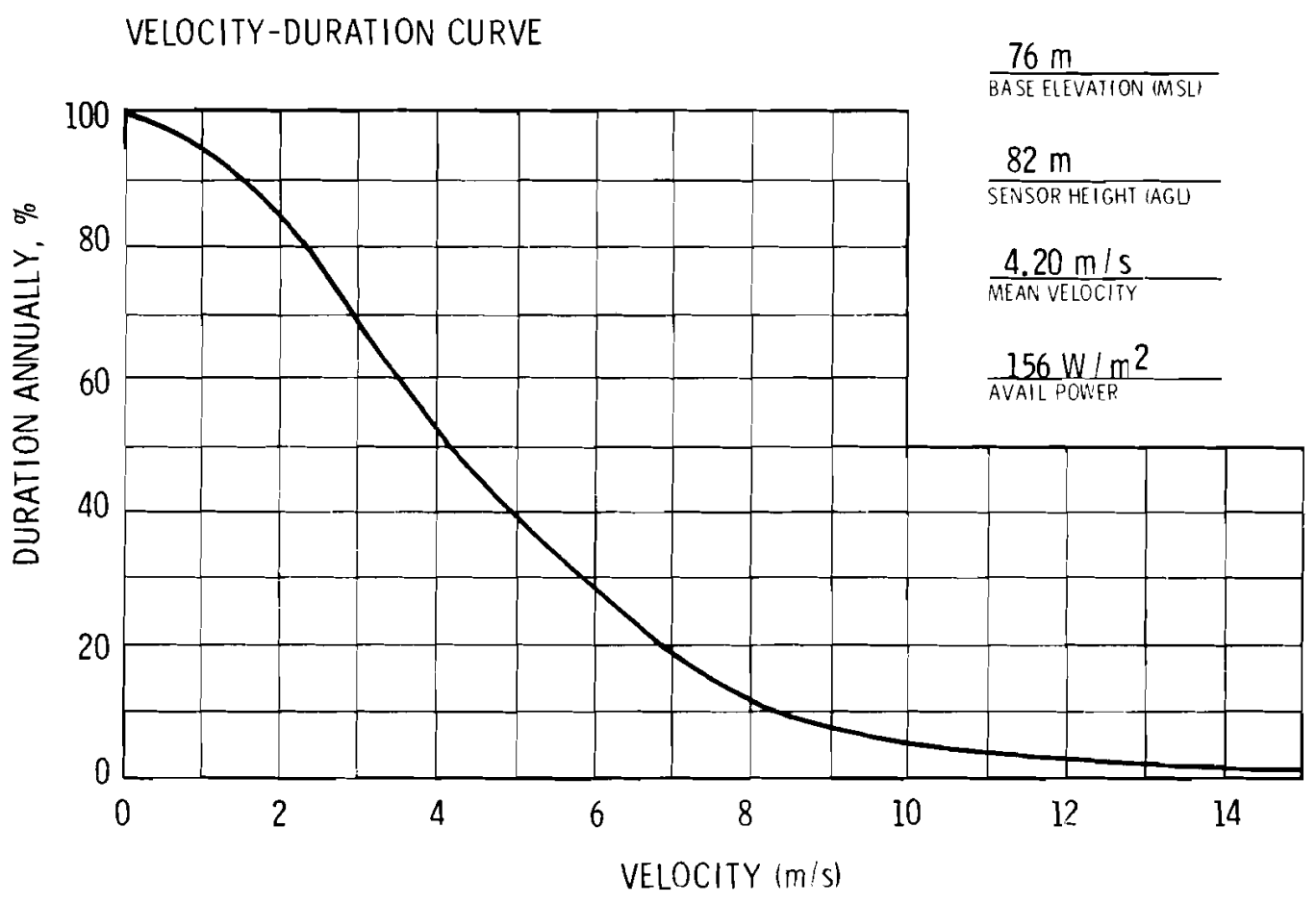


SITE LOCATION:

The Maine Yankee Atomic Power Station site $\left(43.95^{\circ} \mathrm{N} / 69.70^{\circ} \mathrm{W}\right)$ is located in the mid-coastal region of Maine, $16 \mathrm{~km} \mathrm{ENE}$ of Bath and $9 \mathrm{~km}$ SSE of Wiscasset, in Lincoln County.

TOPOGRAPHY :

The mid-coastal region of Maine is characterized by many inlets, bays, channels, harbors, rocky islands, and promontories. The area adjacent to the site also has many small forested hills. ON-SITE WIND MEASUREMENTS:

A 45-m tower was installed at approximately $14 \mathrm{~m}$ (MSL) elevation. Instrumentation consists of a recording Bendix-Friez "Aerovane" system at the top of the tower.

NRC Docket No. 50-309 


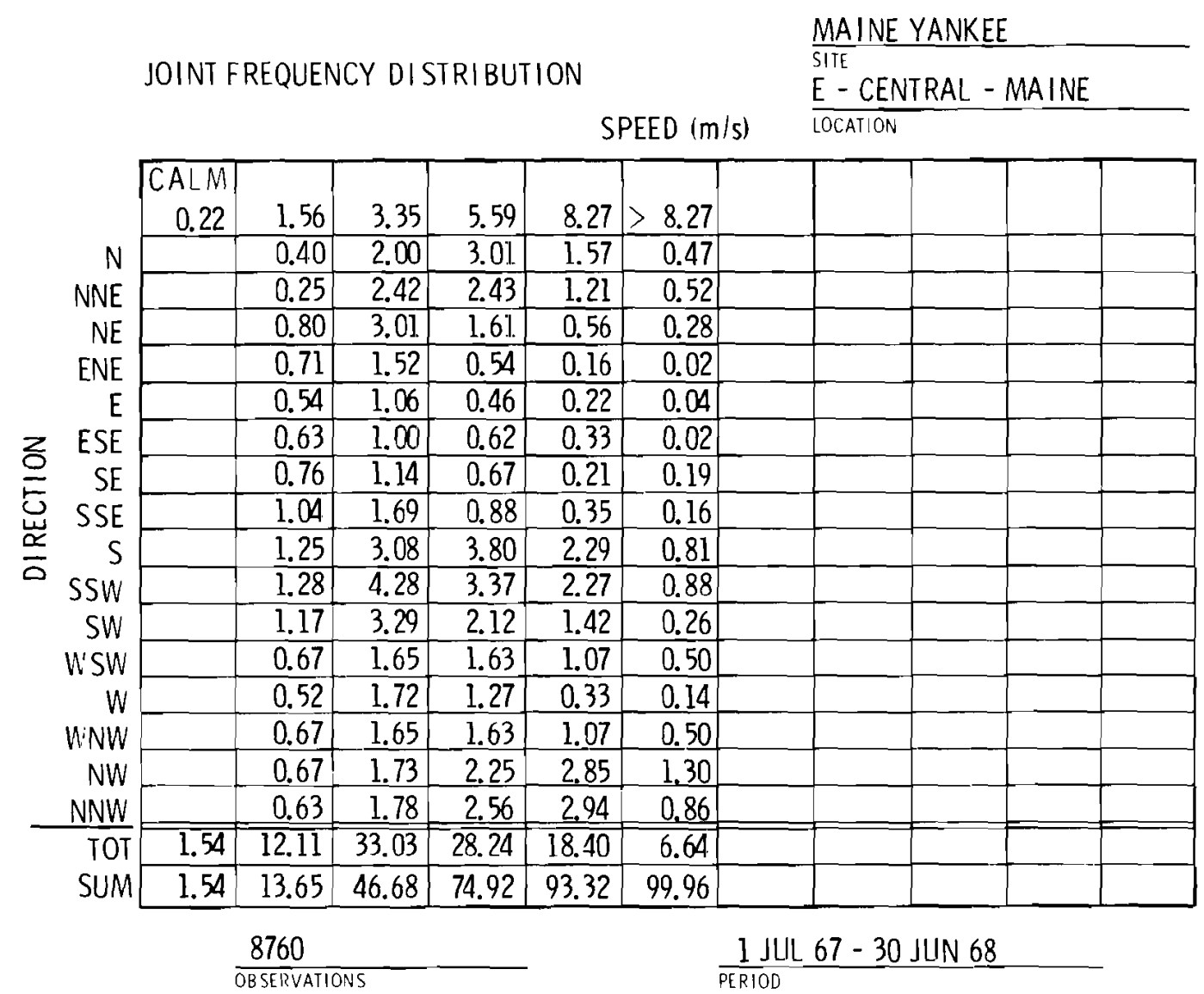

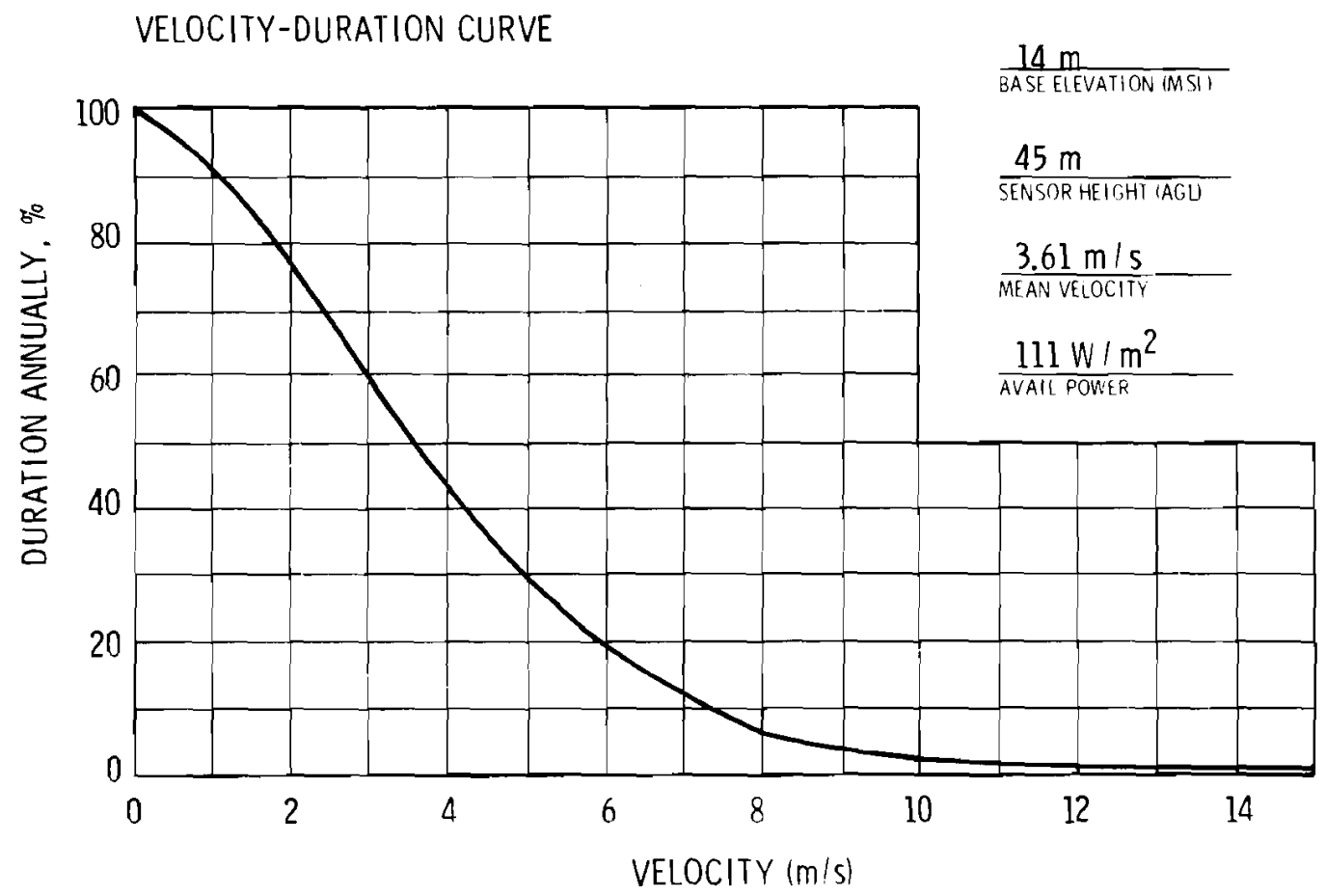


MARBLE HILL

\section{SITE LOCATION:}

The Marble Hill Nuclear Generating station site $\left(38.60^{\circ} \mathrm{N} / 85.45^{\circ} \mathrm{W}\right.$ ) is in SE Indiana, $10 \mathrm{~km} \mathrm{NE}$ of New Washington, in Jefferson County. The site is $48 \mathrm{~km} \mathrm{NE}$ of Louisville, KY, and $105 \mathrm{~km} \mathrm{SW}$ of Cincinnati, OH. It is situated $730 \mathrm{~m} \mathrm{~W}$ of the Ohio River.

\section{TOPGRAPHY :}

Considerable variation exists in the terrain surrounding the Marble Hill station site. Flat to gently rolling terrain characterizes the Indiana side of the Ohio River; however, near the Ohio River, the land becomes very hilly and then changes to ravines and bluffs along the river valley. Into Kentucky, the land becomes rolling and somewhat rough. Elevations range from $135 \mathrm{~m}$ (MSL) along the Indiana floodplain to $275 \mathrm{~m}$ (MSL) in Kentucky •

\section{ON-SITE WIND MEASUREMENTS:}

The on-site meteorological monitoring program began on 1 Jan 1974. There are two towers instrumented as follows. A 60-m tower was erected on a hill above the ohio River at an elevation of about $240 \mathrm{~m}$ (MSL). It was instrumented at $10 \mathrm{~m}$ and $60 \mathrm{~m}$ with Climet WS-011-1 cup anemometers for wind speed, and Climet WD-012-10 direction sensors. A 10-m tower was also erected in the river valley at about $135 \mathrm{~m}$ (MSL), and similarly instrumented.

The attached data are from the 10-m level of the 60-m tower.

NRC Docket No. $50-546$ 


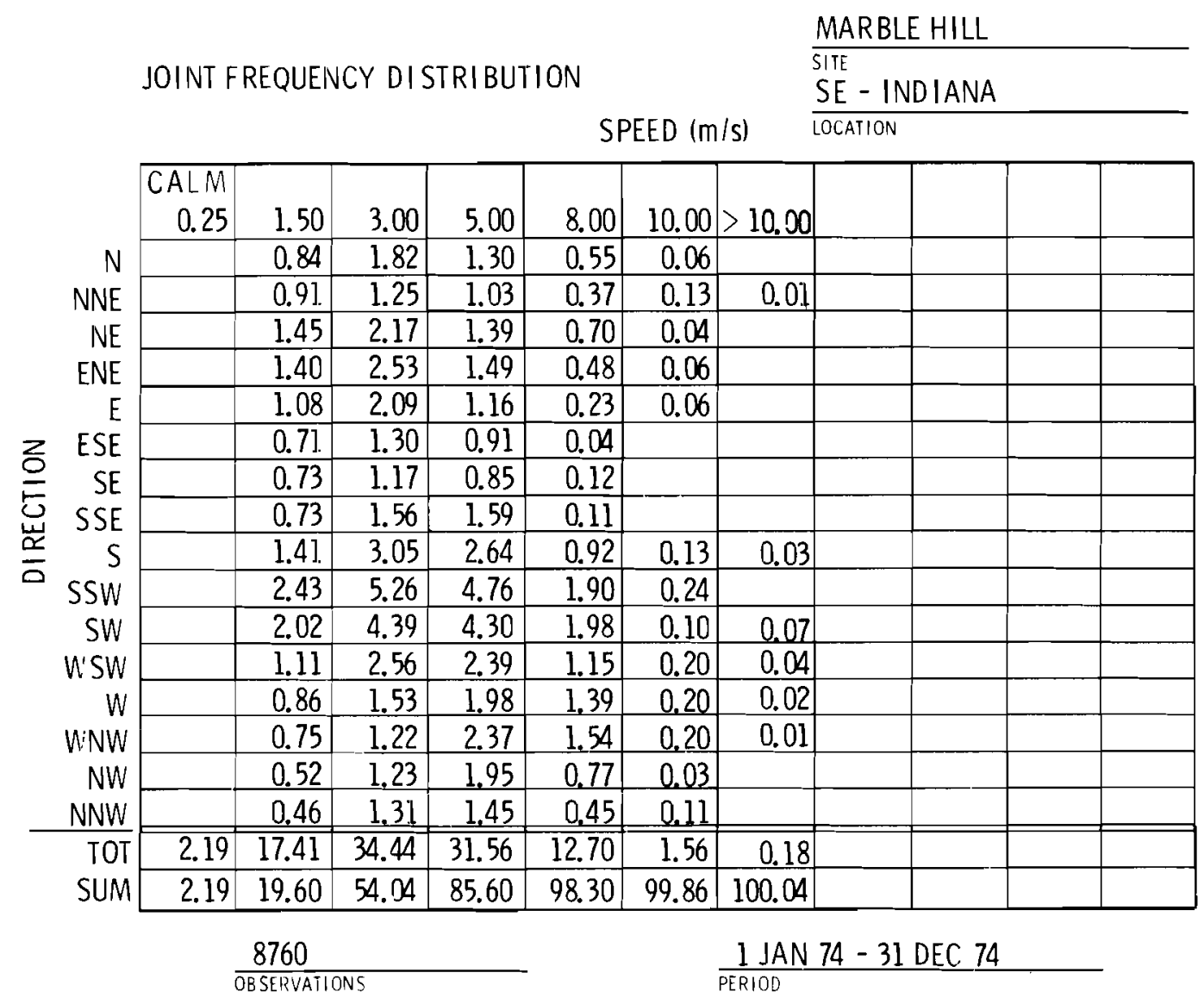

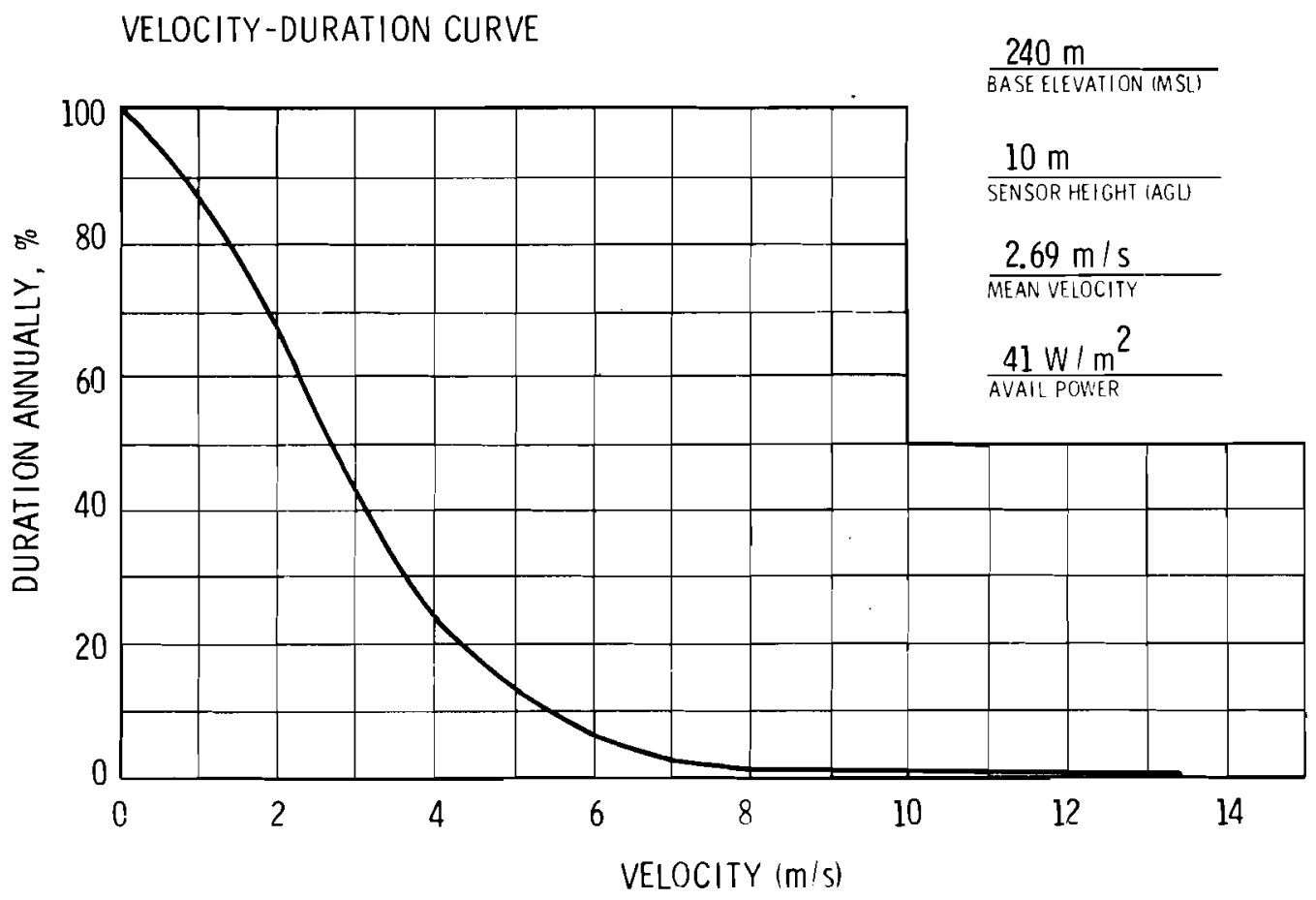


WM. B. MCGUIRE

\section{SITE LOCATION:}

The site $\left(35.43^{\circ} \mathrm{N} / 80.95^{\circ} \mathrm{W}\right)$ is in NW Mechlenburg County, North Carolina, $27 \mathrm{~km}$ NNW of Charlotte. The site is bounded to the west by the Catawba River channel and to the north by the 32,500-acre Lake Norman. Lake Norman is impounded by Duke Power Company's Cowens Ford Dam hydroelectric station, which is immediately west of the site and on the catawba River channel.

\section{TOPOGRAPHY :}

The McGuire site is located in the rolling Appalachian Piedmont area. The site varies in elevation from about $200 \mathrm{~m}$ to $250 \mathrm{~m}$ (MSL). Lake Norman extends some $55 \mathrm{~km}$ northward, and the tail water of Cowan's Ford Dam is the upper limit of Mountain Island Lake, which extends south for about $25 \mathrm{~km}$. The east abutment dike of Cowan's Ford Dam has an elevation of $238 \mathrm{~m}$ while Lake Norman full pond is at $232 \mathrm{~m}$.

ON-SITE WIND MEASUREMENTS:

Wind data are taken at $10 \mathrm{~m}$ and $40 \mathrm{~m}$ using Packard-Bell Model $W / S$ l01B series wind speed-direction systems. The base of the tower is at $232 \mathrm{~m}$ (MSL).

$\overline{\text { NRC Docket No. } 50-369}$ 


\begin{tabular}{|c|c|c|c|c|c|c|c|c|c|c|c|}
\hline & JOINT & REQUEI & CY DI & IRIBU & ON & & & $\begin{array}{l}\text { MCGUIF } \\
\text { SITE } \\
\text { NORTH }\end{array}$ & EAROLI & & \\
\hline & & & & & & EED (m & & LOCATION & & & \\
\hline & $\overline{C A L M}$ & & & & & & & & & & \\
\hline & 0.44 & 1.49 & 2.49 & 3.49 & 4.49 & 5.49 & 6.49 & 7.49 & 8.49 & 9.49 & $>9.49$ \\
\hline $\mathrm{N}$ & & 0.89 & 1.69 & 1.33 & 0.78 & 0.35 & 0.24 & 0.17 & 0.12 & 0.04 & 0.04 \\
\hline NNE & & 0.86 & 2.04 & 1.53 & 1.18 & 0.63 & 0.22 & 0.17 & 0.01 & 0.01 & 0.03 \\
\hline NE & & 1.23 & 3.23 & 3.09 & 2.11 & 0.96 & 0.38 & 0.05 & & & 0.01 \\
\hline ENE & & 0.87 & 2.89 & 2.20 & 0.97 & 0.47 & 0.17 & 0.05 & & & 0.01 \\
\hline$E$ & & 0.83 & 2.07 & 1.61 & 0.70 & 0.26 & 0.01 & & 0.01 & & \\
\hline ESE & & 1.05 & 1.50 & 0.68 & 0.40 & 0.04 & & & & & \\
\hline SE & & 1.81 & 1.16 & 0.47 & 0.17 & 0.08 & 0.01 & & & & \\
\hline SSE & & 1.52 & 0.87 & 0.35 & 0.12 & 0.04 & 0.03 & & & & \\
\hline $\mathrm{S}$ & & 2.90 & 2.13 & $0.9]$ & 0.58 & 0.27 & 0.08 & 0.03 & & & \\
\hline SSW & & 3.18 & 2.15 & 1.43 & 0.89 & 0.59 & 0.31 & 0.13 & 0.13 & 0.01 . & 0.03 \\
\hline SW & & 3.54 & 2.75 & 1.87 & 1.34 & 0.93 & 0.72 & 0.47 & 0.22 & 0.04 & 0.10 \\
\hline U'SW & & 1.84 & 1.46 & 0.82 & 0.69 & 0.46 & 0.33 & 0.22 & 0.20 & 0.03 & \\
\hline$W$ & & 1.24 & 1.35 & 0.83 & 0.89 & 0.51 & 0.31 & 0.12 & 0.06 & 0.01 & \\
\hline UNW & & 0.79 & 0.92 & 0.69 & 0.50 & 0.37 & 0.41 & 0.23 & 0.09 & 0.06 & 0.10 \\
\hline NW & & 0.81 & 1.14 & 0.59 & 0.66 & 0.28 & 0.33 & 0.17 & 0.13 & 0,04 & 0.03 \\
\hline NNW & & 0.59 & 1.05 & 0.72 & 0.55 & 0.38 & 0.22 & 0.28 & 0.08 & 0.09 & 0.01 \\
\hline TOT & $\overline{1.87}$ & 23.95 & 28.39 & 19.10 & 12.52 & 6.61 & 3.76 & 2.07 & 1.05 & 0.35 & 0.36 \\
\hline SUM & 1.87 & 25.82 & 54.21 & 73.31 & 85.83 & 92.44 & 96.20 & 98.27 & 99.32 & 99.65 & 100.01 \\
\hline & & & & & & & רי & 70 - & CT & & \\
\hline
\end{tabular}

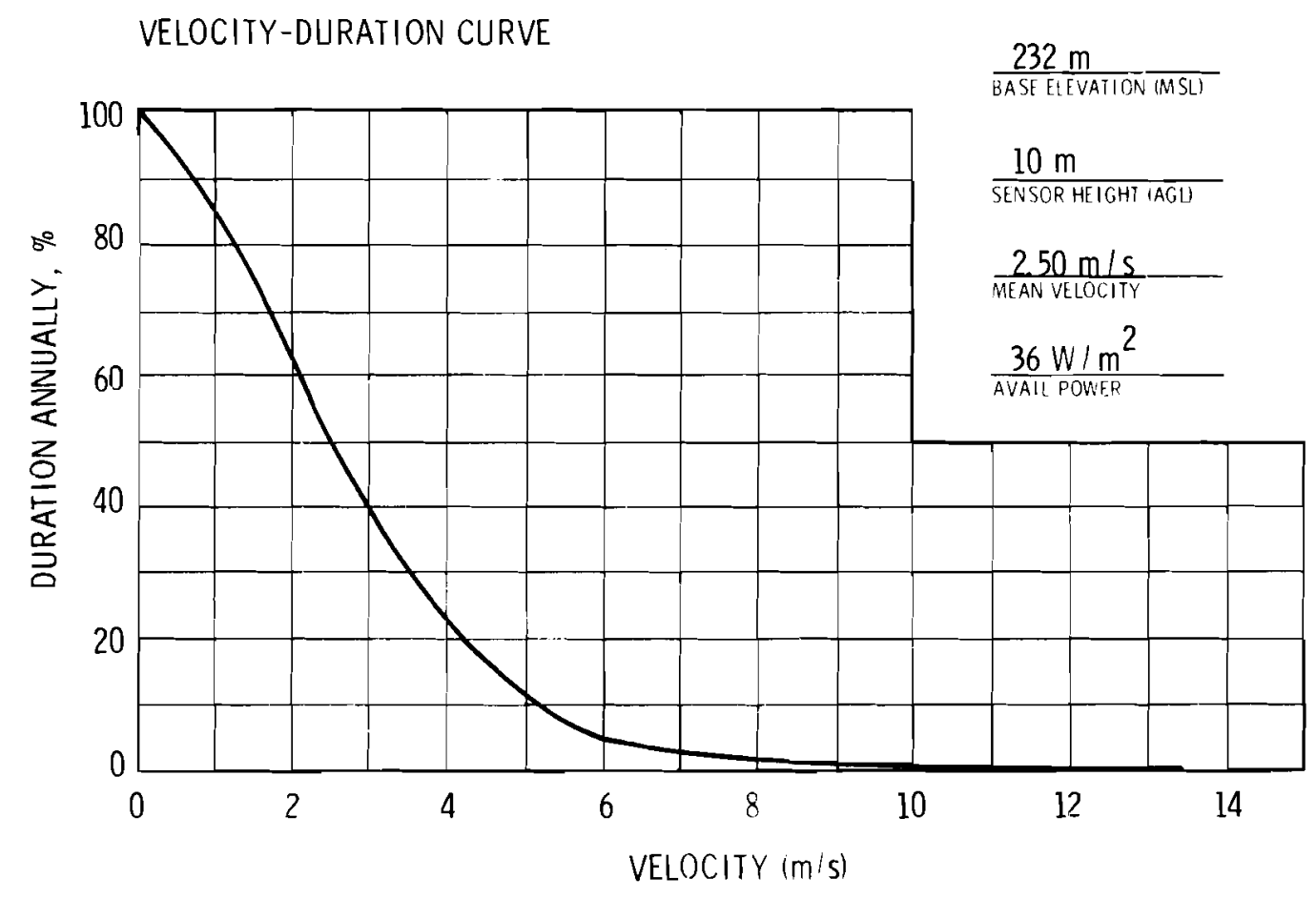




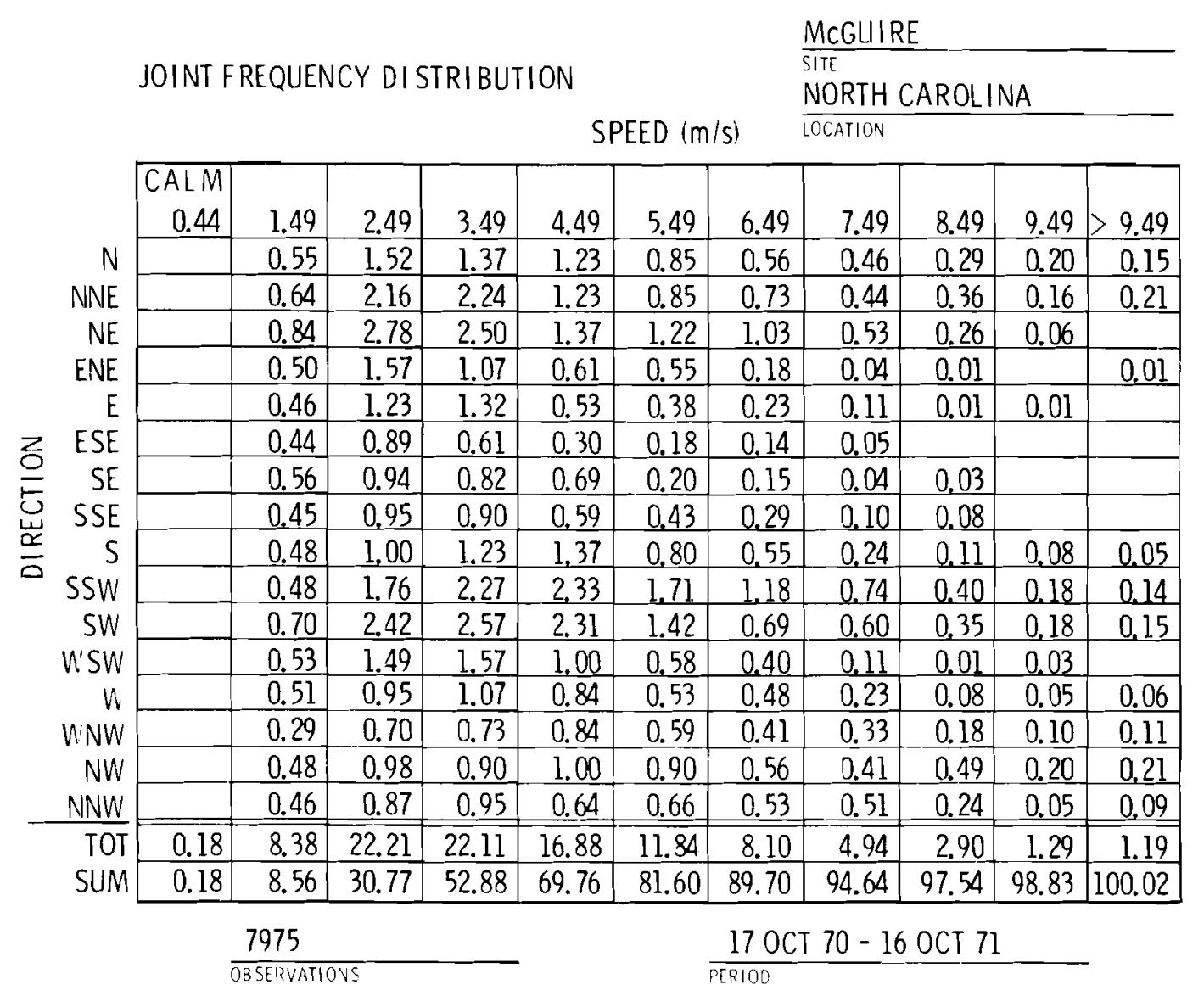

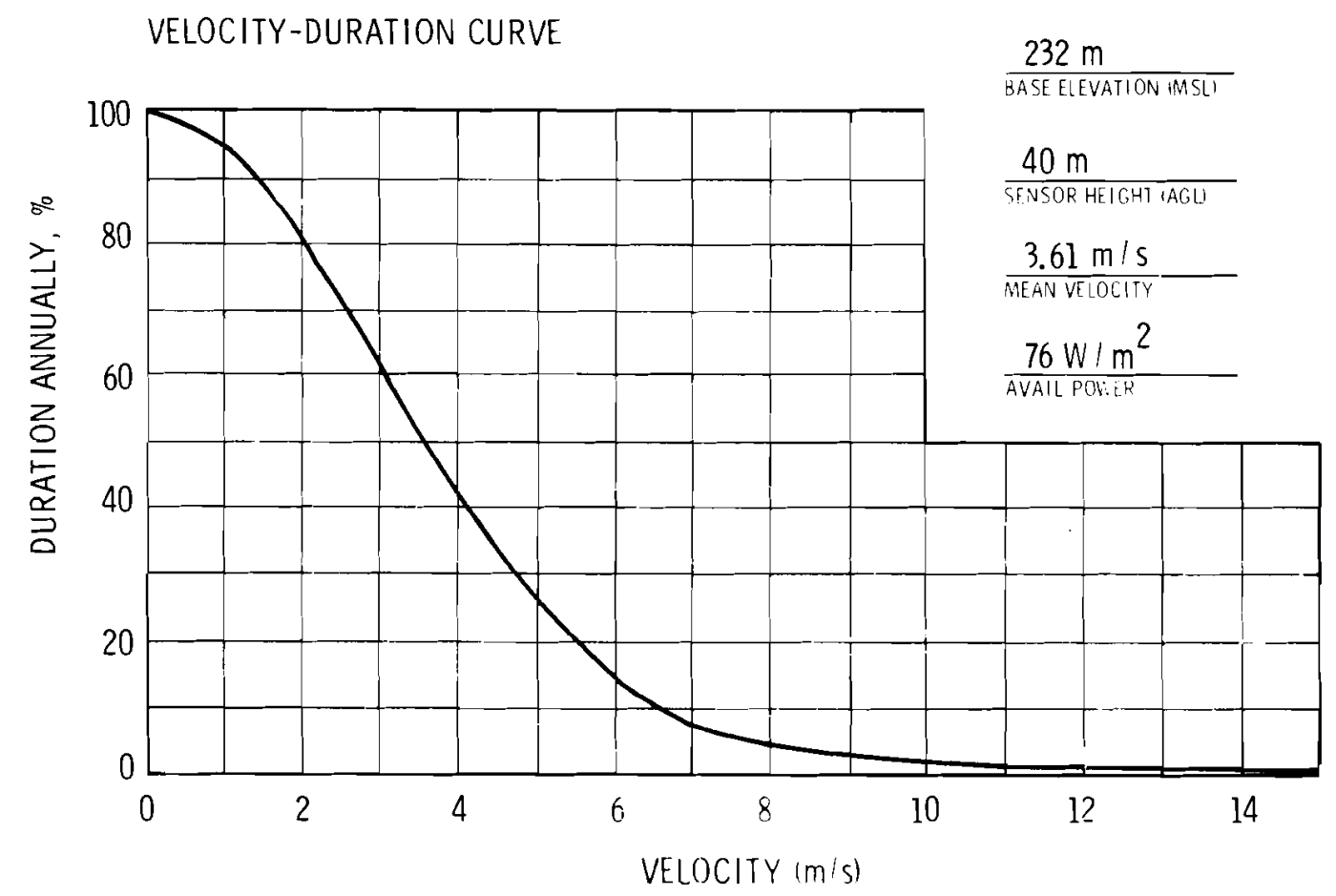


MIDLAND

\section{SITE LOCATION:}

The site $\left(43.58^{\circ} \mathrm{N} / 84.23^{\circ} \mathrm{W}\right)$ is immediately south of Midland, Michigan, in Midland County, in the east central part of lower Michigan. The site location lies south of the Tittabawassee River, outside of the city limits of Midland. Saginaw Bay, an arm of Lake Huron, lies about $27 \mathrm{~km}$ ENE, the city of Saginaw is $28 \mathrm{~km} \mathrm{SE}$ and Flint is $76 \mathrm{~km} \mathrm{SE}$.

\section{TOPOGRAPHY :}

The topography of the site is comparatively flat with elevations ranging from $183 \mathrm{~m}$ to $190 \mathrm{~m}$ (MSL). It is estimated that there are no changes in elevation greater than $15 \mathrm{~m}$ within $80 \mathrm{~km}$. The site is covered with grain type vegetation and occasional groups of trees on the order of $15 \mathrm{~m} \mathrm{high}$.

ON-SITE WIND MEASUREMENTS:

Wind measurements are made from three towers, one $90 \mathrm{~m}$ and two $10 \mathrm{~m}$ towers. The $90 \mathrm{~m}$ tower is used to measure wind speed and direction at $10 \mathrm{~m}$ and $60 \mathrm{~m}$, and also wind speed only at $40 \mathrm{~m}$ and $90 \mathrm{~m}$. Base elevation is at $187 \mathrm{~m}$ (MSL). The two 10-m towers are supplemental - one located near the bank of the Tittabawassee River of $183 \mathrm{~m}$ (MSL) to sample winds from the NE after they traverse the Dow Chemical Co. plant, and the other near the cooling pond at $191 \mathrm{~m}$ (MSL) to sample winds before they traverse the pond. The instruments being used are Climet WS-011-1 (speed) and the Climet WD-012-30 (direction) at all locations. The attached data are from the 10-m level of the 90-m tower.

$\overline{\text { NRC Docket No. } 50-329}$ 


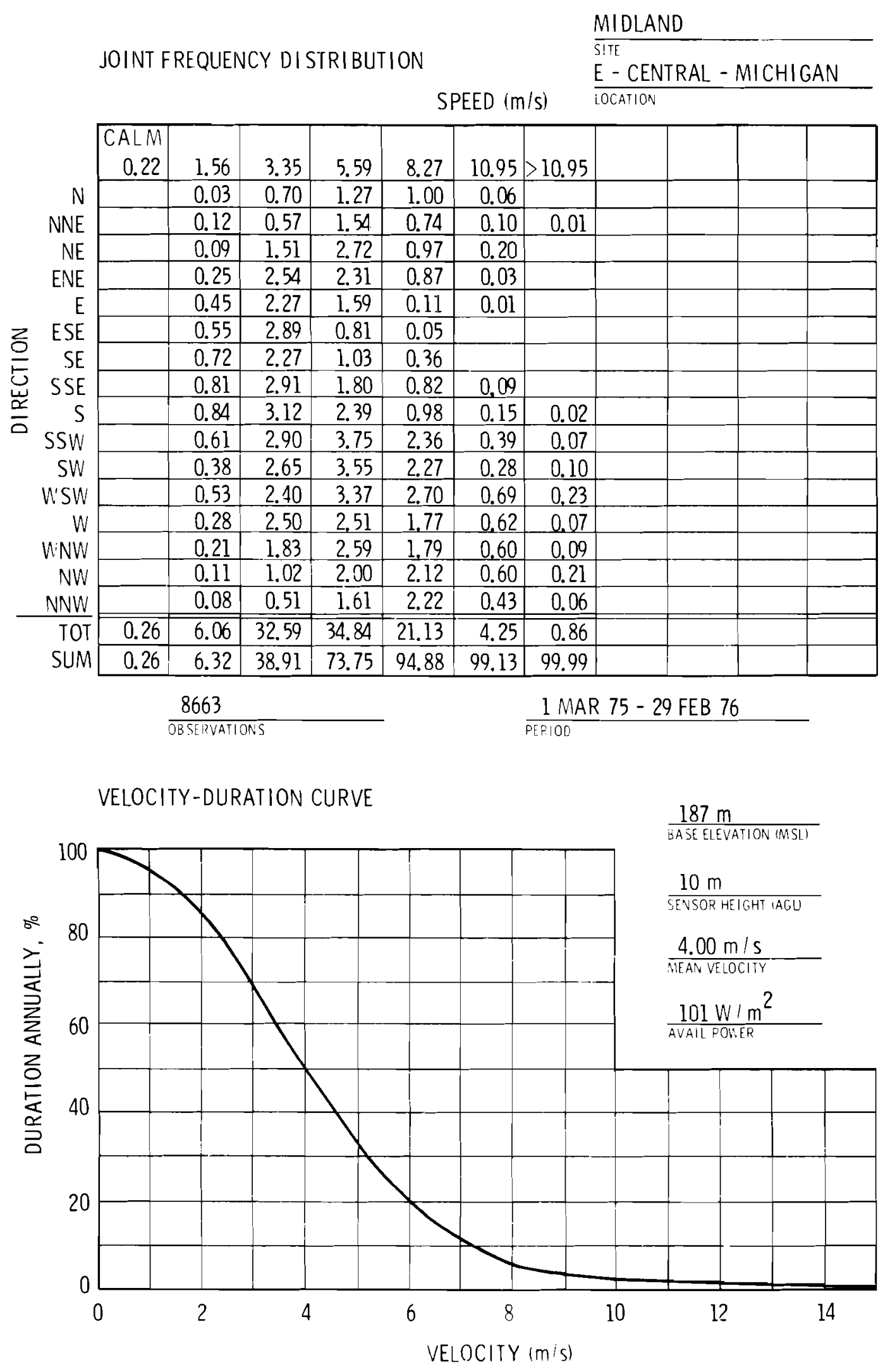


MILLSTONE POINT

\section{SITE LOCATION:}

The Millstone Point site $\left(41.31^{\circ} \mathrm{N} / 72.17^{\circ} \mathrm{W}\right)$ is located in New London County, Connecticut on the north shore of Long Island Sound, on the east side of the Niantic River estuary. The site is about $65 \mathrm{~km} \mathrm{SE}$ of Hartford and $8 \mathrm{~km}$ WSW of New London.

\section{TOPOGRAPHY :}

The terrain in New London County is varied, rising from a coastal plain at sea level near the site to $135 \mathrm{~m}$ (MSL), $16 \mathrm{~km}$ NW in the foothills of the eastern highlands. The topography is marked by low rolling hills rising inland from the shoreline. To the south (E through $W$ ) are the open waters of Long Island Sound.

\section{ON-SITE WIND MEASUREMENTS:}

A 46-m tower was placed in operation in August 1965 at near sea level. Wind speed and direction were measured by Bendix-Friez "Aerovanes" at $10 \mathrm{~m}$ and $46 \mathrm{~m}$. In late 1973, a 136-m tower was installed at $4 \mathrm{~m}$ (MSL) and instrumented at $10 \mathrm{~m}, 43 \mathrm{~m}, 114 \mathrm{~m}$, and $136 \mathrm{~m}$, with Bendix Model 2416914/2416970 wind sensors.

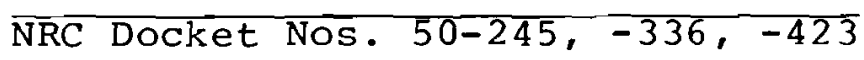




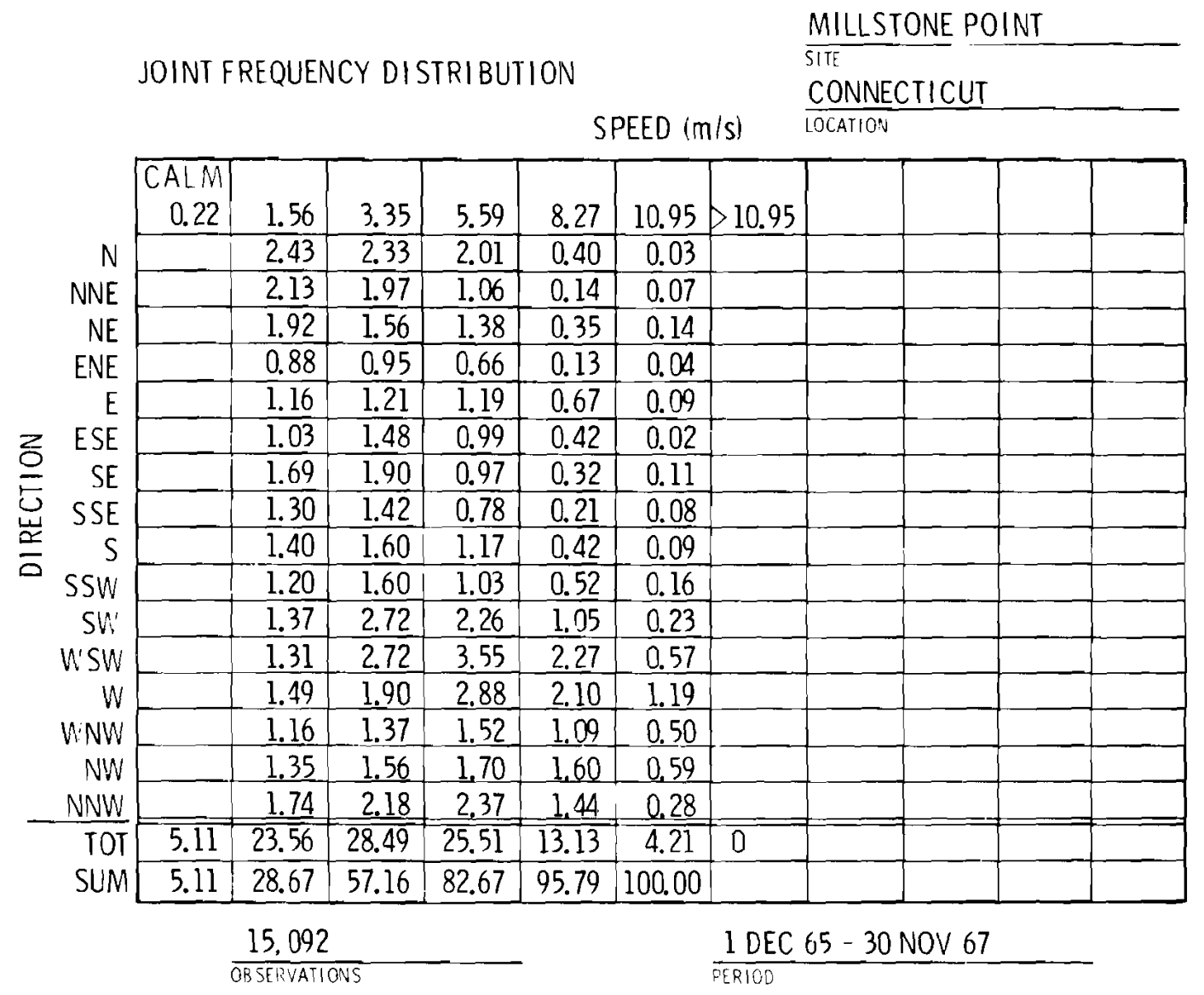

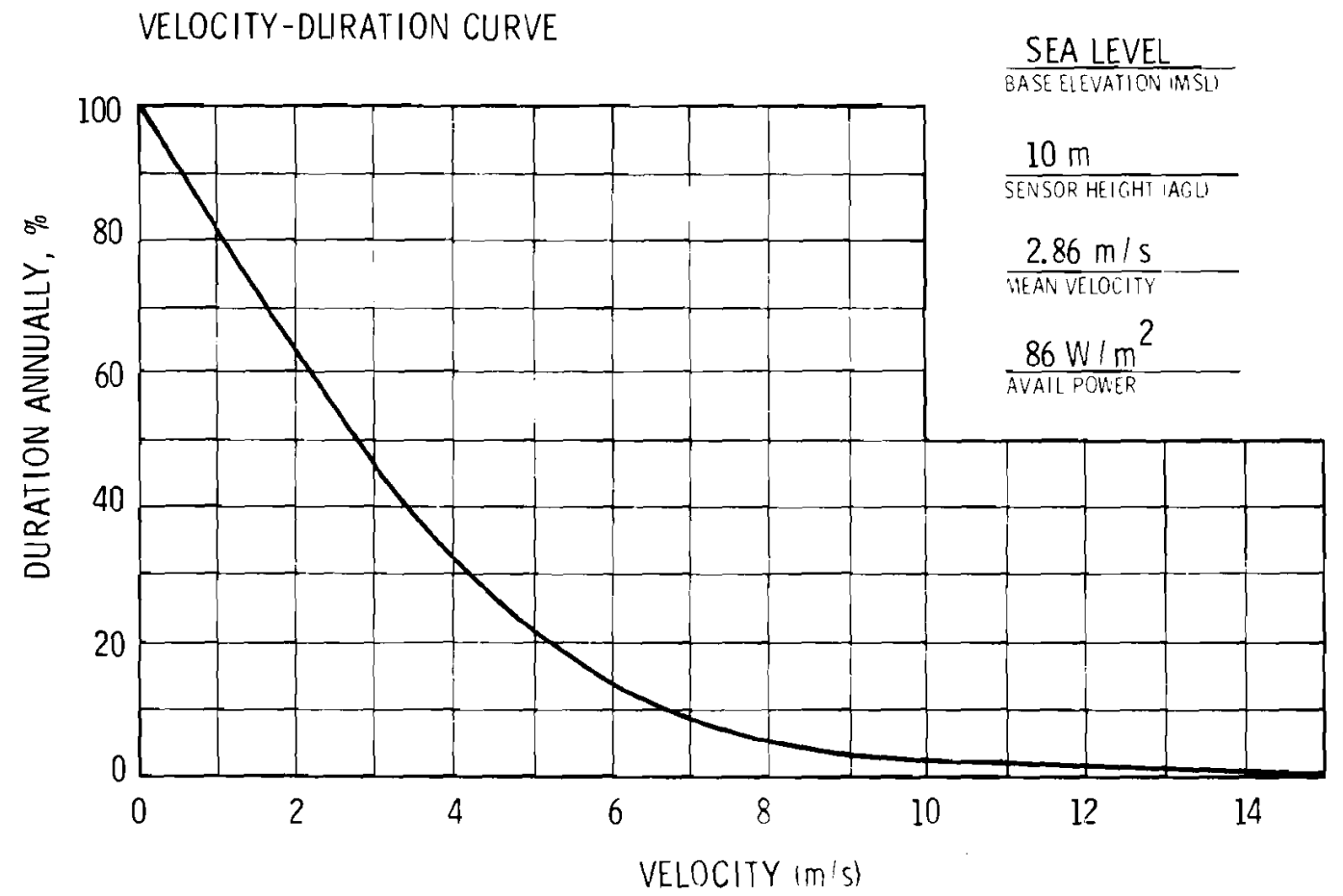

$C-152$ 

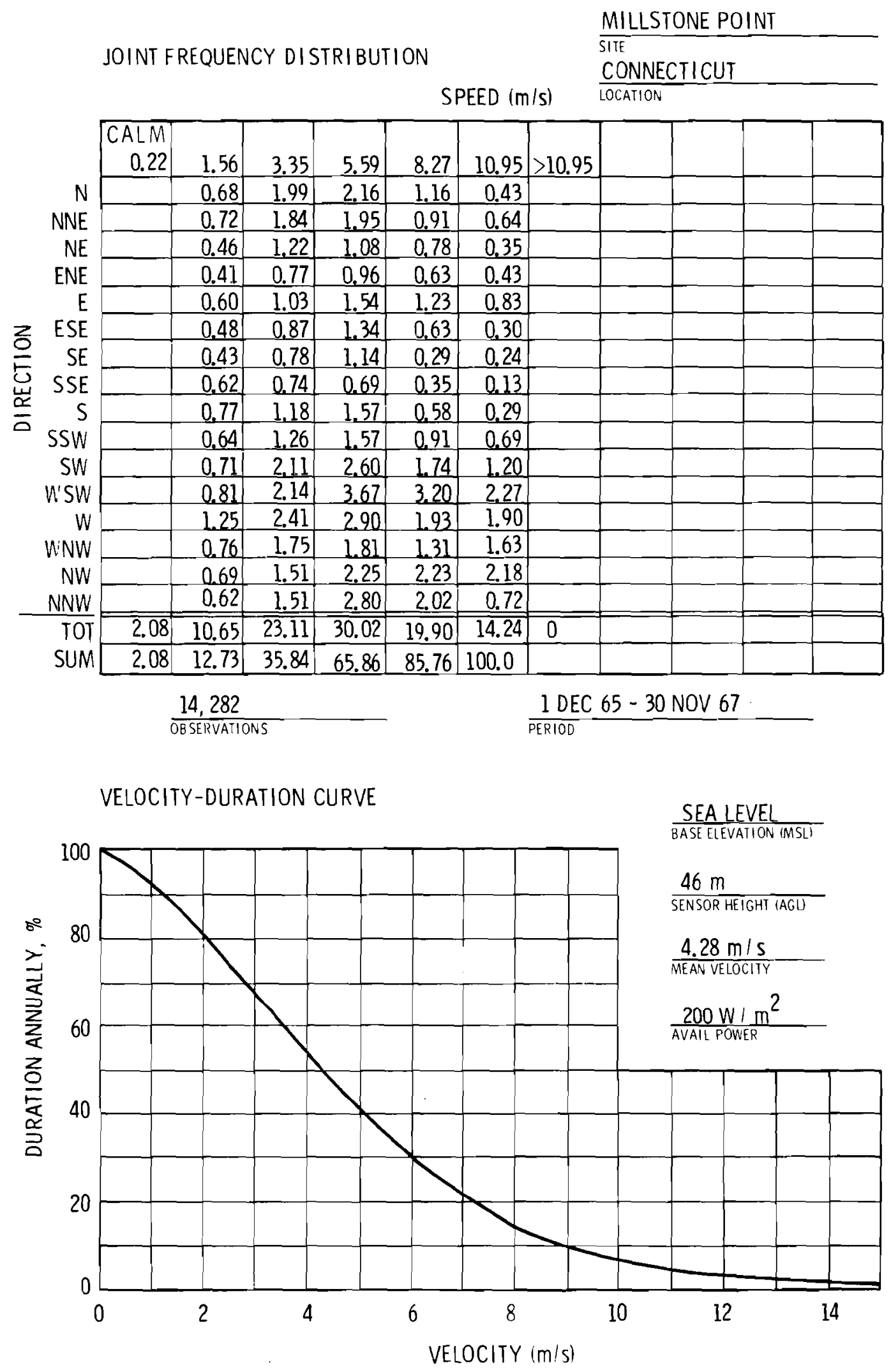


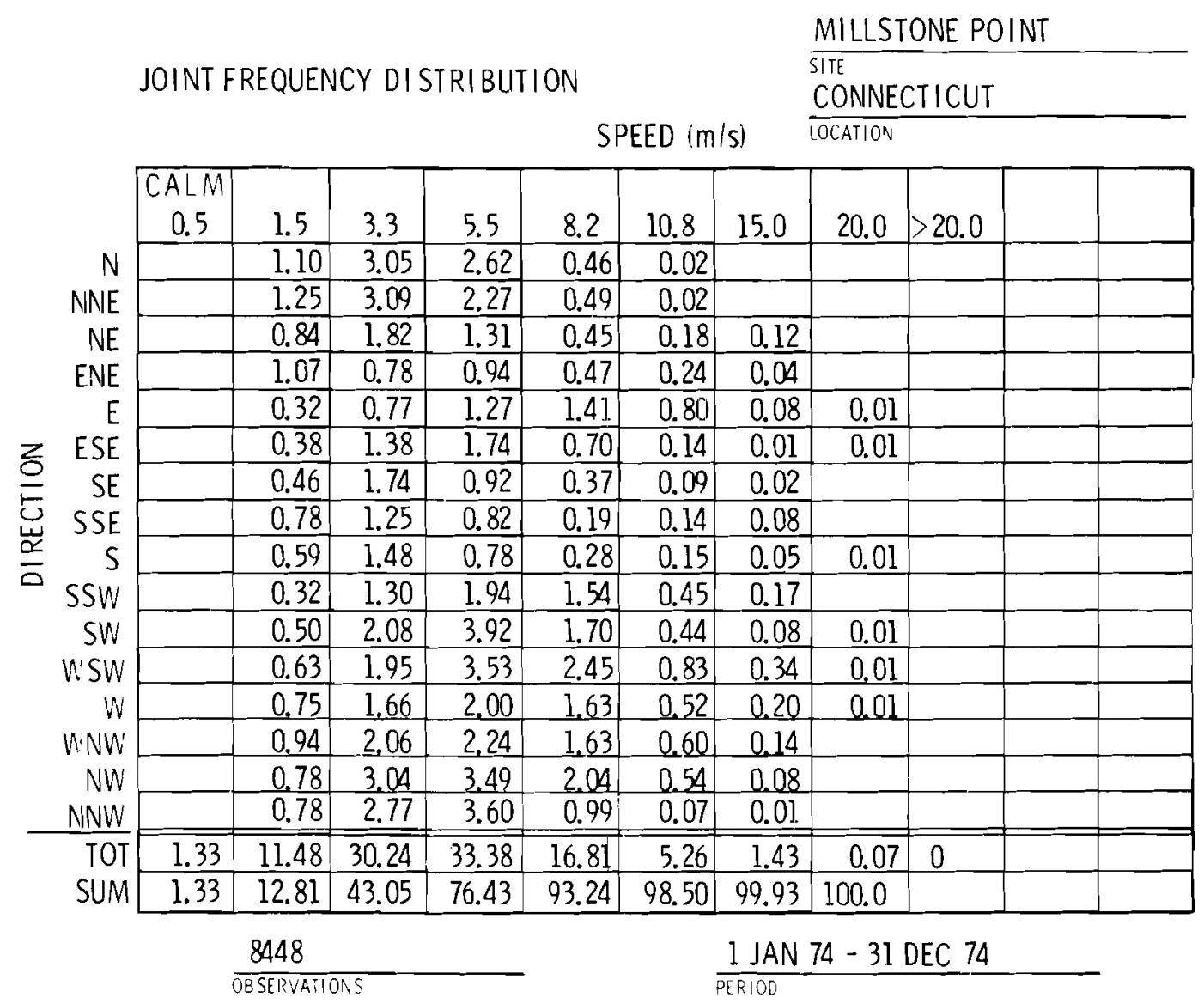

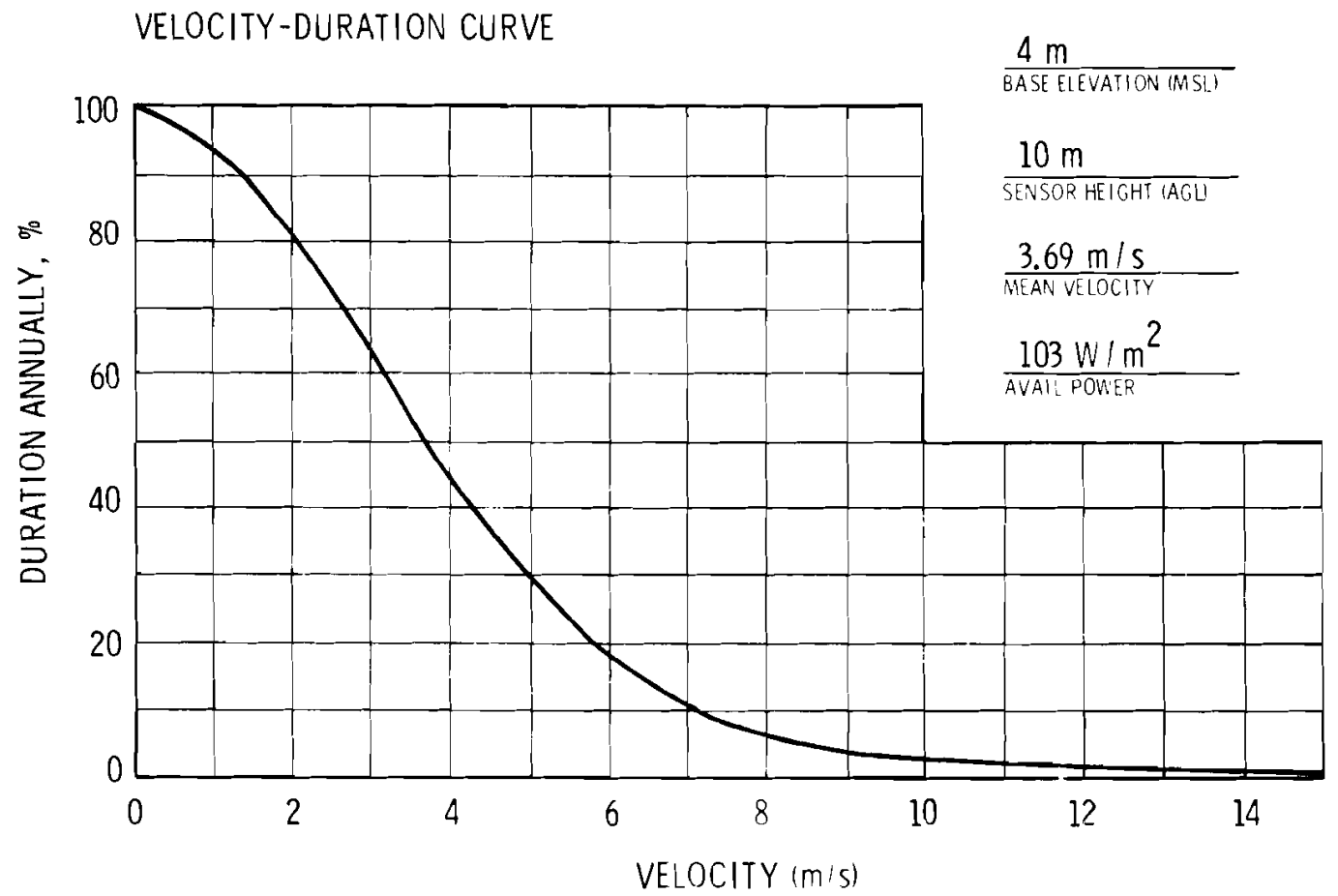



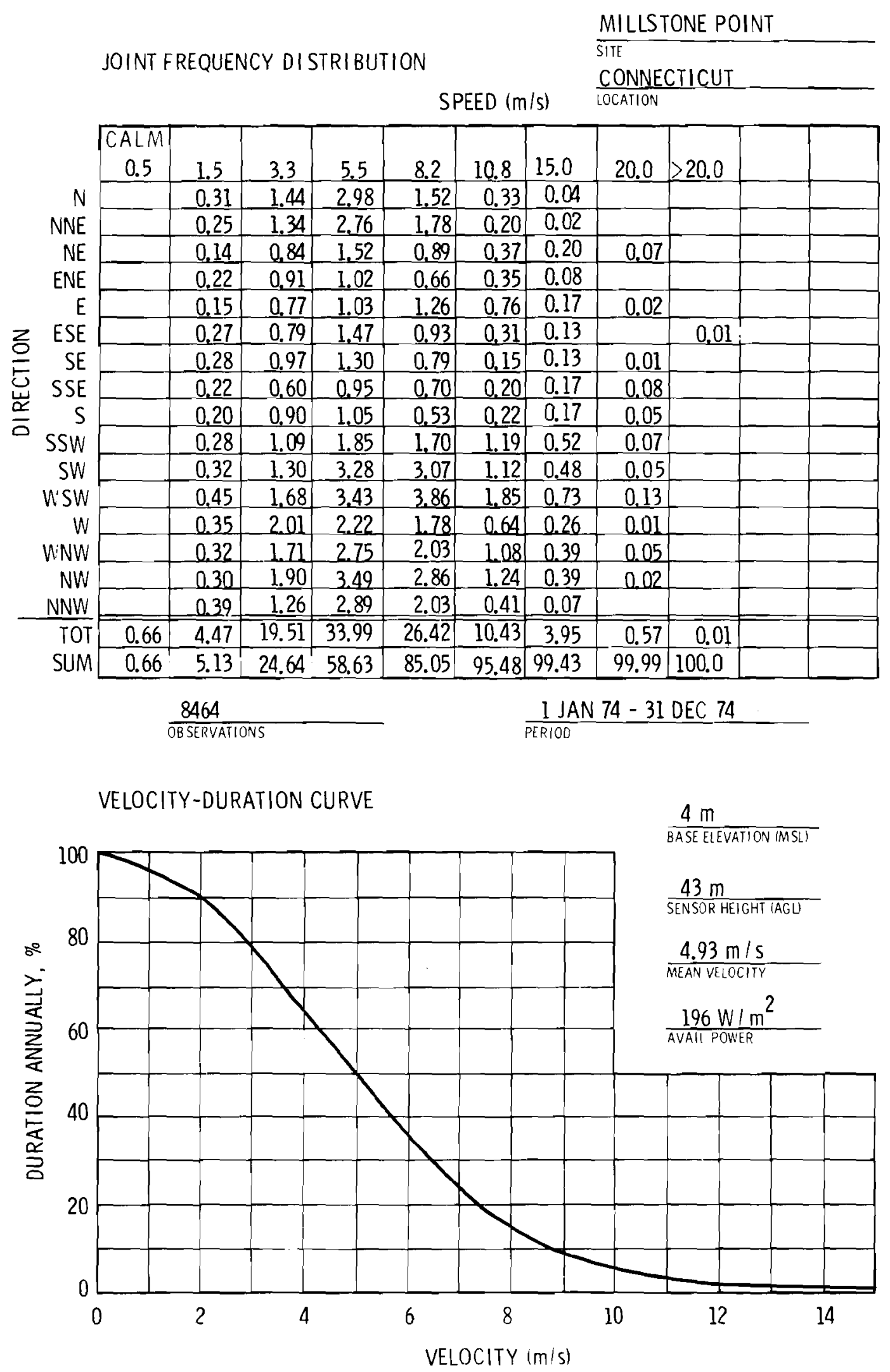

C- 155 


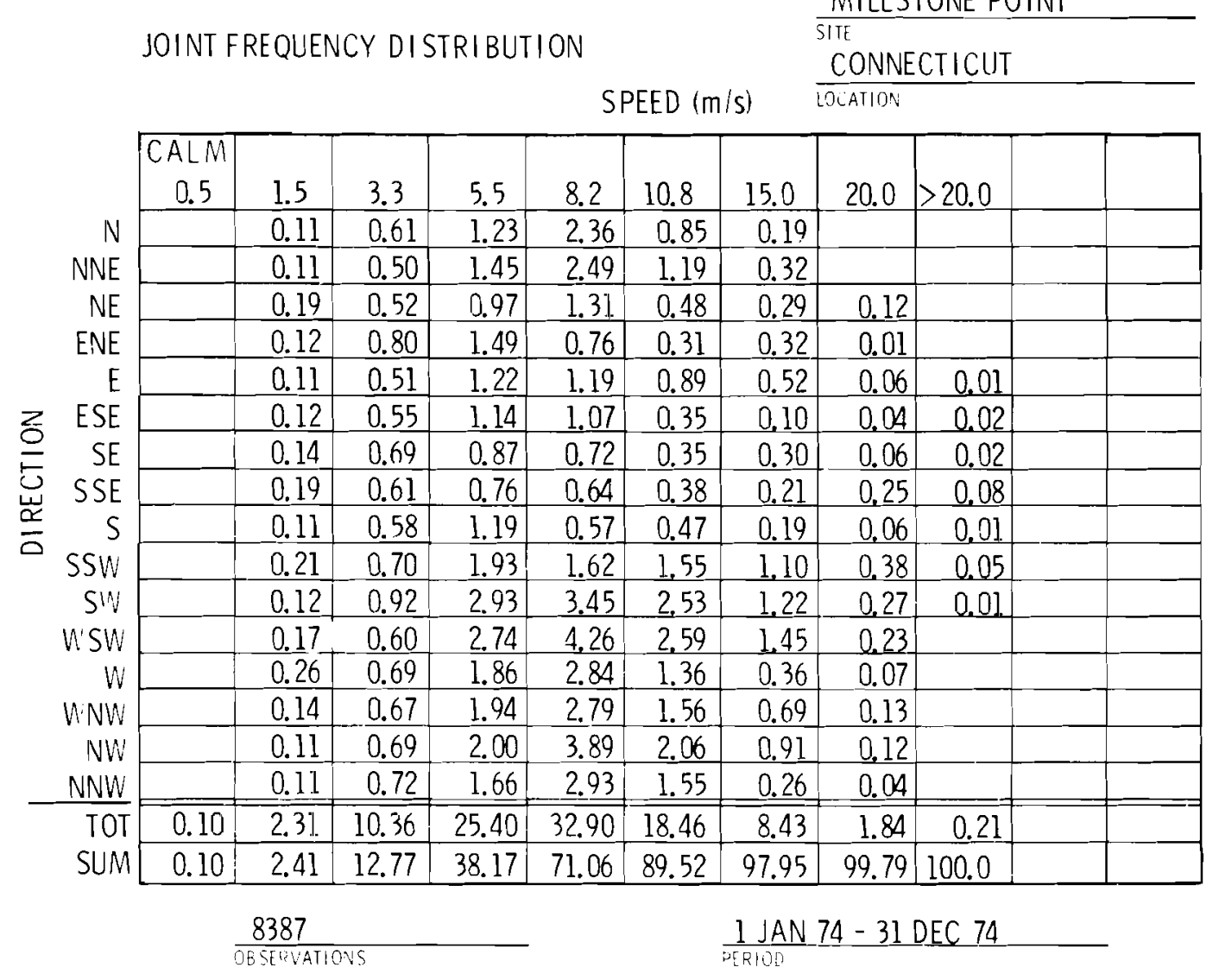

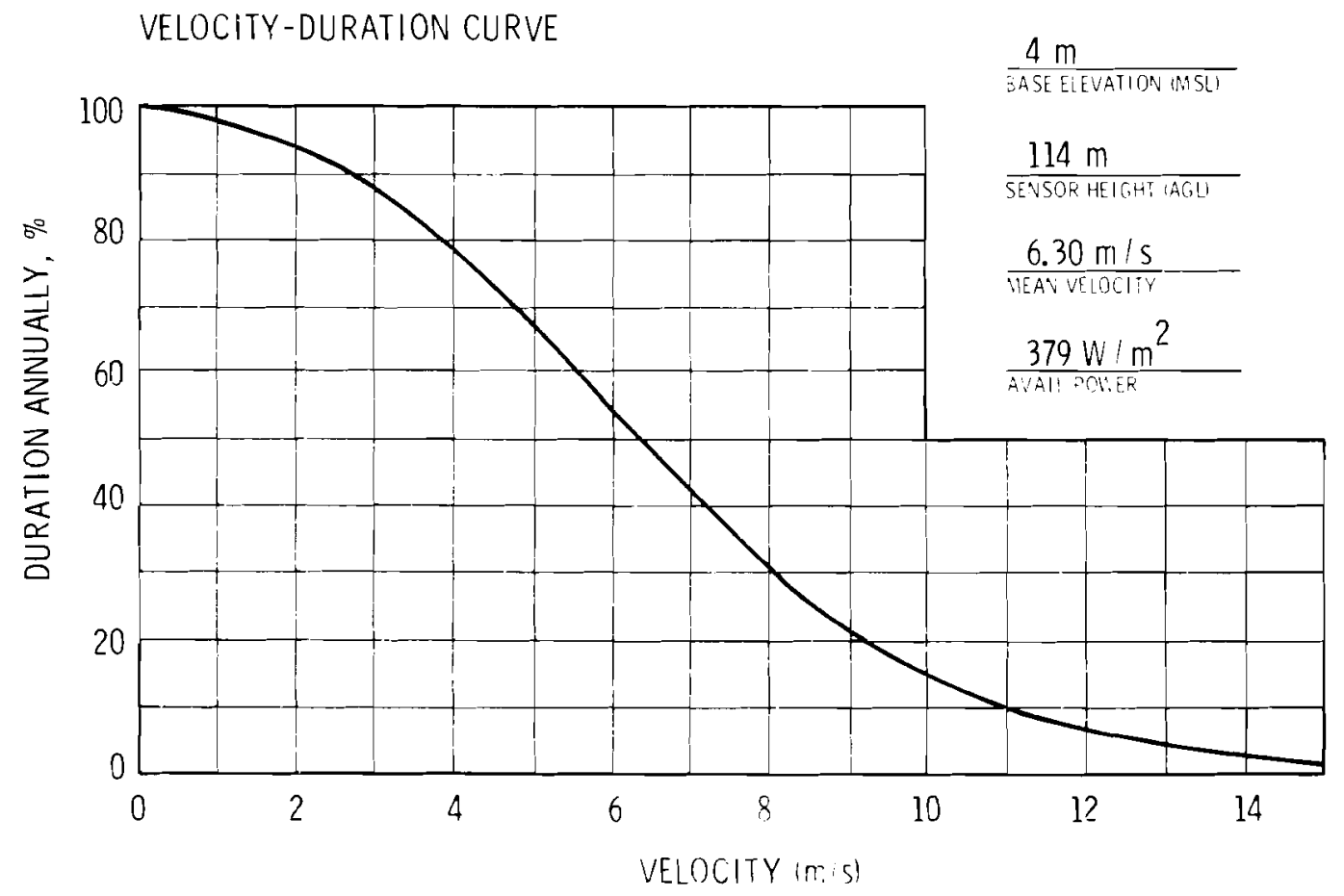



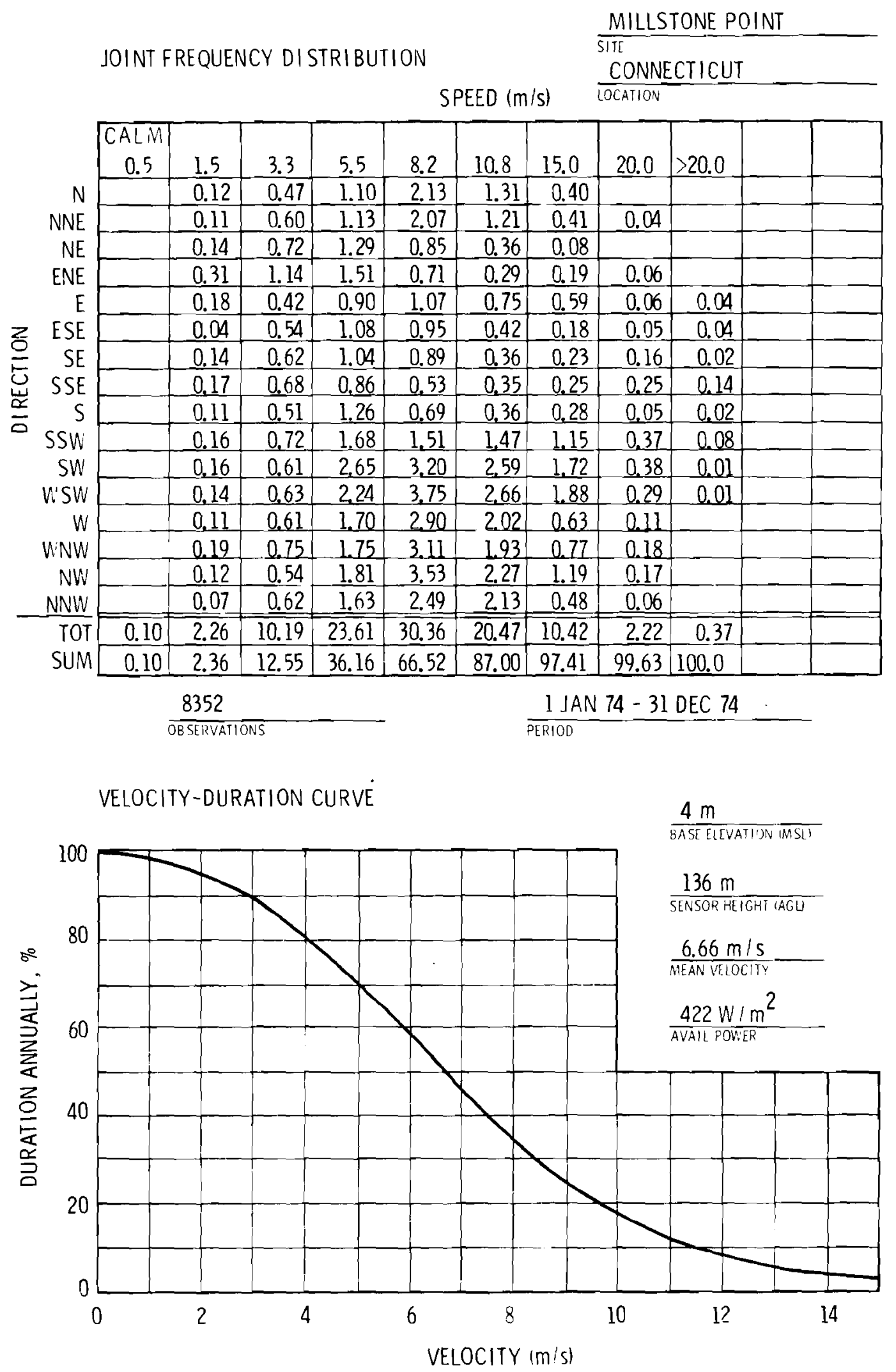
MONTAGUE

\section{SITE LOCATION:}

The Montague site $\left(42.58^{\circ} \mathrm{N} / 72.53^{\circ} \mathrm{W}\right)$ is located in the northwestern Massachusetts township of Montague, Franklin County, $2 \mathrm{~km}$ SSE of Turner Falls and $3 \mathrm{~km} \mathrm{E}$ of the Connecticut River.

\section{TOPOGRAPHY :}

The terrain in the immediate vicinity of the site (plant grade elevation - $105 \mathrm{~m}$ (MSL)) is relatively flat for 2 to $3 \mathrm{~km}$ radial, except for a nearby ridge to the $\mathrm{NW}$ at about $150 \mathrm{~m}$ (MSI). At greater distances from the site (out to $8 \mathrm{~km}$ ), the terrain is gently rolling with peaks to $180 \mathrm{~m}$ (MSL) from the $S$ through $\mathrm{NE}$. In other directions, the terrain is even more rugged in the peaks between $275 \mathrm{~m}$ and $400 \mathrm{~m}$ (MSL).

\section{ON-SITE WIND MEASUREMENTS:}

The on-site meteorological measurements program was initiated on 1 sept 1975. A 152-m tower, at an elevation of $95 \mathrm{~m}$ (MSL) is instrumented with Climatronics Model F460 wind systems at $10 \mathrm{~m}, 46 \mathrm{~m}, 99 \mathrm{~m}$ and $151 \mathrm{~m}$ heights.

NRA Docket No. $50-496$ 

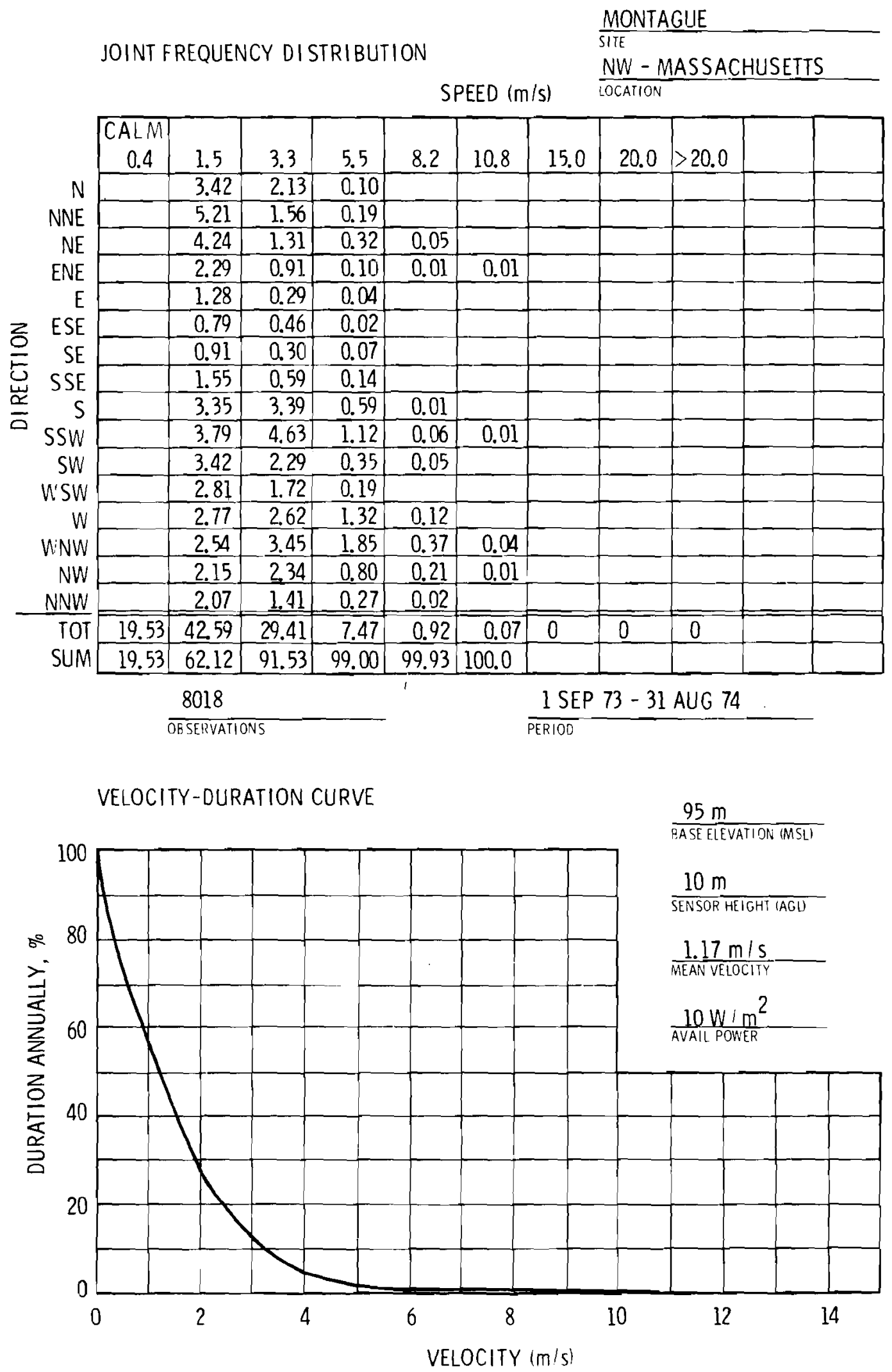


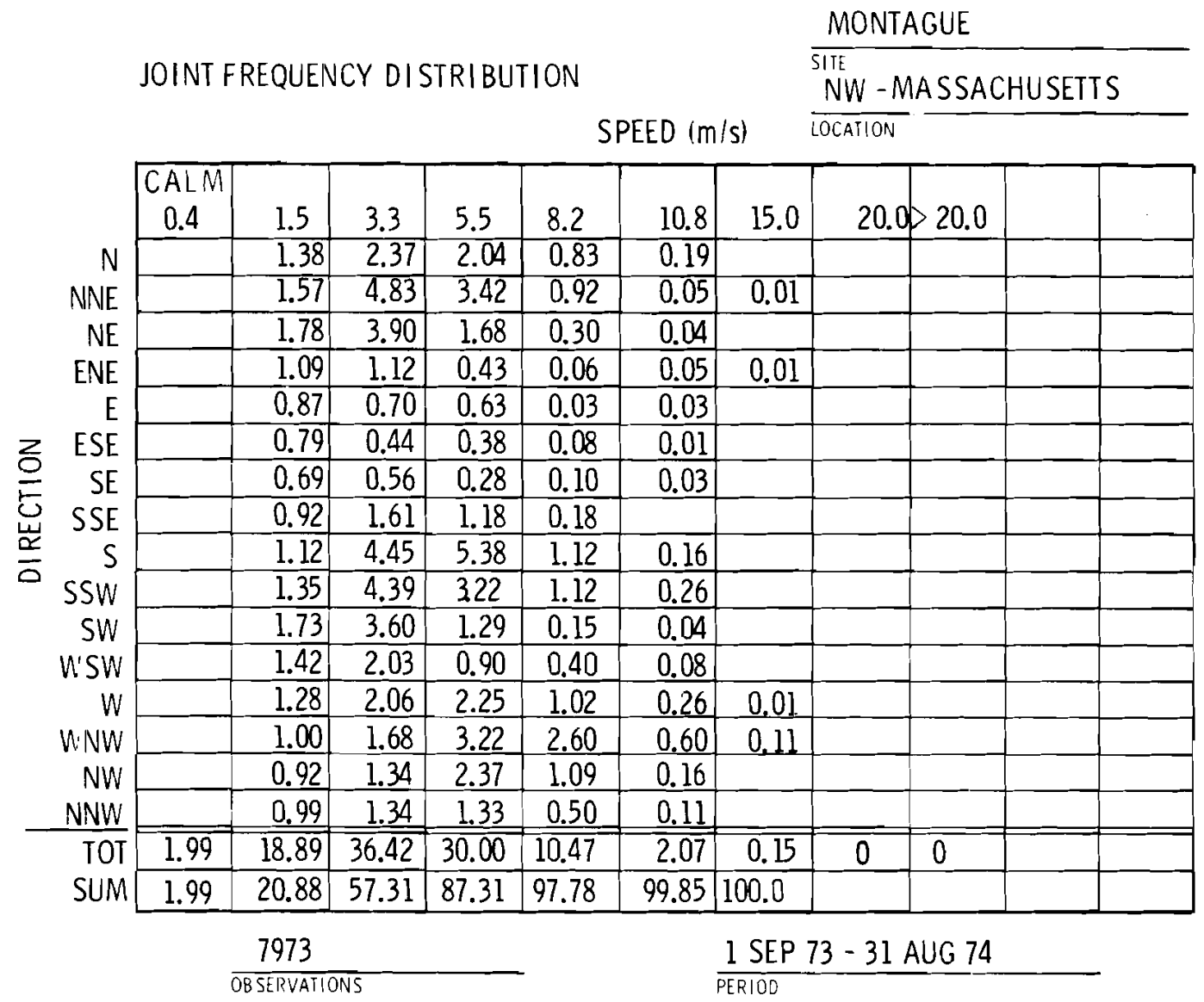

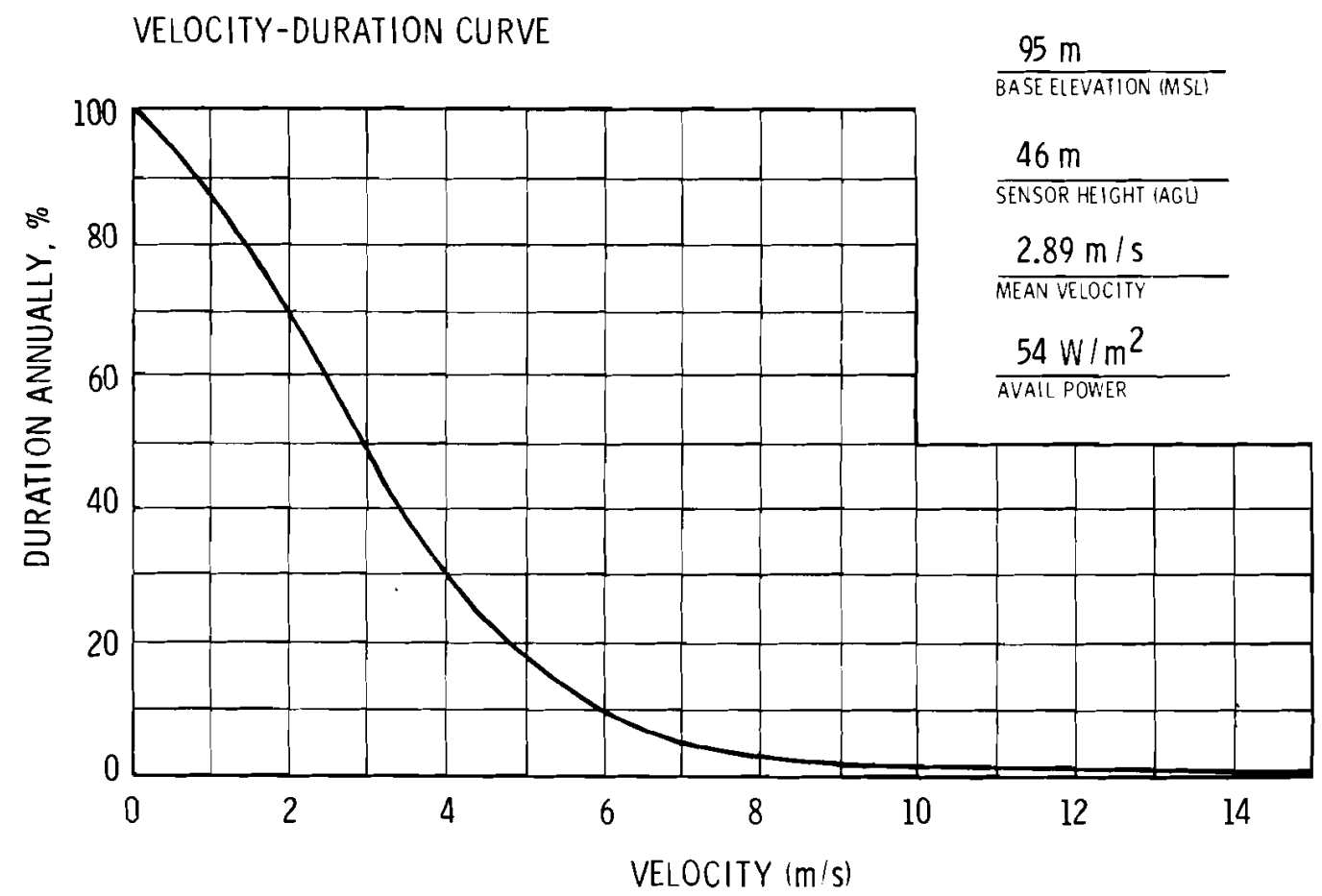




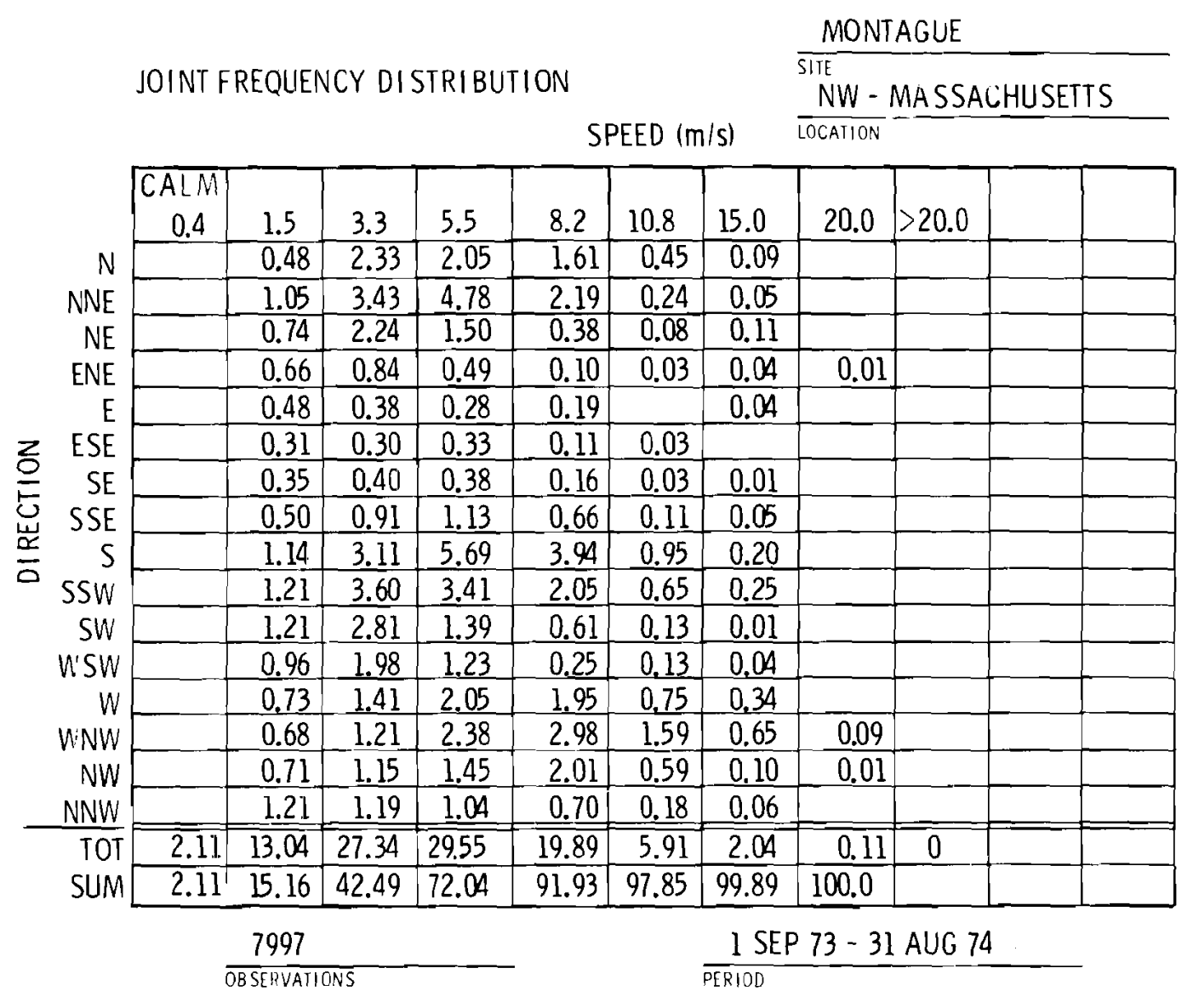

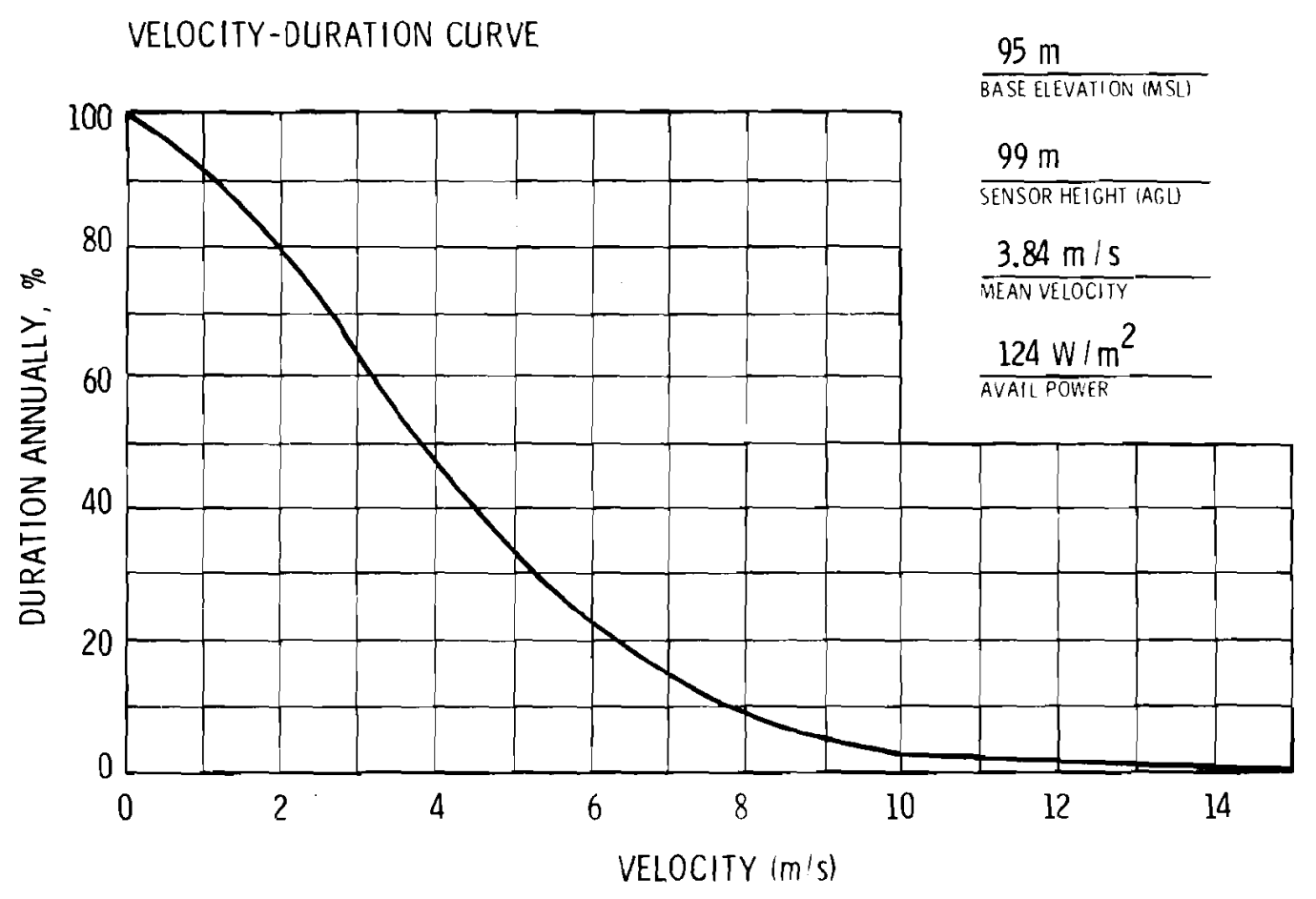




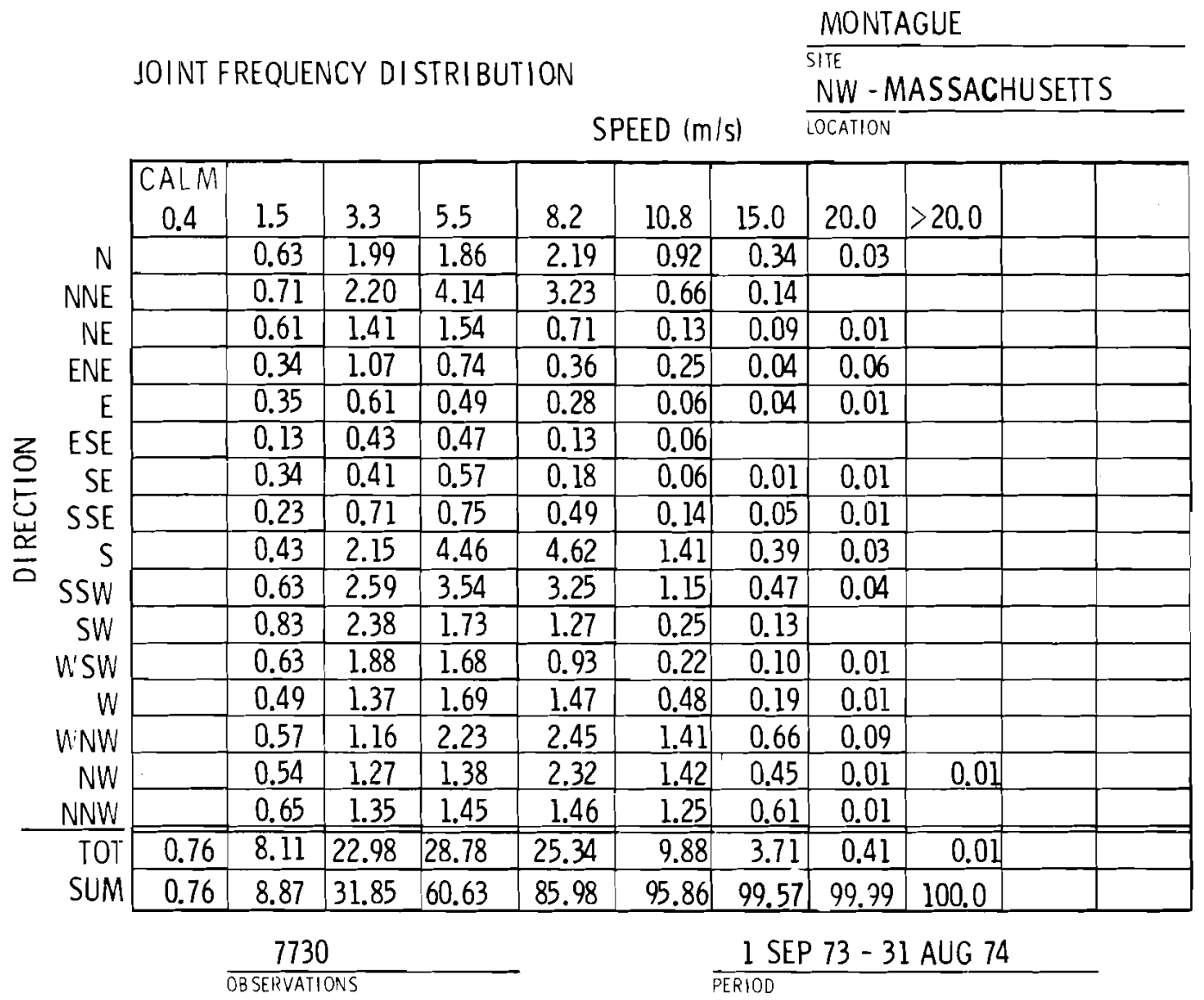

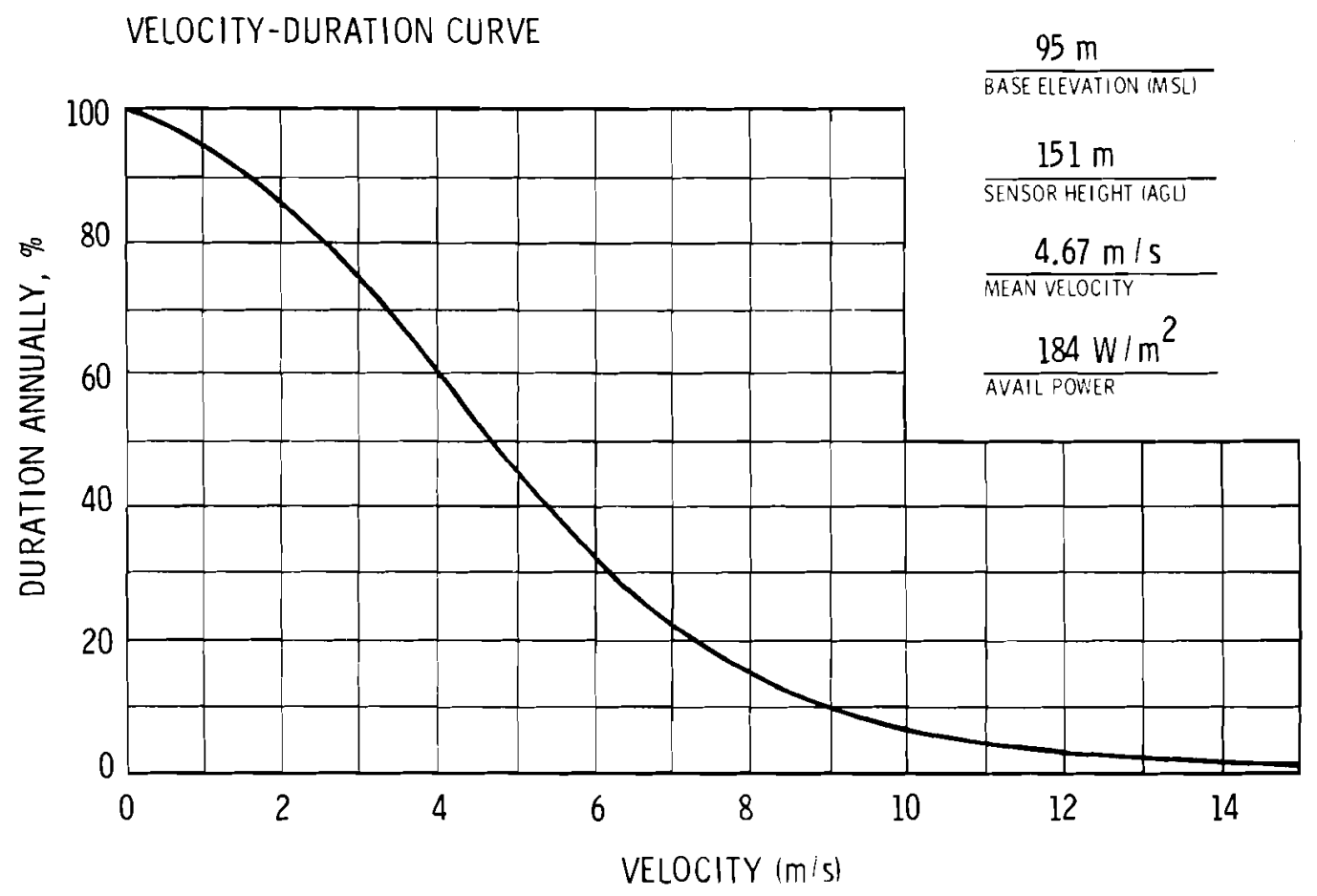


MONTICELLO

SITE LOCATION:

The Monticello site $\left(45.33^{\circ} \mathrm{N} / 93.83^{\circ} \mathrm{W}\right)$ is in east central Minnesota, about $5 \mathrm{~km}$ NW of the village of Monticello, in Wright county. The site is also about $35 \mathrm{~km} \mathrm{SE}$ of St. Cloud and about $50 \mathrm{~km} \mathrm{NW}$ of the nearest suburbs of Minneapolis.

TOPOGRAPHY :

The site is on the SW bank of the Mississippi River, which runs $\mathrm{NW}-\mathrm{SE}$ in the region. The local terrain is characterized by relatively level areas which rise sharply above the river. Three distinct bluffs exist at the site at elevations of $280 \mathrm{~m}$, $283 \mathrm{~m}$, and $286 \mathrm{~m}$ (MSL). Normal river level is $275 \mathrm{~m} \mathrm{(MSL).}$ About $2 \mathrm{~km} \mathrm{~N}$ and $\mathrm{S}$ of the site are bluffs to $290 \mathrm{~m} \mathrm{(MSL).} \mathrm{Be-}$ yond $2 \mathrm{~km} \mathrm{~N}$, the terrain is relatively level with numerous lakes and wooded areas. To the $\mathrm{S}, \mathrm{W}$, and $\mathrm{E}$, the terrain is hilly and dotted with numerous small lakes.

ON-SITE WIND MEASUREMENTS:

In early 1967, a 46-m tower was installed and instrumented with Bendix-Friez "Aerovane" wind systems at 6-m and 43-m heights. Base elevation is at $283 \mathrm{~m}$ (MSL). In early 1973, a 100-m tower was installed at very nearly the same base elevation, and it was instrumented at $10 \mathrm{~m}, 43 \mathrm{~m}$, and $100 \mathrm{~m}$ using climet ws-011-1 and Climet WD-012-10 wind sensor systems.

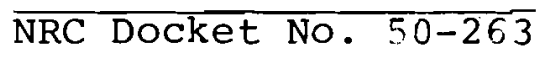




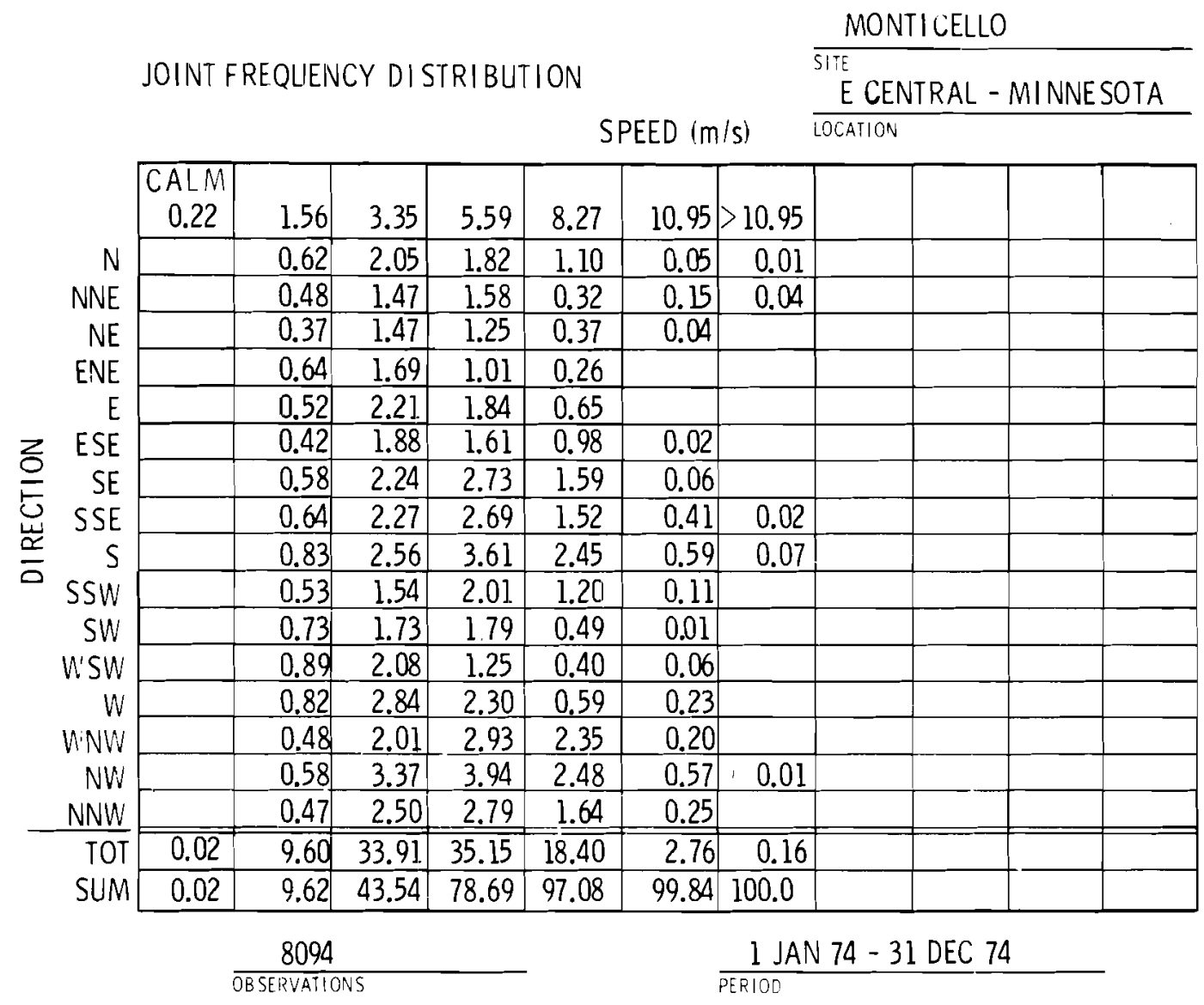

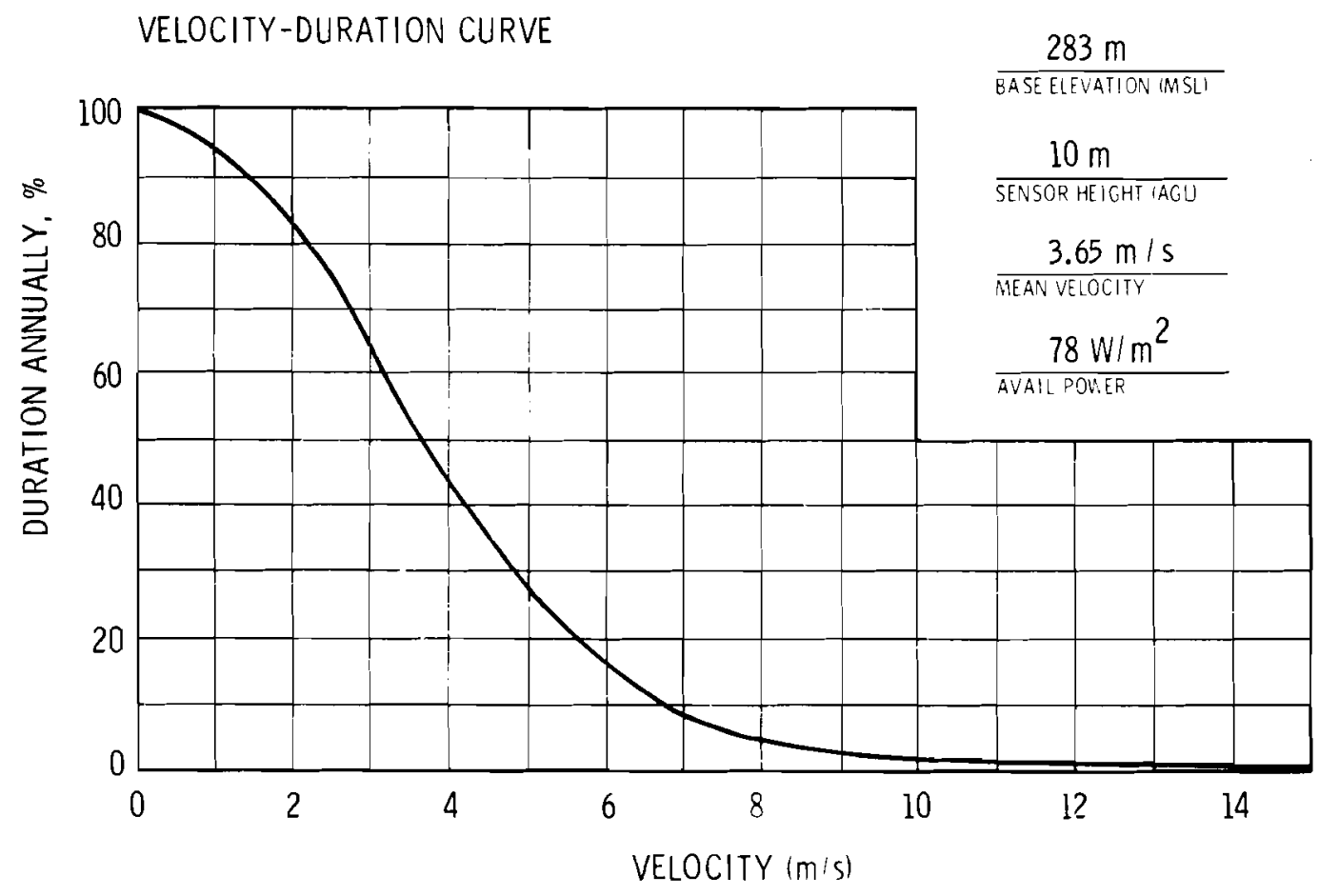




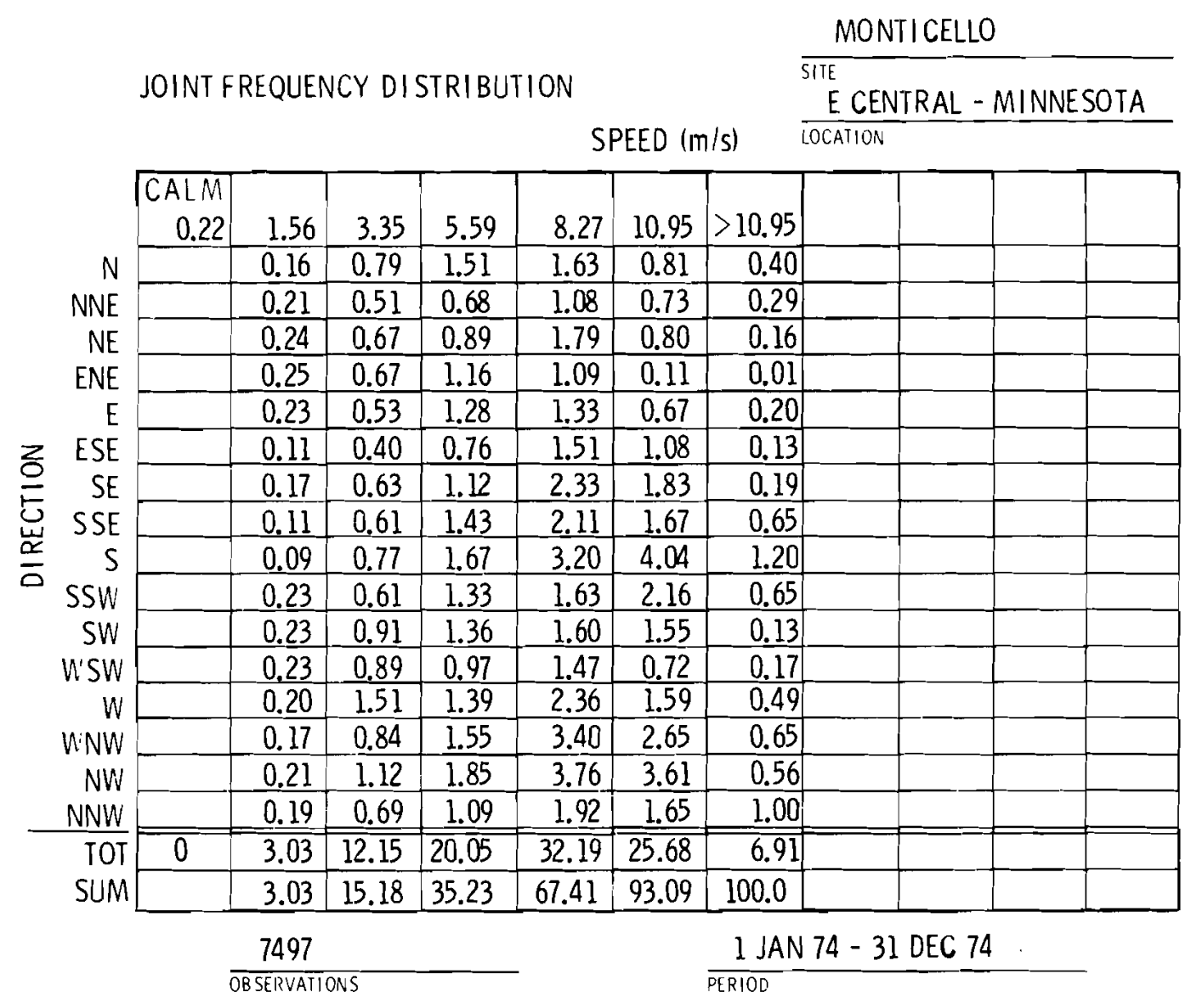

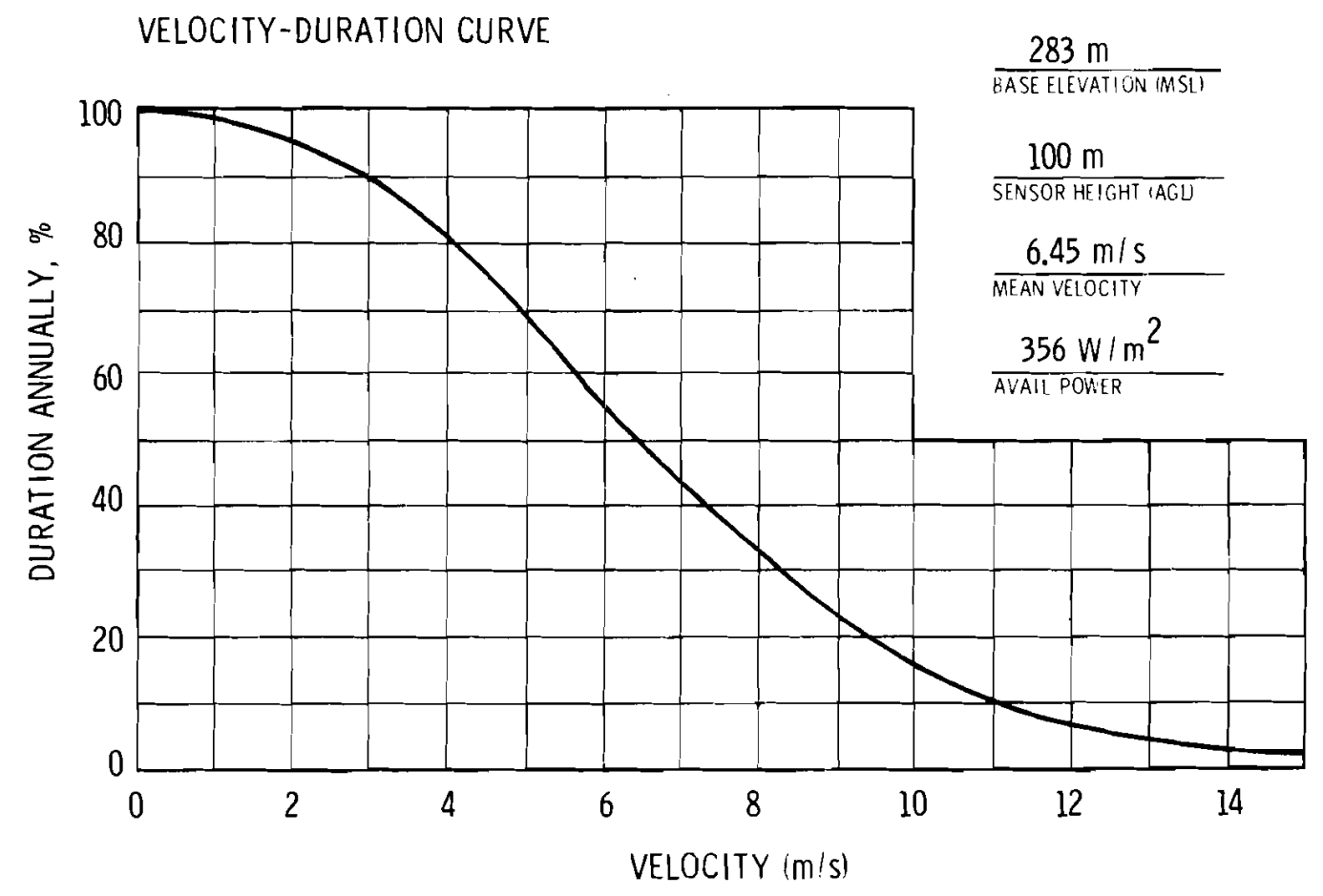




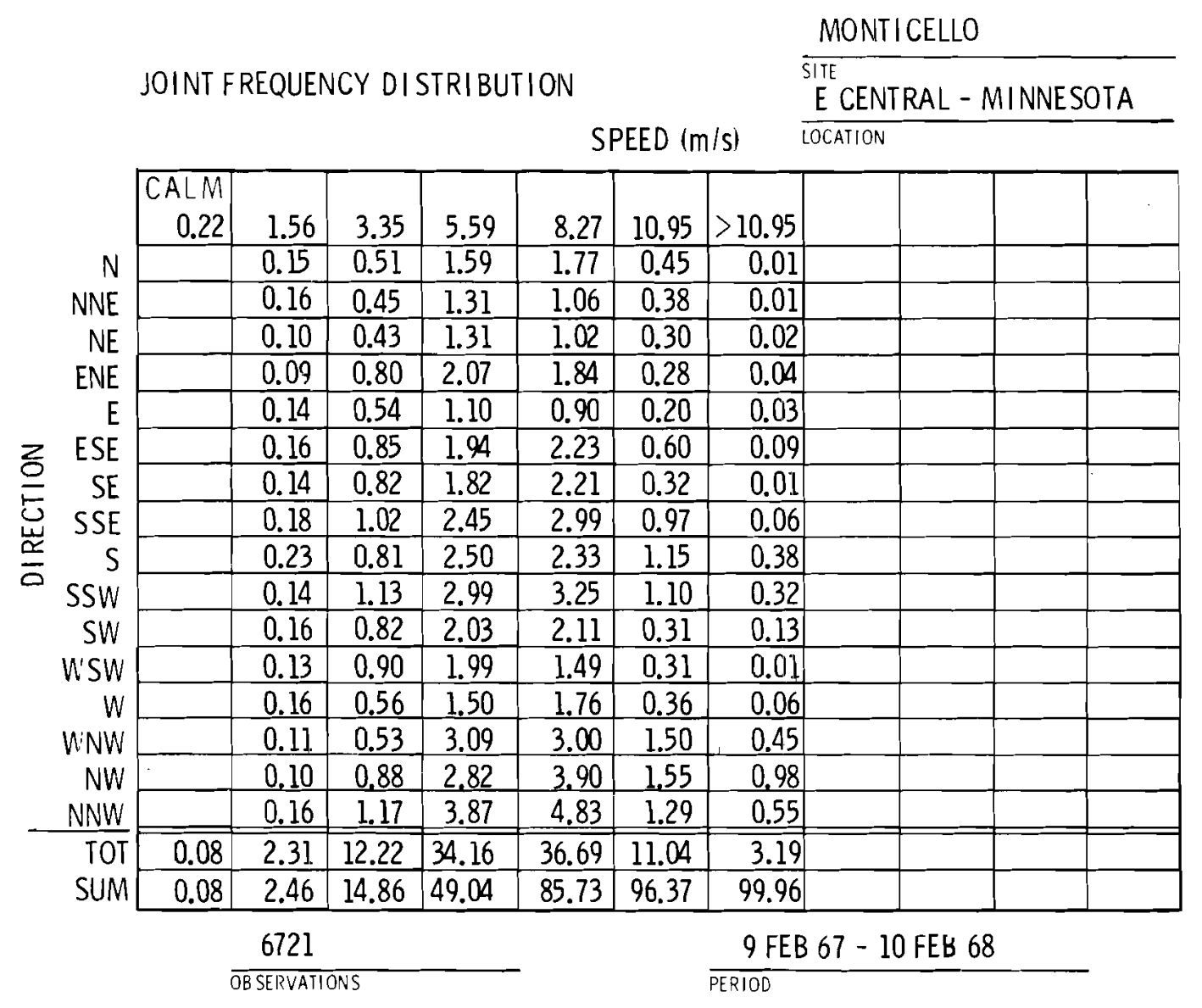

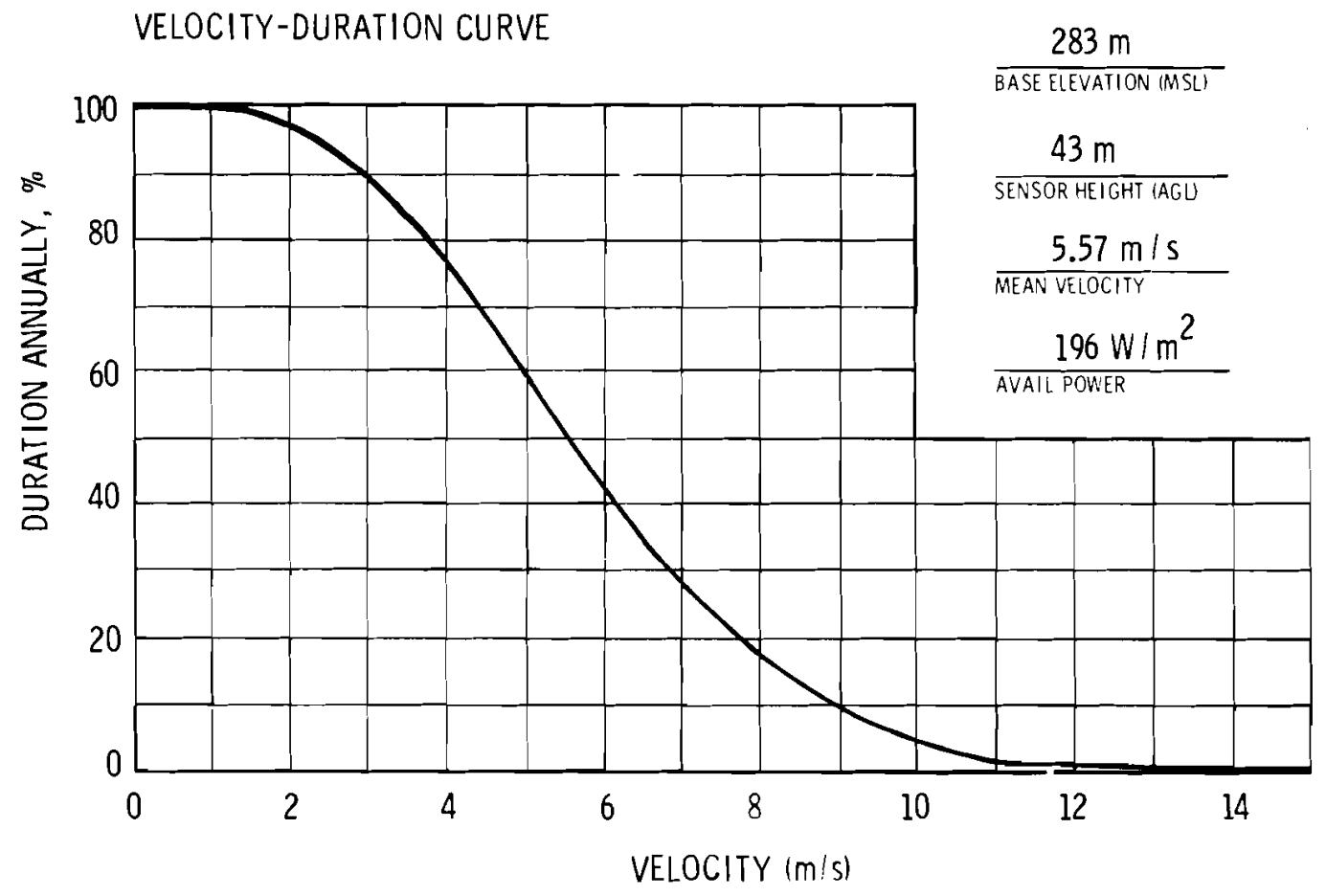


NORTH ANNA

\section{SITE LOCATION:}

The North Anna Power Station site $\left(38.06^{\circ} \mathrm{N} / 77.79^{\circ} \mathrm{W}\right)$ is $10 c a t e d$ in the NE portion of Virginia in Louisa County. The site is $10 \mathrm{~km} \mathrm{ENE} \mathrm{of} \mathrm{Mineral;} 19 \mathrm{~km} \mathrm{E}$ of Louisa; about $65 \mathrm{~km} \mathrm{NNW}$ of Richmond; $60 \mathrm{~km} \mathrm{E}$ of Charlottesville, $40 \mathrm{~km} \mathrm{SW}$ of Fredericksburg, and $110 \mathrm{~km}$ SW of Washington, D.C.

\section{TOPOGRAPHY :}

The site region is characteristic of the central Appalachian Piedmont Plateau with a gently undulating surface varying from $60 \mathrm{~m}$ to $150 \mathrm{~m}$ (MSL). The site is on a peninsula on the southern shore of a newly formed reservoir, Lake Anna. An earth dam about $8 \mathrm{~km}$ SE forms the main reservoir, which is about $27 \mathrm{~km}$ long on the North Anna River. The North Anna River flows $S E$, joining the South Anna to form the Pamunkey about $43 \mathrm{~km} \mathrm{SE}$. The region surrounding the site is covered with forest and brushwood interspersed with an occasional farm. In general, local terrain is mainly forested with few farms.

ON-SITE WIND MEASUREMENTS:

The on-site meteorological program is based on a 46-m tower instrumented with Bendix Friez "Aerovanes" at $11 \mathrm{~m}$ and $46 \mathrm{~m}$. Base elevation is at $81 \mathrm{~m}$ (MSL).

$\overline{\mathrm{NRC}}$ Docket Nos. $5 \overline{0-338,50-404}$ 


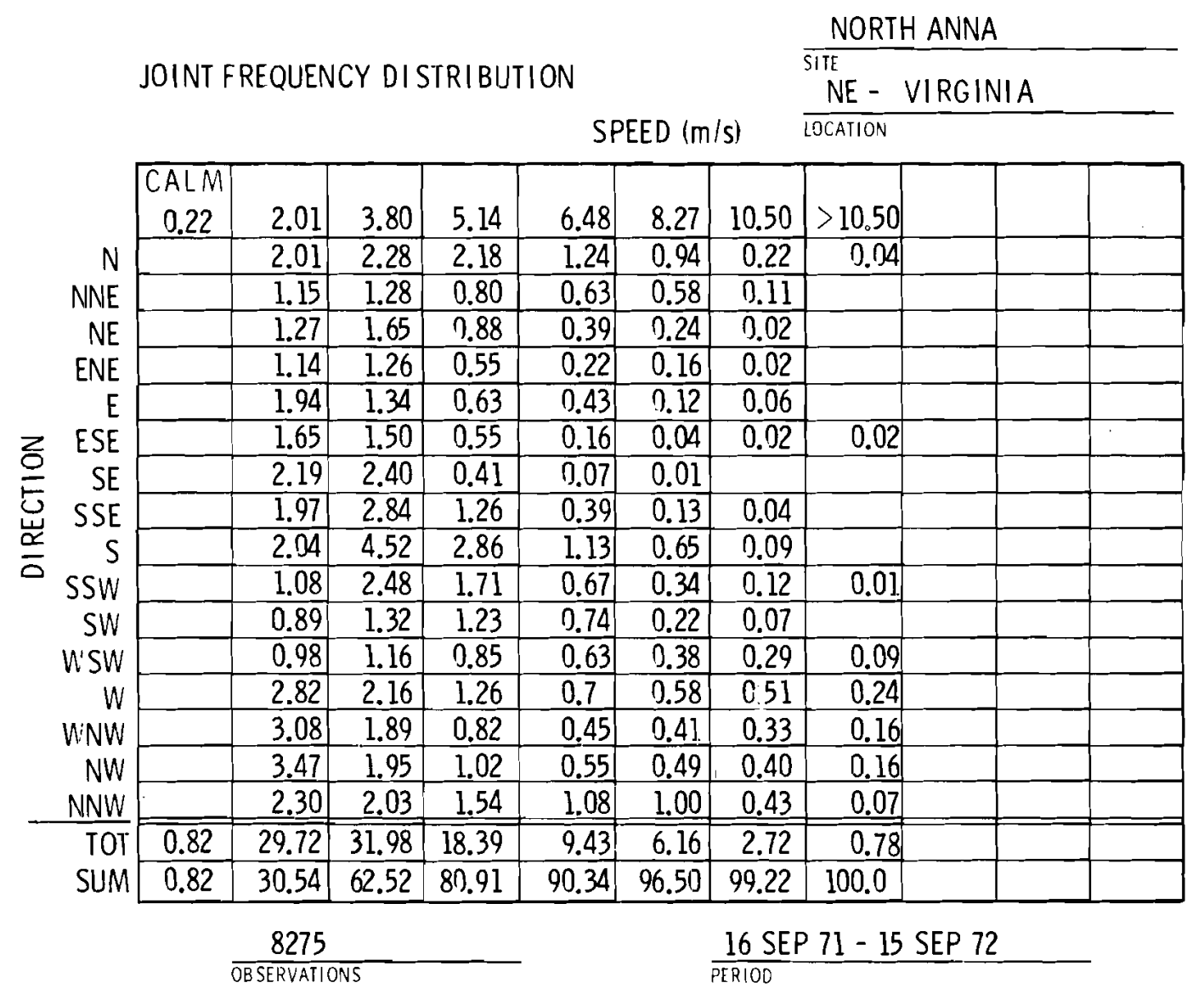

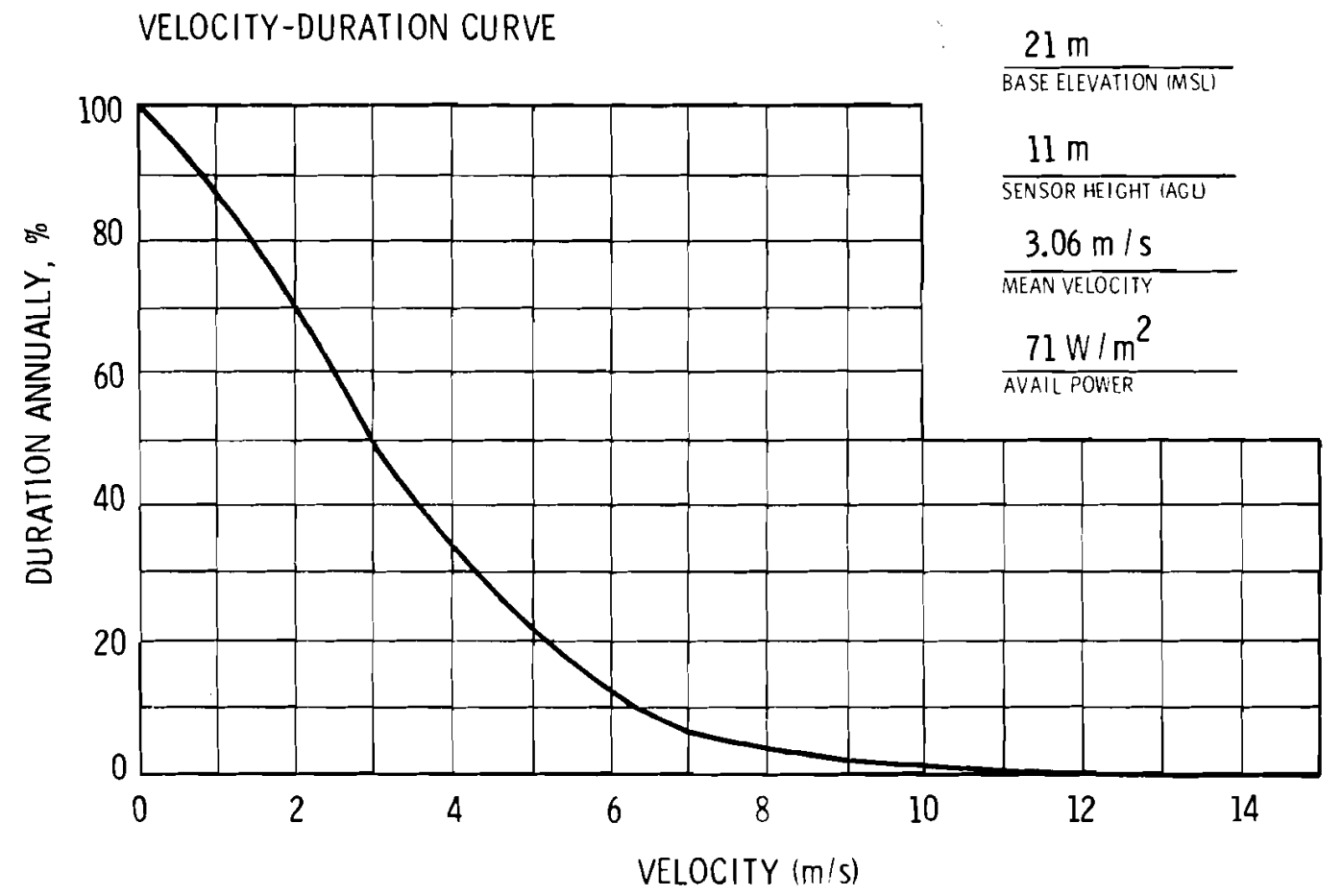




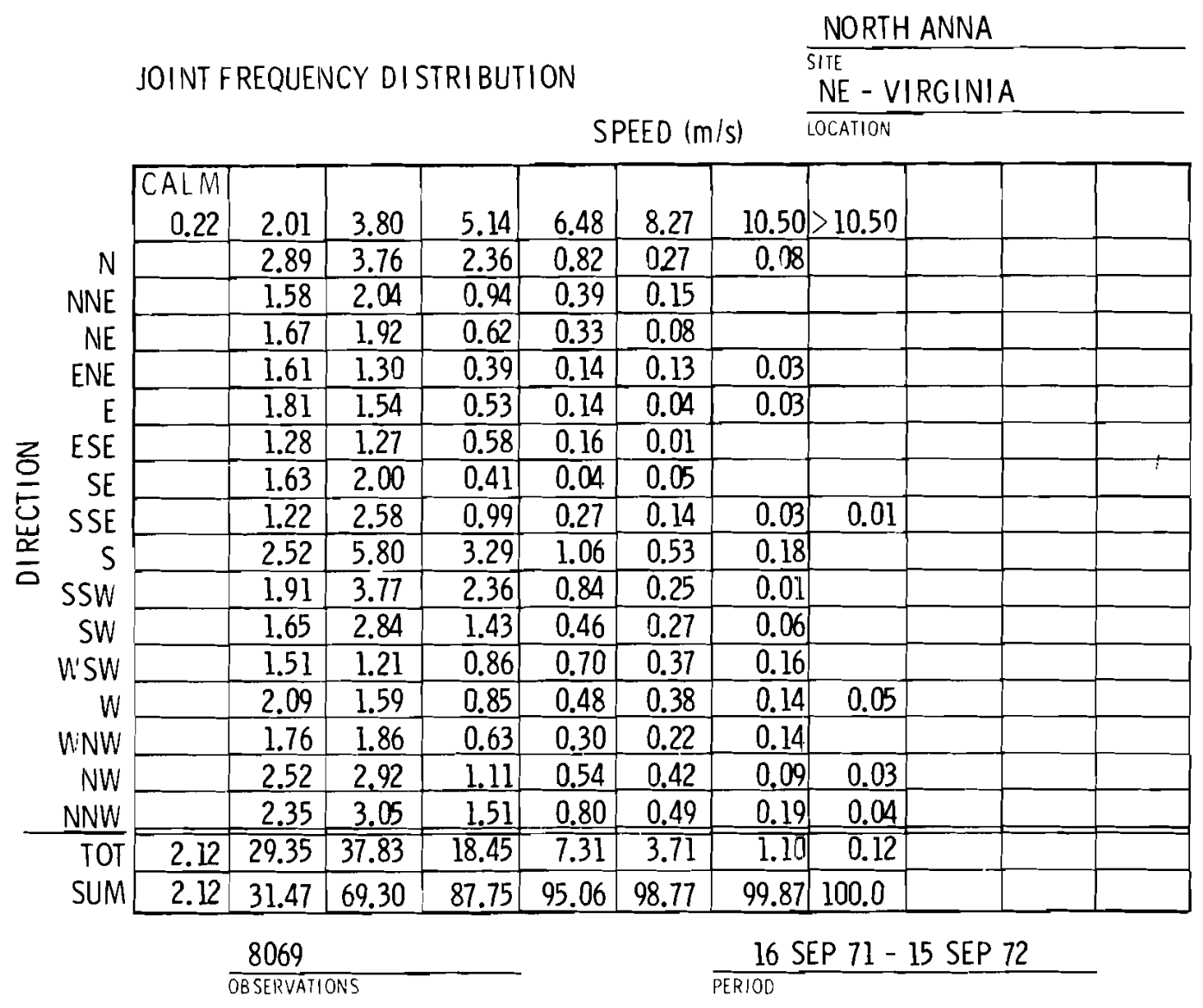

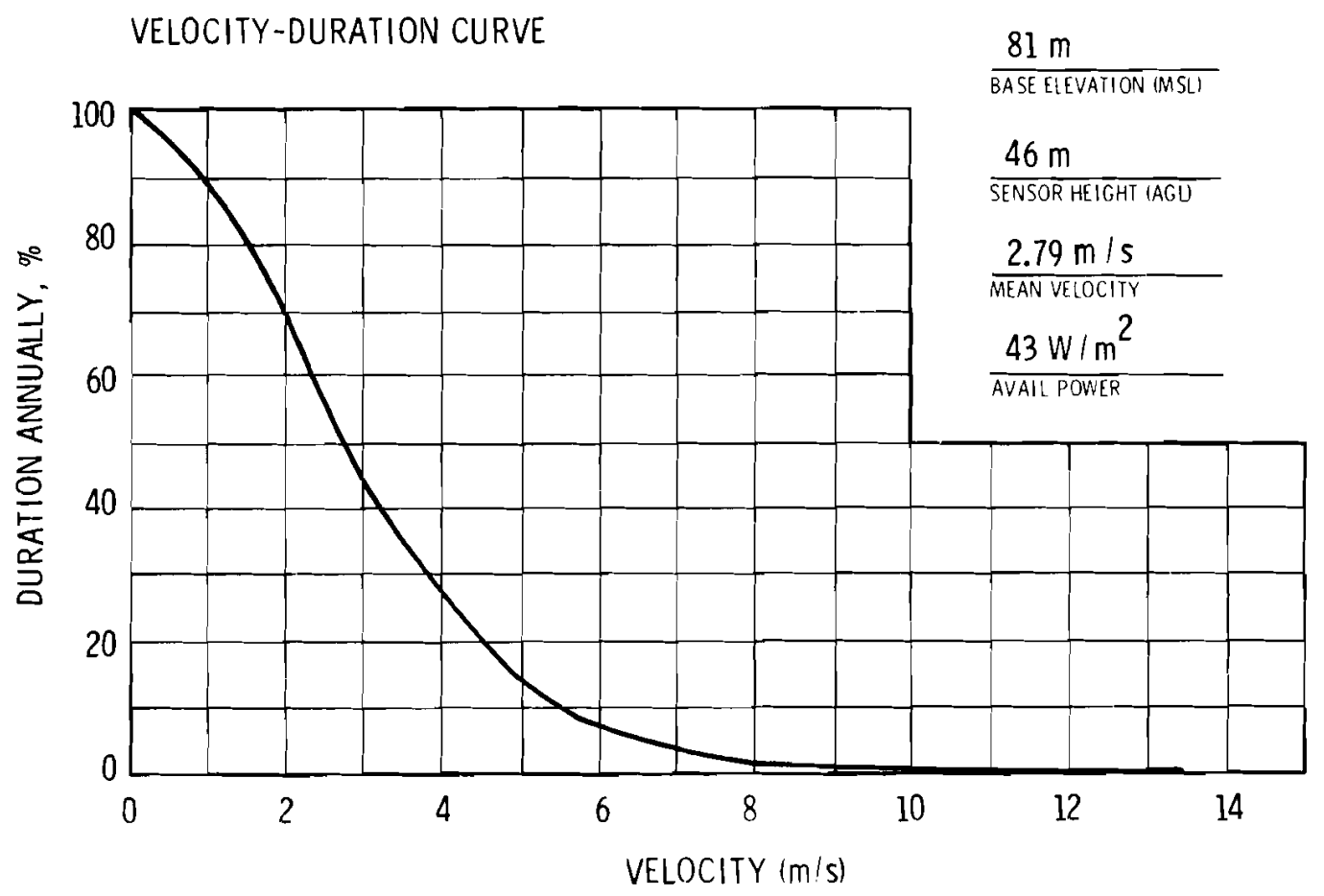


OCONEE

\section{SITE LOCATION:}

The site $\left(34.79^{\circ} \mathrm{N} / 82.90^{\circ} \mathrm{W}\right)$ is located in Oconee County, in extreme western South Carolina, about $13 \mathrm{~km} \mathrm{NE}$ of Seneca. This is also $35 \mathrm{~km} \mathrm{NW}$ of Anderson and $45 \mathrm{~km}$ WSW of Greenville. TOPOGRAPHY :

The region is characterized by the undulating terrain of the southern Appalachian Piedmont Plateau, just SE of the Smokey Mountains. Immediately $\mathrm{N}$ and $\mathrm{W}$ cf the site is Duke Power Company's Lake Keowee. To the $\mathrm{S}$ is Hartwell Reservoir. ON-SITE WIND MEASUREMENTS:

Wind measurements are made from a 46-m tower based at $243 \mathrm{~m}$ (MSL). Wind sensors, Packard-Bell WS-101 systems are at $10 \mathrm{~m}$ and $46 \mathrm{~m}$ (AGL).

NRC DOCKET Nos. 50-269, -287 


\begin{tabular}{|c|c|c|c|c|c|c|c|c|c|c|c|}
\hline & & & & & & & & OCON & & & \\
\hline & JOINT & REQUEI & CY DI & $T R I B U$ & ON & & & $\overline{\text { SIIE }}$ W - SS & OUTH & CAROLII & \\
\hline & & & & & & EED $(\mathrm{m}$ & & LOCATION & & & \\
\hline & $\overline{C A L M}$ & & & & & & & & & & \\
\hline & 0.44 & 1.49 & 2.49 & 3.49 & 4.49 & 5.49 & 6.49 & 749 & 8.49 & 9.49 & $>9.49$ \\
\hline$N$ & & 3.90 & 5.38 & 1.24 & 0.19 & 0,04 & 0.93 & 0.01 & & & \\
\hline NNE & & 2.34 & 2.24 & 1.14 & 0.20 & 0.05 & & & & & \\
\hline NE & & 1.82 & 2.61 & 2.34 & 1.26 & 0.41 & 0.13 & & & & \\
\hline ENE & & 0.97 & 1.92 & 1.62 & 1.30 & 0.51 & 0.13 & 0.07 & 0.01 & & \\
\hline$E$ & & 0.96 & 2.22 & 1.28 & 0.4 .1 & 0.16 & 0.07 & & & 0.01 & 0.91 \\
\hline$z$ ESE & & 0.88 & 1.33 & 0.57 & 0.21 & 0.03 & 0.04 & 0.01 & & & \\
\hline $\mathrm{SE}$ & & 1.18 & 1.76 & 0.67 & 0.08 & 0.01 & 0.04 & 0.03 & 0.01 & 0.01 & 0.01 \\
\hline SSE & $!$ & 1.32 & 1.96 & 1.28 & 0.37 & 0.04 & 0.04 & & 0.03 & & \\
\hline$S$ & & 1.42 & 2.18 & 1.85 & 0.48 & 0.21 & 0.04 & 0.03 & 0.01 & & \\
\hline SSW & & 1.28 & 2.24 & 2.22 & 0.98 & 0.67 & 0.14 & 0.03 & 0.03 & & 0.01 \\
\hline SW & & 1.37 & 2.72 & 2.08 & 1.13 & 0.67 & 0.41 & 0.17 & 0.05 & 0.01 & 0.01 \\
\hline W'SW & & 1.40 & 1.70 & 1.21 & 0.51 & 0.34 & 0.34 & 0.11 & 0.01 & 0.03 & 0.01 \\
\hline W & & 1.84 & 1.70 & 0.78 & 0.44 & 0.54 & 0.37 & 0.12 & 0.11 & 0.07 & 0.07 \\
\hline VINW & & 1.78 & 1.08 & 0.45 & 0.63 & 0.44 & 0.49 & 0.33 & 0.17 & 0.11 & 0.05 \\
\hline NW & & 2.05 & 1.66 & 0.25 & 0.27 & 0.32 & 0.24 & 0.09 & 0.04 & 0.03 & \\
\hline NNW & & 2.73 & 2.62 & 0.43 & 0.13 & 0.09 & 0.01 & & & & \\
\hline$\overline{\text { TOT }}$ & 0.34 & 27.26 & 35.33 & 19.43 & 8.60 & 4.54 & 2.54 & 1.00 & 0.48 & 0.27 & 0.21 \\
\hline SUM & 0.34 & 27.60 & 62.92 & 82.36 & 90.96 & 95.50 & 98.04 & 99.52 & 99.52 & 99.79 & 100.0 \\
\hline & & & & & & & & $75-$ & $\mathrm{DEC}$ & & \\
\hline
\end{tabular}

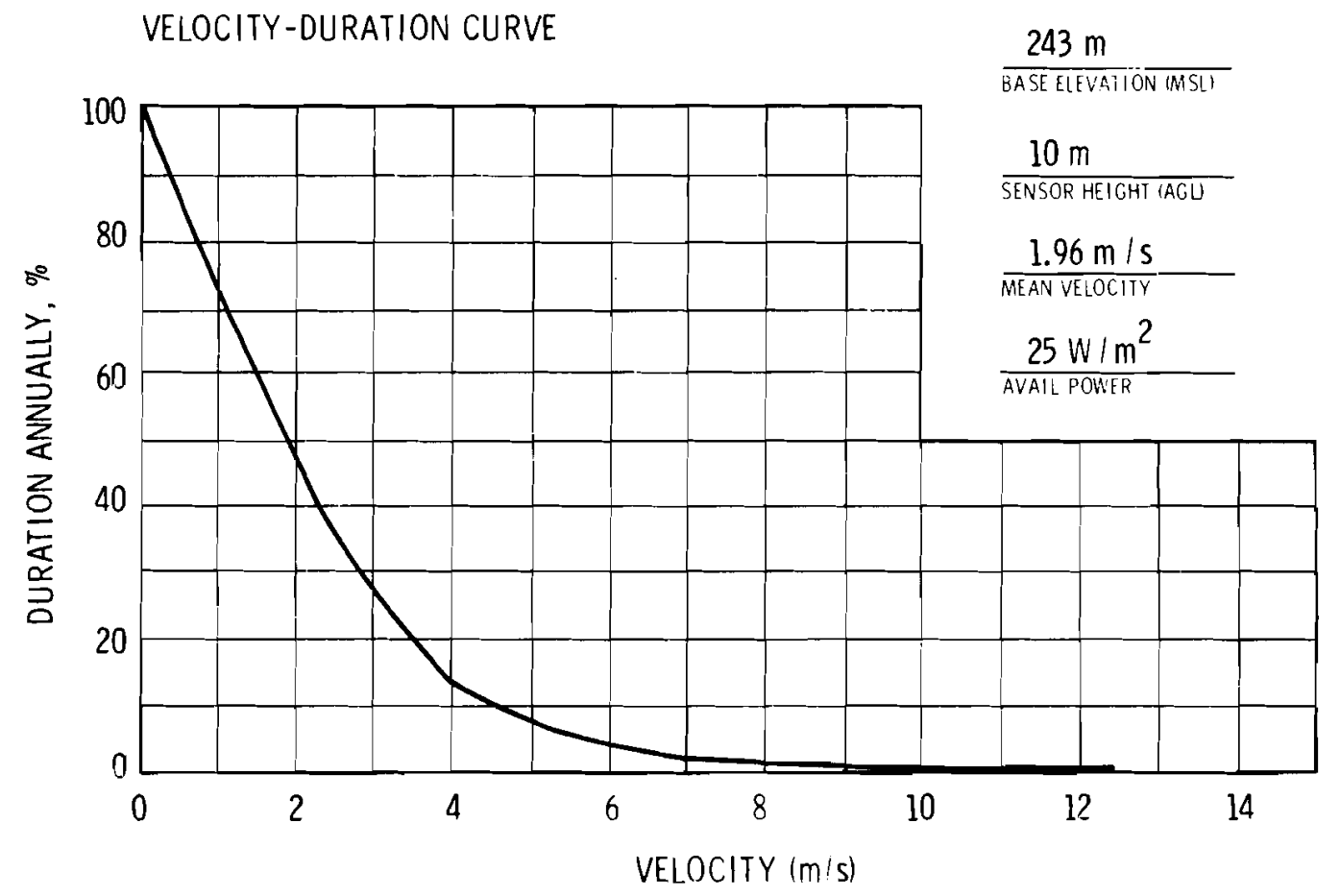




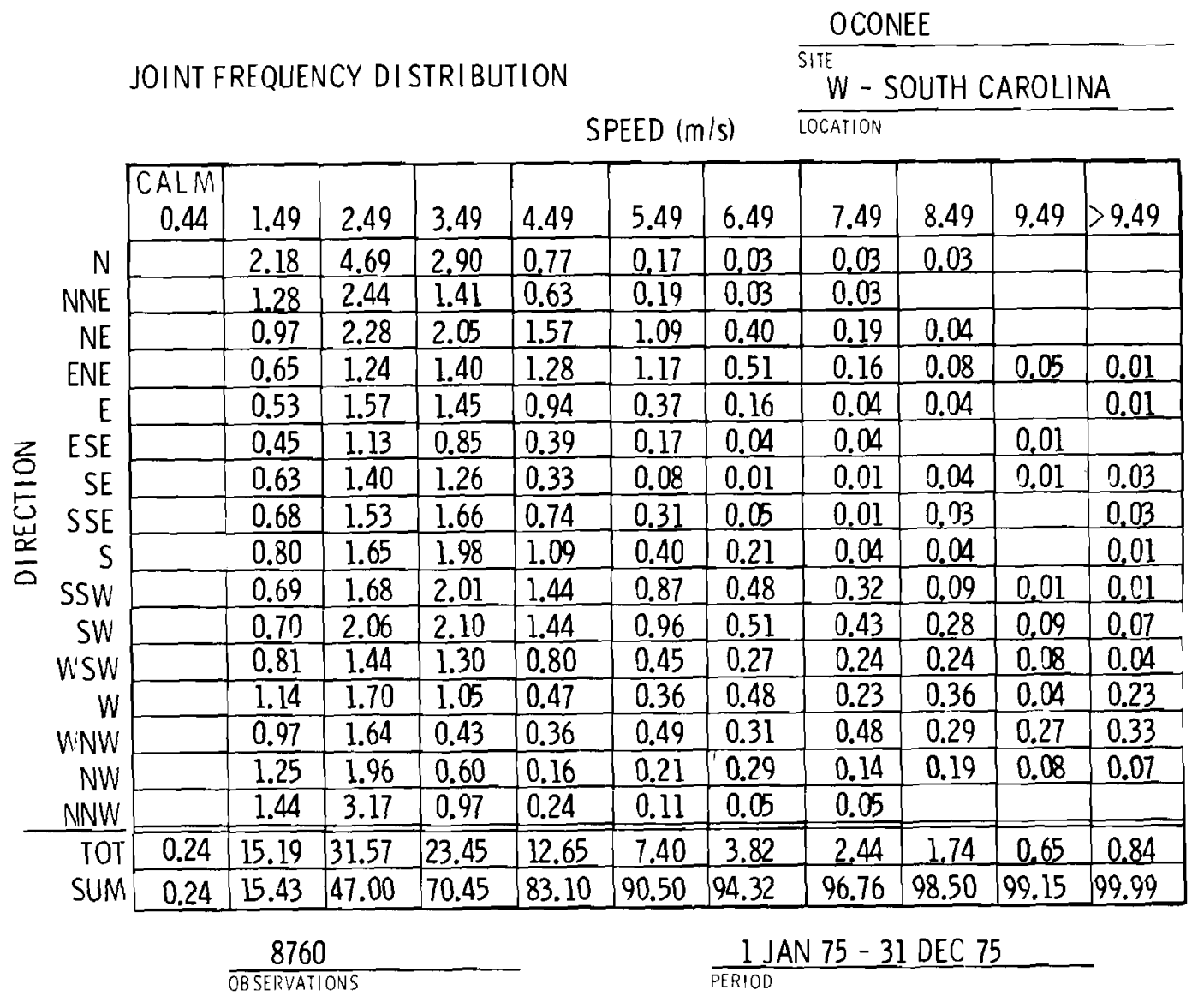

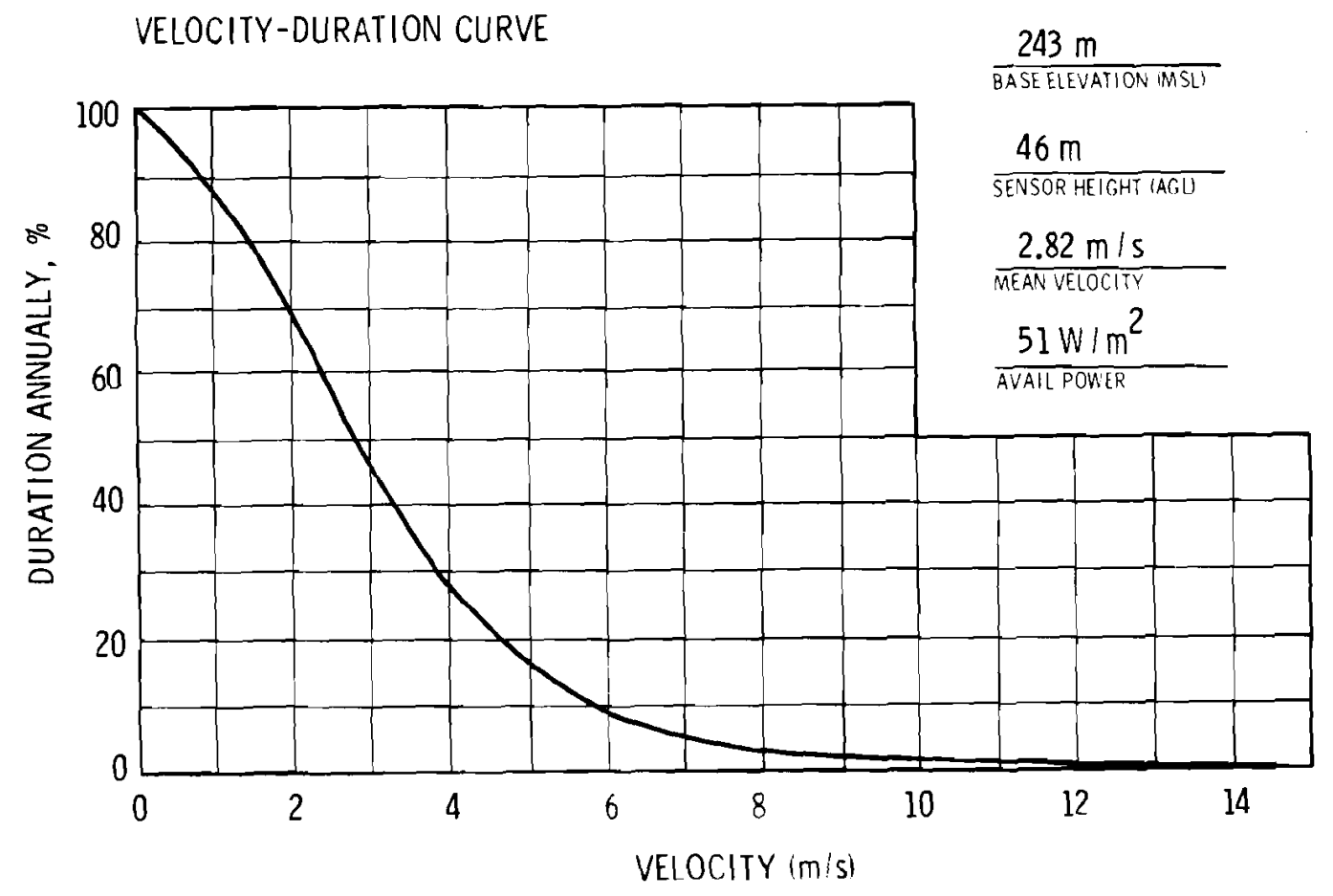




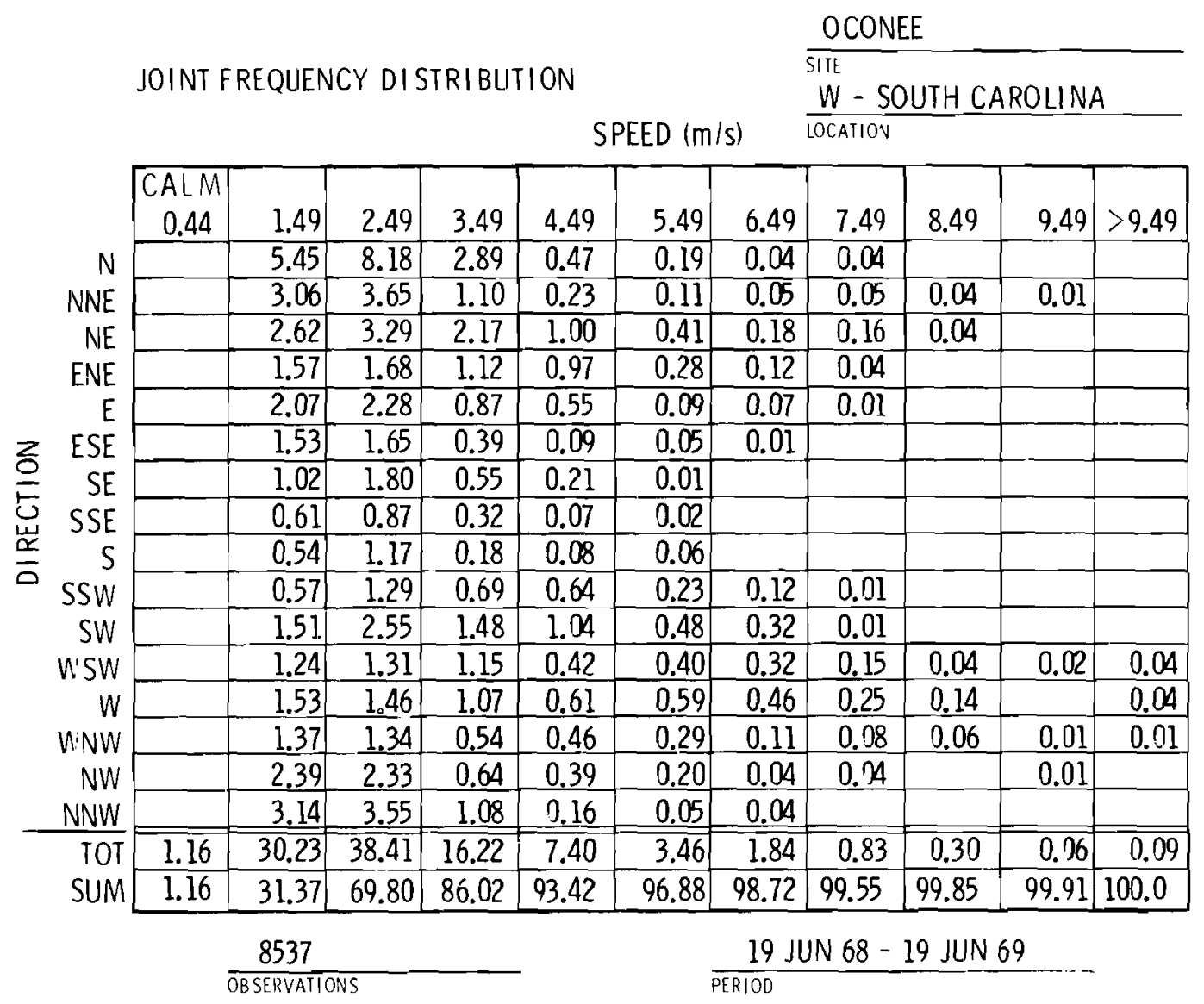

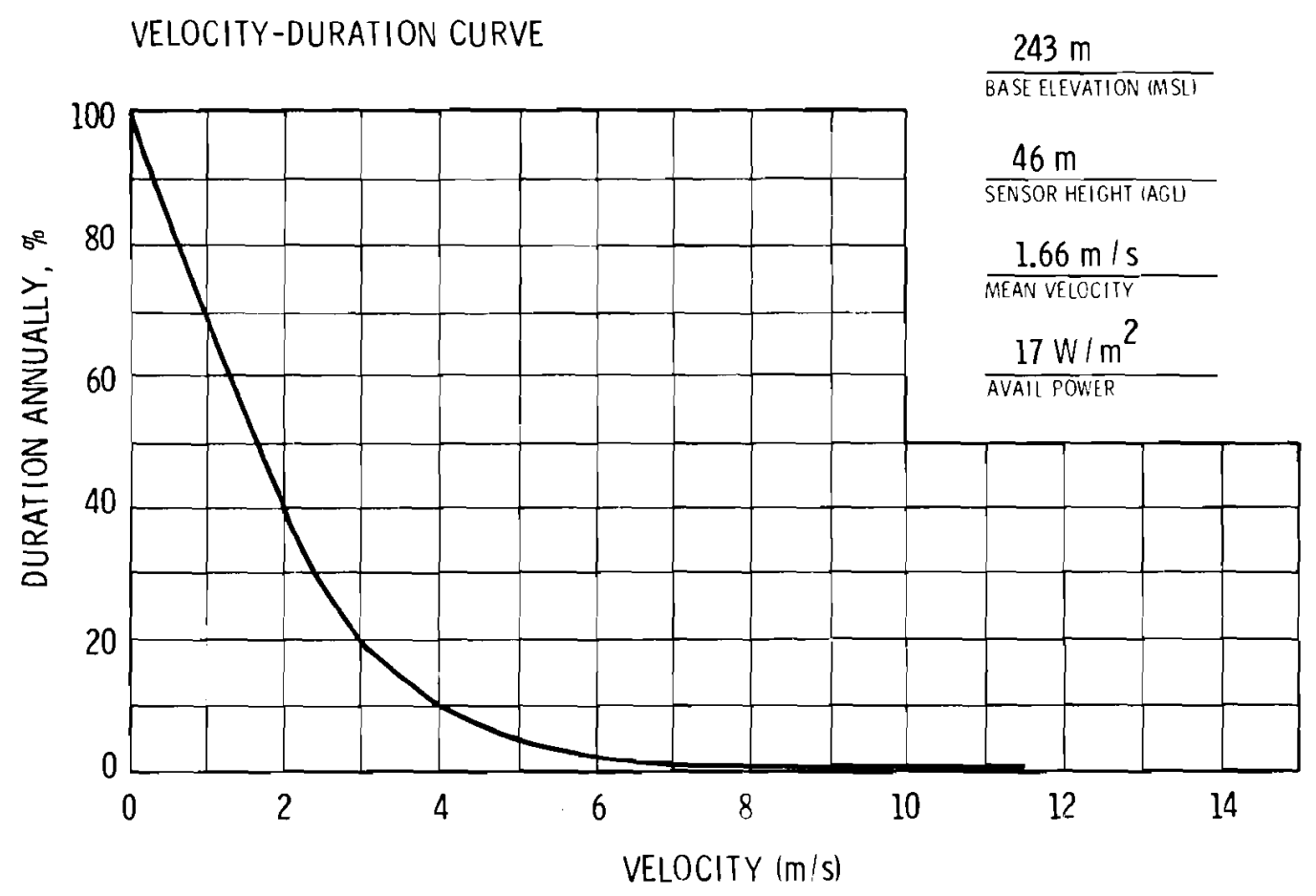


PALISADES

\section{SITE LOCATION:}

The site $\left(42.35^{\circ} \mathrm{N} / 86.23^{\circ} \mathrm{W}\right)$ is on the eastern shore of Lake Michigan, on the SW side of Van Buren County, Michigan, about $7 \mathrm{~km} \mathrm{~S}$ of South Haven. The location is also $95 \mathrm{~km} \mathrm{SW}$ of Grand Rapids and $65 \mathrm{~km} \mathrm{~W}$ of Kalamazoo.

\section{TOPOGRAPHY :}

The 487-acre site consists of rolling sand dunes which extend inland some $1500 \mathrm{~m}$ from Lake Michigan. The dunes rise from the beach level of about $180 \mathrm{~m}$ (MSL) to a maximum of about $230 \mathrm{~m} \mathrm{(MSL)} \mathrm{and} \mathrm{then} \mathrm{drop} \mathrm{off} \mathrm{abruptly} \mathrm{to} 185 \mathrm{~m} \mathrm{(MSL)} \mathrm{about}$ $750 \mathrm{~m} \mathrm{E}$ of the lakeshore. The land inland of the site is slightly rolling. The dunes are wooded, while east from the dunes, the land is partly wooded with many open fields, berry farms, and orchards.

ON-SITE WIND MEASUREMENTS:

The meteorological monitoring program at Palisades uses two 17-m towers, one inland at the eastern foot of the dunes at $185 \mathrm{~m}$ (MSL), and the other part way up the western slope of a dune with the tower base at $220 \mathrm{~m} \mathrm{(MSL).} \mathrm{Wind} \mathrm{sensors} \mathrm{are}$ Gill type propeller vanes, and data are taken every 15 minutes.

NRC Docket No. 50-255 

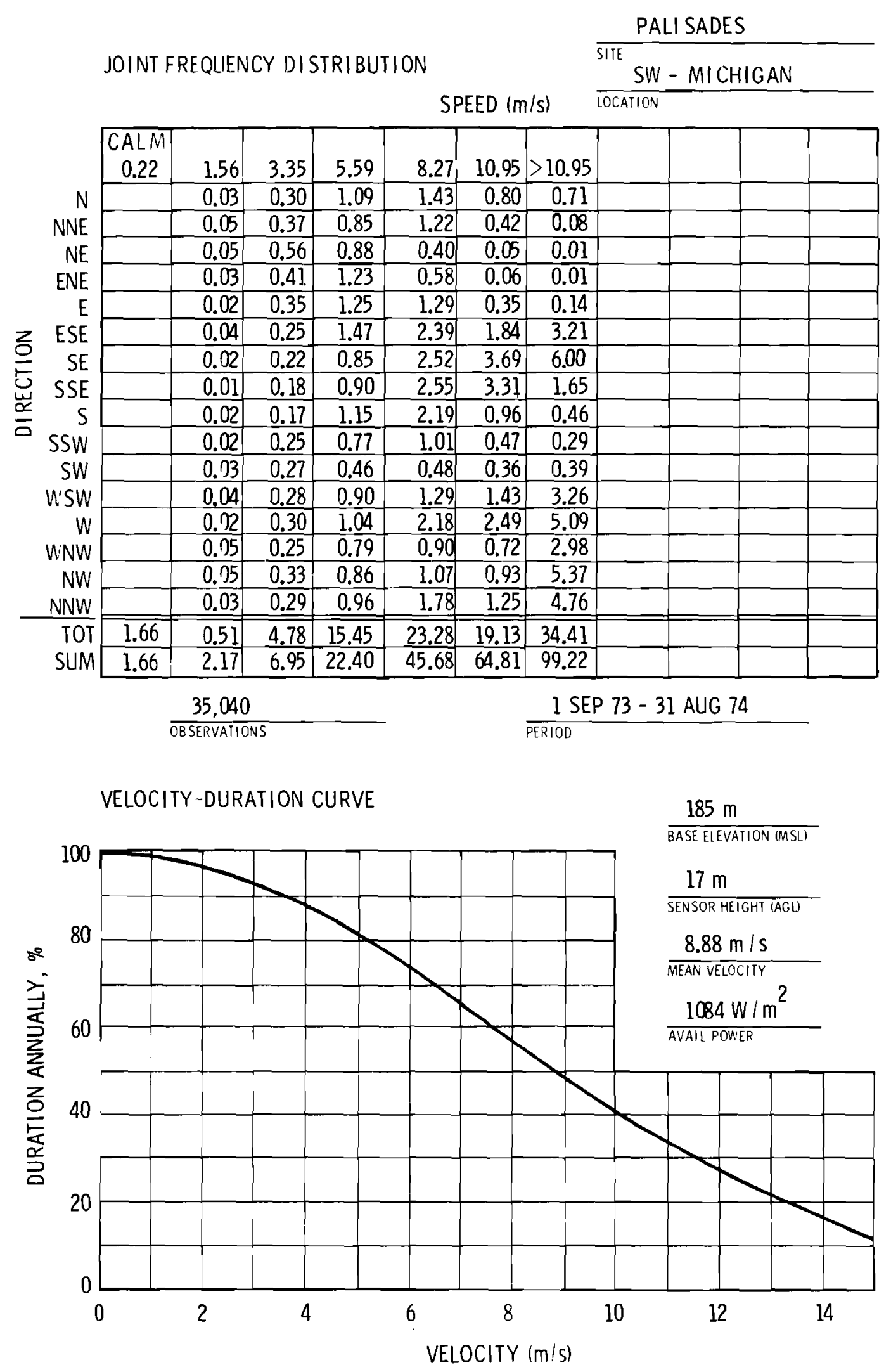
PALO VERDE

\section{SITE LOCATION:}

The site $\left(33.39^{\circ} \mathrm{N} / 112.86^{\circ} \mathrm{W}\right)$ is in Maricopa County, in SW Arizona, $24 \mathrm{~km} \mathrm{~W}$ of Buckeye, and $58 \mathrm{~km} \mathrm{~W}$ of Phoenix.

\section{TOPOGRAPHY :}

The site is rather flat with small, scattered hills often referred to as buttes. About $8 \mathrm{~km}$ to the $\mathrm{W}$ and $\mathrm{NW}$ are the Palo Verde Hills, sharply rising to over $650 \mathrm{~m}$ (MSL). Scattered hills with elevations of about $335 \mathrm{~m}$ (MSL) are numerous within $3 \mathrm{~km}$ of the site, while the site itself is at about $290 \mathrm{~m}$ (MSL).

ON-SITE WIND MEASUREMENTS:

The on-site meteorological measurement program began on $13 \mathrm{Aug}$ 1973. A 61-m tower is instrumented at $11 \mathrm{~m}$ and $61 \mathrm{~m}$ with Climet WS-011-l (speed) and Climet WD-012-10 (direction) sensors.

$\overline{\text { NRC Docket No. } 50-528}$ 


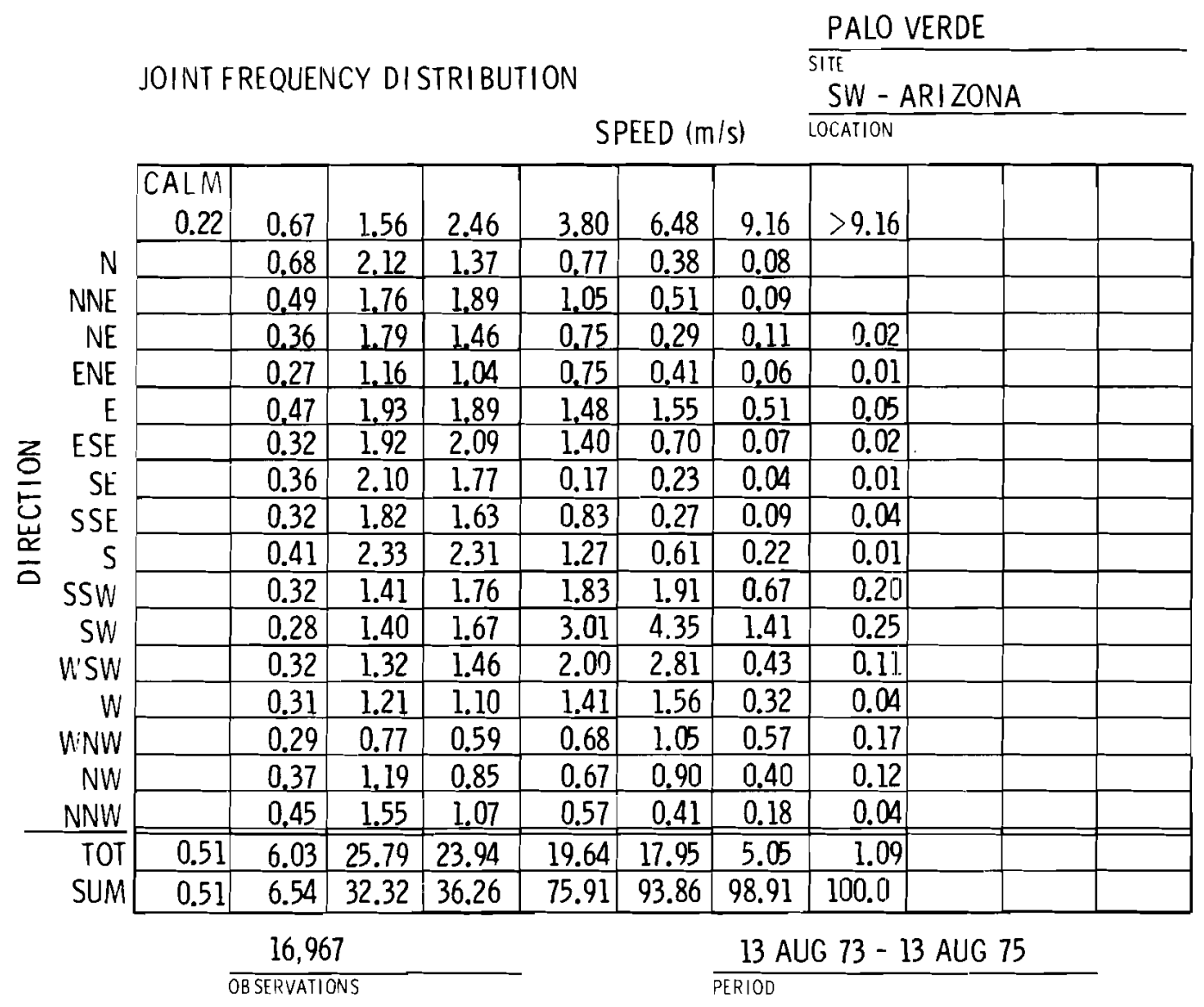

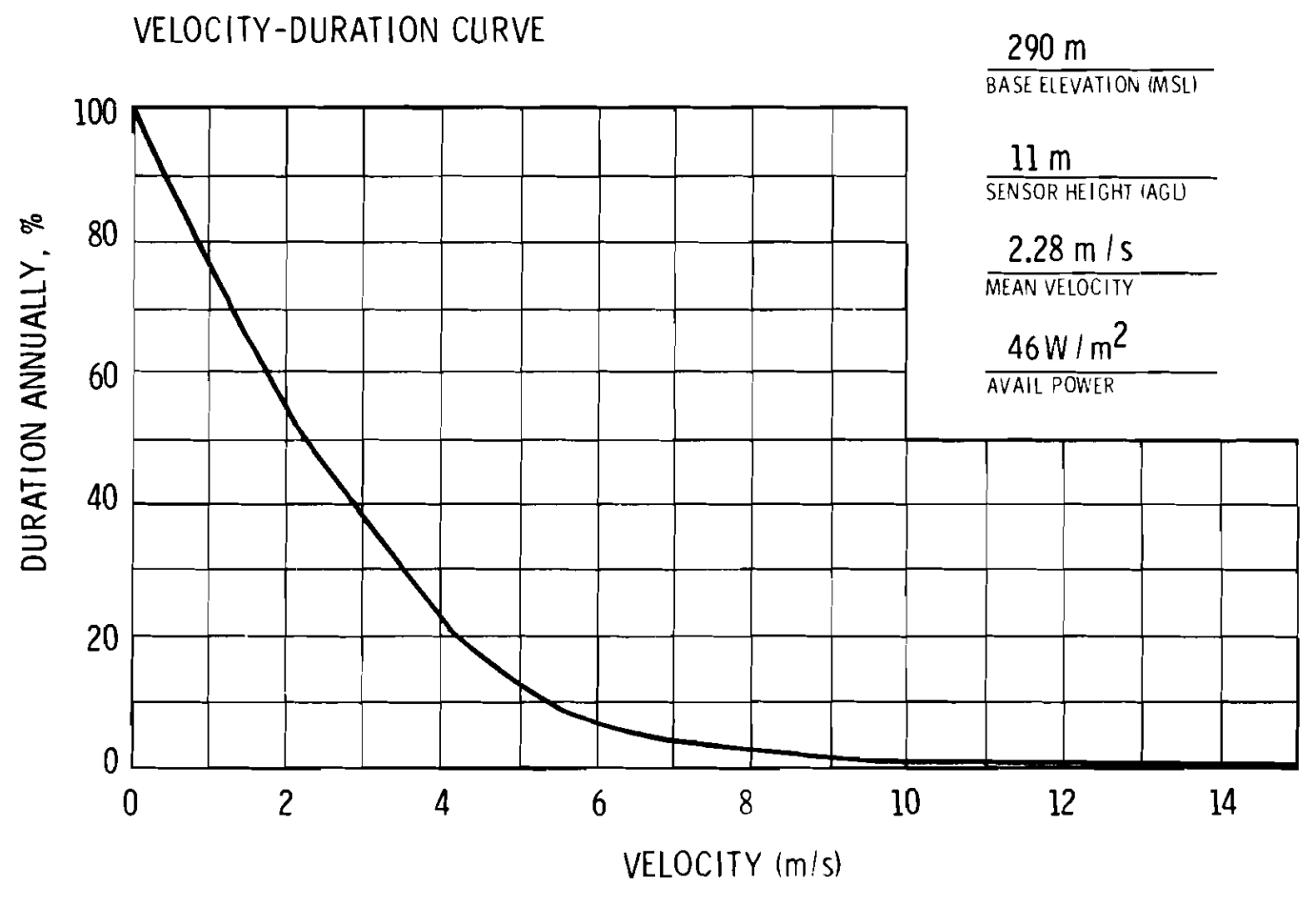




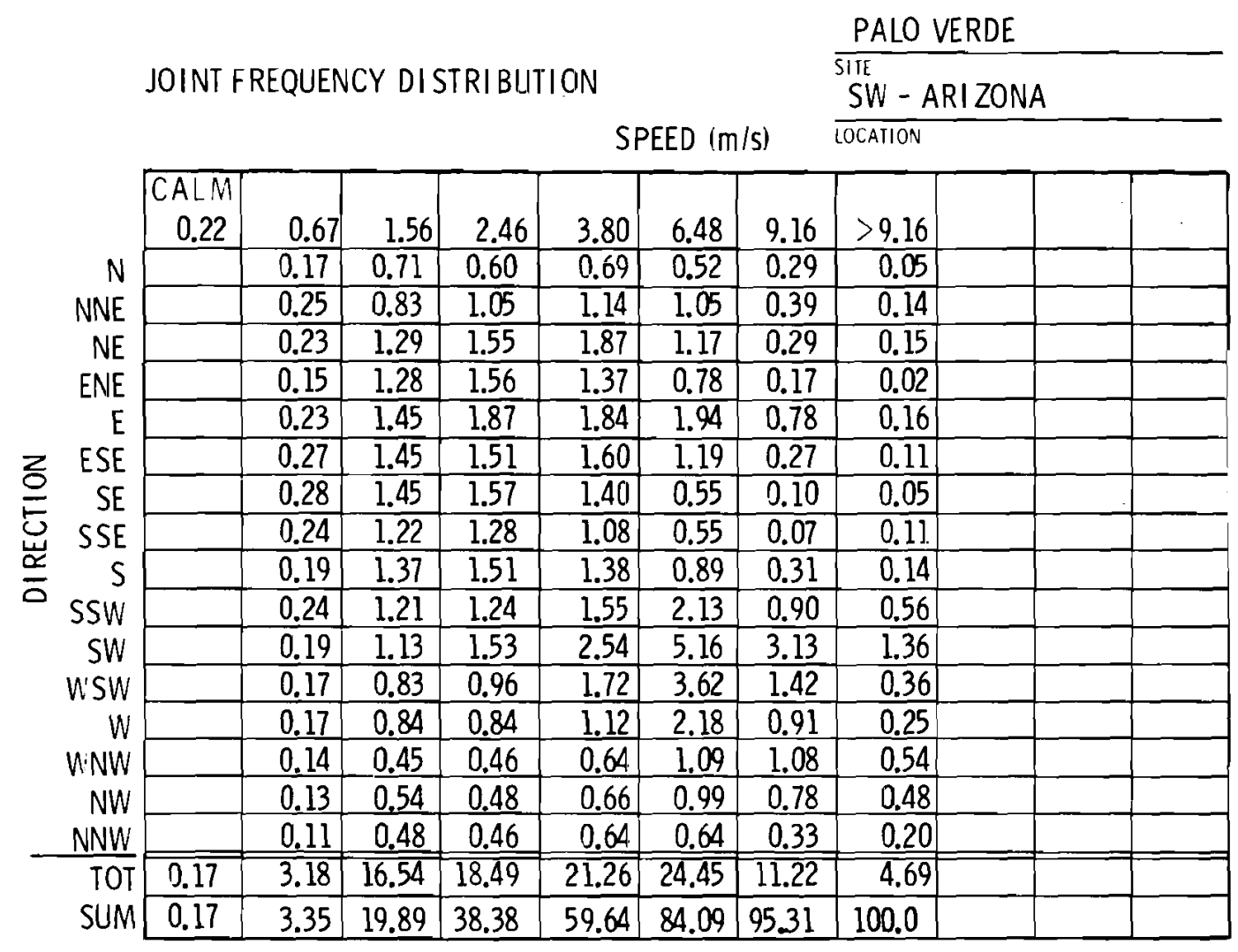

$\frac{16,594}{\text { OBSERVAIIONS }}$
13 AUG 73 - 13 AUG 75

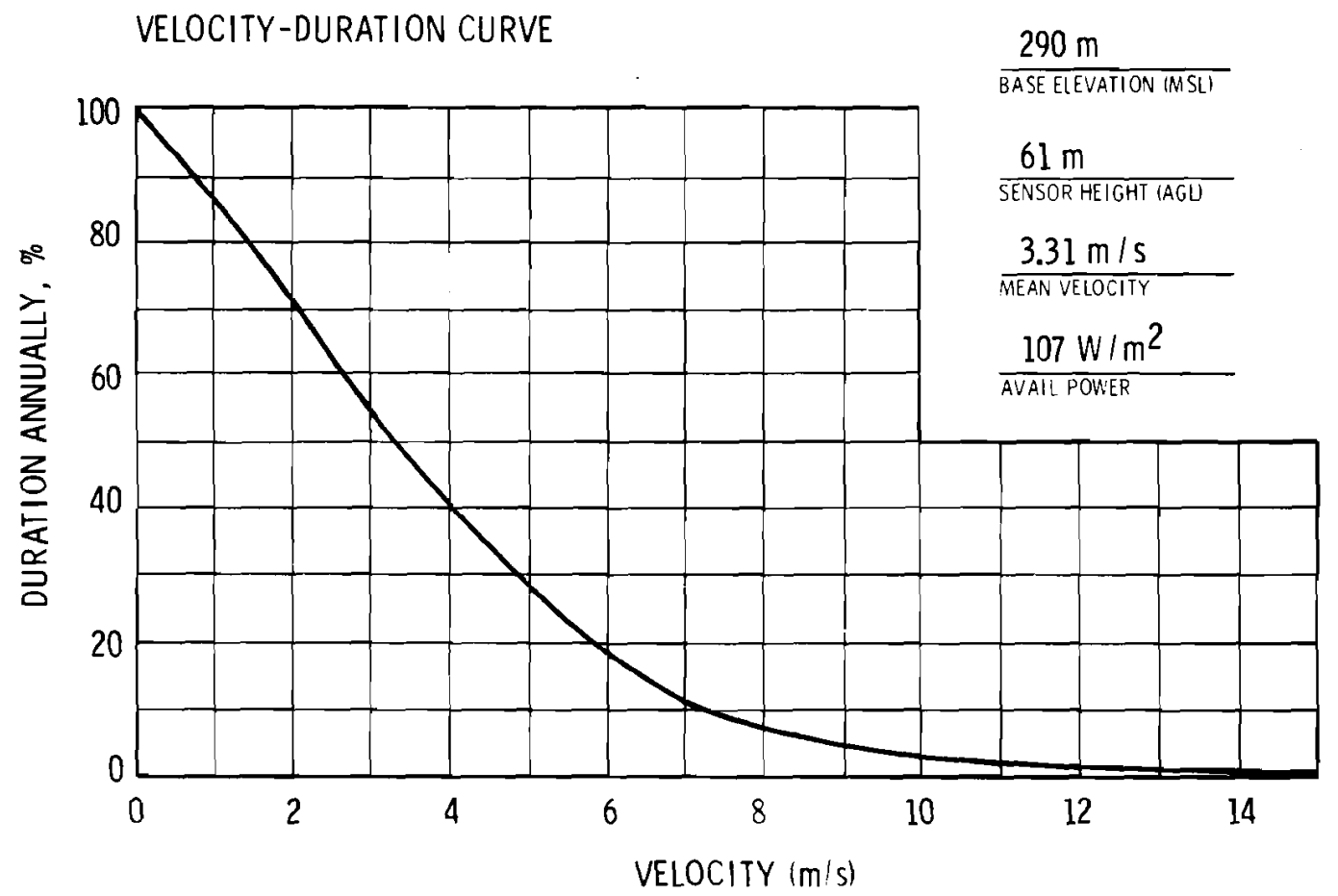


PEBBLE SPRINGS

\section{SITE LOCATION:}

The Pebble Springs site $\left(45.70^{\circ} \mathrm{N} / 120.14^{\circ} \mathrm{W}\right)$ is in Gilliam County, north central Oregon about $5 \mathrm{~km} S E$ of the Columbia River. This location is also $5 \mathrm{~km}$ ESE of Arlington, $84 \mathrm{~km} \mathrm{E}$ of Dallesport, $105 \mathrm{~km} \mathrm{~W}$ of Pendleton and $97 \mathrm{~km} \mathrm{SSE}$ of Yakima, WA.

\section{TOPOGRAPHY :}

The plant site is in the southern part of the columbia Basin. This basin area is bounded by the Cascade Range on the $w$, the high mountains of Canada to the $\mathrm{N}$, the Blue Mountains and $\mathrm{N}$ Idaho plateau to the $\mathrm{E}$ and the mountainous central oregon plateau to the S. The Columbia River Gorge cuts through the Cascades to the $W$. The site is in the $W$ end of a large plain which slopes downward from the mountainous plateau of north central Oregon to the Columbia River at $60 \mathrm{~m}$ (MSL). The mountainous plateau on the $\mathrm{N}$ side of the river and the higher ground to the $W$ mark the eastern end of the Columbia Gorge. The immediate area can be classified as rolling. The site is at $225 \mathrm{~m}$ (MSL) on the $\mathrm{S}$ slope of Hurlburt Flat, a broad flattopped, gently sloping ridge which rises to $275 \mathrm{~m}$ (MSL). Beyond the ridge, about $5 \mathrm{~km} \mathrm{~S}$, the slope upward increases markedly. About $2 \mathrm{~km} \mathrm{~W}$ is a 90-m deep, $\mathrm{N}-\mathrm{S}$ canyon with steep walls. About $6 \mathrm{~km} \quad \mathrm{E}$ is another similar steep-walled canyon oriented NNE-SSW.

\section{ON-SITE WIND MEASUREMENTS:}

A meteorological measurement program began in late December, 1973, using a 70-m tower instrumented at $9 \mathrm{~m}, 40 \mathrm{~m}$, and $70 \mathrm{~m}$ with MRI 1074-1 wind systems. Tower base is at about $220 \mathrm{~m}$ (MSL).

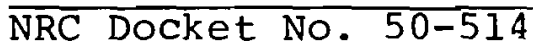


JOINT FREQUENCY DISTRIBUTION

PEBBLE SPRINGS

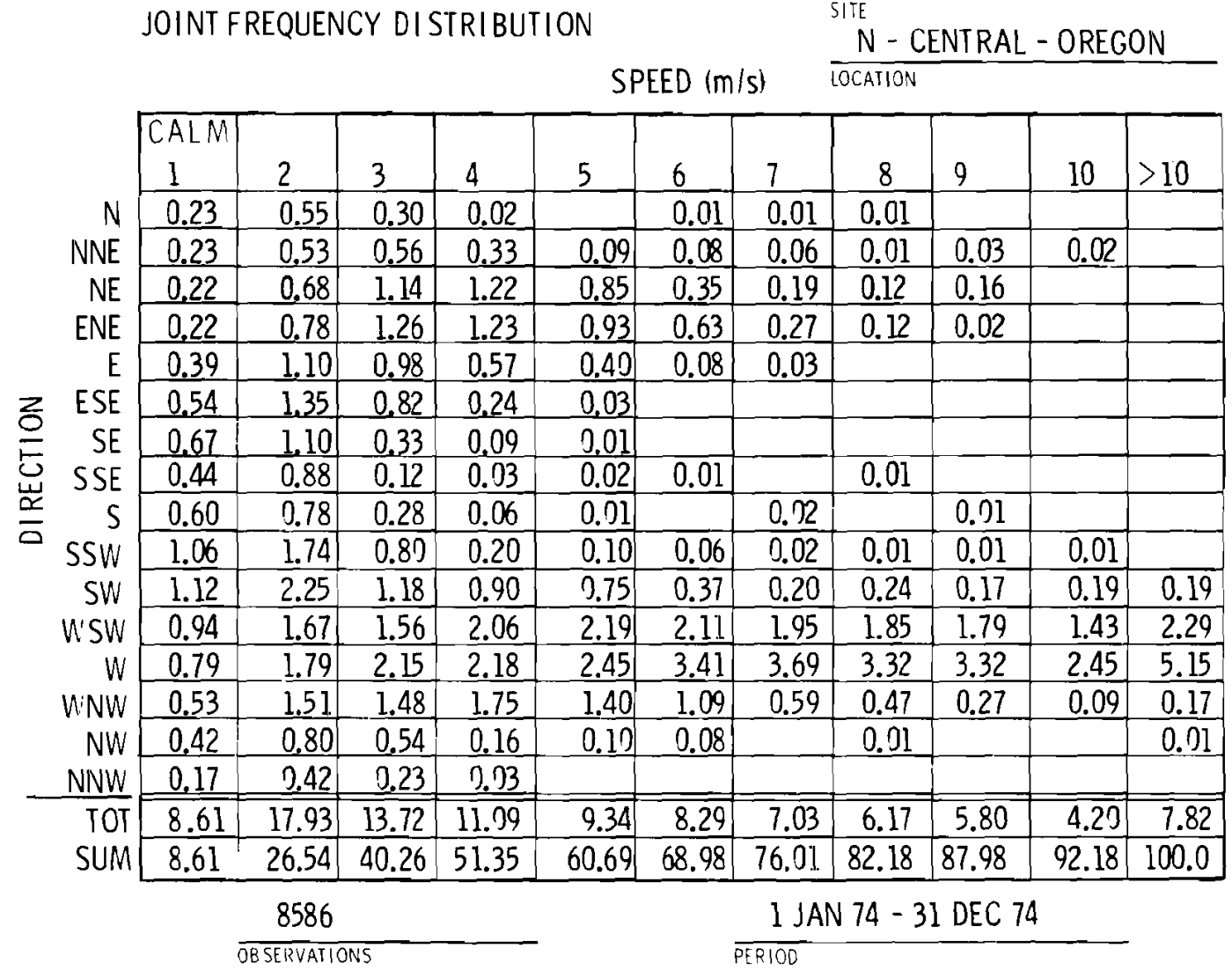

VELOCITY-DURATION CURVE

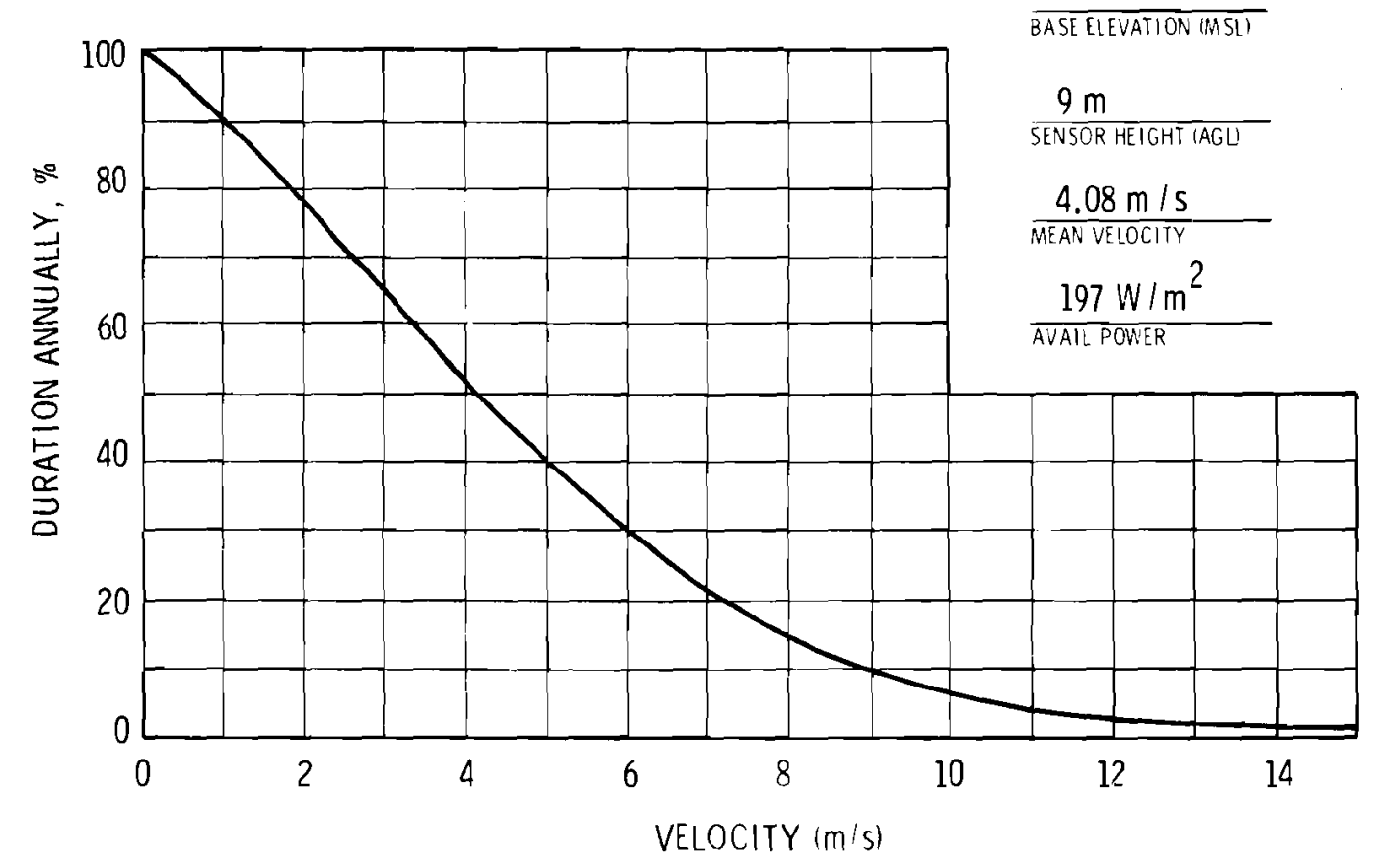




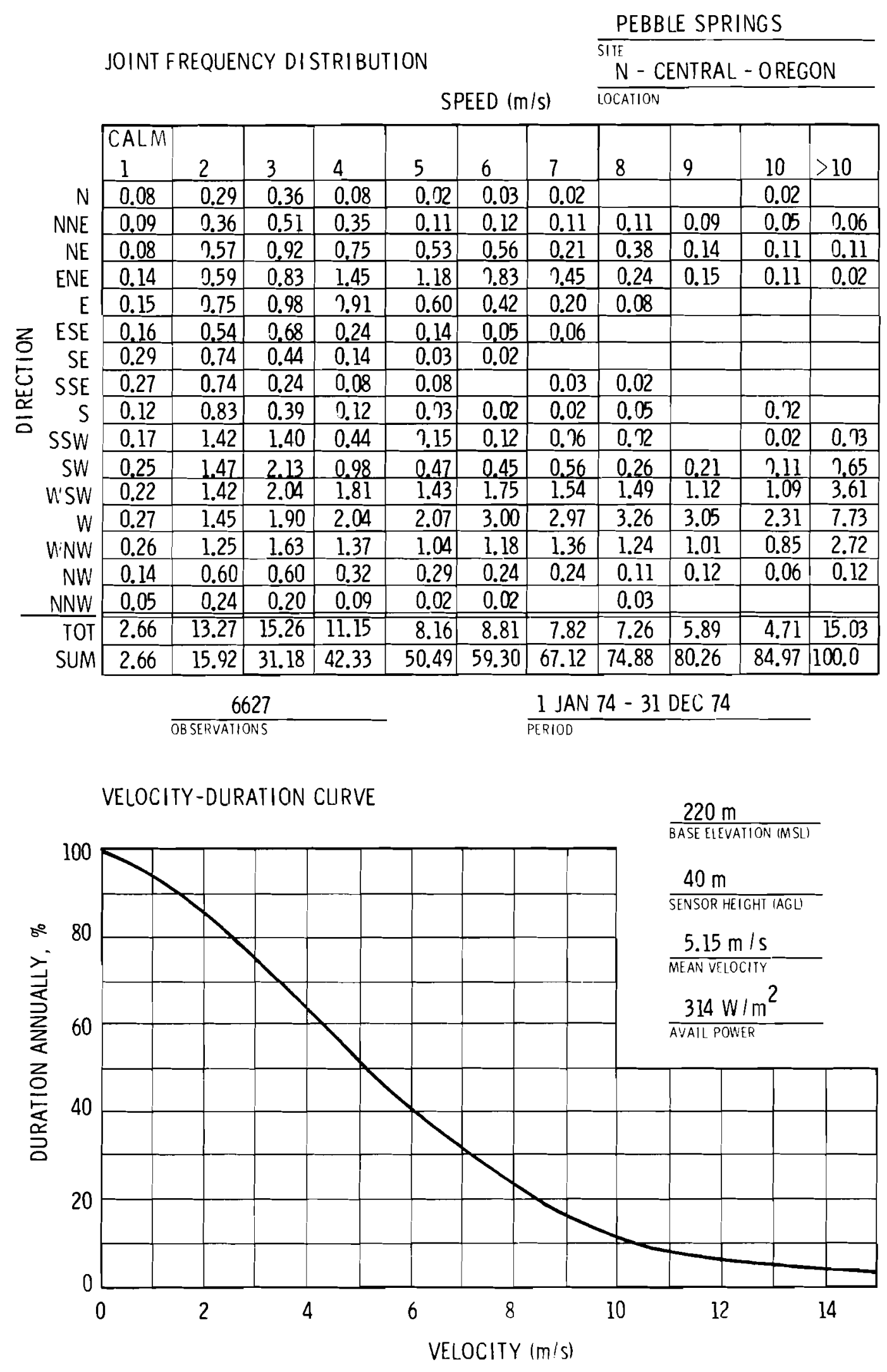




\begin{tabular}{|c|c|c|c|c|c|c|c|c|c|c|c|}
\hline & & & & & & & & PEBBL & E SPR & & \\
\hline & JOINT F & ZEQUEN & CY DI & TRIBU & ON & & & $\overline{\mathrm{STE}} \mathrm{N}-\mathrm{CE}$ & NTRA & OREGO & \\
\hline & & & & & & EED $(m$ & & LOCATION & & & \\
\hline & CALM & & & & & & & & & & \\
\hline & 1 & 2 & 3 & 4 & 5 & 6 & 7 & 8 & 9 & 10 & $>10$ \\
\hline$N$ & 0.05 & 0.49 & $\overline{0.23}$ & 0.11 & 0.06 & 0.04 & $0.0 \mathrm{l}$ & 0.03 & 0.01 & 0.03 & 0.05 \\
\hline NNE & 0.11 & 0.52 & 0.66 & 0.42 & 0.14 & 0.24 & 0.27 & 0.13 & 0.30 & 0.13 & 0.15 \\
\hline$N E$ & 0.07 & 0.47 & 1.00 & 1.04 & 0.75 & 0.49 & 0.35 & 0.13 & 0.15 & 0.10 & 0.09 \\
\hline ENE & 0.18 & 0.72 & 0.80 & 1.05 & 1.05 & 0.52 & 0.44 & 0.18 & 0.09 & 0.03 & 0.94 \\
\hline$E$ & 0.07 & 0.64 & $\overline{0.63}$ & 0.66 & 0.43 & 0.34 & 0.19 & 0.10 & & & \\
\hline ESE & 0.07 & 0.68 & 0.44 & 0.22 & 0.10 & 0.04 & 0.03 & 0.03 & 0.01 & & 0.01 \\
\hline SE & 0.16 & 0.57 & 0.22 & 0.09 & 0.11 & & 0.01 & 0.03 & & & \\
\hline SSE & 0.16 & 0.66 & 0.19 & 0.11 & 0.06 & & 0.71 & & & & 0.01 \\
\hline $\mathrm{S}$ & 0.16 & 0.71 & 0.35 & 0.11 & 0.11 & 0.05 & 0.33 & 0.03 & & 0.01 & 0.03 \\
\hline SSW & 0,11 & 0.80 & 0.56 & 0,33 & 0,14 & 0,20 & 0.14 & 0.20 & 0.14 & 0.08 & 0.23 \\
\hline SW & 0.14 & 1.09 & 1.19 & 1.04 & 0.77 & 0,99 & 0.85 & 1.08 & 1.78 & 0.91 & 4.56 \\
\hline U'SW & 0.11 & 1.05 & 1.84 & 1.98 & 1.89 & 1.98 & 1.83 & 2.27 & 1.88 & 2.00 & 3.48 \\
\hline$W$ & 0.08 & 1.38 & 2.26 & 2.09 & 1.72 & 2.15 & 2.40 & 2.93 & 2.48 & 2.08 & 7.34 \\
\hline WNW & 0.14 & 1.04 & 1.28 & 0.65 & 0.55 & 0.60 & 0.32 & 0.39 & 0.25 & 0.28 & 0.35 \\
\hline$N W$ & 0.09 & 0.80 & 0.52 & 0.24 & 0.05 & 0.05 & 0.03 & 0.04 & 0.04 & 0.01 & 0.01 \\
\hline NNW & 0.09 & 0.37 & 0.15 & 0.11 & 0.03 & & 0.01 & & & & \\
\hline TOT & 1.81 & 12.00 & 12.32 & 10.25 & 8.02 & 7.69 & 6.91 & 7.54 & 6.44 & 5.65 & 21.36 \\
\hline SUM & 1.81 & 13.80 & 26.12 & 36.38 & 44.40 & 52.10 & 59.01 & 66.55 & 72.99 & 78.64 & 100.0 \\
\hline & & 7889 & & & & & $\frac{|\mathrm{A}|}{100}$ & $74-3$ & $D E C$ & & \\
\hline
\end{tabular}

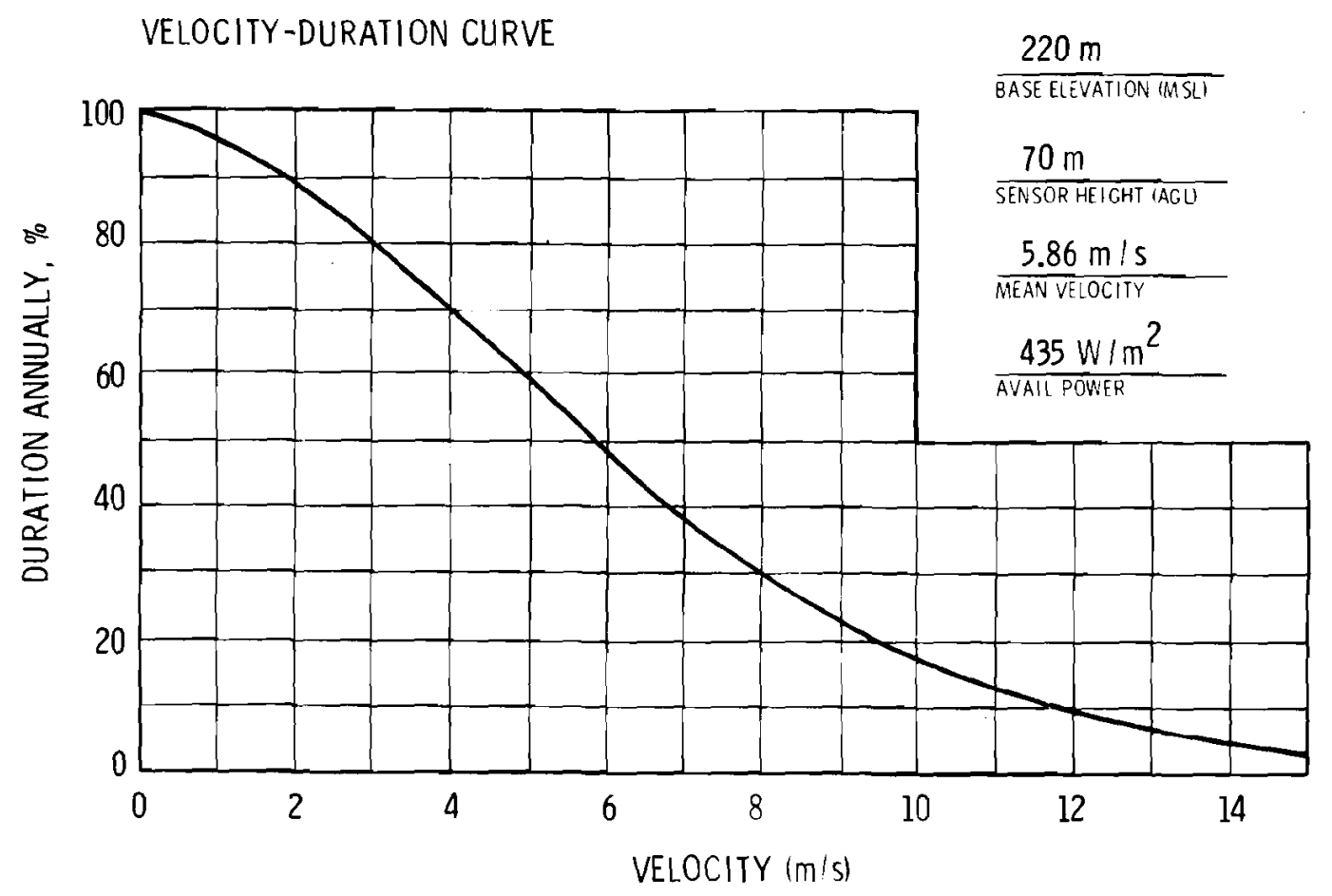


PERKINS

SITE LOCATION:

The Perkins Nuclear Station site $\left(35.85^{\circ} \mathrm{N} / 80.45^{\circ} \mathrm{W}\right)$ is located in SE Davie County in central North Carolina. The site is $11 \mathrm{~km} \mathrm{SE}$ of Mocksville, $18 \mathrm{~km} \mathrm{~W}$ of Lexington, $19 \mathrm{~km} \mathrm{~N}$ of Salisbury and about $30 \mathrm{~km}$ SW of Winston-Salem.

TOPOGRAPHY :

The site is located in the undulating Appalachian Piedmont Plateau. The Yadkin River borders the site on the $\mathrm{S}$ and is oriented ENE-WSW in this sketch. Plant elevation is about 215 m (MSL).

ON-SITE WIND MEASUREMENTS:

On-site meteorological equipment became operational on 11 Oct 1973. A 40-m tower is instrumented at $9 \mathrm{~m}$ and $40 \mathrm{~m}$, using Packard-Bell Model W/S-101B Series Wind Direction-Speed Systems.

NRC Docket No. 50-488 


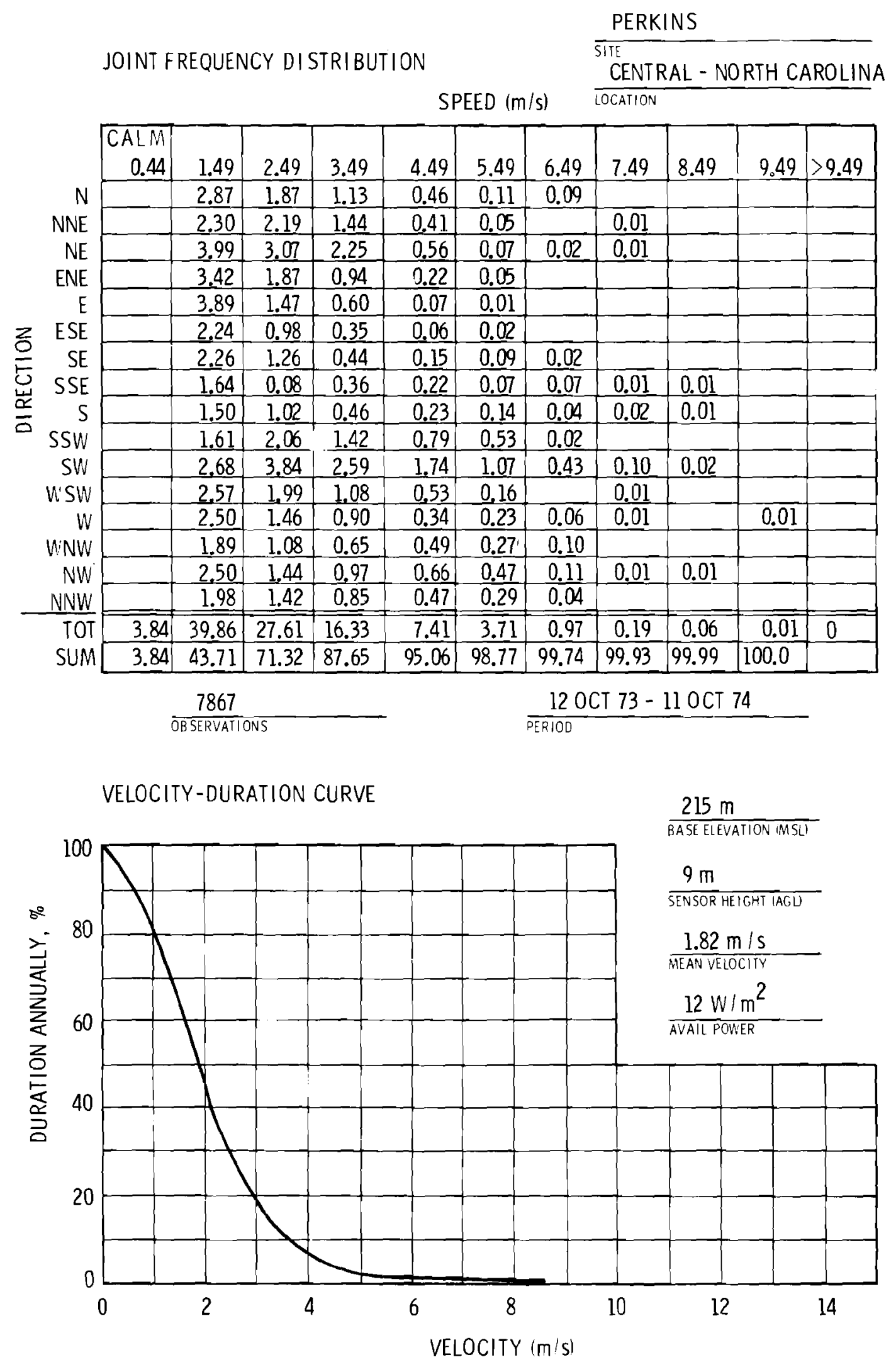


JOINT FREQUENCY DISTRIBUTION

SITE

CENTRAL - NORTH CAROLINA

SPEED $(\mathrm{m} / \mathrm{s})$

LOCATION

\begin{tabular}{|c|c|c|c|c|c|c|c|c|c|c|c|}
\hline & $\begin{array}{r}\text { CALM } \\
0.44\end{array}$ & 1.49 & 2.49 & 3.49 & 4.49 & 5.49 & 6.49 & 7.49 & 8.49 & 9.49 & $>9.49$ \\
\hline $\mathrm{N}$ & & 1.41 & 2.14 & 1.79 & 0.99 & 0.55 & 0.25 & 0.06 & 0.02 & & \\
\hline NNE & & 0.71 & 1.95 & 1.90 & 1.06 & 0.61 & 0.12 & 0.05 & 0.01 & 0.02 & \\
\hline NE & & 1.28 & 2.30 & 2.83 & 2.19 & 0.58 & 0.14 & 0.04 & & 0.02 & \\
\hline ENE & & 0.73 & 1.46 & 1.61 & 0.75 & 0.32 & 0.06 & 0.06 & & & \\
\hline$E$ & & 0.90 & 1.51 & 1.18 & 0.34 & 0.11 & 0.01 & & & & \\
\hline ESE & & 0.58 & 1.11 & 0.87 & 0.15 & 0.09 & 0.01 & & & & \\
\hline SE & & 0.87 & 1.54 & 0.81 & 0.27 & 0.14 & 0.11 & 0.01 & 0.01 & & \\
\hline SSE & & 0.66 & 1.36 & 1.16 & 0.43 & 0.29 & 0.17 & 0.05 & 0.01 & & \\
\hline$S$ & & 0.72 & 1.57 & 1.24 & 0.71 & 0.43 & 0.11 & 0.06 & 0.04 & 0.02 & 0.01 \\
\hline SSW & & 0.52 & 2.18 & 2.75 & 1.98 & 1.02 & 0.73 & 0.55 & 0.12 & 0.02 & 0.04 \\
\hline SW & & 1.02 & 2.95 & 3.71 & 2.18 & 1.26 & 1.11 & 0.58 & 0.40 & 0.14 & 0.06 \\
\hline W'SW & & 0.86 & 1.98 & 1.61 & 0.65 & 0.22 & 0.15 & 0.06 & & 0.01 & \\
\hline$W$ & & 0,67 & 1.75 & 1.08 & 0,61 & 0.41 & 0.36 & 0.11 & 0.05 & 0.05 & 0.06 \\
\hline WNW & & 0.70 & 1.26 & 0.88 & 0.56 & 0.38 & 0.26 & 0.29 & 0.09 & 0.06 & 0.01 \\
\hline NW & & 0.86 & 1.56 & 1.49 & 0.81 & 0.75 & 0.53 & 0.30 & 0.24 & 0.07 & 0.04 \\
\hline NNW & & 1.03 & 1.73 & 1.32 & 0.93 & 0.66 & 0.24 & 0.17 & 0.07 & & \\
\hline TOT & 0.91 & 13.53 & 28.35 & 26.24 & 14.62 & 7.83 & 4.38 & 2.40 & 1.07 & 0.43 & 0.22 \\
\hline SUM & 0.91 & 14.44 & 42.79 & 69.03 & 83.65 & 91.48 & 95.86 & 98.26 & 99.33 & 99.76 & 99.98 \\
\hline & & & & & & & & 72 & & & \\
\hline
\end{tabular}

VELOCITY-DURATION CURVE

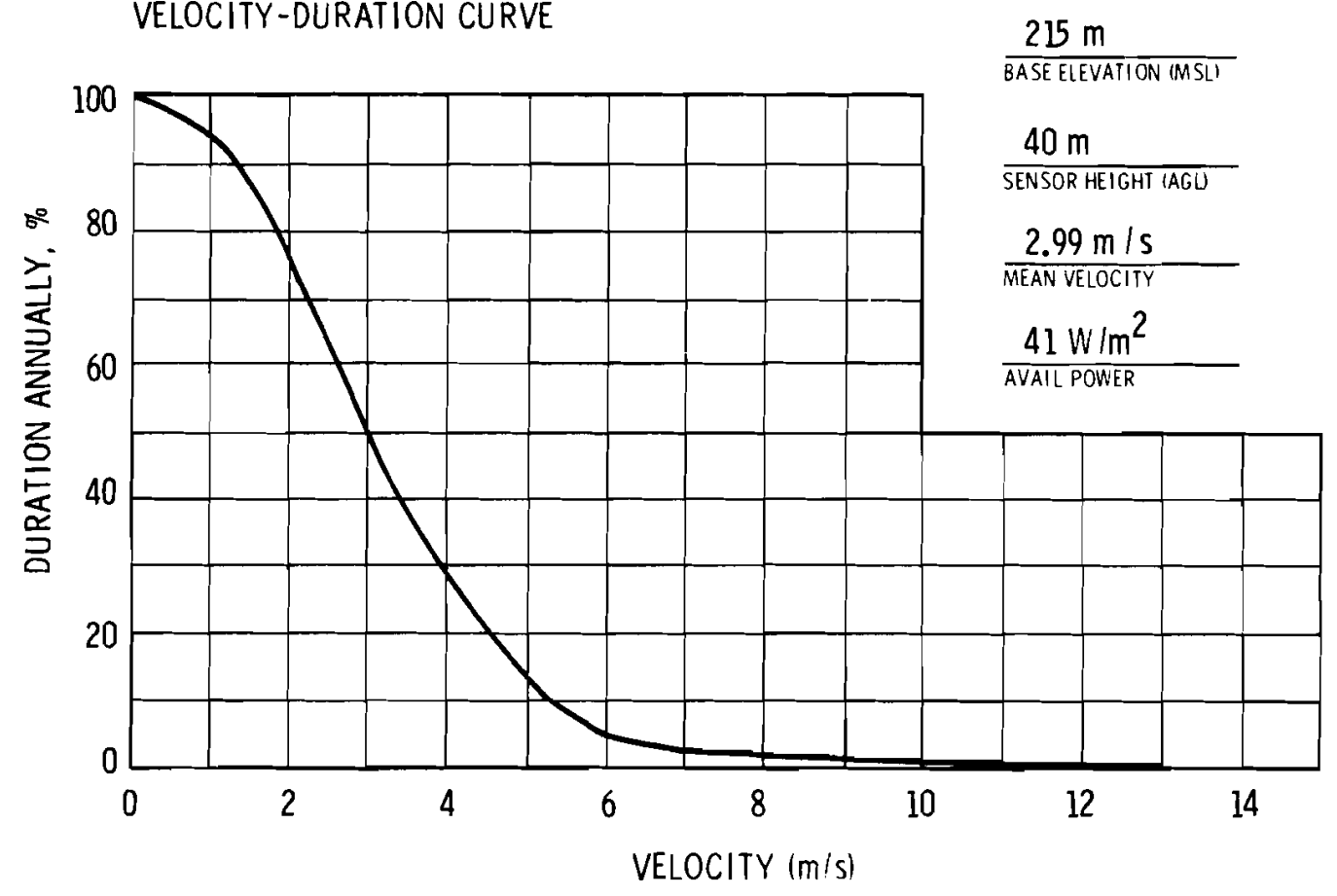


PERRY

\section{SITE LOCATION:}

The Perry site $\left(41.80^{\circ} \mathrm{N} / 81.14^{\circ} \mathrm{W}\right)$ is located in Lake county, $\mathrm{NE}$ Ohio on the southeast shoreline of Lake Erie. It is partially within the boundary of the village of North Perry, $11 \mathrm{~km}$ $\mathrm{NE}$ of Painesville, $53 \mathrm{~km} \mathrm{NE}$ of Cleveland and $30 \mathrm{~km}$ WSW of Ashtabula.

\section{TOPOGRAPHY :}

The plant site is located on the SE shoreline of Lake Erie on an ancient lake plain about $15 \mathrm{~m}$ above the lake. The 1100acre site, though relatively flat, has a very gentle slope toward the lake and is dissected by small streams draining into the lake. The terrain around the site is gently rolling except for the 6-15 m bluff at the lake's shoreline, and is divided between light to heavy woodland, and farmland or nursery stock.

\section{ON-SITE WIND MEASUREMENTS:}

The on-site meteorological program began in April 1972. The program includes a $61-\mathrm{m}$ tower instrumented at $11 \mathrm{~m}$ and $61 \mathrm{~m}$ with Climet WS-011-1 (speed) and Climet WD-012-10 (direction) sensors. The tower is located about $1130 \mathrm{~m}$ inland from the lake at an elevation of about $190 \mathrm{~m}$ (MSL).

$\overline{\text { NRC Docket No. } 50-440}$ 


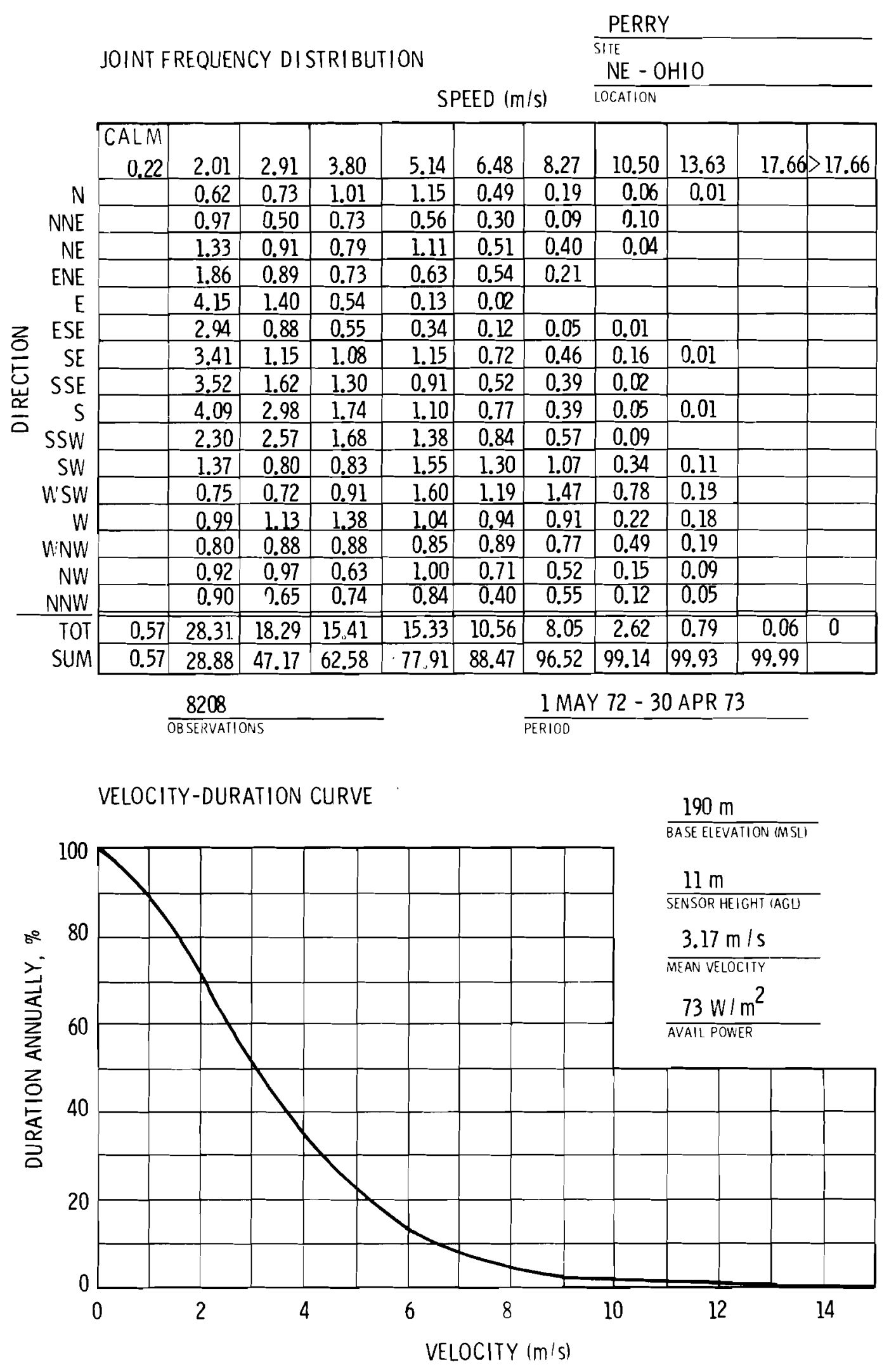




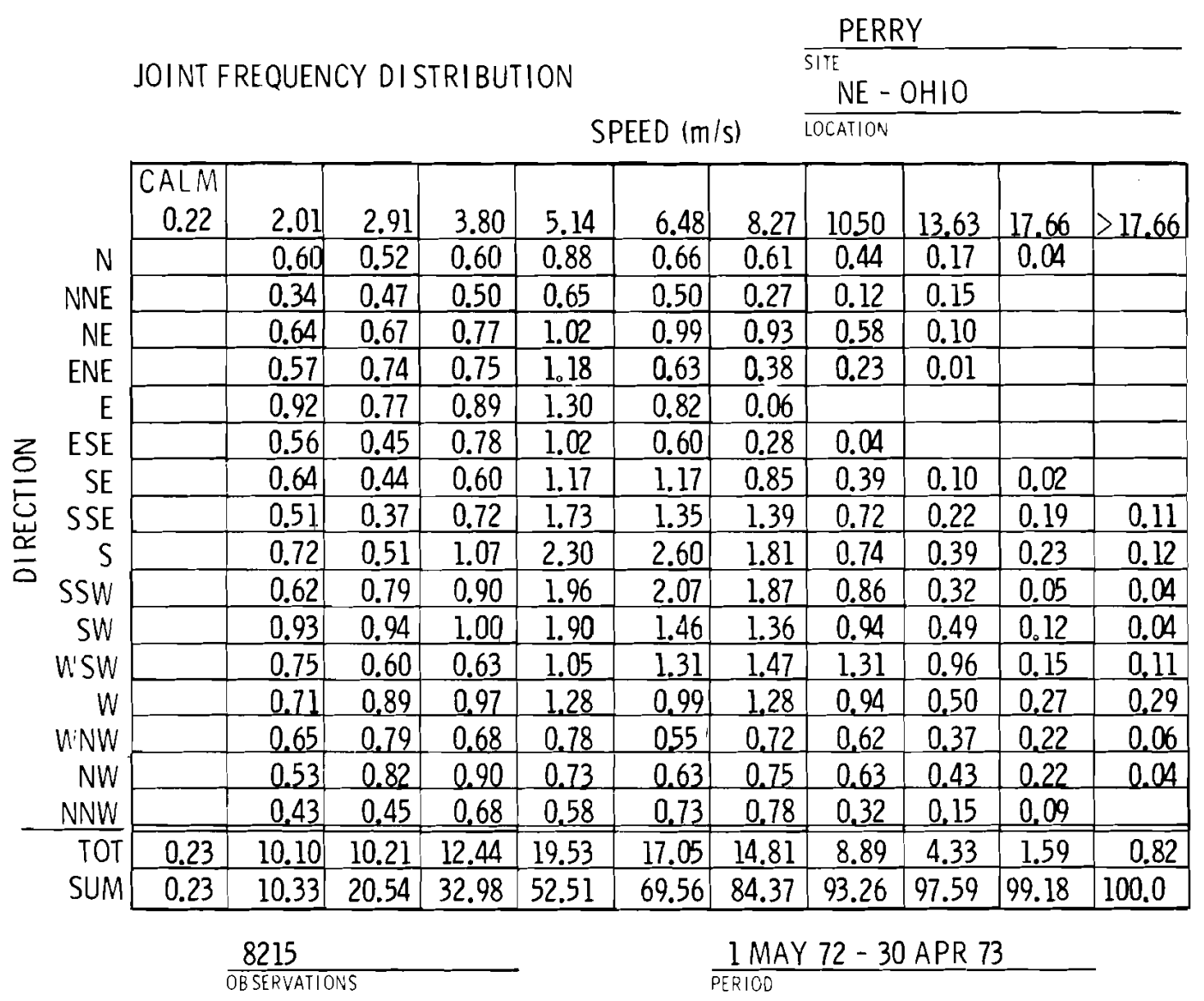

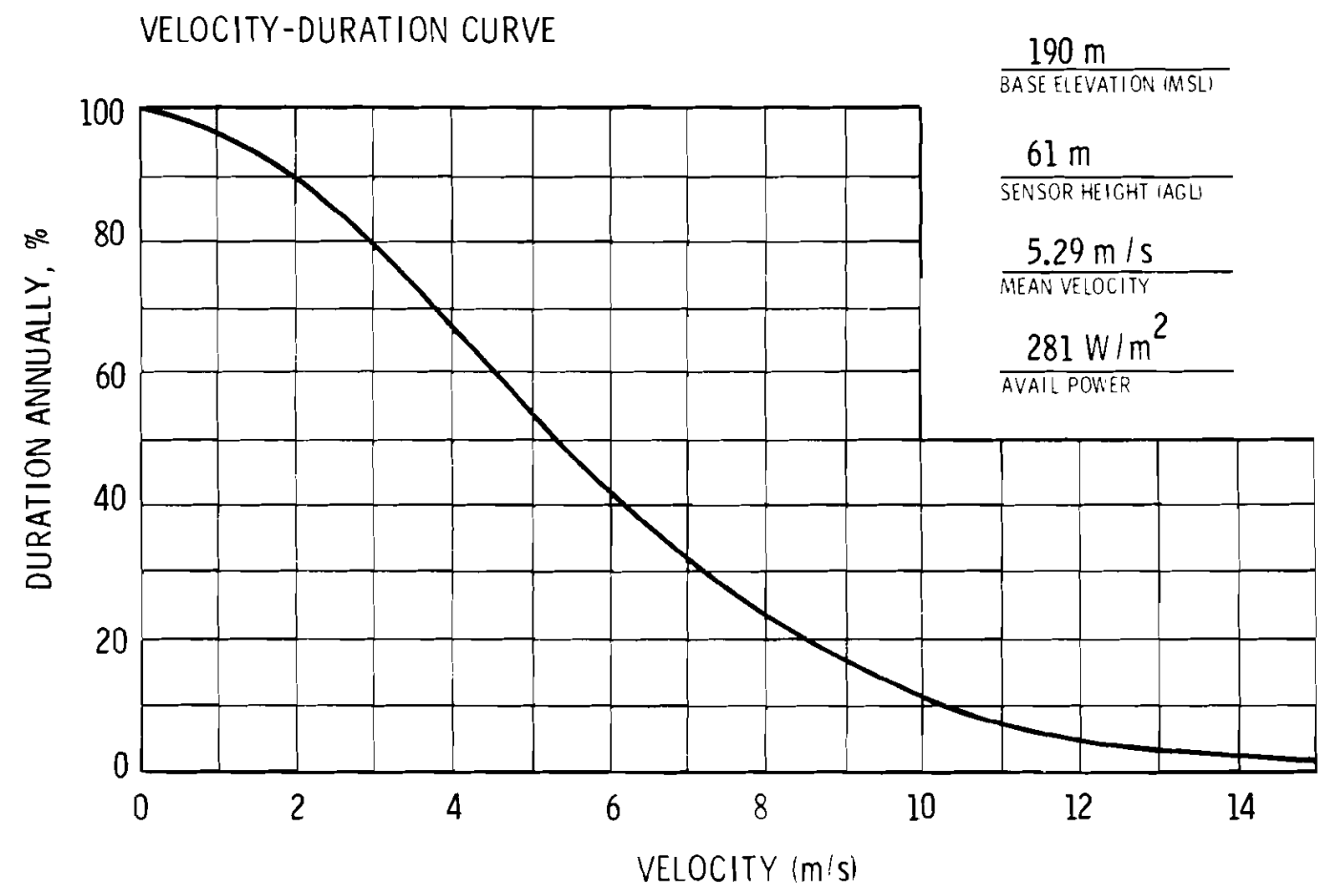


PHIPPS BEND

SITE LOCATION:

The Phipps Bend site $\left(36.46^{\circ} \mathrm{N} / 82.81^{\circ} \mathrm{W}\right)$ is located in Hawkins County, in extreme northeast Tennessee, about $24 \mathrm{~km} \mathrm{SW}$ of Kingsport, on the Holston River. It is also $110 \mathrm{~km} \mathrm{NE}$ of Knoxville.

TOPOGRAPHY :

The site is located in extreme northeast Tennessee in the upper Tennessee Valley of the southern Appalachian Region. The Holston River Valley is oriented NE-SW and is flanked by mountain ranges on both sides which rise to $1200 \mathrm{~m}$ and in places to $1800 \mathrm{~m}$ (MSL). The terrain rises well over $300 \mathrm{~m}$ above plant grade within $6 \mathrm{~km} \mathrm{~S}$ and $S E$ of the site. The highest nearby terrain is River Mountain Ridge, $2 \mathrm{~km} \mathrm{SE}$, which extends $185 \mathrm{~m}$ above plant grade of $360 \mathrm{~m}$ (MSL).

ON-SITE WIND MEASUREMENTS:

The Phipps Bend temporary meteorological facility began collecting data in December 1973. The facility includes a 46-m tower at $362 \mathrm{~m}$ (MSL), which is instrumented at $10 \mathrm{~m}$ and $46 \mathrm{~m}$ with Climet WS-011-1 (speed) and Climet WD-012-10 (direction) sensors.

$\overline{\text { NRC Docket No. } 50-553}$ 


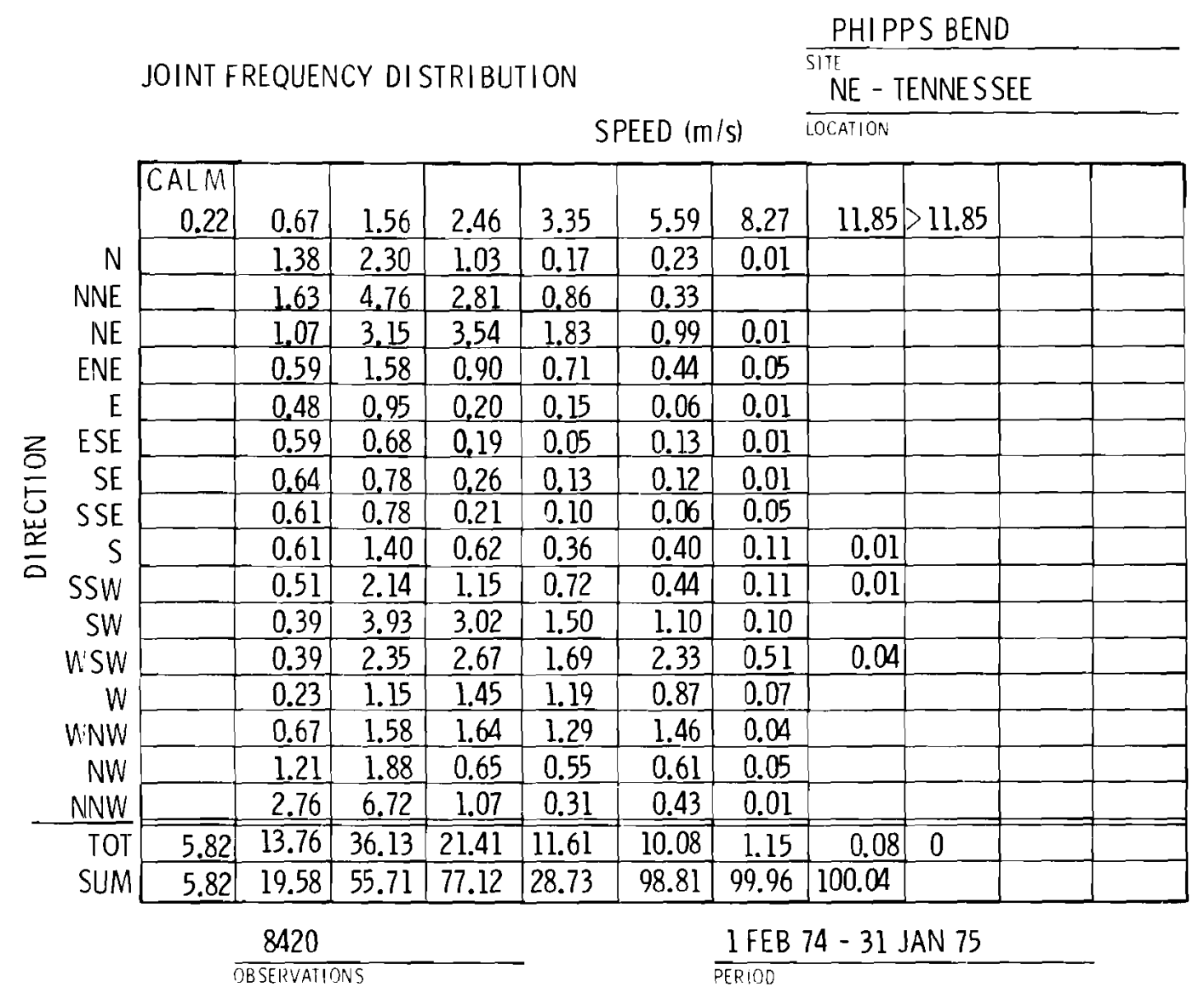

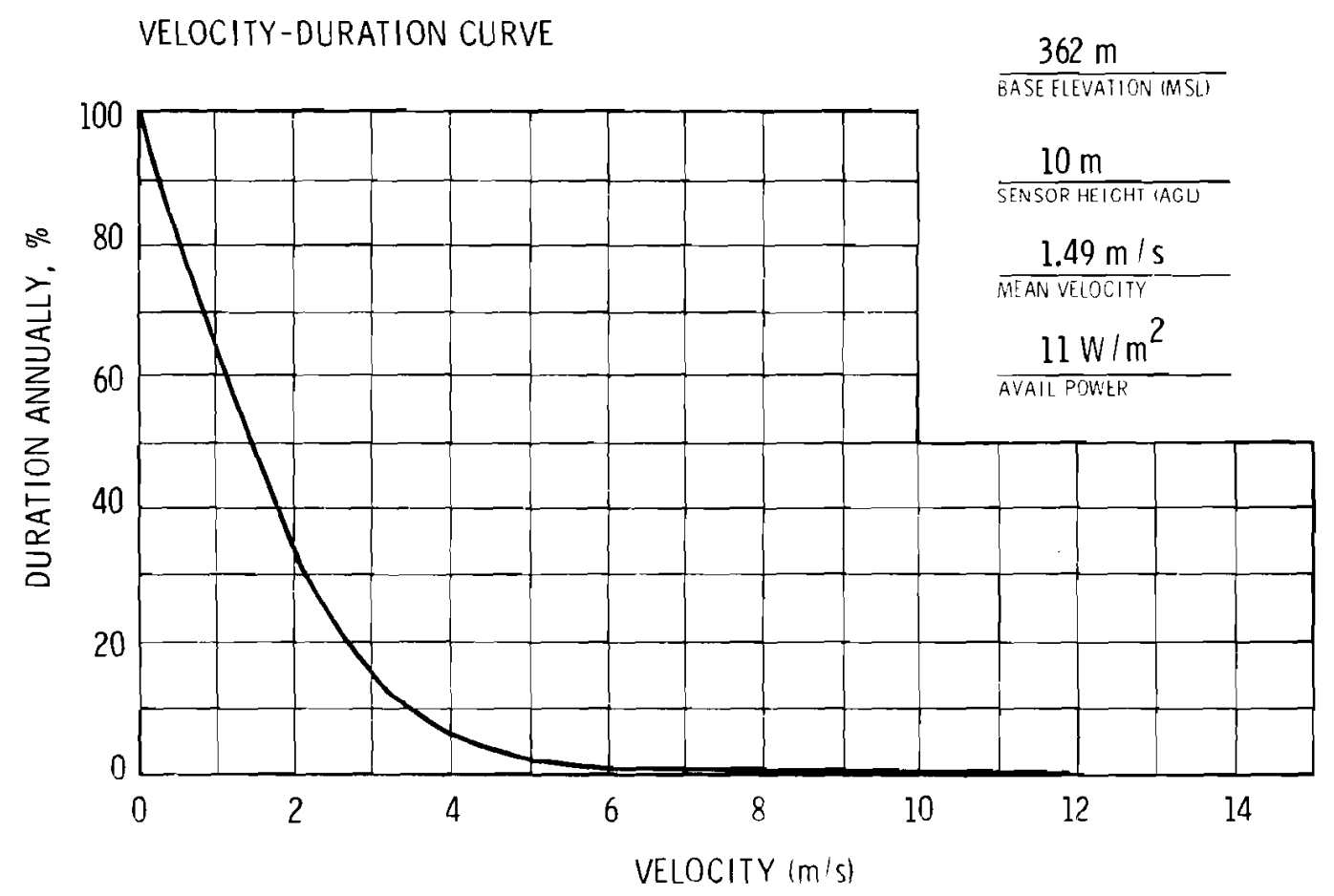


PHIPPS BEND

JOINT FREQUIENCY DISTRIBUTION

SITE

NE - TENNESSEE

LOCATION

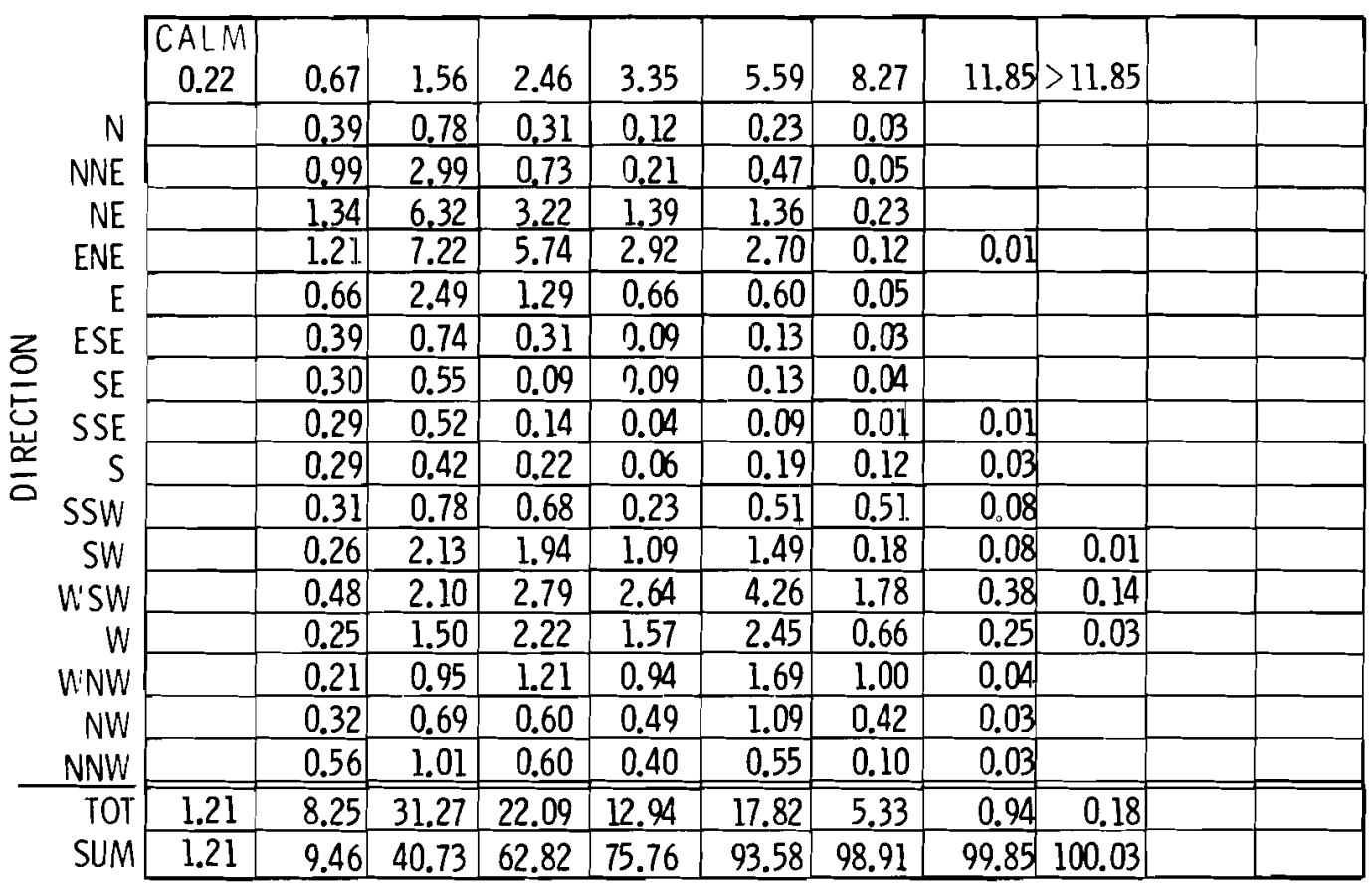

7700

I FEB $74-31$ JAN 75

VELOCITY-DURATION CURVE

$$
\text { ๖̊ }
$$

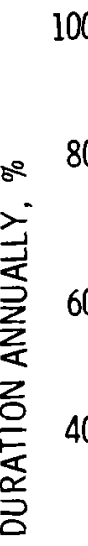

100

80

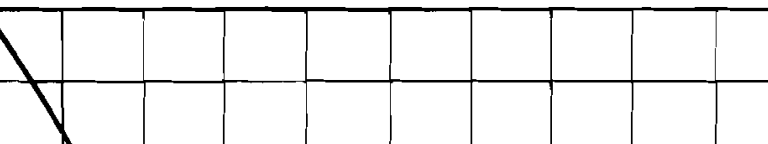

60

$+$

10

政

20

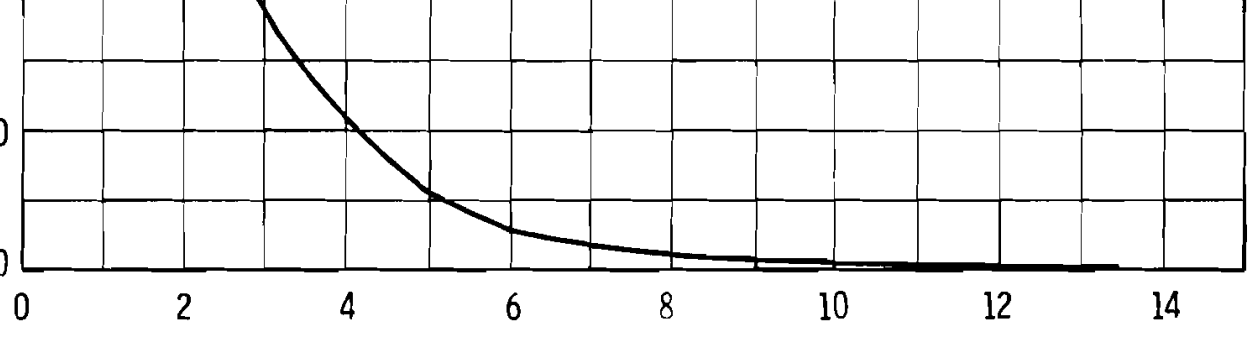

VELOCITY $(\mathrm{m} / \mathrm{s})$
$362 \mathrm{~m}$

BASE ELEVATION (MSL)

$46 \mathrm{~m}$

$\overline{\text { SENSOR HE I GHT IAGU }}$

$2.40 \mathrm{~m} / \mathrm{s}$

MEAN VELOCITY

$37 \mathrm{~W} / \mathrm{m}^{2}$

AVAIL POWER 


\section{PILGRIM}

\section{SITE LOCATION}

The Pilgrim site $\left(41.94^{\circ} \mathrm{N} / 70.58^{\circ} \mathrm{W}\right)$ occupies about 517 acres of land on the western shore of Cape cod Bay in the town of Plymouth, Plymouth County, Massachusetts. The site is about $7 \mathrm{~km}$ ESE of the center of Plymouth and about $60 \mathrm{~km} \mathrm{SE}$ of Boston.

\section{TOPOGRAPHY :}

To the $\mathrm{N}$ and $\mathrm{E}$ is the open water of Cape Cod Bay. A ridge immediately $W$ and extending from Plymouth Bay southward for over $6 \mathrm{~km}$ is the dominant inland topographical feature. The ridge rises to over $120 \mathrm{~m}$ (MSL) and, in effect, separates the site from Plymouth Bay, $0.5 \mathrm{~km}$ WNW.

\section{ON-SITE WIND MEASUREMENTS:}

A 67-m tower was initially placed in operation on the site at $24 \mathrm{~m}$ (MSL) in May 1968. The total meteorological program was upgraded in April 1974 by installing new equipment on the 67$\mathrm{m}$ tower and erecting a new $49-\mathrm{m}$ tower at $7 \mathrm{~m}$ (MSL). Winds are now measured by Climatronics F460 wind systems at $10 \mathrm{~m}$ and $49 \mathrm{~m}$ on the 49-m tower and at $22 \mathrm{~m}$ and $67 \mathrm{~m}$ on the $67-\mathrm{m}$ tower.

$\overline{\mathrm{NRC}}$ Docket Nos. 50-293, -471 


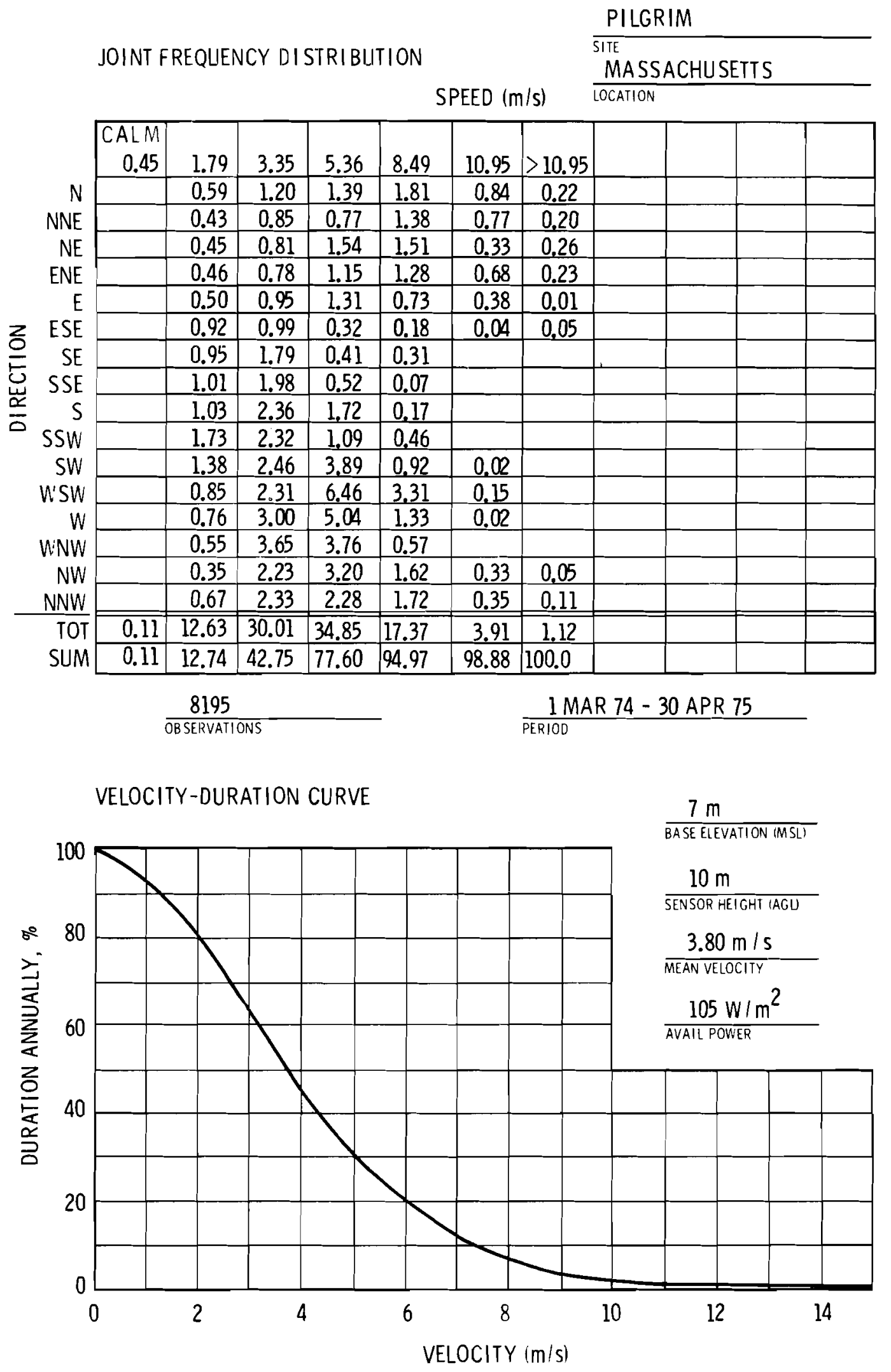




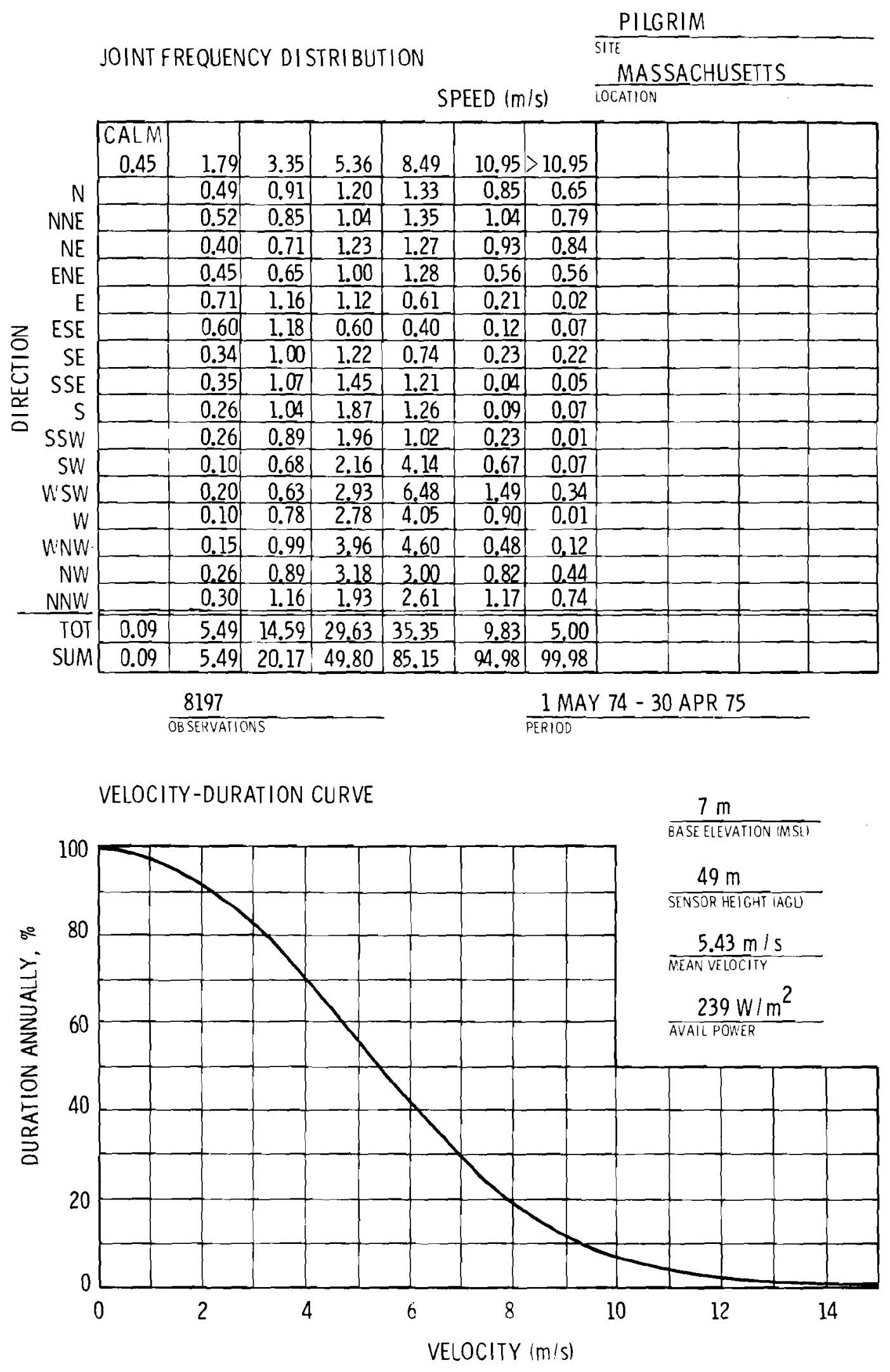




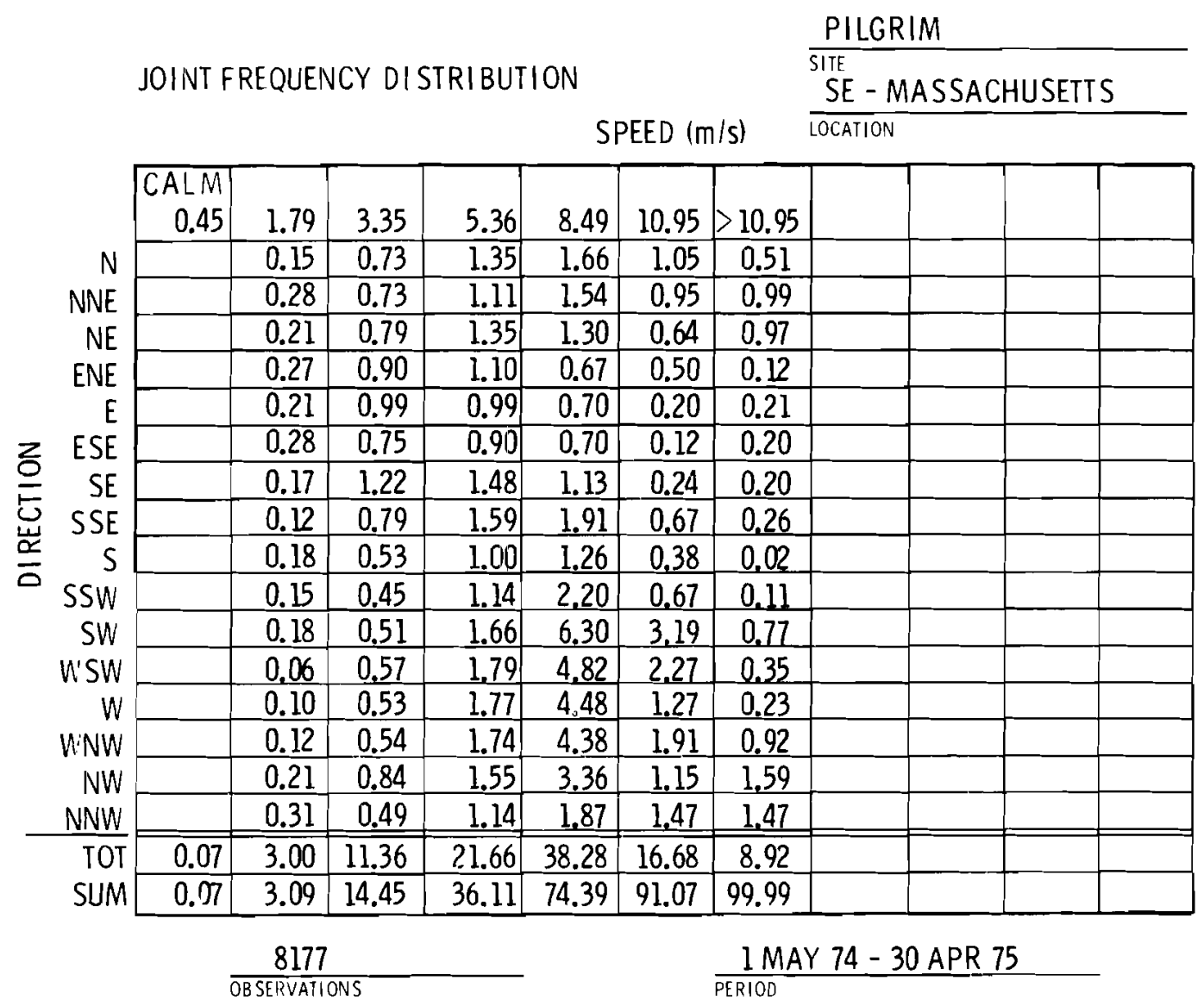

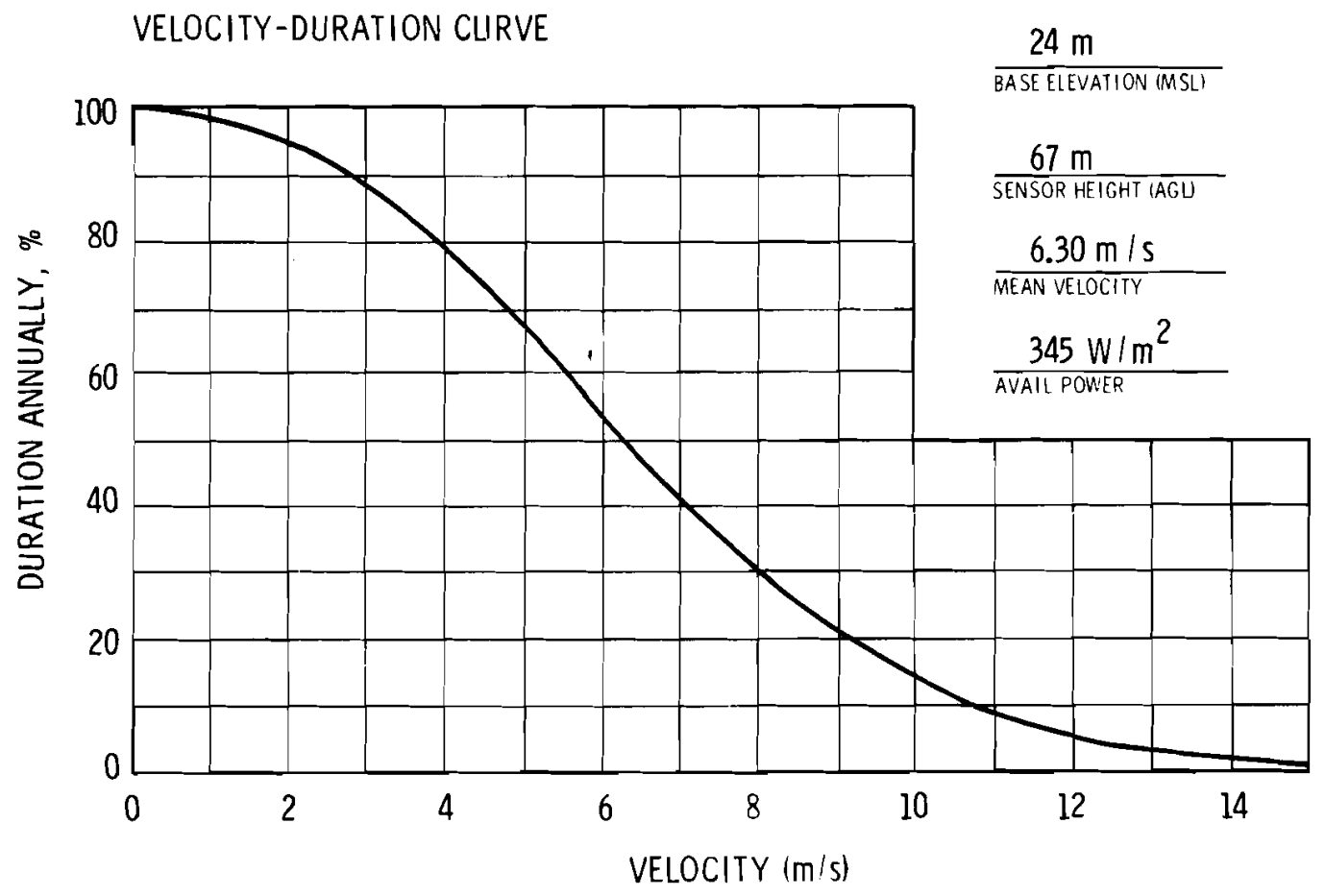




\section{POINT BEACH}

\section{SITE LOCATION:}

The site $\left(44.28^{\circ} \mathrm{N} / 87.54^{\circ} \mathrm{W}\right)$ is in east central Wisconsin on the west shore of Lake Michigan, about $50 \mathrm{~km} \mathrm{SE}$ of Green Bay and $145 \mathrm{~km}$ NNE of Milwaukee. The site is in the town of Two Creeks in the NE corner of Manitowoc County. The international boundary between Canada and the United States is about $325 \mathrm{~km}$ $\mathrm{NE}$ of the site.

TOPOGRAPHY :

The site is on the western shore of Lake Michigan in a relatively flat region of Wisconsin. Within a $15 \mathrm{~km}$ radius, the scattered hills and knolls do not exceed $245 \mathrm{~m}$ (MSL). Plant grade is 185 m (MSL).

ON-SITE WIND MEASUREMENTS:

Site data collection began in April 1967. A set of Belfort Type $M$ wind instruments were installed on top of a $46-m$ tower at about $185 \mathrm{~m} \mathrm{(MSL).}$

NRC Docket Nos. $50-266,-301$ 


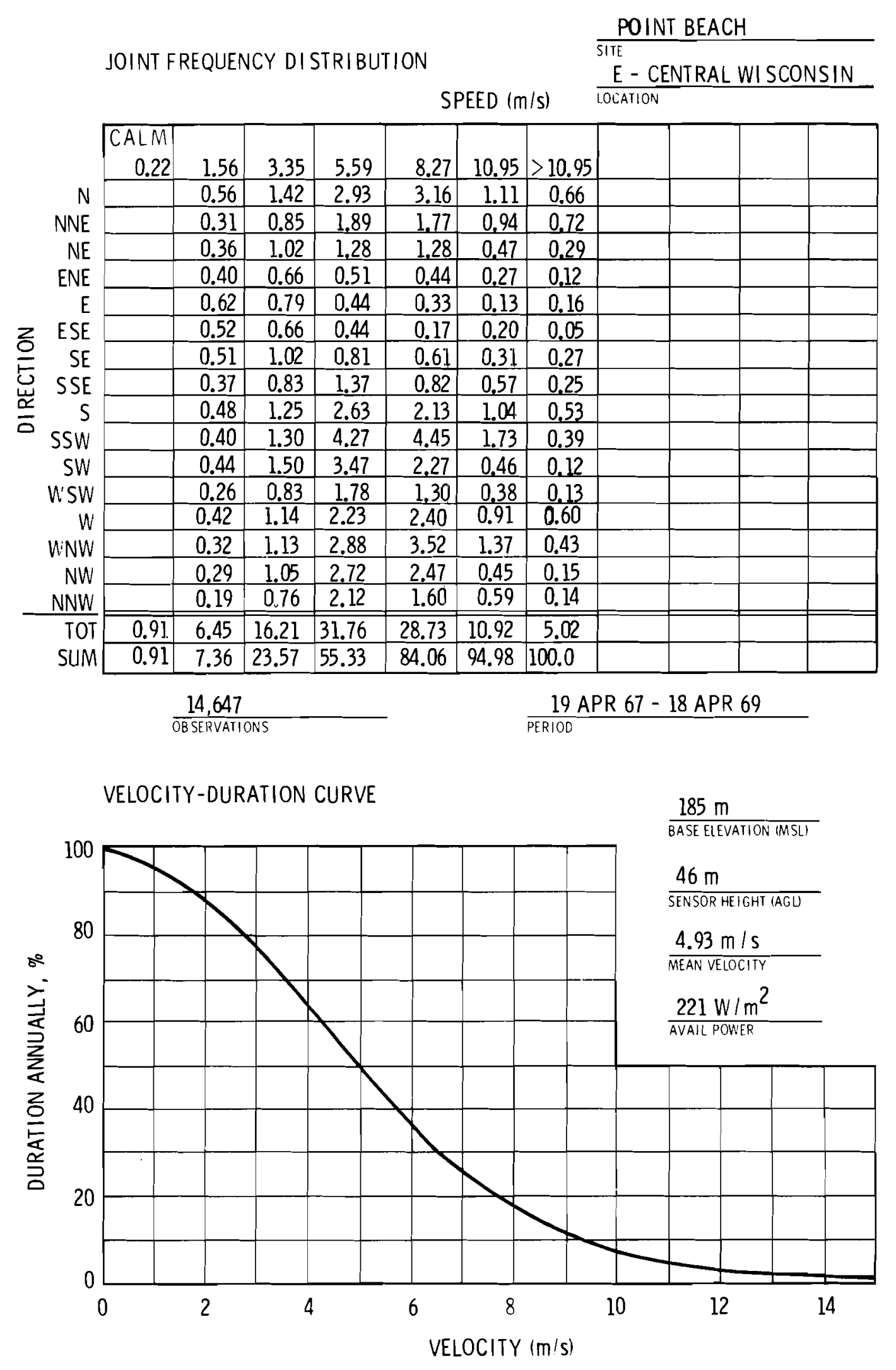


PRAIRIE ISLAND

\section{SITE LOCATION:}

The site $\left(44.62^{\circ} \mathrm{N} / 92.63^{\circ} \mathrm{W}\right)$ is located about $10 \mathrm{~km} \mathrm{NW}$ of Red Wing, Minnesota, in Goodhue County, on the SE bank of the Mississippi River. It is also $45 \mathrm{~km} \mathrm{SE}$ of Minneapolis, St. Paul and $145 \mathrm{~km}$ NW of La Crosse, WI.

\section{TOPOGRAPHY :}

The site is on the fairly level to slightly rolling ground of the Mississippi River Valley floodplain. The valley is about $5 \mathrm{~km}$ wide and elevation ranges from $205 \mathrm{~m}$ (MSL) at the river to about $215 \mathrm{~m}$ (MSL). The surface slopes gradually toward the Mississippi River on the $\mathrm{NE}$ and the Vermillion River on the SW. The Mississippi flows from NW to $\mathrm{SE}$ and is enclosed by very distinct bluffs over $90 \mathrm{~m}$ high that reach elevations over $300 \mathrm{~m}$ (MSL) at about $2.5 \mathrm{~km} \mathrm{NE}$ and $\mathrm{SW}$ of the site. Beyond the bluffs elevation ranges from $300 \mathrm{~m}$ to $365 \mathrm{~m}$ (MSL) and the terrain is marked by many deeply eroded coulees.

\section{ON-SITE WIND MEASUREMENTS:}

Measurements of on-site wind parameters began in May 1968. A 43-m tower was instrumented at the $12 \mathrm{~m}$ and $43 \mathrm{~m}$ levels using Belfort Type "M" systems. Data consist of 15-minute averages.

NRC Docket Nos. 50-282, -306 


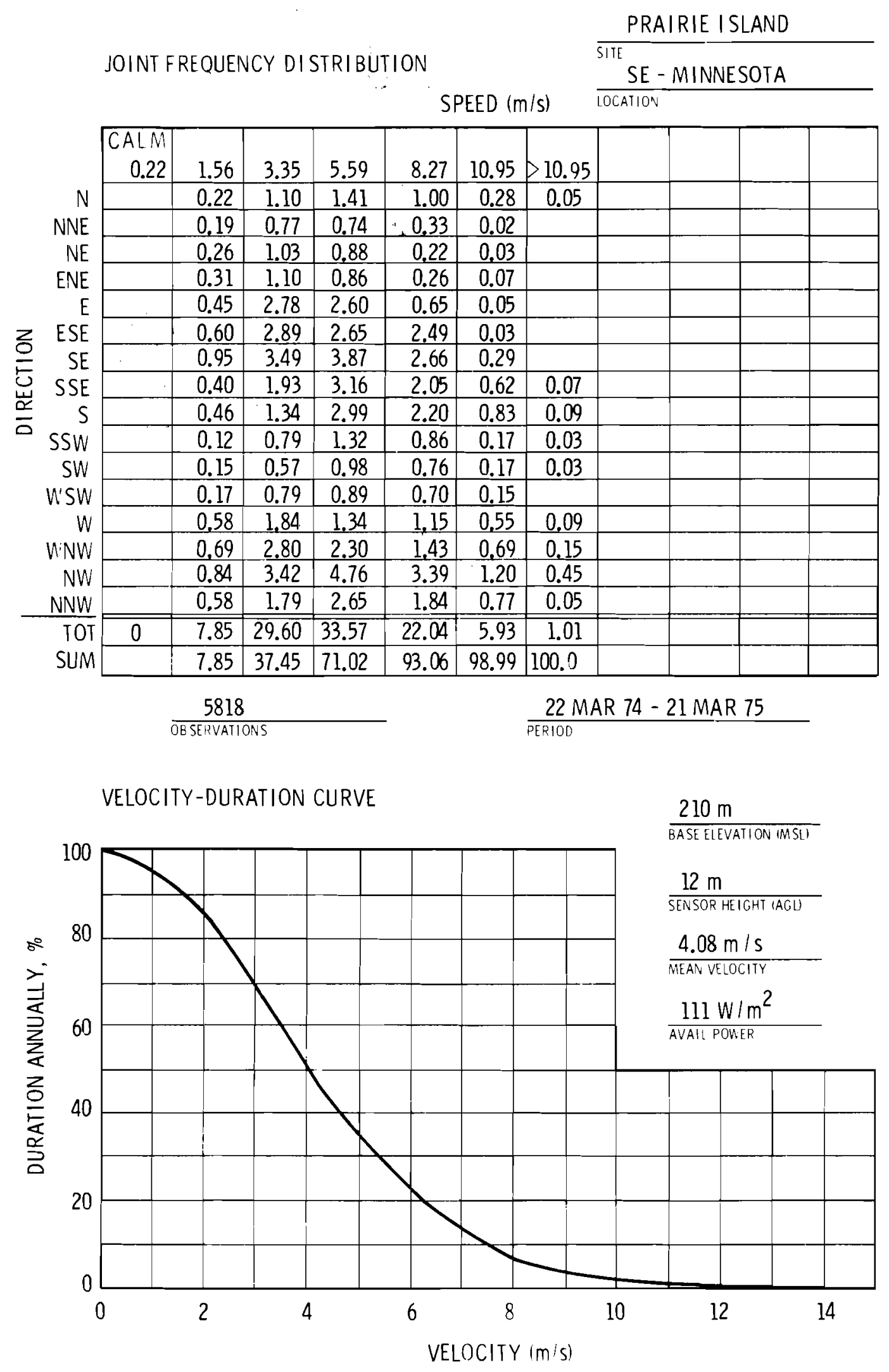


PUERTO RICO

\section{SITE LOCATION:}

The North Coast Nuclear Plant site $\left(18.49^{\circ} \mathrm{N} / 66.62^{\circ} \mathrm{W}\right)$ is located at Islote on the north central coast of Puerto Rico. The site is about $10 \mathrm{~km} \mathrm{E}$ of Arecibo, and $55 \mathrm{~km} \mathrm{~W}$ of San Juan. TOPOGRAPHY :

The site is $850 \mathrm{~m} \mathrm{~S}$ of the shoreline at $5.5 \mathrm{~m}$ (MSL). The surrounding area is relatively flat with a slight rise from $\mathrm{SE}$ through SW beyond $4 \mathrm{~km}$.

ON-SITE WIND MEASUREMENTS:

Data have been collected since January 1974 using a $76 \mathrm{~m}$ tower at $14 \mathrm{~m}$ (MSL) and at a distance of $400 \mathrm{~m} \mathrm{~s}$ of the shoreline. The wind instrument is a combined cup and vane sensor, MRI Model 1074-2, at $10 \mathrm{~m}$ (AGL).

$\overline{\text { NRC Docket No. } 50-376}$ 
JOINT FREQUENCY DISTRIBUTION

PUERTO RI CO

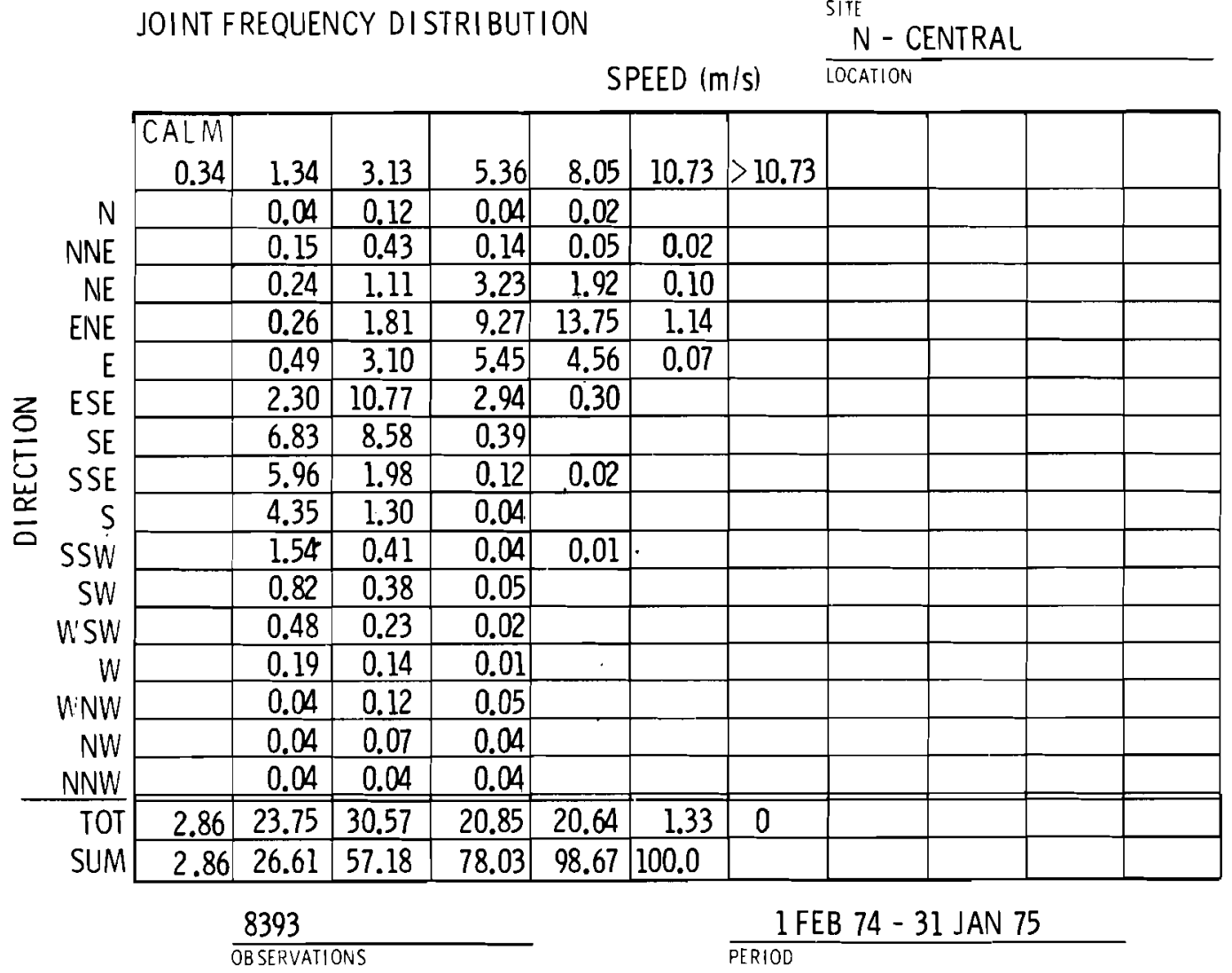

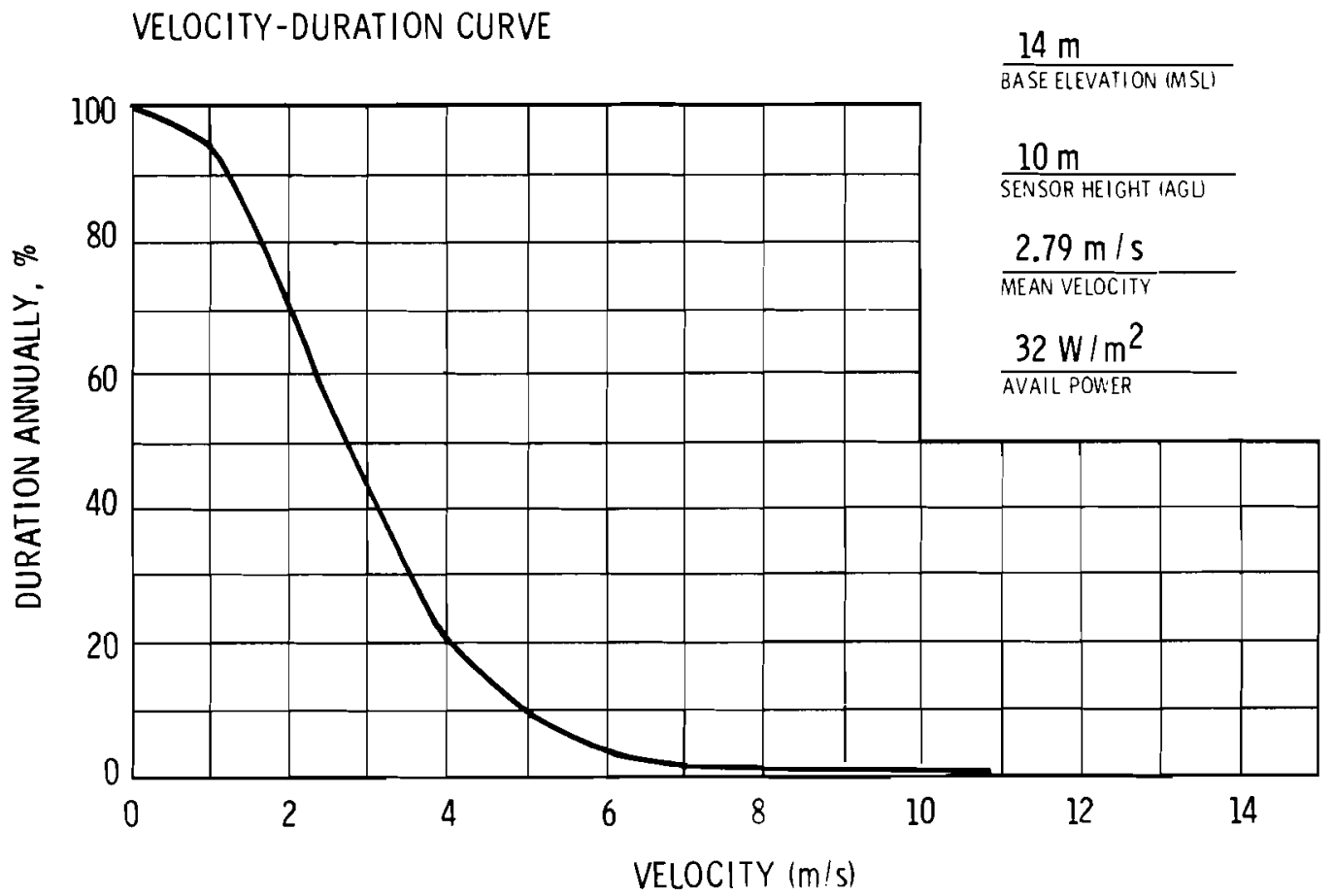


QUAD CITIES

\section{SITE LOCATION:}

The Quad Cities site $\left(41.72^{\circ} \mathrm{N} / 90.32^{\circ} \mathrm{W}\right)$ is in Rock Island County, Illinois, on the E bank of the Mississippi River, opposite the mouth of the Wapsipinicon River, and about $5 \mathrm{~km} \mathrm{~N}$ of Cordova, Illinois. It is also $32 \mathrm{~km} \mathrm{NE}$ of the Quad-Cities (Davenport, Iowa; Rock Island, Moline, East Moline, Illinois).

\section{TOPOGRAPHY :}

The site is relatively flat, with a mean elevation of $184 \mathrm{~m}$ (MSL). At the river, the surface drops off abruptly, forming a bluff about $9 \mathrm{~m}$ high.

ON-SITE WIND MEASUREMENTS:

Wind measurements are made at $11 \mathrm{~m}, 38 \mathrm{~m}$, and $91 \mathrm{~m}$ using Belfort Type L sensor systems.

NRC Docket Nos. $50-254,2 \overline{65}$ 


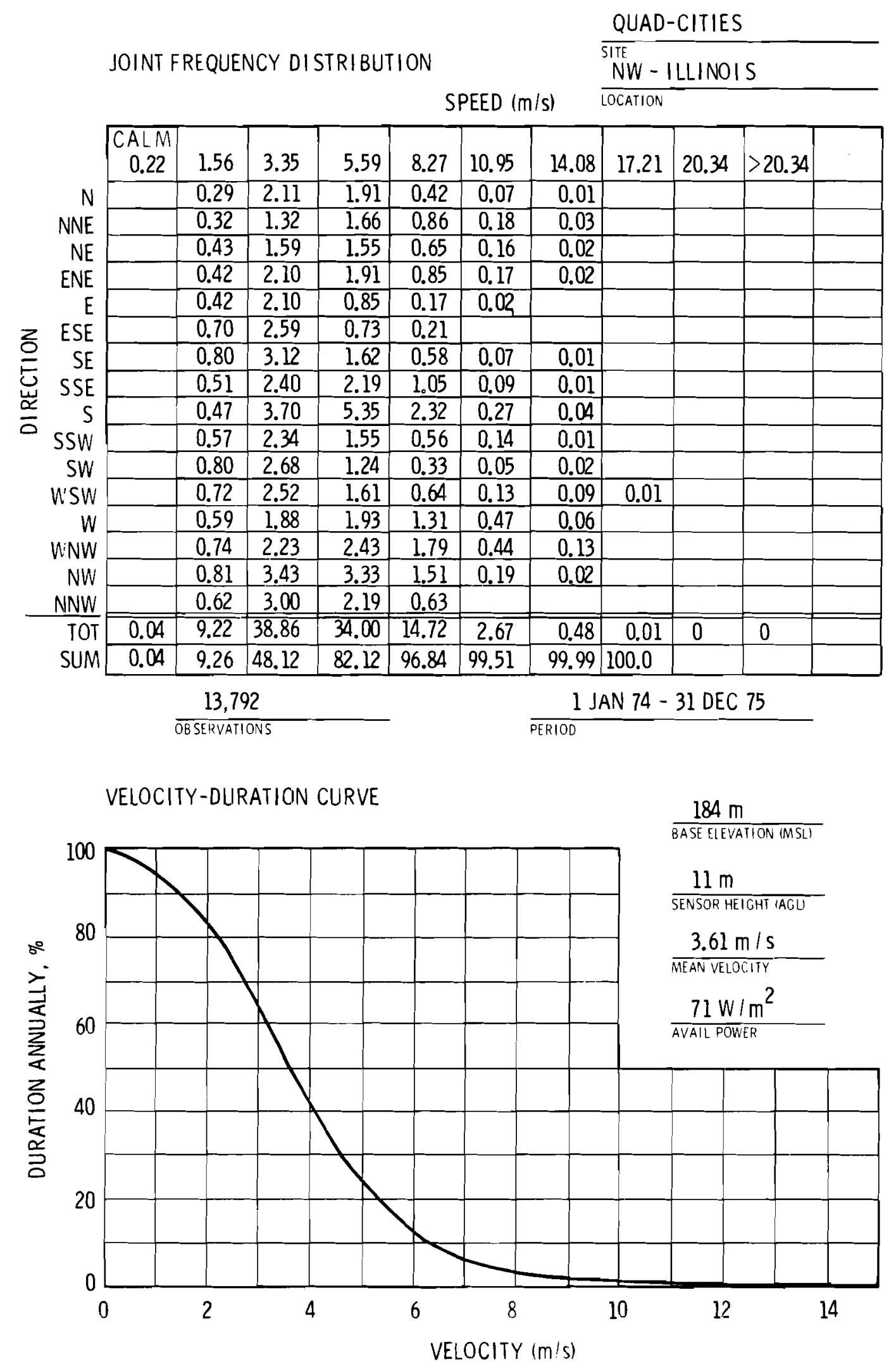




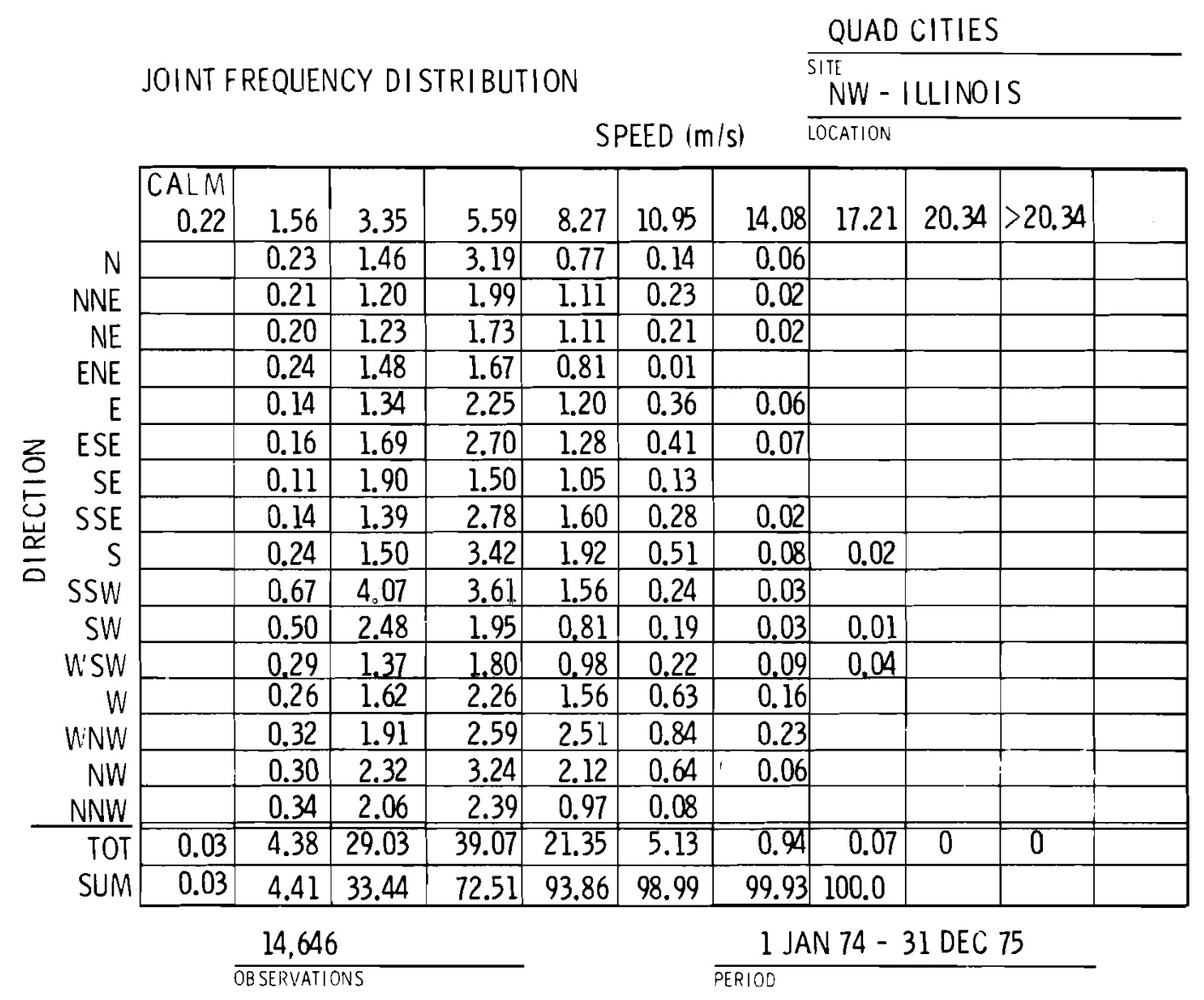

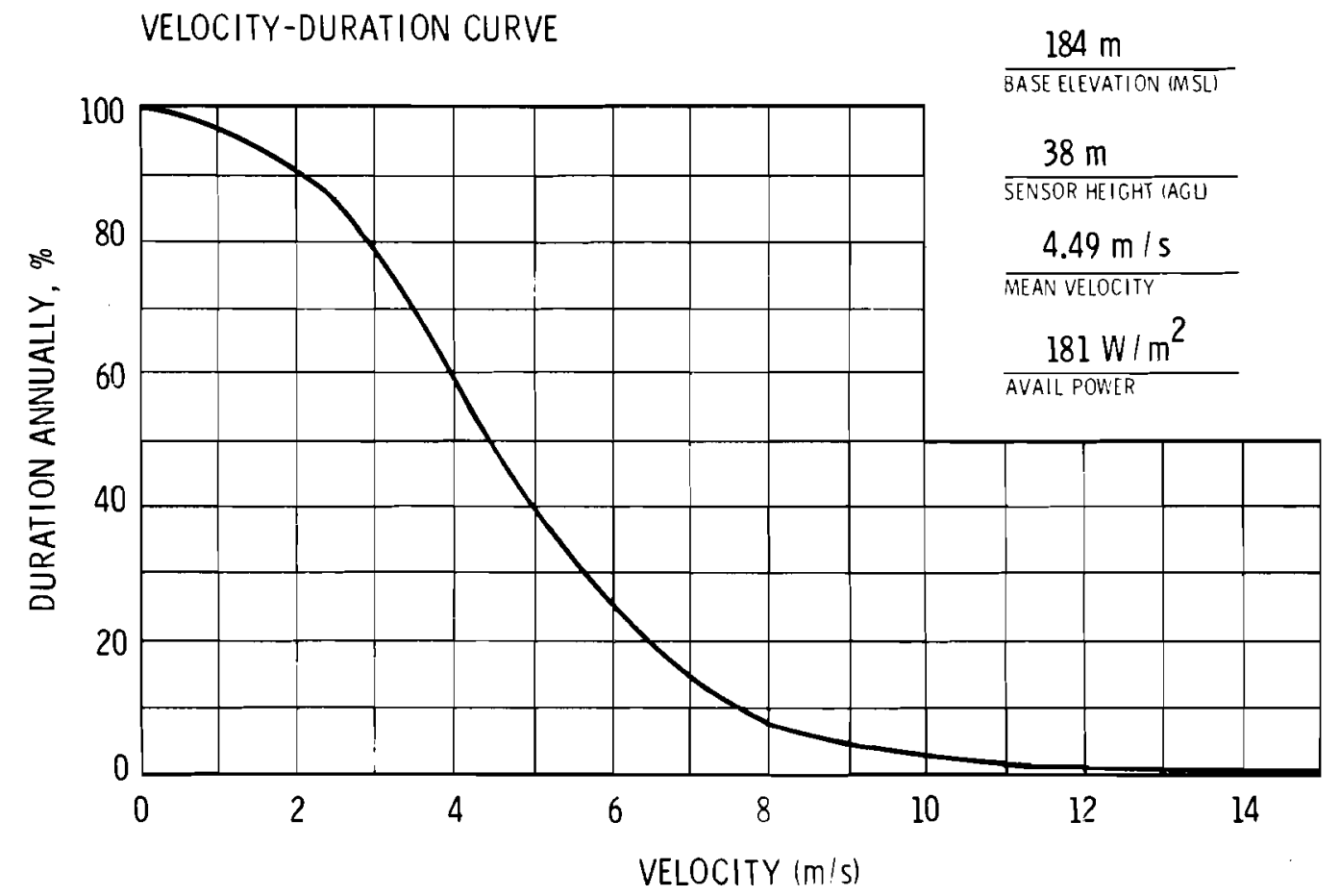




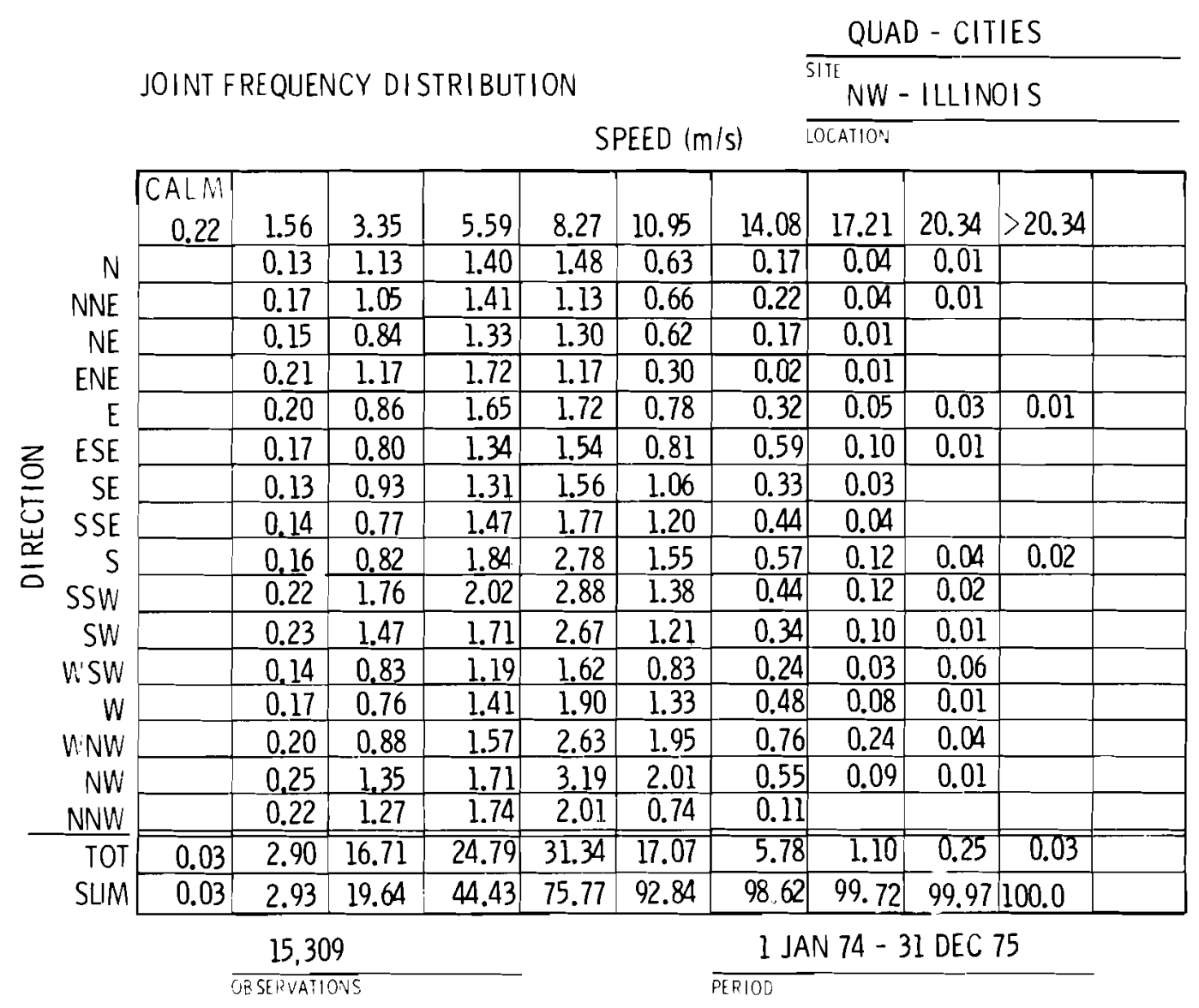

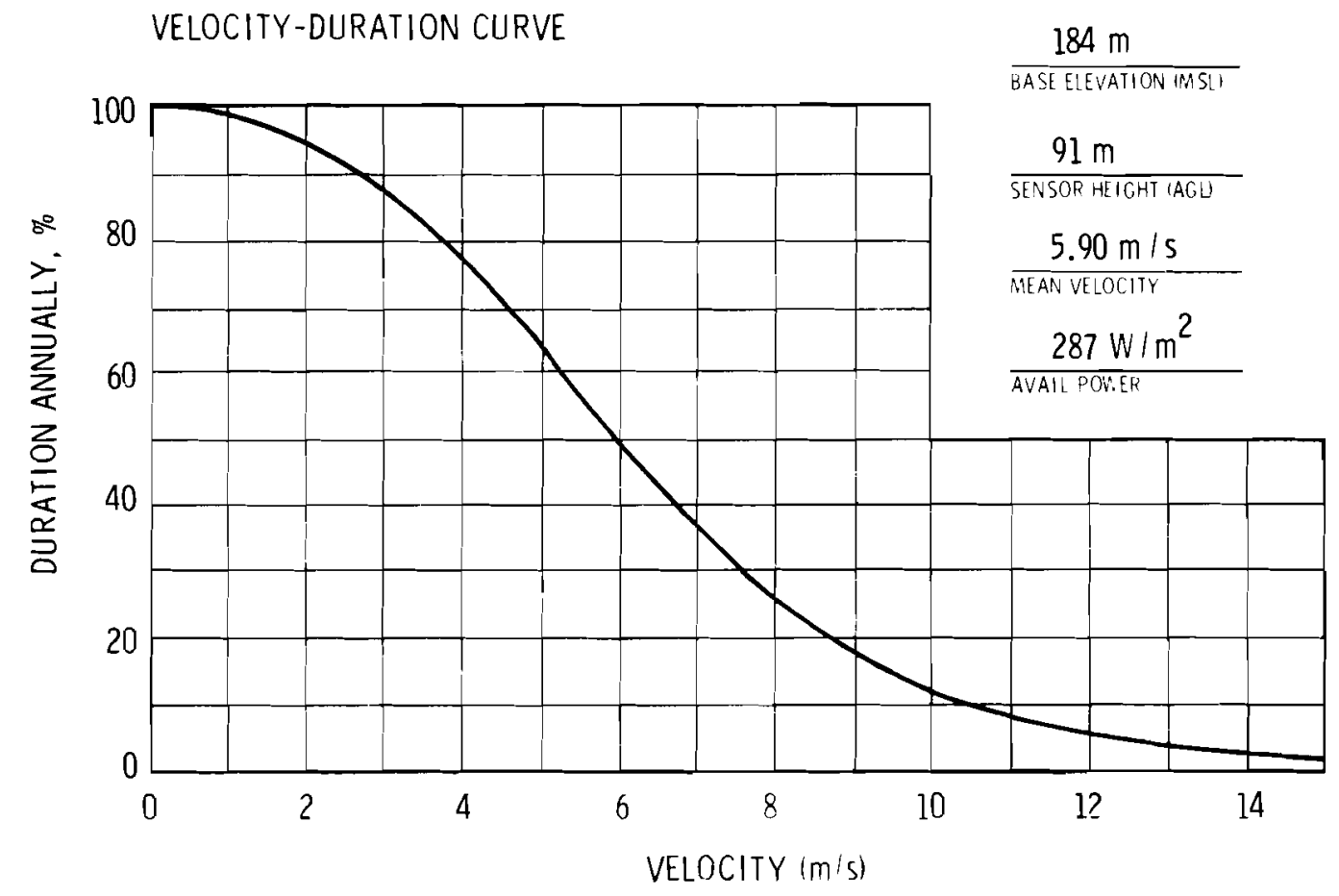


QUANICASSEE

\section{SITE LOCATION:}

The site $\left(43.59^{\circ} \mathrm{N} / 83.77^{\circ} \mathrm{W}\right)$ is in Bay County, Michigan on the south shore of Saginaw Bay, $3 \mathrm{~km}$ NW of the village of Quanicassee. The site is also $10 \mathrm{~km} \mathrm{E}$ of Bay City, $25 \mathrm{~km} \mathrm{NE}$ of Saginaw and about $60 \mathrm{~km}$ s of Flint.

\section{TOPOGRAPHY :}

The site is located on the southern edge of Saginaw Bay. Beginning NW of the site, the Bay shoreline runs in the NW-SE direction. At $2 \mathrm{~km}$ E of the site, the shoreline gradually changes direction and runs from SW-NE. The mean level of Lake Huron is $177 \mathrm{~m}$ (MSL), and the site is relatively flat with elevations within $5 \mathrm{~km}$ radius ranging from zero to $2 \mathrm{~m}$ above the normal level of Saginaw Bay. The inland area around the site is relatively flat also with elevations ranging from $177 \mathrm{~m}$ to $183 \mathrm{~m}$ (MSL) within $8 \mathrm{~km}$, and is characterized by generally flat farmland with occasional trees to $15 \mathrm{~m}$.

\section{ON-SITE WIND MEASUREMENT:}

Wind data are collected at five locations on and near the site. The primary location is a 100-m tower, which is instrumented with a Gill-type propeller vane (Model 35001, 2-19 cm blades) at $10 \mathrm{~m}$ and $80 \mathrm{~m}$. Base elevation is about $180 \mathrm{~m}$ (MSL).

$\overline{\text { NRC Docket No. } 50-475}$ 

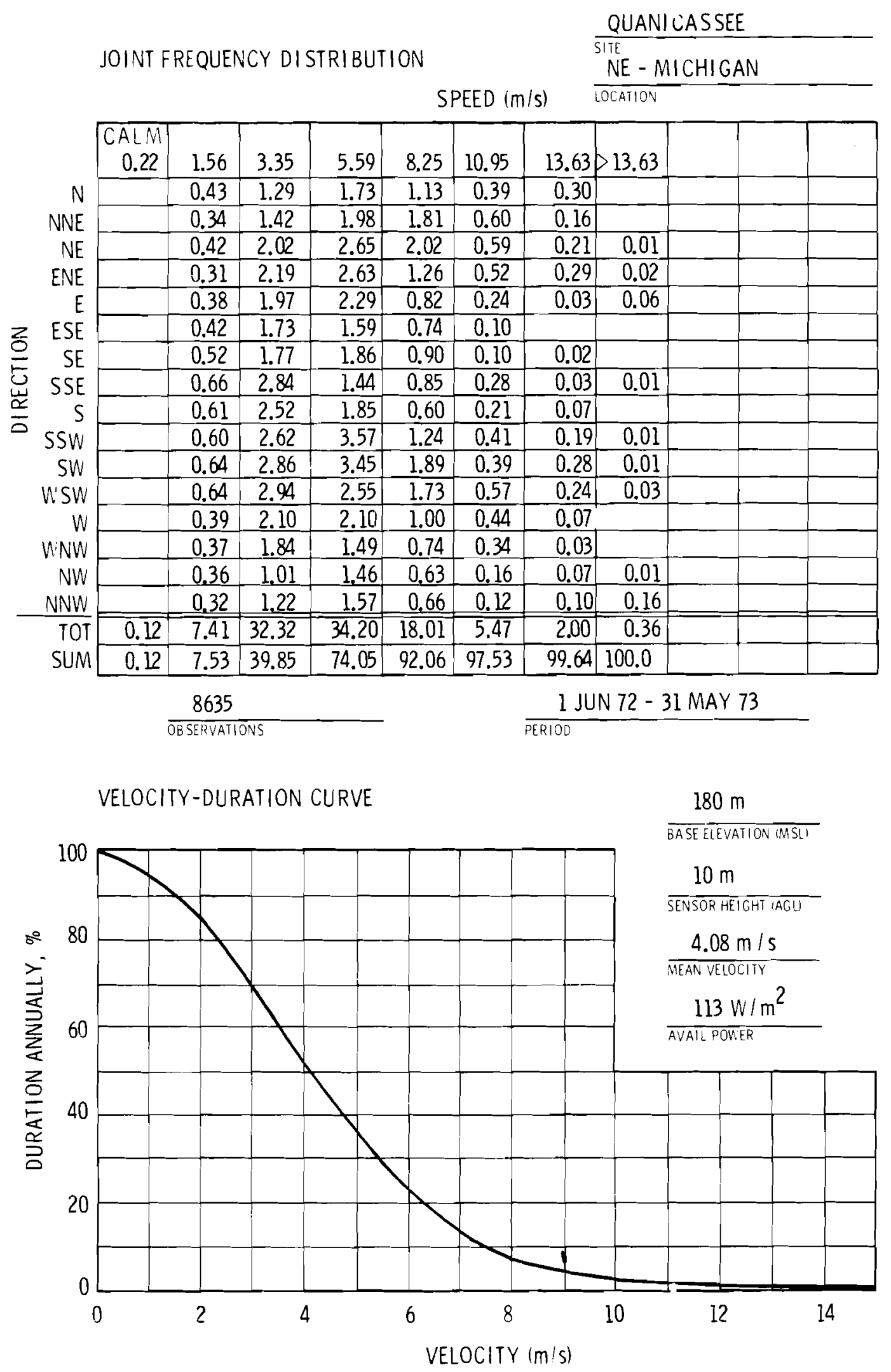
RANCH SECO

\section{SITE LOCATION:}

The site $\left(38.30^{\circ} \mathrm{N} / 121.14^{\circ} \mathrm{W}\right)$ is in SE Sacramento County, central California, near the town of Clay. The location is $42 \mathrm{~km} \mathrm{NNE}$ of stockton and $40 \mathrm{~km} \mathrm{SE}$ of sacramento.

\section{TOPOGRAPHY:}

The 2,480-acre site is located in the lower end of the Sacramento Valley between the sierra Nevada range to the east and the coast Range along the Pacific Ocean to the west.

The region is flat to slightly rolling with a site elevation of $61 \mathrm{~m}$ (MSL), having risen from $5 \mathrm{~m}$ (MSL) at sacramento. East of the site, the land becomes more rolling, rising to an elevation of $185 \mathrm{~m} \mathrm{(MSL)} \mathrm{at} 1 \mathrm{lkm}$ and increasing in elevation thereafter approaching the Sierra Nevada. Elevations of over $3000 \mathrm{~m}$ occur $100 \mathrm{~km} \mathrm{E}$ of the site.

ON-SITE WIND MEASUREMENTS:

Meteorological measurements were initiated in April 1967 using MRI Vector Vane on top of a 16-m tower. In June 1968, the 16-m temporary tower was replaced with a 61-m tower, instrumented at $15 \mathrm{~m}$ with an MRI Vector vane and at $61 \mathrm{~m}$ with an MRI 1074 system.

$\overline{\text { NRC Docket No. } 50-312}$ 


\begin{tabular}{|c|c|c|c|c|c|c|c|c|c|c|c|}
\hline & & & & & & & & RAN & HO SE & & \\
\hline & JOINT F & REQUE & $|C Y D|$ & STRIBU & $10 N$ & & & SITE & $2 A L-C$ & ALIFO & RNIA \\
\hline & & & & & & DEED in & & LOCATION & & & \\
\hline & CALM & & & & & & & & & & \\
\hline & 0.5 & 1.0 & 2.0 & 3.0 & 4.0 & 5.0 & 6.0 & 7.0 & 8.0 & 9.0 & $>9.0$ \\
\hline$N$ & & 0.51 & 1.47 & 0.91 & 0.54 & 0.50 & 0.33 & 0.14 & 0.09 & 0.05 & 0.11 \\
\hline NNE & & 0.37 & 1.15 & 0.62 & 0.31 & 0.24 & 0.20 & 0.09 & 0.04 & 0.11 & 0.05 \\
\hline$N E$ & & 0.39 & 0.87 & 0.90 & 0.35 & 0.08 & 0.06 & 0,03 & 0.01 & & 0.04 \\
\hline ENE & & 0.36 & 0.84 & 0.61 & 0.17 & 0.04 & 0.01 & 0.01 & & & 0.01 \\
\hline$E$ & & 0.33 & 1.00 & 0.88 & 0.41 & 0.09 & 0.02 & & & & \\
\hline ESE & & 0.38 & 1.03 & 1.04 & 0.63 & 0.44 & 0.15 & 0.03 & & & 0.02 \\
\hline SE & & 0.23 & 1.44 & 1.43 & 0.83 & 0.53 & 0.26 & 0.13 & 0.21 & 0.11 & 0.30 \\
\hline SSE & & 0.29 & 1.53 & 1.50 & 0.89 & 0.63 & 0.32 & 0.13 & 0.15 & 0.11 & 0.42 \\
\hline$S$ & & 0.63 & 1.65 & 1.49 & 1.10 & 0.70 & 0.39 & 0.11 & 0.05 & 0.05 & 0.14 \\
\hline SSW & & 0.45 & 1.55 & 1.65 & 1.11 & 0.57 & 0.32 & 0.25 & 0.18 & 0.16 & 0.76 \\
\hline SW & & 0.51 & 1.69 & 1.73 & 1.21 & 0.51 & 0.40 & 0.23 & 0.09 & 0.06 & 0.19 \\
\hline$u^{\prime} S W$ & & 0.64 & 2.35 & 2.78 & 2.61 & 1.13 & 0.39 & 0.20 & 0.05 & 0.03 & 0.05 \\
\hline$W$ & & 0.51 & 2.99 & 3.90 & 2.49 & 0.56 & 0.33 & 0.05 & 0.04 & 0.02 & \\
\hline WiNW & & 0.63 & 2.28 & 1.81 & 1.37 & 0.68 & 0.32 & 0.21 & 0.09 & 0.03 & 0.03 \\
\hline NW & & 0.51 & 1.97 & $\begin{array}{l}1.01 \\
2.19\end{array}$ & 1.89 & 1.28 & 0.87 & 0.13 & 0.20 & 0.09 & 0.11 \\
\hline NNW & & 0.78 & 1.88 & 1.28 & 1.07 & 0.73 & 0.53 & 0.20 & 0.20 & 0.17 & 0.22 \\
\hline TOT & 4.30 & 7.52 & 25.69 & 24.72 & 16.98 & 8.71 & 4.90 & 2.24 & 1.40 & 0.99 & 2.55 \\
\hline SUM & 4.30 & 11.82 & 37.51 & 62.23 & 79.21 & 87.92 & 92.82 & 95.06 & 96.46 & 97.45 & 100.0 \\
\hline & & 11,6 & & & & & & 67 & D & & \\
\hline
\end{tabular}

VELOCITY-DURATION CURVE

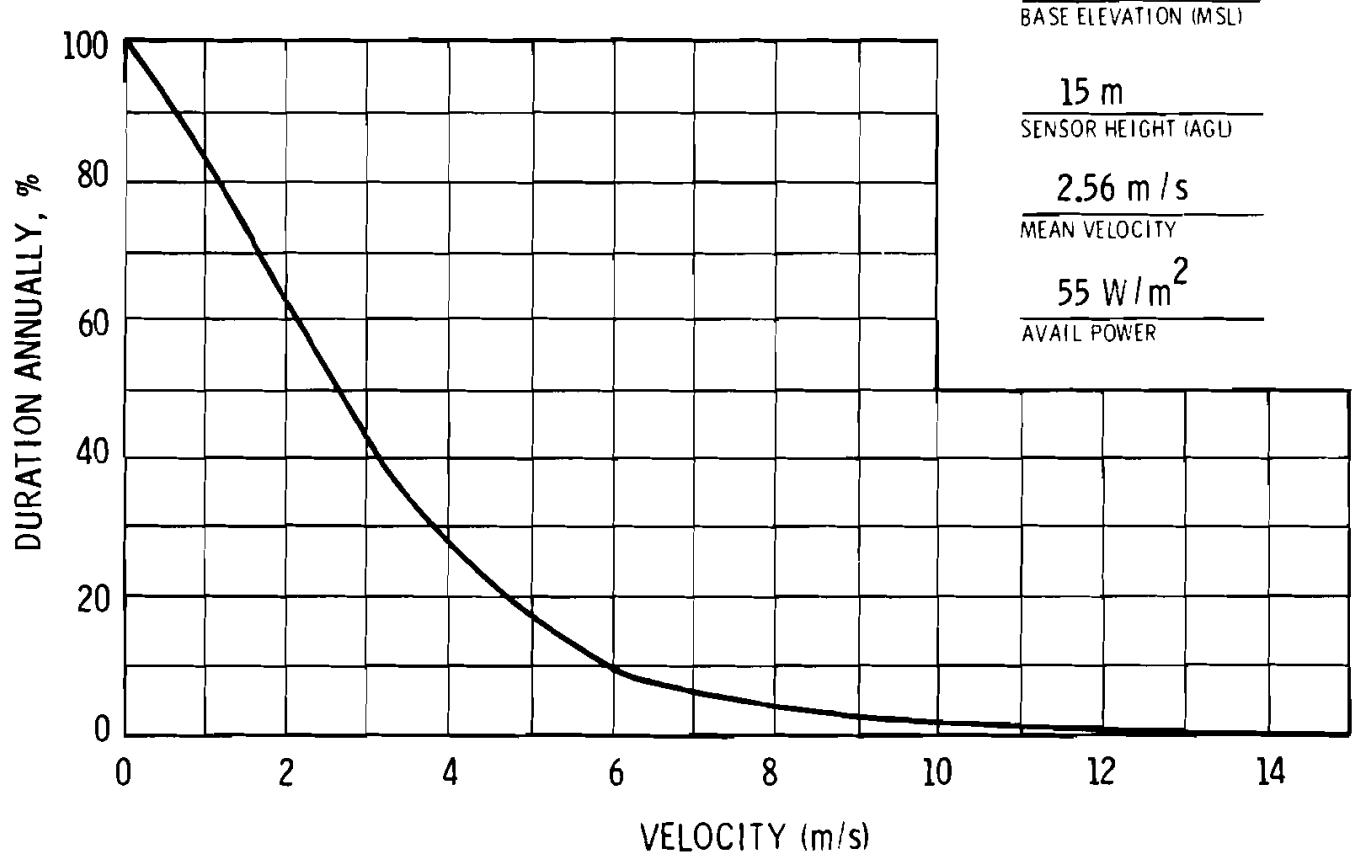


RIVER BEND

\section{SITE LOCATION:}

The River Bend site $\left(30.76^{\circ} \mathrm{N} / 91.33^{\circ} \mathrm{W}\right)$ is in West Feliciana Parish (County), Louisiana, on the Mississippi River about $40 \mathrm{~km}$ NNW of Baton Rouge. The village of St. Francisville is $5 \mathrm{~km} \mathrm{~N}$ of the site.

\section{TOPOGRAPHY :}

The terrain in the area is essentially flat with some small rolling hills. The greatest elevation within $8 \mathrm{~km}$ is $67 \mathrm{~m}$ (MSL), which is $38 \mathrm{~m}$ higher than the site $(29 \mathrm{~m})$. The site is on two levels, one is an alluvial floodplain along the river at an elevation of about $11 \mathrm{~m}$ (MSL) and the other is an upper terrace with an average elevation of $30 \mathrm{~m}$ (MSL). Numerous intermittent bayous and streams cross the site and drain to the $\mathrm{E}$ and $\mathrm{W}$. The site is heavily wooded with several open fields dotting the landscape.

ON-SITE WIND MEASUREMENTS:

The meteorological measurement program was begun in December 1971, using a 46-m tower instrumented at $9 \mathrm{~m}$ and $46 \mathrm{~m}$ with weathermeasure $\mathrm{W}-103$ (speed) and $\mathrm{W}-104$ (direction) sensors.

NRC Docket No. $50-458$ 


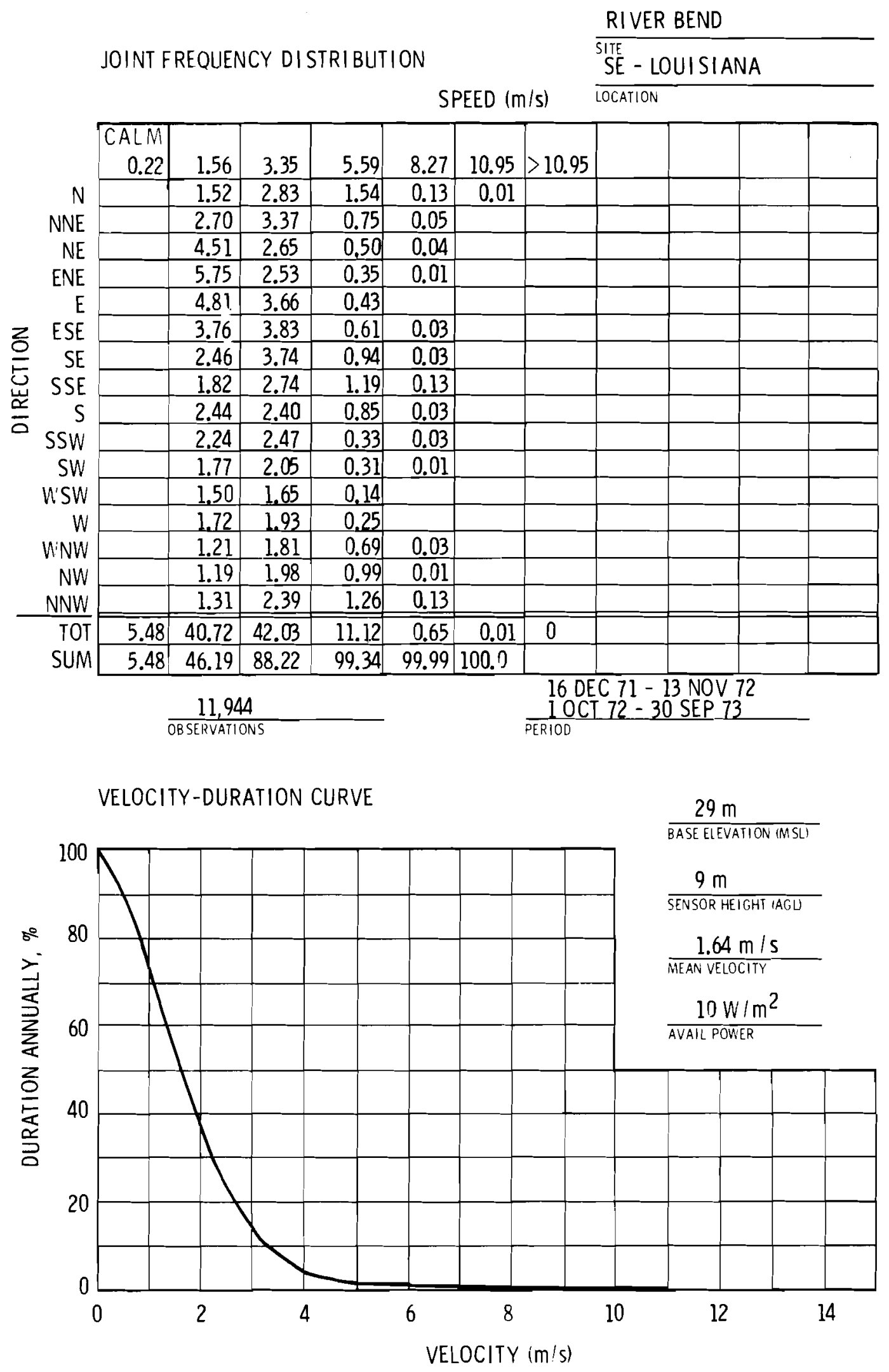




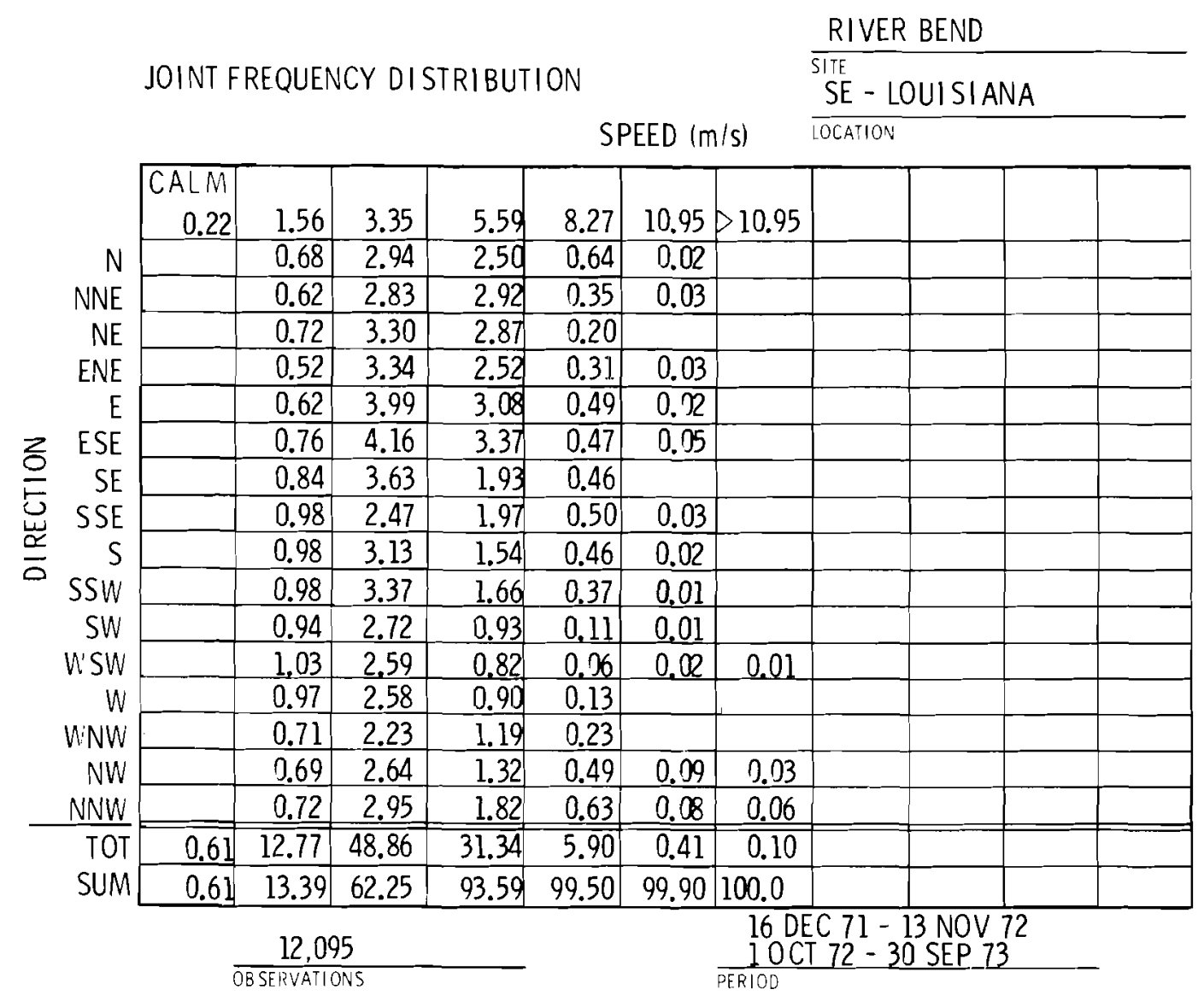

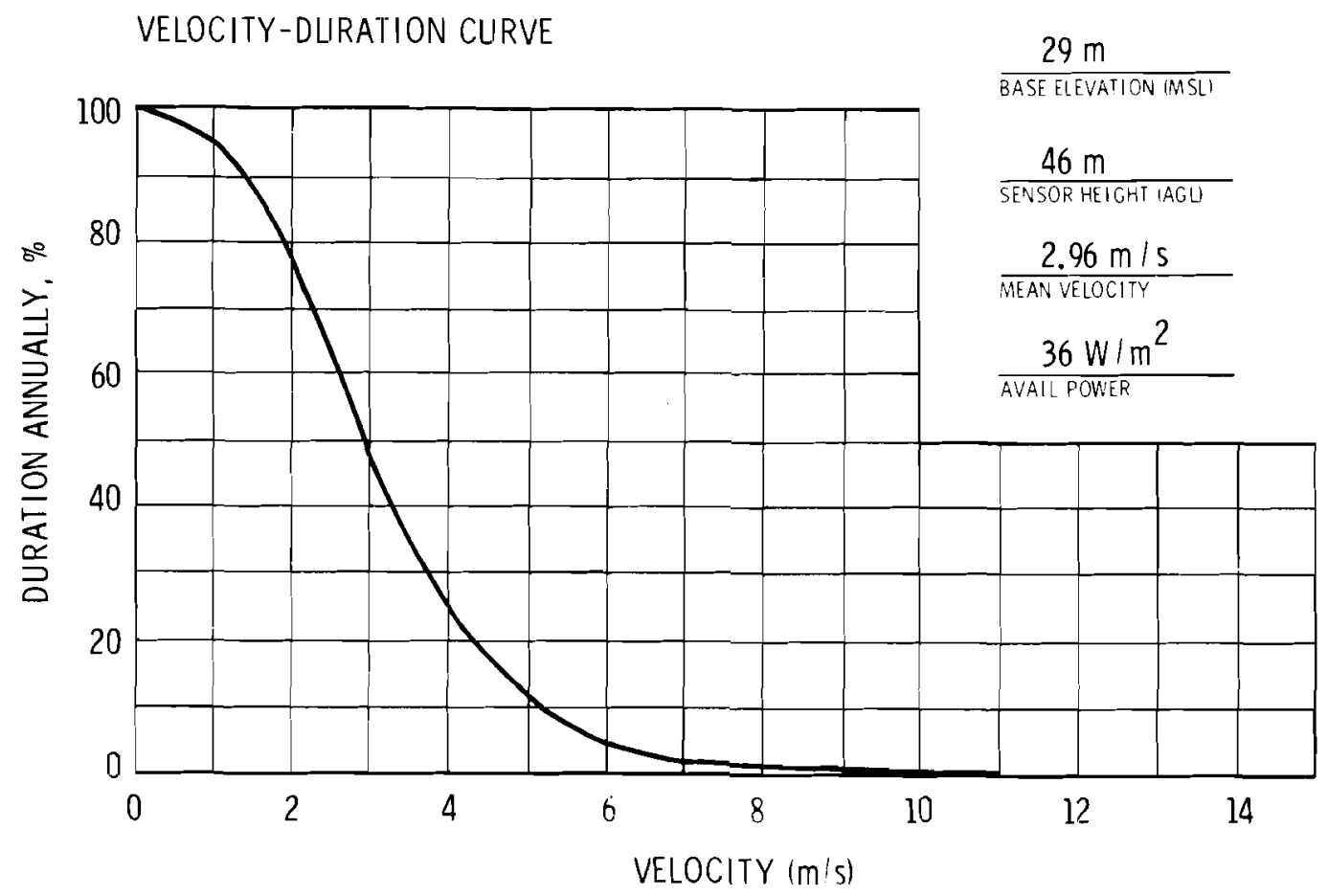


H. B. ROBINSON

\section{SITE LOCATION :}

The site $\left(34.40^{\circ} \mathrm{N} / 80.16^{\circ} \mathrm{W}\right)$ is located in the western corner of Darlington County, South Carolina, on the SW shore of lake Robinson, about $7 \mathrm{~km}$ WNW of Hartsville. The location is also $40 \mathrm{~km} \mathrm{NW}$ of Florence, $56 \mathrm{~km} \mathrm{NNE}$ of Sumter and $90 \mathrm{~km}$ ENE of Columbia. The Atlantic Ocean is about $142 \mathrm{~km} \mathrm{SE.}$

\section{TOPOGRAPHY :}

The site is on the southern edge of the Sand Hills region of South Carolina. The region is typified by rolling hills interspersed with water courses and covered with wooded areas. To the $S$ and $E$, the terrain becomes flat and swampy in the coastal plain. Lake Robinson is about $1200 \mathrm{~m}$ wide and $12 \mathrm{~km}$ long at an elevation of $68 \mathrm{~m}$ (MSL). The land surface rises 12-15 $\mathrm{m}$ above the lake, with an elevation of $155 \mathrm{~m}$ (MSL) being reached at $8 \mathrm{~km} \mathrm{NE.} \mathrm{Site} \mathrm{elevation} \mathrm{is} 83 \mathrm{~m} \mathrm{(MSL).}$

ON-SITE WIND MEASUREMENTS:

Wind measurements are made at $11 \mathrm{~m}$ and $61 \mathrm{~m}$ (AGL) using MRI Model 1074-22 sensors.

$\overline{\text { NRC }} \overline{\text { Doc }} \overline{\text { ket IJO. } 50-261}$ 


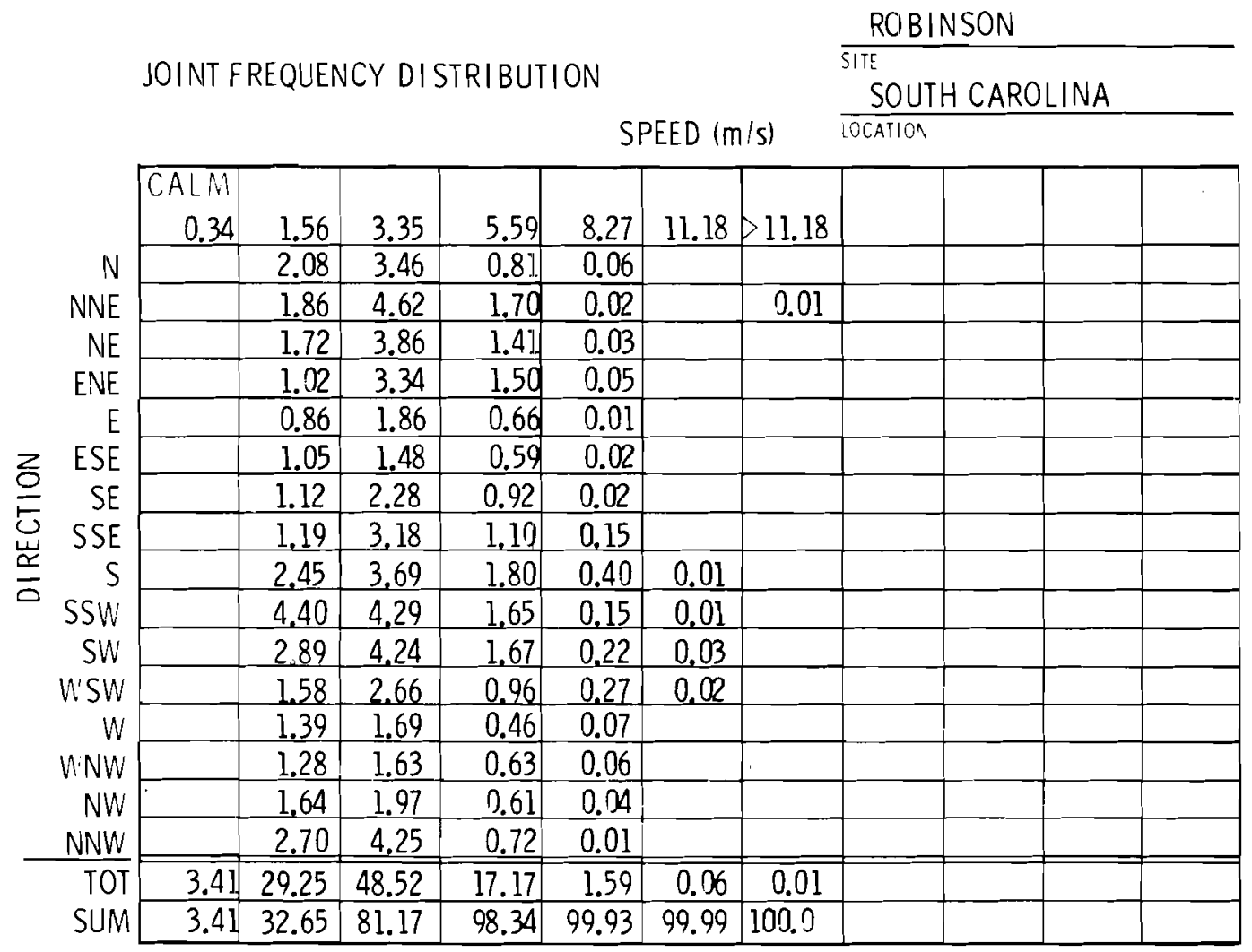

$$
\frac{20,859}{\text { OBSERVATIONS }}
$$

VELOCITY-DURATION CURVE

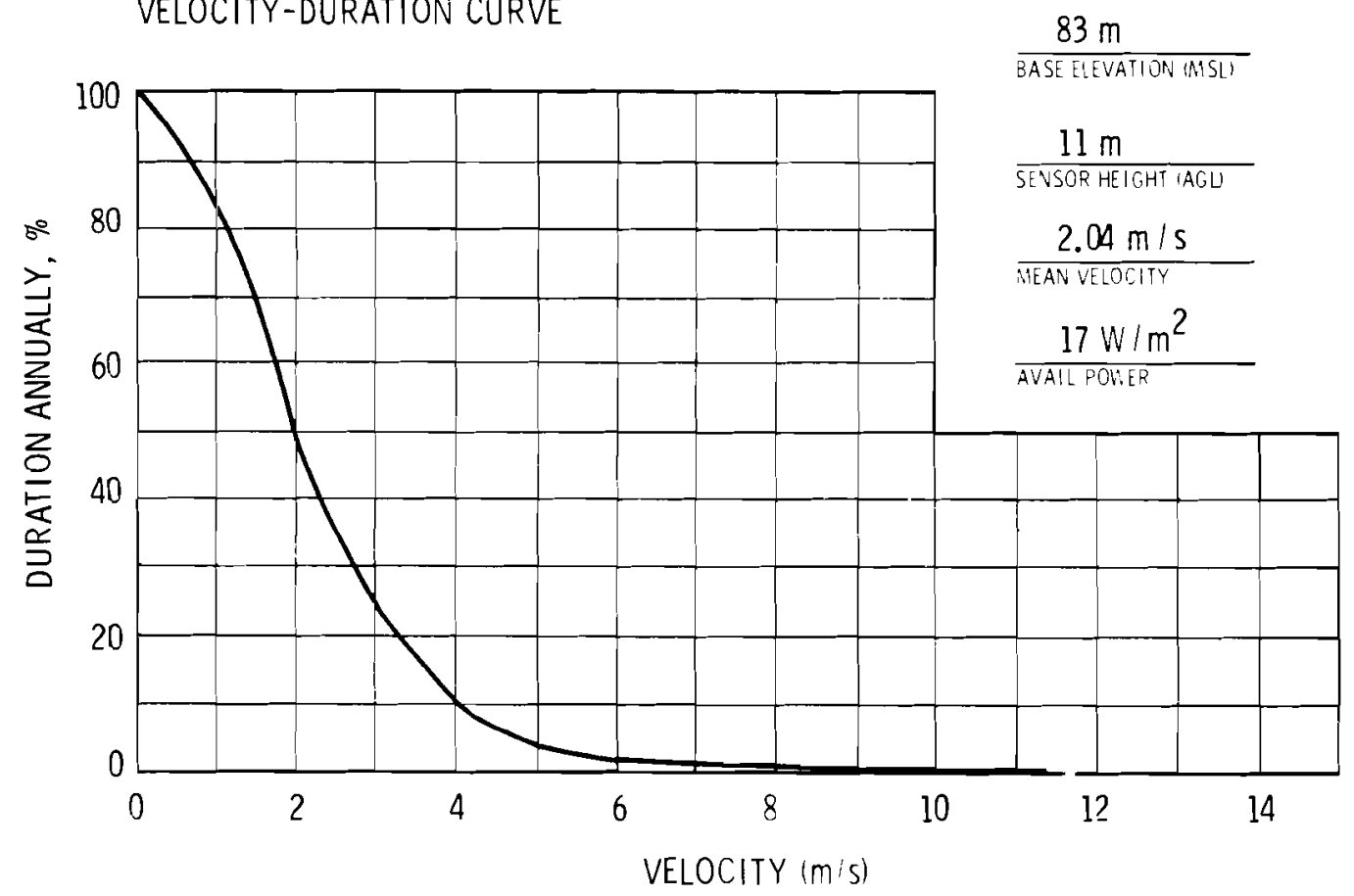




\begin{tabular}{|c|c|c|c|c|c|c|c|c|c|c|}
\hline & & & & & & & & & BINSON & \\
\hline & JOINT & EQUEN & CY DI & STRIBU & & & & SITE SOL & JTH CAROLINA & \\
\hline & & & & & & EED $(\mathrm{m}$ & & & & \\
\hline & $\longdiv { C A L M }$ & & & & & & & & & \\
\hline & 0.34 & 1.56 & 3.35 & 5.59 & 8.27 & 11.18 & $>11.18$ & & & \\
\hline$N$ & & 0.45 & 1.86 & 2,73 & 2.02 & 0.39 & 0.13 & & & \\
\hline NNE & & 0.59 & 2.59 & 3.31 & 1.73 & 0.14 & 0.01 & & & \\
\hline NE & & 0.69 & 2.47 & 2.95 & 0.84 & 0.05 & & & & \\
\hline ENE & & 0.55 & 2.08 & 2.34 & 0.56 & 0.02 & & & & \\
\hline$E$ & & 0.60 & 1.70 & 1.18 & 0.35 & 0.01 & 0.01 & & & \\
\hline ESE & & 0.70 & 1.78 & 1.06 & 0.19 & 0.01 & & & & \\
\hline $\mathrm{SE}$ & & 0.74 & 2.01 & 1.63 & 0.34 & 0.02 & & & & \\
\hline SSE & & 0.45 & 1.79 & 2.16 & 0.82 & 0.13 & & & & \\
\hline $\mathrm{s}$ & & 0.32 & 2.25 & 3.74 & 1.24 & 0.39 & 0.02 & & & \\
\hline SSW & & 0.43 & 2.87 & 5.09 & 1.82 & 0.55 & 0.06 & & & \\
\hline SW & & 0.36 & 2.32 & 4.66 & 1.85 & 0.37 & 0.12 & & & \\
\hline W'SW & & 0.37 & 2.18 & 3.06 & 1.28 & 0.35 & 0.10 & & & \\
\hline$w$ & & 0.43 & 1.91 & 1.77 & 0,66 & 0.17 & 0.07 & & & \\
\hline WNW & & 0.33 & 1.40 & 1.37 & 0,86 & 0.13 & 0,05 & & & \\
\hline NW & & 0.36 & 107 & 1.43 & 0.86 & 0.12 & 0.01 & & & \\
\hline NNW & & 0,29 & 1,01 & 1,60 & 1.39 & 0,17 & 0,01 & & & \\
\hline TOT & 0.55 & $7 \overline{7.66}$ & 31.30 & 40.10 & 16.79 & 3.01 & 0.58 & & & \\
\hline SUM & 0.55 & 8.21 & 39.52 & 79.62 & 96.41 & 99.42 & 100.0 & & & \\
\hline
\end{tabular}

\section{$\frac{32.661}{\text { OB SERVATIONS }}$}

VELOCITY-DURATION CURVE

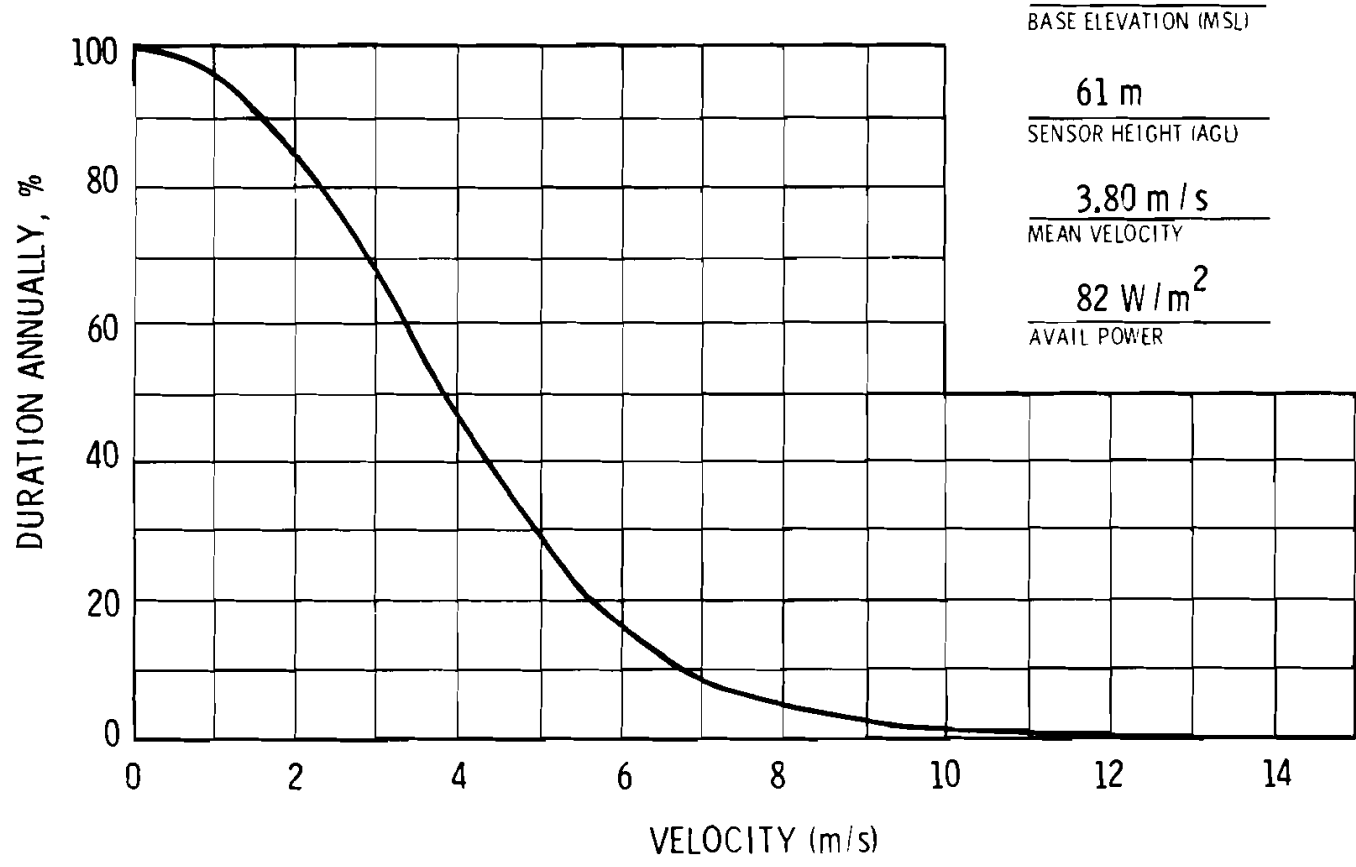

$\frac{1 \text { JAN } 75}{\text { PERIOD }} 31$ DEC 75

$\frac{83 \mathrm{~m}}{\text { BASE EIEVATION IMSLI }}$

$61 \mathrm{~m}$

$82 \mathrm{~W} / \mathrm{m}^{2}$

AIL POWER 
SAINT LUCIE

\section{SITE LOCAIION:}

The site $\left(27.33^{\circ} \mathrm{N} / 80.25^{\circ} \mathrm{W}\right)$ is a 1,132 -aere tract on Hutchinson Island in St. Lucie county on the central east coast of Florida. It is about $14 \mathrm{~km} \mathrm{SE}$ of Ft. Pierce, about $12 \mathrm{~km} \mathrm{~N}$ of stuart, and about $180 \mathrm{~km} \mathrm{~N}$ of Miami.

\section{TOPOGRAPHY:}

The site is generally flat, covered with water and has a dense vegetation characteristic of Florida coastal mangrove swamp. At the ocean shore, the land rises slightly in a dune or ridge of about $5 \mathrm{~m}$ height.

\section{ON-SITE WIND MEASUREMENTS:}

The meteorological program has been in operation since 1970 . There is a 61-m tower located on relatively flat terrain. Its instrumentation includes 6-bladed Bendix-Friez "Aerovanes" mounted at the $15 \mathrm{~m}$ and $61 \mathrm{~m}$ levels. Strip chart recording is reduced to hourly means.

$\overline{\text { NRC Docket Nos. } 50-335,-389}$ 


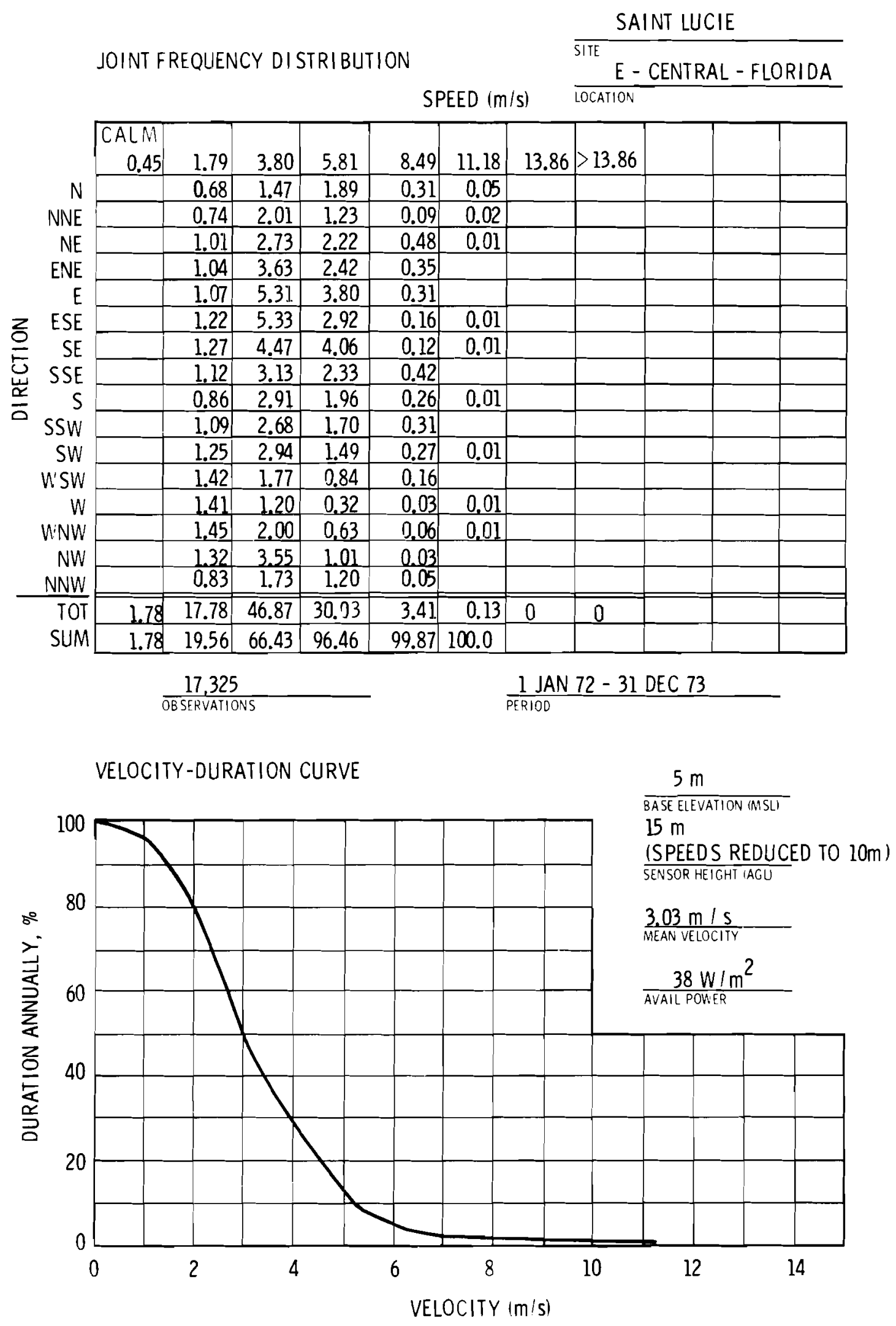




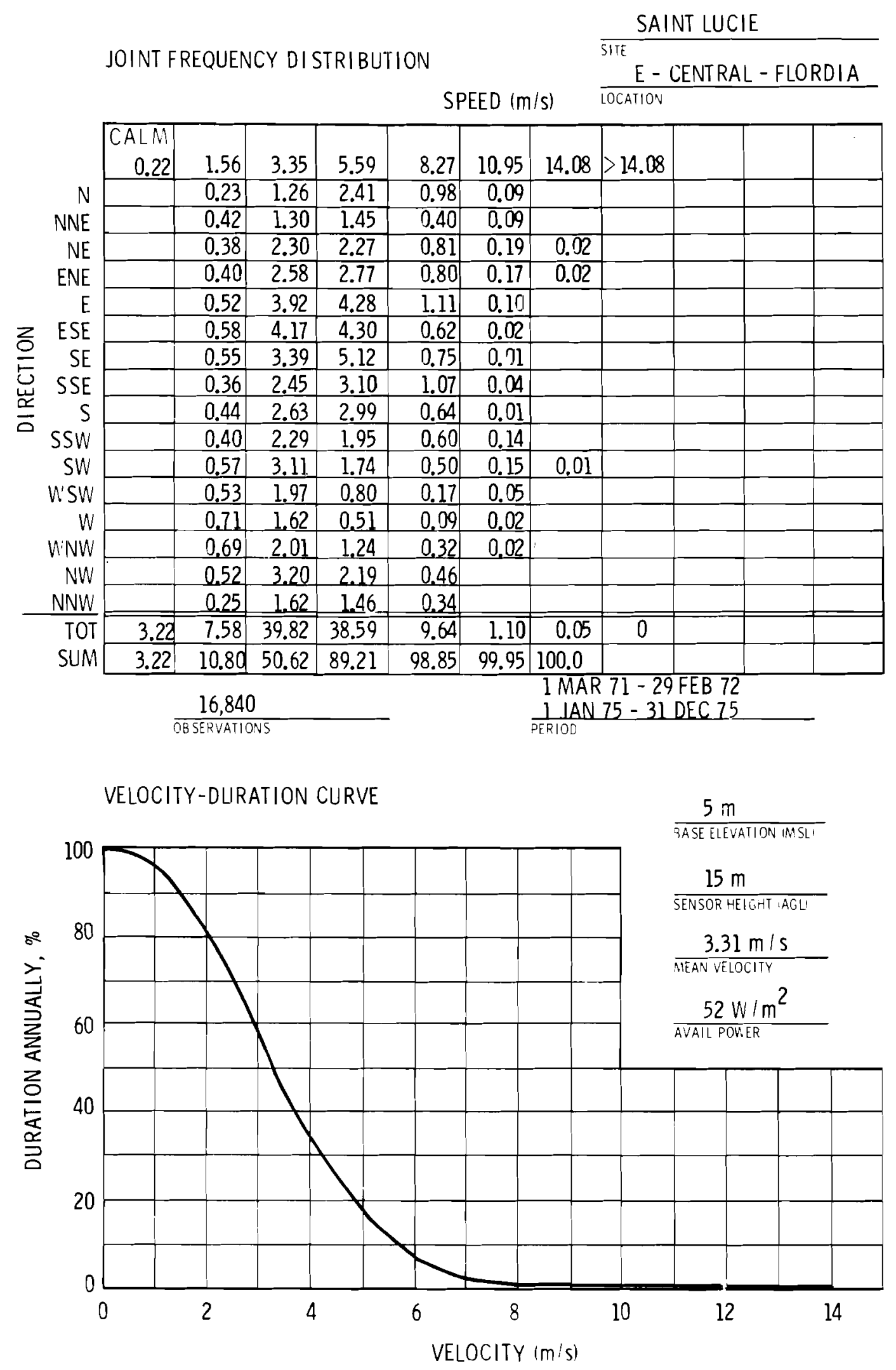


SAN ONOFRE

\section{SITE LOCATION:}

The San Onofre site $\left(32.37^{\circ} \mathrm{N} / 117.56^{\circ} \mathrm{W}\right)$ is on the $\mathrm{W}$ coast of California, in San Diego County, about $100 \mathrm{~km} \mathrm{SE}$ of

Los Angeles and $80 \mathrm{~km} \mathrm{NW}$ of San Diego. It is located entirely within the Camp Pendleton Marine Corps Base near the NW end of its $29 \mathrm{~km}$ shoreline.

\section{TOPOGRAPHY :}

The site is on the west coast of California, which is oriented SE-NW in this area. The dominant features of the surrounding terrain are the steep undulating hills which rise to over $500 \mathrm{~m}$ (MSL) just $\mathrm{E}$ of the site and to over $250 \mathrm{~m}$ in all onshore directions within $6 \mathrm{~km}$. The San onofre canyon is $\mathrm{N}$ of the site and is oriented WSW-ENE for 5 to $6 \mathrm{~km}$ inland before it splits into several smaller canyons which persist for 11 to $13 \mathrm{~km}$ from the coast. The site is located on a slight plateau above the beach.

ON-SITE WIND MEASUREMENTS:

A $20 \mathrm{~m}$ tower was installed in late 1964 and replaced before 1973 by a $40 \mathrm{~m}$ tower. Vector Vane wind systems were used on top of the $20 \mathrm{~m}$ tower and at the $10 \mathrm{~m}$ and $37 \mathrm{~m}$ level on the $40 \mathrm{~m}$ tower. The high level sensor was raised to $40 \mathrm{~m}$ in october 1975. The tower location is atop a bluff at $45 \mathrm{~m}$ (MSI) and about $38 \mathrm{~m}$ from the edge, overlooking the beach.

$\overline{\text { NRC Docket Nos. } 50-206,-361}$ 


\begin{tabular}{|c|c|c|c|c|c|c|c|c|c|c|c|}
\hline & & & & & & & & SAN & NOFF & & \\
\hline & JOINT F & EQUIEN & CY DIS & TRIBU & ON & & & SW - & CALIF & RNIA & \\
\hline & & & & & & $E D(\mathrm{~m})$ & & OCATION & & & \\
\hline & $\begin{array}{c}\text { CALM } \\
0.25 \\
\end{array}$ & 1 & 2 & 3 & 4 & 5 & 6 & 7 & 8 & 9 & $>9$ \\
\hline$N$ & & 0.35 & 1.39 & 0.89 & 0.43 & 0.23 & 0.06 & 0.06 & 0.02 & & \\
\hline NNE & & 0.46 & 2.25 & 2.81 & 2.30 & $\begin{array}{l}.62 \\
\end{array}$ & 0.87 & 0.41 & 0.15 & 0.04 & 0.02 \\
\hline $\mathrm{NE}$ & & 0.38 & 2.42 & 3.19 & 2.74 & 2.34 & 1.62 & 0.92 & 0.29 & 0.10 & 0.04 \\
\hline ENE & & 0.28 & 1.15 & 0.52 & 0.23 & 0.20 & 0.20 & 0.13 & 0.10 & 0.04 & 0.03 \\
\hline$E$ & & 0.28 & 0.67 & 0.39 & 0.10 & 0.05 & 0.04 & 0.73 & 0.03 & 0.03 & 0.01 \\
\hline ESE & & 0.21 & 0.67 & 0.64 & 0.39 & 0.13 & 0.07 & 0.04 & 0.01 & 0.02 & 0.22 \\
\hline SE & & 0.14 & 1.04 & 1.28 & 1.17 & 0.54 & 0.23 & 0.16 & 0.12 & 0.16 & 0.09 \\
\hline SSE & & 0.20 & 1,43 & 1.77 & 1.56 & 1.04 & 0.45 & 0.26 & 0.11 & 0.04 & 0.12 \\
\hline$S$ & & 0.30 & 1.33 & 1.54 & 1.31 & 0.95 & 0.50 & 0.27 & 14.27 & 0.08 & 0.17 \\
\hline SSW & & 0.33 & 1.53 & 1.55 & 1.40 & 0.68 & 0.35 & 0.12 & 0.03 & 0.02 & 0.06 \\
\hline SW & & 0.25 & 1.33 & 1.62 & 1.24 & 0.52 & 0.16 & 0.04 & 0.06 & 0.05 & 0.24 \\
\hline W'SW & & 0.33 & 1.52 & 2.11 & 1.57 & 0.50 & 0.13 & 0.11 & 0.05 & 0.03 & 0.03 \\
\hline W & & 0.26 & 1.48 & 2.34 & 2,52 & 1.32 & 0.30 & 0.13 & $0, \mathbb{B}$ & 0.06 & 0.13 \\
\hline WINW & & 0.25 & 1.36 & 2.59 & 3.07 & 1.89 & 0.79 & 0.35 & 0.12 & 0.15 & 0.20 \\
\hline NW & & 0.20 & 1.02 & 1.37 & 1.29 & 0.98 & 0.57 & 0.29 & 0.18 & 0.12 & 0.13 \\
\hline NINW & & 0.27 & 0.91 & 0.74 & 0,60 & 0.34 & 0.17 & 0.09 & 0.04 & 0.01 & 0.03 \\
\hline$\overline{\text { TOT }}$ & 0.07 & 4.53 & 21.50 & 25.34 & 21.92 & 13.32 & 6.5] & 3.41 & 1.50 & 0.86 & 1.05 \\
\hline SUM & 9.77 & 4.60 & 26.17 & 51.44 & 73.36 & 86.68 & 93.19 & 96.60 & 98.10 & 98.96 & 100.01 \\
\hline & & & & & & & 25 & $73-2$ & JAN & & \\
\hline
\end{tabular}

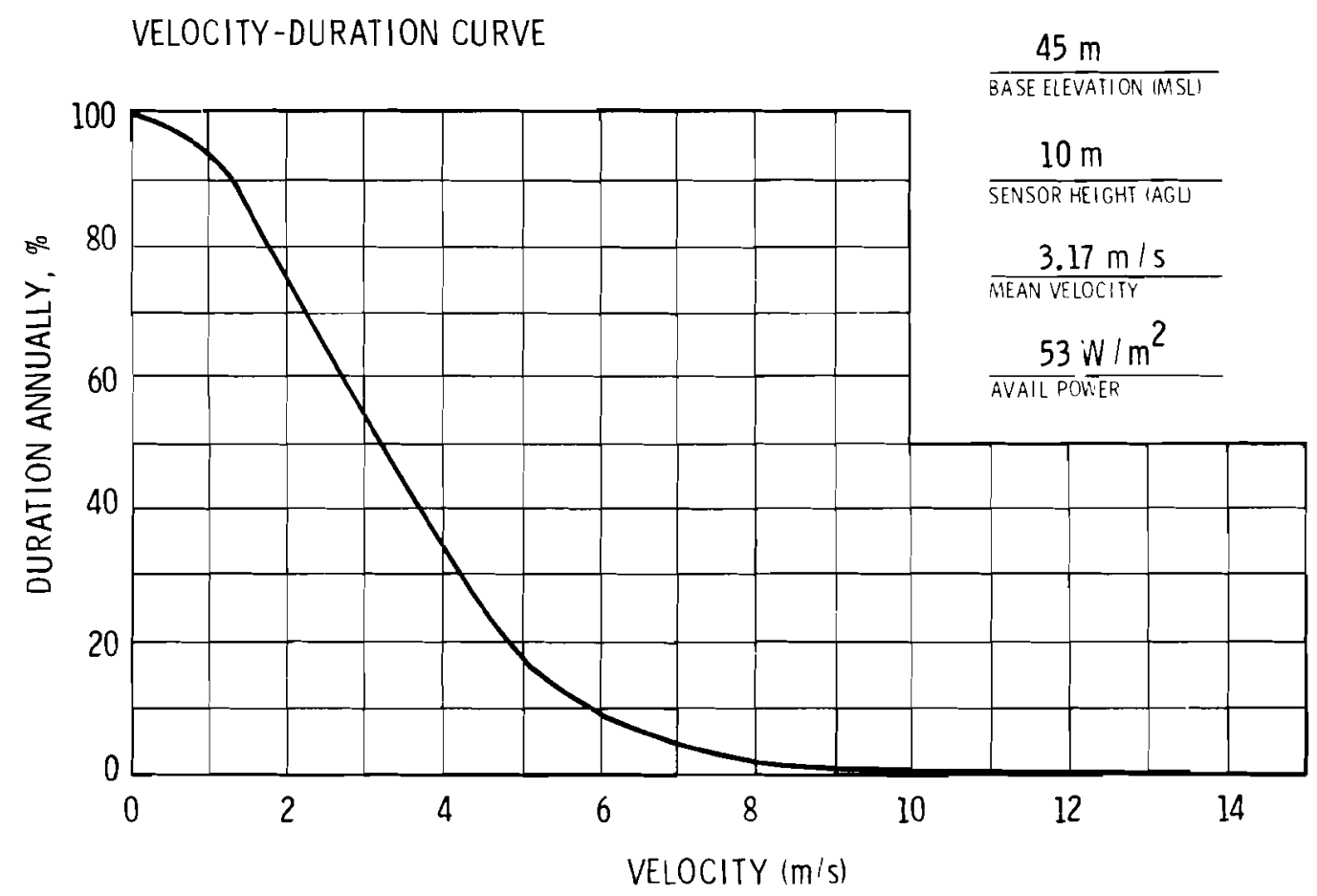




\begin{tabular}{|c|c|c|c|c|c|c|c|c|c|c|c|}
\hline & JOINT & REQU & ICY DI & [RIBUT & ION & & & $\begin{array}{l}\text { SAN OI } \\
\text { SITE } \\
\text { SW - C }\end{array}$ & $\begin{array}{l}\text { NOFRE } \\
\text { ALIFOF }\end{array}$ & $N \mid A$ & \\
\hline & & & & & & DEED (n & & LOCATION & & & \\
\hline & $\begin{array}{c}\text { CALM } \\
0.25\end{array}$ & l & 2 & 3 & 4 & 5 & 6 & 7 & 8 & 9 & $>9$ \\
\hline $\mathrm{N}$ & & 0.56 & 1.85 & 1.57 & 0.85 & 0.51 & 0.24 & 0.06 & 0.05 & 0.01 & \\
\hline NNE & & 0.48 & 2.00 & 2.06 & 1.72 & 1.22 & 0.77 & 0.39 & 0.18 & 0.08 & 0.09 \\
\hline NE & & 0.61 & 1.46 & 1.25 & 0.95 & 0.57 & 0.29 & 0.25 & 0.19 & 0.10 & 0.15 \\
\hline ENE & & 0.58 & 1.02 & 0.37 & 0.15 & 0.09 & 0.10 & 0.08 & 0.03 & 0.06 & 0.08 \\
\hline$E$ & & 0.59 & 1.16 & 0.58 & 0.23 & 0.09 & 0.03 & 0.02 & 0.02 & 0.02 & 0.07 \\
\hline ESE & & 0.56 & 1.31 & 1.16 & 0.69 & 0.21 & 0.10 & 0.07 & 0.04 & 0.02 & 0.03 \\
\hline SE & & 0.60 & 1.76 & 1.83 & 1.58 & 1.02 & 0.49 & 0.22 & 0.14 & 0.06 & 0.19 \\
\hline SSE & & 0.42 & 1.45 & 1.56 & 1.41 & 0.92 & 0.68 & 0.27 & 0.11 & 0.07 & 0.09 \\
\hline$S$ & & 0.37 & 1.51 & 1.59 & 1.24 & 0.88 & 0.42 & 0.15 & 0.09 & 0.08 & 0.09 \\
\hline SSW & & 0.50 & 1.36 & 1.53 & 1.29 & 0.61 & 0.24 & 0.09 & 0.05 & 0.04 & 0.04 \\
\hline SW & & 0.41 & 1.35 & 1.88 & 1.27 & 0.56 & 0.18 & 0.09 & 0.05 & 0.03 & 0.05 \\
\hline W'SW & & 0.39 & 1.53 & 2.12 & 1.86 & 0.74 & 0.26 & 0.11 & 0.08 & 0.03 & 0.09 \\
\hline$W$ & & 0.43 & 1.49 & 2.24 & 2.60 & 1.69 & 0.70 & 0.34 & 0.15 & 0.12 & 0.22 \\
\hline WNW & & 0.44 & 1.23 & 1.88 & 2.12 & 1.71 & 1.04 & 0.64 & 0.30 & 0.28 & 0.42 \\
\hline NW & & 0.34 & 1.07 & 1.18 & 1.02 & 0.74 & 0.45 & 0.29 & 0.17 & 0.07 & 0.10 \\
\hline NNW & & 0.47 & 1.17 & 0.90 & 0,67 & 0,22 & 0.12 & 0.07 & 0.02 & 0.01 & \\
\hline TOT & 0.72 & 7.71 & 22.68 & 23.70 & 19.65 & 11.78 & 6.12 & 3.13 & 1.68 & 1.08 & 1.73 \\
\hline SUM & 0.72 & 8.43 & 31.11 & 54.81 & 74.46 & 86.24 & 92.36 & 95.49 & 97.17 & 98.25 & 99.98 \\
\hline & & & & & & & 10 & $1-$ & AN 7 & & \\
\hline
\end{tabular}

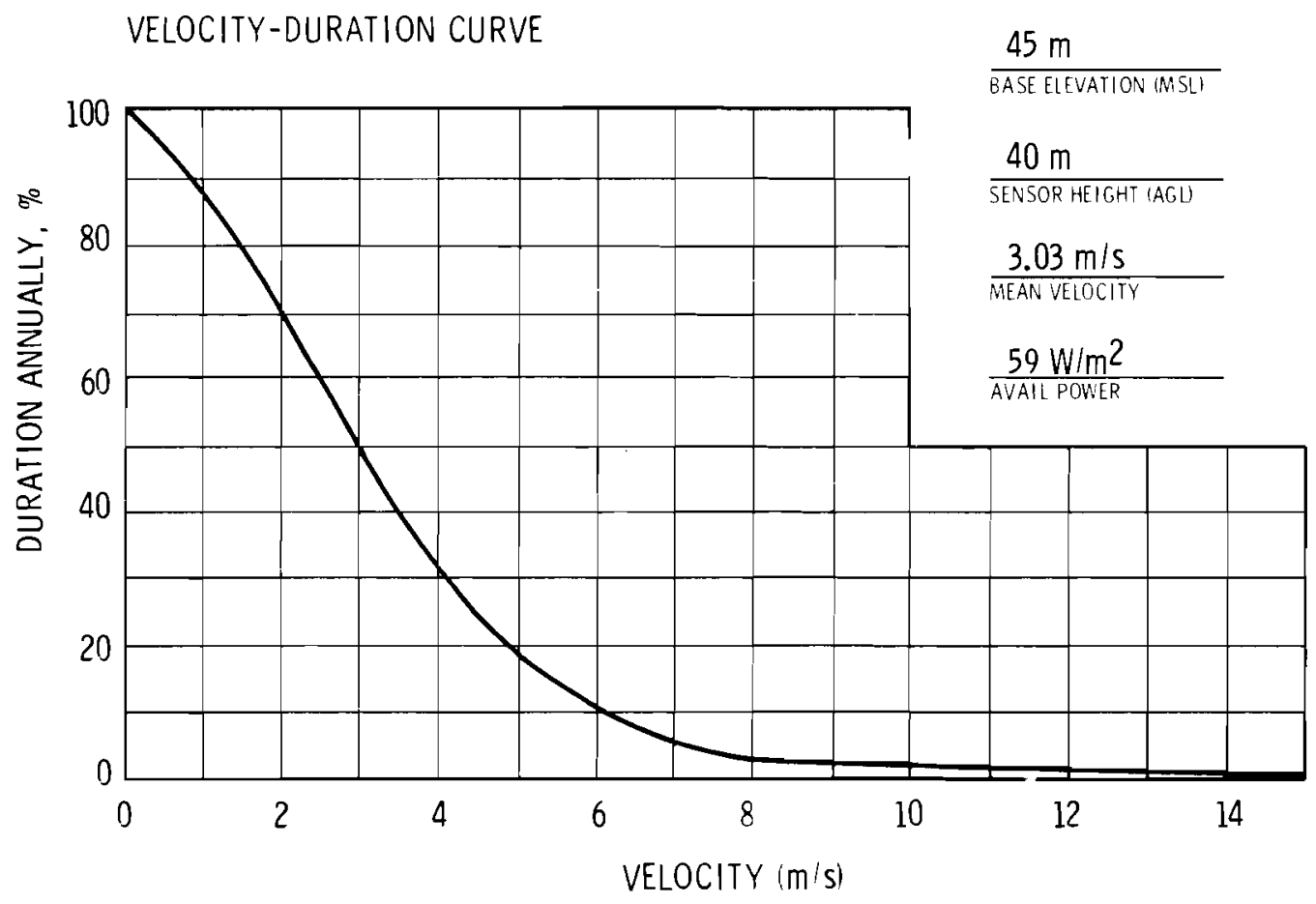


SEABROOK

SITE LOCATION:

The site $\left(42.90^{\circ} \mathrm{N} / 70.85^{\circ} \mathrm{W}\right)$ is located near the northern boundary of the town of Seabrook in Rockingham County, New Hampshire, about $13 \mathrm{~km} \mathrm{SE}$ of Exeter. $8 \mathrm{~km} \mathrm{NE}$ of Amesbury, MA, $3 \mathrm{~km} \mathrm{~W}$ of the Hampton Harbor inlet, and about $65 \mathrm{~km}$ NNE of downtown Boston, MA.

TOPOGRAPHY :

The site is on the western edge of the tidal marshes that surround the Hampton Harbor. The harbor opens directly into the Atlantic Ocean through the Hampton Harbor Inlet, $3 \mathrm{~km}$ to the $\mathrm{E}$. This inlet is about $250 \mathrm{~m}$ wide where it breaks through the sandy seacoast. There are no islands offshore. The immediate site area is tidal marsh with short grass, reeds and tidal channels. Short trees begin at the edge of the marsh as the terrain becomes slightly irregular. A few short ridges and hills occur within the first $8 \mathrm{~km}$ from the site. The first hills and ridges of the White Mountains of New Hampshire occur 30-40 km SW, W, and NW. Hilly terrain with peaks between 60 and $150 \mathrm{~m}$ are found 40 to 60 $\mathrm{km}$ away. The $300 \mathrm{~m}$ contour first occurs about $70 \mathrm{~km} \mathrm{~W}$ and beyond $80 \mathrm{~km}$ in other directions.

ON-SITE WIND MEASUREMENTS:

A $46 \mathrm{~m}$ tower became operational in November 1971. The tower, based at $3 \mathrm{~m}$ (MSL) and located near the $S$ edge of Browns River north of the site, was instrumented at $9 \mathrm{~m}$ with a 6 -bladed Bendix "Aerovane". In November 1972, the Aerovane was replaced with a Bendix P/N 2414914, 3-cup anemometer and P/N 2416970 vane system. Another Bendix system was also installed at the $40 \mathrm{~m}$ level.

$\overline{\mathrm{N}} \overline{\mathrm{RC}}$ Docket Nos. $\overline{50-340, \overline{-443}}$ 


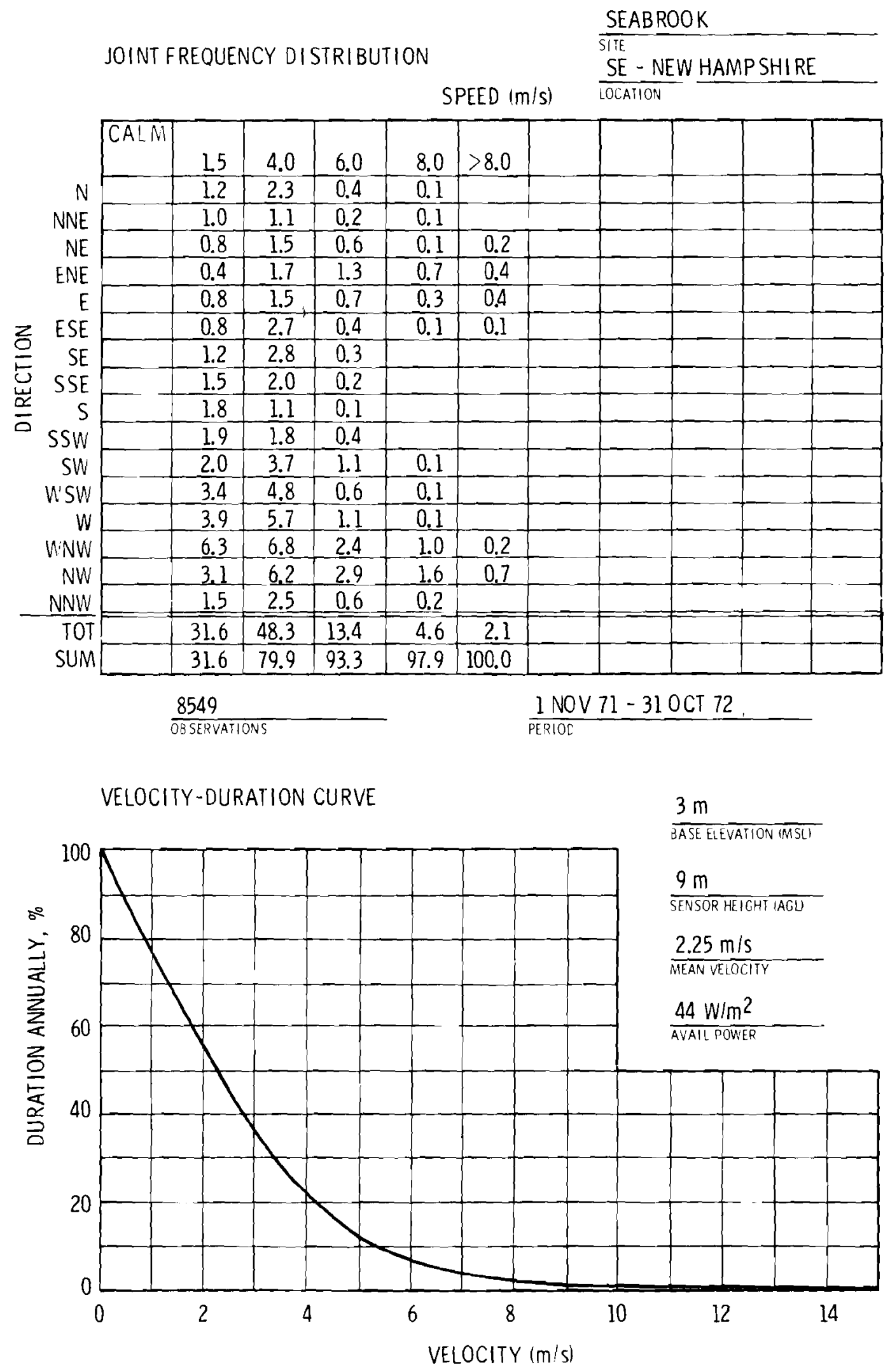


SEQUOYAH

\section{SITE LOCATION:}

The Sequoyah site $\left(35.23^{\circ} \mathrm{N} / 85.09^{\circ} \mathrm{W}\right)$ is near the center of Hamilton County, in SE Tennessee, about $12 \mathrm{~km} \mathrm{NE}$ of Chattanooga, $23 \mathrm{~km}$ WNW of Cleveland and about $50 \mathrm{~km} \mathrm{SSW}$ of TVA's Watts Bar Nuclear Plant.

\section{TOPOGRAPHY :}

The 525-acre site is situated on the western shore of Chickamauga Lake on the Tennessee River. This region is the eastern Tennessee portion of the Southern Appalachian Highlands. The rugged mountain ridge and valley terrain is aligned $N E-S W$ with the high Cumberland Plateau at 480-550 $\mathrm{m}$ above the valley floor (210 m (MSL)). The Tennessee River flows SW through the narrow valley area. The valley floor where the site is located is relatively flat to slightly undulating.

ON-SITE WIND MEASUREMENTS:

A $91 \mathrm{~m}$ tower became operational in April 1971 at an elevation of about $230 \mathrm{~m}$ (MSL) or $15 \mathrm{~m}$ above plant grade. Wind direction and speed are measured at 10 and $91 \mathrm{~m}$ using Climet wS-011-11 (speed) and Climet WD-012-11 (direction) sensors.

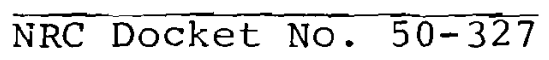




\begin{tabular}{|c|c|c|c|c|c|c|c|c|c|c|c|}
\hline & & & & & & & & SEQUO & YAH & & \\
\hline & JOINT F & REQUEI & $C Y D I S$ & $T R \mid B U T$ & ION & & & $\begin{array}{l}\text { STIE } \\
\text { TENNES S }\end{array}$ & & & \\
\hline & & & & & & PEED (n & & LOCATION & & & \\
\hline & $\widehat{C A L M}$ & & & & & & & & & & \\
\hline & 0.22 & 0.67 & 1.56 & 2.46 & 3.35 & 5.59 & 8.27 & 10.95 & 10.95 & & \\
\hline$N$ & & 0.79 & 2.70 & 1.35 & 0.63 & 0.27 & & & & & \\
\hline NNE & & 1.65 & 6.49 & 4.16 & 2.19 & 1.88 & 0.10 & & & & \\
\hline NE & & 1.31 & 5.13 & 2.83 & 1.21 & 0.81 & 0.12 & & & & \\
\hline ENE & & 0.67 & 1.38 & 0.41 & 0.10 & & & & & & \\
\hline$E$ & & 0.50 & 0.56 & 0.05 & 0.01 & & & & & & \\
\hline ESE & & 0.37 & 0.27 & 0.08 & 0.01 & & & & & & \\
\hline $\mathrm{SE}$ & & 0.33 & 0.70 & 0.19 & 0.01 & 0.01 & & & & & \\
\hline SSE & & 0.43 & 0.83 & 0.33 & 0.12 & 0.12 & 0.01 & & & & \\
\hline$S$ & & 0.53 & 2.52 & 154 & 0.94 & 0.84 & 0.06 & & & & \\
\hline SSW & & 0.62 & 3.90 & 4.67 & 3.43 & 1.99 & 0.11 & & & & \\
\hline SW & & 0.63 & 4.04 & 5.27 & 3.24 & 2.46 & 0.15 & 0.01 & & & \\
\hline W'SW & & 0.46 & 1.72 & 1.22 & 0.73 & 0.58 & 0.05 & 0.02 & & & \\
\hline$W$ & & 0.33 & 0.71 & 0.47 & 0.37 & 0.42 & 0.04 & & & & \\
\hline UNW & & 039 & 0.68 & 0.39 & 0.33 & 0.53 & 0.02 & & & & \\
\hline NW & & 0.40 & 0.78 & 0.60 & 0.63 & 0.04 & 0.05 & & 0.01 & & \\
\hline NNW & & 0.75 & 2.40 & 1.57 & 0.91 & 1.12 & 0.06 & & & & \\
\hline TOT & 2.25 & 10.16 & 34.81 & 25.13 & 14.86 & 1197 & 0.77 & 0.03 & 0,02 & & \\
\hline SUM & 2.25 & 12.41 & 47.24 & 72.35 & 87.21 & 99.18 & 99.95 & 99.98 & 100.0 & & \\
\hline
\end{tabular}

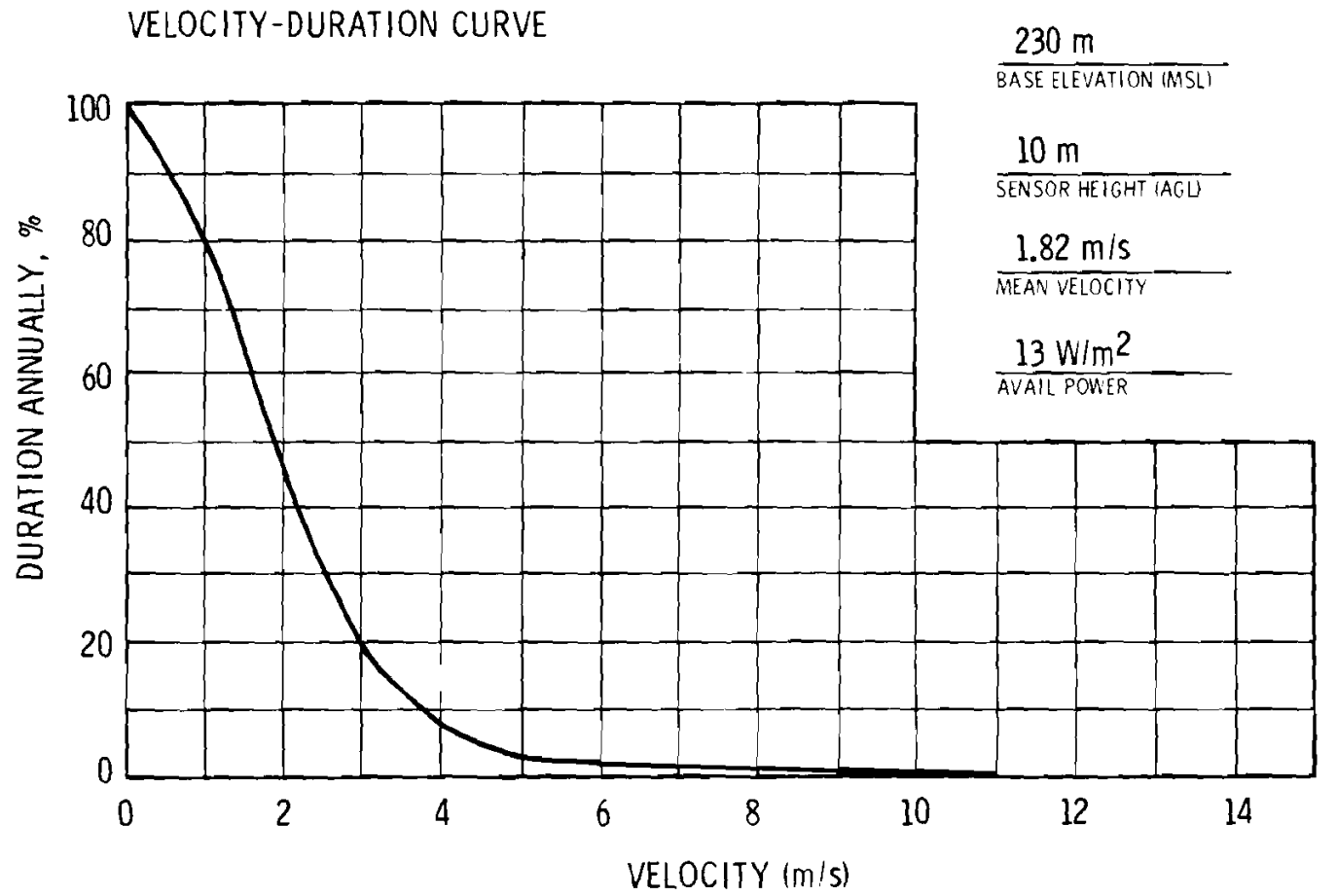




\section{SITE LOCATION:}

The shoreham site $\left(40.96^{\circ} \mathrm{N} / 72.87^{\circ} \mathrm{W}\right)$ is located in the town of Brookhaven, Suffolk County, New York on the $\mathrm{N}$ shore of Long Island about $80 \mathrm{~km}$ ENE of New York City and $5 \mathrm{~km} \mathrm{NE}$ of Rocky Point.

\section{TOPOGRAPHY :}

The 500-acre site, on the $\mathrm{N}$ shore of Long Island, is slightly rolling and sloping up from beach level at the sound to about $60 \mathrm{~m}$ (MSL) inland. It is mostly wooded with wetlands along the $E$ and $W$ boundaries, extending almost $1 \mathrm{~km}$ back from the shore. Wading River creek flows through the wetlands on the $E$ side of the site. The coastline runs $E-W$ along the northern site boundary.

ON-SITE WIND MEASUREMENTS

A 122-m tower began collecting data in september 1973. Wind instrumentation includes Climatronics F460 wind sets (3-cup anemometer and vane) at $10 \mathrm{~m}, 46 \mathrm{~m}$, and $122 \mathrm{~m}$.

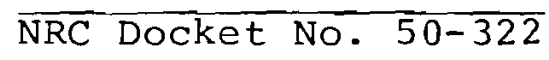



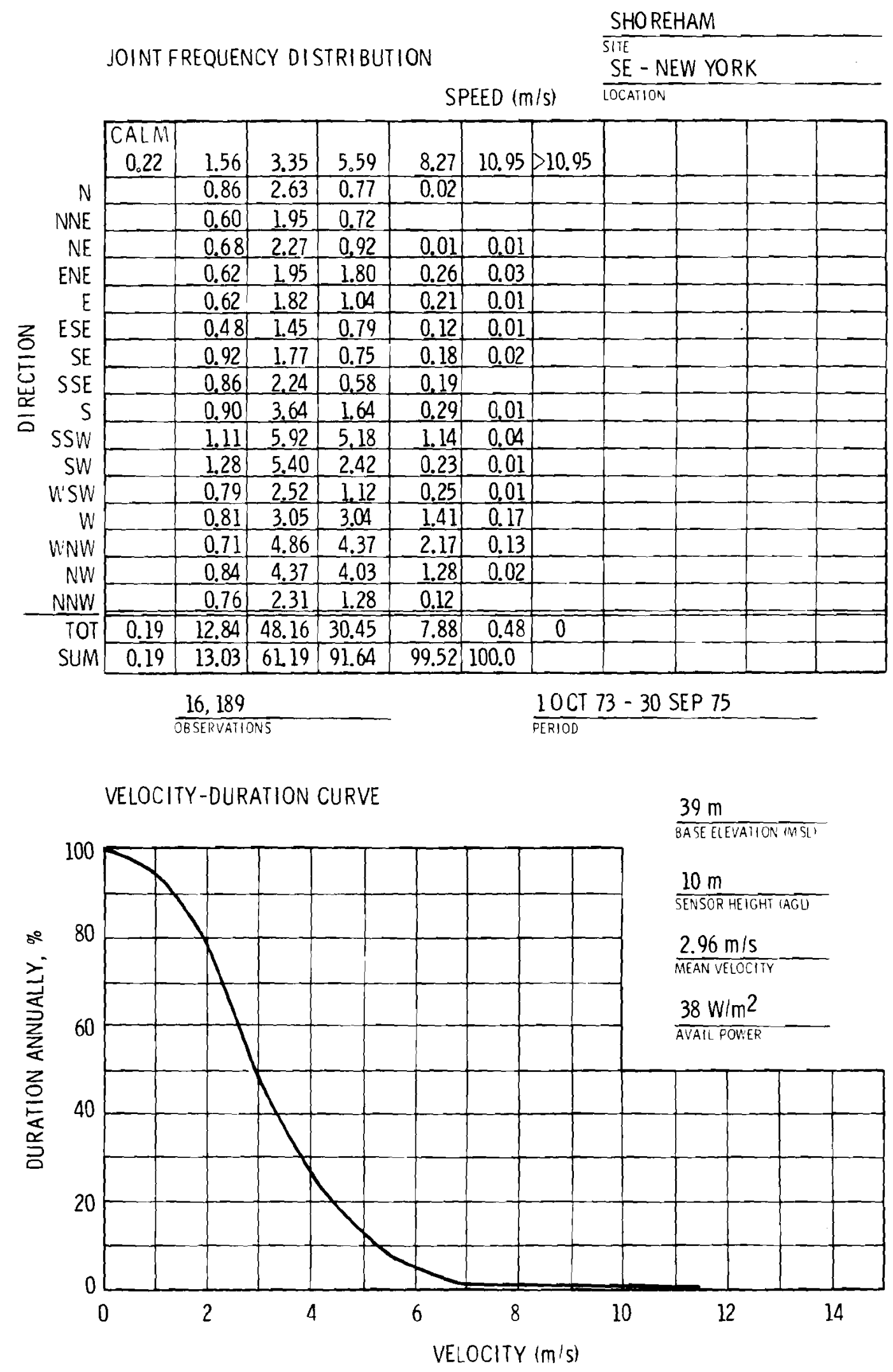

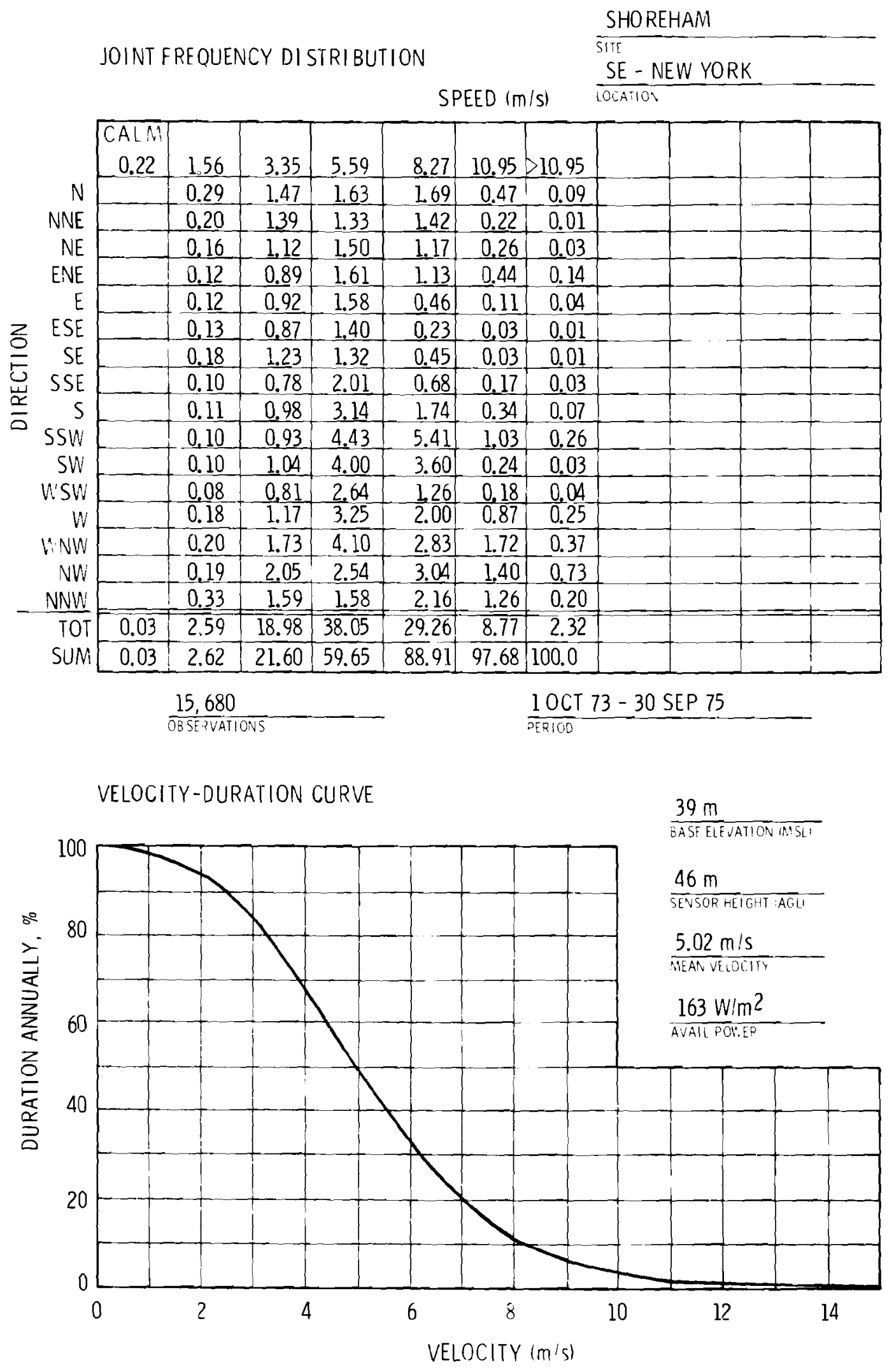
SKAGIT

\section{SITE LOCATION:}

The site $\left(48.53^{\circ} \mathrm{N} / 122.09^{\circ} \mathrm{W}\right)$ is in eastern skagit county, Washington about halfway between seattle, WA and Vancouver, BC. It is also $37 \mathrm{~km}$ SE of Bellingham, $10 \mathrm{~km}$ ENE of Sedro Woolley and $103 \mathrm{~km} \mathrm{~N}$ of seattle.

\section{TOPOGRAPHY :}

The site is situated within the forested western foothills of the northern Cascade Mountains. The 1500-acre site is about $128 \mathrm{~m}$ (MSL) and more than $100 \mathrm{~m}$ above the skagit River floodplain. The skagit River is about $2 \mathrm{~km} \mathrm{~S}$ of Lake Minkler, a small shallow-water lake adjacent to the southern boundary of the site. The Nooksack River is about $9 \mathrm{~km} \mathrm{NE}$. The skagit River Valley is oriented $W$ to $E$ and is about $5 \mathrm{~km}$ wide in the vicinity of the site. The mouth of the valley is about $8 \mathrm{~km} \mathrm{~W}$ and opens onto the lowlands bordering Puget Sound, some $27 \mathrm{~km}$ $W$ of the site. Land surfaces are generally flat to gently rolling in the lowlands, but rise rather abruptly along the western edge of the Cascades. Progressing eastward, the terrain becomes increasingly more rugged and mountainous. The ridge directly $N$ of the site rises to over $1200 \mathrm{~m}$ (MSL) within $5 \mathrm{~km}$, while elevations on the $\mathrm{s}$ side of the skagit exceed $1200 \mathrm{~m}$ within $11 \mathrm{~km}$.

ON-SITE WIND MEASUREMENTS:

A 60-m tower was established in April 1973 at $128 \mathrm{~m}$ (MSL). Climet WS-011-1 (speed) and Climet WD-012-10 (direction) sensors are located at $10 \mathrm{~m}$ and $60 \mathrm{~m}$.

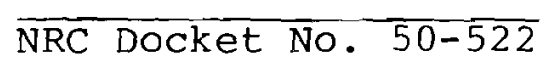



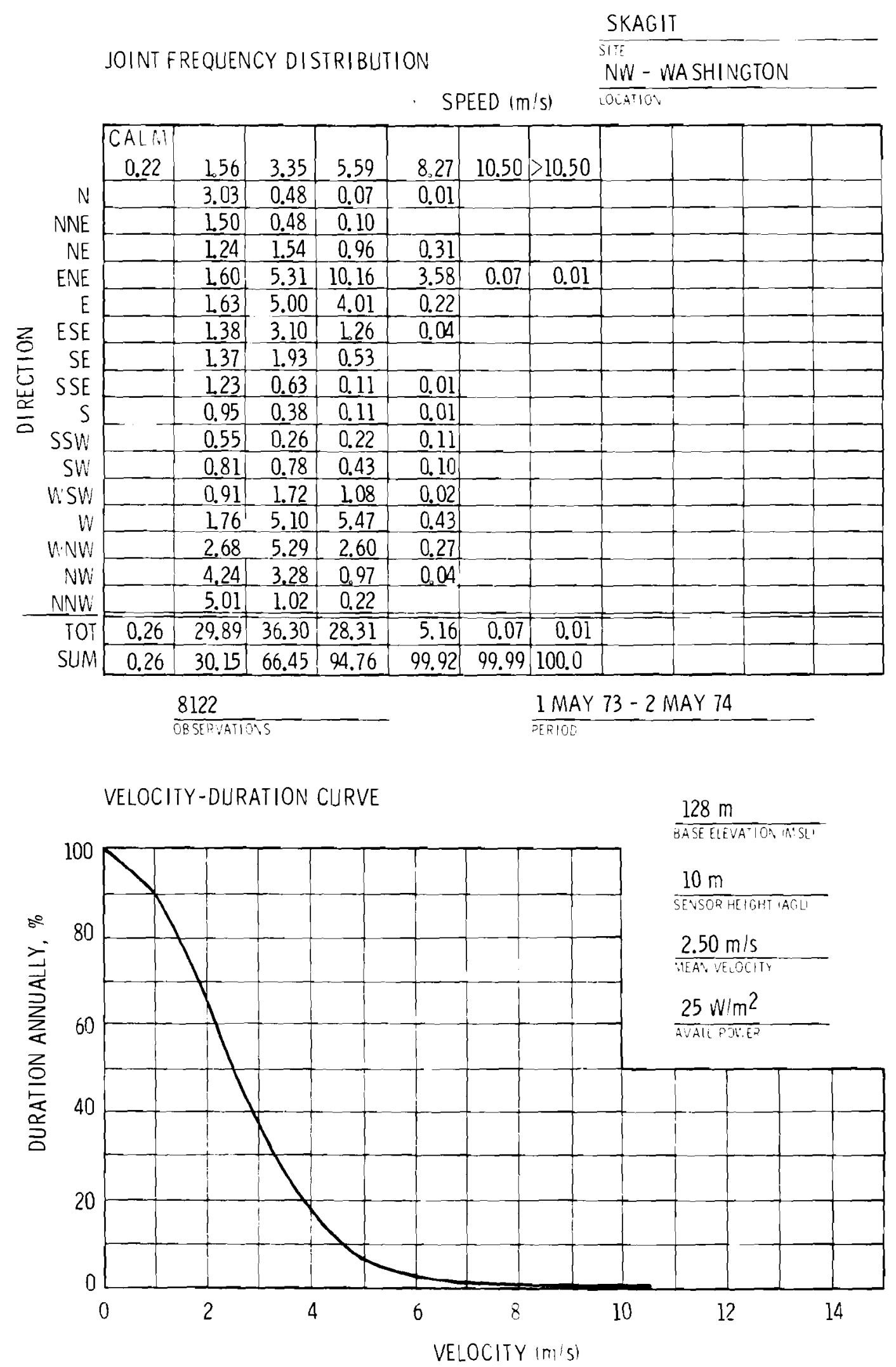


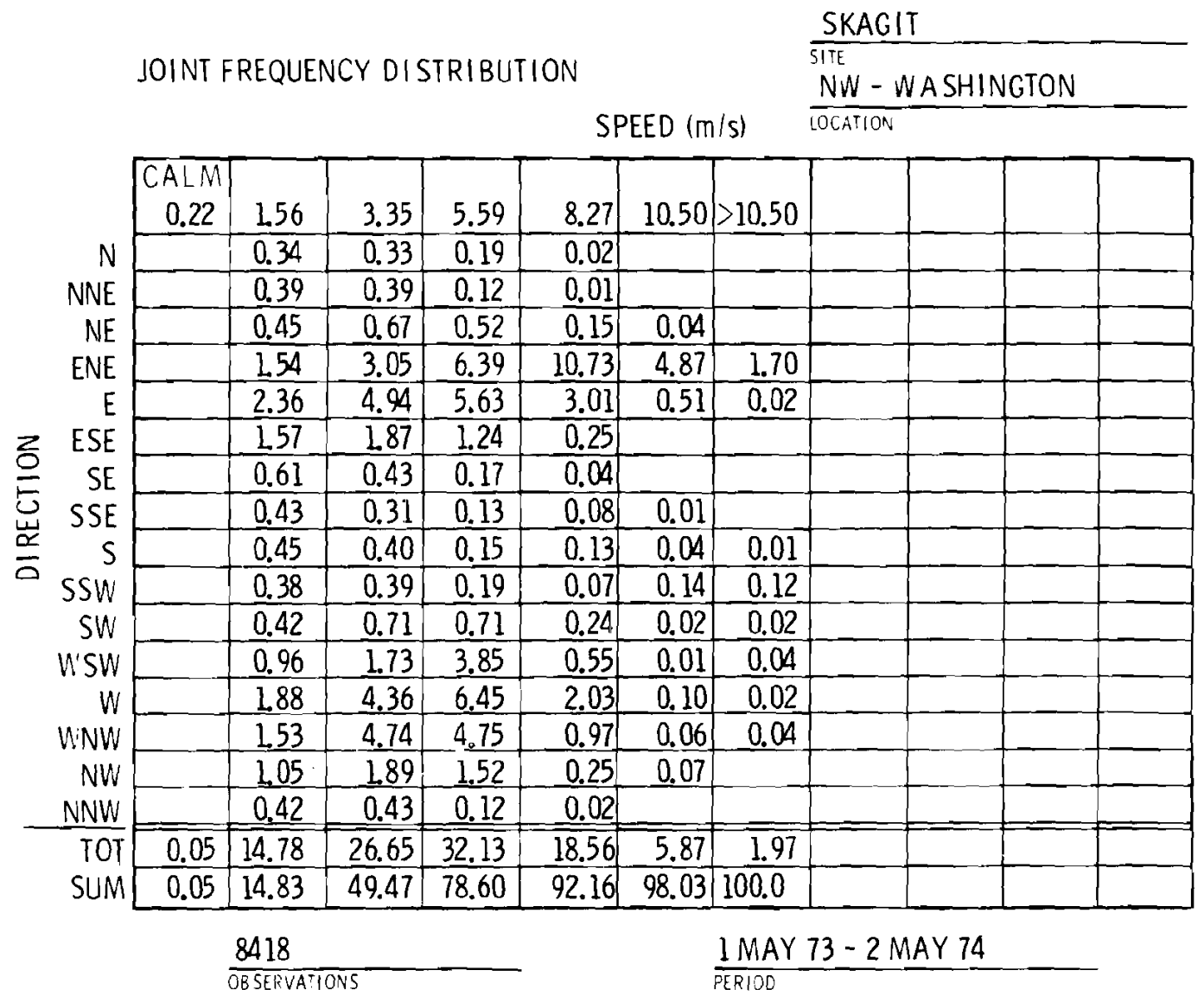

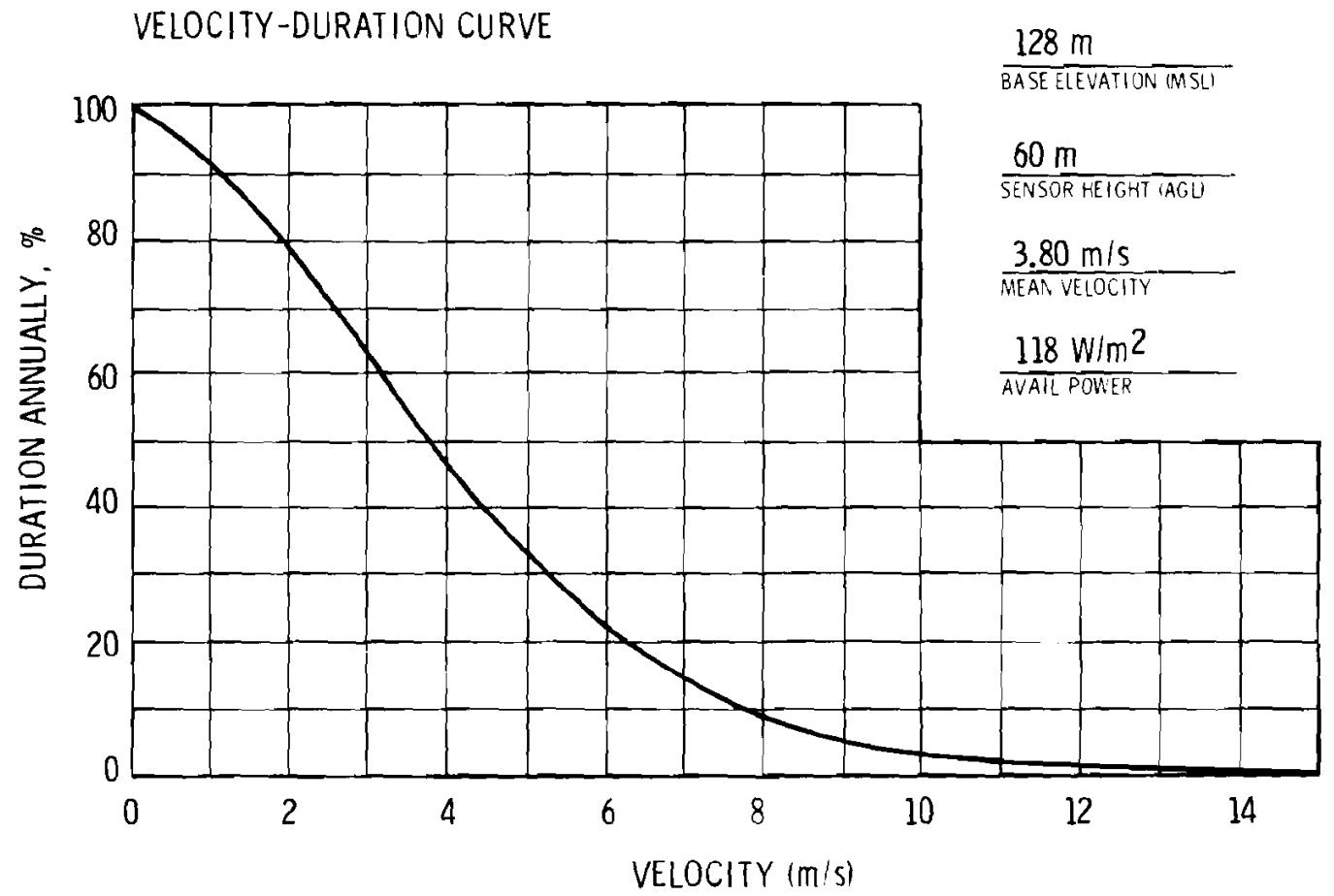


SOUTH TEXAS

SITE DESCRIPTION:

The site $\left(28.80^{\circ} \mathrm{N} / 96.05^{\circ} \mathrm{W}\right)$ of the South Texas Project (STP) is located in a rural area of Matagorda county, along the central Gulf coast of Texas, about $19 \mathrm{~km}$ SSW of Bay City, 16 $\mathrm{km} \mathrm{N}$ of Matagorda Bar, $6 \mathrm{~km} \mathrm{~W}$ of Wadsworth and about $120 \mathrm{~km}$ sSw of Houston. The Allens Creek site is about $95 \mathrm{~km} \mathrm{~N}$ of the STP site.

TOPOGRAPHY :

Local relief of the area is generally flat, about $7 \mathrm{~m}$ (MSL). The west branch of the colorado River, as well as several sloughs, flow through the site. One of the sloughs feeds Kelly Lake, a 35-acre lake in the NE corner of the site. This region is part of the coastal Prairie, which extends as a broad band parallel to the Texas Gulf coast for some 60-80 $\mathrm{km}$ inland.

ON-SITE WIND MEASUREMENTS:

On-site measurements began in July 1973 at the $10-\mathrm{m}$ and $60-\mathrm{m}$ level of a 60-m tower. Climet wS-011-l (speed) and Climet WD-012-10 (direction) sensors are used.

$\overline{\mathrm{NR}} \overline{\mathrm{C}}$ Docket No. $\overline{50-498}$ 


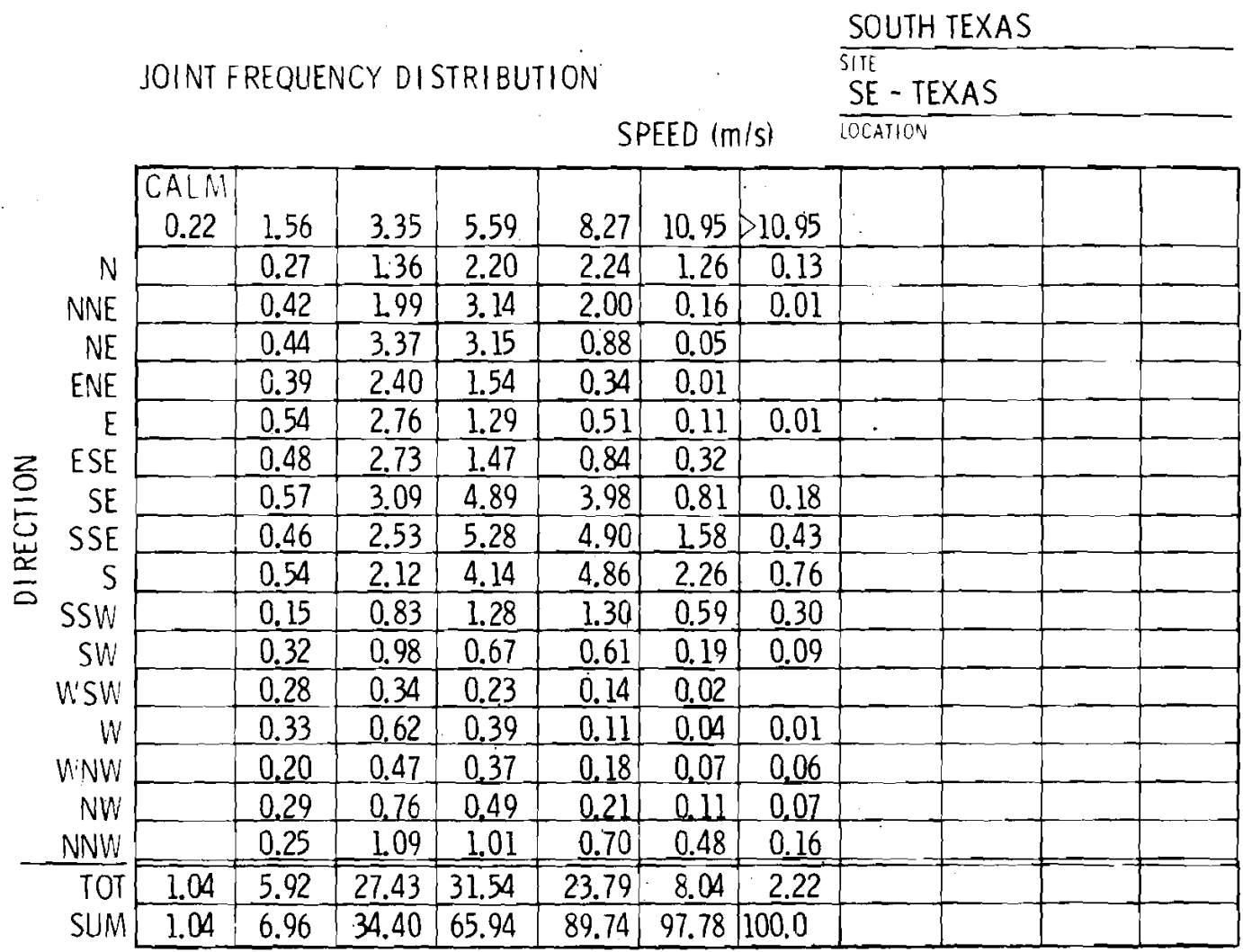

8544

OBSERVATIONS

$20 J U L 73-20 J U L 74$

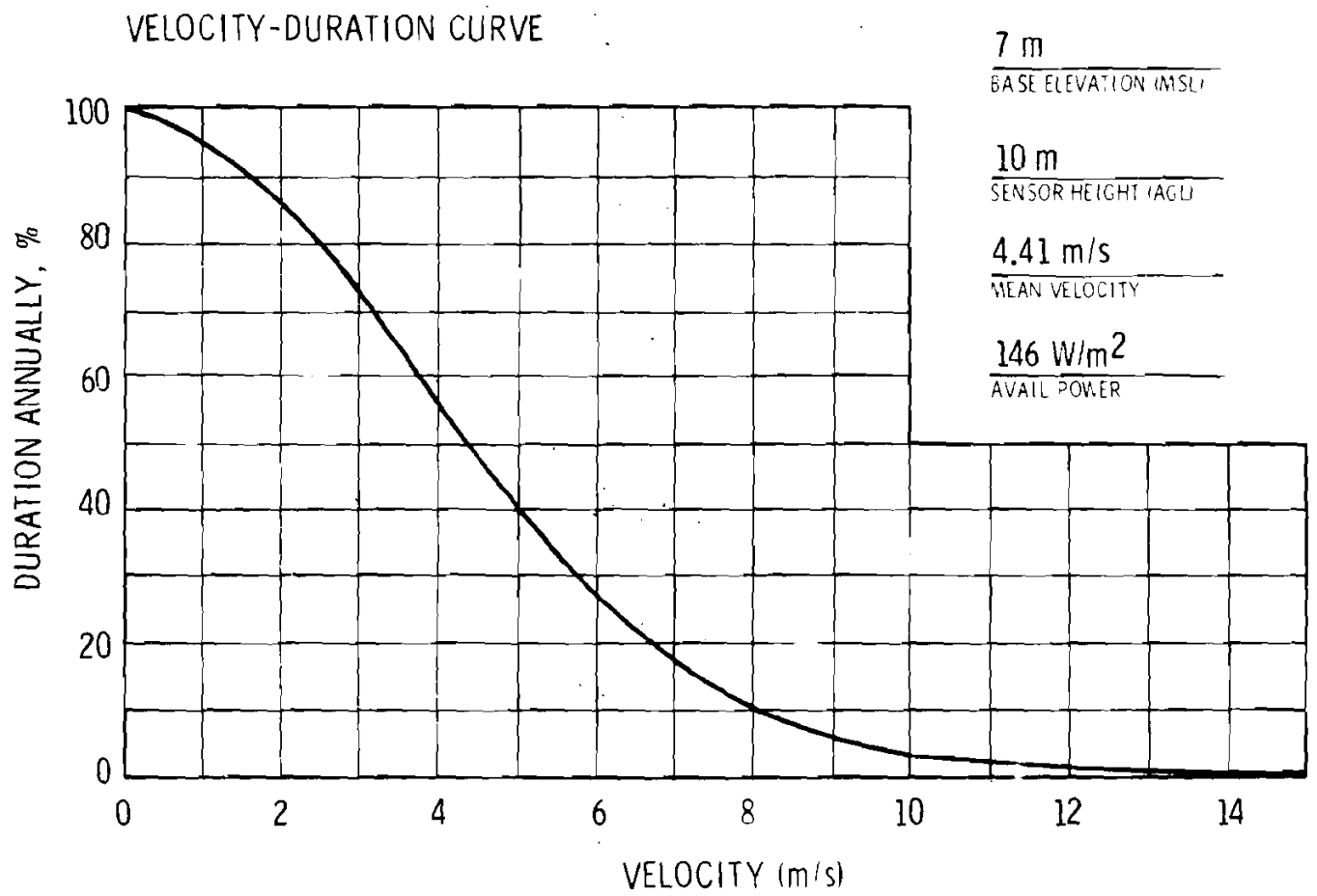



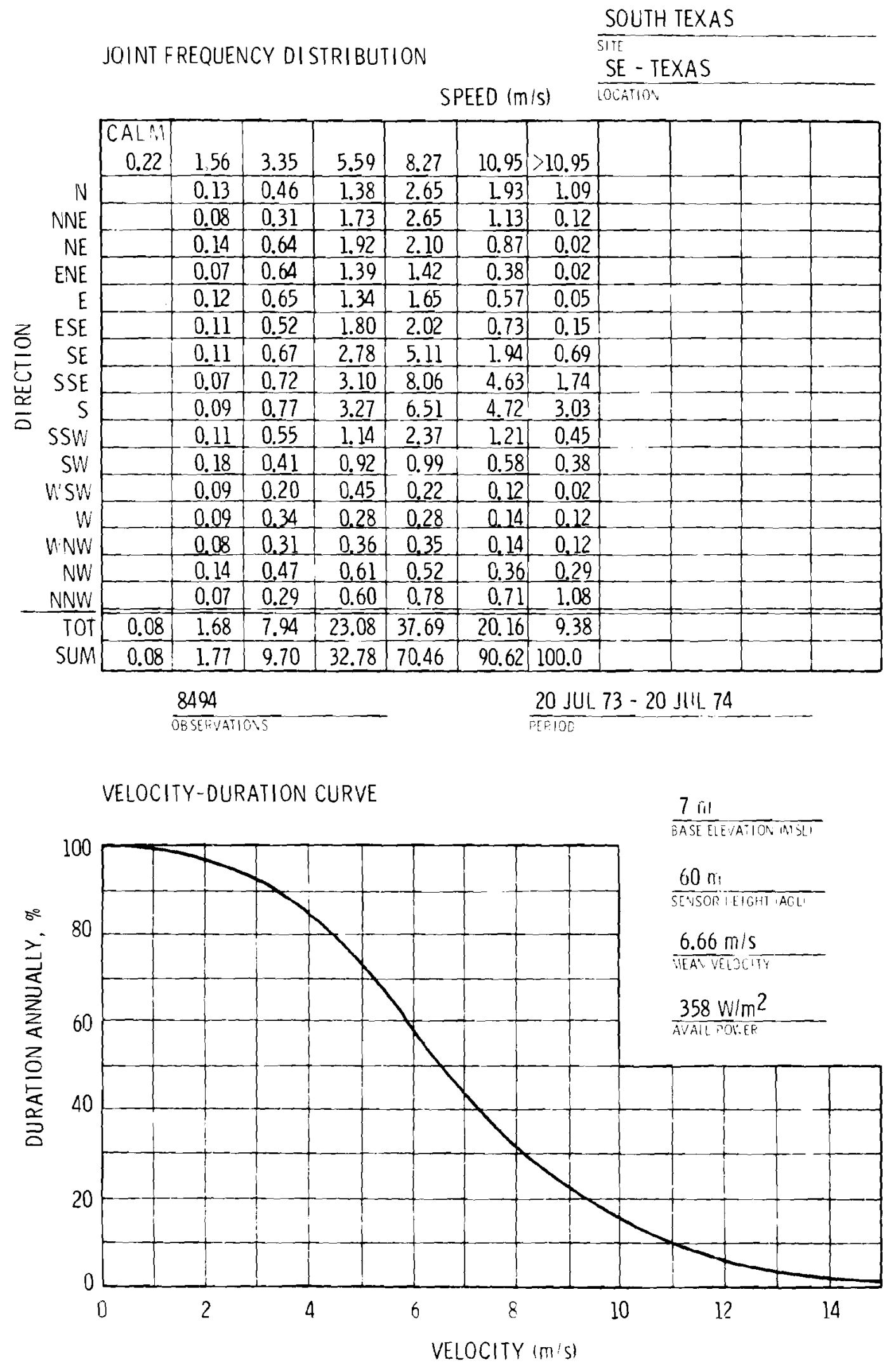
STERLING

\section{SITE LOCATION:}

The site $\left(43.39^{\circ} \mathrm{N} / 76.98^{\circ} \mathrm{W}\right)$ is located on the south shore of the SE corner of Lake ontario, in oswego County, New York, about $13 \mathrm{~km}$ WSW of Oswego. Syracuse is $60 \mathrm{~km} \mathrm{SE}$ and Rochester is $78 \mathrm{~km}$ WSW.

\section{TOPOGRAPHY :}

The terrain rises rather sharply from the lake (75 $\mathrm{m}$ (MSL)) for more than $30 \mathrm{~m}$, and even forms cliffs to the $\mathrm{SW}$ toward Fair Haven. Back from the shore, the terrain is gently rolling and rises more gradually inland. Some hills to the SW, S, SE, and $E$ rise to heights of 30 to $60 \mathrm{~m}$ within 5 to $8 \mathrm{~km}$ of the lake. The shoreline in front of the site is NNE-SSW, but changes sharply $W$ at Fair Haven, $5 \mathrm{~km}$ to the $\mathrm{SSW}$. At Burnt Point, $3 \mathrm{~km} \mathrm{NNE,} \mathrm{the} \mathrm{shoreline} \mathrm{turns} \mathrm{ENE.}$

\section{ON-SITE WIND MEASUREMENTS}

A 104-m tower is instrumented at $10 \mathrm{~m}, 46 \mathrm{~m}$, and $104 \mathrm{~m}$ with Teledyne Model 50.1 Anemometers and Teledyne 50.2 "Quick-2" vanes. Base elevation is about $105 \mathrm{~m}$ (MSL).

NRC Docket No. $\overline{50-485}$ 

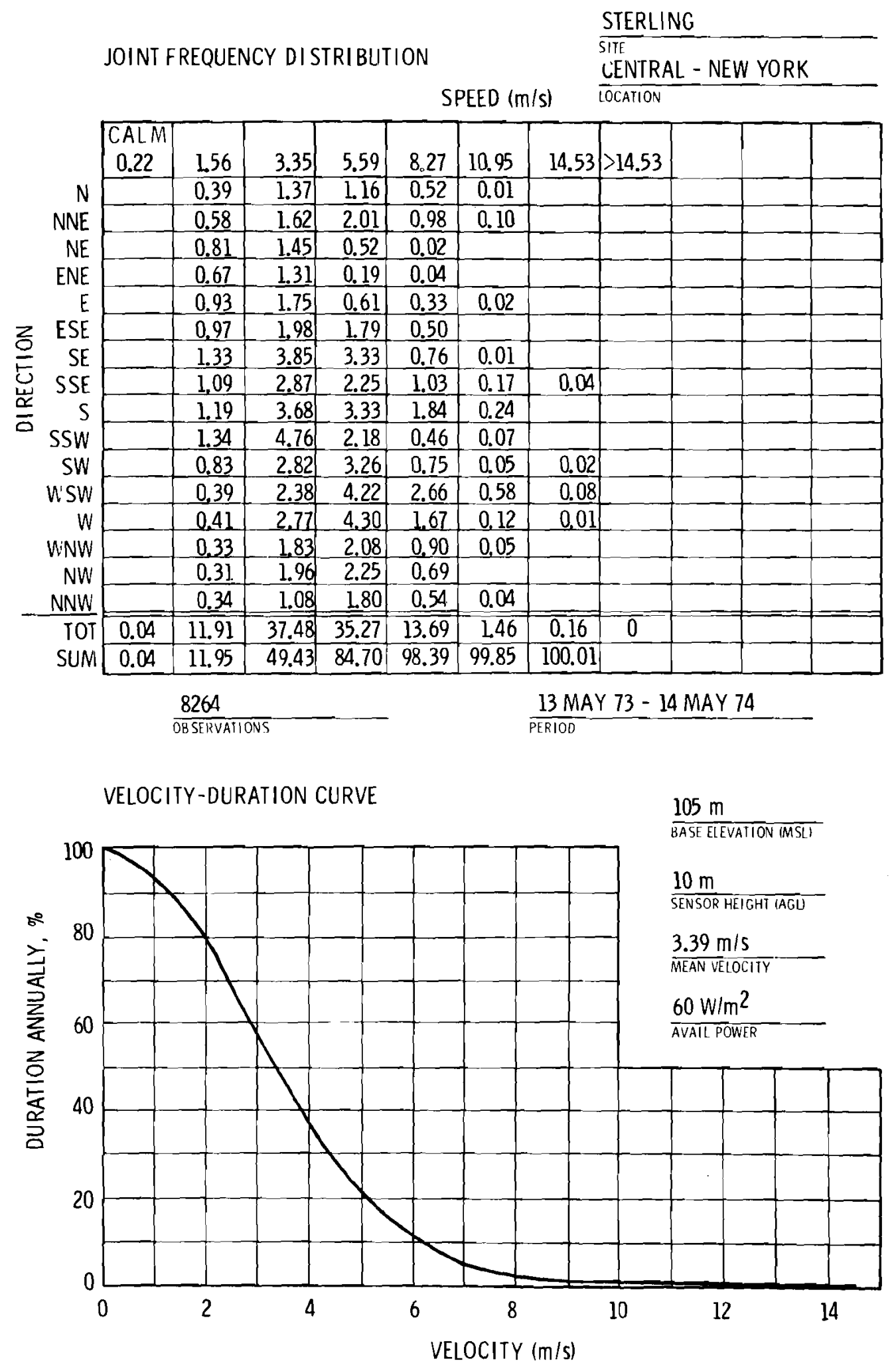
VIRGIL C. SUMMER

\section{SITE LOCATION :}

The site $\left(34.30^{\circ} \mathrm{N} / 81.32^{\circ} \mathrm{W}\right)$ is located in Fairfield County, central South Carolina, $24 \mathrm{~km}$ SW of Winniboro and $42 \mathrm{~km}$ NW of Columbia. The nearest community is Jenkinsville, about $5 \mathrm{~km}$ SE.

\section{TOPOGRAPHY:}

The site is a heavily wooded area in the rolling and hilly Appalachian Piedmont Plateau. Elevations range from $78 \mathrm{~m}$ (MSL) at the Parr Reservoir on the Broad River, $2 \mathrm{~km} \mathrm{~W}$, to over $150 \mathrm{~m}$ at the tops of hills and ridges. Site elevation ranges from 135 to $150 \mathrm{~m}$ (MSL). The valley of the Broad River lies in a N-S direction, $W$ of the site. The site is also $225 \mathrm{~km} \mathrm{NW}$ of the Atlantic Ocean and $160 \mathrm{~km} \mathrm{SE}$ of the Appalachian Mountains.

\section{ON-SITE WIND MEASUREMENTS:}

A 60-m tower, at $100 \mathrm{~m}$ (MSL) is instrumented at the top with a Bendix-Friez "Acrovane".

NRC Docket 'No. 50-395 


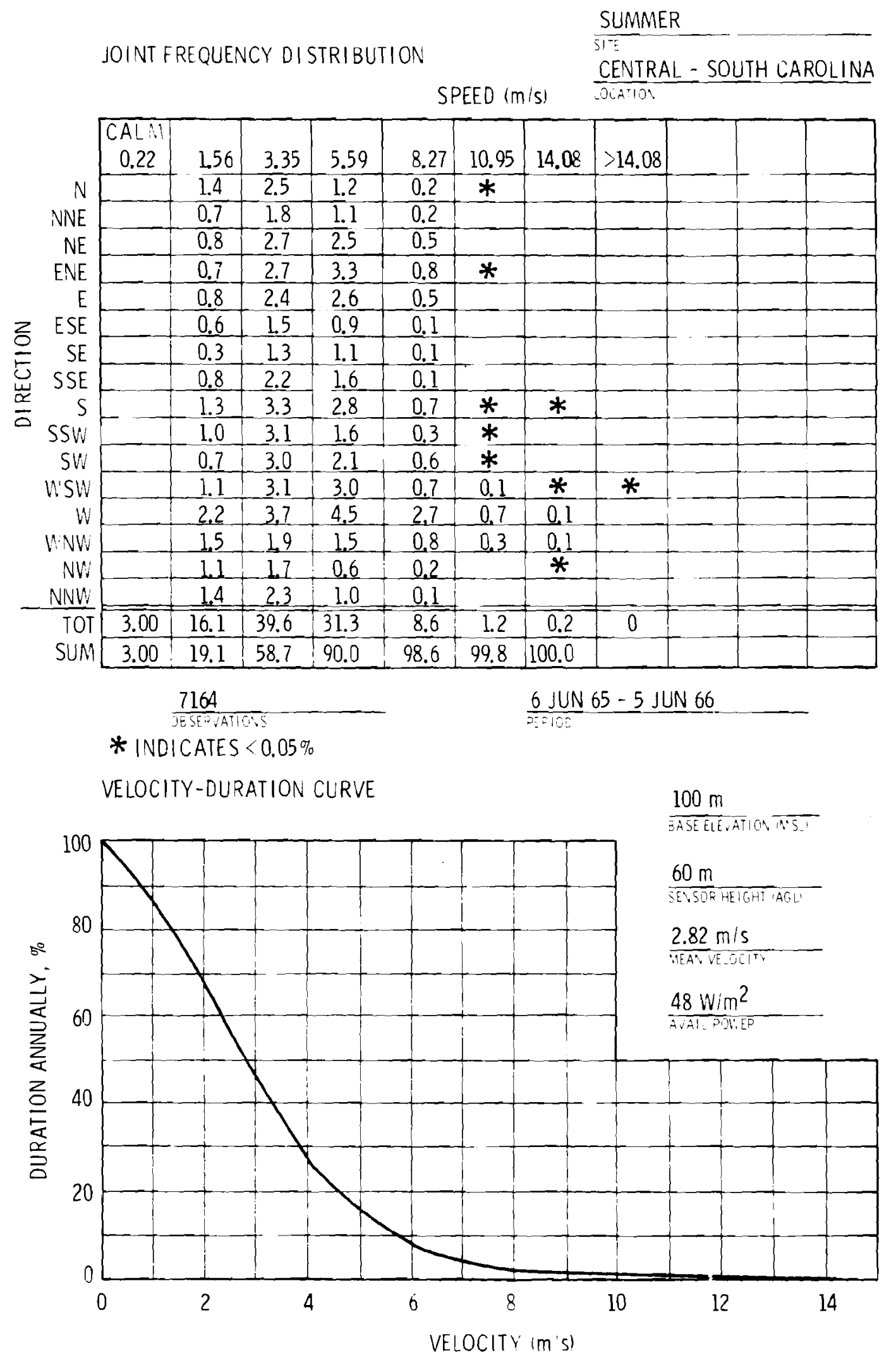


SUMMIT

\section{SITE LOCATION:}

The Summit Power station site $\left(39.52^{\circ} \mathrm{N} / 75.69^{\circ} \mathrm{W}\right)$ is in New Castle County, in northern Delaware, $8 \mathrm{~km}$ NNE of Middletown $24 \mathrm{~km}$ SSW of Wilmington and $48 \mathrm{~km}$ SW of Philadelphia, PA. The site is $2 \mathrm{~km} \mathrm{~S}$ of the Chesapeake and Delaware Canal. The Salem Power station is $15 \mathrm{~km}$ ESE of summit.

\section{TOPOGRAPHY:}

The topography is flat for an $8 \mathrm{~km}$ radius. The Delaware River is $12 \mathrm{~km} E$ and the Elk River, which empties in to the Chesapeake Bay, is $15 \mathrm{~km}$, but neither accounts for any terrain relief.

ON-SITE WIND MEASUREMENTS:

In July 1973, a 61-m tower was established with instruments at $9 \mathrm{~m}$ and $60 \mathrm{~m}$. Wind data are taken using Teledyne Geotech 50.1 (speed) and 50.2 (direction) sensors.

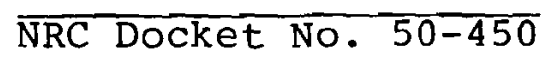



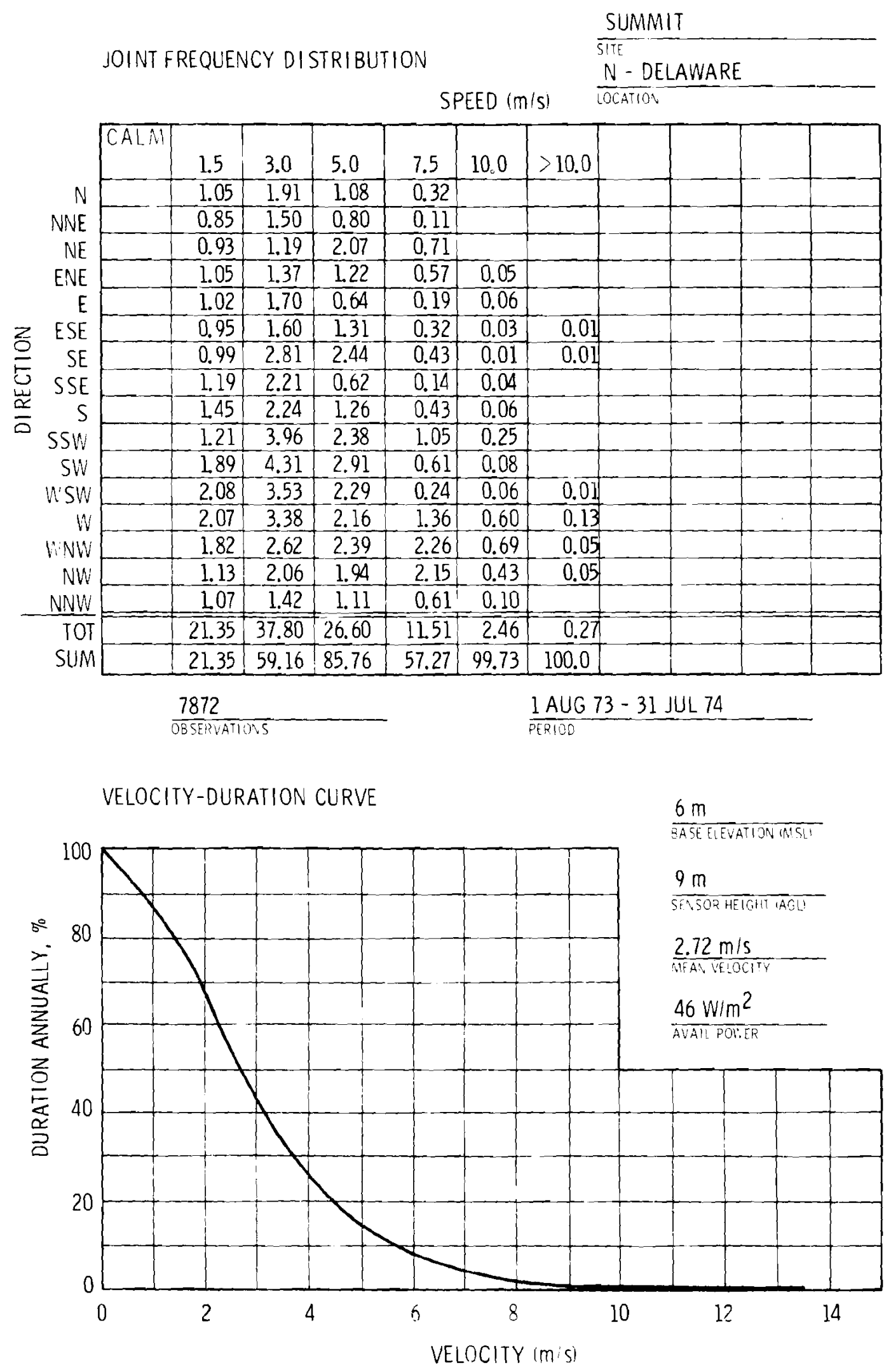
SURRY

\section{SITE LOCATION :}

The Surry Power Station $\left(37.17^{\circ} \mathrm{N} / 76.70^{\circ} \mathrm{W}\right)$ is in Surry County, Virginia on a point of land called Gravel Neck, which juts into the James River from the south. The James River runs generally NW-SE with considerable meander. The site is across the river from Newport News.

\section{TOPOGRAPHY :}

The terrain at the site is generally flat, with steep banks sloping down to the river. Maximum elevation is about $12 \mathrm{~m}$ (MSL) and station grade is $8 \mathrm{~m}$. Beyond the site boundaries, maximum land elevations within $8 \mathrm{~km}$ are in the range of $12 \mathrm{~m}$ to $18 \mathrm{~m}$. Further away the terrain is gently rolling, with few hills over $60 \mathrm{~m}$ (MSL) within $80 \mathrm{~km}$. The Atlantic Ocean lies some $65 \mathrm{~km} \mathrm{E}$.

\section{ON-SITE WIND MEASUREMENTS:}

Wind data have been taken at two locations. A temporary $6 \mathrm{~m}$ tower was erected on Hog Island, the tip of a peninsula jutting out into the James River. The tower had a Belfort 1250-1275 wind system on top. A $46 \mathrm{~m}$ tower in the middle of the site, at about $8 \mathrm{~m}$ (MSL) is also instrumented with a Belfort 1250-1275 wind system. There is a $23 \mathrm{~m}$ clearing among $20 \mathrm{~m}$ trees surrounding the $46 \mathrm{~m}$ tower. The Hog Island station was situated on sandy marshland with only low scrub bush.

NRC Docket Nos. $50-28 \overline{80,-434}$ 


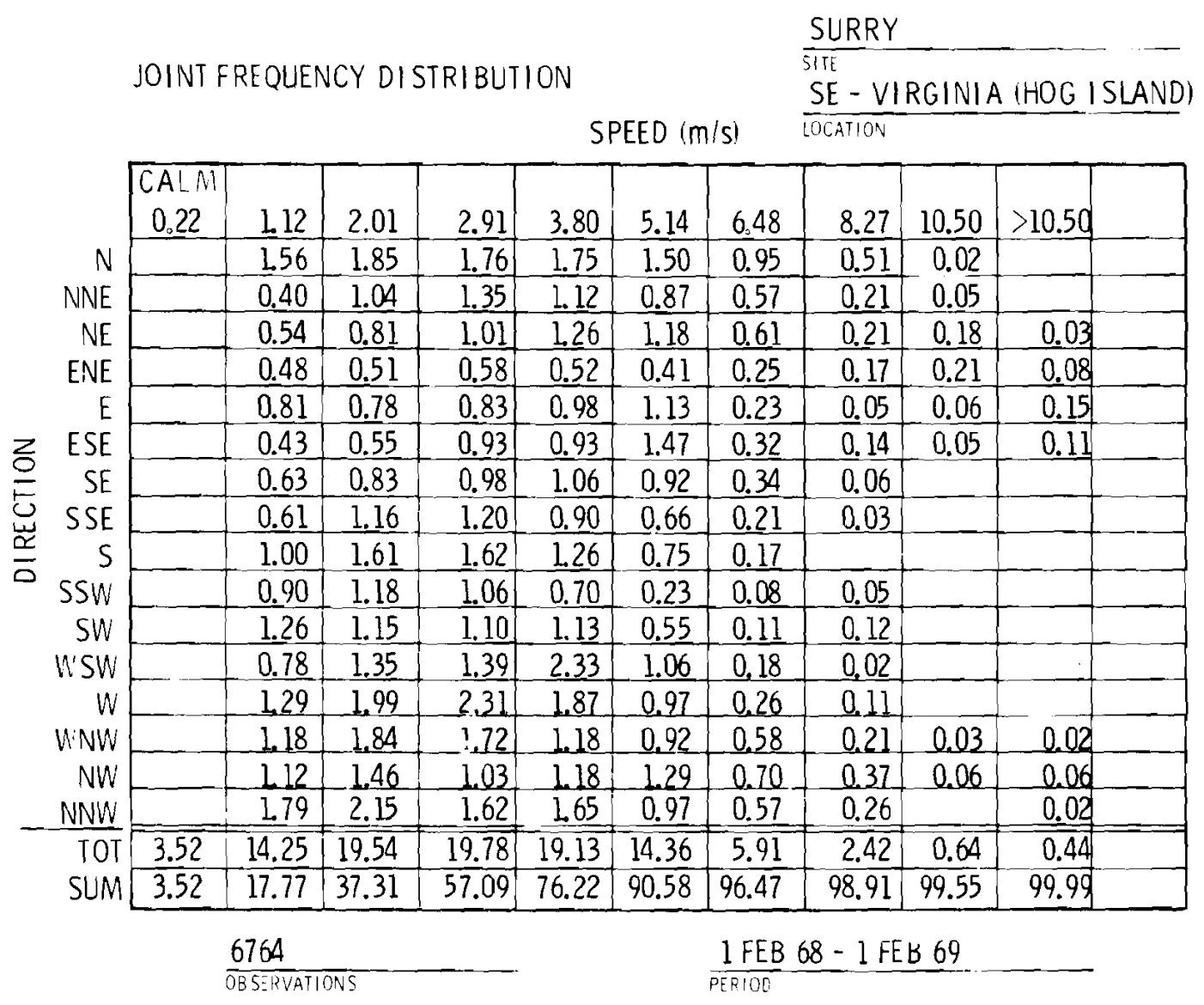

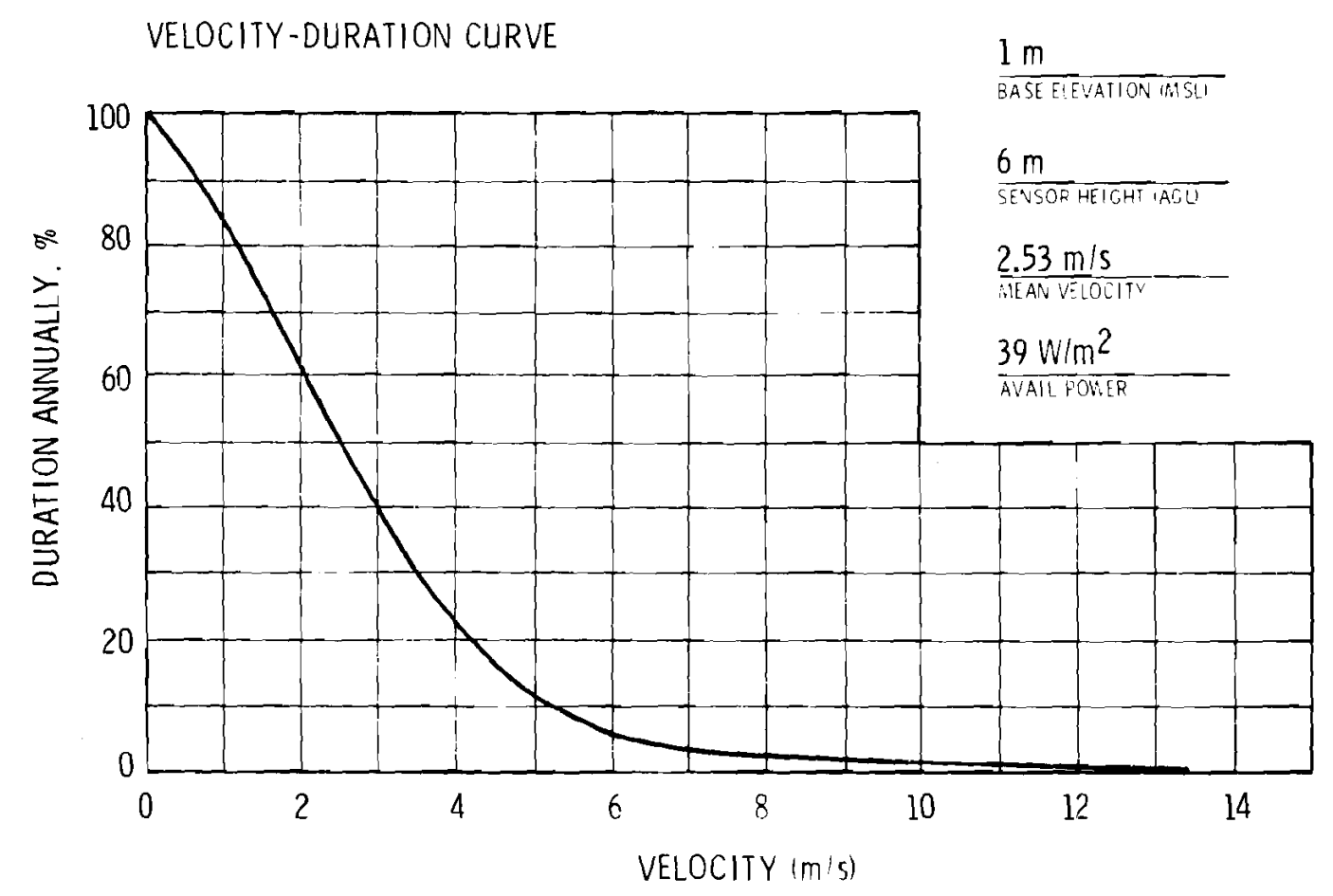




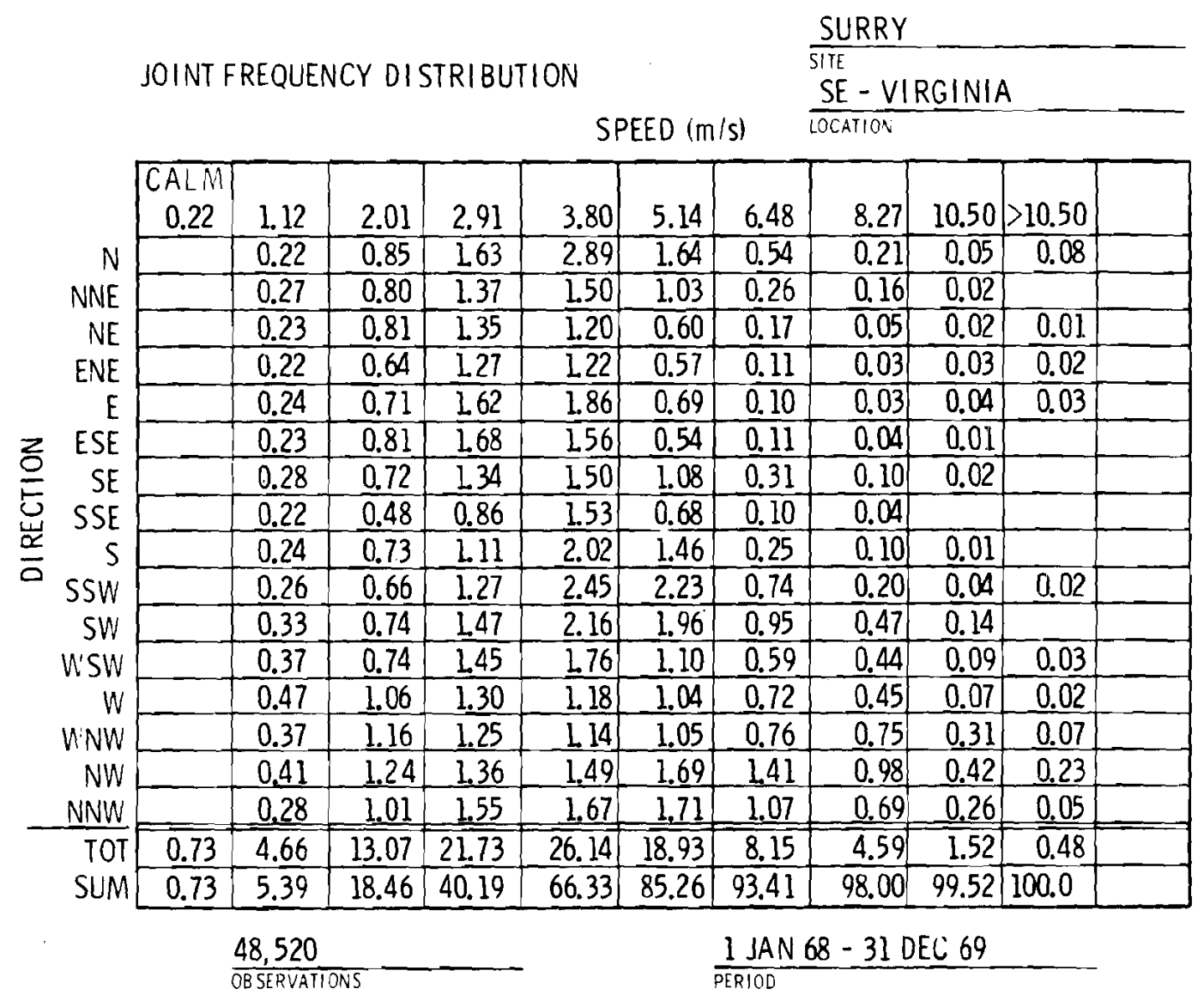

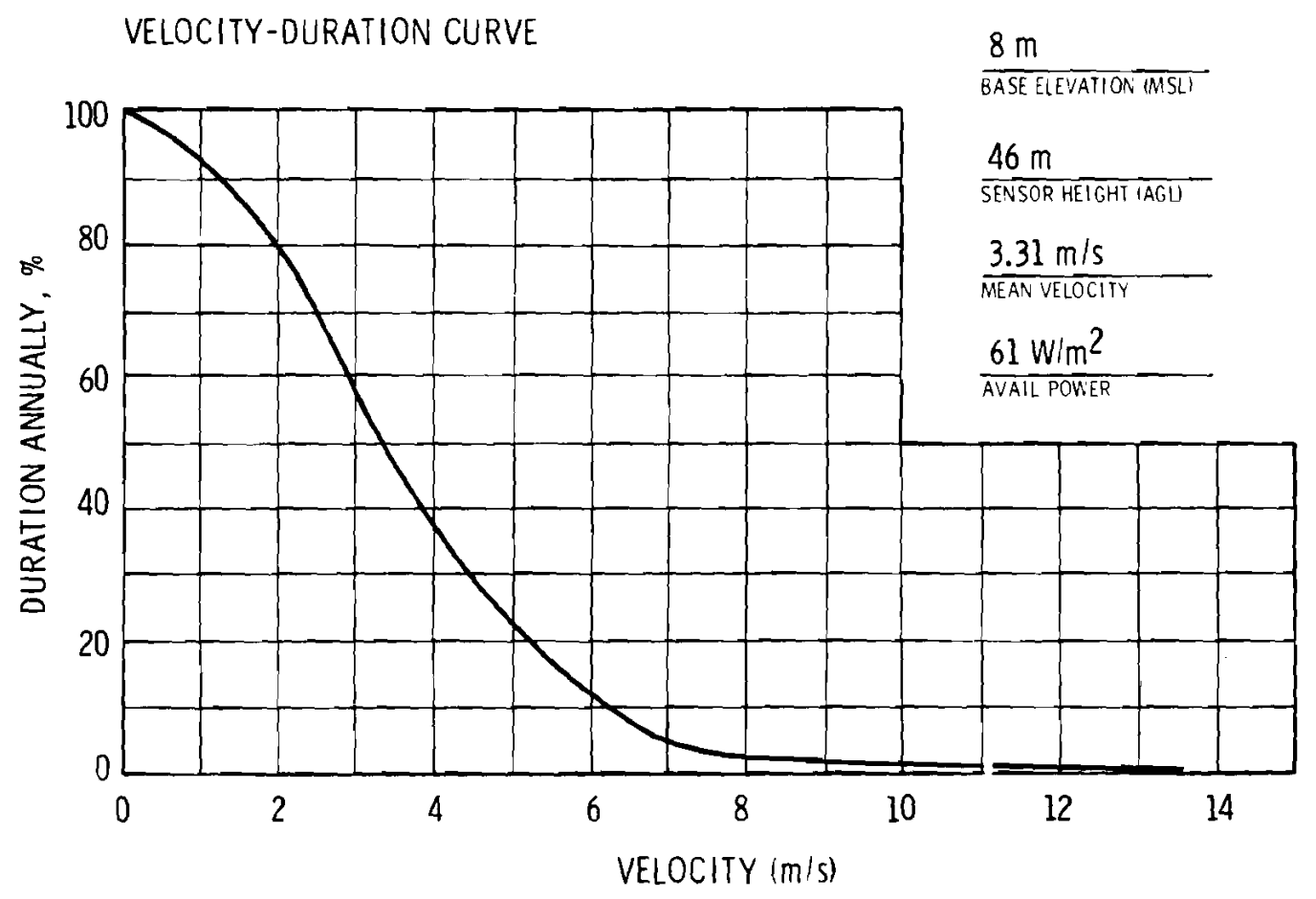


SUSQUEHANNA

\section{SITE LOCATION:}

The site $\left(41.10^{\circ} \mathrm{N} / 76.14^{\circ} \mathrm{W}\right)$ is in east central Pennsylvania, on the west bank of the Susquehanna River, in Luzerne County. It is $6 \mathrm{~km} \mathrm{~S}$ of Shickshinny; $8 \mathrm{~km} \mathrm{NE}$ of Berwick; $19 \mathrm{~km} \mathrm{NNW}$ of Hazleton; $24 \mathrm{~km}$ sW of Wilkes-Barre; $80 \mathrm{~km}$ NW of Allentown; and $113 \mathrm{~km} \mathrm{NE}$ of Harrisburg.

\section{TOPOGRAPHY :}

The site is located on a plateau above the Susquehanna River, in the rugged Appalachian Highlands of Pennsylvania. The river valley is rather flat-bottomed, running $\mathrm{N}-\mathrm{S}$ and widening to the $S$ and $W$. Moderately steep slopes rise on both sides of the river.

ON-SITE WIND MEASUREMENTS:

A $91 \mathrm{~m}$ tower was installed at $199 \mathrm{~m}$ (MSL) and instrumented at $9 \mathrm{~m}$ and $91 \mathrm{~m}$ with Climet WS-011-1/WD-012-10 data systems. Supplementary data are taken at two other locations, but data have not been published.

NRC Docket No. $\overline{50-387}$ 


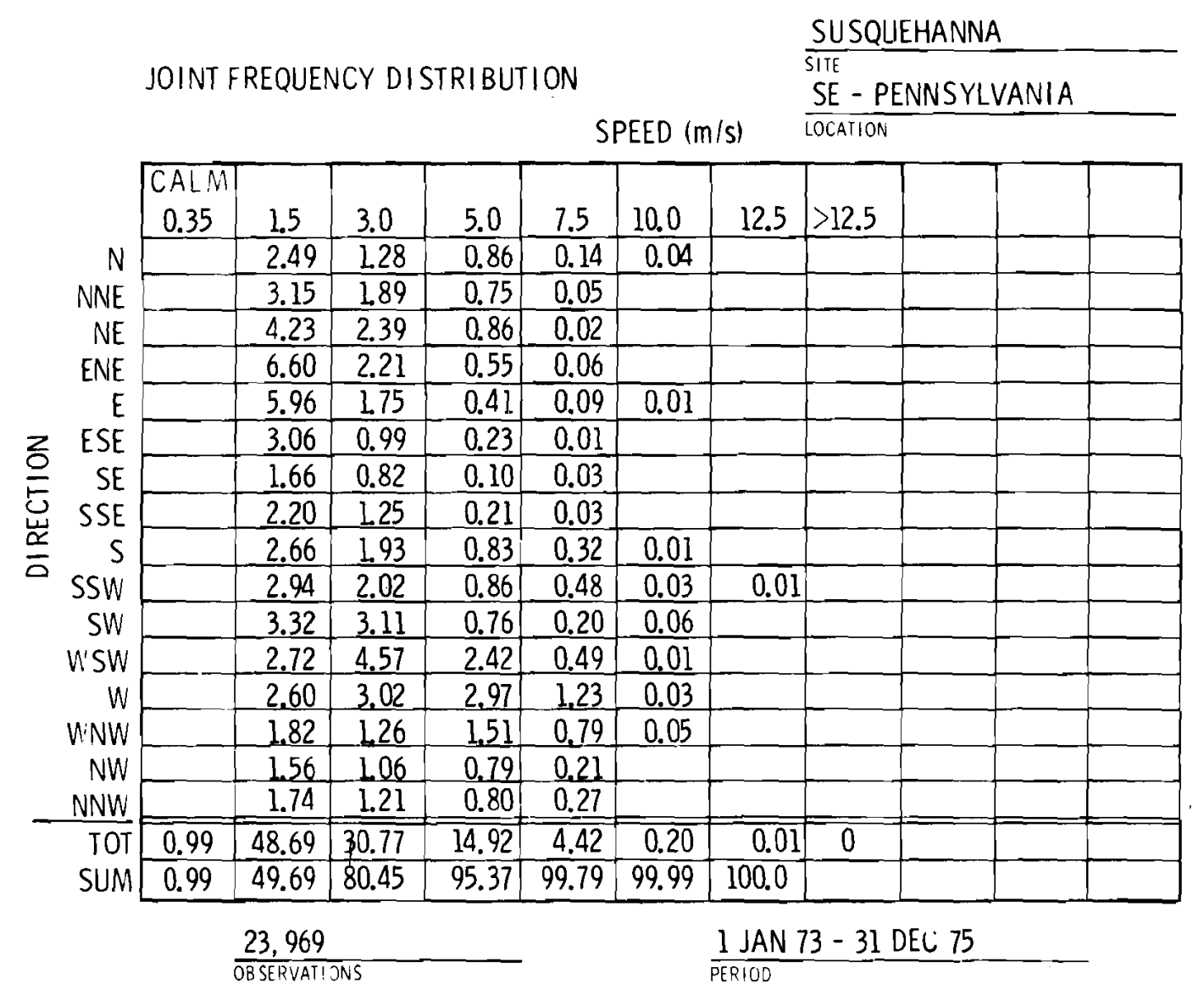

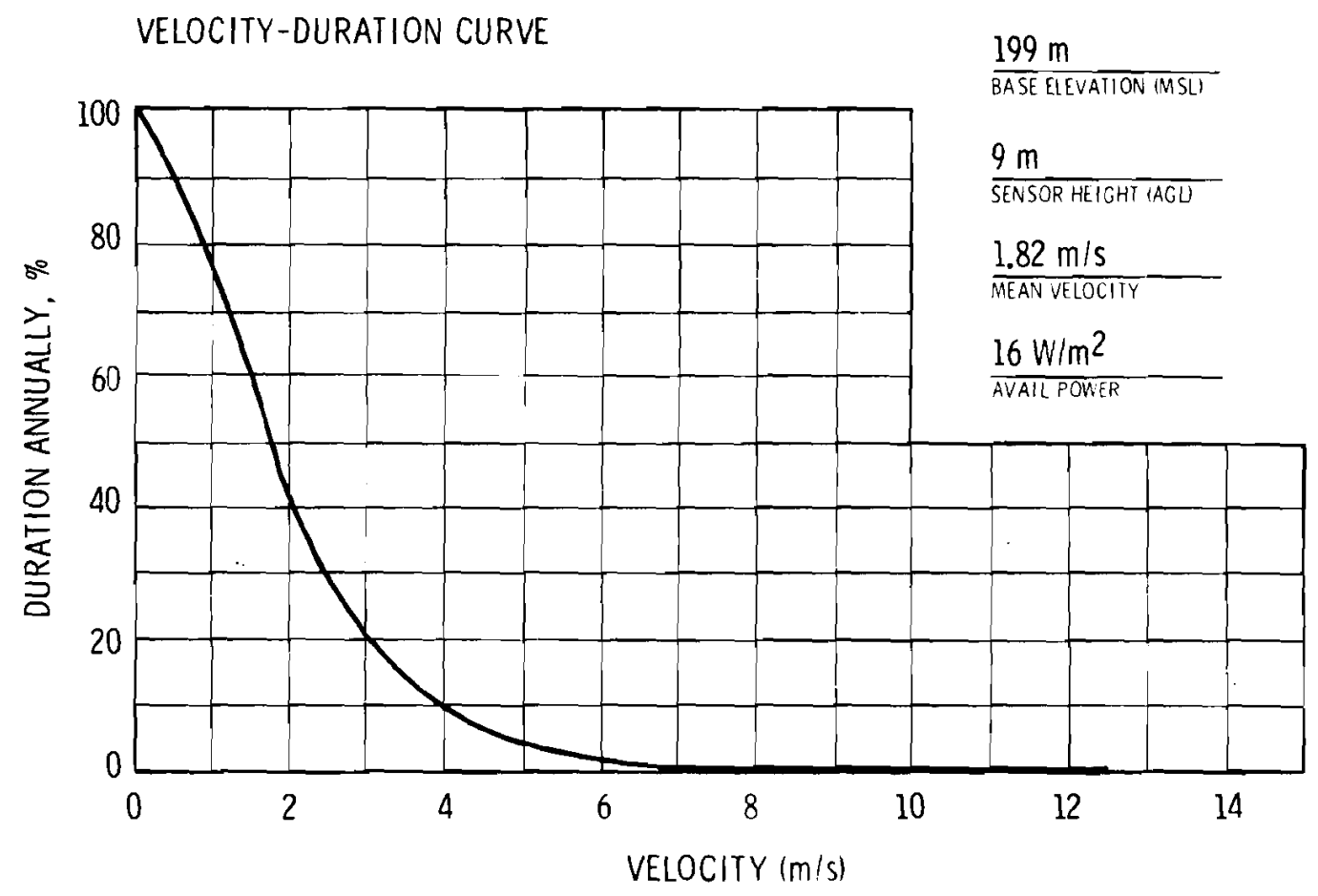




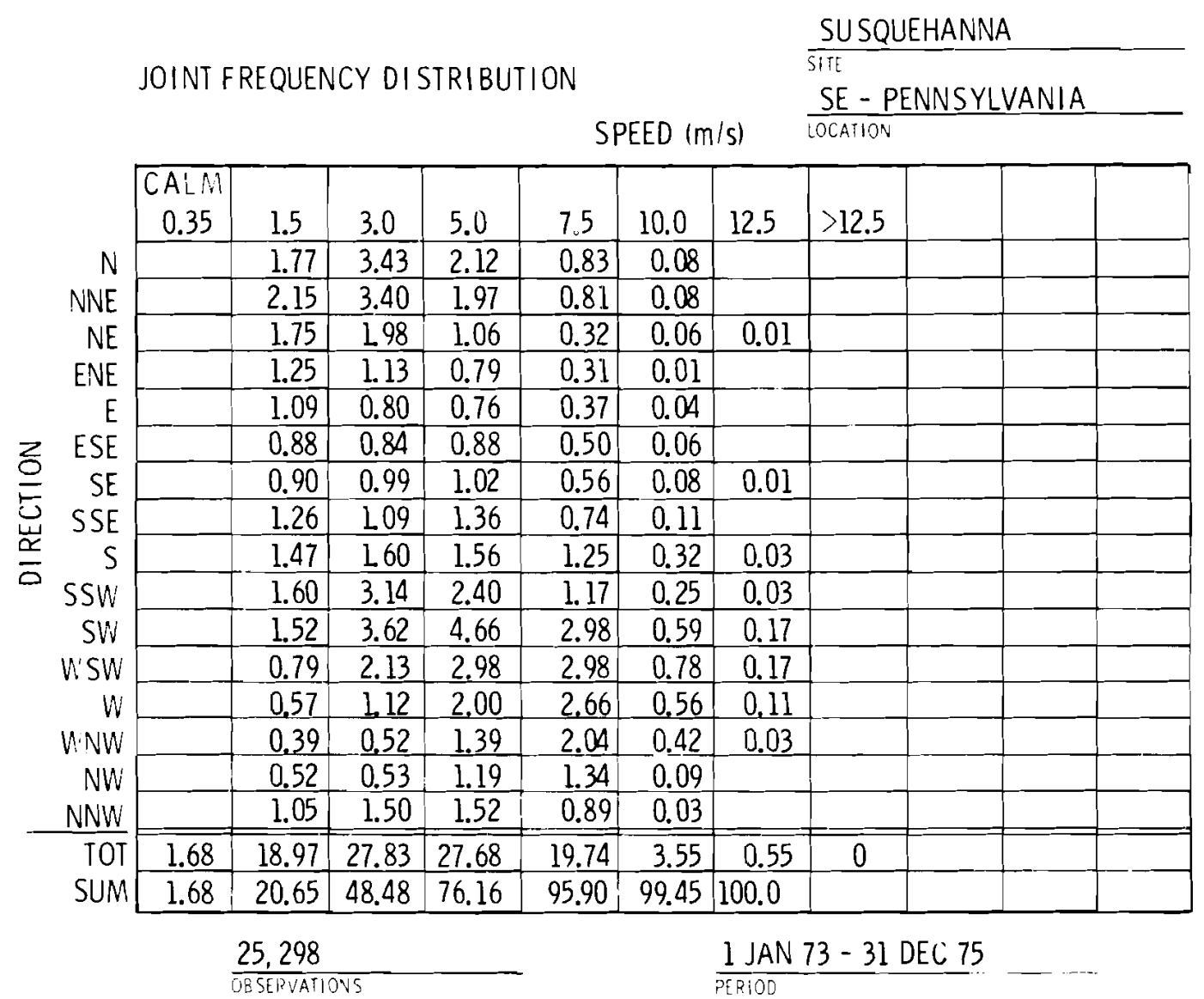

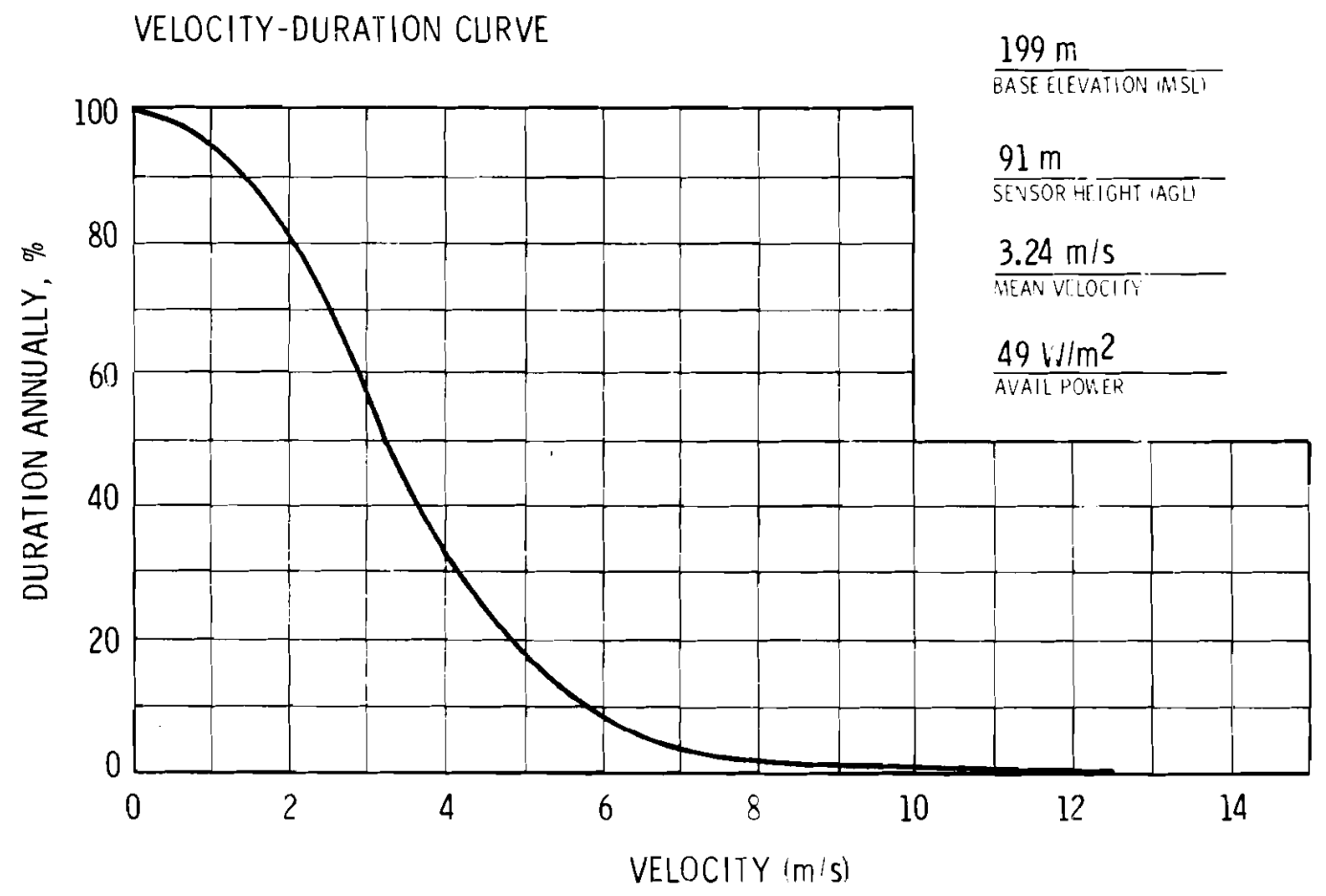


THREE MILE ISLAND

SITE LOCATION:

The site $\left(40.13^{\circ} \mathrm{N} / 76.73^{\circ} \mathrm{W}\right)$ is located about $4 \mathrm{~km} \mathrm{~s}$ of Middletown, Pennsylvania in Dauphin County. Harrisburg is 18 $\mathrm{km} \mathrm{NW}$; Lancaster is $37 \mathrm{~km} \mathrm{ESE}$, and Philadelphia is about $125 \mathrm{~km}$ E.

\section{TOPOGRAPHY:}

The site is an island in the Susquehanna River in southeast Pennsylvania. The $500 \mathrm{~m}$ by $3300 \mathrm{~m}$ island is one of the largest of a group of several islands in the river and is situated about $275 \mathrm{~m}$ from the east bank. It is elongated, parallel to the N-S flow of the river. The southeast-flowing Susquehanna River makes a sharp change in direction, to nearly due south, in the vicinity of Middletown, just north of Three Mile Island, and widens to about $2.5 \mathrm{~km}$. The river cuts across the NE-SWoriented low ridges of the foothills of the Appalachian Range to the northwest. This is the Piedmont Plateau region of Pennsylvania, consisting of rolling uplands, low hills and fertile valleys. The long ridge of the Blue Mountains, with elevations of about $300 \mathrm{~m}$ above the site, begins to rise about $30 \mathrm{~km} \mathrm{NW}$. The land surrounding the site slopes to the NW-SE river valley floor, while the terrain slopes generally upward to the NW toward the Appalachians.

ON-SITE WIND MEASUREMFNTS:

On-site data collection began in May 1967. Two 30-m towers were located on the southern half of the island. Teledyne Geotech 50.1 (speed) and 50.2 (direction) instruments were used to take wind data. Base elevation is $91 \mathrm{~m}$ (MSL).

NRC Docket Nos. $50-289,-320$ 

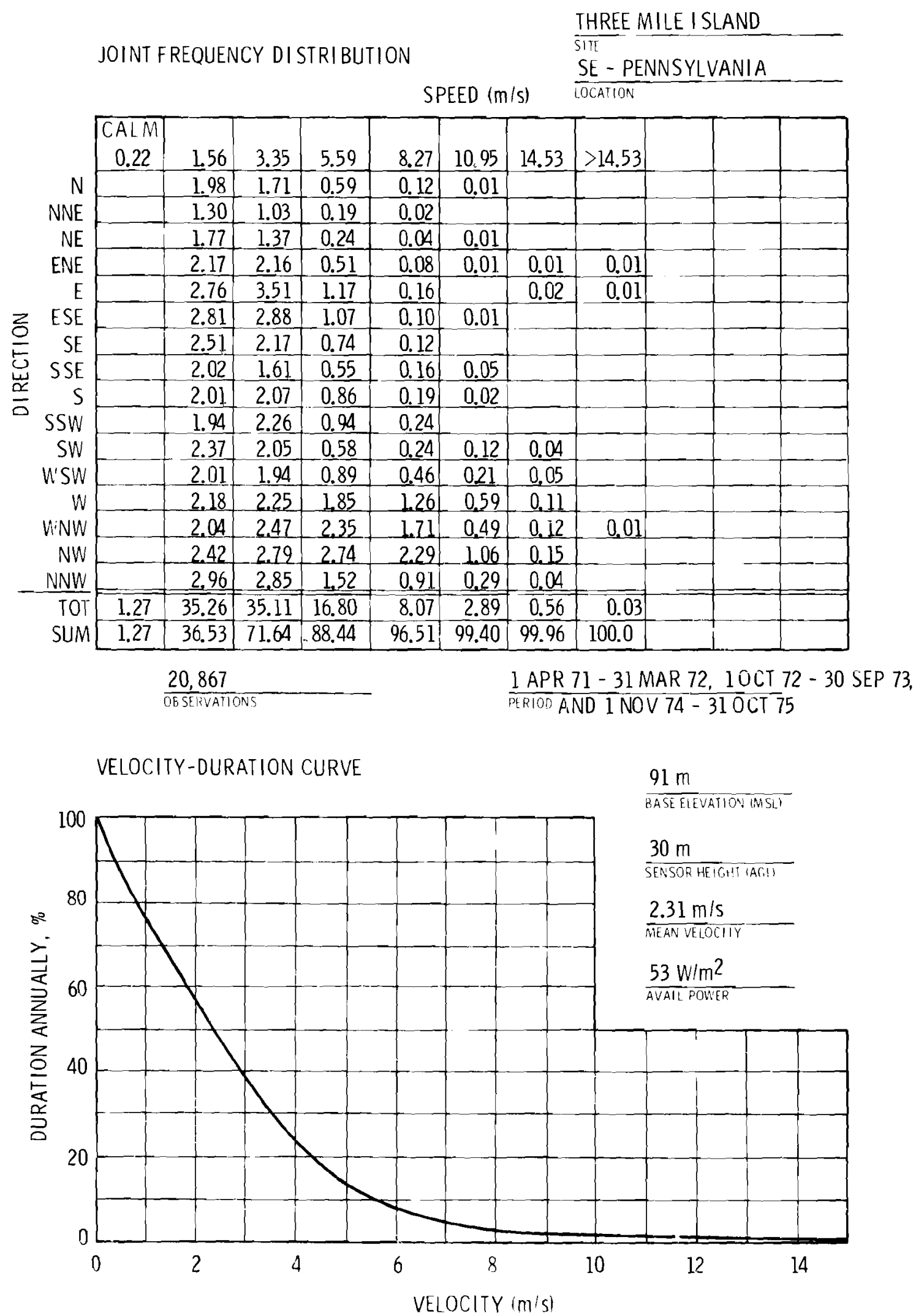
TROJAN

\section{SITE LOCATION :}

The Trojan Nuclear Plant site $\left(46.04^{\circ} \mathrm{N} / 122.87^{\circ} \mathrm{W}\right)$ lies along the bank of the Columbia River, in Columbia County, Oregon, about $70 \mathrm{~km} \mathrm{~N}$ of Portland. Rainier, OR is $7 \mathrm{~km} \mathrm{NW}$; Kalama, WA is $5 \mathrm{~km} \mathrm{SE}$; Longview, WA is $10 \mathrm{~km} \mathrm{NE;} \mathrm{Carrolls,} \mathrm{WA} \mathrm{is} 4 \mathrm{~km} \mathrm{NE}$; Gable, OR is $2.4 \mathrm{~km} \mathrm{SE}$; and Prescott, OR is $0.8 \mathrm{~km} \mathrm{~N}$.

\section{TOPOGRAPHY :}

The site is in the Columbia River Valley, which in this locale runs generally $S-N$, having shifted from its $E-W$ flow near Portland. It swings generally westward again after Longview. In the immediate vicinity, there is a bluff $400 \mathrm{~m} \mathrm{~W}$, rising sharply to $120-150 \mathrm{~m}$ (MSL). North of the site is a wooded hill that rises to $30 \mathrm{~m}$. The remaining area in the immediate vicinity of the plant is flat and low. The Columbia River is about $3 \mathrm{~km}$ wide just $\mathrm{E}$ of the site and widens to $5 \mathrm{~km}$ at Longview-Kelso, $10 \mathrm{~km} \mathrm{NE}$. In general, the terrain is mountainous and cut-through by the Columbia River and its tributaries. The Kalama River flows into the Columbia about a kilometer north. The valley walls rise to over $300 \mathrm{~m}$ (MSL) within $3 \mathrm{~km}$ to the west and only slightly lower to the east.

\section{ON-SITE WIND MEASUREMENTS:}

On-site data collecting began in October 1969 from a 152-m tower (tower A) instrumented at $67 \mathrm{~m}, 113 \mathrm{~m}$ and $152 \mathrm{~m}$, using Bendix Aerovanes, and from a $9 \mathrm{~m}$ tower (tower $B$ ) on the bank of the Columbia, also instrumented with a Bendix Aerovane. Another $9 \mathrm{~m}$ tower (C) was installed in February 1971, using a Climet WS-011-1 (speed) and Climet WD-012-10 (direction) system. Tower A is at $6 \mathrm{~m}$ (MSL), tower $B$ at $7 \mathrm{~m}$ (MSL) and tower $\mathrm{C}$ at $6 \mathrm{~m}$ (MSL).

NRC Docket No. $\overline{50-344}$ 


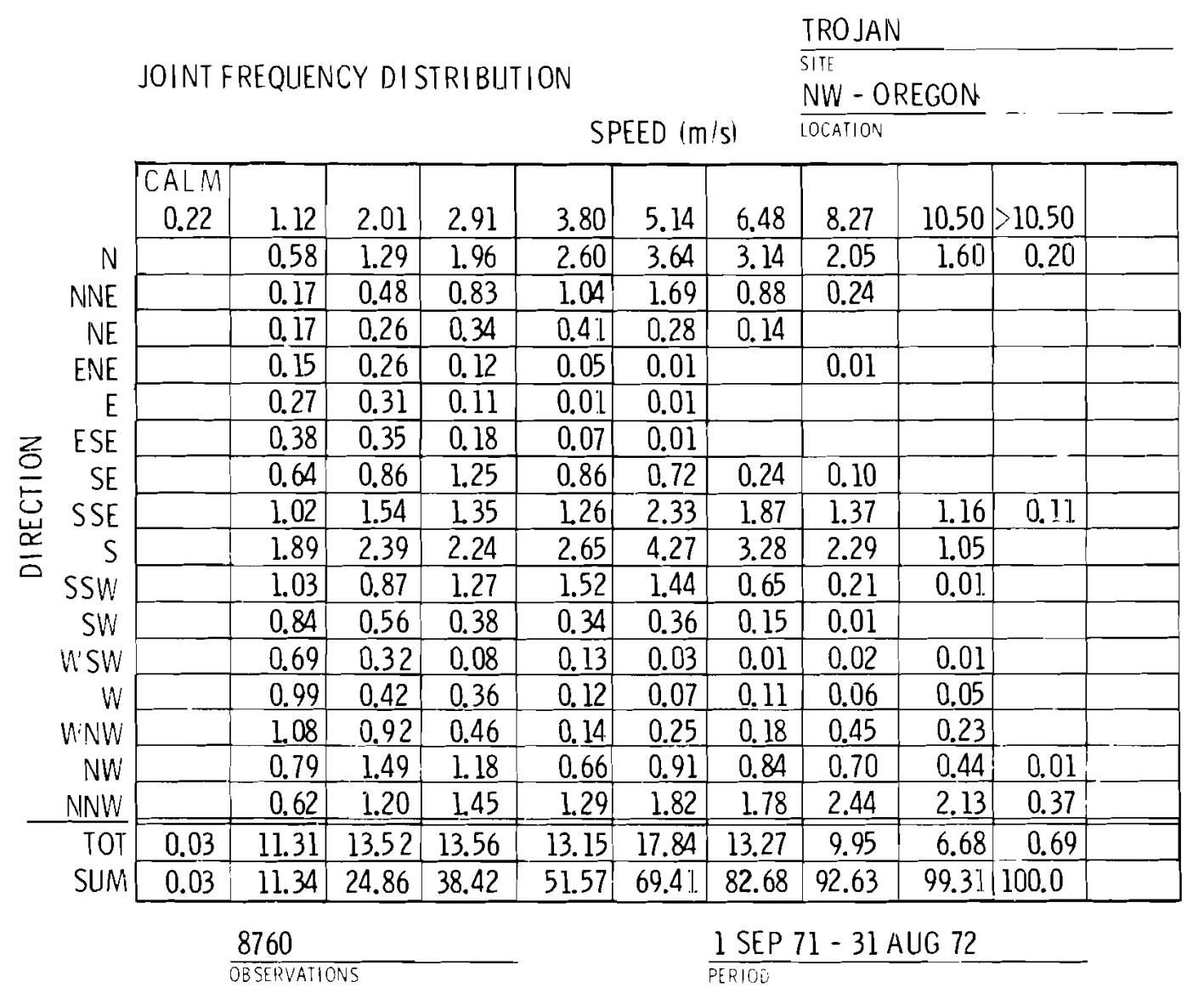

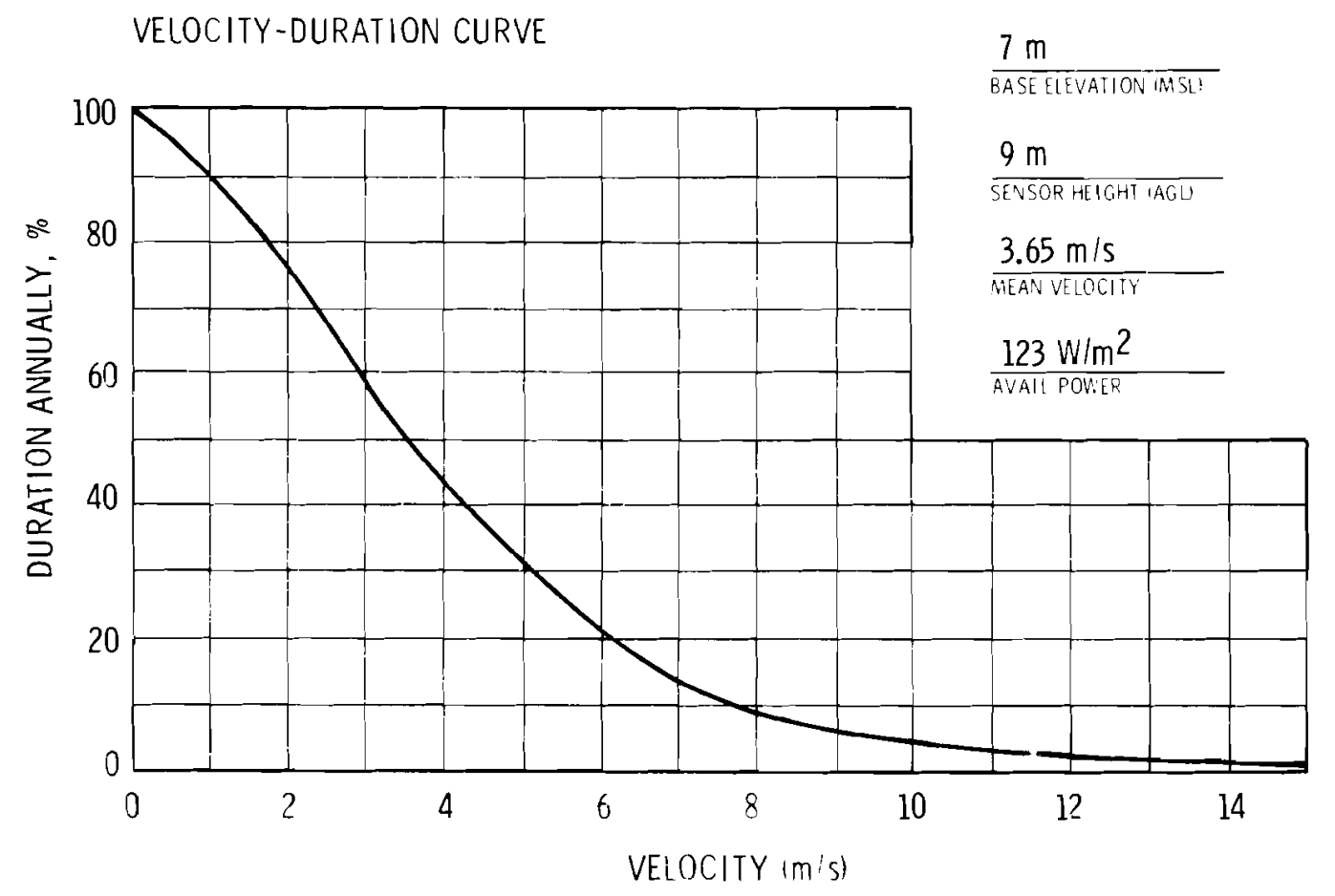


TURKEY POINT

SITE LOCATION:

The site $\left(25.43^{\circ} \mathrm{N} / 80.33^{\circ} \mathrm{W}\right)$ is located on the western shore of Biscayne Bay, $40 \mathrm{~km}$ S of Miami, in Dade County, Florida.

TOPOGRAPHY:

The western shore of Biscayne Bay is flat terrain that has a gentle slope from an elevation of sea level at the shoreline up to an elevation of $3 \mathrm{~m}$ at about $15 \mathrm{~km}$ inland. The land in and around the shoreline area of the site is mostly mangrove swamps which extend 5-7 km inland (clockwise SW to lJNW). Open fields extend inland from the edge of these swamp areas. The entire Dade County area is quite flat with the highest level on a ridge in the Miami area. The ridge parallels the shoreline and reaches an elevation of about $6 \mathrm{~m}$, some $50 \mathrm{~km} \mathrm{~N}$.

\section{ON-SITE WIND MEASUREMENTS:}

The on-site meteorological program became operational in late 1967. Bendix-Friez Aerovanes (6-bladed) were mounted at $9 \mathrm{~m}$ (MSL) near the Ranger House and at $73 \mathrm{~m}$ (MSL) atop a water tower.

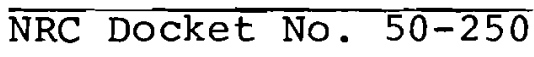




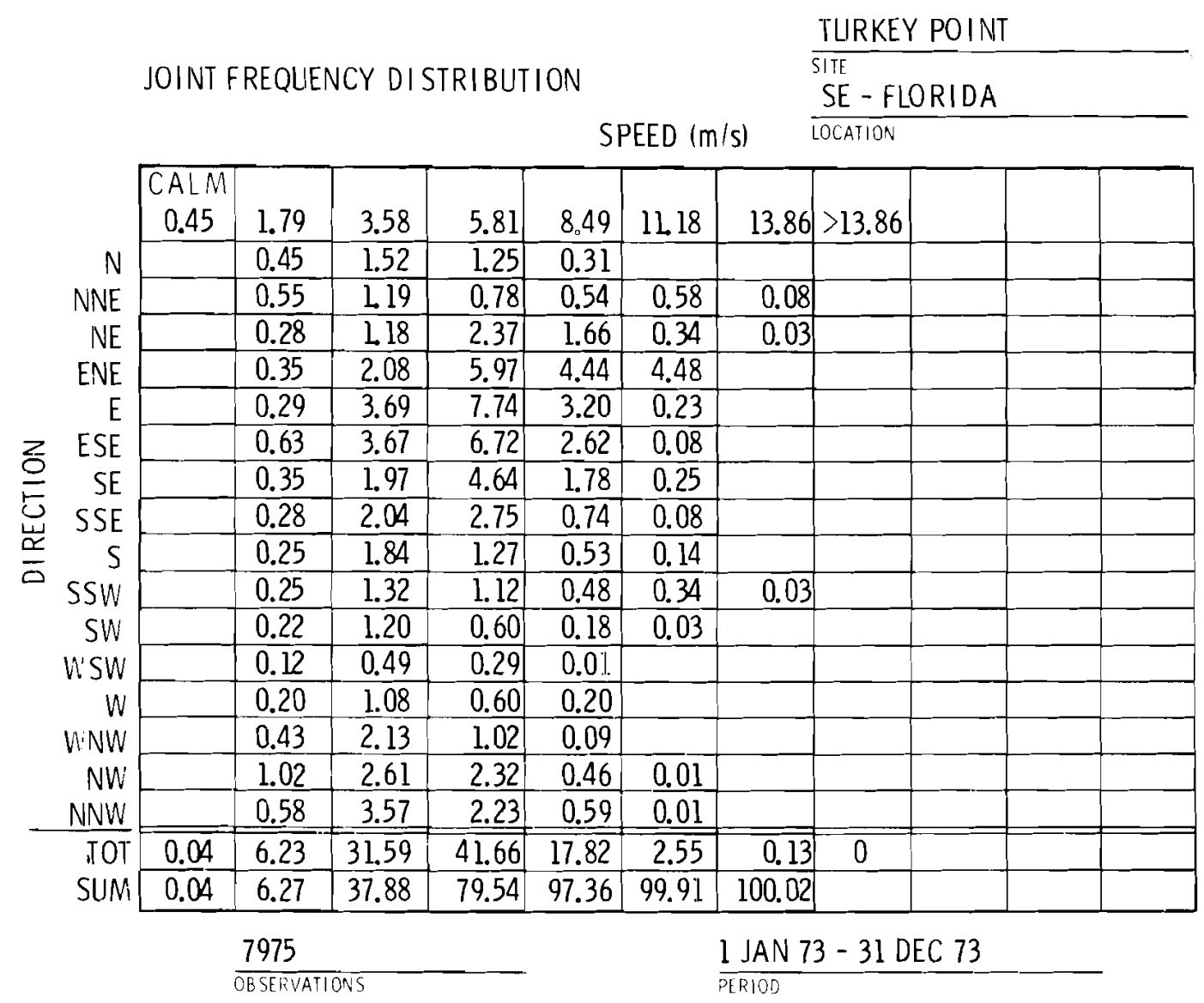

VELOCITY-DURATION CURVE

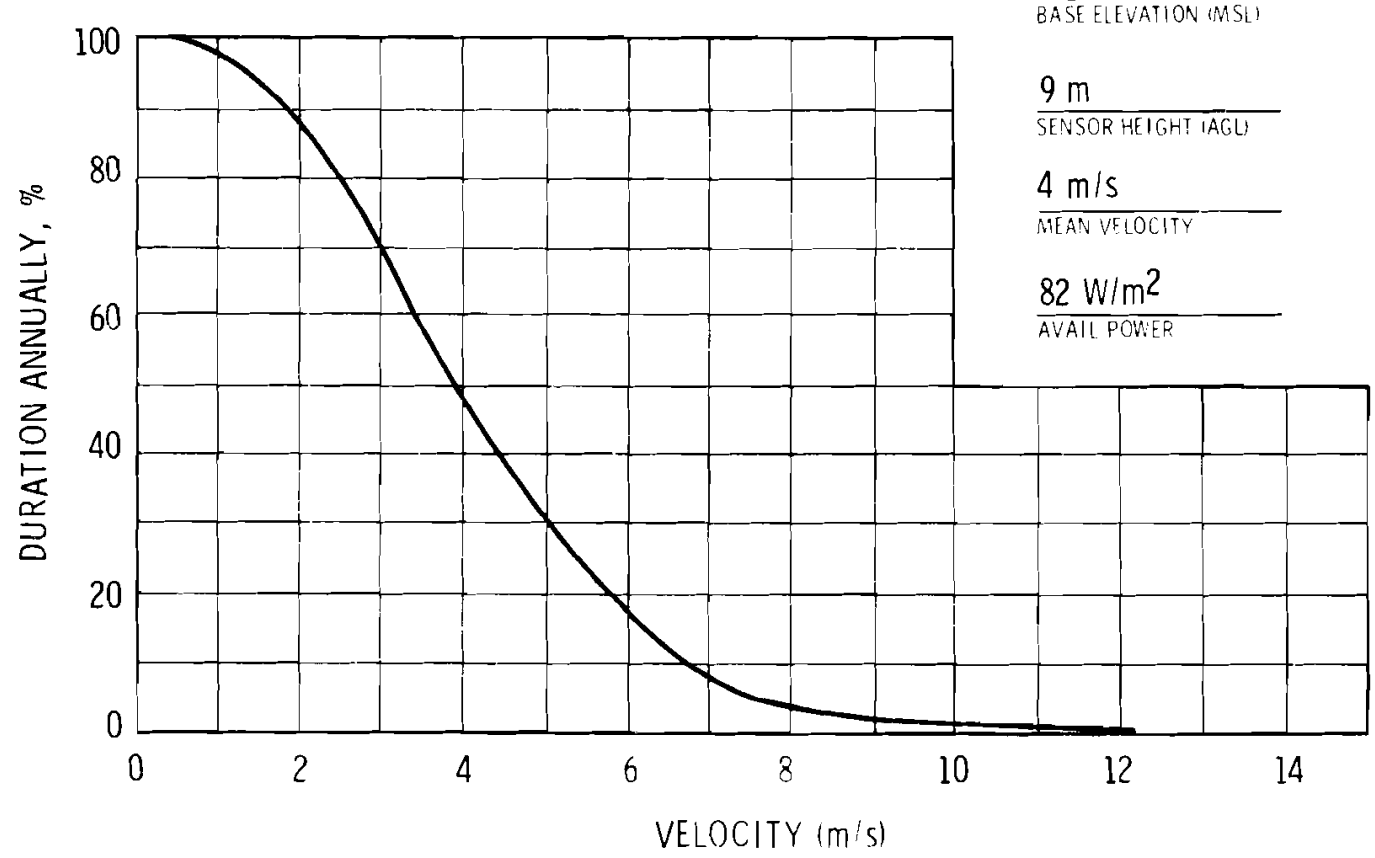

$\frac{\text { NEAR SEA LEVEL }}{\text { BASEELEVATION (MSL) }}$

$9 \mathrm{~m}$

$4 \mathrm{~m} / \mathrm{s}$

MEAN VELOCITY

$82 \mathrm{~W} / \mathrm{m}^{2}$ 
TYRONE

SITE LOCATION:

The site $\left(44.70^{\circ} \mathrm{N} / 91.83^{\circ} \mathrm{W}\right)$ is located in southern Dunn county, west central Wisconsin, about $13 \mathrm{~km} \mathrm{NE}$ of Durand and $30 \mathrm{~km}$ WSW of Eau Claire.

TOPOGRAPHY :

West central wisconsin is generally gently rolling. The site, which varies in elevation from 250 to $258 \mathrm{~m}$ (MSL), is located on the $S$ bank of the Chippewa River, about $30 \mathrm{~m}$ above the river valley. Plant grade is $256 \mathrm{~m}$ (MSL). The 4700-acre site is level with gently rolling hills. Two creeks dissect the site and flow into the Chippewa River which flows NE-SW. The largest hills are located in a ridge to the SE that rises to $370 \mathrm{~m} \mathrm{(MSL)} \mathrm{at} \mathrm{about} 7 \mathrm{~km}$ and to about $390 \mathrm{~m}$ (MSL) at about $8 \mathrm{~km}$.

ON-SITE WIND MEASUREMENTS:

The on-site meteorological program began in May 1973. The system includes Climet WS-011-1 (speed) and Climet WD-012-10 (direction) sensors at $11 \mathrm{~m}, 61 \mathrm{~m}$, and $104 \mathrm{~m}$ on a $104 \mathrm{~m}$ tower, based at $253 \mathrm{~m}$ (MSL). The tower is in a wheat field, with a grove of 6-8 $\mathrm{m}$ pines beginning $365 \mathrm{~m} \mathrm{~S}, 4-6 \mathrm{~m}$ pine windbreaks about $200 \mathrm{~m} \mathrm{E}$ and $\mathrm{W}$, and a field of $1 \mathrm{~m}$ high replanted pines to the $\mathrm{N}$.

$\overline{\mathrm{NRC}}$ Docket No. $\overline{50-484}$ 

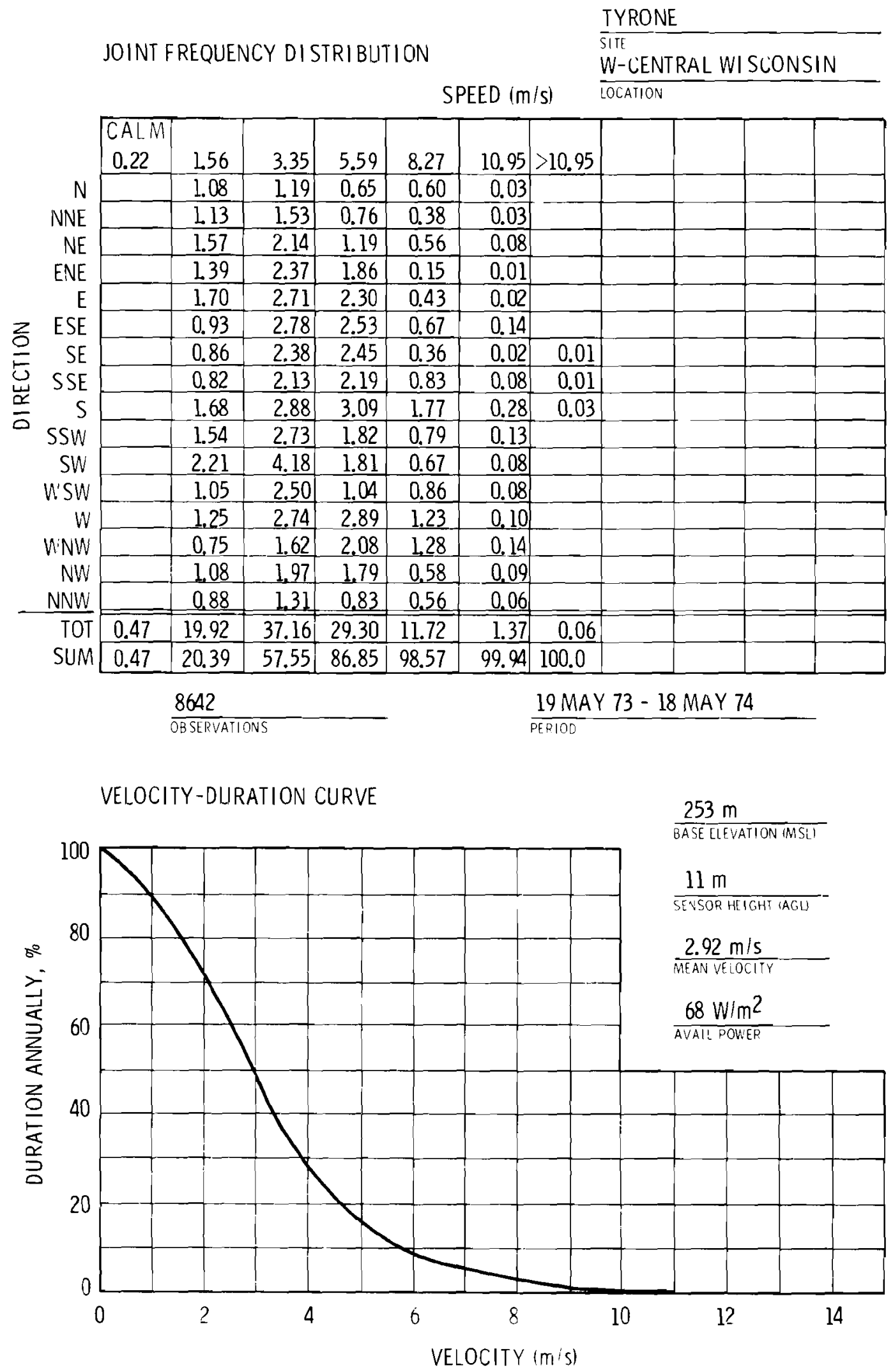
VERMONT YANKEE

\section{SITE LOCATION:}

The site $\left(42.78^{\circ} \mathrm{N} / 72.52^{\circ} \mathrm{W}\right)$ is located in Vernon, extreme SE Vermont, in Windham County on the west shore of the Connecticut River, immediately upstream of the Vernon Hydroelectric Station dam. Brattleboro is $8 \mathrm{~km} \mathrm{~N}$ and Northampton, $M A$ is $50 \mathrm{~km} \mathrm{~S}$.

\section{TOPOGRAPHY :}

The terrain is dominated by the presence of the Connecticut River valley, which runs SSE in this area. The region is typical of the northern Appalachian highlands, with rolling to rugged hills. The Pisgah Mountains are about $8 \mathrm{~km} \mathrm{NE}$ and several peaks above $500 \mathrm{~m}$ (MSL) abound within $15 \mathrm{~km}$.

ON-SITE WIND MEASUREMENTS:

A 43-m tower was installed at an elevation of about $84 \mathrm{~m}$ (MSL). Instrumentation consists of a Bendix "Aerovane" wind system at the top of the tower.

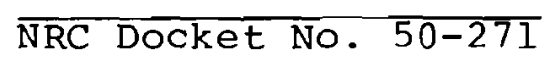




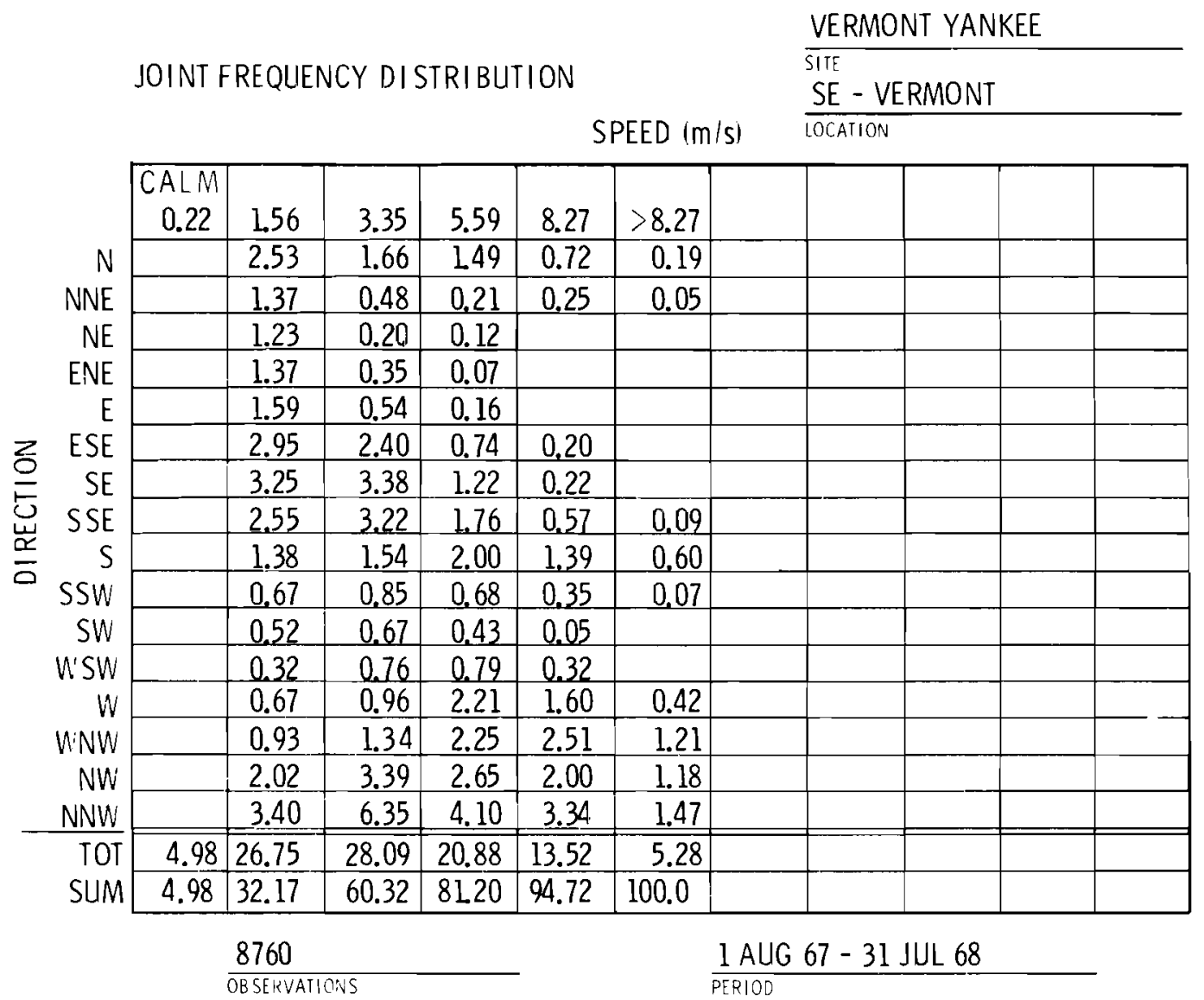

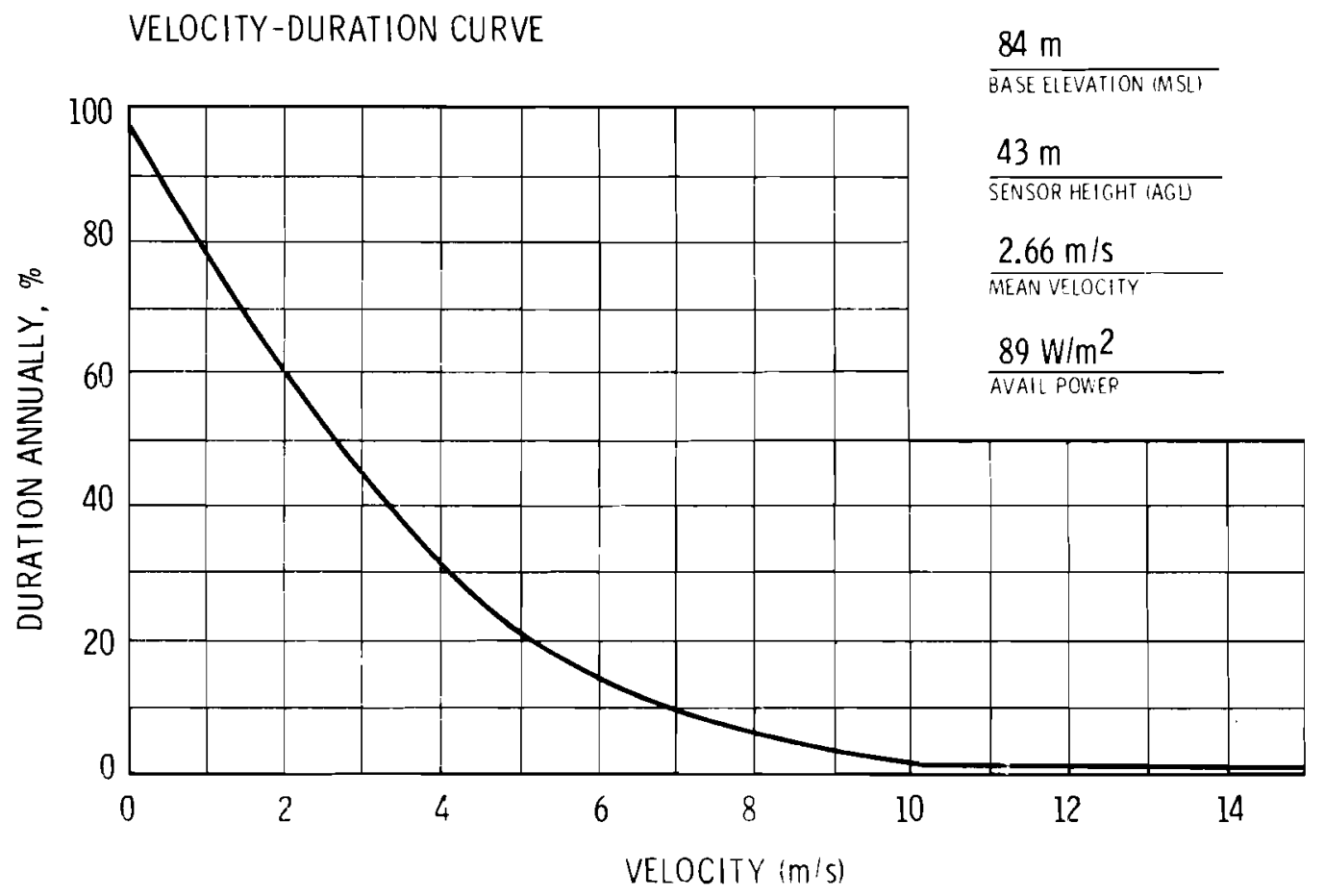


ALVIN W. VOGTLE

SITE LOCATION:

The site $\left(33.14^{\circ} \mathrm{N} / 81.76^{\circ} \mathrm{W}\right)$ is in Burke County, northeast Georgia, across the Savannah River from the United States Govenment's Savannah River Plant. This location is about 24 $\mathrm{km}$ ENE of Waynesboro, GA and $42 \mathrm{~km}$ SSE of Augusta.

TOPOGRAPHY :

The site is in the rolling Appalachian Piedmont Plateau, generally 45-76 $\mathrm{m}$ (MSL). The site terrain is generally flat with the 3-8 $\mathrm{km}$ wide Savannah River valley representing a depression of about $43 \mathrm{~m}$ and running $\mathrm{NW}-\mathrm{SE}$ about $900 \mathrm{~m}$ to the NE. Plant grade is at $67 \mathrm{~m}$ (MSL).

ON-SITE WIND MEASUREMENTS:

The on-site meteorological measurement program began in April 1972. A 46-m tower is located at plant grade in a clearing south of the plant. Data are taken by Climet ws-011-1 (speed) and WD-012-10 (direction) sensors.

NRC Docket No. 50-424 


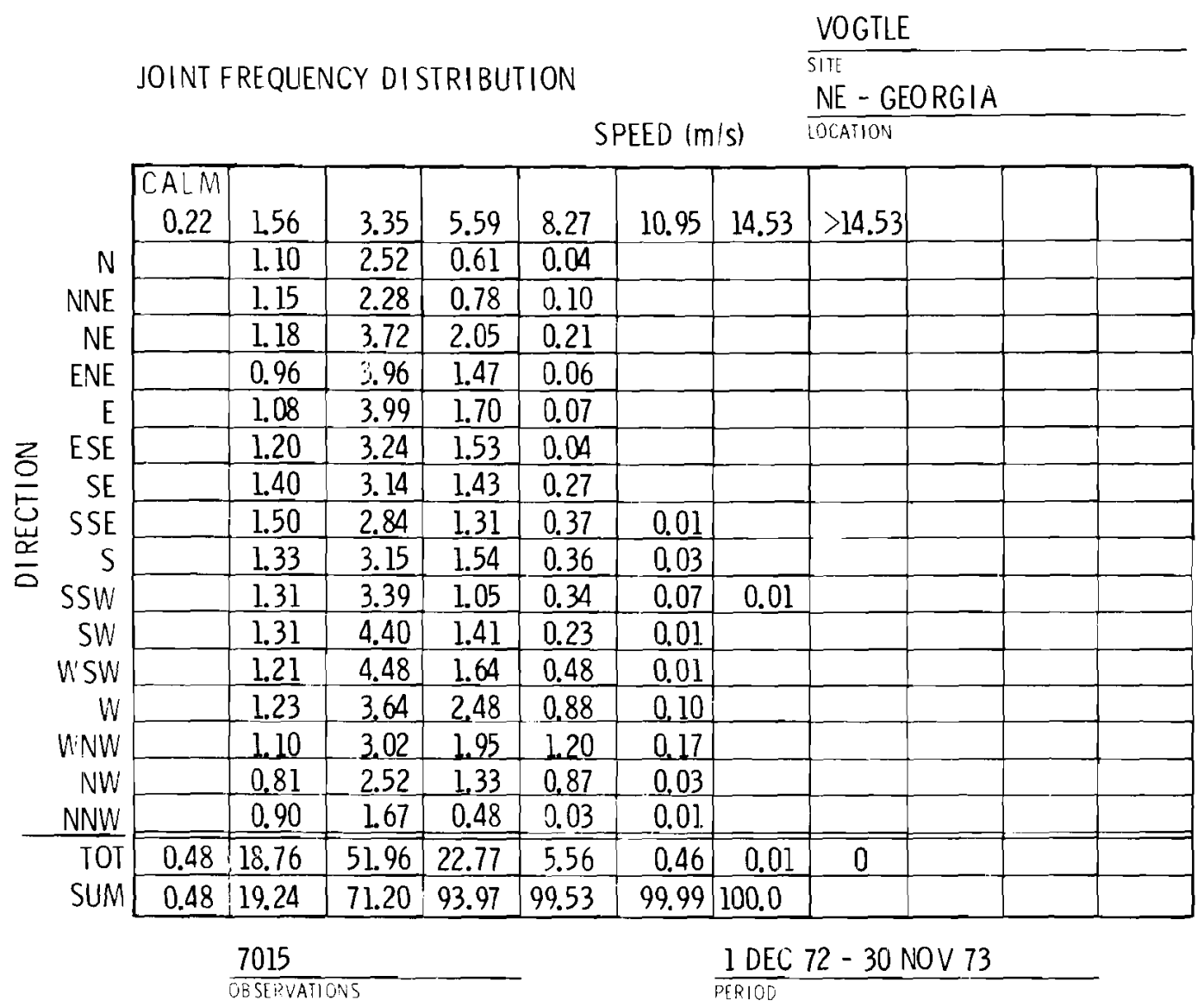

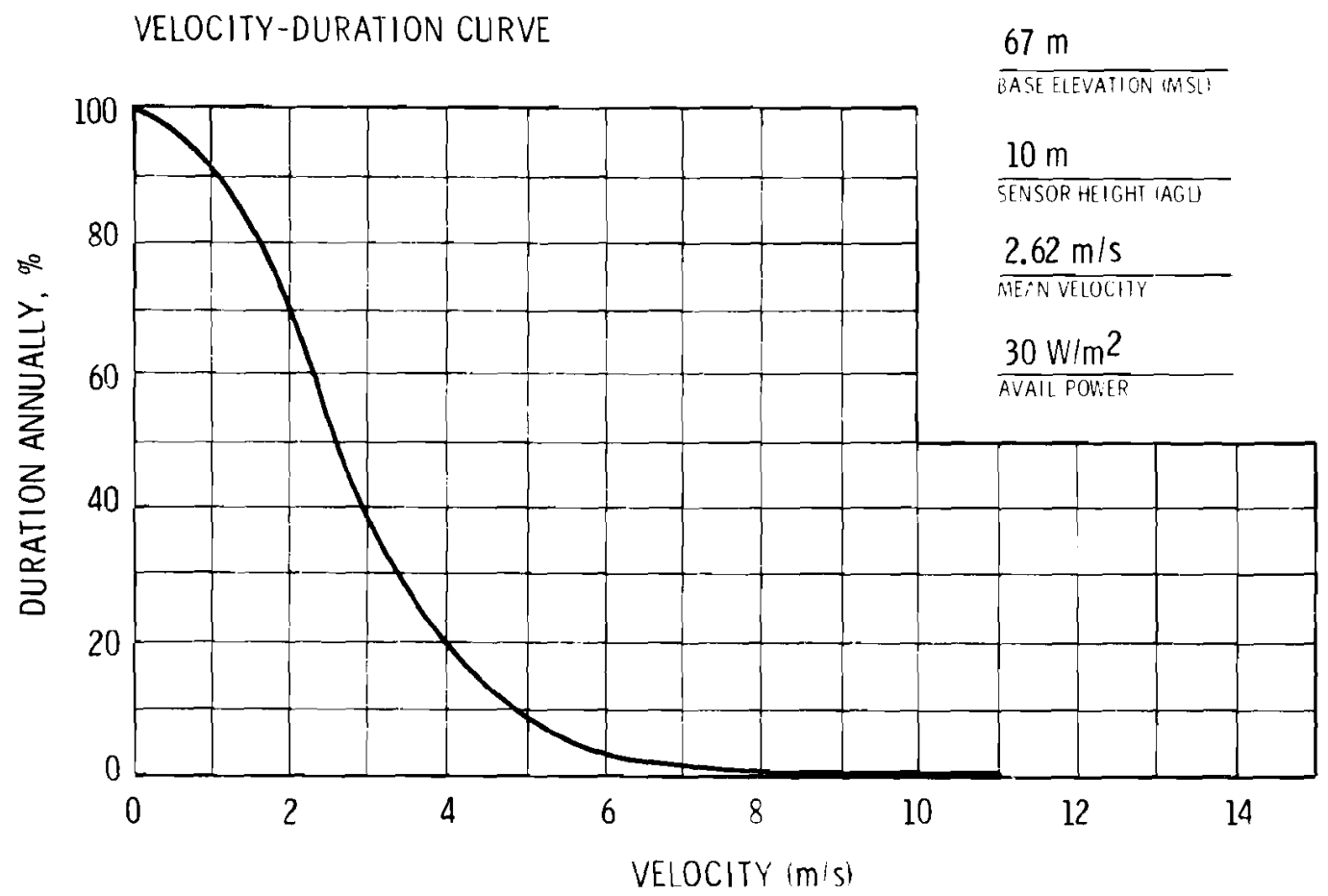


WATERFORD

\section{SITE LOCATION:}

The site $\left(30.00^{\circ} \mathrm{N} / 90.47^{\circ} \mathrm{W}\right)$ is im southeast Louisiana, on the former Waterford Plantation and a part of the Killona Plantation on the west bank of the Mississippi River near Taft, LA, in northwest St. Charles Parish (County). New Orleans is about $35 \mathrm{~km}$ ESE and Baton Rouge is $80 \mathrm{~km} \mathrm{NNW}$.

TOPOGRAPHY :

The region is very flat and very near sea level. The Mississippi River is restrained by levees through much of the area, and Lake Pontchartrain, about $8 \mathrm{~km} \mathrm{NE}$, is open directly to the Gulf of Mexico.

\section{ON-SITE WIND MEASUREMENTS:}

An on-site meteorological monitoring program was initiated at the Waterford site in June, 1971. A 40-m tower is located in a sugarcane field in a flat area at about $4 \mathrm{~m}$ (MSL). Only during late summer and early fall does the cane reach $2.5-3 \mathrm{~m}$, and then a $9 \mathrm{~m}$ diameter clearing is maintained around the tower. The tower is equipped with a Weathermeasure W1034 wind system at $9 \mathrm{~m}$ height, and a Gill Anemometer Bivane and a 4bladed Weathermeasure W101-P Skyvane I wind sensor as backup at the 60-m level.

NRC Docket No. $\overline{50382}$ 

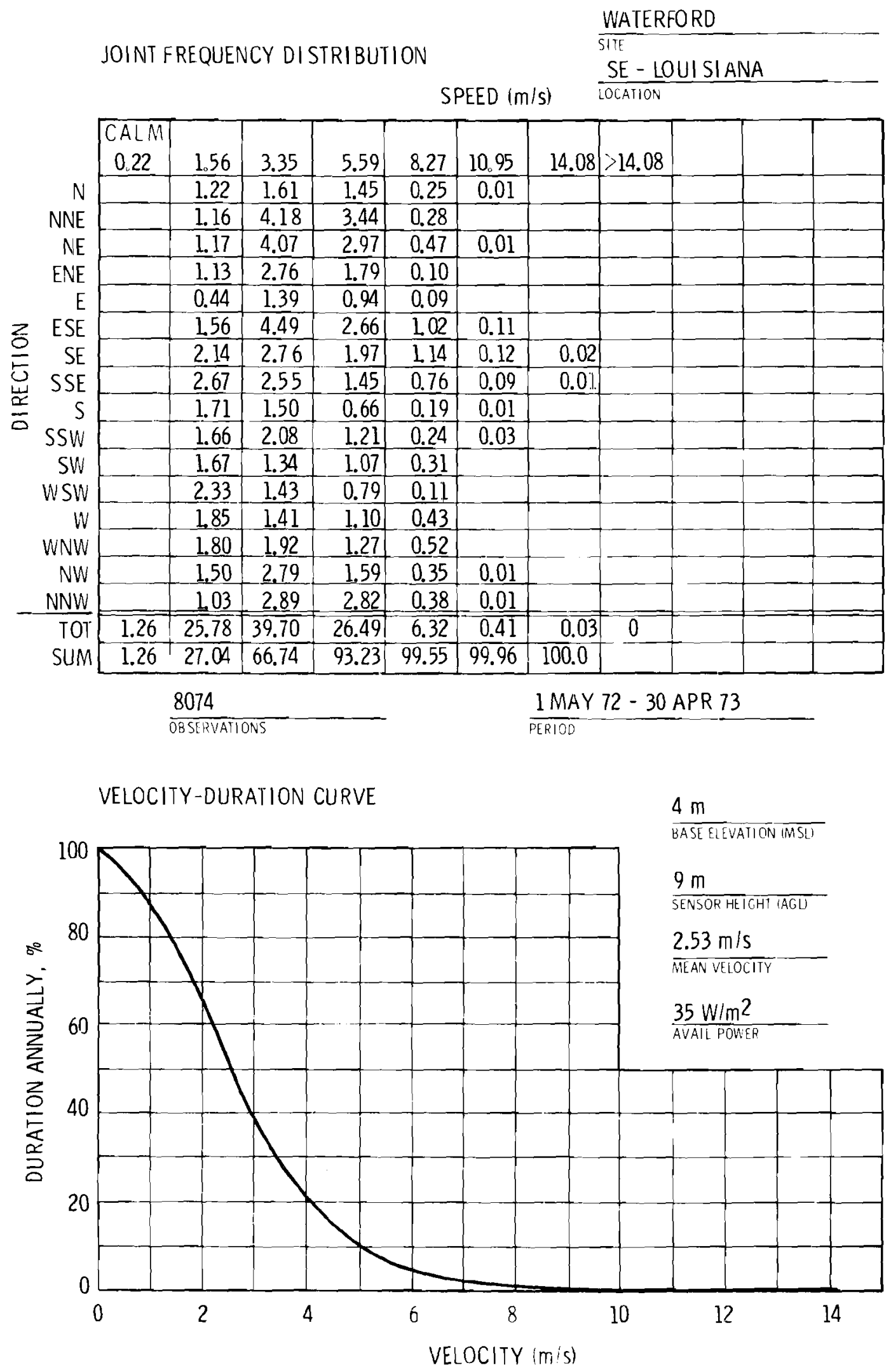
WATTS BAR

\section{SITE LOCATION:}

The site $\left(35.63^{\circ} \mathrm{N} / 84.79^{\circ} \mathrm{W}\right)$ is in Rhea County in eastern Tennessee, $80 \mathrm{~km}$ NNE of Chattanooga and $24 \mathrm{~km} \mathrm{NE}$ of Dayton. The site is on the $W$ bank of Chickamauga Lake on the Tennessee River, about $3 \mathrm{~km} \mathrm{~S}$ of the Watts Bar Dam. The Sequoyah Nuclear Plant is $50 \mathrm{~km} \mathrm{SSW}$.

\section{TOPOGRAPHY :}

The Watts Bar site is in the eastern Tennessee portion of the Southern Appalachian Region. The region is typified by moderately wooded rolling hills. The site is on the $w$ bank of Chickamauga Lake (normal pool elevation $208 \mathrm{~m} \mathrm{(MSL))} \mathrm{on} \mathrm{the}$ Tennessee River, just $3 \mathrm{~km}$ below Watts Bar Reservoir (normal pool elevation $226 \mathrm{~m}$ (MSL)). The Tennessee River Valley runs generally NE-SW with a shallow, undulating valley floor, $15 \mathrm{~km}$ wide here, while the lake adjoining the site averages $400 \mathrm{~m}$ wide. The site is near the center of the valley, which is flanked to the $W$ by 275 to $550 \mathrm{~m}$ Walden Ridge and to the $\mathrm{E}$ by a series of 250 to $300 \mathrm{~m}$ ridges.

\section{ON-SITE WIND MEASUREMENTS:}

On-site meteorological measurements began in June 1971 from a temporary 40-m tower at $220 \mathrm{~m}$ (MSL). Climet WS-011-1 (speed) and WD-012-10 (direction) sensors were installed at $10 \mathrm{~m}$ and $40 \mathrm{~m}$. A permanent 91-m tower was installed in late 1972 at $217 \mathrm{~m}$ (MSL), about $17 \mathrm{~m}$ lower than plant grade. Climet instruments were installed at $10 \mathrm{~m}$ and $91 \mathrm{~m}$.

$\overline{\text { NRC Docket No. } 50-390}$ 

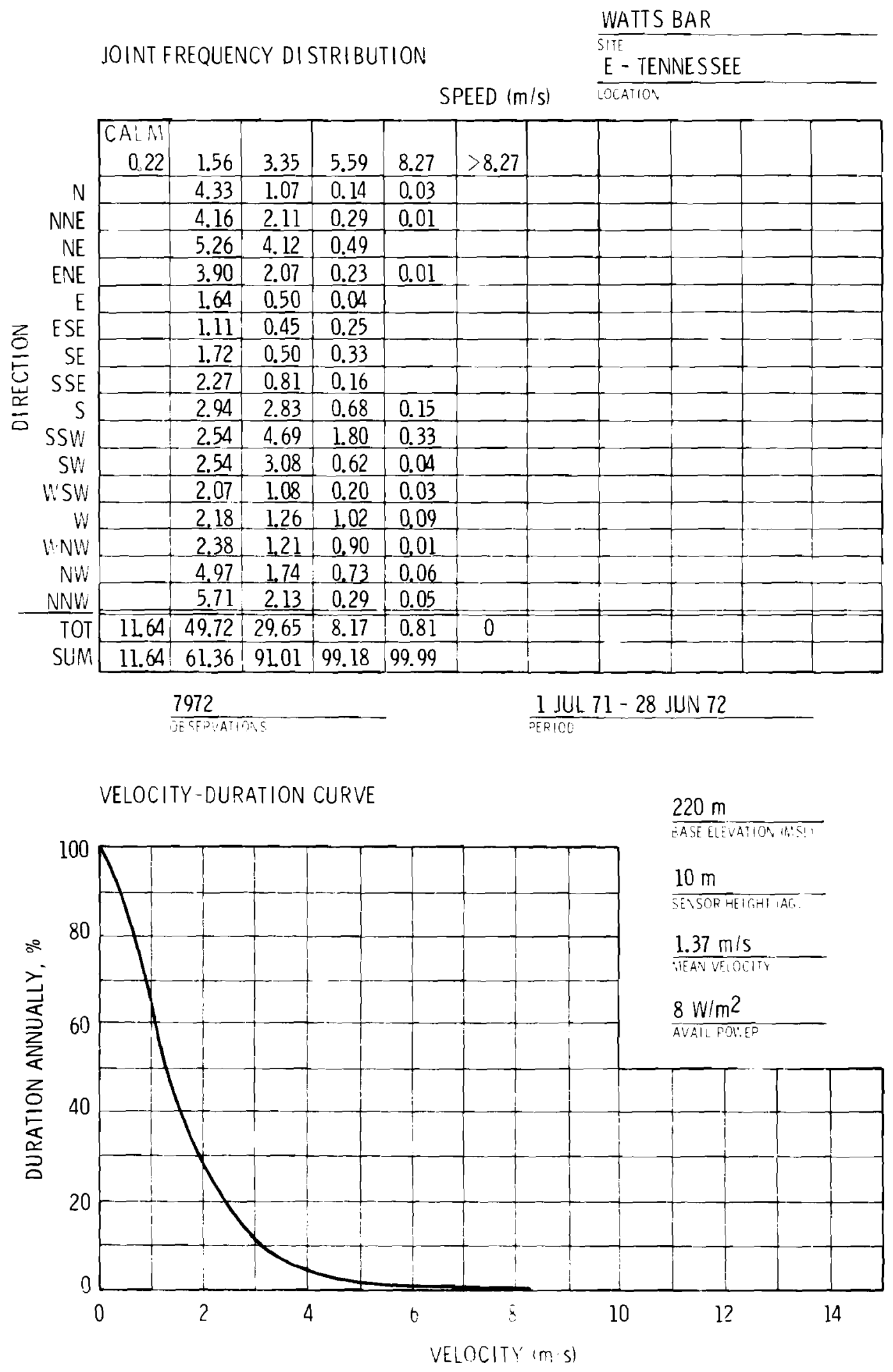


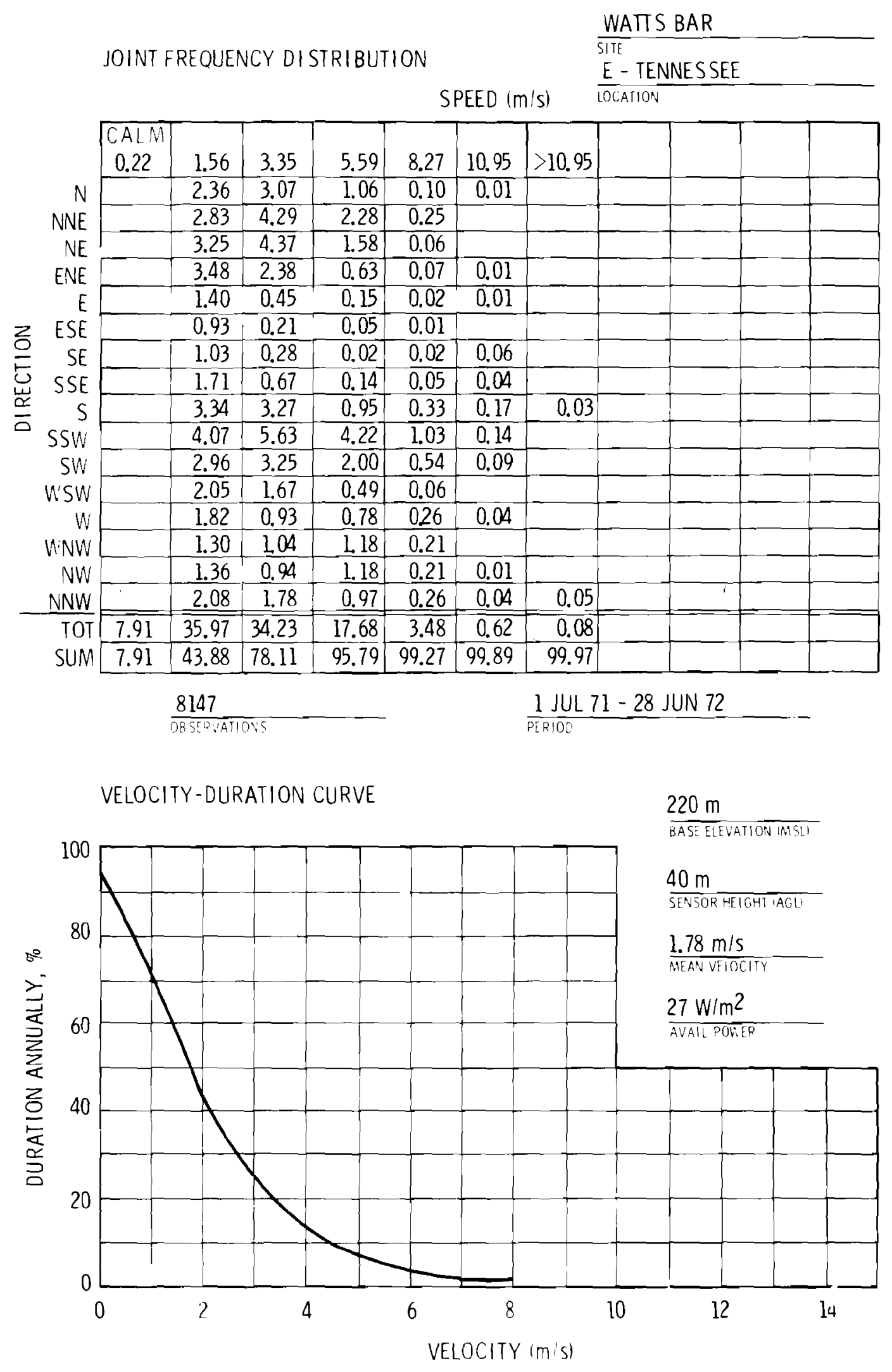




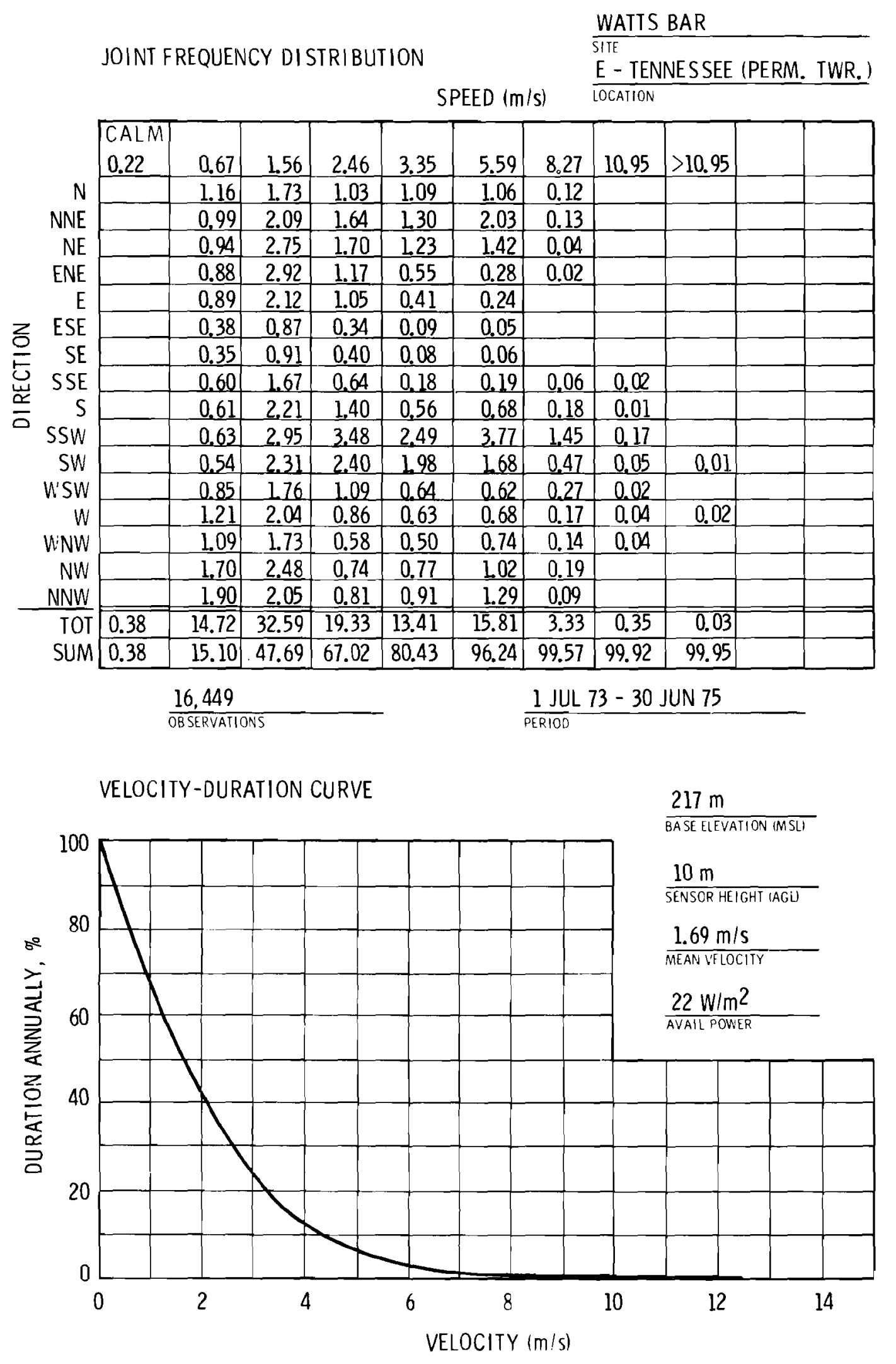




\begin{tabular}{|c|c|c|c|c|c|c|c|c|c|c|}
\hline & & & & & & & & WATT & $S$ BAR & \\
\hline & JOINT & REQLIEI & CY DIS & TRIBU & TION & & & SITE & NESSEE & (PERM. TWR) \\
\hline & & & & & & EED $(m$ & & LOCATION & & \\
\hline & $C A L M$ & & & & & & & & & \\
\hline & 0.22 & 0.67 & 1.56 & 2.46 & 3.35 & 5.59 & 8.27 & 10.95 & $>10.95$ & \\
\hline$N$ & & 0.18 & 0.61 & 0.86 & 0.84 & 1.64 & 1.15 & 0.06 & & \\
\hline NNE & & 0.18 & 1.40 & 2.17 & 1.88 & 3.31 & 1.46 & 0.23 & 0.01 & \\
\hline NE & & 0.19 & 1.86 & 3.14 & 2.55 & 4.16 & 1.18 & $0.1]$ & & \\
\hline ENE & & 0.12 & 1.26 & 1.53 & 1.29 & 1.46 & 0.19 & 0.03 & 0.01 & \\
\hline$E$ & & 0.07 & 1.07 & 1.15 & 0.74 & 0.88 & 0.13 & & 0.01 & \\
\hline ESE & & 0.04 & 0.58 & 0.61 & 0.33 & 0.26 & 0.04 & & & \\
\hline SE & & 0.12 & 0.54 & 0.43 & 0.12 & 0.16 & 0.04 & 0.01 & & \\
\hline SSE & & 0.08 & 0.79 & 0.46 & 0.14 & 0.29 & 0.08 & 0.01 & 0.01 & \\
\hline$S$ & & 0.08 & 0.85 & 0.73 & 0.53 & 0.55 & 0.33 & 0.21 & 0.06 & \\
\hline SSW & & 0.08 & 1.37 & 2.30 & 1.69 & 2.82 & 1.77 & 0.67 & 0.15 & \\
\hline SW & & 0.09 & 1.49 & 3,14 & 3.14 & 5.94 & 3.14 & 1.15 & 0.21 & \\
\hline W'SW & & 0.10 & 1.05 & 1.56 & 1.48 & 2.75 & 1.44 & 0.40 & 0.11 & \\
\hline W & & 0,06 & 0.75 & 0.72 & 0.58 & 0.95 & 0.61 & 0.18 & 0.13 & \\
\hline NNW & & 0,08 & 0.53 & 0.38 & 0.29 & 0.92 & 0.69 & 0,16 & 0.03 & \\
\hline NW & & 0.08 & 0.51 & 0.35 & 0.34 & 1.21 & 0.81 & 0.21 & 0.01 & \\
\hline NNW & & 0.11 & 0.65 & 0.40 & 0.45 & 1.21 & 0.79 & 0.12 & 0.01 & \\
\hline TOT & 0.04 & 1.66 & 15.31 & 19.94 & 16.39 & 28.51 & 13.85 & $3 . \overline{55}$ & 0.75 & \\
\hline SUM & 0.04 & 1.70 & 17.01 & 36.95 & 53.34 & 81.85 & 95.70 & 99.25 & 100.0 & \\
\hline & & & & & & & 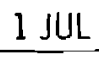 & $73-30$ & IN 75 & \\
\hline
\end{tabular}

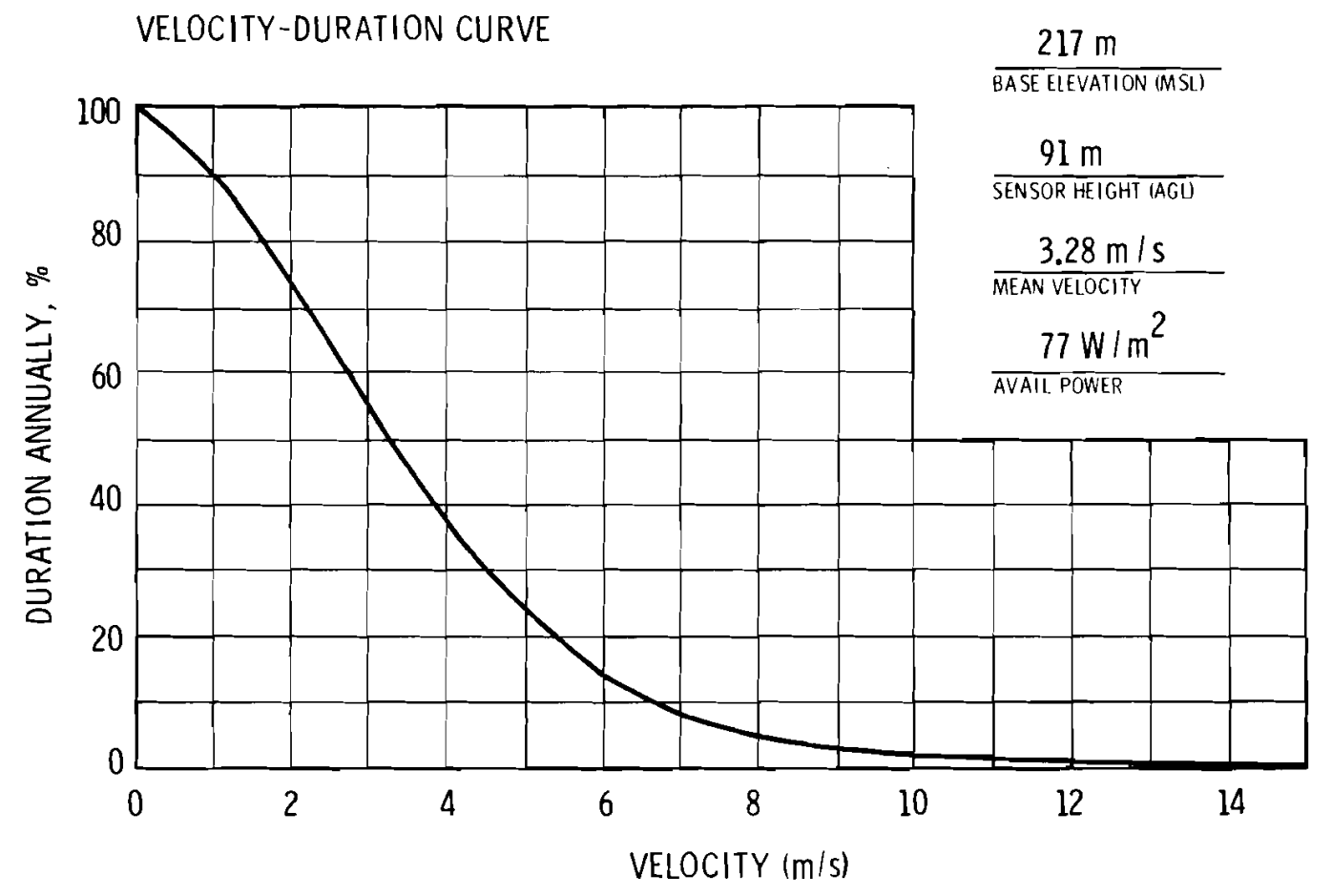


WOLF CREEK

\section{SITE LOCATION:}

The site $\left(38.24^{\circ} \mathrm{N} / 95.69^{\circ} \mathrm{W}\right)$ is about $6 \mathrm{~km}$ NE of Burlington in Coffey County, east central Kansas, and also $120 \mathrm{~km} \mathrm{SW}$ of Kansas City and $160 \mathrm{~km} \mathrm{NE}$ of Wichita. The spillway of the John Redmond Reservoir on the Neosho River is $6 \mathrm{~km} \mathrm{~W}$.

TOPOGRAPHY :

The site is situated in the level to gently undulating, dissected uplands $E$ of the Neosho River Valley. Elevations in the region range from 310 to $340 \mathrm{~m}$ (MSL). The greatest variation in elevation along an $8-\mathrm{km}$ radial is $40 \mathrm{~m}$ to the NNE. Within $80 \mathrm{~km}$, maximum elevations occur to the and $\mathrm{NW}$ where the terrain rises to between 105 and $125 \mathrm{~m}$ above plant grade at distances from 55 to $65 \mathrm{~km}$.

ON-SITE WIND MEASUREMENTS:

A 90-m tower with instrumentation was palced in operation in May 1973. It is located in an open field on a flat ridge, at $338 \mathrm{~m}$ (MSL) and variations in elevation do not exceed $17 \mathrm{~m}$ for at least $2 \mathrm{~km}$ out. Climet WS-011-l (speed) and WD-012-10 (direction) sensors are mounted at $10 \mathrm{~m}, 35 \mathrm{~m}$, and $60 \mathrm{~m}$.

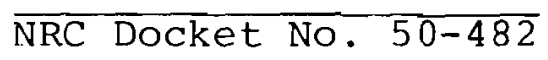



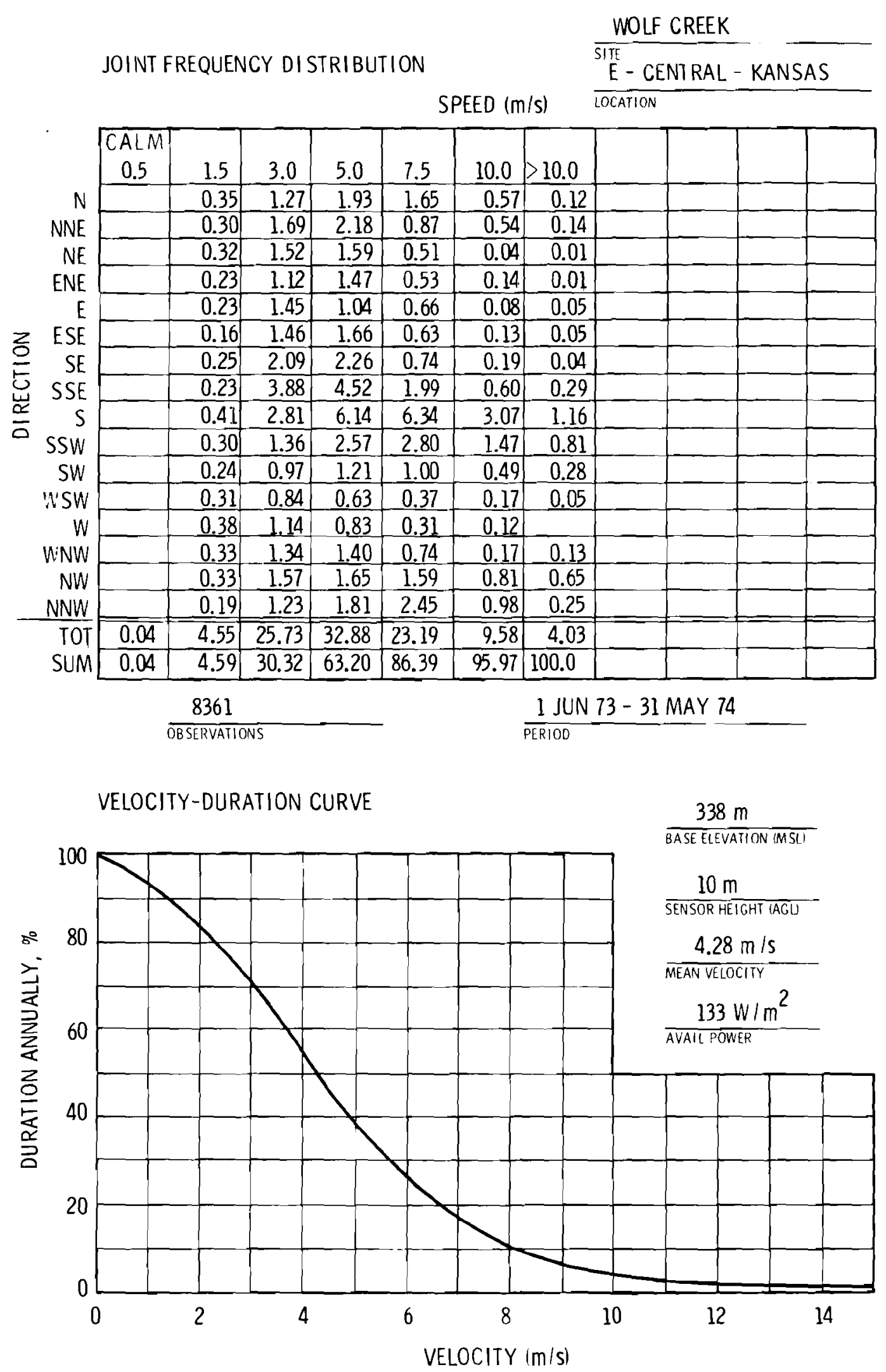


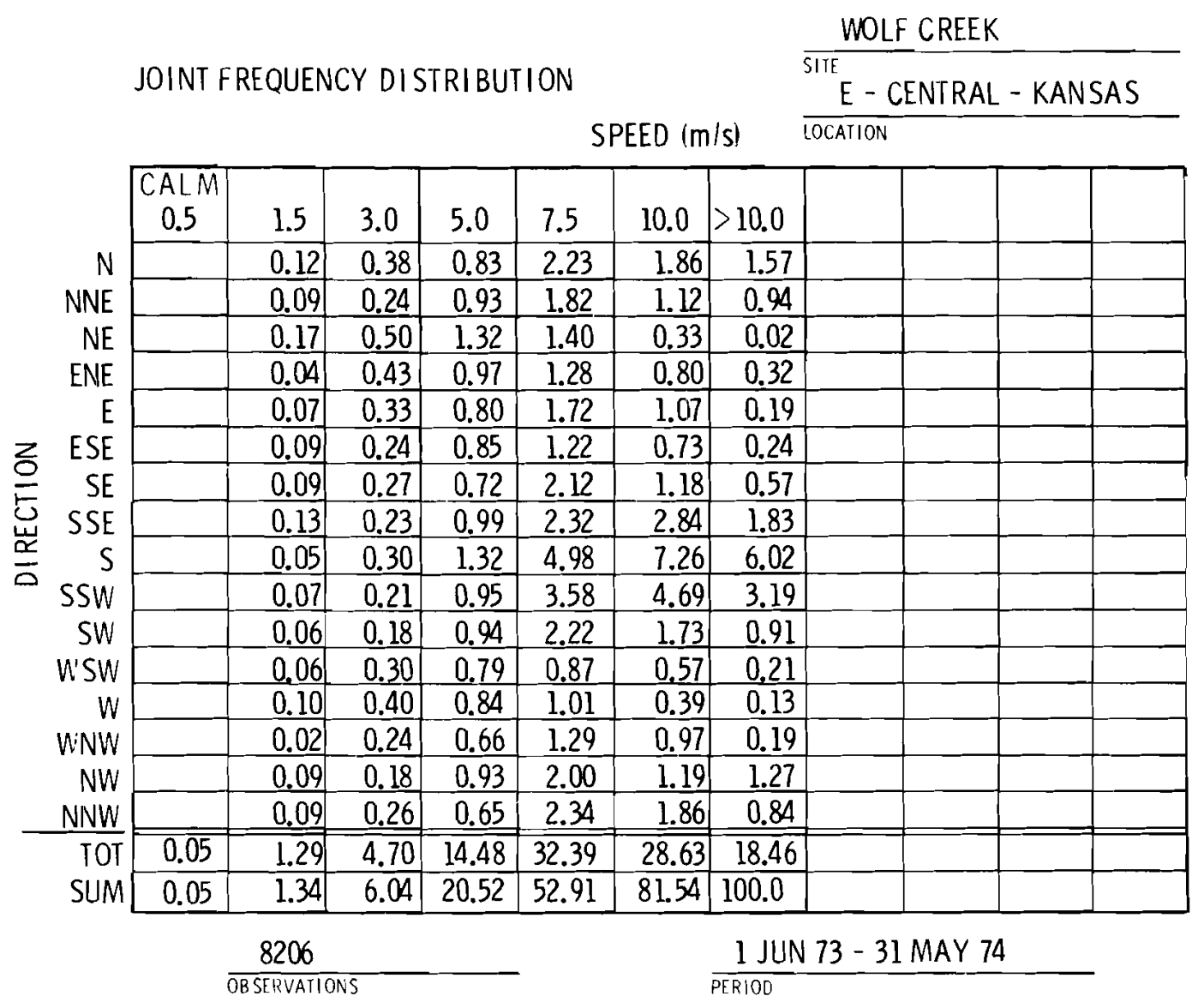

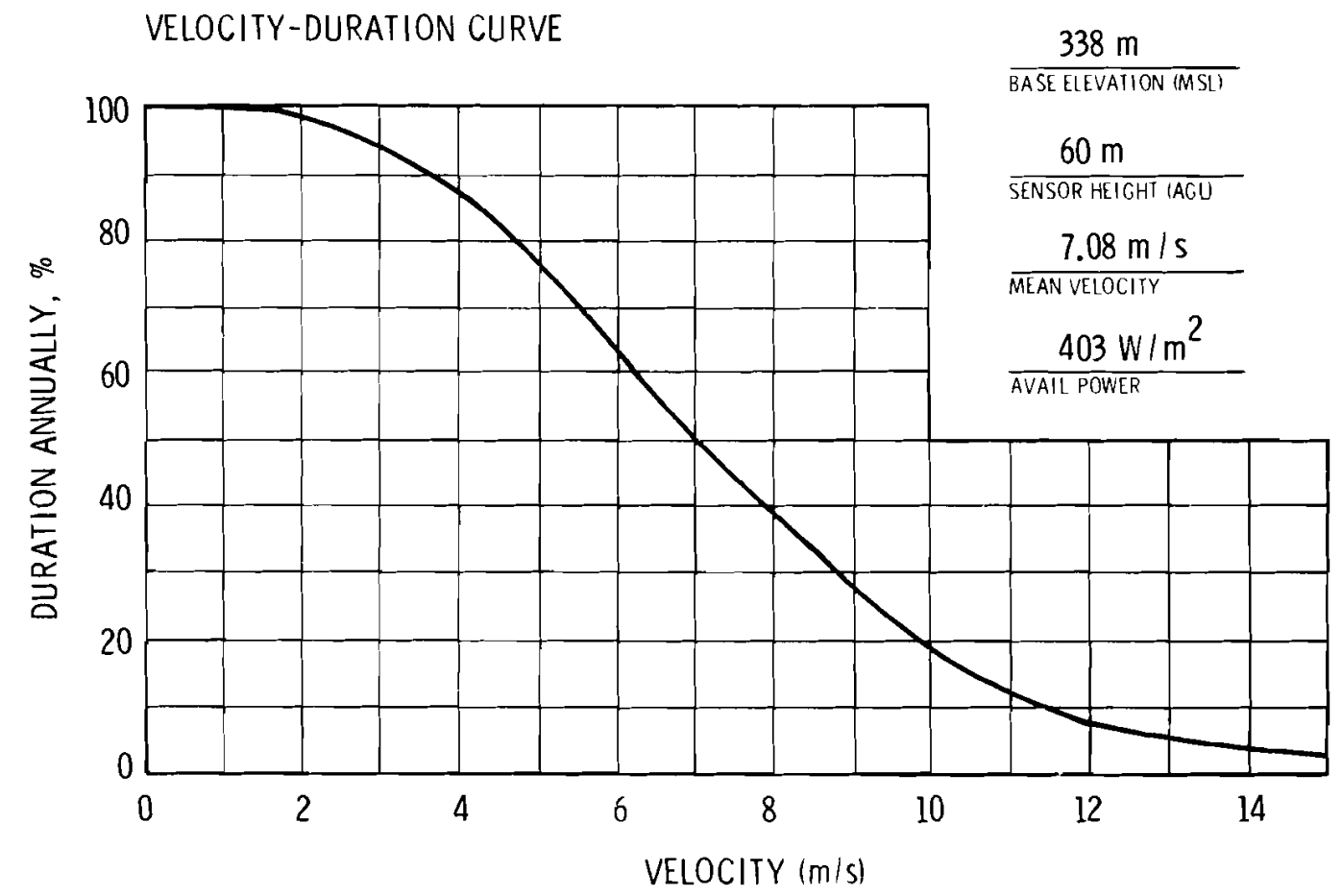


WPPSS (HANFORD)

SITE LOCATION:

The site $\left(46.47^{\circ} \mathrm{N} / 119.32^{\circ} \mathrm{W}\right)$ of Washington Public Power Supply System Nuclear Projects No. 1 and No. 4 is adjacent to No. 2, all within ERDA's Hanford Reservation in south central Washington. Hanford includes parts of Benton, Franklin and Grant Counties, and is about $50 \mathrm{~km} \mathrm{~N}$ of oregon and $160 \mathrm{~km} \mathrm{~W}$ of Idaho. The sites are about $4 \mathrm{~km} w$ of the columbia River and $3 \mathrm{~km} \mathrm{~N}$ of Richland, WA.

TOPOGRAPHY :

The site is located in the Lower Columbia Basin, $150 \mathrm{~km} \mathrm{E}$ of the Cascade Mountains and $120 \mathrm{~km}$ NW of the Blue Mountains. The dominant regional features are the Rattlesnake Hills $15 \mathrm{~km} \mathrm{SW}$ and $\mathrm{W}$ at over $1000 \mathrm{~m}$ (MSL); the Saddle Mountains 30 $\mathrm{km} \mathrm{NW}$ and $W$ over $750 \mathrm{~m}$; and the steep, river-cut bluffs forming the east bank of the Columbia River about $4 \mathrm{~km} \mathrm{E}$.

\section{ON-SITE WIND MEASUREMENTS:}

The Hanford Reservation is a large federal reservation managed by ERDA. It contains many installations besides the wPPSS units and has a major meteorological monitoring program, in addition to meteorologi al towers adjacent to WPPSS-2 and one at the $\mathrm{N}$-Reactor.

The Hanford Meteorological station (HMS) provides the primary meteorological support to the ERDA activities on the reservation. Bendix-Freiz Aerovanes (Model 120) are used at $15 \mathrm{~m}, 61 \mathrm{~m}$, and $122 \mathrm{~m}$, on the $122 \mathrm{~m}$ tower located on a plateau at $223 \mathrm{~m}$ (MSL) about $40 \mathrm{~km}$ NW of Richland, and slightly north and west of the center of the reservation.

The WPPSS-2 tower is at $134 \mathrm{~m}$ (MSL) in the southeast corner of the reservation. Climet WS-011-1 and WD-012-10 instruments are located at 2, 10 and $75 \mathrm{~m}$ (AGL) on the 75-m tower.

NRC Docket Nos. $50-397,-460,-513$

BNWL- 1605 


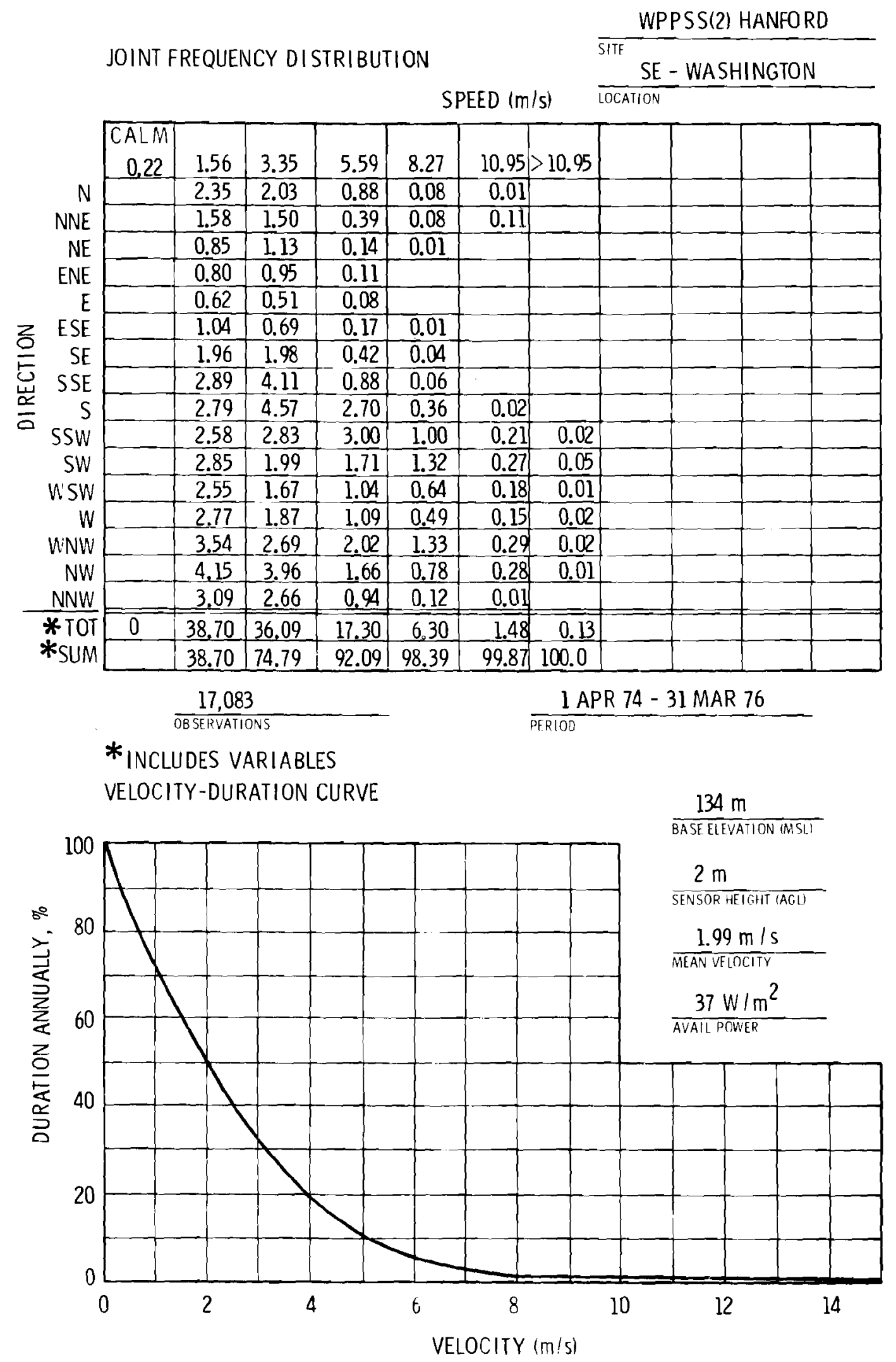




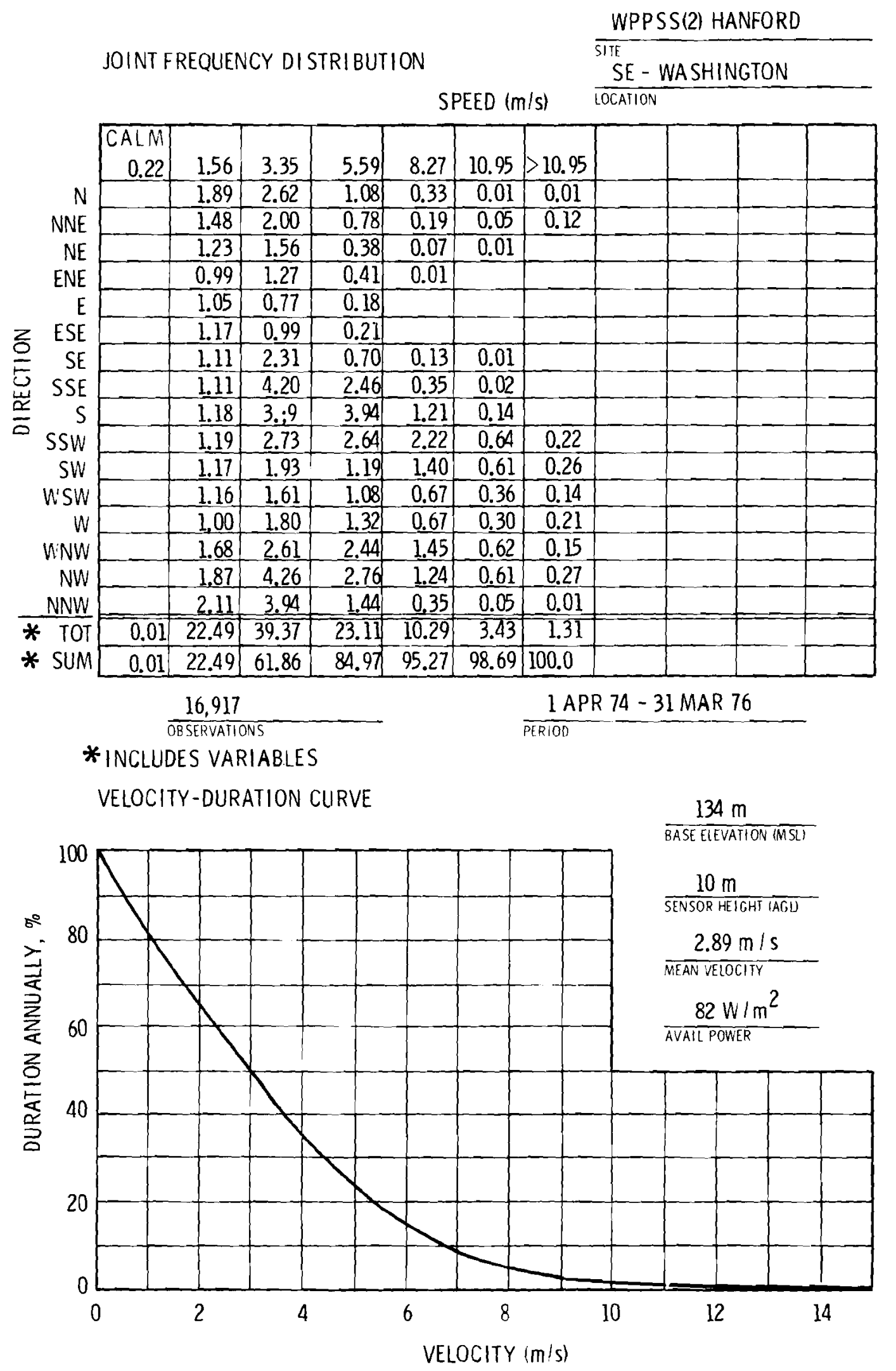




\begin{tabular}{|c|c|c|c|c|c|c|c|c|c|c|}
\hline & & & & & & & & WP & S(2) HANFORL & \\
\hline & JOINT F & REQUE & CY DI & RIBUT & ION & & & SE - & WASHINGTON & \\
\hline & & & & & & $\mathrm{EED}$ (n) & & LOCATION & & \\
\hline & CALM & & & & & & & & & \\
\hline & 0.22 & 1.56 & 3.35 & 5.59 & 8.27 & 10.95 & $b 10.95$ & & & \\
\hline$N$ & & 0.82 & 2.40 & 1.51 & 0.61 & 0.11 & 0.01 & & & \\
\hline NNE & & 0.65 & 1.80 & 1.33 & 0.36 & 0.77 & 0.18 & & & \\
\hline NE & & 0.49 & 1.30 & 0.96 & 0.23 & 0.05 & 0.03 & & & \\
\hline ENE & & 0.41 & 1.14 & 0.73 & 0.11 & 0.04 & & & & \\
\hline$E$ & & 0.54 & 1.08 & 0.43 & 0.05 & 0.01 & & & & \\
\hline ESE & & $0 . \overline{63}$ & 1.30 & 0.58 & 0.09 & 0.05 & & & & \\
\hline SE & & 0.68 & 1.97 & 1.25 & 0.45 & 0.14 & 0.04 & & & \\
\hline SSE & & 0.69 & 2.71 & 2.56 & 1.33 & 0.21 & 0.04 & & & \\
\hline$S$ & & 0.76 & 2.62 & 3.68 & 2.60 & 0.84 & 0.14 & & & \\
\hline - SSW & & 0.71 & 1.99 & 2.14 & 2.73 & 1.46 & 1.30 & & & \\
\hline SW & & 0.74 & 1.58 & 1.17 & 1.12 & 1.0 .1 & 0.88 & & & \\
\hline W'SW & & 0.62 & 1.34 & 1.05 & 0.82 & 0.44 & 0.51 & & & \\
\hline$W$ & & 0.65 & 1.61 & 1.25 & 1.23 & 0.65 & 0.35 & & & \\
\hline WNW & & 0.78 & 1.75 & 2.13 & 2.49 & 2.26 & 1.38 & & & \\
\hline NW & & 0.78 & 2.75 & 3.06 & 2.57 & 1.13 & 0.59 & & & \\
\hline NNW & & 0.73 & 2.76 & 2.12 & 1.22 & 0.14 & 0.02 & & & \\
\hline TOT & 0 & 11.15 & 30.68 & 26.04 & 18.07 & 8.59 & 5.47 & & & \\
\hline SUM & & 11.15 & 41.83 & 67.87 & 85.93 & 94.53 & 100.0 & & & \\
\hline & & 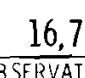 & & & & & $1 \mathrm{~A}$ & 74 & MAR 76 & \\
\hline
\end{tabular}

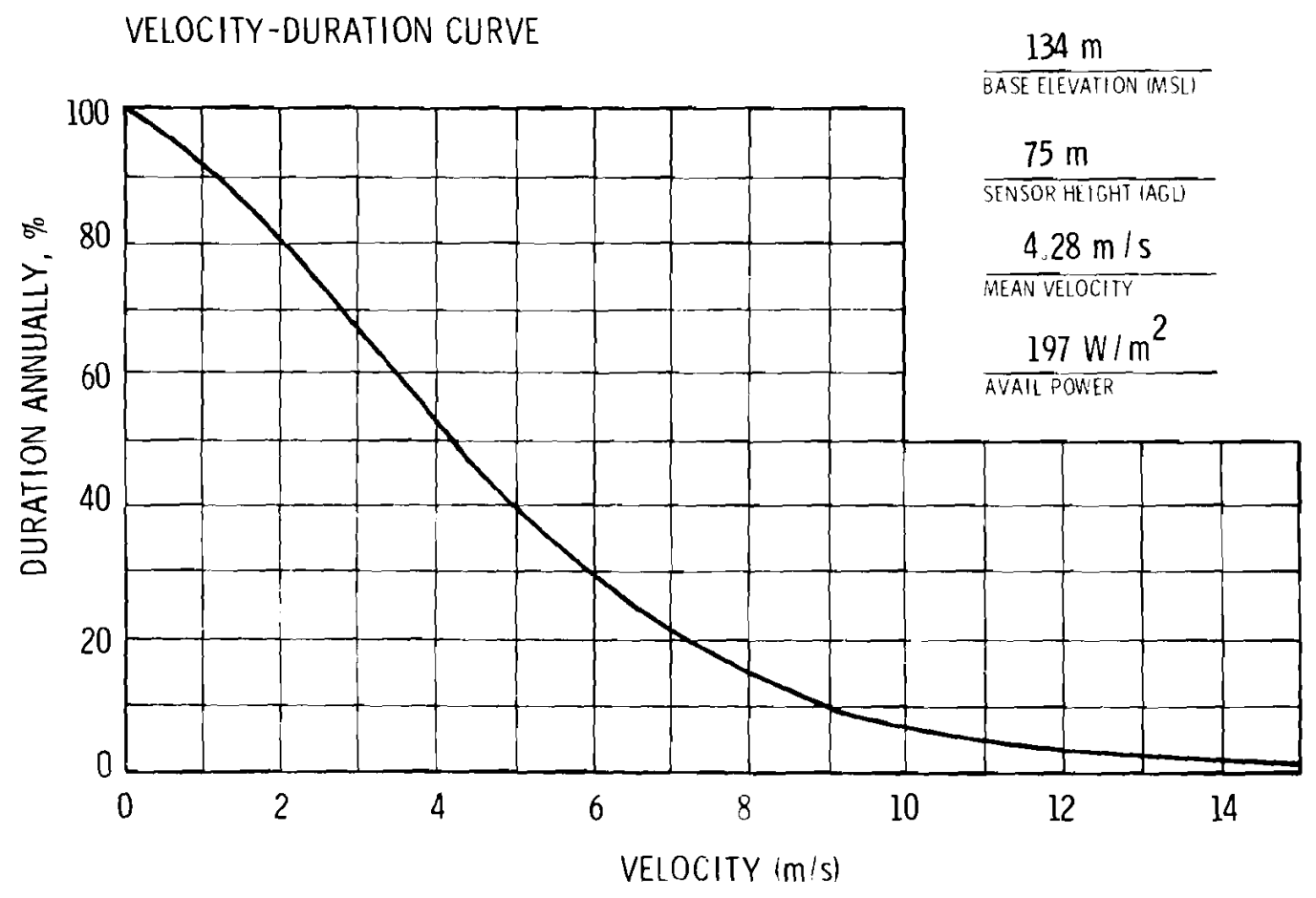



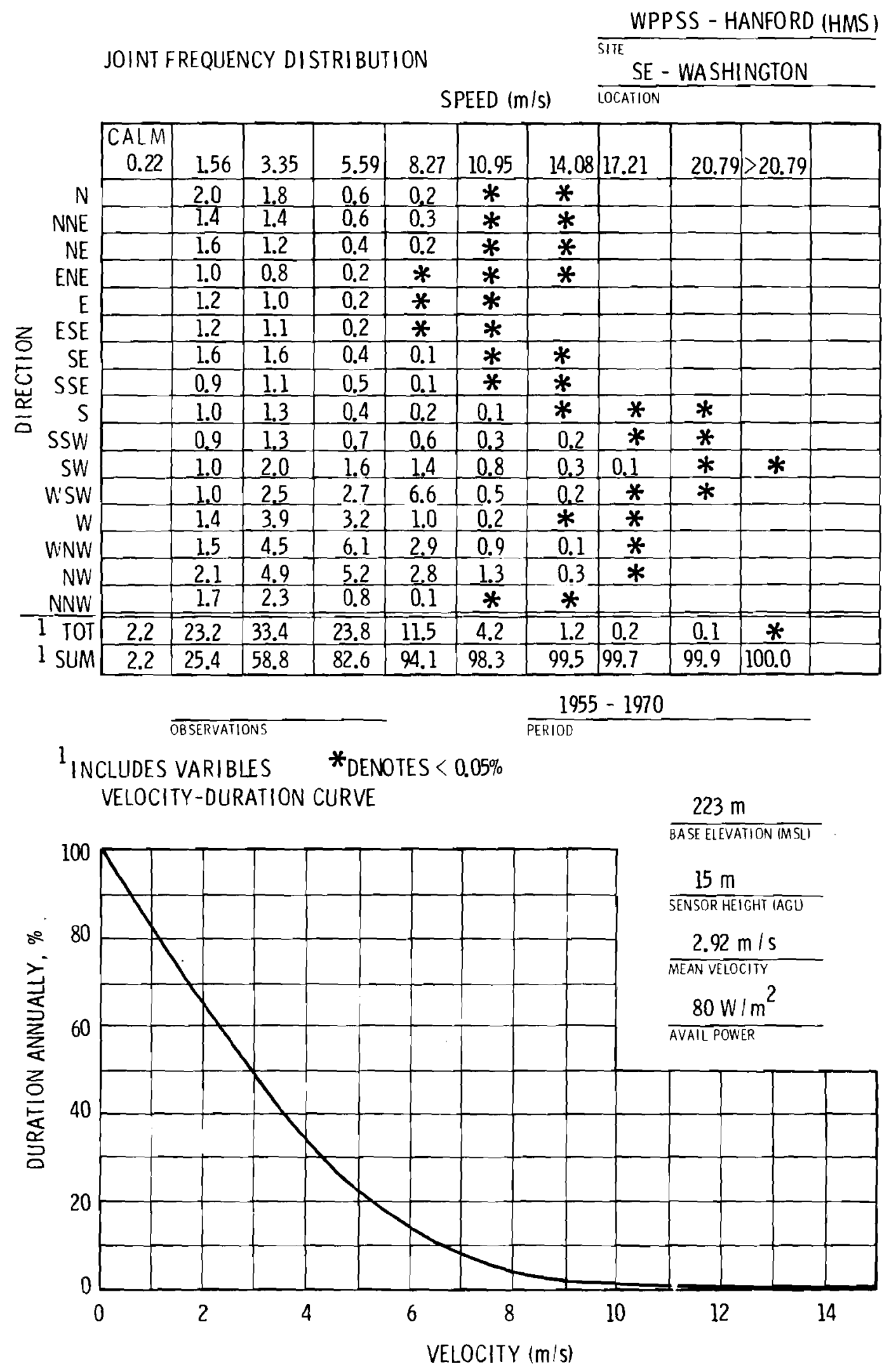


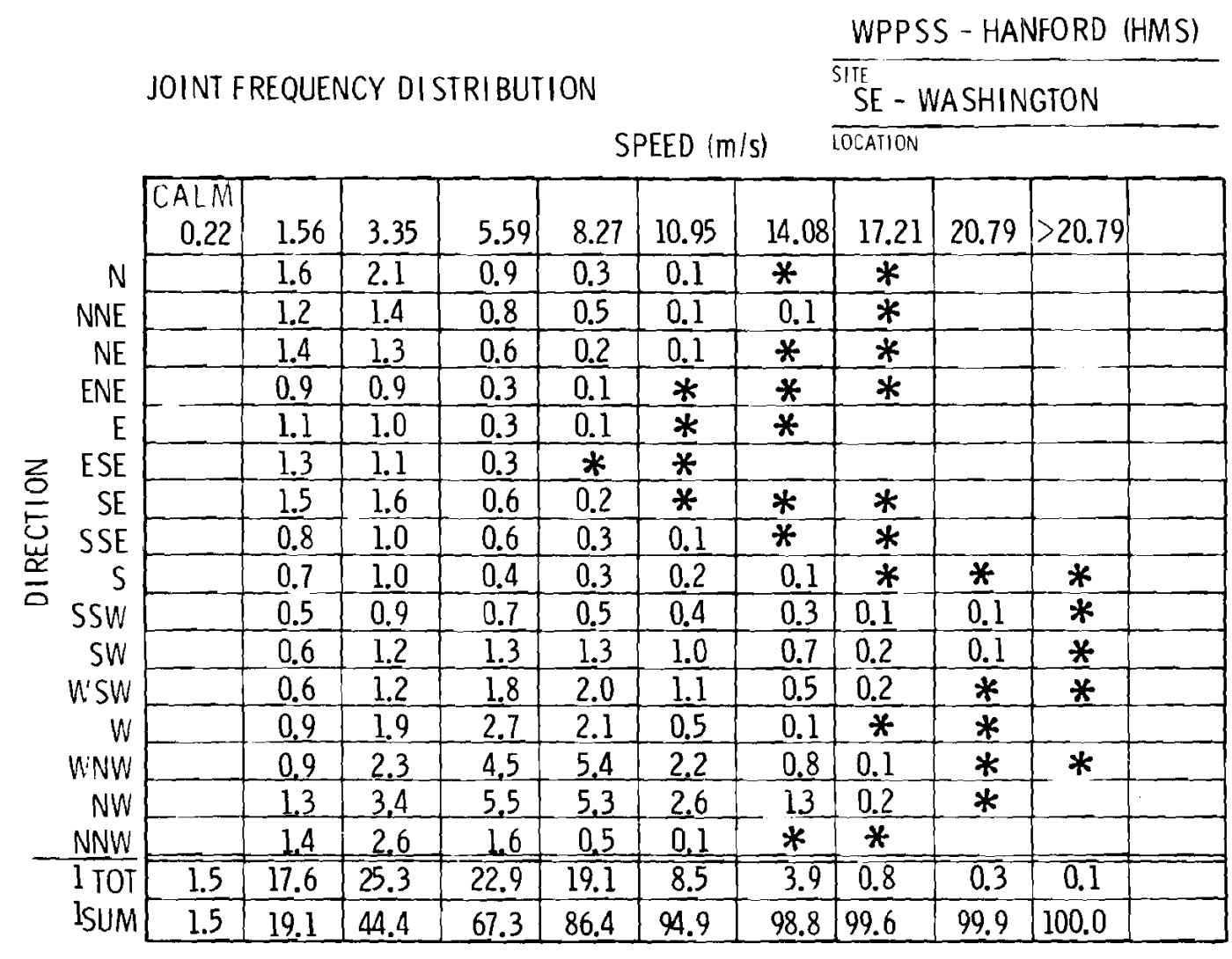

$1_{\text {INCLUDES VARIABLES }} \quad *_{\text {DENOTERATIONS }}<0.05 \%$ VELOCITY-DURATION CURVE

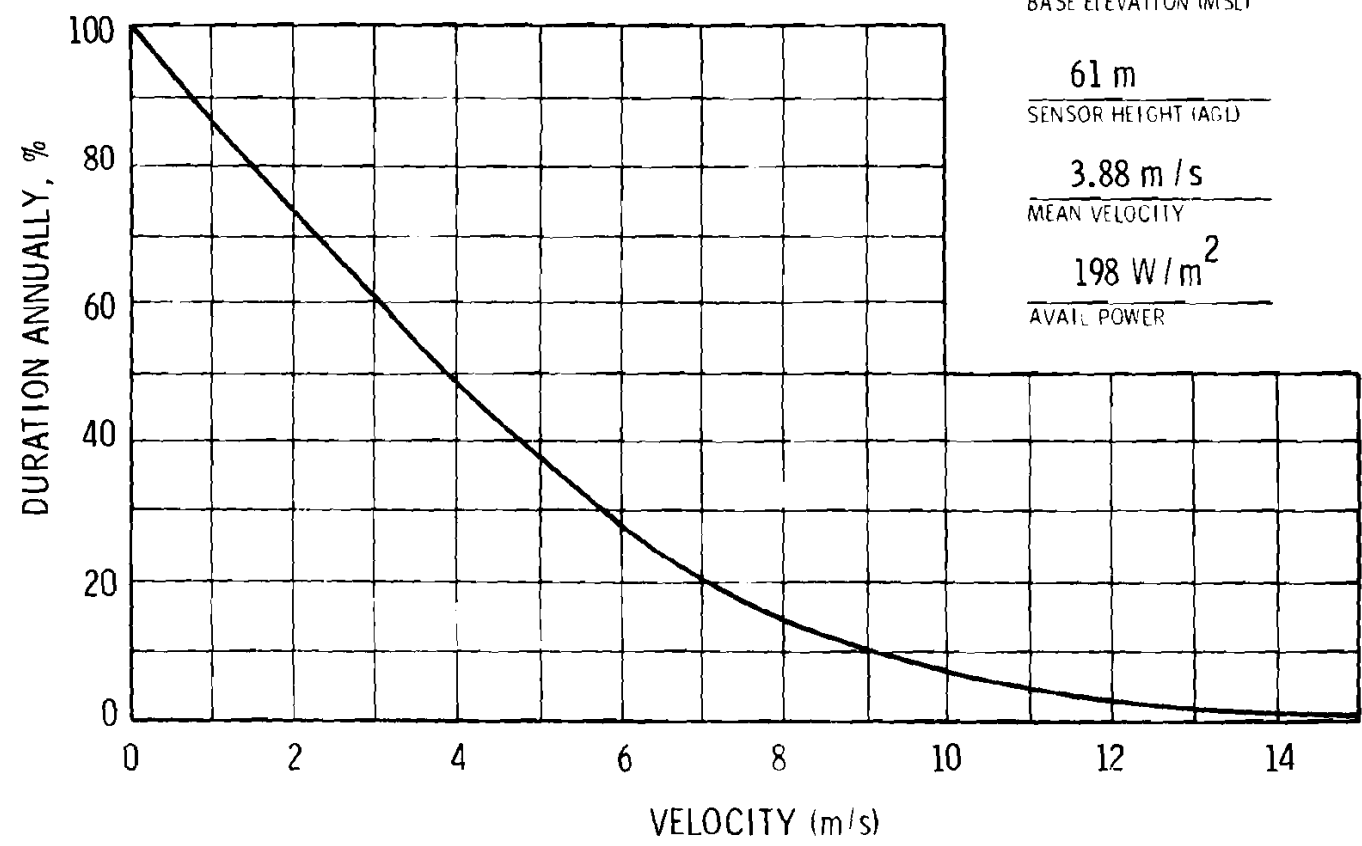




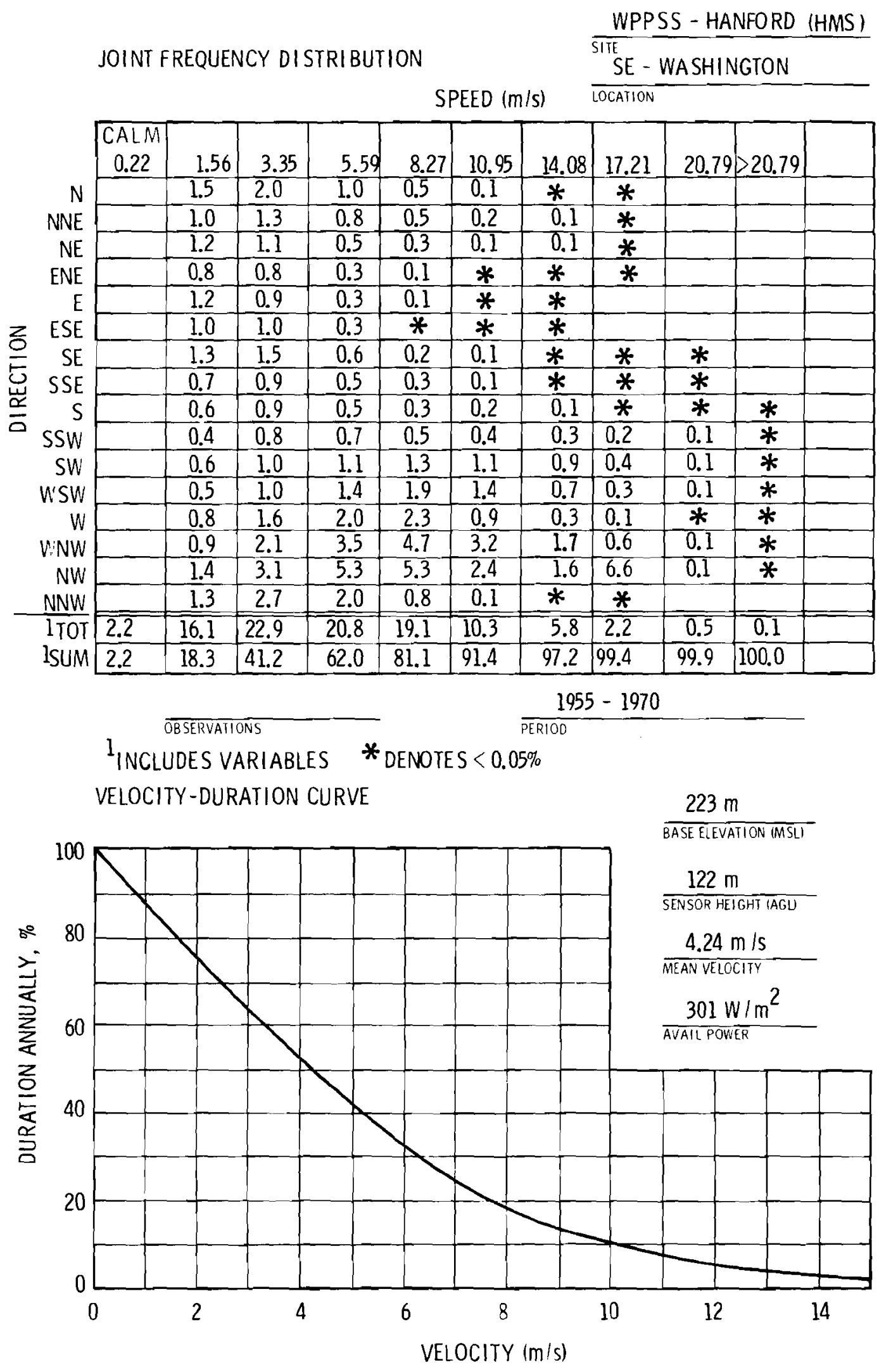


WPPSS (SATSOP)

SITE LOCATION:

The site $\left(46.96^{\circ} \mathrm{N} / 123.47^{\circ} \mathrm{W}\right)$ of the Washington Public Power Supply System (WPPSS) Nuclear Projects Nos. 3 and 5 are in southeast Grays Harbor County, Washington, $42 \mathrm{~km}$ SW of Olympia, $26 \mathrm{~km} \mathrm{E}$ of Aberdeen, and $3 \mathrm{~km} \mathrm{~S}$ of satsop. The confluence of the Chehalis River and the satsop River is about $2 \mathrm{~km}$ north.

\section{TOPOGRAPHY :}

The site is located at the southern end of the olympic Peninsula where the terrain is still quite rolling and heavily forested. The site is on the southern edge of the broad valley of the chehalis River. The land rises rapidly to the south to over $500 \mathrm{~m}$ (MSL), while the broad flat river valley with elevations near sea level lies to the north. Plant elevation is at about $122 \mathrm{~m}$ (MSL).

\section{ON-SITE WIND MEASUREMENTS:}

A 60-m tower was established on Fuller Hill, a clear, flat pasture at about $90 \mathrm{~m}$ (MSL). There are stands of fir trees on the north and west edges of the pasture. To the north, tree heights are $13-17 \mathrm{~m}$, while to the west, they are $18-23 \mathrm{~m}$. Distances from the trees to the tower are about $70 \mathrm{~m}$ at the closest point. Wind speed and direction are measured at both $10 \mathrm{~m}$ and $60 \mathrm{~m}$ using MRI 1074-2 wind systems.

$\overline{\text { NRC Docket No. }} \overline{50-508}$ 


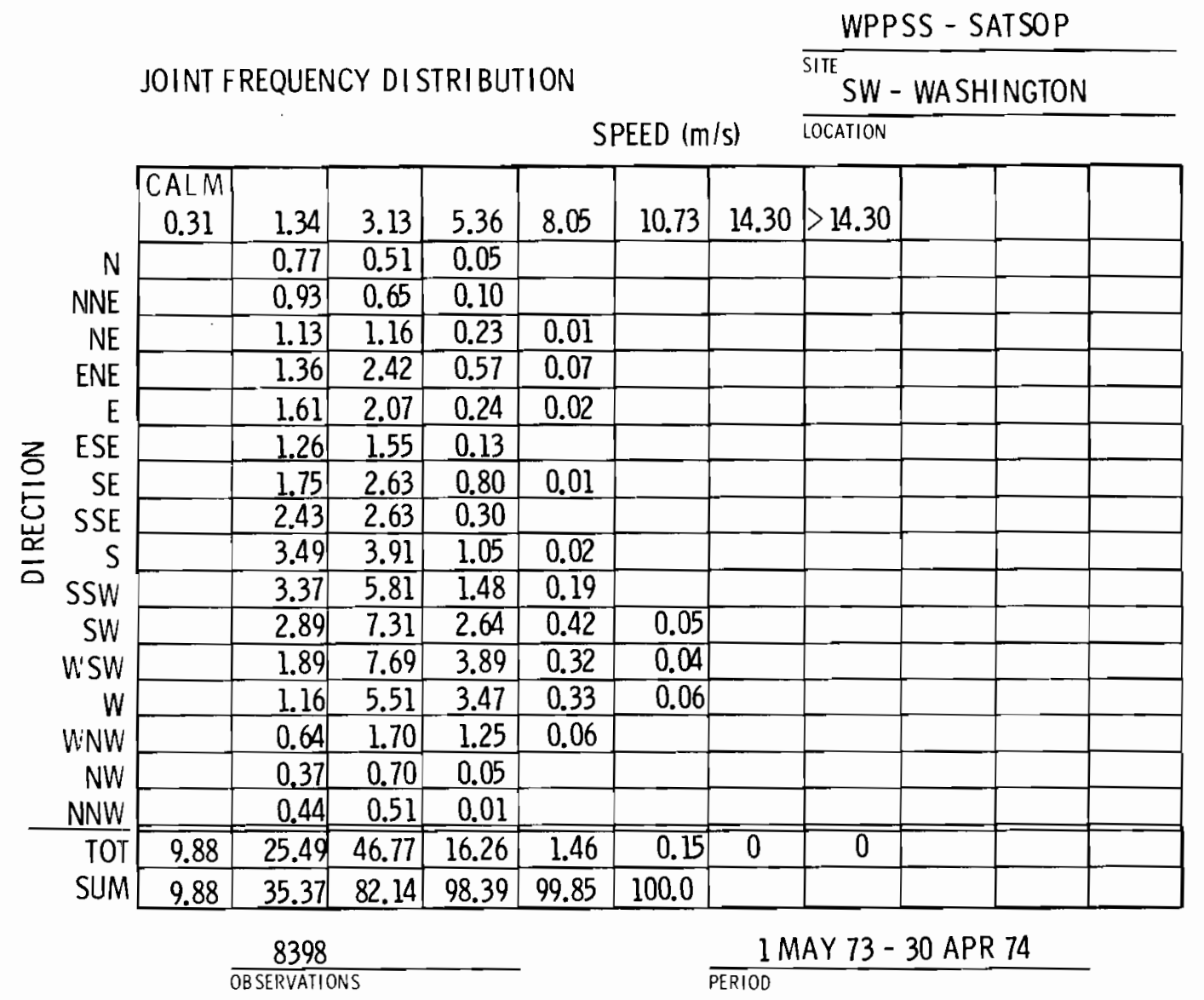

VELOCITY-DURATION CURVE

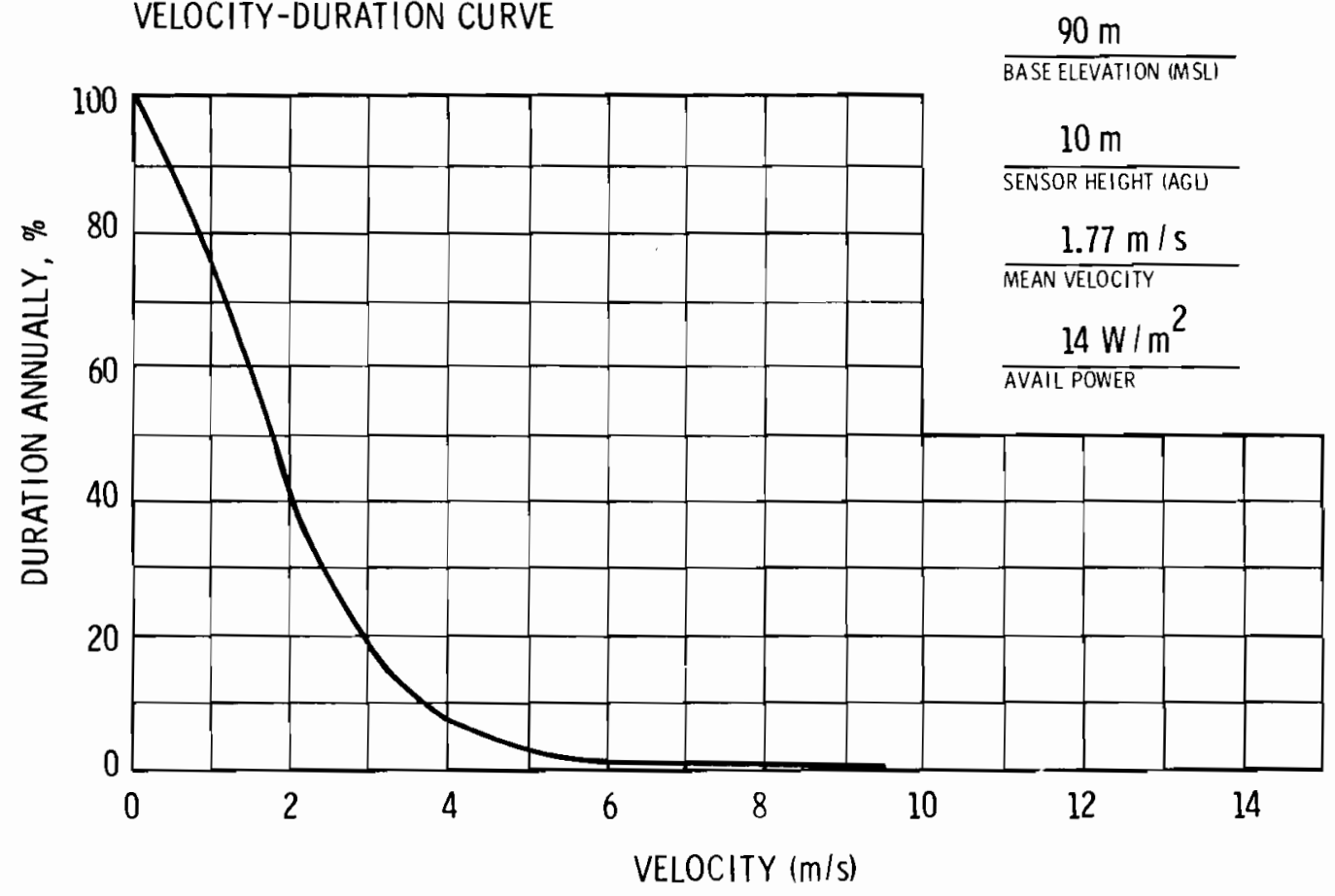




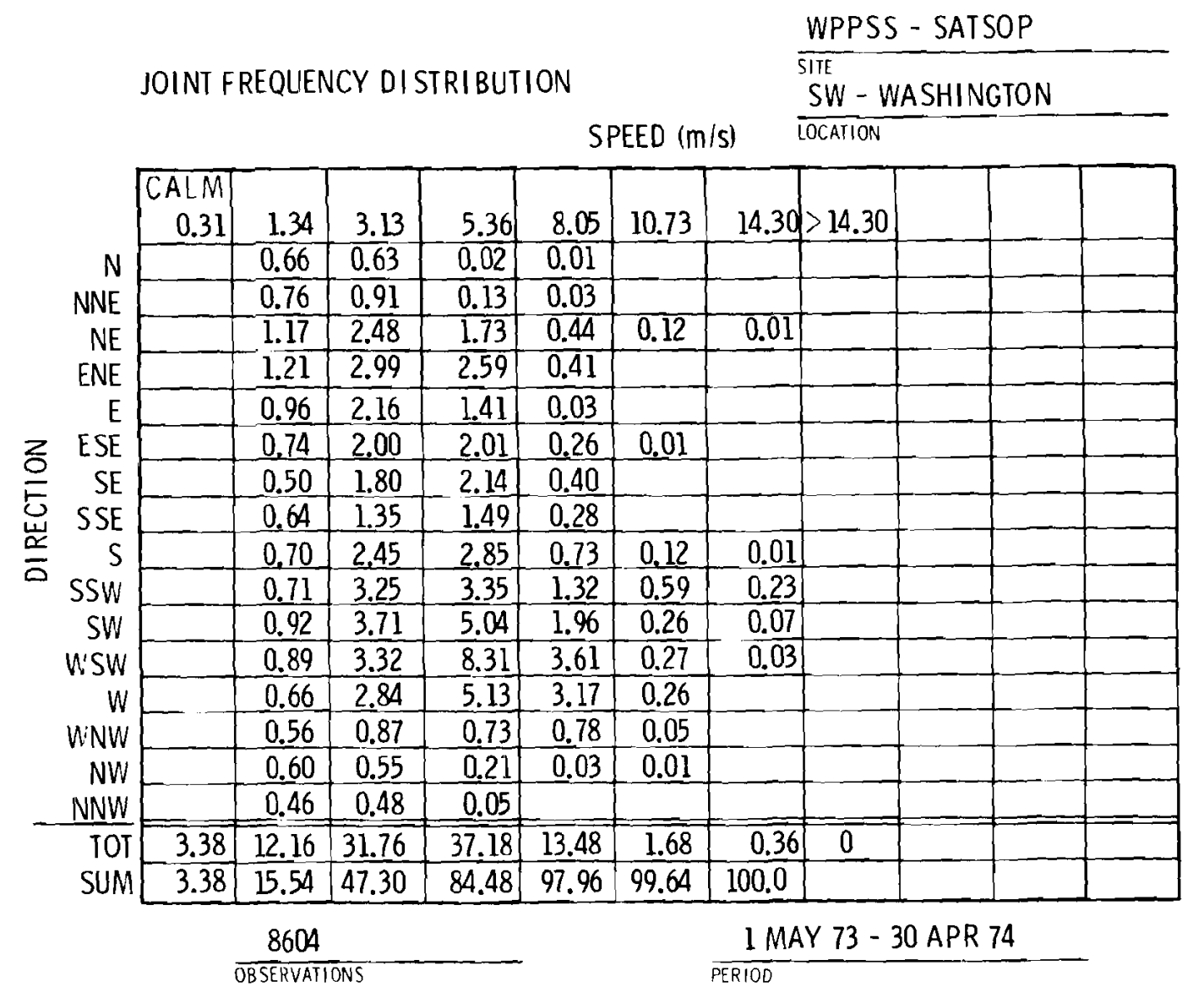

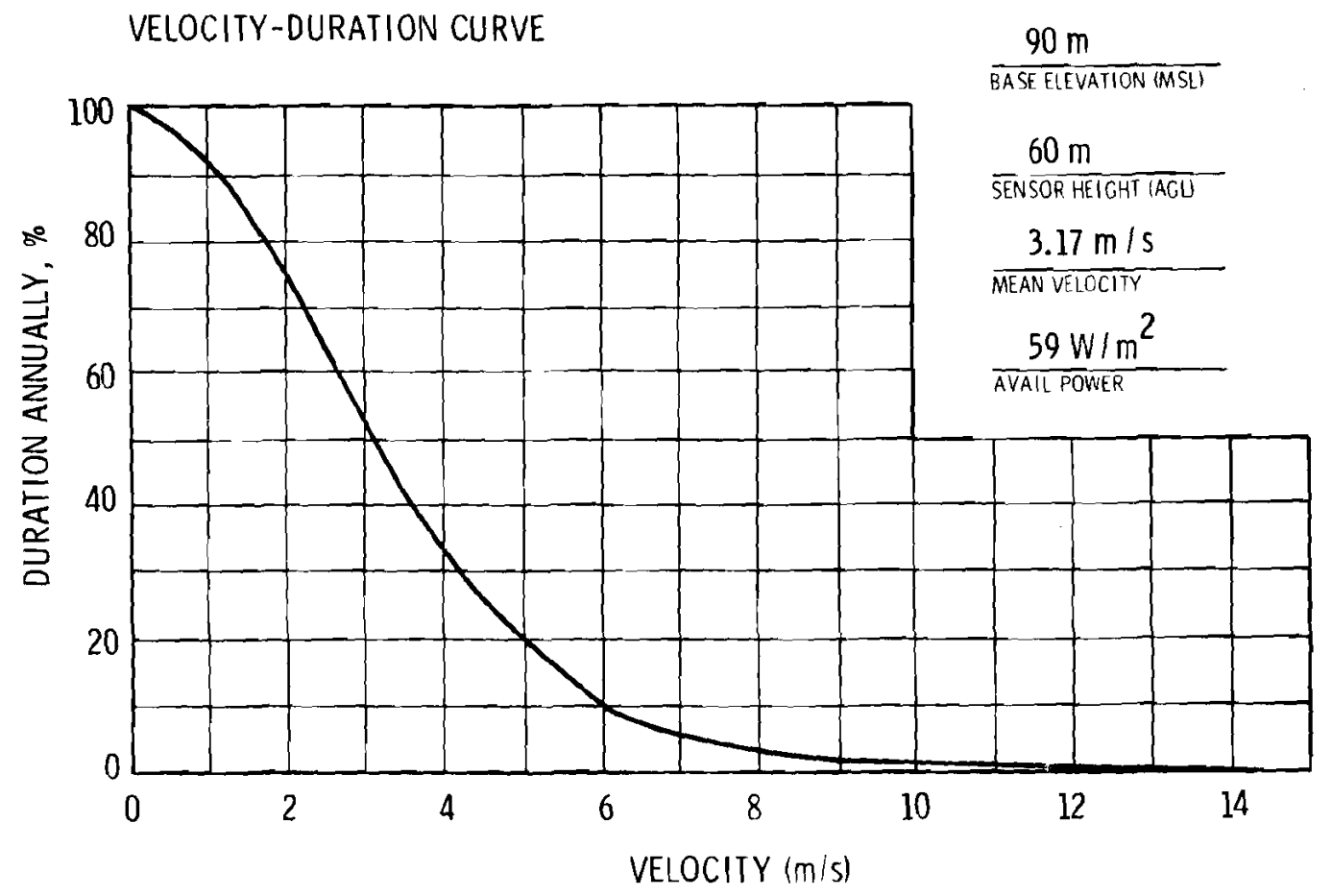




\section{SITE LOCATION:}

The site $\left(42.73^{\circ} \mathrm{N} / 72.93^{\circ} \mathrm{W}\right)$ is located in Franklin County, northwest Massachusetts, about $40 \mathrm{~km} \mathrm{NE}$ of Pittsfield, $20 \mathrm{~km} \mathrm{~S}$ of Wilmington, VT and $13 \mathrm{~km}$ NNW of Charlemont, MA. The site is on the south end of Sherman Dam, on the Deerfield River.

\section{TOPOGRAPHY :}

The site is located at the bottom of a deep river valley in the hilly and forested Berkshire Hills region of northwest Massachusetts. At the site, the elevation is about $350 \mathrm{~m}$ (MSL). The steep-sloped valley rises to over $600 \mathrm{~m}$ (MSL) on both sides of the NNE-SSW river. The course of the river is very erratic with a general decrease in elevation to the $\mathrm{S}$.

\section{ON-SITE WIND MEASUREMENTS:}

During the summer of 1971, a 43-m tower was erected adjacent to Sherman Pond. A low threshold Climet Cl25 system is located at $9 \mathrm{~m}$ above the ground.

NRC Docket No. $5 \overline{0-029}$ 


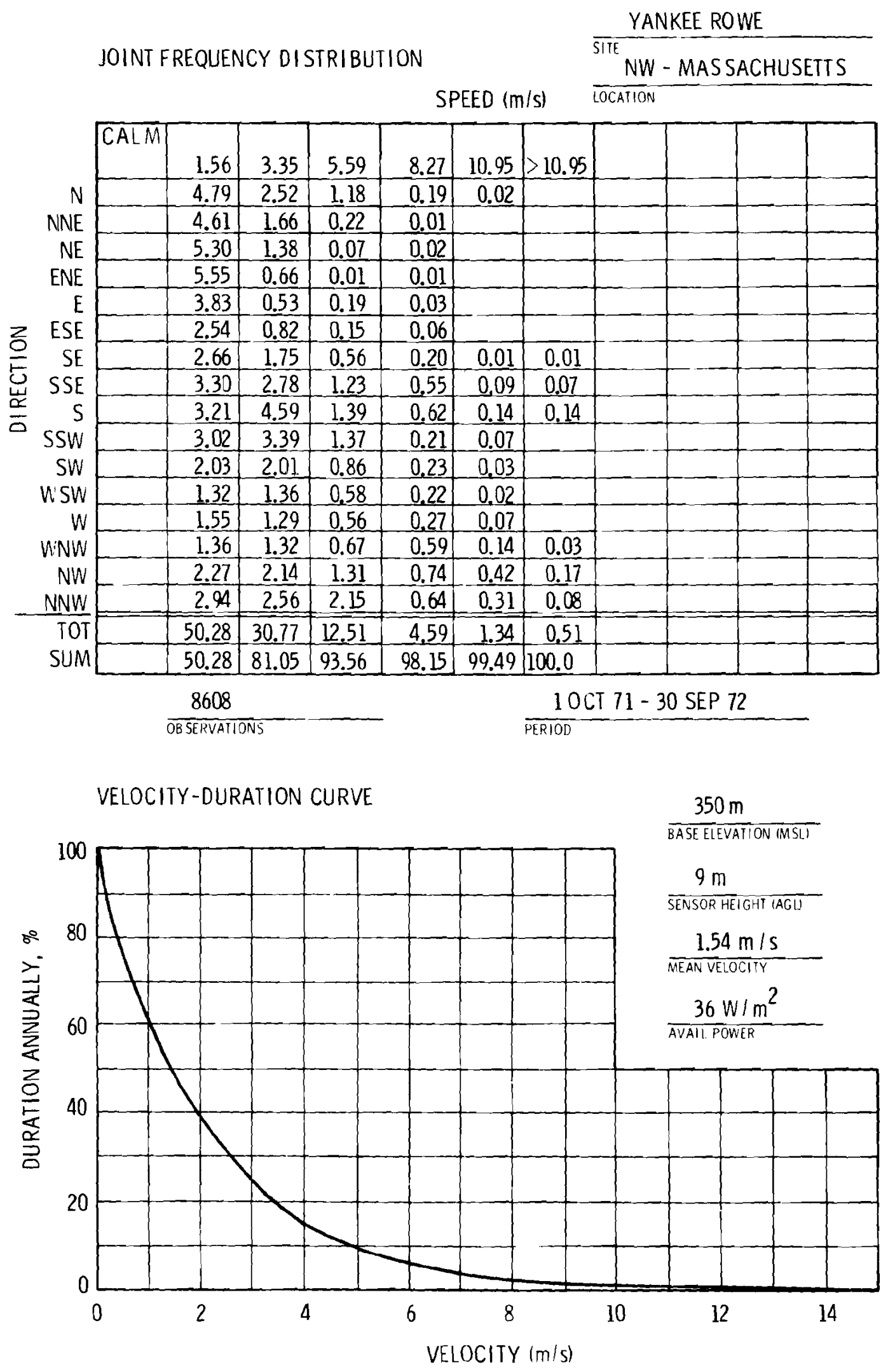


YEIJOW CREEK

\section{SITE LOCATION:}

The Yellow Creek site $\left(34.96^{\circ} \mathrm{N} / 88.22^{\circ} \mathrm{W}\right)$ is located in extreme northeast Mississippi, in Tishomingo County, on the right bank of the Yellow Creek embayment, about $24 \mathrm{~km} \mathrm{E}$ of Corinth. TVA's Pickwick Landing Dam on the Tennessee River is about $1 \mathrm{l} \mathrm{km} \mathrm{N}$; Memphis, TN is $160 \mathrm{~km} \mathrm{E}$; and Huntsville, AL is $145 \mathrm{~km} \mathrm{E}$.

\section{TOPOGRAPHY:}

The site is on the western side of a peninsula, which projects $\mathrm{N}$ into Pickwick Reservoir with the Tennessee River to the $\mathrm{E}$ and the Yellow Creek embayment on the $w$, both of which flow $N$. The site is located in a band of hills which extend through TN from $\mathrm{N}$ to $\mathrm{S}$ along both sides of the Tennessee River, crossing the river in the site area, and extending to the $S$ and $S E$ into Mississippi and Alabama. The elevation of the hills is generally 180-210 $\mathrm{m}$ (MSL). The general terrain slopes very gradually downward to the $w$, with elevations generally about $100 \mathrm{~m}$ (MSL) near Memphis and as low as $75 \mathrm{~m}$ (MSL) in the Mississippi River floodplain both $N$ and $S$ of Memphis. To the $E$, the Tennessee River Valley broadens through northern Alabama to the southern reaches of mountains associated with the Cumberland Plateau, near Huntsville. The valley floor slopes upward from about $150 \mathrm{~m}$ (MSL) a few $\mathrm{km} \mathrm{E}$ of the site to over $200 \mathrm{~m}$ (MSL) near Huntsville.

ON-SITE WIND MEASUREMENTS:

A 46-m tower is located on the west side of the Yellow creek embayment, in a large clearing at an elevation of about $154 \mathrm{~m}$ (MSL), near the center of the base of the peninsula which extends eastward into the Yellow Creek embayment. Climet WS-011-1 (speed) and WD-012-10 (direction) sensors are located at $10 \mathrm{~m}$ and $46 \mathrm{~m}$.

NRC Docket No. $50=566$ 


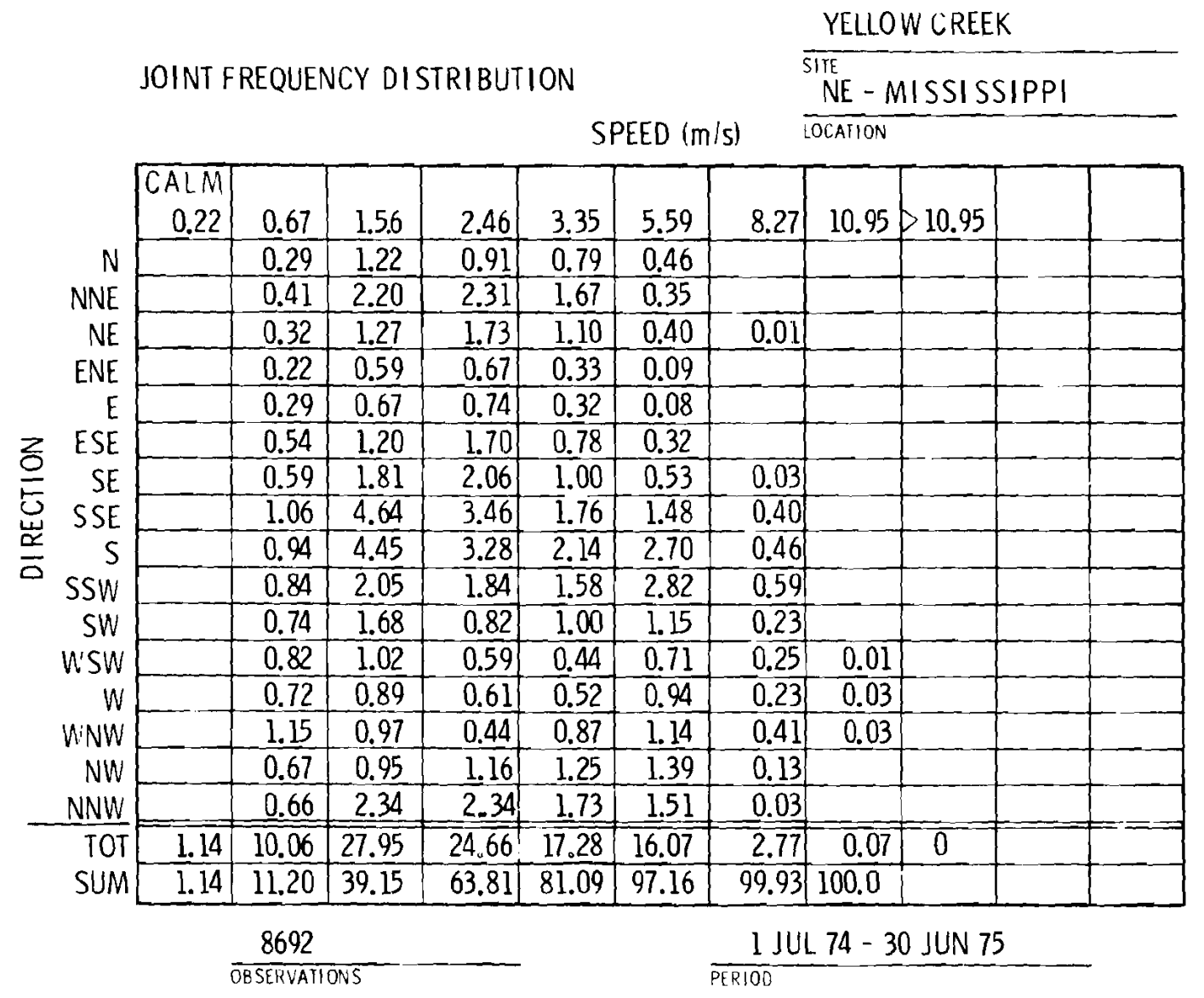

VELOCITY-DURATION CURVE

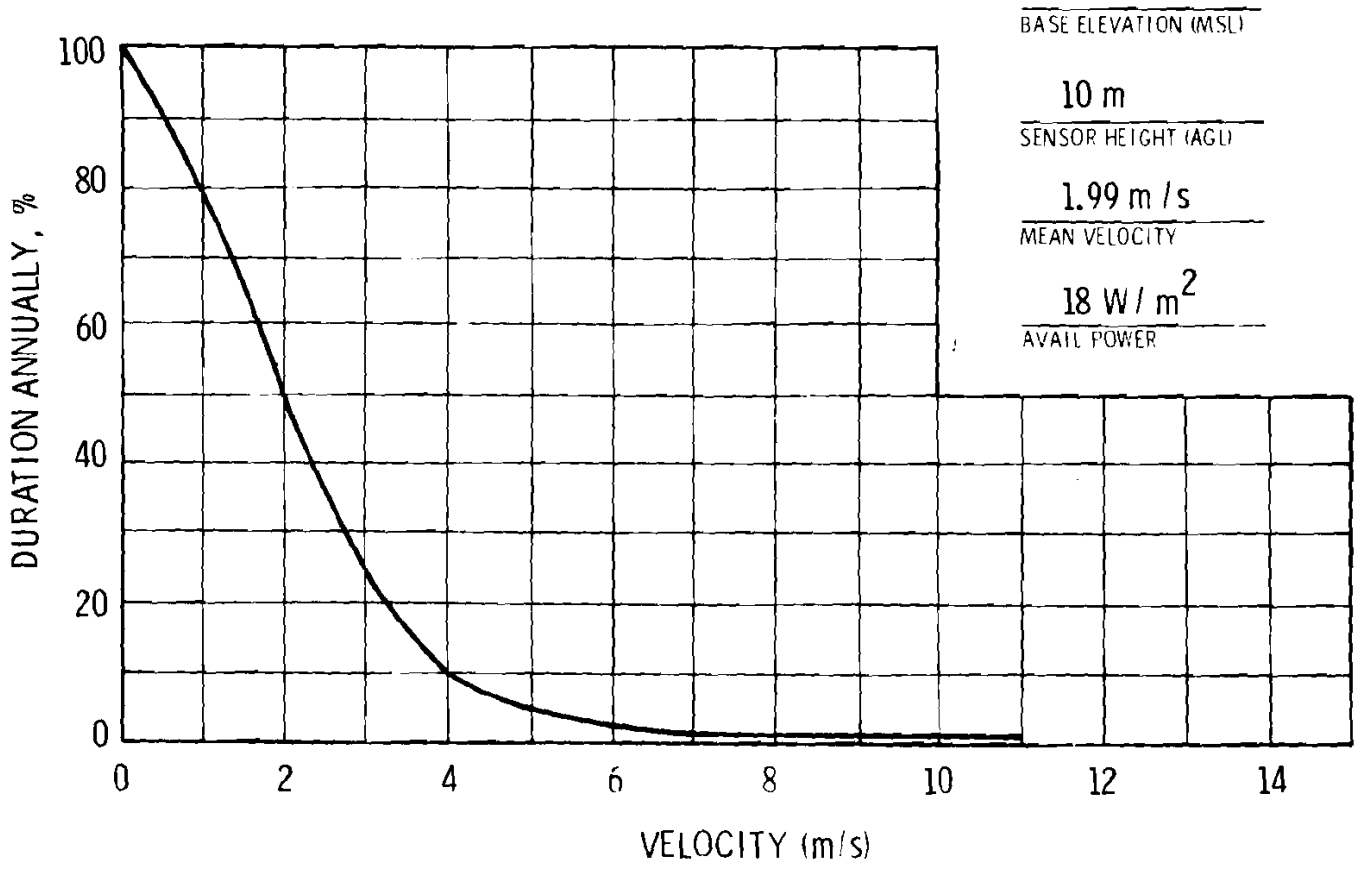

$\frac{154 \mathrm{~m}}{\text { BASE ELEVATION (MSLI }}$

$10 \mathrm{~m}$

SENSOR HEIGHT $\overline{A G G L}$

$1.99 \mathrm{~m} / \mathrm{s}$

$18 \mathrm{~W} / \mathrm{m}^{2}$

VAIL POWER - 


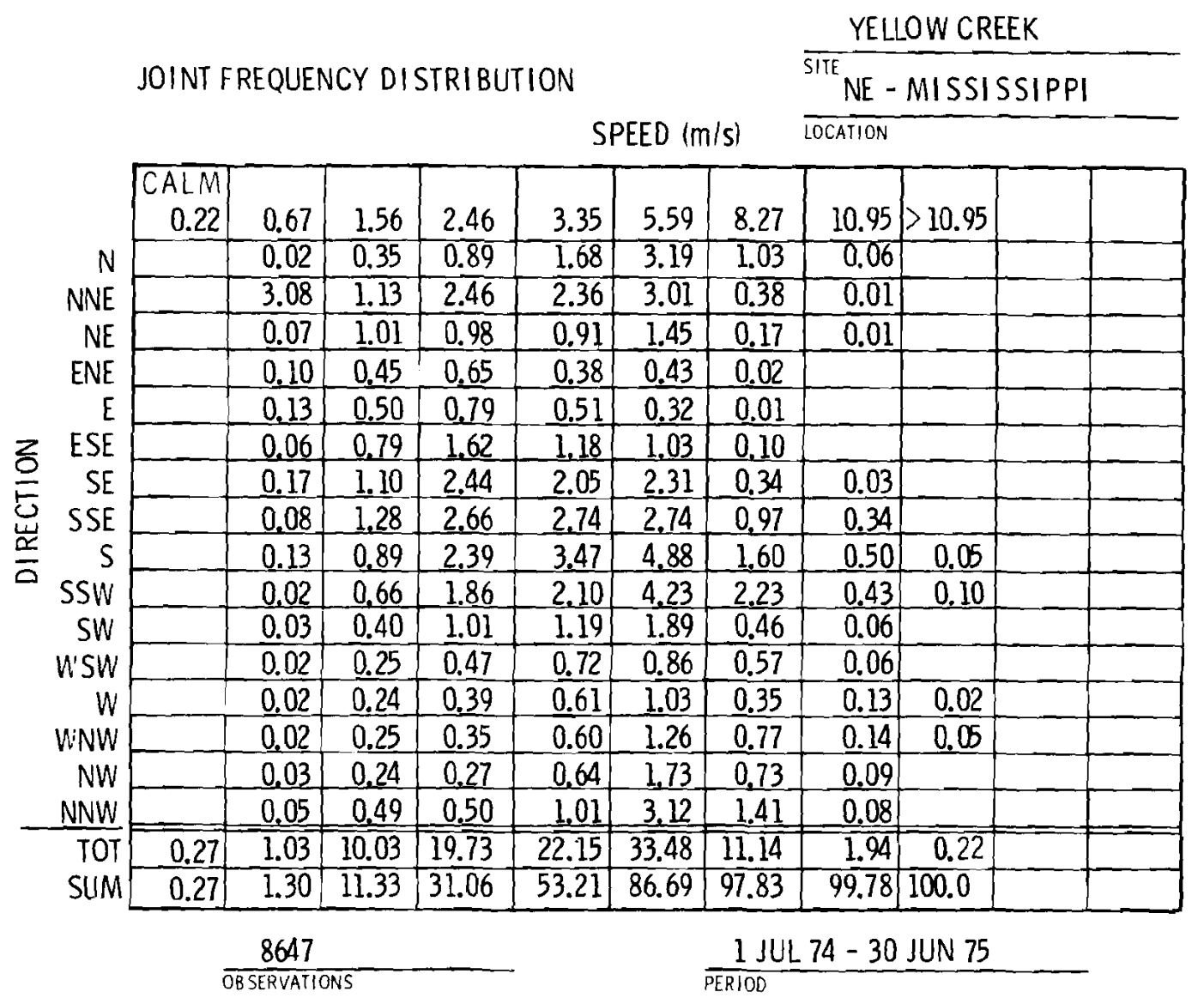

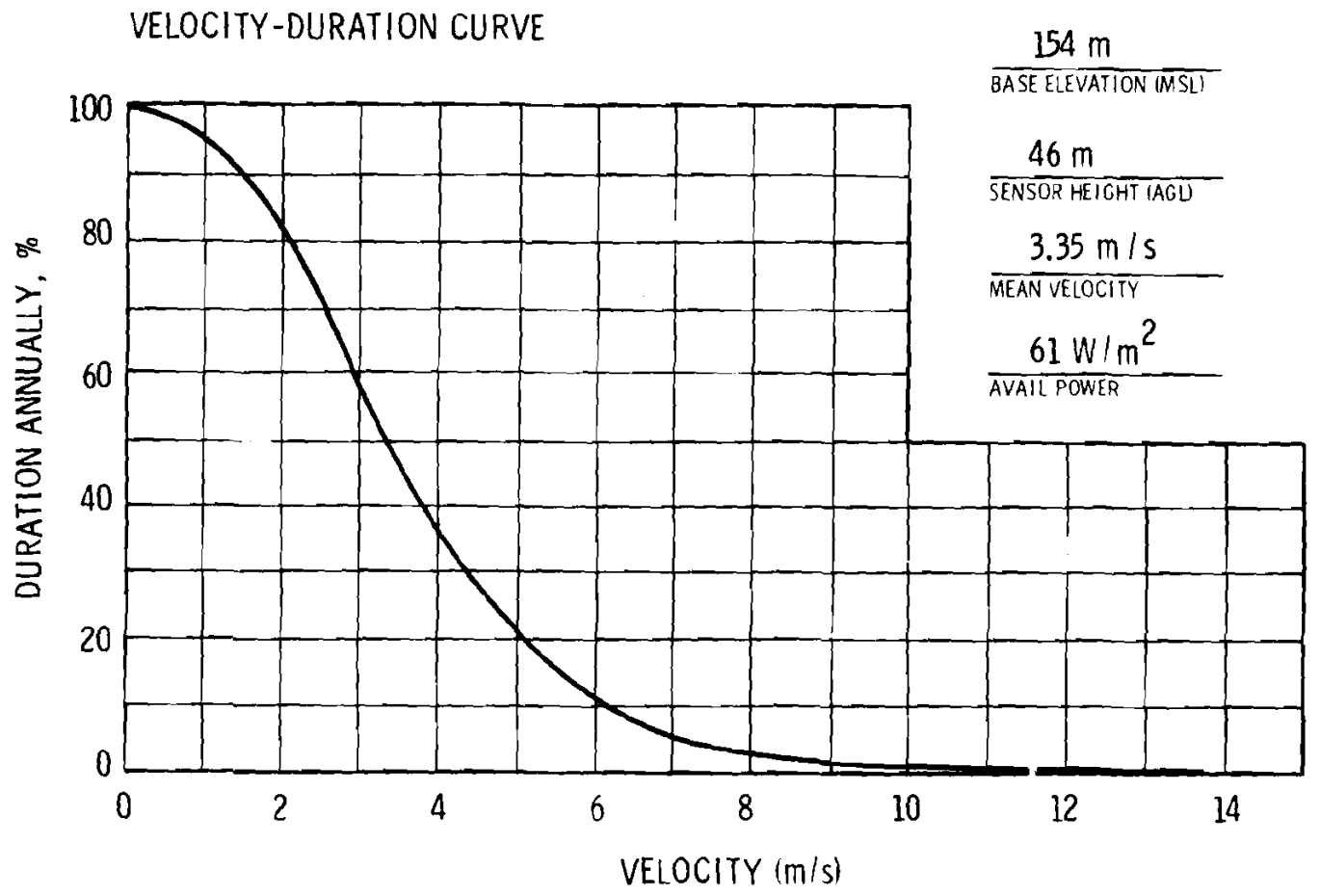


WM. H. ZIMMER

SITE LOCATION:

The site $\left(38.87^{\circ} \mathrm{N} / 84.23^{\circ} \mathrm{W}\right)$ is located in southwest Ohio, Clermont County, $39 \mathrm{~km} \mathrm{SE}$ of Cincinnati and $1 \mathrm{~km} \mathrm{~N}$ of Moscow, on the east bank of the Ohio River, which flows $\mathrm{N}$ in this area.

POPOGRAPHY :

The site is on the floodplain of the ohio River Valley, which is rather pronounced and has rather high bluffs rising to over 240 $m$ (MSL) within $2 \mathrm{~km}$ of the river. The immediate site locale is relatively level, with an average elevation $150 \mathrm{~m}$ (MSL). At the site, the floodplain is about $2 \mathrm{~km}$ wide, after rising sharply up from the river at $140 \mathrm{~m}$ (MSL) normal pool elevation. The general rolling terrain around the site is wooded, with shrubs and brush along the creeks.

ON-SITE WIND MEASUREMENTS:

Two towers were installed in April 1971. A dual-level 61-m tower is located along the bank of the ohio River, at $155 \mathrm{~m}$ (MSL). The tower has MRI 1074-1 sensors at $9 \mathrm{~m}$ and $61 \mathrm{~m}$. A $15-\mathrm{m}$ tower is located at $270 \mathrm{~m}$ (MSL) on a hilltop to the NE, and is instrumented with an MRI 1074-2 on top.

NRC Docket No. 50-358 


\begin{tabular}{|c|c|c|c|c|c|c|c|c|c|c|c|}
\hline & & & & & & & & & & & \\
\hline & JOINT F & REQUEI & CCY DI & TTRIBU & ON & & & SITE - & $\mathrm{HIO}$ & & \\
\hline & & & & & & EED (m & & LOCATION & & & \\
\hline & $\begin{array}{c}\text { CALM } \\
0.5\end{array}$ & 1 & 2 & 3 & 4 & 5 & 6 & 7 & 8 & 9 & $\geq 9$ \\
\hline$N$ & 1.00 & 1.26 & 1.99 & 1.11 & 0.62 & 0.15 & 0.02 & & & & \\
\hline NNE & 0.90 & 0.81 & 0.84 & $0 . \overline{40}$ & 0.13 & & & & & & \\
\hline NE & 0.94 & 0.65 & 0.73 & 0.34 & 0.06 & & 0.01 & & & & \\
\hline ENE & 0.76 & 0.44 & 0.63 & 0.34 & 0.06 & 0.02 & & & & & \\
\hline$E$ & 1.05 & 0.72 & 0.61 & 0.41 & 0.12 & 0.04 & 0.02 & & & & \\
\hline ESE & 1.75 & 1.63 & 1.17 & 0.59 & 0.16 & 0.08 & 0.06 & 0.01 & & & \\
\hline SE & 2.75 & 3.82 & 3.70 & 1.41 & 0.53 & 0.24 & 0.15 & 0.09 & 0.01 & 0.01 & 0.01 \\
\hline SSE & 1.22 & 2.38 & 4.06 & 2.28 & 1.35 & 0.85 & 0.44 & 0.16 & 0.07 & 0.07 & 0.04 \\
\hline$S$ & 0.69 & 1.12 & 2.52 & 2.36 & 1.56 & 1.15 & 0.72 & 0.36 & 0.18 & 0.06 & 0.08 \\
\hline SSW & 0.42 & 0.77 & 1.80 & 1.51 & 0.86 & 0.65 & 0.32 & 0.16 & 0.07 & 0.06 & 0.01 \\
\hline SW & 0.62 & 1.08 & 2.10 & 1.34 & 0.81 & 0.54 & 0.18 & 0.05 & 0.03 & 0.01 & 0.02 \\
\hline W'SW & 0.64 & 1.11 & 1.78 & 1.07 & 0.66 & 0.23 & 0.08 & 0.01 & & & \\
\hline$w$ & 0.64 & 1.10 & 1.63 & 0.86 & 0,58 & 0,24 & 0.05 & & & & \\
\hline UNW & 0.74 & 1.23 & 1.59 & 1.13 & 0.74 & 0.32 & 0.17 & 0.01 & & & \\
\hline NW & 0.61 & 1.01 & 1.55 & 0.83 & 0.50 & 0.16 & 0.02 & 0.01 & & & \\
\hline NNW & 0.84 & 1.22 & 1.96 & 1.41 & 0.51 & 0.20 & 0.10 & & & & \\
\hline TOT & 15.57 & 20.35 & 28.65 & 17.42 & 9.24 & 4.87 & 2.34 & 0.85 & 0.36 & 0.21 & 0.14 \\
\hline SUM [ & 15.57 & 35.92 & 64.57 & 81.99 & 91.23 & 96.10 & 98.44 & 99.29 & 99.65 & 99.86 & 100.0 \\
\hline & & & & & & & & R $72-$ & EFP & & \\
\hline
\end{tabular}

VELOCITY-DURATION CURVE

خ

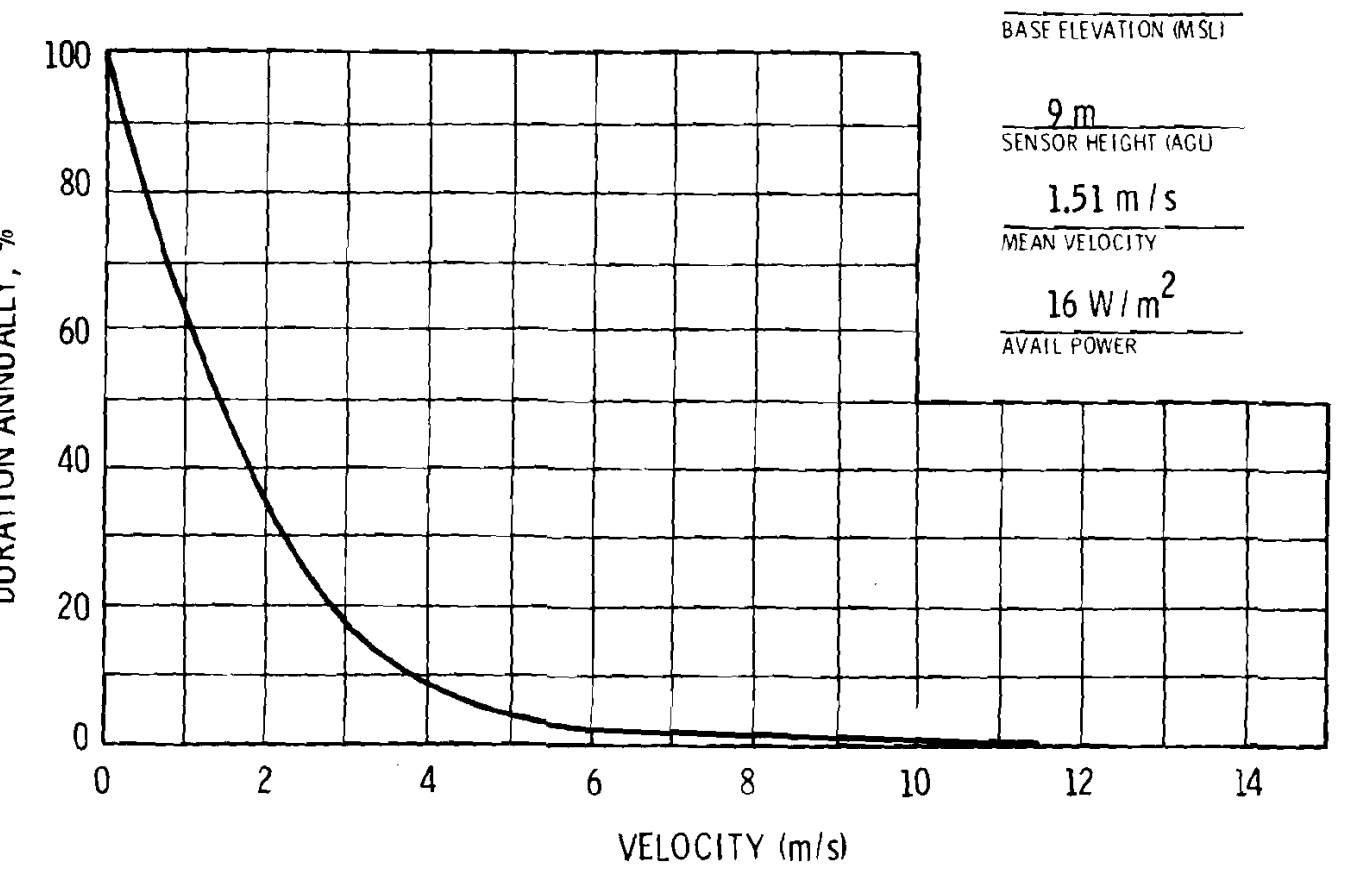


SITE LOCATION:

The site $\left(42.45^{\circ} \mathrm{N} / 87.80^{\circ} \mathrm{W}\right)$ is in the extreme eastern portion of the city of zion, Lake County, Illinois, on the west shore of Lake Michigan, about $10 \mathrm{~km}$ NNE of Waukegan. Ii, and $13 \mathrm{~km} \mathrm{~S}$ of Kenosha, WI.

TOPOGRAPHY :

The terrain is relatively flat with elevations varying from $176 \mathrm{~m}$ (MSL) at the Lake Michigan shoreline to $182 \mathrm{~m}$ (MSL) inland. Just behind the beach, there is a low line of bluffs about 2 to $3 \mathrm{~m}$ high. The site itself has very little slope and is rather flat.

ON-SITE WIND MEASUREMENTS:

Wind speed and direction are measured at $11 \mathrm{~m}, 38 \mathrm{~m}$, and $76 \mathrm{~m}$ on the zion meteorological tower. Base elevation is at about $180 \mathrm{~m}$ (MSL), which is grade level. Measurements are made with Belfort-type $L$ wind systems.

$\widehat{\text { NRC Docket No. } 50-295,-304}$ 


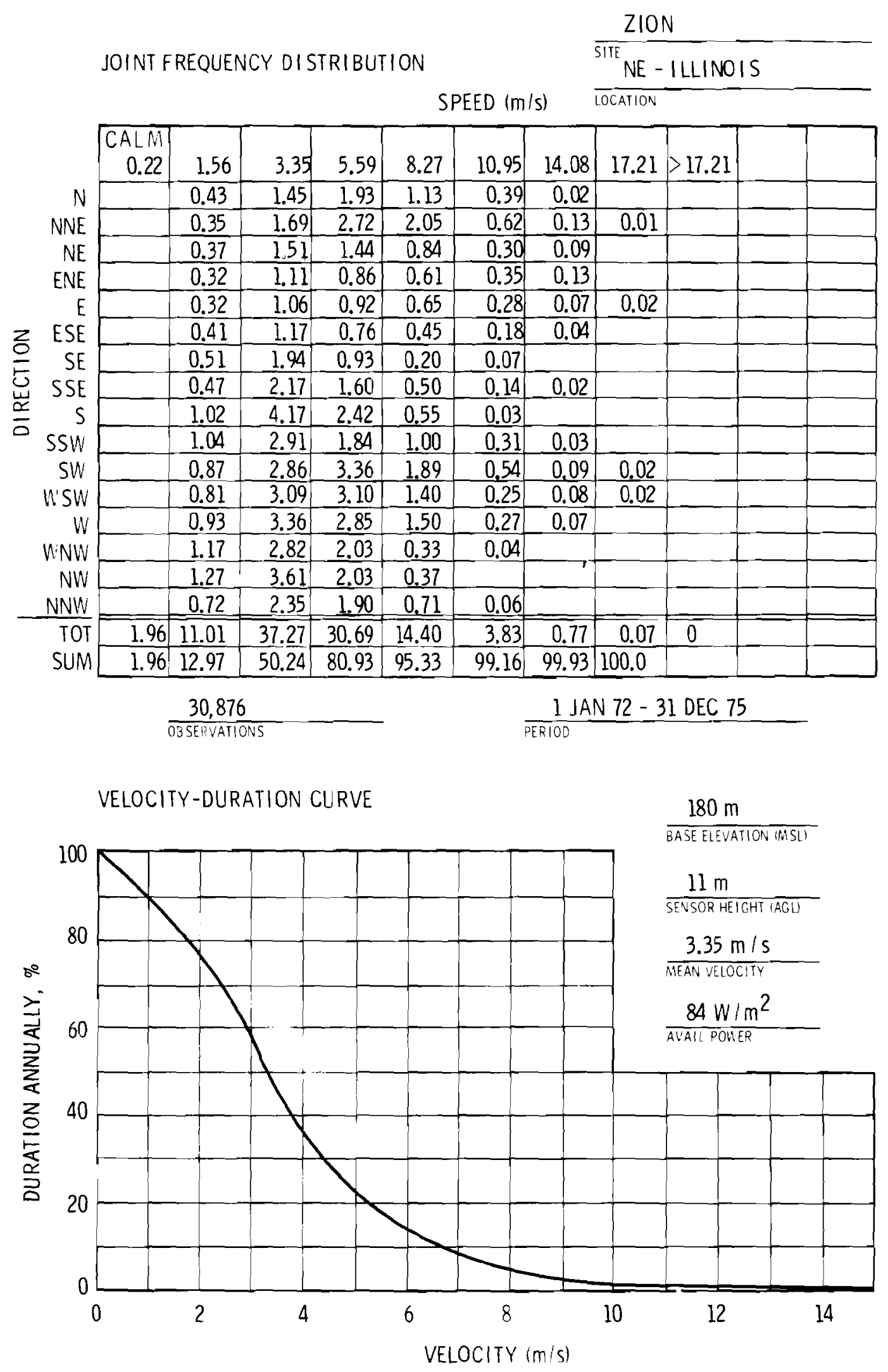




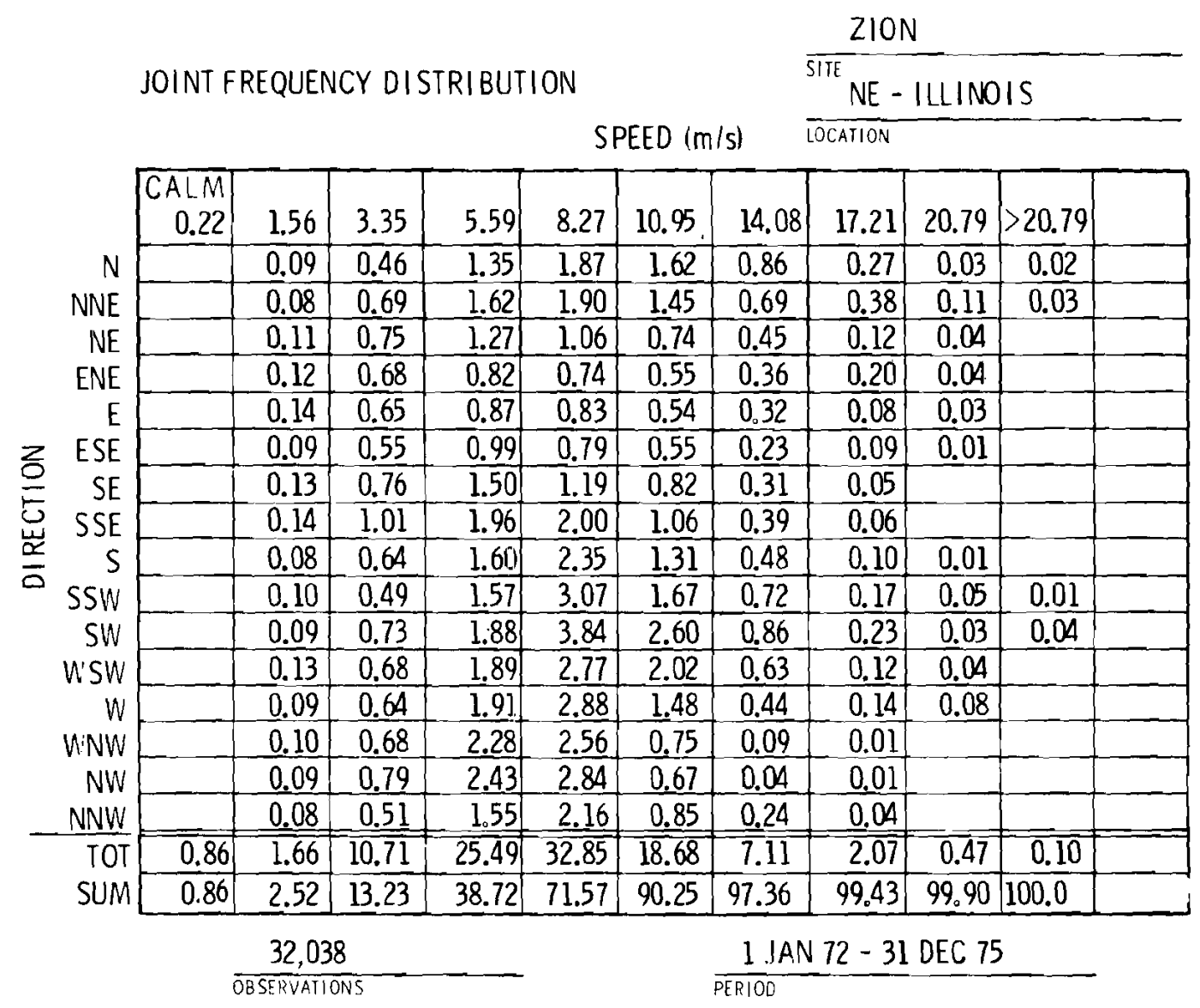

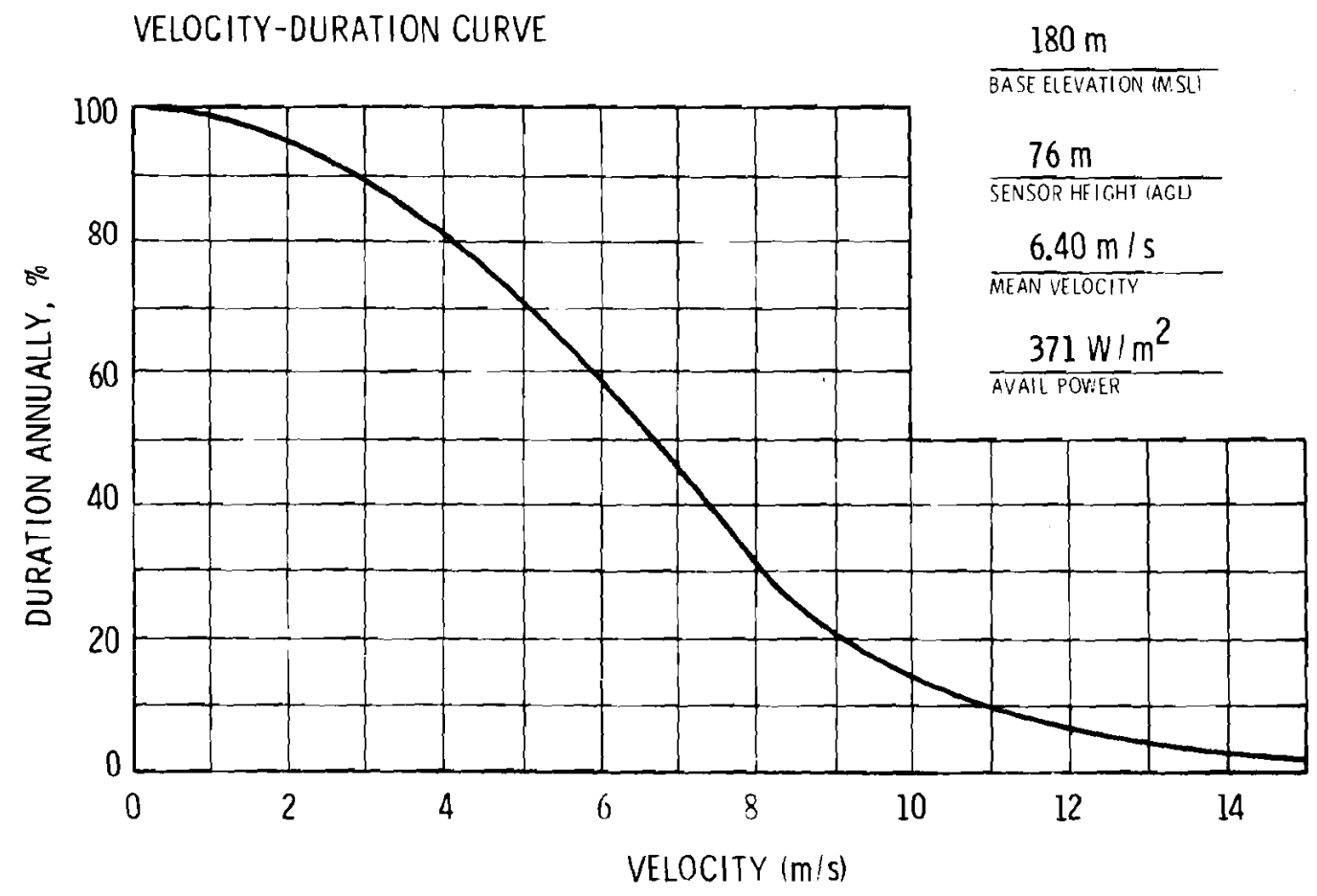




\section{DISTRIBUTION}

No of

Copies

OFFSITE

1 ERDA Chicago Patent Group

9800 South Cass Avenue

Argonne, Illinois 60439

A. A. Churm

265 ERDA Technical Information center

No of

Copies

ONSITE

1 ERDA Richland Operations office

G. L. Liffick

98 Battelle-Northwest

C. E. Elderkin (80)

J. V. Ramsdell

L. L. Wendel1

R. I. Drake

W. C. Cliff

D. S. Renne

M. G. Verholek (5)

R. L. Conley

H. Harty

R. I. Watts

Technical Information (3)

Technical Publications (2) 
